\title{
Desenho Urbano e Revitalização na Área Portuária do Rio de J aneiro A Contribuição do Estudo da Percepção Ambiental
}

\section{Vicente del Rio}

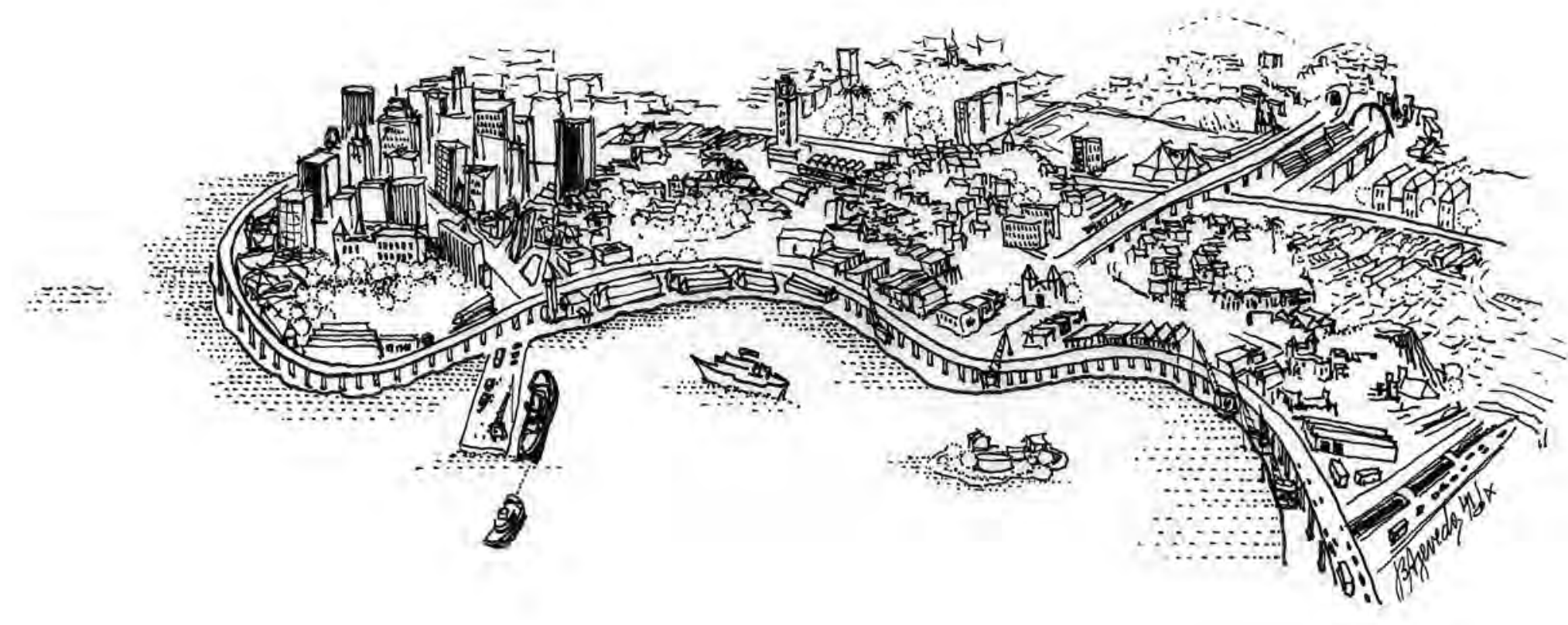




\title{
DESENHO URBANO E REVITALIZAÇAO \\ NA AREA PORTUARIA DO RIO DE JANEIRO
}

A Contribuição do Estudo da Percepção Ambiental

\author{
Vicente del Rio
}

Tese apresentada á Faculdade de Arquitetura e Urbanismo, Universidade de săo Paulo, para obtenção do grau de Doutor.

Orientador: Prof. Dr. Lauro Bastos Birkholz

São Pau10 


\section{RESUMO}

Contribuiçăo sobre a importância e a aplicabilidade dos estudos de percepção ambiental para o desenho urbano na revitalização de uma área central urbana em processo de declinio e sub-utilização de seus potenciais para o desenvolvimento.

$\mathrm{Na}$ Primeira Parte é desenvolvido o embasamento tedrico através de conceituaç̋es sobre revitalização de centros de cidade, desenho urbano e seu papel neste processo, percepcão ambiental e sua aplicabilidade. A evolução, caracterização e atuais tendências de desenvolvimento da Area Portuária do Rio de Janeiro, tomada como estudo de caso, são temas abordados na Segunda Parte. A Terceira e Ultima Parte apresenta as anditises sobre a questão da percep̧̧ão da Area Portuária atravès da investigaçăo de fontes direta e indiretas, encerrando-se com consideraçoses gerais sobre a validade e a aplicabilidade dos achados para intervençôes de desenho urbano e revitalizaçăo.

\section{ABSTRACT}

Contribution on the importance and applicability of the studies of environmental perception for urban design in the revitalization of a city center suffering a process of decline and underutilization of its development potentials.

Theoretical support is developed in Part one through conceptualizations on revitalization of city centers, urban design and its role in this process, and the applicability of environmental perception studies. The Port Area of Rio de Janeiro is taken as the case-study and its evolution, developmental aspects and tendencies are considered in the Part Two. The Third and last Part presents an analysis of environmental perception at the Port Area through an investigation of direct and indirect sources, culminating in considerations on the validity and applicability of the findings for interventions of urban design and revitalization. 
A memória de meu pai Edgard. Amor fundamenta1, para sempre.

E ainda muito forte a presença da sua ausência.

A mirha mãe, Beatriz, pela batalha da vida. 


\section{AGRADECIMENTOS}

- desenvolvimento de um trabaino desta envergadura é um caminho demasiadamente longo e penoso. E uma verdadeira batalha: muitos mortos e feridos vão ficando pelo caminho, muitos inocentes são sacrificados, muitas cicatrizes são deixadas. Mas, como todo objetivo de vida, uma vez definido, não cumpri-lo é culpar-se para sempre. Só espero que os sacrificados me perdoem.

Muitos amigos, pessoas e entidades, foram essenciais para o cumprimento desta batalha; dirigir-thes os agradecimentos são um minimo necessário que podemos fazer por seu apoio e incentivo. Correndo o risco de ser 1 imitado nesta tarefa, cito alguns:

o Professor Dr. Lauro Bastos Birkholz, cuja sábia orientação, incentivo e amizade foram fundamentais para que eu conseguisse chegar ao fim deste objetivo de vida.

A Professora Dra. Livia de oliveira, do Instituto de Geociências e Ciências Exatas, UNESP-Rio Claro, pelo incentivo e inestimàvel ajuda no campo da percepção ambiental.

Os diversos tènicos e profissionais entrevistados, relacionados em um dos anexos, pela gentileza e informacões elucidativas. Em especial a RIOPART, nas pessoas dos Srs. Amaury Temporal e Sérgio Aguiar. 
Os amigos que foram envolvidos diretamente e ajudaram em distintas fases do trabalho: Glauco Guedes (pesquisa de campo), Ana Helena Mayhoffer (quantificação de questionários), Helena de Souza Britto (pesquisa de 1iteratura), Luciana Martins (pesquisa sobre o porto), Christina Costa (pesquisa de legislação), Maria Fernanda Quental, Cláudia Ricci e Erika Kupac (mapeamentos), Andréa Göpfert (tabulação em LOTUS) e Martha Moura (comentários sobre psicologia). O grande amigo Mihai Cauli, pela amizade e grande ajuda com computação e impressão do trabalho.

A assistência inestimåvel do Joel Gomes da silva Jr. (Mestrando em Estatistica, UFRJ). A grande forca do Josemar Dias Ferreira (monitor do Laboratório de Computação, CLA/UFRJ) e do Armando Leite Ferreira (MSC, COPPEAD/UFRJ).

- pessoal da secretaria de pós-graduacão da FAU/USP, em especial à Ruth Tamarindo, Hayds Lemos e Cida de Souza.

Os meus tios Roberto e stella e primos Ary e Sania, o meu amigo e irmão Marcio, pelo carinho e apoio, tão importantes em Săo Pauto.

A Faculdade de Arquitetura e Urbanismo e a meus colegas de departamento, em especial: Ulysses Burlamaqui, Heloisa Carvalho, Luiz Paulo Fernandez Conde, Carlos Alberto Carvalho, Milton Feferman e Trajano Quinhőes. A secretária da FAU, Norma Ciri110.

- Programa Partners of the Americas, o Department of Housing and Community Development (City of Baltimore) e o METRO Center da Johns Hopkins University, pela oportunidade de desenvolver trabalhos e pesquisa em revitalizacăo urbana.

- CNPq e a Capes, por seu apoio financeiro em distintas fases deste trabalho. 
Um modelo de cidade ideal em sua mente, do qual extrala todas as cidades imaginàveis, todas as combinacões posstveis; assim Marco Polo era capaz de relatar as suas viagens pelo império do grande Kublaj Khan, conquistador mongol e imperador da China, na obra fantástica de Italo CALVINo "As cidades Invistveis". O tema da cidade, como simbolo maior da humanidade, e seus mistèrios, atraiu o escritor que percebeu o poder da mente, do sonho, da história e do imaginário, na nossa percepcăo e compreensão do real. Em uma de suas falas, Marco Polo exclama que a cidade é redundante, repetindo-se para fixar alguma imagem na mente, e que, igualmente redundante é a memória, pois repete os stmbolos para que a cidade comece a existir. Para este personagem, cada pessoa tem em mente uma cidade feita exclusivamente de diferenças, de incongruências, sem figuras e sem forma espectfica, que vai sendo substitulda pelas realidades das cidades existentes.

Obra prima da literatura contemporânea ita1iana, "As Cidades Invisiveis" nos ajuda a mostrar a importância de estudar os processos conformadores das imagens dos objetos reais em nossa mente, em particular da percepcăo. Da mesma forma que um texto literário, jà dizia victor HUGo em seu tempo, a cidade é passivel de ser 1ida; serão tantas leituras quantas as imaginaçóes dos 
leitores. Os modelos mentais vão adaptando-se ás realidades e á experiência, e as cidades reais possiveis vão sendo construidas, como o fazia Kublai Khan através dos olhos de Marco Polo.

- urbanismo demorou a dar-se conta disto, como aliás todas as ciências sociais, e durante muito tempo as decisões que se tomava a respeito de nossas cidades e meio ambiente se baseavam exclusivamente naquilo que acreditávamos ser a realidade "objetiva". Isto era tipicamente o caso das metodologias de planejamento e organização do território, urbano ou regional, em que os levantamentos, as análises e os diagnósticos eram conduzidos tecnocraticamente, sob a ótica da objetividade e do cientificismo. A falência destas posturas foi sucedida pela emergência de uma maior consciência politica e social nos processos de planejamento e gestão urbana e regional.

Nos anos 70 já era evidente que o planejador deveria atuar a partir de realidades auscultadas da populaçăo-alvo, que faria vingar suas reivindicaçoses atravès dos processos politicos. 0 discurso da participaçăo comunitária dominava nossos campos de trabalho, mas na maioria das vezes acabava por justificar práticas tão personalistas e politicamente direcionadas quanto anteriormente.

De qualquer maneira, o planejador sempre acabava por atuar a partir de dados ditos objetivos que, supunha-se, reconstituiam a realidade. Muitos apontavam que esta realidade, seus problemas e seus atributos eram, na verdade, sempre deduzidos através da ótica e das interpretaçós dos técnicos que, evidentemente, possuem seus próprios valores e ideologias. Evidentemente, a resposta que as metodologias deram a isto, através principalmente 
das ciencias sociais, foi o chamado planejamento participativo, as gestóos onde o cidadăo atingido pelos planos poderia expressar, e ás vezes, fazer valer seus pontos de vista. Esta era uma saida eminentemente politica; a atividade do dia a dia do planejador ou do arquiteto, no entanto, năo torna viável a participação em todos os ntveis nem em todos os momentos.

Por outro 1ado, tambèm questionava-se que, afinal, os profissionais tinham um "oficio" para responder á sociedade, e qual seria a saida para este impasse? Sem ignorar os avanços democráticos possibilitados pelos processos participativos, como ir mais adiante e incorporar as diversas "realidades subjetivas" nos processos de desenho? Como utiliza-las como fontes confiàveis de decisôes que pudessem ter maior aceitaçăo pública? Quais seriam as metodologias de pesquisa e projetuais que, ainda através de bases cientificas confiàveis, nos permitissem compreender estas "realidades subjetivas"?

A importância disto fica evidente quando nos conscientizamos de que "a compreensăo individual e coletiva que o Homem possui do meio ambiente é... forca major em moldar este meio ambiente através da açăo das escolnas e do comportamento do Homem" (WHYTE 1977: 11). Neste sentido LOWENTAL (1967 in GOODEY 1976: 33) afirmava que "sem uma compreensăo prévia das bases da percepcão e do comportamento, o planejamento e a melhoria ambiental são meros exercicios acadêmicos, fadados a falhar porque desvencilhados dos termos pelos quais as pessoas pensam e as metas que selecionam".

Foi LYNCH (1960) o primeiro a trazer á pủblico um corpo teórico-conceitual que, apoiado em metodologia de pesquisa 
sólida, apontava caminhos férteis para a saida deste impasse. LYNCH defendia qualidades flsico-espaciais inerentes na forma urbana, e mostrava métodos de investigação para que elementos especificos de desenho pudessem ser identificados. Ele foi o pioneiro em promover um encontro frutifero entre a psicologia da percepção e a prática do desenho urbano.

Depois dele, muito já se estudou neste fertit campo disciplinar, em que o objetivo principal o de compreender como - Homem percebe a realidade, qual è esta realidade percebida, como esta realidade é organizada em sua mente, e quais as condutas geradas, seja sob forma de comportamento, seja sob forma de conhecimento adquirido, valores e sensaços. Porque, como entendeu CALVINO e defendia CARR (1970: 519), "...a cidade é o que as pessoas pensam que ela e...", a cidade da mente determina em grande parte $\circ$ mundo em que tentamos nos satisfazer diariamente.

Se, como defendeu RAPOPORT (1976), o desenho urbano è poder dar expressăo flisica a um ambiente ideal que existe em imagens mentais, as decisores de desenho devem refletir imagens publicas. Ou seja, aquelas que săo largamente aceitas e que possuem major chance de aceitacăo do que aquelas que refletem imagens de grupos muito 1 imitados, como as dos arquitetos e planejadores, que são mais idiossincráticas.

Mas felizmente, o pensamento de ponta atual jà encara a politica pública como expressão de valores públicos e, portanto, um "... mecanismo através do qual as demandas coletivas da sociedade são monitoradas pelo sistema politico para serem transformadas em ação" (O'RIORDAN in ZUBE 1984: 17). E como, 
talvez, nosso relacionamento mais sério com o meio ambiente seja nossa capacidade de alterá-10, as politicas públicas a serem seguidas $\Theta$ as metas perseguidas para nossa qualidade de vida, devem incorporar nossos pensamentos, valores e sentimentos relativos ao meio ambiente (MACHADO 1988). E neste sentido que os usuários devem ser entendidos como instrumentos de medicão e identificação da qualidade de diferentes ambientes $\theta$, portanto, suas experiências, percepções e expectativas devem constar da atividade avaliativa (ZUBE 1984).

Por isto, importa-nos comprovar, com os resultados de nossos estudos sobre a a Area Portuária do Rio de Janeiro, que os conceitos e metodologias de estudos da percepcão ambiental são sólidos o bastante a ponto ser viável sua operacionalizaçăo e sua contribuicăo ás diretrizes de desenho urbano para que a revitalizaçăo daquela àrea possa realizar-se da forma mais conveniente possivel para os seus próprios usuários; esta é a nossa tese. 
Prologo.......................... $v i$ Lista de figuras... . . . . . . . . . . . . . . . xiii

Lista de Tabelas... . . . . . . . . . . . . . X XV Lista de Quadros....... . . . . . . . . . . xvi Introdução . . . . . . . . . . . . . . . . . . . . . . xvii

\section{Parte I: o Quadro Teórico}

1: Revitalizaçăo de Areas Urbanas Centrais . . . . . . . 2

2: Desenho Urbano, Organizaçăo Flsico-Ambiental das Cidades . 58

3: Psicologia, Percepcão Ambiental e Imagens Mentais . . 9 98

4: Operacionalização do Estudo da Percepcão Ambiental para o Desenho Urbano e a Revitalização . . . . . . . . . 142

Parte II: o Estudo de Caso, Area Portuária do Rio de Janeiro

5: Evolução Histórica da Area Portuảria . . . . . . . . . 181

6: Tendências Operacionais do Porto do Rio de Janeiro. . . . 227

7: Caracterização e Dinâmica Recente da Area de Estudo . . 253

8: Grupos de Interesse, Planos e Propostas . . . . . . . 290

9: Tendências de Desenvolvimento da Area Portuària . . . 312 
Parte III: A Realizacão da Pesquisa

10: Objetivos, Metodologia e Procedimentos da Pesquisa . . 319

11: A Percepção da Area Portuária Através da Literatura e da Imprensa . . . . . . . . . . 325

12: A Percepcão da Area Portuária Através da Pesquisa de Campo . . . . . . . . . . . . 361

13: Desenho Urbano e Revitalização na Area Portuária do Rio de Janeiro . . . . . . . . . . 447

Anexo I : Relaçăo de Entrevistados . . . . . . . . . . . . . 465

Anexo II: Relaçăo de Bens Tombados . . . . . . . . . . . . . 467

Anexo III: Instrumento de Medida - Questionário . . . . . . 469

Anexo IV: Tabelas com Dados da Pesquisa de Campo . . . . . . 474

Anexo V: Relaçăo de Elementos Flsicos Citados . . . . . . 499 Bibliografia . . . . . . . . . . . . . . . . . . . . . 503 
1: Planta do Rio com as Intervençes de Pereira Passos . . . 10

2. Charge sobre P. Passos e o endividamento municipal . . . . 10

3. Plano Voisin para Paris, Le Corbusier . . . . . . . . . . 16

4. Esquema de interelaçס̃es de conjuntos, C. Alexander . . . . 16

5. Projeto de A. Reidy para a Esplanada St'Antonio . . . . . 32

6. Vista aérea da àrea da Esplanada de St. Antonio . . . . . 32

7. Aspecto da área da Cidade Nova, Rio . . . . . . . . . . . 34

8. Nova proposta municipal para a Cidade Nova. . . . . . . . 34

9. Aspecto de South Street Seaport, Nova Iorque . . . . . . . 34

10. Aspecto de Cannary Warf, Londres . . . . . . . . . . . . 43

11. Aspectos do Corredor Cultural, Rio . . . . . . . . . . . 43

12. Vista geral do Projeto Inner Harbor, Baltimore . . . . 46

13. Esquemas da evolução de áreas portuárias centrais . . . . 46

14. Imagens incentivadas pelo plano de Săo Francisco . . . . 55

15. Vista geral do Inner Harbor, Baltimore . . . . . . . . . 55

16. Esquema téorico do processo de conhecimento ambienta1 . . 111

17. A lei da continuidade das figuras na Gestalt . . . . . . 111

18. Esquema teórico do processo de interaçăo ambienta1 . . . 124

19. Exemplo da dependência entre percepção e cultura . . . . 124

20. O cristo Redentor: imagens publicas ou coletiva . . . . . 136

21. Imagem mental tipo simbolico/figurativo . . . . . . . . . 154

22. Imagem mental tipo estrutural/operativo . . . . . . . . . 154

23. Mapa mental de Gould e as curvas de preferências . . . . 159

24. A forma visual em mapa mental composto de Lynch . . . . . 159

25. Os elementos estruturadores da imagem da cidade . . . . . 159

26. Plantas esquemáticas da evolução do Centro do Rio.. . . 185

27. Croquis de caracterizaçăo da Area Portuária . . . . . . . 185

28. Aspecto geral do Rio em gravura de 1624 . . . . . . . . . 188

29. Carta topográfica do Rio de 1775 . . . . . . . . . . . . 188

30. Planta do centro do Rio em 1812 . . . . . . . . . . . . . 191

31. Planta da Area Portuària do Rio em fins do Séc. XIX . . . 200

32. Vista do oratório e favela no Morro da Providência . . . 200

33. Aspecto geral do Porto do Rio em 1875 . . . . . . . . . . 200

34. Charge de 1903 sobre o embelezamento da cidade . . . . . 207

35. Planta do projeto e aspecto geral da AV. Central . . . 207

36. O novo cais na primeira página do jorna 1 o Pałz, 1903. . 214

37. Aspectos de conjuntos históricos na Area Portuária . . . 218

38. Antigo Prédio do Touring Club na Praça Mauá . . . . . . 218

39. Conjunto Habitacional dos Portuários . . . . . . . . . . 218

40. Mapa geral da cidade e sistema viário principal . . . . 223

41. Aspecto da Rodoviăria Novo Rio . . . . . . . . . . . . . 225

42. Aspectos do Viaduto da Perimetra1 . . . . . . . . . . . . 225

43. Hinterlandia e localizaçăo da rede de portos do Rio . . 229

44. Movimentação de valores pelo Porto do Rio, 1983/87 . . . 236

45. Movimentaçăo de Carga pelo Porto do Rio, 1984/87 . . . . 236

46. Planta gera1 do Porto do Rio de Janeiro . . . . . . . . . 241 
47. Planta de conflitos e tendências do Porto do Rio . . . 252

48. Delimitação e componentes principais da Area de Estudo . 256

49. Vistas aéreas da Area de Estudo . . . . . . . . . . . . . 257

50. Vistas aéreas da Area de Estudo. . . . . . . . . . . . . 258

51. Planta de usos predominantes na Area de Estudo . . . . . 262

52. Planta do perfil fundiário principal . . . . . . . . . . 267

53. Planta do estado de conservação dos imóveis . . . . . . . 269

54. Armazéns e lejto da RFFSA abandonados . . . . . . . . . . 270

55. Armazém abandonado na AV. Rodrigues Alves . . . . . . . . 270

56. Vista geral do pátio da RFFSA . . . . . . . . . . . . . . 270

57. Potencial de transformaça da Area Portuảria . . . . . . 272

58. Planta com principais equipamentos na Area Portuåria . . 279

59. Planta do zoneamento da Area Portuária e entôrno . . . . 282

60. Planta de localização dos imóveis tombados . . . . . . . 286

61. Aspectos de imóveis e conjuntos em tombados . . . . . . . 286

62. Localização de planos e projetos para a Area Portuária . 291

63. Aspecto geral da proposta da NTT . . . . . . . . . . . . 298

64. Aspecto do ediflcio centro empresarial Rio Branco I . . . 298

65. Aspecto da maquete do projeto da Academia de Policia. . 298

66. Potencial para o desenvolvimento da Area Portuảria . . . 318

67. Localizaçăo dos pontos de aplicação de questionários . . 369

68. Mapa de percepcóes e territórios de bairros . . . . . . . 379

69. Mapa de primeiras imagens referentes a bairros . . . . . 388

70. Mapa de primeiras imagens referentes á Area Portuária . . 394

71. Mapa mental composto de primeiros elementos fisicos citados em relação a Bairros . . . . . . . . . . . . . . 400

72. Mapa mental composto com os cinco elementos fisicos citados em relação a Bairros . . . . . . . . . . . . . . 401

73. Mapa mental composto de primeiros elementos fisicos citados em relação á Area Portuária. . . . . . . . . . . 408

74. Mapa mental composto com os cinco elementos fisicos citados em relação á Area Portuảria... . . . . . . . . 409

75. Gráfico intensidade de atitudes/atributos segundo campos perceptivos, relativo a Bairros (gera1) . . . . . 423

76. Gráfico intensidade de atitudes/atributos segundo campos perceptivos, relativo a Bairros (P. Mauá) . . . . 424

77. Grafico intensidade de atitudes/atributos segundo campos perceptivos, relativo a Bairros (B. Tefé) . . . . 425

78. Gráfico intensidade de atitudes/atributos segundo campos perceptivos, relativo a Bairros (P. Harmonia) . . 426

79. Gráfico intensidade de atitudes/atributos segundo campos perceptivos, relativo a Bairros (Sto Cristo) . . . 427

80. Gráfico intensidade de atitudes/atributos segundo campos perceptivos, relativo a Bairros (Rodoviária) . . . 428

81. Gráfico intensidade de atitudes/atributos segundo campos perceptivos, relativo a Area Portuária.. . . . . 435

82. Gráfico distribuicão de preferências por cenários de desenvolvimento para a Area Portuária... . . . . . . . 438

83. Gráfico intensidade de expectativas relativas a expectativas ambientais para a Area Portuária. . . . . . 443 
1. Evolução do intercámbio comercial . . . . . . . . . . . 235

2. Distribuiçăo de domiclilios por condicão de ocupaçăo . . . 266

3. Perfil fundiário da Area Portuária . . . . . . . . . . . 266

4. Populacăo residente na Area Portuária . . . . . . . . . . 275

5. Projeçóes de população nos bairros da Area Portuária . . . 275

6. Populacăo favelada na Area Portuảria . . . . . . . . . . . 275

7. População economicamente ativa (PEA) na Area Portuária . . 276

8. Distribuicăo da população da A.P. por Idade e Sexo . . . . 276

9. Escolaridade da populaçăo da Area Portuária . . . . . . . 276

10. Rendimentos da populaçăo da Area Portuária . . . . . . . 276

11. Distribuição de respondentes por sexo e faixas etárias. . 475

12. Distribuicăo de respondentes por sexo e escolaridade . . 475

13. Distribuiçăo de respondentes por domici1io/tempo . . . . 476

14. Distribuicăo de respondentes por local/tempo de traba1ho. 476

15. Frequência ao local de aplicacăo do Questionário. . . . 477

16. Atividades dos Respondentes no local de aplicacão. . . 478

17. Respostas á "Em que Bairro nós estamos?" segundo locais de aplicacão . . . . . . . . . . . . . . . 479

18. Respostas a "Primeira imagem do bairro" segundo locais de aplicacão.. . . . . . . . . . . . . . 480

19. Tipologia dos Elementos Fisicos citados como "primeira imagem do Bairro e da Area Portuária, segundo locais de aplicacão . . . . . . . . . . . . . . . 481

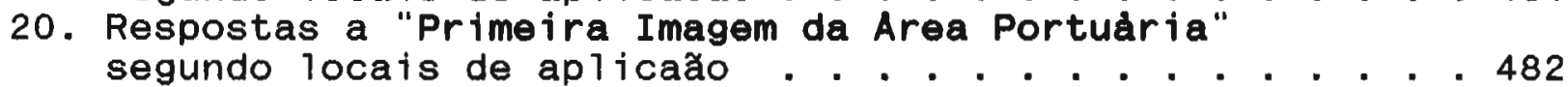

21. Tipologia de Elementos Fisicos citados em Primeiro Lugar dos Cinco citados para o Bairro e Area Portuária, segundo locais de aplicacăo . . . . . . . . . 483

22. Os Cinco Elementos Fisicos mais citados em Primeiro Lugar para o Bairro, segundo locais de aplicacão . . . . 484

23. Tipologia dos Elementos Fisicos citados para o Bairro e Area Portuária segundo locais de aplicacão . . . . . . 485

24. Os Cinco Elementos Fisicos mais citados para o Bairro segundo locais de aplicacâo. . . . . . . . . . . . . . 486

25. Os Cinco Elementos Flsicos mais citados em Primeiro
Lugar para Area Portuária, segundo locais de aplicacão . 487

26. Os Cinco Elementos Fisicos maís citados para a Area Portuária, segundo locais de aplicacão. . . . . . . . . 488

27. Atitudes relativas a Participaça Comunitária no planejamento do Bairro e da Area Portuária. . . . . 489

28. Atitudes e Atributos Percebidos relativos a Bairro, segundo campos perceptivos no conjunto de respondentes . 490

29. Atitudes e Atributos Percebidos relativos a Bairro, segundo campos perceptivos na Praça Mauá . . . . . . . . 491

30. Atitudes e Atributos Percebidos relativos a Bairro, segundo campos perceptivos na Praça Barăo de Tefé . . . . 492 
31. Atitudes e Atributos Percebidos relativos a Bairro, segundo campos perceptivos na Praca Harmonia . . . . . . 493

32. Atitudes e Atributos Percebidos relativos a Bairro, segundo campos perceptivos na Praça Sto. Cristo . . . . . 494

33. Atitudes e Atributos Percebidos relativos a Bairro, segundo campos perceptivos na Rodoviária . . . . . . . . 495

34. Atitudes e Atributos Percebidos relativos a Aárea Portuária, segundo campos perceptivos... . . . . . . . . 496

35. Preferéncias Ambientais relativas a Cenários de Desenvolvimento para a Area Portuária. . . . . . . . . . 497

36. Expectativas Ambientais por Cenários de Desenvolvimento para a Area Portuária. . . . . . . . . 498

\section{LISTA DE QUADROS:}

1. Avaliacão de imagens transmitidas pelas obras e Periódicos segundo Campos de Valores Positivo/Negativo por Referenciais Imagéticos . . . . . . 359 


\section{INTRODUÇAO:}

Este trabalho baseia-se na hipotese principal de que intervencões de desenho urbano para revitalizacăo de àreas centrais devem lidar conscientemente com os processos de Dercepcăo e e cognicăo dos seus usuários, a fim de atingir objetivos que possam por eles ser considerados bons, ou positivos.

As perguntas fundamentais que nos fazemos são, portanto, sobre quais seriam as informaçoes e atributos ambientais percebidos e mentalmente organizados, para a formaça das imagens, atitudes, preferências e expectativas sobre uma área urbana para a sua população?

Ao mesmo tempo, duas outras hipóteses se apresentam, que atè mesmo a precedem. A primeira por defendermos a revitalizacão de áreas centrais, ao invés de sua renovacão ou qualquer outra prática urbanistica. A segunda, por acreditarmos que $\circ$ desenho urbano è um campo disciplinar fundamental para 0 processo de revitalizaçăo, possibilitanto um acúmulo conhecimentos e um instrumental metodológico que complementam os processos tradicionais de planejamento e geståo urbantstica.

Com este objetivo, neste trabaiho a Area Portuària do Rio de Janeiro será tomada como estudo de caso, onde aplicaremos conceitos de percepção ambiental e metodologias ligadas ao estudo 
desta temática, na busca pela comprovaça de nossas hipóteses de trabaiho. A àrea em muito se presta a isto pois desde o intcio dos 80 se debate a possibilidade de sua utilizaça para expansăo e fortalecimento de algumas funçoes da cidade central.

Assim, o quadro teórico a ser desenvolvido na Parte I parte da necessária conceituaçăo destas três questôes: revitalizaçăo de centro de cidade, desenho urbano e percepcão ambiental. Além disto, impõe-se definir como elas poderem ser interrelacionadas em termos operativos para sua aplicabilidade no estudo de caso adotado.

\section{Revitalizacão de centros de cidade:}

Muito do que a sociedade classifica como problemas que afligem nossas cidades têm sua origem na percepção, na avaliaçăo e na consequente opiniăo formada a respeito de determinados aspectos, sejam eles sociais, econômicos ou físico-espaciais. A situação em que se encontram as áreas centrais das grandes cidades reflete a evoluçăo destas diferentes percepçós e das intervenções (ou não-intervencões) pủblicas em suas respostas aos paradigmas de desenvolvimento e suas imagens ideais impostos pela evolucão dos sistemas de valôres da sociedade.

Nas grandes cidades tem se verificado há mais de três décadas um nitido processo de fortes mudanças nas àreas centrais. Por um 1ado, os processos de desenvolvimento que elas ajudaram a iniciar impuseram novas lógicas econômicas que năo mais se viabilizavam através das velhas estruturas, ou simplesmente não necessitavam delas. Por outro lado, os novos valores da sociedade renegavam os aspectos ambientais e sociais que caracterizavam 
estas àreas, buscando realizar suas atividades diàrias (morar, comprar e trabalhar, passear) em outros locais, mais condizentes com "os novos tempos". Suas populaçôes, jả reduzidas e tornadas pobres pelo êxodo das classes mais abastadas para bairros mais confortáveis, e suas velhas e arcaicas estruturas tornaram-se um estôrvo para o desenvolvimento urbano. As áreas centrais seriam renegadas ao abandono ou, quando objeto de intervençăo pliblica, recebiam traumáticos projetos de renovação.

A imagem resultante destas áreas centrais, portanto, perante os novos valores da sociedade modernista era extremamente negativa. O capital imobiliário e financeiro também as percebia como um estôrvo á realizaçăo de maiores 1ucros, principalmente através da das possibilidades geradas por sua centralidade. A percepcão dos politicos e tecnocratas lá viam as causas de diversos males, mormente patologias sociais graves e estruturas fisicas que não correspondiam ás suas logicas funcionalistas ou categorias classificatorias simplórias.

Assim, grandes programas e projetos de intervencão renovadora seriam promovidos pelo poder público ou incentivadas por ele, tratando de impor novas lógicas econômicas e sociais, assim como novas imagens nas áreas centrais. Comunidades seriam expulsas, prédios e morfologias históricas desapareceriam, a variedade substitulda pela previsibilidade e monofuncionalidade, na perseguiça do simplismo do paradigma desenvolvimentista e dos modelos e imagens ideais modernistas.

Dentre as áreas centrais que mais sofrem com as alteraçóes dos ciclos de desenvolvimento urbano das grandes cidades encontram-se aquelas que originalmente eram dedicadas a 
atividades vinculadas ao movimento portuário. A dinâmica urbana fez com que estes antigos "corações urbanos" se vissem ultrapassados nas capacidades de suas sobre e infra estruturas alem de sufocados pelas imposicões e necessidades do restante da cidade. Mais ainda, os próprios sistemas portuários e as transformações no campo dos transportes em gera1, e maritimo em especifico, geraram enormes dificuldades na continuidade e viabilidade das operaçôs até entăo verificadas: diminuicăo relativa dos custos dos outros meios de transporte (também mais rapidos e flextveis), problemas de limitacăo do calado nos piers antigos face aos novos transatiânticos, limitaçóes na disponibilidade de retro àreas e encarecimento dos sistemas de operação portuária. Isto gerou um deslocamento das operacões portuárias para àreas mais propicias, sua concentracão, especialização e racionalização de seus processos, gerando abandono de áreas centrais antes por elas ocupadas.

Uma das maneiras encontradas atualmente para enfrentar esta queståo, que vem obtendo sucesso em diversos casos, é a promocão de politicas, programas e projetos de revitalizacåo. ou seja, objetivos de desenvolvimento urbano e aços conjuntas que venham a promover "nova vida" áquelas áreas, tanto econômica quanto socialmente. Como os corpos d'àgua efetivamente possuem profundo envolvimento com o Homem, seja por suas conotações simbólicas que nos remetem ás origens, seja por seu papel fundamental no surgimento das cidades, era natural que as áreas portuárias centrais, em especial ás margens, adquirissem um valor estratégico. Portanto, nestes casos, busca-se também recuperar a simbiose perdida entre o Homem e a água, nos centros urbanos. 
Com a revitalização como politica de desenvolvimento, iniciada nas àreas centrais e "waterfronts" em são Francisco e Boston, são incontåveis as cidades que experimentam bem sucedidas investidas nesta questão: Baltimore, Nova Iorque, Londres, Hamburgo, Barcelona, Nápoles, para citar apenas algumas. Suas áreas centrais, originalmente dedicadas ás atividades portuảrias com seus armazéns e piers antigos, agora oferecem um misto animado de atividades comerciais, serviços, lazer e habitacăo.

Evidentemente, nada disto conseguiu-se sem sacriftcios e imensos esforcos quando tratava-se, sobretudo, de atrair novos investimentos, novos usos, novos usuários, novos moradores. Para tanto era preciso, primeiramente, alterar a imagem da àrea de intervença perante a populaça e os potenciais investidores. As imagens das áreas a receberem os esforços e ações conjuntas promovidas pelo poder público deveriam mudar de "negativas" para "positivas", de "decadentes" para "em recuperaçă", de "perigosas" para "seguras e animadas".

\section{Desenho Urbano como Instrumental de Intervencão:}

Um dos crescentes campos de atuacão na organização das cidades, e evidentemente na revitalização de suas àreas centrais, é o Desenho urbano. Expressão que virou moda no Brasi1, poucos realmente pararam para pensar o que realmente significaria em nosso contexto, a partir de sua origem anglo-saxã, suas conotaçóes, possibilidades e práticas usuais. Muitos utilizam a expressåo importada para justificar práticas que, na verdade, não passam de "arquitetura grande" ou de "planejamento pequeno". Ou 
seja, continuam a utilizar o embasamento teorico-conceitual $\theta$ o instrumental metodológico da Arquitetura e do Planejamento Urbano, apesar das evidentes 1 imitacóes que acarretam quando aplicados na esfera da qualidade fisico-ambiental da cidade. Explicando-nos melhor, as confunsóes reinantes a este respeito podem ser resumidas a três aspectos principais.

A primeira grande confusão a respeito do Desenho Urbano é a de que ele reporta-se a uma "pequena escala" urbana, ao bairro, a rua ou conjunto de quarteirões. Um equivoco compreensivel pois como seu interesse são as percepcões, experiências e trocas sociais e as relaçóes da populaçăo com a esfera fisico-espacial, - normal que isto se expresse a nivel da escala do bairro, a dimensão urbana mais próxima e acesstvel ao nosso cotidiano. Na verdade, seu objeto de estudo e atuação é toda a ambiência urbana e suas qualidades fisico-espaciais manifestas: isto, portanto, vale tanto para a escala de bairro como para a de cidade. Vale, por exemplo, para um percurso entre a casa e o trabaiho, para as imagens e o caráter que se quer promover para uma cidade ou para as formas de conciliar a integracăo do velho com o novo desenvolvimento.

A segunda confusão è quanto á natureza de sua conformação, se ele é um "projeto". Aqui o problema talvez seja de natureza semântica uma vez que o termo inglês "design" conota processo, enquanto sua traduçăo desenho é mais estático, fechado e final. Nossa concepcăo usual de projeto tambem vaj por at, algo que concebemos para a contrução, reprodução fiel de nossos objetivos e que busca uma forma final espectfica e eterna. Mas, fundamentalmente, o Desenho Urbano è parte integrante do processo 
de Planejamento, ele mesmo um processo que busca responder aos anseios por qualidades fisico-ambientais; portanto, não necessariamente promove um resultado de projeto especifico e nem sempre uma imagem definitiva.

Finalmente, a terceira confusăo que reconhecemos è quanto a dificuldade de reconhecer o Desenho Urbano como campo disciplinar especifico, que busca conciliar os conhecimentos integrados de diversas áreas disciplinares em busca da qualidade fisicoambienta1. Note-se que utilizamo-nos da expressão flsicoambienta1, e năo fisico-espacial, pois o Desenho Urbano reconhece que esta qualidade é gerada não apenas por aspectos fisicos e espaciais, mas por outros intimamente ligados $e$ interdependentes a eles, como potencial de trocas sociais ou acessibilidade a funçôes variadas. Portanto, faz-se uso de campos teóricoconceituais e metodologias de diversas disciplinas que estudam as expressões do Homem no espaço: arquitetura, geografia, psicologia, sociologia, antropologia, economia, etc.

A importancia do Desenho Urbano é justamente por ele refletir a dimensão vivencial que mais afeta as percepç̃es e comportamentos da populaçăo no seu uso cotidiano da cidade. As imagens que a populaçăo possui de áreas urbanas, prédios, ruas, etc, e a interpretação destas imagens, văo conformar a base para as tomadas de decisăo e afericăo de qualidades. Pode-se dizer que existem então imagens coletivas, ou publicas, coincidentes a grupos de cidadãos, formando um repertório comum e relativo a um lugar e seus elementos urbanos, que servirăo para caracterizar a percepção deste lugar segundo estes grupos populacionais. 
A Percepcão do Meio Ambiente urbano:

A pesquisa em psicologia ambiental urbana esta geralmente interessada em compreender como as pessoas vivenciam a cidade, dão significado ao que percebem, como compreendem e organizam a cidade, identificam, categorizam e classificam seus elementos, assim como as condutas e comportamentos derivados disto.

A importância disto pode ser exemplificada citando uma passagem com minha sobrinha que, aos dois anos de idade já reconhecia marcos urbanos em sua "navegação" no bairro: sabia quando estavamos próximos da casa dela ou de um parente mais chegado. Tatvez se possa dizer que estes marcos fisicos possuem forte carga afetiva porque a criança é capaz de relacionà-1os a pessoas queridas, e provavelmente apenas por isto estes marcos possuem algum significado para ela. Segundo PIAGET, esta fase, que se repete em todo o processo de aprendizado, è a do conhecimento topológico do mundo.

Por outro 1ado, todos nós jà proferimos nossa opinião a respeito de áreas urbanas que nos parecem "decadentes"; algumas das vezes nós as conheclamos, outras só de passagem, de ouvir falar ou atravès de fotos, filmes ou jornais. Geralmente todos compartimos, em maior ou menor grau, de imagens publicas ou grupos delas, conforme nosso sub-grupo e seus valores sociais. Mas será que o "decadente" è uma imagem que interpreta a verdade? Será que outros grupos, os moradores da área por exemp 10, năo discordam e acham a àrea "boa de se morar"? será que a rua ou os edificios dos quais nos lembramos naquela área são os mesmos a que a populacão atribui os mais fortes valores sentimentais? 
Para fins de compreensão teỏrica, podemos dizer que estas imagens coletivas săo formadas a partir de dois processos cognitivos básicos que são fortemente interelacionados e coexistentes, o direto e o indireto. No processo direto, a representaçăo interna $\Theta$ a atribuiçăo de significados que fazemos do meio ambiente em nossa mente se dá a partir da captação de uma grande gama de informaçooses sensoriais diretamente da fonteobjeto, captadas pelos nossos cinco sentidos mas principalmente pelo visual. No processo indireto, este processo cognitivo se då através do acúmulo de informaçôes recebidas por outros meios em que nåo temos contacto direto com o objeto; è o aprendizado social, da leitura, das salas de aula, da experiência acumulada.

A importância disto para o estudo e a intervençăo urbanistica é bastante evidente. Toda percepção leva á formaçăo de um quadro referencial, carregado de significados oriundos de experiências acumuladas, cuja interpretaça levará á atribuicăo de valores e tomada de decisóes, seguidas por condutas que podem chegar a ser açōes ou comportamentos.

Se existe uma hipótese básica comum a todos os trabainos sobre a "imagem da cidade" é o da possibilidade de concluirmos "imagens publicas" a partir do estudo de imagens individuais. Evidente que o todo será sempre maior que a simples soma das partes, mas pode-se inferir aspectos cognitivos comuns compartidos pela população e conformadores de uma essência imagètica da àrea estudada.

Portanto, para se promover a revitalização de uma área, transformando sua imagem publica, e preciso compreender estes processos perceptivos e cognitivos, quais as representacões 
internas, seus valores e atributos, a fim de que as acões possam atingir objetivos imageticos positivos. A manipulaçăo consciente e consequente destes novos repertórios de imagens, ou velho repertório revitalizado, è que irà garantir grande parte do sucesso esperado pelos usuários potenciais e pelos investidores. Assim a revitalização urbana obterá uma forte base para a promoção de ações e transformaçôes socio-economicamente efetivas e verdadeiramente democráticas nas àreas centrais.

\section{Estudo de Caso e Verificacão da Hiótese:}

A operacionalizaçăo das possibilidades definidas através do quadro teórico da Parte I se dará através do caso da Area Portuária do Rio de Janeiro. Na Parte II de nosso trabalho apresentaremos a caracterização desta área examinando a sua evolucăo, o seu estágio atual no contexto portuário nacional e regiona1, seu pape1 no desenvolvimento urbano da cidade, e a problemática politica existente entre os principais grupos de pressão interessados na área. Procuraremos demonstrar que a área de estudo é estratégica para o desenvolvimento urbano central da cidade e que realmente encontra-se em processo de estagnação econômica e social.

Veremos que o desenvolvimento possivel da Area Portuária é definido por dois campos de forca complementares. Por um lado, exige-se o seu melhor aproveitamento devido a muitas de suas áreas e edificacóes estarem simplesmente abandonadas ou utilizadas aquém de seu potencial, face ás caracteristicas próprias de sua evoluçăo. Por outro 1ado, as funções portuárias, razăo que ditou toda sua evoluçăo e aspectos fisicos, sociais e 
econômicos, ameaçam retrair-se ainda mais face ás necessårias alteraçóes que devem processar-se no perfil operativo do Porto do Rio de Janeiro, considerado ineficiente e com servicos até $544 \%$ mais caros que os da Europa (in "Folha de são Paulo", Caderno Economia pàg. 1, 3/11/90)

Em seguida, a Parte III de nosso trabaiho apresenta o desenvolvimento da pesquisa propriamente dita onde serăo aplicados métodos e instrumentos relativos ao estudo de percepçôes e imagens que a população possue da área, conformando suas imagens públicas. Aos comentários e anảitise dos dados obtidos seguirão consideraçôes sobre sua aplicabilidade entorno a questőes gerais de desenho urbano para o desenvolvimento de um processo de revitalizaçăo da àrea.

Nossa pesquisa será composta de duas partes complementares. Primeiramente estudaremos a percepça ino ireta da Area Portuària, através do estudo de como ela é apresentada ao público leitor da literatura e de velculos de imprensa. Para tanto analisaremos as principais obras literárias publicadas desde fins do século passado e que incluem referências sobre a área, assim como as materias veiculadas pelos dois maiores jornais da cidade em um periodo recente de cinco anos.

Por seu 1ado, a pesquisa de campo será desenvolvida junto á população usuâria da Area Portuảria, em busca de dados diretos sobre a sua percepção ambienta1. Como instrumento de medida destes dados de campo, iremos nos utilizar de um questionário, com questões abertas e fechadas, aplicado a duzentos e cinquenta transeuntes, em cinco locais especificos prè-selecionados distribuldos ao longo da àrea em estudo. 
Através desta pesquisa de campo, buscaremos identificar diferenças que sub-grupos populacionais possuem da àrea, quais as imagens publicas, os elementos fisico-ambientais que formam estas imagens, os seus atributos e qualidades, assim como as preferencias e expectativas que os respondentes possuem para seu futuro. A avaliaça dos dados finais comparados nos permitirão considerar a aplicabilidade destes estudos de percepcão nas intervenções de desenho urbano participantes de processos de revitalização da área. Buscaremos identificar imagens pủblicas importantes que destacam a área flsico-ambientalmente para os usuarios, elementos urbanos formadores de mapas mentais que deveriam ser preservados ou consolidados, qualidades e atributos a serem consolidados, servicos e obras a serem promovidos, expectativas futuras a serem respeitadas.

Veremos se nossas conclusões permitem confirmar a validade de nossa nipótese inicial, sobre a importancia e a aplicabilidade de estudos sobre a percepcão ambiental no processo de desenho urbano e revitalização de àreas centrais. 


\section{P A R T E I}

\section{O Quadro Teórico}

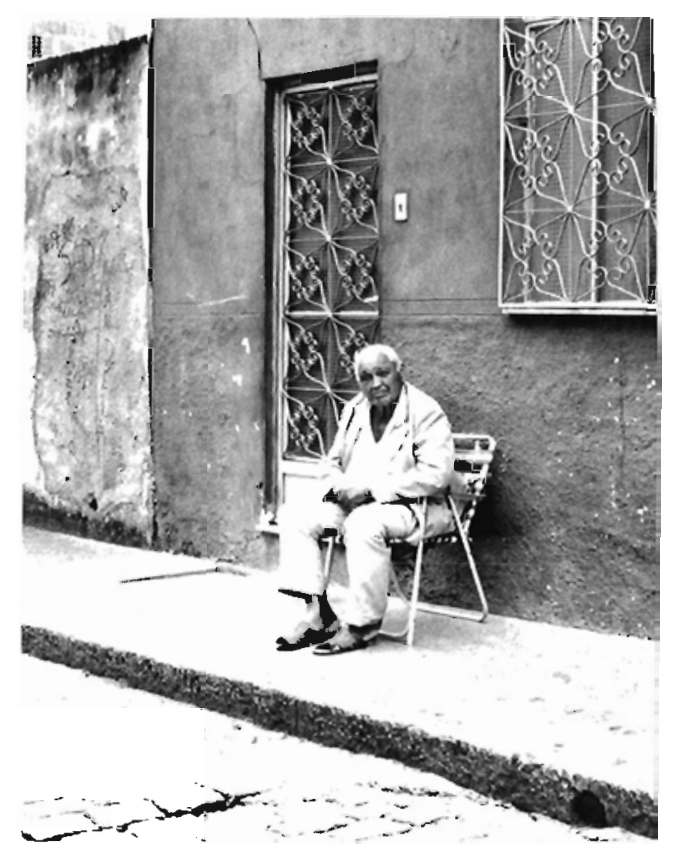

"... das inumeras cidades imaginåveis, devem-se excluir aquelas em que os elementos se juntam sem um fio condutor, sem um código interno, uma perspectiva, um discurso... as cidades, como os sonhos, são construldas por desejos e medos, ainda que o fio condutor de seu discurso seja secreto, que suas regras sejam absurdas, as suas perspectivas enganosas, e que todas as coisas escondam uma outra coisa."

(Marco Polo a Kublai Khan in CALVINo, Italo "As cidades Invistreis", Såo Paulo: Companhia das Letras, 1990, pag. 44) 


\section{CAPITULO I:}

\section{A REVITALIZAÇAO DE AREAS URBANAS CENTRAIS}

"The city in its complete sense is a geographical plexus, an economic organization, an institutional process, a theater of social interaction, and an esthetic symbol of collective unity"

( $L$. MUNFORD in ALBRECHT 1985)

Termos tomado a Area Portuária do Rio de Janeiro como estudo de caso para a aplicacão de nossas hipóteses de trabalho depende fundamentalmente de que esta área esteje carente de intervencão por parte do poder público no sentido de sua revitalizaçăo. Esta carencia serà concluida a partir da constatação de um quadro de desenvolvimento fisico, económico e social que, além de beirar a estagnação, năo corresponde ao potencial instalado na área em nenhuma de suas dimensóes.

Veremos através das consideraçós constantes na parte Segunda, que este quadro è real, mas também que é muito evidente - potencial da Area Portuária de efetivar a implementacăo de politicas públicas que privilegiem diversos temas, dentre os quais a expansão do centro de negócios, a reorganizacão das atividades económicas ligadas ás atividades portuárias e de comércio exterior e a implementacăo de atividades turisticorecreativas, culturais e comerciais. $E$ neste quadro de desenvolvimento posstvel que vai revelar-se a conceituaçăo de revitalizaçåo apresentada nas 1 inhas seguintes. 
A seguir comentaremos as caracteristicas e a evolução das intervenços urbantsticas no centro urbano. Ficara bastante claro que o conceito contemporâneo de revitalizaçăo urbana deriva destas experiências e que o desenho urbano, de cuja conceituação trataremos no Capitulo seguinte, se revela instrumento essencial no processo de intervenção para a conquista desta revitalizacăo.

Por outro lado, ficará evidenciado também que qualquer intervenção em área consolidada, e em especial em áreas centrais devido á seu papel histórico na cidade e sua carga simbólica, deverá ter como uma de suas preocupacóos fundamentais o estudo da percepcão ambienta1, uma das dimensôes do desenho urbano, porque permite 1 idar com os paradigmas, as imagens e as expectativas do público usuário e potencial.

I. 1. Centro urbano e Evolucão das Intervencões em Areas Centrais:

Para sermos capazes de discutir o conceito de revitalizaça urbana adotado neste trabalho e preciso definir um quadro conceitual prévio sobre dois conceitos que o precedem: 0 de Centro Urbano e o de renovação urbana, uma forma de intervencão urbanistica largamente praticada em áreas centrais.

No Brasil, qualquer conceito térico de cidade vai mostrar um choque entre a realidade vivida pela sociedade e a classificação institucional, que define como cidade apenas as sedes municipais. E amplamente aceito que a origem das cidades se confunde com a origem da sociedade de classes, representando-a em suas lógicas sociais expressadas espacialmente. Mas ir adiante e desenvolver toda uma discussăo sobre o que é uma cidade foge 
totalmente dos objetivos a que nos propusemos inicialmente; remetemos ás obras existentes ${ }^{1}$.

Entretanto, $\&$ importante que registremos nosso pensar básico, como ponto de referência para as discussóes e conceituações posteriores. Por isto, apresentamos a citação de Lewis MUNFORD na abertura deste Capitu1o, bastante representativa de como toda uma corrente de pensamento conhecida como "humanistica" compreende a Cidade. Assim, também concordamos com CHOMBART DE LOWE (in TANGHE et al. 1984 ) quando afirma que a cidade eriadora de liberdades apenas na medida em que permite maiores escolhas.

Esta será a essência tanto do conceito de cidade quanto de Centro Urbano em nosso traba1ho. Aliás, sâo as caracteristicas de intenso intercâmbio social, seja apenas pela simples concentraçăo humana, que têem permitido á cidade ser sempre o palco dos movimentos revolucionários.

Foi só a partir da ascenção da sociedade burguesa moderna que a cidade se tornaria assunto capitalista: geraçăo de renda do solo, clarificaçăo dos niveis de apropriaçăo e consumo do espaço, organização e hierarquizaçăo deste espaço. Com a ascenção da burguesia ao poder e o fortalecimento das funçóes económicas urbanas, vai ficando cada vez mais transparente que á organizaçăo espacial corresponde uma prática social (CASTEX et al. 1977, SINGER 1978).

1: Ver p. e. MUNFORD 1961, CASTELLS 1971 \& 1979, SINGER 1978. 
As intervençoes urbanas de HAUSSMANN quando prefeito de Paris, de 1853 a 1882, săo sempre citadas cumo os melhores exemplos desta ruptura e trarıformaçăo das 1ógicas urbanas mais "pluralistas" para as lógicas mais capitalistas (CHOAY 1969, CASTEX et a1. 1977, CHIAVARI 1985). A partir de então, o solo urbano se tornaria uma valiosa mercadoria e cada coisa teria o "seu Tugar" no espaço. Passa a dominar o pensamento que, em ủtima instancia, a justificativa unica para a existência das cidades deriva das vantagens que elas oferecem aos processos de produçăo e consumo (CASTELLS 1971, 1972; ALBRECHT 1985). Este U1timo autor chega a defender que "..este conceito $\&$ orincipal responsável pelas atuaîs condicões deploráveis das cidades e por um conceito reducionista de vida " (ALBRECHT 1985: 12 ).

No Brasil tamberm \& bastante evidente o momento desta superação de lógicas politico-sociais, como o têm demonstrado diversos estudos, alguns dos quais veremos com mais vagar em Capitulo adiante. No Rio de Janeiro, foi a partir do final do Século XIX que iniciou-se uma progressiva inserça das práticas capitalistas de reprodução e consumo nas lógicas espaciais e seu consequente rebatimento na hierarquizacão do território (ABREU 1987, CHIAVARI 1985).

Desde então as acões pủblicas têem progressivamente contribuido para esta institucionalização diferenciada do espaço, promovendo, por exemplo, dicotomias como as de núcleo/periferia e reforçando determinadas apropriaçôes espaciais. BENCHIMOL (1985) chegou a afirmar que foi na época de Rodrigues Alves, na virada de seculo, que o Estado apareceria por primeira vez como "interventor racional" da globalidade das açóes capitalistas 
sobre o espaço urbano. E neste contexto que o planejamento urbano, recém nascido, vai sempre vir a reboque dos eventos que visa controlar e, ao assumir um enfoque supostamente técnico, vai colocar-se a servico das classes dominantes (BENEVOLO 1963).

I.1.1. O Conceito de Centro Urbano:

Dentro da conceituacão de cidade e desta argumentação, destaca-se o papel assumido pelo Centro Urbano na 1ógica socioespacial prevalescente. CASTELLS (1971) delineia as funçoos principais assumidadas pelo centro em nossa sociedade, que sempre gravitam em torno a uma noça integradora e simbolica.

Segundo CASTELLS, primeiramente o Centro destaca-se por seu pape 1 de integraçăo funcional, tornando-se assim 1ugar geogrảfico "centra1" e administativamente importante. Em segundo 1ugar, è nele que se dà a maior especialização de serviços na cidade. Por ủltimo, è no Centro que também se encontra a maior expressão da dimensão 1 údica das grandes cidades.

Esta análise evidencia a importância do lugar central de uma cidade, visto como centro inovador, de intercâmbios $\theta$ simbólico, caracterlsticas presentes nas expectativas de qualquer pessoa relativas a um "centro de cidade". CASTELLS ainda destaca - centro simbólico como sendo a maior caracteristica de uma cidade; afirmativa que, embora claramente derivada do contexto europeu, é facilmente verificàvel nestas expectativas pois a maioria das cidades (com raras excessões, como o Rio de Janeiro) săo descrita a partir de seu centro: são Paulo com as imediaços do Páteo do Colégio (jà concorrendo com a AV. Paulista), Londres e a City, Nova Iorque com Manhattan, Paris com o Champs Elisèes, etc. 
Portanto, acreditamos que o Centro Urbano concentra uma imensa carga simbolica, por um lado representativa de toda um sociedade urbana e de um modo de producão, pelo outro representativa da cristalizacăo flsico-espacial resultante da evoluçăo das pràticas politicas, sociais e culturais especificas a uma cidade. o centro do Rio, portanto, não poderia ser representativo de nenhuma outra cidade, nem de nenhum outro momento histórico.

Estas caracteristicas que destacamos tornam o Centro Urbano em local privilegiado pelas poltticas publicas e programas de intervencão urbanistica. Como simbolo máximo de detencão de poder, ele revela-se extremamente moldável aos sucessivos paradigmas imageticos das classes dominantes.

Isto verifica-se principalmente a partir do ja mencionado momento de definicão dos rebatimentos espaciais da sociedade capitalista e sua 1ógica. Até então, mesmo nas cidades do Primeiro Mundo, as intervenções urbanisticas expressivas no urbano ocorriam mais como excecão á regra e, por isto mesmo, seriam bastante coincidentes com as 1 dgicas anteriores.

A seguir, apresentamos um breve relato sobre a evolucão das prâticas institucionais de intervenção nas àreas centrais.

\section{I.1.2. Evolução das Intervençðes em Areas Centrais:}

As primeiras açôes neste sentido que temos notlcia foram as obras do Papa sixtus V, nos fins do século XVI e intcio do XVII, ao retificar e ampliar algumas vias e construir quatro novos obeliscos no centro de Roma. Ele implantou um novo sistema simbolico superposto ao tecido existente, promovendo a 
hierarquização dos espaços e interligando o percurso dos visitantes desde a porta principal da cidade ás principais bastlicas (BACON 1974, ROSSI 1966).

Mais tarde, outros importantes exemplos de grandes intervençoes, embora com resultantes ainda limitados em sua totalidade, foram as obras de reconstrucão dos centros de Lisboa e Londres. O centro de Lisboa foi em grande parte destruido por terremoto no século 17 e os planos de reconstruçăo de 1756, que estiveram a cargo do Marquês de Pombal, em muito respeitaram as estruturas pre-existentes. Londres teve grande parte da city destrutda por um incêndio em 1666 e, embora nenhum dos nove planos de reconstrucăo apresentados (um do arquiteto sir Christopher Wren) tenham sido realmente aproveitados, a cidade ressurgiu segundo o tecido pre-existente e os novos controles sanitários chegaram mesmo a determinar que, com excessão das igrejas, nenhuma edificaçăo poderia ter altura superior a quatro andares (MARMOT \& WORTHINGTON 1987).

E a atuação do Prefeito HAUSSMANN em Paris que pode ser considerada como o verdadeiro marco nas transformaçóes das práticas de Estado para com a cidade. Os novos espacos e elementos surgidos iriam contrariar as estruturas existentes e impor novas 1ógicas. Como já frisamos, foi apenas a partir do "aburguesamento" do espaço urbano, da consolidacăo do capitalismo e de sua expansão permitida pela Revolução Industrial, que as cidades, principalmente os seus centros, viriam a receber ampla e sistematicamente o impacto decorrente de politicas públicas e suas ações "corretivas". Os centros Urbanos, por toda sua carga simbólica já comentada, tornar-se-iam então locais privilegiados. 
No Rio de Janeiro e, depois, såo Paulo, as grandes metrópoles brasileiras, também vai destacar-se o centro como lugar privilegiado de intervençôes urbanisticas paradigmàticas, viabilizando também o avanço do Capital imobiliário e financeiro. $\mathrm{Na}$ entåo Capital Federa1, o presidente Rodrigues Alves incumbia o Prefeito Pereira Passos de promover intensos programas e projetos de renovação, na busca por uma maior internacionalizaçăo da economia nacional e investimentos extrangeiros (Figs. 1 \& 2 ). Veremos esta queståo mais detalhadamente adiante, no capitulo $V$, inclusive o rebatimento da obras públicas da época na Area Portuåria.

Não nos deteremos nesta discussão, desenvolvida com mais vagar adiante e em inumeros outros trabalhos de maior vulto (ABREU 1987, CHIAVARI 1985 e BENCHIMOL 1985). Entretanto, fazemos notar a importancia do Centro Urbano carioca como lugar de mais intensa preocupação na determinação da nova imagem do Brasil para - exterior: be10, moderno $\theta$ funcional. Neste sentido implantavase uma larga e retilinea Avenida Central, ladeada de prédios que nada deviam a seus pares europeus, um novo Porto, pronto para a importação e exportação, fartas demolições de edificações insalubres, e inumeras outras obras de "embelezamento".

No final dos anos 20 , o Rio ainda perseguiria a mesma lógica de reposição do velho, através dos planos do urbanista francês Alfred AGACHE, e promover-se-ia o final da demolicăo do Morro do Castelo e a implantaçăo de regulamentos edilicios para, novamente, modernizar o perfil do centro, com galerias de pédirejto triplo nos andares térreos. Depois, veio a construçăo da monumenta1 Avenida President Vargas durante o perlodo do Prefeito 


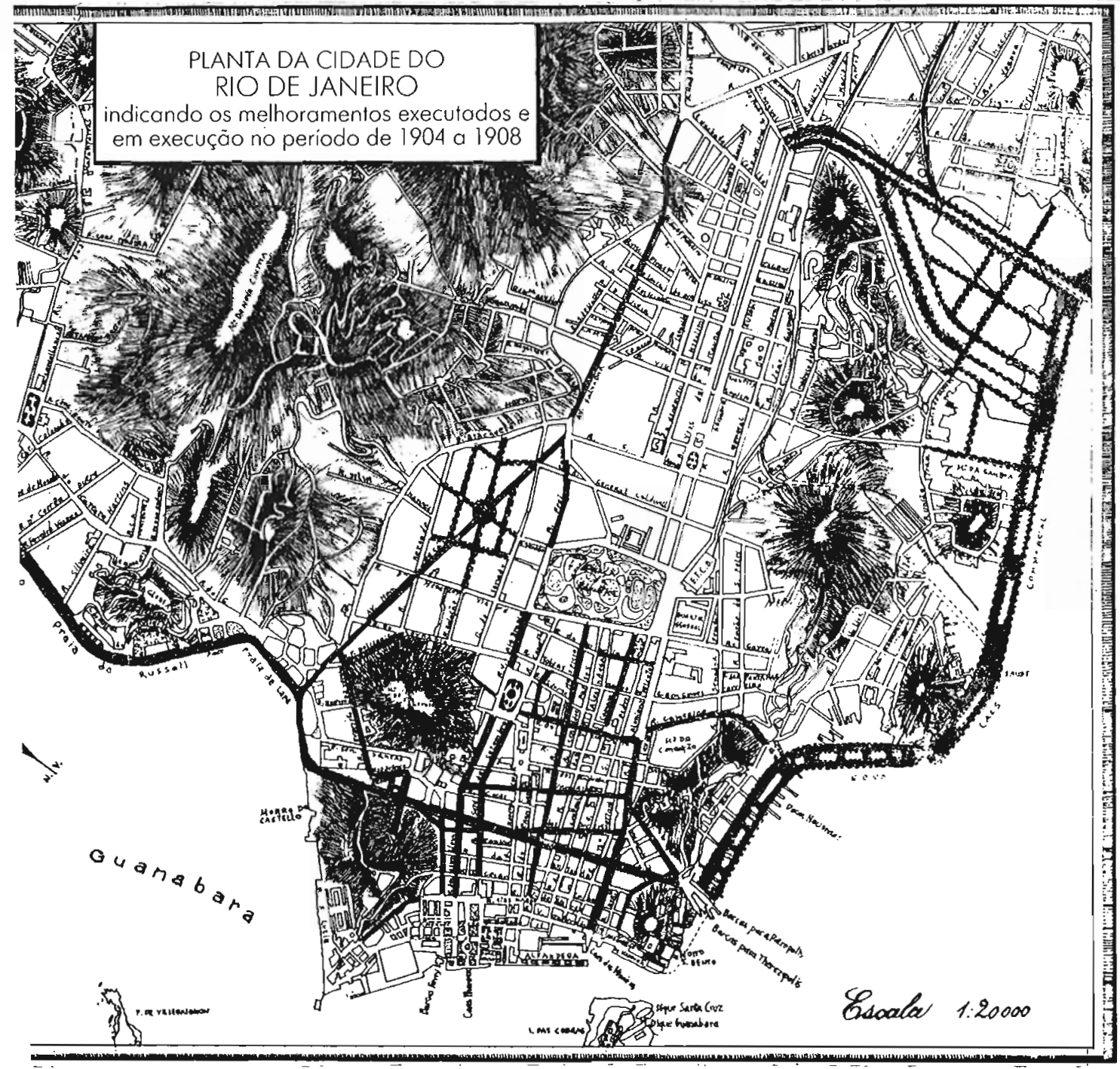

Fig. 1: Trechó de planta da cidade indicando as reformas do período Pereira Passos, 1904/08 (in ABREU 1987).

Fig. 2: Charge de época criticando o Prefeito Passos pelo enorme endividamento contraído para suas réfonmas (in BRENNA 1985).

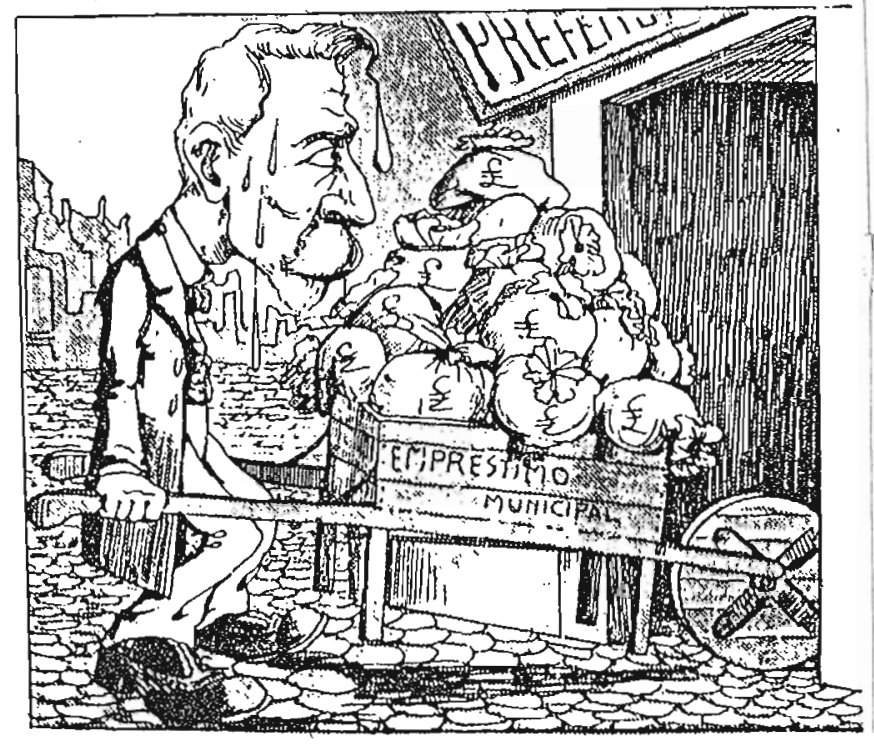


Henrique DODSWORTH, de 1937 a 1945, uma nova modernizacão cirúrgica que involveu a demolicăo de uma longa faixa edificada de três quarteirões.

Até este momento histórico, nos palses do Primeiro Mundo $\theta$ no Brasil, as intervenções urbanisticas de reposição de velhas estruturas davam-se em uma escala e de uma forma que, embora arrasadora, não tiveram as consequências amplas e desastrosas que viriam a ter os programas e projetos que se caracterizariam de renovação urbana. Antes, as novas morfologias e tipologias implantadas ainda tinham alguma relacăo com o extstente.

Esta ruptura dar-se-ia principalmente pela incorporacão dos conceitos e objetivos do Movimento Moderno ás açôes governamentais. Com a expansão do capital financeiro, industrial e imobilialrio, $\theta$ os consequentes rebatimentos de produção e consumo no urbano, os projetos de renovação urbana modernistas caracterizariam e seriam marca do "bom administrador púb1ico" durante um bom tempo, desde o pertodo pós II Guerra atè o fim dos anos 70 , deixando suas marcas em praticamente todas as metrópoles do mundo.

I.1.3. O Movimento Moderno e a Cidade:

Ainda hoje as cidades năo se livraram totalmente do fantasma da renovação urbana e de sua metodologia "arrasa quarteirão". Por um lado porque a força do capital por vezes impoẽ soluçoses deste tipo para uma melhor valorizacão do espaco urbano, seja para obtenção de maiores densidades, seja para expulsăo de população residente ou para livrar-se de "deseconomias" de mercado. Pelo outro lado, grande parte da 
classe dominante $e$, até mesmo muito do publico em geral, ainda hoje só consegue uma interpretaçăo parcial $\theta$ moralmente distorcida do que são áreas "deterioradas" e de suas "consequencias sociais". As discussões sobre as "patologias" destas àreas afetadas são sintomàticas desta distorção: cânceres urbanos, doencas sociais, marginalidade crescente, etc.

O intcio do século XX via as cidades já acumulando as contradições geradas pelas necessidades de produção e consumo do capital e as condicõos de vida de grande parte da populacão. Esboçava-se, nas grandes metrópoles, uma primeira "migração" dos grupos de maior renda para os bairros mais novos a distantes dos centros urbanos e da poluição, da alta densidade, do congestionamento, da concentração de problemas sociais. Com a crise dos 30 , fortes problemas sociais iriam rebater-se nas grandes cidades dos palses industrializados do Primeiro Mundo, revelando a precariedade das estruturas e economias urbanas em incorporar toda a massa de trabalhadores. As cidades mostravam, na verdade, as consequências socio-politicas que estavam acumulando-se desde a Revoluçăo Industrial e seus primeiros reflexos nas condições de moradia e trabalho.

Os paradigmas do Movimento Moderno surgiriam como resposta dos arquitetos á esta situação, entendida como insustentável. Era necessário colocar toda a técnica e o progresso industrial na perseguicăo de melhores condiçôes de vida e moradia, numa visăo futurista ingênua e otimista, peseguindo uma estética ideal numa sociedade de tipo "coletivismo democrático" (BLAKE 1974).

Esta questão já foi estudada por inumeros trabalhos que evidenciaram que os Congressos de Arquitetura Moderna, 
principalmente o de 1933 e sua "Carta de Atenas", e os escritos e obras de le CORBUSIER foram os principais responsáveis pela expansão dos conceitos arquitetônicos e urbanisticos modernistas (BENEVOLO 1960, JENCKS 1973, FRAMPTON 1981). A casa como "máquina de morar" uniria-se a conceitos como o do paradigma da cidade idea1 e suas funçơes higiênicamente dispostas: morar, trabalhar, circular e cultivar o corpo e o espirito.

Nas palavras de famoso urbanista da época os bairros de baixo nivel que a maioria das cidades possuem săo "... zonas de deterioração e obsolescência onde florescem o crime e o vicio" (SAARINEN 1967: 17). Consonante com le CORBUSIER, ele tambèm defendia que a ordem morfológica e a ordem social da cidade são inseparàveis; "... o único remèdio a estas circunstâncias è uma cirurgia radical ... o melhor caminho, a decentralizacăo orgância" (SAARINEN 1967: 34). Este processo, ainda segundo o urbanista, deveria ser dirigido por intelectos de visão, "capazes de colocar as coisas em ordem".

A negação da cidade existente, a recusa de considerar condiçôs especificas de implantaçăo, a autonomia relativa da forma e o espaço visto em termos absolutos e eternos, săo as principais caracteristicas que, segundo CASTEX et a1. (1977), demonstram a redução teórica da visão de le corbusier e dos modernistas que passaria a imperar nos projetos urbanos a partir do final dos anos 20. Até mesmo Lewis MUNFORD chegou a criticar a "insuficiencia humanistica" dos projetos de le CORBUSIER (in prefácio, JOHNSON-MARSHALL 1979).

Paradigmas urbanos perseguidos durante anos traduziam-se atraves as imagens ideais da ville Radieuse e a citè 
Contemporaine, de le CORBUSIER, que traziam para os urbanistas soluçóes radicais, completas e simples para enfrentar o entåo considerado "confuso e obsoleto" tecido urbano tradicional (Fig. 3). Visava-se a "... substituicăo pura e simples das estruturas fisicas existentes como condicăo apriorlstica da adaptacão das cidades herdadas ás necessidades da vida moderna" (PORTAS 1985).

Entretanto, "o que começou com uma visão romântica da tecnologia moderna, libertando o individuo das limitacões da tradicăo, revelou-se admiravelmente adaptável á repetiçăo burocrática inconsciente e aos cortes de despesas de empresários gananciosos" (BARNETT 1982). Tambèm năo nos caberia aqui extendermo-nos em consideracôes criticas e avaliativas aos ambientes modernistas, para isto reportamos ás principais obras existentes, mencionando a seguir apenas duas obras representativas do despertar de uma nova época em que comecava-se a descobrir as 1 imitaçoos do modernismo.

E muito representativo do surgimento de toda esta nova postura o sucesso do livro de JACOBS (1974) sobre a vida nas grandes cidades americanas e como estava sendo afetada negativamente pelos planos e projetos urbanisticos modernistas. Seus argumentos mostravam que a tecnocracia $\theta$ a ingenuidade tedrica dos planejadores ignoravam importantes caracteristicas urbanas como a vida comunitária, as vantagens das altas

2: Alèm destas, outras obras criticas podem ser apontadas como instrumentais nos 60, como: LYNCH 1960, CULLEN 1961, ABRAMS 1964, DAVIDOFF 1965, VENTURI 1966, MANGIN \& TURNER 1968, GANS 1968, KELLER 1968, GOODMAN 1977 \& ROSSI 1979. 
densidades e da diversidade de funçóes e tipologias edilicias. As cidades, ela dizia, constituiam problemas de "complexidades organizadas", e que "os teóricos do planejamento moderno convencional confundiram consistentemente as cidades como problemas de simplicidade e complexidade desorganizada, tentando analisa-las e trata-las como tal" e reduzindo seu pensamento a sistemas de duas variàveis (como populaçăo/àreas livres) (JACOBS 1974: 448). Para ela, a remoçăo dos "slums" (habitacõos em condiçoos precárias) falhavam porque tenta resolver um problema escondendo os sintomas.

Seus argumentos derivavam principalmente de estudos empiricos sobre o bairro em que morava, Greenwich Village de Nova Iorque, cujas caracteristicas ainda compunham uma complexidade urbana de resultados sociais altamente positivos. Eram exatamente estas caracteristicas que atrafram toda uma nova populaçăo, formada de principalmente intelectuais de classe média e médiaalta, e que acabaram incitando um forte processo de valorizaçăo imobiliária e "aburguesamento" (gentrification), um processo do qual, segundo seus criticos, a própria JACOBS foi participante.

Destacamos que também é desta época o influente artigo de ALEXANDER (1965) onde contestava o modelo da árvore como a estrutura ideal para uma cidade, adotado pelo modernismo. 0 autor defendia que a complexidade do fato urbano e a superposicão de sub-sistemas sociais indicava, no máximo, um modelo urbano com uma composição estrutural por semi-reticula, onde os pontos năo obedecem a hierarquias simplistas (Fig. 4 ).

Como simbolo da destruição do paradigma modernista, muitos autores, como JENCKS (1977) citam o exemplo do conjunto 


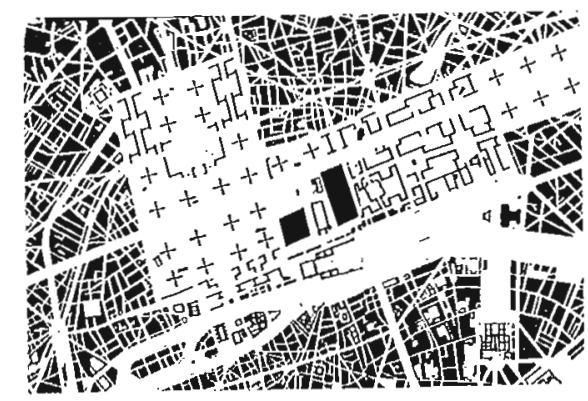

Fig. 3: Plano Voisin (1925) e vista de projeto para um Quarteirão insalubre (1936); Le Corbusier.

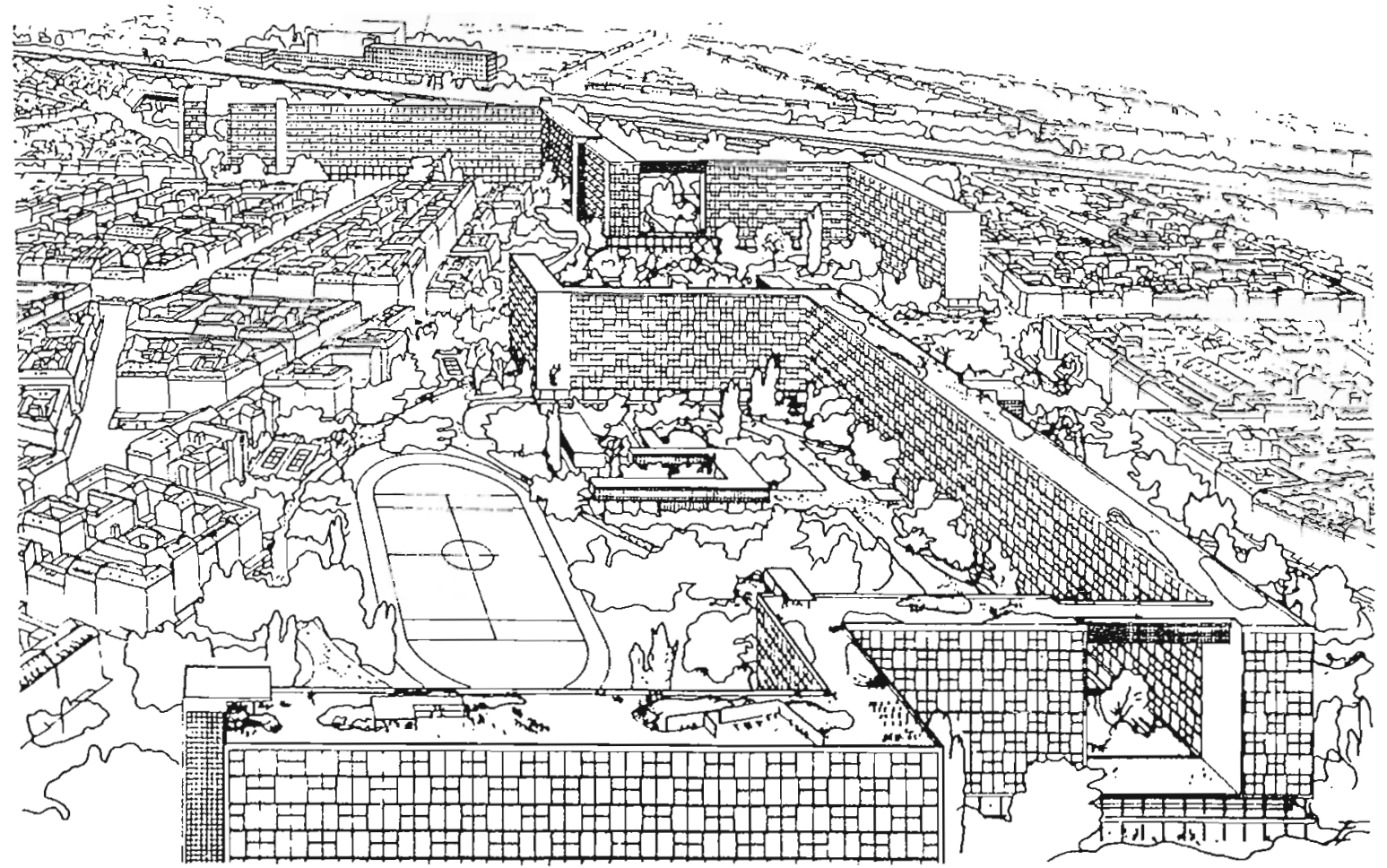

Fig. 4: Esquema de interelações em árvore (A) e em semiretícula (B) de C. ALEXANDER: a cidade não é uma árvore.
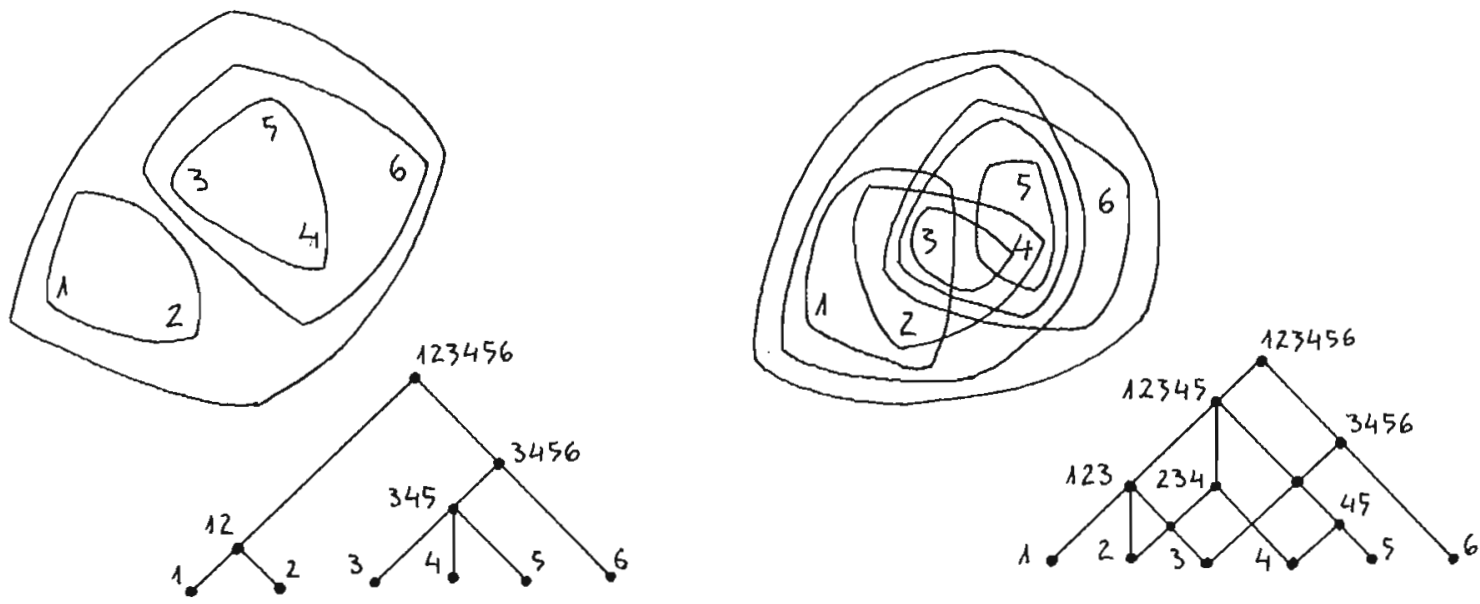
habitacional de Pruitt-Igoe, em St. Louis (EUA), premiado projeto de 1955 de autoria do arquiteto modernista Minoru YAMASAKI. De grandes proporções, comportando 33 ediflcios de 11 pavimentos rigorosamente idênticos, o conjunto abrigava 2.764 familias de baixa-renda. Em 1972 ele teve de ser dinamitado como derradeira atitude pois todas as medidas do governo foram incapazes de superar o vandalismo, a marginalidade e o alto Indice de abandono que se instalara nas unidades, consequências da insatisfacăo dos moradores com o ambiente estéri1, impessoal e autoritårio do projeto, conforme demonstraram as pesquisas de época (NEWMAN 1972, BLAKE 1974, ROWE \& KOETTER 1978). Os reflexos mais intensos parecem ser, principalmente, no aumento da criminalidade e delinquência juvenil (TANGHE et a1.1984).

Suficiente lembrar que foi a partir do fim dos anos 60 que a populaçăo em geral e a critica especializada começou a mobilizar-se e manifestar-se contra os ambientes modernistas. Evidenciava-se que era um equivoco grotesco assumir um modelo de Homem universal e reduzir a vida urbana aos poucos sistemas de variáveis herméticamente compartimentadas das reduçóes teóricas modernistas. A população provou, a duras penas, que os seres humanos não eram máquinas de comportamento totalmente previsivel e controláve 1 .

Pior de tudo \& que nem mesmo em termos funcionais a cidade modernista revelou-se bem sucedida. A reducão teórica de seu planejamento e a supervalorização de suas dimensões fisicoestéticas acabaram por gerar estruturas e espacos urbanos, tipologias edilicias e sistemas de circulaça que simplesmente não respondiam aos seus objetivos funcionais. Com as densidades $\theta$ 
tipologias promovidas, por exemplo, todos os sistemas infraestruturais modernistas mostram-se extremamente caros em suas instalação e manutenção. Este, como demonstraram diversos estudos, é um dos problemas básicos de Brasilia, o nosso exemplo máximo de modernismo (PAVIANI 1985).

A este respeito, BLAKE (1974) deu a seu livro o sugestivo titulo "a forma segue o fiasco". Nele, o autor relacionava as "onze fantasias" da Arquitetura Moderna: funcăo, planta livre, pureza, tecnologia, arranha-cé, cidade ideal, mobilidade, zoneamento, habitaçăo, forma e da arquitetura como solução final. Estas, realmente, săo as tematicas em que se podem classificar as principais problemáticas decorrentes da exacerbacão dos conceitos modernistas. Sobre o tema da redução teórica na compreensão da cidade e seus reflexos mais evidentes no espaço urbano, BLAKE (1974) nos mostra, por exemplo, como os efeitos do vento numa plaza modernista podem ser perigosos: o que apelidou "efeito Mary Poppins" aos pés da torre comercial John Hancock, em Boston, săo, no minimo, extremamente desagradáveis para os pedestres, ou até perigosos.

Portanto, concordamos que "... tanto como construcão psicológica quanto modelo flsico, a cidade da Arquitetura Moderna revelou-se trágicamente ridicula" e que "...os prospectos de um planejamento cientifico devem, na realidade, ser vistos como equivalentes aos prospectos de uma politica cientifica" (ROWE \& KOETTER 1978: 4, 105).

Os próprios produtos urbantsticos e arquitetónicos da era da renovaçăo urbana, portanto, inspirados na tópica modernista, 
irăo gerar inumeros problemas de "rejeicăo" da populaçăo, tantos os residentes, diretamente afetados, como os simples usuários. Estas caracterlsticas, que podemos dizer săo mais formais, irăo somar-se aos problemas causados pela conceituação de renovaçăo urbana e seu processo de implementacăo, para completar o "pesadelo urbano" vivido durante muitos anos e que ainda pesa sobre as cabecas de muitos grupos sociais nas nossas cidades.

I. 2. Os Quatro Periodos de Intervencóes Urbanisticas:

A maioria dos estudos sobre a evolucăo das intervencoôs urbantsticas sistemàticas em àreas urbanas centrais são concordantes em separar as açôs em perfodos caracterizados pela natureza de seus objetivos e, consequentemente, pelos resultados obtidos (APPLEYARD 1979, BENEVOLO 1985, BOUCHER 1979, PORTAS 1985). Assim, podertamos identificar quatro pertodos de açôs que podem se verificar de uma forma geral em todas as grandes metrópoles mundiais.

o primeiro pertodo foi o que sucedeu a Segunda Grande Guerra e deu oportunidade para intervençőes baseadas, principalmente, em tentativas fundamentadas na reconstrucăo $\theta$ recuperaçăo do parque habitaciona1. Nos pałses da Europa, isto devia-se não só á grande destruicăo dos bombardeios mas também ao simples fato que a maioria das edificaçóes estavam em precàrias condiçres por idade e má conservaçăo. Estima-se que em Londres, por exemplo, mais de 2.5 milhões de metros quadrados construldos foram destruldos pelas blitz, o que representava perto de $1 / 3$ do estoque da cidade (MARMOT \& WORTHINGTON 1987). Nas palavras de 
JOHNSON-MARSHALL (1979: 139), referindo-se ao caso de Ber 1 in, isto representaria "... uma rara oportunidade de aplicacăo das mais modernas teorias do planejamento cientifico, teorias que muitas vezes haviam se mostrado inaplicáveis em cidades normais" (grifo nosso).

No segundo periodo, a recuperacão econômica e a reconstrucão do pós-guerra foram ainda ampliados em seu poder demolidor pelo "boom" econômico e o histerismo desenvolvimentista que caracterizaria os anos 60 . Esta histeria promoveria uma descentralização intensa, principalmente para a habitação de classe média, e uma exacerbada importancia para a engenharia viària, resultando seguidas vezes em absurdos. Por um 1ado, planos viários extremamente destrutivos e desrespeitosos da cidade existente; um caso tipico foi o projeto de uma via expressa elevada pela margem norte de Veneza, felizmente nunca construida (APPLEYARD 1979).

Por outro 1ado, a exemplo da maioria das cidades industriais europeias e norte-americanas, SAMUELS (1987) menciona que desde o pós-guerra até intcios dos 70, Glasgow fomentou politicas de decentraiizaçao intensa e grandes conjuntos habitacionais de periferia, em cidades novas ou projetos de expansão a até $160 \mathrm{~km}$ distantes do centro, hoje estes conjuntos são extremamente problemáticos tanto por suas distancias aos centros quanto por suas caracteristicas tipológicas, como vimos no caso americano de Pruitt-Igoe.

Além disto, contribuindo com esta nova era de demolicões nas principais metropoles, surgia um novo fenômeno até então desconhecido, que APPLEYARD (1979: 12) chamou de "institucional 
creep": a expansão fisica de estabelecimentos públicos localizados nas àreas centrais, como hospitais, universidades e centros administrativos, absorvendo áreas significativas.

- terceiro grupo de ações surgiu a partir de uma reação ás caracteristicas e resultados dos programas do perfodo anterior, de renovação urbana irrestrita. Esta reaça foi principalmente movida a partir de um crescente "nacionalismo" e de uma crescente industria de turismo que justificavam a "sacralizaçăo" de lugares - edificaçoos pela sociedade (APPLEYARD 1979). Interessante è que, a partir deste momento compreendeu-se a atuaçăo da Polónia e seu nacionalismo que, depois dos bombardeios da guerra havia reconstruldo integralmente o seu centro histórico, perseguindo as imagens pủblicas de consenso em seu nacionalismo, ao invés de "aproveitar a oportunidade" para promover um conjunto modernista como afirmava na época a critica especializada.

Estes conceitos iniciais de patrimônio ampliaram-se, dando Tugar a movimentos de oposicáo mais amplos, abrangendo a conservaçăo de forma geral, fisica e social, bem como, mais tarde, ao conceito de ecologia. Na verdade, este grupo de aços não exatamente caracterizou um periodo histórico mas impôs-se a partir de um perlodo de crises: polttica, com ampliaçăo das participaçôes de base; social, com a conscientização da amplitude da pobreza; energética, com 1 imitaçăo dos gastos com recursos não renováveis; ecológica, com consclentizaçăo dos reflexos na natureza; e, finalmente, econômica, com diminuiçăo do capital investido no desenvolvimento urbano.

Esta foi a "era" do conservacionismo nos palses do Primeiro Mundo, quando tudo era motivo de preservaçăo e a açăo de grupos 
comunitários muitas vezes radicais garantiria a institucionalização de tombamentos, áreas históricas, relatórios de impacto ambienta1, controle de poluifăo, etc. Multiplicariamse os produtos desta onda inicial de preservacionismo sobre os centros urbanos, como na identificacăo pioneira de distritos históricos na Holanda (1961), Polonia (1962), e Inglaterra e a aprovação do plano para a cidade italiana de Bolonha, em fins de 1969, cujas metodologias de implantacăo e resultados são hoje tidos como exemplares. Como afirma BENEVOLO (1985), o procedimento "mais cientifico" para intervencão em áreas históricas iriam surgir na Itália, nos fins dos 60 , e a metodologia italiana é aceita internacionalmente no simpósio do Conselho de Europa de 1974.

- perfodo que se sucedeu, caracterizou-se pela desaceleração do ritmo do desenvolvimento urbano, um reflexo da crise econômica e energética sobre as grandes cidades. Vimos revelada a fragilidade de nosso sistema económico e social, mostrando que as cidades grandes eram o "tendăo de Aquiles" de nossas sociedades de desperdlcio e da falência da vida pública como a conhectamos (SCHUMACHER 1973; SENNETT 1970, 1974). Crises ciclicas de desinvestimento passariam a ser normais nas metrópoles e se refletirtam em todos as suas dimensões: na qualidade dos servicos, na conservacão de todos os sistemas públicos, na concentraçăo da miséria, nas relações humanas e na insegurança geral instalada, etc.

Estes fatores, aliados á crescente mobilizacăo comunitária e insatisfacão com o meio-ambiente construido, fez com que os 
^[rgãos públicos buscassem novas saldas para a crise que se instalava, viabilizando, ao mesmo tempo, a expansăo da economia capitalista. Disto, acabaram surgindo três posturas que iriam refletir-se diretamente sobre a qualidade fisico-ambiental até hoje, no que diz respeito ao desenvolvimento urbano: uma maior consciencia de património construido instalado e no uso de recursos năo renovàveis, a ampliação do conceito de patrimônio, que agora passaria a importar-se com a "memória coletiva" e não apenas com ediftcios vistos como pecas de museus, e a busca de maiores processos colaborativos entre os principais grupos politicos interessados (comunidade e empresários).

Nos paises do Primeiro Mundo as "sociedades" entre o governo local e os empresários interessados tornaram-se os métodos usuais de implementação de muitos dos programas e projetos de desenvolvimento urbano. Este tem sido, por exemplo o caso da cidade de Baltimore, E.U.A., que desde o final dos anos 50 tem promovido métodos de implementação de suas politicas, programas e projetos públicos através de alianças e acordos com o setor empresarial; este também tem sido o enfoque bem sucedido na revitalizacåo de seu centro urbano (DEL RIO 1985, 1990).

\section{3. A Renovacão Urbana: Consfderacôes Conceituais}

Para esclarecer nossa compreensão de revitalizaçăo urbana, tornam-se necessários alguns comentários sobre a evolucão das poltticas de renovação urbana e seus conceitos bảsicos. Veremos como a revitalizaçăo terá origens numa retomada das polfticas de intervençăo nas áreas centrais, mas agora redirecionadas, seguindo um conceito mais amplo e socialmente menos disruptor. 
- que caracteriza um programa ou projeto de renovação urbana é seu objetivo de "... saneamento do espaco coletivo - o restabelecimento de um principio de ordem como totalidade racional e cultural" (FERRARA 1988: 63). E, como vimos anteriormente, podemos apontar três causas principais para o surgimento de polfticas de renovaça urbana com estas caracteristicas: a implantaçăo urbana dos conceitos modernistas, a expansão do capital financeiro $\Theta$ imobiliảrio nas àreas centrais, e tentativas de intervir na queståo habitacional.

Podemos dizer que a renovaçăo foi uma politica intervencionista em áreas centrais intensamente institucionalizada nos EUA $\theta$, por sua escala de operacóos, ficou reconhecida como um "fenômeno norte-americano". MCQUADE (1972) lembrava que, no periodo de vinte cinco anos que precedia a publicação de seu artigo, aproximadamente 70 das cidades de mais de 100.000 habitantes nos EUA haviam remodelado 0 seu CBD ("central business district": distrito central de negócios). 0 interesse institucional por estes programas è facilmente compreendido se apenas notarmos, como faz MCQUADE, os a1tos ganhos orçamentarios dos governos locais: a remodelaçăo do centro de Chicago, por exemplo, teve 2,3 milhóes de dolares publicos investidos e, apenas dez anos depois, arrecadava-se mais de 84 milhôes por ano! Nós nos reportaremos principalmente á experiência norte-americana de renovação urbana.

Nos EUA, uma legislação do Congresso, conhecida por Housing Act, reconhecia em 1949 que a habitaça era vital para o desenvolvimento da familia americana, promovendo uma certa confusão conceitual ao misturar o problema habitacional com a 
deterioração dos centros urbanos (SCOTT 1969; CASTELLS 1971, 1979). Na verdade, desde 1937, aplicava-se a ideia de equivalência em que para cada unidade habitacional removida, haveria que construir-se outra.

Entretanto, os problemas iniciavam-se com o próprio conceito de habitação ou àrea deteriorada: os "slums" eram definidos como "uma área com predominio de habitações que, por razões de dilapidaçăo, superocupacăo, organização ou desenho faltosos, falta de ventilação, 1 uz ou instalaçoses sanitárias, ou por qualquer combinaçăo destes fatores, são ameaçadores á segurança, à saúde e á moral" (Housing Act 1937, in ROTHEMBERG 1972: 132). Numa conferência em 1966, o vice-presidente americano chegava a afirmar que era preciso "... lutar contra o 'slumismo', o inimigo interno, um virus que se extende... temos de declarar guerra a este ma1, como ofizemos com a agressåo comunista" (in GOODMAN 1977: 53).

Esta subjetividade inerente ao conceito de "slum" também aparece no conceito de "blight", que aplica-se mais ao processo de deterioração de uma área seja por alguma externalidade ou por fatores oriundos em si própria. Os programas governamentais norte-americanos de renovaçăo visavam, primordialmente, a eliminação de "blights" e "slums", a ampliação da base econômica da cidade e reviver as áreas centrais de negócios. Talvez o grande instrumento urbanistico viabilizado pela legislaçăo de 1949 tenha sido o conceito de "interesse publico preferencial" (eminent domain) aplicável pelos governos locais para impor a desapropriação de imóveis considerados "deteriorados" ou por localizarem-se em área de projeto de renovacão. Além desta 
facilidade, o governo federal garantia ainda praticamente $70 \%$ da verba total para implantacaao do projeto.

Autores como SCOTT (1969) e CASTELLS (1971, 1979) mostram com detaines a lógica capitalista de mercado por trás da renovação urbana e as suas implicaços para a organizaçăo socioespacial das cidades norte-americanas. A renovaçáo urbana viria tornar-se um ótimo negdcio imobiliário, em que era garantida a fácil desapropriaçăo de imóveis e a venda do terreno, pela prefeitura, a preços fixados em média a $30 \%$ do valor do mercado, viabilizando a atração fácil dos empresários para a àrea de projeto. Na verdade, os $70 \%$ de diferenca no preço eram garantidos pelos financiamentos federais; calcula-se que os empresários não desembolsavam mais de $3 \%$ dos custos totais (GOODMAN 1977, CASTELLS 1979).

Os novos pacotes legislativos norte-americanos até 1968 , dariam ênfase maior á renovação em detrimento á construçăo de habitacões sociais e, atè aquele ano, os resultados apontavam que das 400.000 unidades habitacionais demolidas nas áreas centrais, apenas pouco mais de $10 \%$ das familias viriam a ser atendidas com novas habitaçôes na àrea de projeto (SCOTT 1969, CASTELLS 1971). - novo estoque habitacional previsto nos projetos de renovacăo eram pequenos e destinavam-se majoritåriamente a famflias de classe média.

- êxodo das famllias de classe média para os suburbios era como uma bola de neve pois a mudança das áreas centrais não seria apenas acarretada pela deterioracão física dos imóveis e saida das grandes companhias. Entre os fatores que mais influenciavam 
estava o racismo: năo aceitar que os vizinhos pudessem ser negros ou de renda mais baixa, ou que os filhos frequentassem as mesmas escolas públicas. Assim, a "bola de neve" aumentava com a saida de uma familia ou a chegada de uma familia "não-branca", que demonstrava a queda do valor do imóvel e prenunciava a vinda de outras familias do mesmo grupo sócio-econômico.

Portanto, grande parte do interesse em intervir nas àreas habitacionais centrais era de origem discriminatoria, pois via nos grupos de baixa renda e minorias étnicas a causa da própria deterioraçăo e marginalidade. A expressão "urban renewal", inclusive, era comumente apelidada "negro removal", numa alusão a que a maioria da população desalojada pelos projetos era negra. Calcula-se que até 1963, uma média de $60 \%$ desta populacăo era constituida de familias "năo-brancas", chegando práticamente a 100\% em cidades como Baltimore, Washington e Chicago (SCOTT 1969, CASTELLS 1971).

Como lembrava scotT (1969: 471), "... as àreas de 'blight' eram os repositórios de todas as questões perigosas e negligenciadas que uma sociedade materialista teme mas que năo consegue mais varrer para baixo do tapête. Ela espera transformar de alguma forma a deterioraçao fisica sem se involver com a deterioração social". CASTELLS (1971: 270) diria que "o mito da renovacáo urbana é um dos pilares da ideologia tecnocrática de reforma social através de soluções físicas".

o governo americano investia tanto na renovaçăo urbana que até mesmo um órgão federal foi criado em 1954, a Urban Renewa1 Administration, comparável em importancia á Federal Housing Administration e que iria, em breve, ultrapassa-la em vulto de 
recursos disponiveis e facilidades governamentais. Os programas habitacionais, por ser necessariamente subsidiados, tinham a antipatia dos politicos e administradores, os programas de renovação, ao contrário, eram a1tamente rentáveis. CASTELLS (1971) comenta que entre 1949 e 68 manejou-se mais de 7 bilhões de dolares nos 1946 projetos de renovacăo aprovados nos EUA.

Entretanto, mesmo este programa seria ultrapassado pelo vulto de recursos liberados para a construcăo de rodovias em 1956: 100 bilhơes de dólares para 13 anos, nunca um outro programa recebeu tantos recursos publicos (SCOTT 1969). O poder instituiria-se, entåo, nas agências e departamentos de engenharia viária e transportes. Algumas vozes já se manifestavam contra na época, como o famoso urbanista Lewis MUNFORD, argumentando que o programa de rodovias iria expandir os suburbios, gerar dificuldades para renovação das àreas centrais, e exacerbar as tensores polfticas e raciais entre a 'inner city' e os munictpios vizinhos (SCOTT 1969). Além disto, as práticas de "arrasaquarteirăo" indiscriminadas persistiriam ou até chegariam a intensificar-se para a implantaçăo dos novos e ambiciosos projetos viários.

Finalmente, é importante fazer notar que, devido á grande demanda habitacional de baixa-renda, os "slums" tornar-se-iam mais rentáveis e seriam ainda mais procurados pelas próprias familias expulsas por projetos de renovação e que raramente eram atendidas por programas habitacionais. Um fenômeno de mercado similar ao que se verificava aqui com as favelas e programas habitacionais e que foi estudado por PERLMAN (1977) e VALLADARES 
(1978). SCOTT (1969) ainda menciona uma pesquisa de 1961 que avaliou os programas de renovação em 11 cidades norteamericanas e que concluiu que a relocacão das familias proporcionou-1hes pouca melhoria geral e apenas acelerou a deterioraça de outras áreas. Neste sentido, o trabalho de ROTHEMBERG (1967) è bastante instigante pois, já na época de sua publicaçăo, apontava que as áreas habitacionais deterioradas, os "slums", faziam parte de um equilibrio de mercado: o contexto institucional e o próprio mercado norte-americano incentivaria a perpetuacão dos "slums". A demanda por habitaçóes de baixo custo, o perfil tributário dos imóveis que permitia a depreciacão dos valores de imóveis "deteriorados", e a dificuldade de obtencăo de crèditos para reformas, conformavam os fatores formadores desta perpetuaçăo.

Os "slums", na verdade, seriam uma forma lucrativa e barata de lidar com a demanda habitacional na medida que os proprietários não são reprimidos pela má conservação de seus imóveis e lucram com isto. O proprietário obtém o maior lucro se sua propriedade mal conservada enquanto que as de seus vizinhos se mantêm bem conservadas: toda propriedade tenderia, assim, á má conservação. Por isto, ROTHEMBERG afirma que é muito mais fácil criar "slums" do que eliminá-1os: uma casa deteriorada tenderia a deteriorar sua vizinhança, enquanto que uma casa bem conservada, por si, diflcilmente causaria o efeito inverso. ROTHEMBERG ainda afirma, dentro desta 1ógica, que a eliminação dos "slums" produziria beneficios apenas na medida que representassem um resposta ineficiente ao mercado.

Nas grandes cidades européias o quadro não era muito diferente, se bem que bem menos intenso. Na França a renovaça 
urbana foi regulamentada por um decreto presidencial em 1958, e a politica nacional de urbanismo, em plano de 1962/64, viria ratifica-la como justificativa para grandes intervencôes. Foi neste contexto, por exemplo, que desenvolveu-se colossal projeto de renovação para o centro de Paris em 1961 e que culminou na demolicão de extensa área conhecida por les Halles e seu importante patrimônio arquitetônico, como o famoso mercado em estrutura de ferro, em 1971. Após muitas polêmicas e até mesmo a anulaçăo do resultado de um concurso pủblico internacional para a área, quando demoliu-se o trecho já construido do projeto vencedor do espanhol Ricardo BOFFIL, parece que só agora, com o intenso renascimento cultural da Capital francesa promovido pelo governo Mitterrand é que vai-se finalmente resolver o destino do "buraco".

$\mathrm{Na}$ Inglaterra, até meados dos anos 60 , a renovação urbana era praticada em larga escala e fundamentada, como já mencionamos anteriormente, na melhoria do estoque habitacional. SAMUELS (c.1987), por exemplo, cita que aproximadamente $33 \%$ deste estoque havia sido construldo anteriormente a 1919, ou seja, quase seis mithões de unidades habitacionais. Um dos casos mais famosos de resistência à politica de "bota abaixo" na Inglaterra e que ajudaria a mudá-1a foi o de covent Garden.

Em 1963 foi decidida a mudança do antigo mercado de covent Garden, na àrea central e cerca do famoso picadilly circus, e a renovacăo do bairro onde se inseria, julgado excessivamente deteriorado tanto fisica quanto socialmente. Entretanto, em 1971, a população, talvez já demasiadamente escaldada pelos projetos 
modernistas do pós-guerra, conseguiu forcar o governo a instalar um processo de consulta popular ("public inquiry"). Disto resultou um novo projeto iniciado em 1980 que buscava a preservaçăo do prédio do antigo mercado, hoje reciclado em conjunto de lojas e restaurantes, e programa de recuperacão de 250 edificações de seu entôrno, inclusive a antiga ópera.

Na cauda da lei francesa conhecida por MALRAUX, os ingleses passariam a considerar áreas de conservaçao por seu valor de conjunto em 1967 e, em 1974, adotariam politicas de intervenção em àreas urbanas mais respeitosas do existente, dentro de intenso processo de participaçăo da populaçăo envolvida. A partir deste principio desenvolveu-se a concepçăo atualmente prevalente que reza uma intervenção progressiva, flexlvel e continua, através de etapas muitas vezes pequenas em áreas concentradas.

- caso do Rio de Janeiro, por sua vez, é exemplar das concepções de renovação urbana prevalecentes no Brasil até pouco tempo. No pertodo que se seguiu á segunda Guerra e coincidente com a consolidaçăo das polfticas desenvolvimentistas, as àreas centrais seriam palco de dois grandes projetos de renovação. No intcio dos cinquenta, o projeto para a esplanada de Santo Antônio, no lugar da major parte do morro de mesmo nome e que deixou apenas o pedaço correspondente ao convento, seguia os tracos modernistas de Afonso REIDY (Fig. 5 \& 6). Aparte a problemática econômica e politica que impediu sua completa implantação, toda uma série de intensos problemas morfológicos (conflitos de tecidos e tipologias, distancias percorridas, etc) e sociais (expulsăo de moradores, esvaziamento da área, etc) tipicos do Movimento Moderno ainda hoje são ali identificados. 

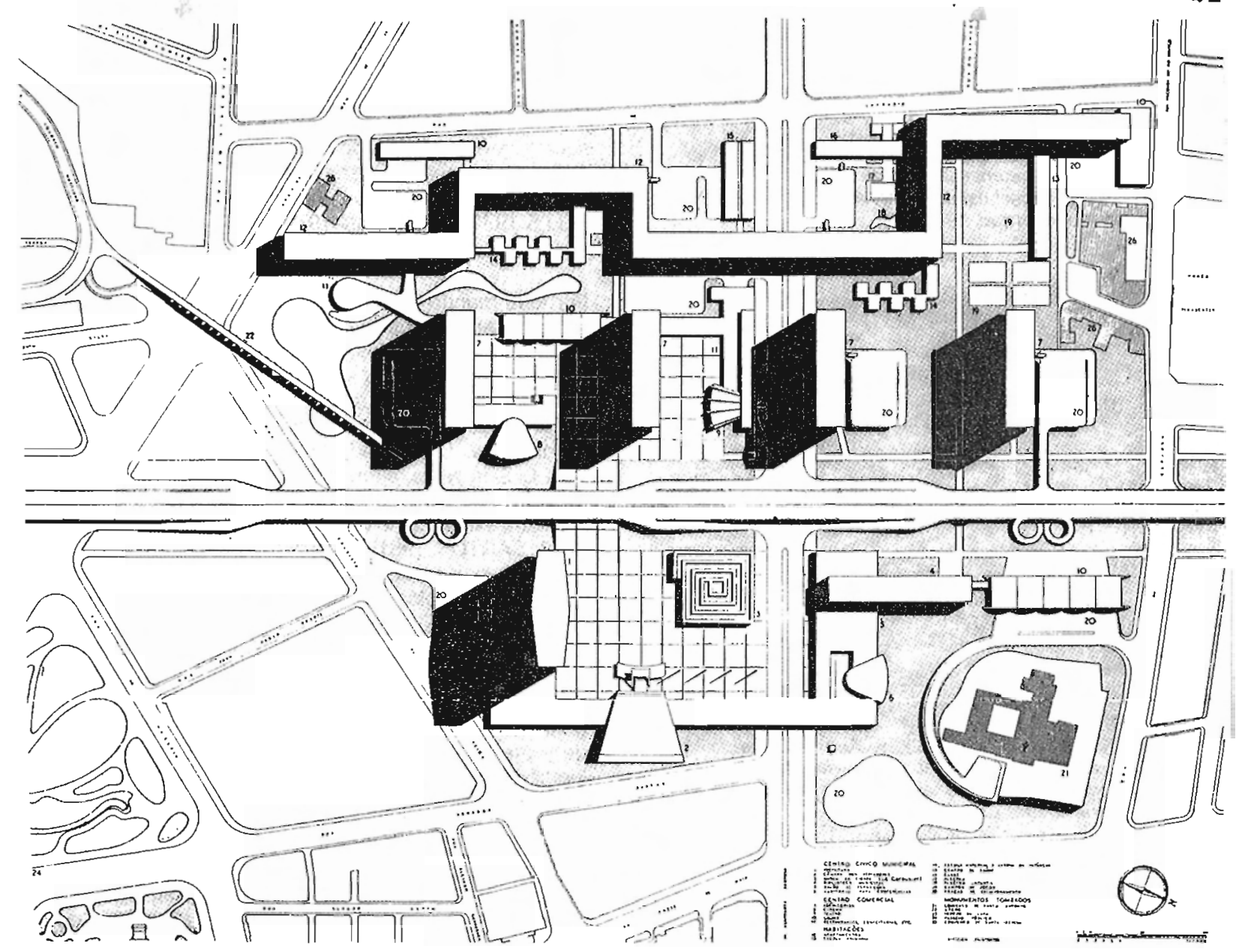

Fig. 5: Projeto de A. REIDY para a Esplanada de StO Antonio (1948)

Fig. 6: Vista aérea da mesma área em 1980.

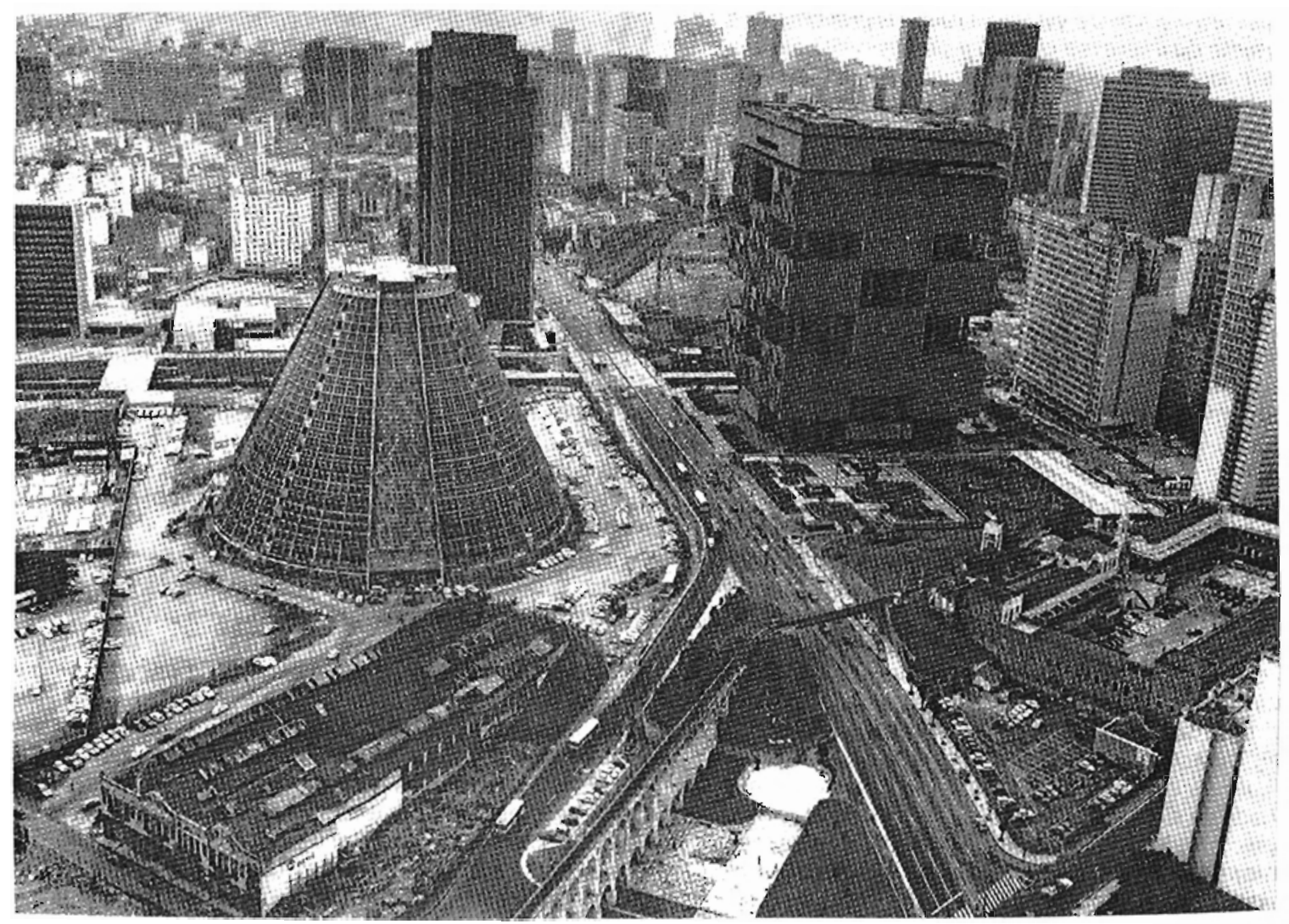


Nos intcio dos 60 , um grande projeto viàrio 1igando a Area Portuária a Laranjeiras foi a justificativa para um outro grande projeto de renovaçăo, o da Cidade Nova, que demoliu dezenas de quarteirôes dos bairros imediatamente periféricos á área central, Catumbi e Fátima. o impacto destas intervençôes sobre o tradicional bairro do Catumbi foi objeto de algumas pesquisas, que concluiram dos prejuizos causados pela imposiçăo de uma ordem flsica e social racionalista sobre a morfologia e a comunidade existente (SANTOS org.1981\& 1981) (Fig. 7).

No projeto da Cidade Nova havia tambèm um intenso viés moralista pois acabava-se também com a maior área de baixo meretricio da cidade, a Zona do Mangue. Para ali, o paradigma promovido era de um novo centro administrativo municipal e um conjunto de edificios comerciais. A área encontra-se praticamente deserta até hoje, tendo sido recentemente objeto de um projeto de "re-desenho" da Prefeitura, que tem esperancas de conseguir recompor um tecido verdadeiramente urbano e de uso intensamente misto (Fig. 8). o problema agora parece ser o de imposicão de um outro paradigma, embora de cunho mais "culturalista".

Evidentemente, os projetos urbanisticos cariocas modernistas năo se limitaram aos dois citados; estes, por seu porte e caracteristicas, são tipicos de renovaçăo urbana e perseguiam expressamente estes objetivos. Poderlamos mencionar projetos de erradicação de favelas, como o da construçăo do conjunto de classe média conhecido por Selva de Pedra, no Leblon (SANTOS org. 1981), ou de implantaçăo de projetos viários, como os da construção do metrô. Estes, entretanto, não se justificavam como de renovação urbana, mas buscavam outros objetivos, embora 


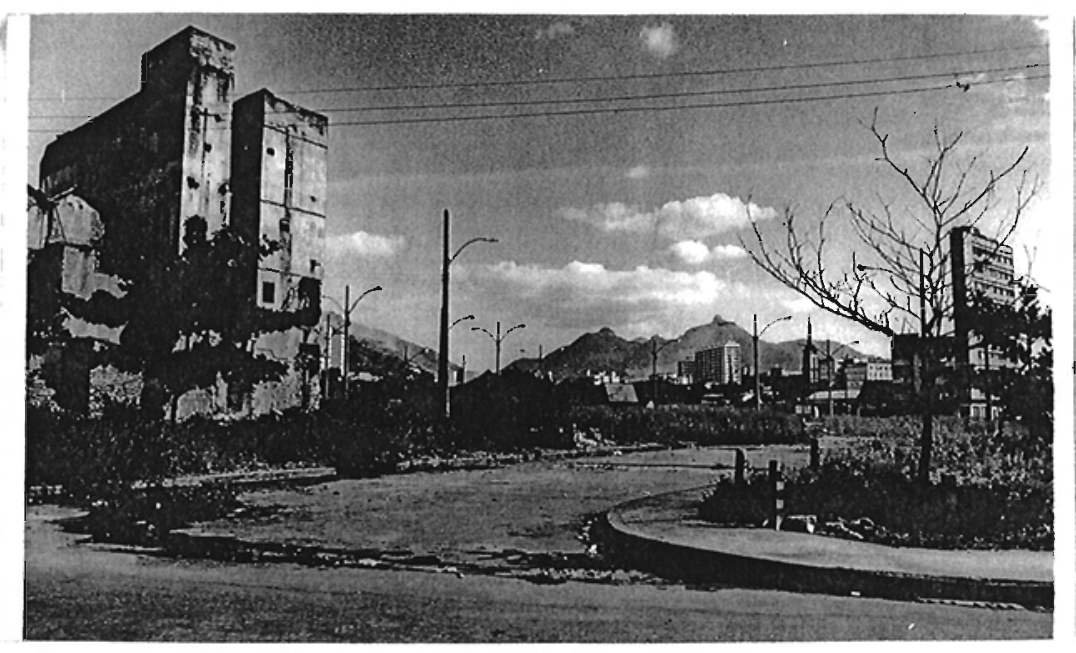

Fig. 7: Desolação na área da Cidade Nova, demolida em fins dos 60, e ainda semi-abandonada em 1985.

Fig. 8: O novo projeto para ocupação da área da Cidade Nova, 1987.

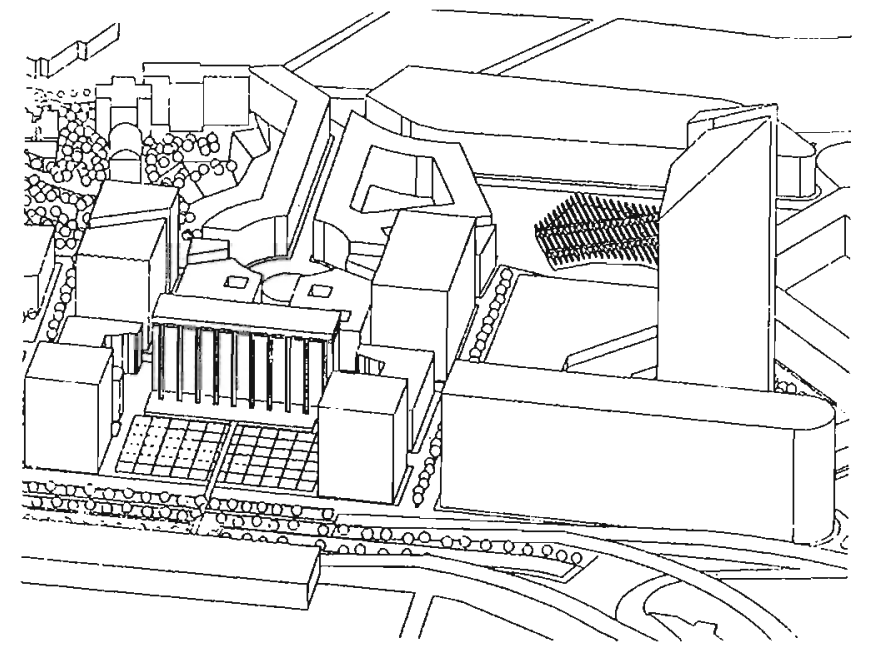

Fig. 9: Vista parcial do projeto South Street Seaport, N. Iorque.

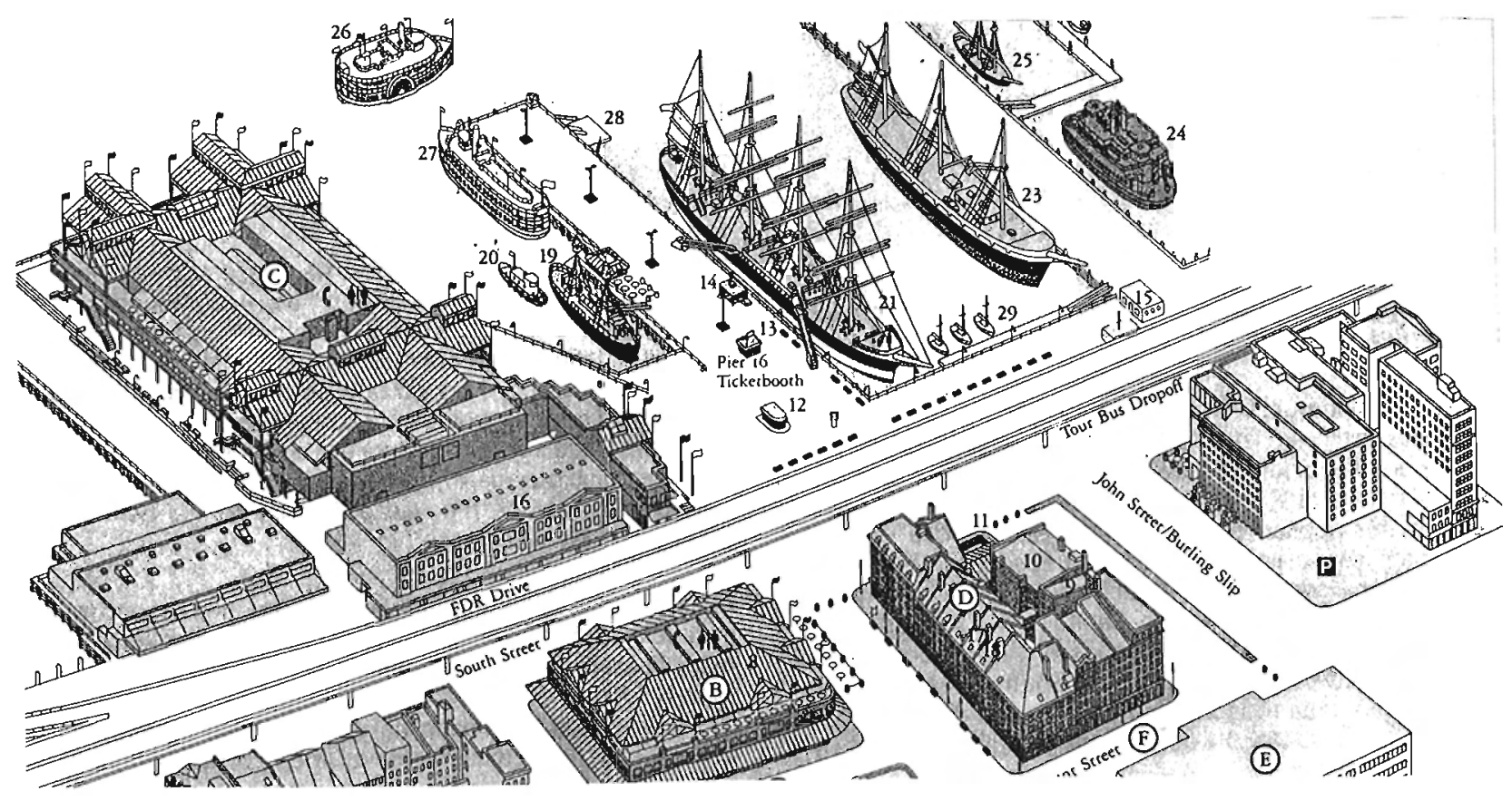


sua consecução seguisse os mesmos métodos $\Theta$ tenham gerado resultados semelhantes áqueles.

A nivel nacional, até que 0 BNH tentou uma maior popularizacão de seu programa conhecido por Projeto CURA (Comunidade Urbana de Recuperacăo Acelerada). O Projeto oferecia financiamento para que as prefeituras promovessem a renovacão da infraestrutura instalada em uma àrea centra1, com densidade minima estabelecida pelo programa e com a obrigatoriedade do aumento de suas taxas municipais, que passariam a ser recolhidas diretamente ao $\mathrm{BNH}$ durante alguns anos. As caractertsticas do CURA conformavam evidente tentativa de gerar "turn over" da populacão local, valorizaçăo imobiliária e transformações funcionais.

Entretanto, de uma maneira geral nas grandes metrópoles, jà se tem consciência de que os problemas sociais e de deterioracăo flsica das áreas centrais são resultantes de uma complexa situaçăo estrutura1. Esta situação manifesta-se com maior intensidade nas àreas habitacionais centrais, principalmente sobre as minorias etnicas ou outros subgrupos mais expostos aos impactos ciclicos da economia, ao desemprego e aos desinvestimentos localizados (HOME 1982). Esta consciência permite a governos locais mais representativos e legitimamente interessados na qualidade do meio-ambiente construfdo, como vem ocorrendo no Primeiro Mundo, buscarem processos de desenvolvimento e intervenção em áreas centrais distantes dos conceitos de renovaçăo urbana e mais vinculados a uma realidade compartida por diversos segmentos da comunidade; discutiremos esta questão e a conceituaçăo de revitalizaça a seguir. 


\section{I.4. Um Novo conceito: a Revitalizacão Urbana}

Ao contrário da renovação urbana que pressupunha sempre um processo "destrutivo" precedente ao "construtivo", como vimos anteriormente, em busca de um "princlpio de ordem", uma "totalidade racional" (FERRARA 1988), a revitalizaçăo urbana è conceito abrangente. Na medida em que incorpora pràticas anteriores, é mais que a sua simples adicăo, pois as excede e supera na busca de uma nova vitalidade (econômica, social, cultural e flsico-espacial) para as àreas da cidade central.

Mais uma vez, recorremos a palavras de FERRARA (1988: 68) que diz ser o "re-desenho" (por nós entendido como revitalização) a prática da "... reidentificaçăo do passado no espaço presente" que "... ressucita a tradicão, alvoroça a memória coletiva mas nåo inibe a modernidade". Neste sentido é concordante PORTAS (1985: 8) que defende que a intervencão na cidade existente não implica em que se "... sacralize toda a edificaçăo pelo fato de já existir, mas sim que toma como um dado econômico e cultural a estrutura e a forma da cidade ... e tambem como um dado socia1 a trama de relaçoos sociais e de atividades que (elas)... suportam e refletem".

Portanto, estamos diante de uma nova postura que se distancia igualmente tanto dos processos traumáticos de renovaçăo quanto das atitudes exageradamente conservacionistas. Na revitalizacăo urbana convivem práticas tão diferentes quanto a renovacão seletiva de áreas deterioradas, o desenvolvimento de áreas desocupadas, a preservação de interesse histórico e 
cultura1, a reciclagem cuidadosa de usos em imóveis históricos, a promoção de novos usos, a recuperaçăo ambienta1, etc.

Trata-se de assumir o "urbanismo como estilo de vida" no nosso dia a dia (KRIER 1975). Não se trata de tão somente gerar uma bela imagem para uma área, mas de compo-1a com o seu conteudo social e econômico, atuanto mais no controle dos processos de câmbio e de desenvolvimento (BOUCHET 1979, TANGHE 1984).

Refletindo a "recessão econômica latente", os anos 80 viriam a caracterizar-se pela difusăo de politicas urbanas que privilegiariam as açoos rápidas, com objetivos mais integrados e mais cientes de seus reflexos sociais e económicos (BOUCHET 1979). Os planos urbanos, que "...ate entåo haviam se destacado por sua ênfase no crescimento, espraiamento da maina e desenvolvimento disperso..." passariam a buscar maior integracão das funçôes, preenchimento dos vazios urbanos, respejto ás àreas centrais, variedade e continuidade (TANGHE et a 1. 1984: 145).

Para dar uma idéia da mudança de postura que se procedeu nas instituicoóes públicas, principalmente na Europa, nos ultimos dez anos, basta citar uma das publicações governamentais da Feira Internacional da Construçăo em Berlin, que afirmava que "a desolaçăo desastrosa de áreas centrais se deve, sem dúvidas, á consequência social e econômica catastrófica da separaçăo planejada e nistóricamente forçada das funcơos urbanas, e a ignorar as necessidades humanas do ambiente urbano. Inquestionavelmente, um novo comeco é necessảrio" (I.B.E. 1984 ). Outro bom exemplo disto é a evoluça dos projetos para desenvolvimento da área conhecida por Battery Park, em Manhattan, Nova Iorque. Em 1972 foram construldas as duas torres do World 
Trade Center, um projeto tipicamente modernista de Minoru YAMASAKI, o mesmo arquiteto do conjunto habitacional de Pruitt Igoe, jà comentado anteriormente. Em 1975 o projeto de desenho urbano para a área do Battery Park era constituido de megaestruturas modernistas, de alto custo e completamente conflitante com o entorno. Um novo plano foi desenvolvido em 1979, com caracteristicas morfologicas mais respeituosas do existente e, a partir de 1985, vem se implementando um plano do arquiteto cesar PELLI, que utiliza uma linguagem tipológica com imagens de fortes conotaçóes "novaiorquinas".

Além dos evidentes objetivos de recuperação do patrimônio e de ampliação da base econômica dos centros urbanos, estas novas posturas de intervençăo geralmente caminham coincidentes aos objetivos maiores de promocão da habitação e do turismo. Por um 1ado, principalmente nas cidades europeias, ainda encontrava-se habitaçoses em grande numero nas àreas centrais históricas. o deficit habitacional para os grupos menos favorecidos, o comprovado insucesso das politicas habitacionais anteriores e a crônica falta de recursos para programas subsidiados, fizeram com que os pollticos e administradores publicos passassem a aceitar a utilização dos estoques construldos existentes e a promoção da habitacão nas áreas centrais. PORTAS (1985) chama a atenção que, como a habitação è o uso que dita o "ritmo e a essência dos bairros", ela vai tornar-se "palavra de ordem" nas novas poltticas para os centros urbanos.

o problema maior nisto, como comentamos anteriormente para - caso da renovaçăo urbana, as próprias melhorias urbanisticas, a conscientizaçăo das vantagens de localização, principalmente, 
para os jovens profissionais e estudantes, e o simples modismo reinante, principalmente nos EUA, faz com que a elevaçăo do preço do solo determine que a larga maioria das unidades habitacionais implantadas sejam destinadas a grupos de média e média-alta renda. Não raramente os grupos menos favorecidos são expulsos pela valorizaçăo imobiliária. Entretanto, a dimensăo "habitaçăo" tem estado sempre presente nos projetos de revitalização.

Por outro 1ado, cada vez mais nos palses do Primeiro Mundo, a sociedade moderna, facilitada pelos meios de comunicaça, libera maior tempo para o lazer e a recreacăo, fazendo com que o conteúdo histórico e pitoresco das àreas centrais passassem a ser valorizados (APPLEYARD 1979, SAMUELS c.1987). Este u1timo autor apresenta dados impressionantes a este respeito na Inglaterra, citando que uma pesquisa domiciliar de 1980 descobriu que a maior atividade de lazer fora de casa para os adultos, além de caminhar, era visitar edificacooses históricas. A indústria do turismo tem participado intensamente dos projetos de revitalizaçăo de áreas centrais históricas, como nos mostra o recente sucesso de diversos projetos, tais como o jà citado Covent Garden, em Londres (1963/83), O Faneuil Hall e Quincy Market em Boston (1965/79), South Street Seaport (1968/1983) em Nova Iorque, e tantos outros (Fig. 9). Este setor económico torna-se ainda mais importante por ser gerador de um numero significativo de empregos, muitos dos quais năo-especializados. A industria do turismo, os programas habitacionais, principalmente de classe-média, o interesse histórico e cultura1, a expansão das funcõos tradicionalmente centrais de comércio, servicos e financeiras, bem como a consolidação do centro como 
lugar simbolico por excelência, foram os fatores mais importantes para conformar um movimento de "volta ao centro" nas principais metrópoles do Primeiro Mundo. Identificamos este movimento com mais forca, mais completo e abrangente, nos palses europeus, que não tiveram um êxodo da classe média e alta para os subúrbios tão intensa quanto teve a sociedade norte-americana, e possuem maior grau de interação social no uso da estrutura urbana e seus equipamentos.

SAMUELS (c. 1987: 3) afirma que "o movimento gera1 parece ser na direção de centros urbanos que são dominados por funções profissionais de alto nivel, financeiras e administrativas, habitações de média e alta renda, e as facilidades hoteleiras, de lazer, transportes e culturais para servir a esta população e a turistas".

Uma outra importante pré-condicão para o desenvolvimento de programas e projetos de revitalização é a participação programada do setor privado. Nos principais paises do Primeiro Mundo, a partir de 1970 os governos iniciaram procedimentos viabitizando a participação ativa do capital privado nos programas e projetos de intervencăo pủblica. As soluçôes de colaboração entre as partes afetadas pelo desenvolvimento urbano se tornariam cada vez mais intensamente buscadas; RAGGETT (1987) chega a afirmar que a colaboraçăo entre poder público e o poder privado se tornara o método tradicional de implementar um grande numero de projetos de intervenção.

$\mathrm{Na}$ Inglaterra esta visão, em conjunto com a situaçåo econômica favorável gerada pela desregulamentação do mercado de capitais em 1986, levou a um ambiente ideal para o 
desenvolvimento imobiliário. o presidente da companhia de desenvolvimento das docas de Londres (London Docklands Development corporation-LDDC) expressa exemplarmente este raciocinio, quando afirma que "o empresário privado, com sua própria intuicăo e sentimento, é muito mais capaz de dizer o que - mercado quer e originar propostas ...tudo que é preciso para estimular o desenvolvimento é a oportunidade, o clima certo e o estimu10" que traduz-se principalmente em compromisso duradouro por parte do poder público (COLLINS 1987). A LDDC é uma empresa de capital misto, criada pelo governo inglês para promover o desenvolvimento de uma extensa àrea portuària e de margens do Tâmisa; sua filosofia e metodologias de atuaçăo săo extremamente empresariais.

Hoje, ironicamente, discute-se os reflexos da "internacionalizaçăo" de Londres e das fortes pressões para recontruçăo das áreas centrais movidas pelos grandes grupos financeiros; estas pressóes levaram á busca por sitios alternativos, principalmente incentivados e viabilizados em àreas sob controle da LDDC, numa àrea de $20 \mathrm{~km} 2$ ao 10 no do Tamisa, onde anularam-se todas as regulamentaçôes urbantsticas e "năo há plano global" (BENEVOLo 1985). A questão transformou-se numa equação de marketing de vendas, em que a LDDC busca atrair capitais a partir de promocăo de imagens, da não existência da "burocracia dos planejadores" e da confiabilidade produzida pela nova situação (HOME 1982, DAVIES 1987). Muitos destes empreendimentos são promovidos por concorrência do tipo empresario-arquiteto, quando deve ser apresentado um "pacote" que 
inclui toda a proposta de desenvolvimento, inclusive o projeto de arquitetura.

Entretanto, a verdade é que, como na época dos grandes projetos de renovaçăo, por suas caracteristicas ambientais e sociais, as novas áreas que surgem estão sendo altamente criticadas $\Theta$ parecem não merecer ser chamadas de urbanas; os ambientes gerados não correspondem ás imagens e expectativas de uma área urbana ideal, como e caso dos projetos para canary Wharf (DAVEY 1986, DAVIES 1987) (Fig. 10). Em interessante artigo ALBRECHT (1985) critica os projetos de intervenção de cunho meramente formalistas citando Platão, que denunciava que qualquer cidade que satisfaca apenas os aspectos fisicos da vida è uma cidade de bàrbaros.

Uma situação como esta não deixa de ser irônica pois durante a crise econômica mundial do final dos 70 e dos anos 80 , os governos das grandes metrópoles encontravam-se praticamente em situacăo de colapso orçamentário. Hoje, com o "boom" das bolsas, - enriquecimento das multinacionais, o estabelecimento de "enterprize zones" e os jà populares "joint ventures" entre o poder público e o privado, cidades como Londres, Nova Iorque, Paris e Berlim precisam tentar impedir que o dinamismo financeiro - econômico acabe por destruir o próprio potencial destas áreas de serem recuperadas de uma maneira ambientalmente positiva.

No Brasil ainda năo existem experiências de intervencão urbanistica que pudessam ser exatamente classificadas como de revitalizacăo, com excessăo do projeto corredor cultural, da prefeitura do Rio de Janeiro (Fig. 11). A partir de uma ideia de 


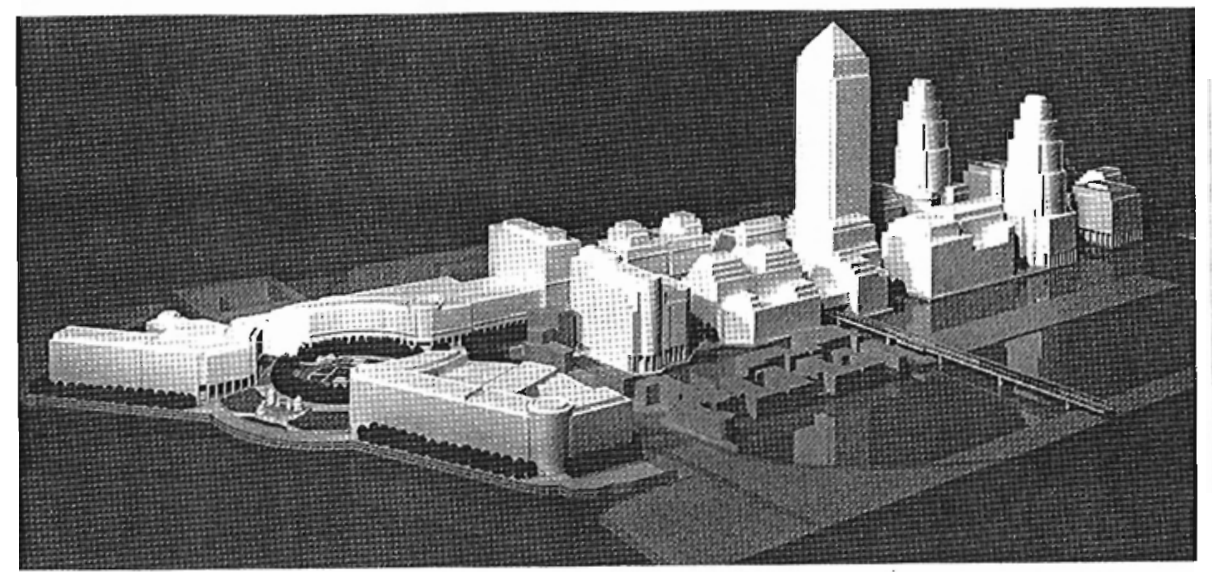

Fig. 10: Maquete do projeto para Cannary Warf, na área portuária de Londres, início dos 80 .

Fig. 11: Área de abrangência do Corredor Cultural, no Rio, e sobrados recuperados na Av. Passos, fim dos 80 .
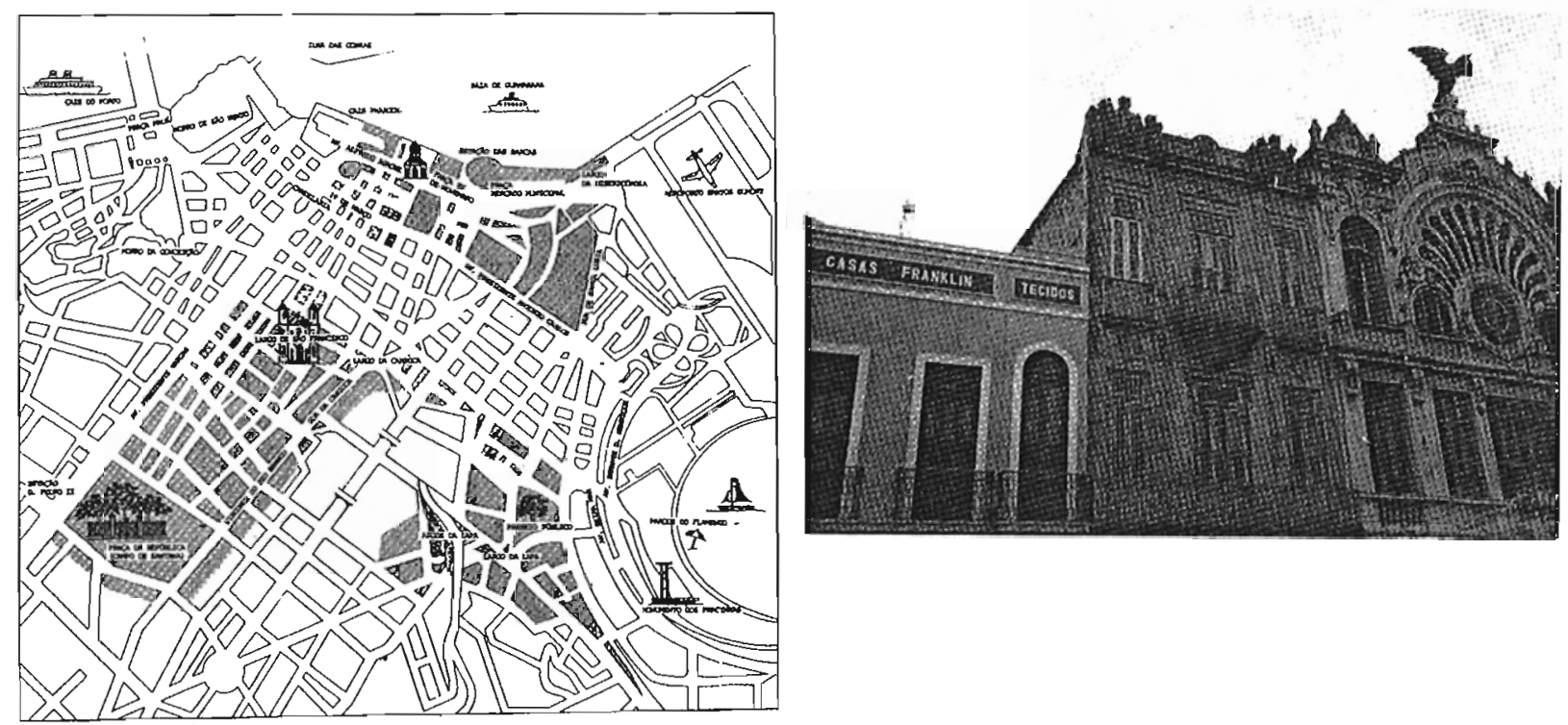
1979, inspirada nos modelos europeus de preservacão, o projeto foi finalmente instituido como zona especial cujo objetivo principal è a recuperação da ambiência do conjunto históricoarquitetônico de uma grande área central (IPLAN-Rio 1985, PINHEIRO 1985). O sucesso do projeto, hoje transformado em programa urbantstico dada sua abrangência, deve-se á incorporação de diversos instrumentos para garantir seu sucesso, entre eles incentivos fiscais (DEL RIO 1990).

o incentivo planejado aos investimentos atravès de processos de desenvolvimento e ações viabilizadoras por parte do setor público vem sido buscada por grupos de empresários no Rio de Janeiro. Este tem sido o caso da Area Portuária, motivo do presente estudo, que desde 1982 é objeto de especulaçôes para seu desenvolvimento e revitalizaçăo, principalmente no sentido de incentivo ao comércio exterior. Foi especulado atè mesmo o estabelecimento de uma "zona franca" como meio de atrair investimentos, como veremos com detalhe mais adiante. As imagens da àrea 1 idadas por estas especulaçôes tratam quase sempre de seu potencial para o desenvolvimento, conteúdo histórico, caracteristicas ambientais, potencial turistico e comercial, e consolidação da habitação.

\section{5. Revitalizacăo de Areas Portuárias Centrais}

Dentro do elenco dos programas e projetos de revitalizacão de àreas centrais, em todas as metrópoles do mundo as àreas portuàrias assumiram destacada importancia. Jà se tornaram comuns e são inumeros os exemplos de intervençôs bem sucedidas em àreas onde originalmente encontravam-se instalaços portuărias, como, 
por exemplo, em Baltimore, Boston, Nova Iorque, Londres e Hamburgo, para citar apenas alguns. o caso de Baltimore já foi, inclusive, motivo de nossa análise mais detalhada alhures (DEL RIO 1985, 1990) (Fig. 12).

Todas as àreas portuárias centrais passaram ou tendem a passar por processos semelhantes de intensa transformacão. Históricamente, elas foram um imperativo na fundaçăo da maioria das cidades, quando a proximidade de rio ou mar era necessário para a comunicação e o transporte, o abastecimento de água, e o esgotamento. Depois, só o primeiro imperativo se manteve e, durante muito tempo as áreas portuárias representaram o que havia de mais dinâmico social e econômicamente em uma cidade. O tamanho e a importância da cidade media-se pelo seu porto $\theta$, consequentemente, por sua área portuária. 0 desenvolvimento urbano dava-se a partir dela. O Rio de Janeiro não era diferente, como serà comentado detalhadamente no Capitulo $v$; sua àrea portuária viria tambèm a sofrer o mesmo tipo de evolucăo e, depois, de decadência.

o perfil evolutivo de desenvolvimento que se reflete nas åreas portuàrias centrais, gerando sua decadência, apresentam as seguintes caracteristicas principais (WRENN 1983) (Fig. 13). Primeiramente, reduziu-se a importancia e a intensidade do transporte marttimo pelo crescimento do transporte aeroviário e rodoviário, ambos com maiores vantagens quanto ao tempo $e$ a flexibilidade dos processos envolvidos. Em segundo lugar, a mudança do calado dos navios, com os modernos cargueiros e transatiânticos exigindo bem mais profundidade para atracacão, 


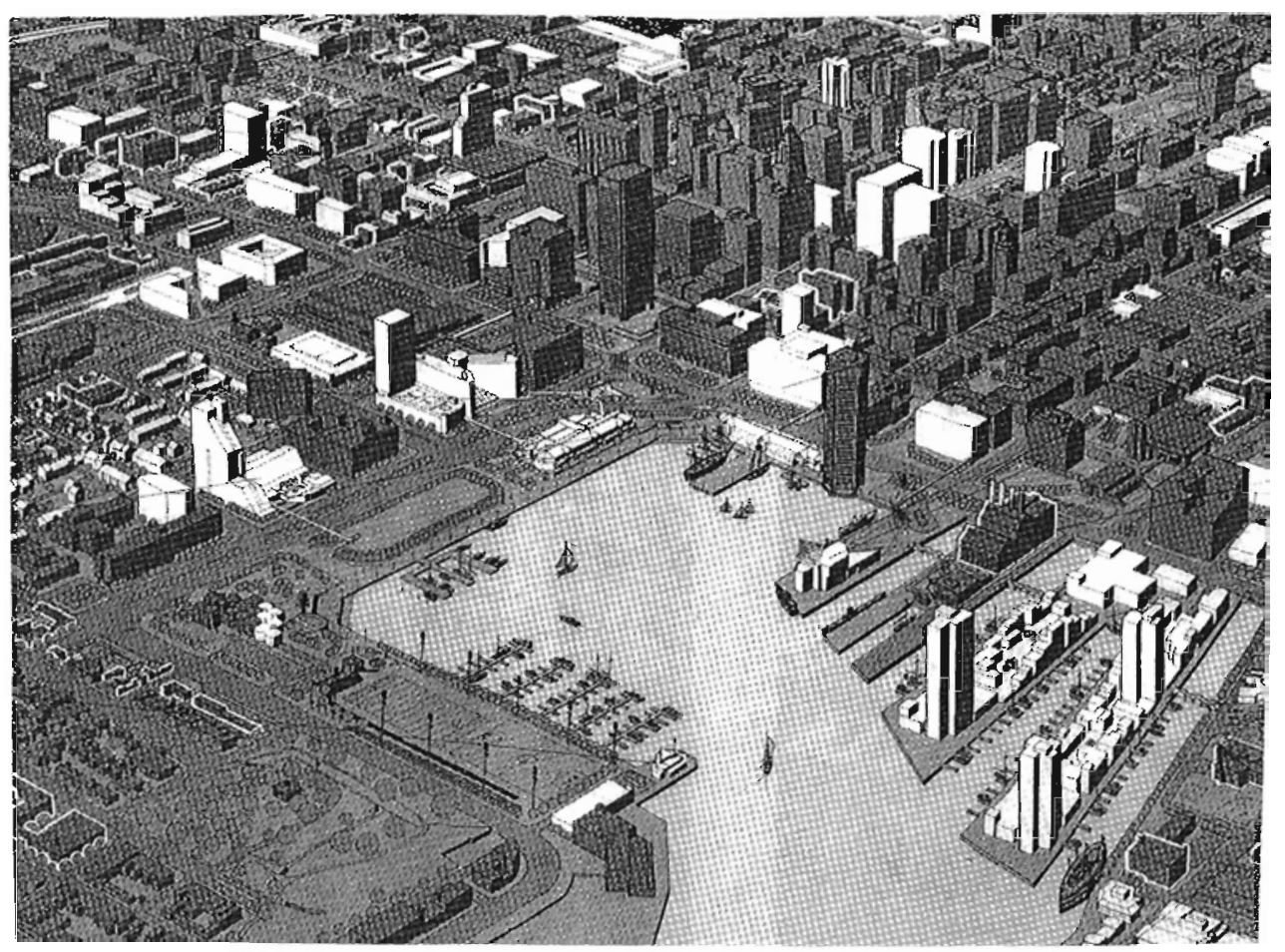

Fig. 12: Vista geral do Inner Harbor, a área portuária central de Baltimore, com os cenários de construções projetadas em 1979.

Fig. 13: Esquemas do processo de evolução do porto e da área central de uma cidade.
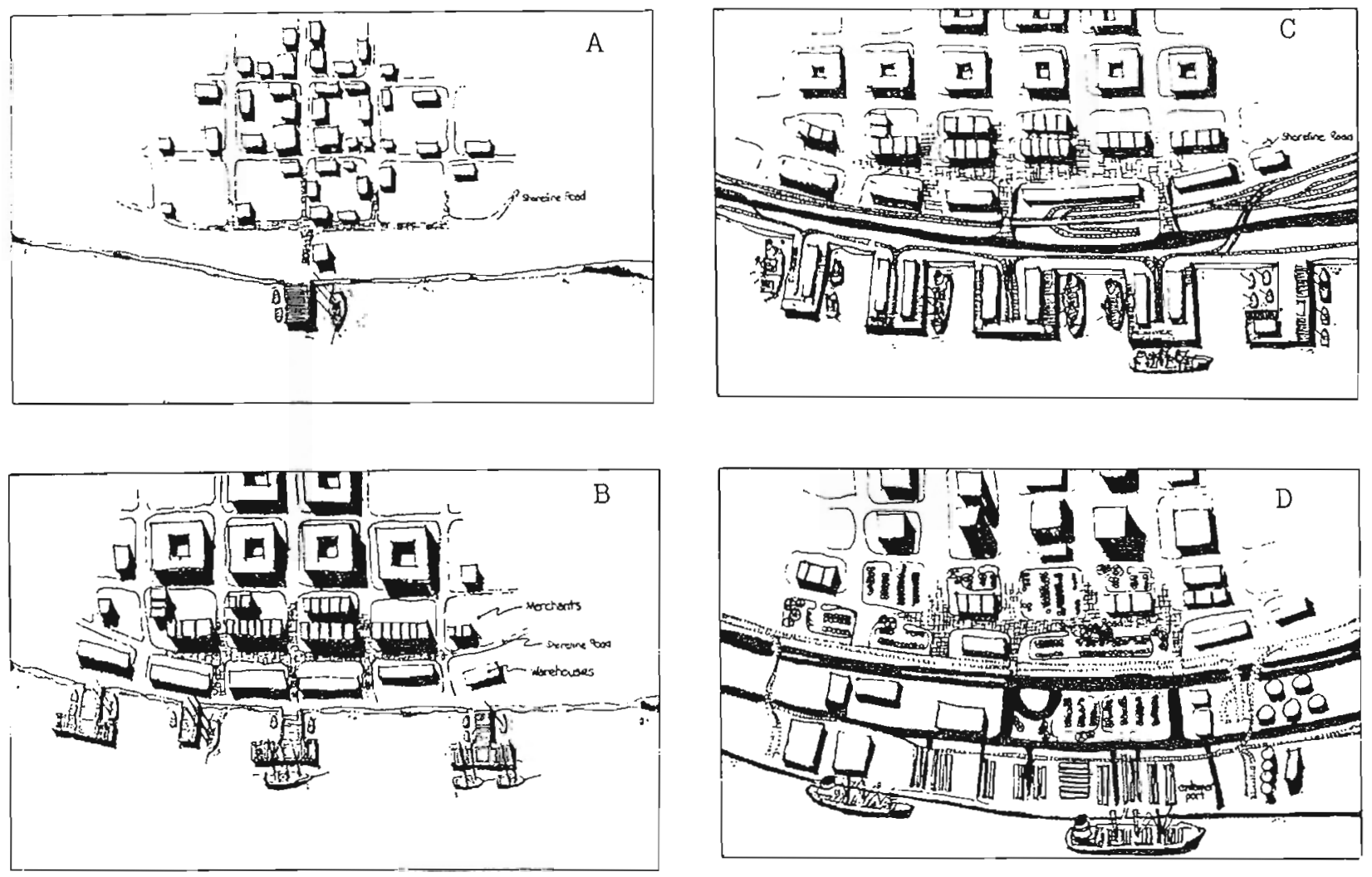
inviabilizaram a grande maioria dos chamados "portos interiores" que ficam em águas pouco profundas e geralmente sujeitas a processo de assoreamento, causado principalmente pelo próprio desenvolvimento urbano á sua volta.

Em terceiro lugar, as instalações portuàrias modernas e os processos de carga-descarga necessitam de grandes àreas de apoio, conhecidas por retroporto, que viabilizem, por exemplo, terminais de "containers" e pátios de "rol1 on-rol1 off", para embarque de velculos; estas àreas necessàrias săo impedidas pela existência da cidade que, irônicamente, o porto fez nascer. Por ủtimo, mencionamos a mudança das industrias para as zonas periféricas em busca de maiores áreas e maior acessibilidade ao sistema rodoviário, e por exigências ambientalistas, e a pressão por àreas para desenvolvimento gerada pela expansão da economia que se reflete nas àreas centrais.

Desta forma, as áreas portuárias centrais das grandes metrópoles têem apresentado significativas porç̃es e imóveis subutilizados ou em abandono total, remanescentes de épocas anteriores de maior dinamismo portuário. Hoje, as grandes cidades năo mais precisam do porto para sobreviver e nem, muito menos, de estar fisicamente interligado ou sequer próximo a ele. Portanto, estas àreas têm sido palco de programas e projetos de revitalização e desenvolvimento que buscam torna-las novamente uma parte integrante e dinâmica da cidade. Dos casos que estudamos, podemos destacar os seguintes componentes principais presentes e responsáveis por este dinamismo: 
- patrimônio histórico-arquitetónico: inủmeras edificações testemunhas de tempos de maior dinamismo social e econômico da àrea e, muitas vezes, ultimos exemplos remanescentes da arquitetura portuária de fim do século XIX e inicio do XX; apresentam-se em estado de conservação variado mas sua recuperação e reciclagem com novos usos tem sido muito bem recebida pe10 pủblico; recuperação e embelezamento dos espaços púb1 icos;

- plena utilização dos espaços existentes: promocão de novas edificações em àreas abandonadas ou subutilizadas e ocupação cuidosa de espacos intersticiais com novos usos publicos; os novos espaços construidos recebem o potencial de expansão das funcões da àrea central e de outras novas evidenciadas ou criadas pela intervenção;

- recuperaçăo da simbiose cidade-corpo d’água: utilização do potencial recreativo e paisagistico das faixas marginais com sua recuperação para o uso público, valorização e promocão de usos intensivos, como marinas, parques, quadras, belvederes, rotas cênicas, navios para visitaçăo, etc.

- mistura de usos e atividades: intensa implantação de usos e atividades púb1icas, principalmente recreativas, culturais e comerciais de varejo/alimentacão; o uso publico \& condicão básica para o dinamismo da área, principalmente na faixa diretamente defronte ao corpo dágua e nos dois primeiros pavimentos das edificaçôes junto ás vias e espaços públicos; promocão de uso habitacional, principalmente de classe média-a1ta e hoteleiro; 
- promocăo turistica: plena utilização comercial turistica do potencial identificado nos pontos anteriores, não só atraindo os turistas sasonais de fora da cidade, mas atraindo a própria populaçăo como usuária intensiva das ofertas;

- participacão setor público/setor privado: por isto entendese um processo de planejamento/implementaçăo que envolva os grupos diretamente interessados na intervencão e seus produtos; \& a participação efetiva e comprometida destes grupos que garante os resultados positivos e a longo prazo.

Estes componentes aparecem com maior ou menos intensidade conforme o caso espectfico mas geralmente estăo todos presentes nas politicas de revitalizacão paras as áreas portuárias. Fica evidente, tambe̊m, da anàlise dos diversos programas jà implantados, que muito se aplica dos conceitos de "marketing". Em grande parte, as intervençôes de revitalização dependem da formação de uma nova imagem: a de uma área que possui diversos atrativos que garantem o seu sucesso nos mais diferentes niveis.

Assim como no planejamento de um shopping-center, com a importancia assumida por suas lojas-âncora que garantem o sucesso das vendas, as diferentes funçoses a serem promovidas em uma àrea de revitalizaçăo possuem as suas "âncoras" como agentes catalizadores do desenvolvimento. São eles que irão garantir que a revitalização "pegue" e, em grande parte, o sucesso do empreendimento como um todo. Evidentemente que a implantacăo das diversos catalizadores nos casos estudados dependeu de planejamento estratégico cuidadoso, respondendo a especificidades locais e potencialidades de mercado. 
Nos casos estudados, os catalizadores mais utilizadas são os centros de comércio internacional, hoteis, marinas públicas, conjuntos de lojas e restaurantes, museus e, por último, habitação. No caso de Saint Catherines Docks, em Londres, por exemplo, um empresário apoiado pelo setor público, nos fim dos anos 70, utilizou-se da proximidade da famosa Torre de Londres (castelo das jóias de coroa) e da Ponte da Torre, para instalar um centro de comécio internacional, um hotel de 1 uxo, escritórios, habitação e um marina, utilizando-se de antigos armazens abandonados; atualmente, todo o entorno sofre intenso desenvolvimento ao longo do Tâmisa. Em Hamburgo, Alemanha, desde - inicio dos 80 vem-se implementando uma polftica de revitalizaçăo que reflete-se nas antigas instalaços portuàrias e na ocupação das margens do Rio Elba.

Nos EUA, como produto sintomático do sistema politicoeconômico do pals, as experiências de revitalização das àreas portuárias vem se realizando de forma intensa $e$, muitas vezes, com resultantes demasiadamente comerciais e soluções repetitivas (WRENN 1983). A primeira experiências bem sucedida foi a jà citada de Faneuil Hal1 e Quincy Market, em Boston, onde a hoje famosa companhia de emprendimentos ROUSE reciclou um antigo mercado e grupo de edificaços em um animado conjunto de lojas e restaurantes que, calcula-se, atraiam em 1980, logo depois de inaugurado, aproximadamente um milhão de visitantes por mês (PROCESS 1984). A "ancora" norte-americana, sem dúvidas, evidenciou-se como sendo uma fórmula que mistura "shopping-mal1" e usos recreativos, tão bem sucedida que tem sido empregada em todas as intervencoôes de revitalização de áreas portuárias de 
diversas cidades norte-americanas, na maioria das vezes pela mesma Rouse Company: Săo Francisco, Baltimore, Nova Iorque, Jacksonvil1e, Miami, Nova Or leans e outras.

As criticas, entretanto, existem pois, além do evidente consumismo exacerbado das mesmas imagens e produtos oferecidos, com o risco futuro de esgotamento do mercado por repeticão, como afirma ALBRECHT (1985), este tipo de revitalização renega a essência da vida urbana e gera um ambiente que chega até a ser negativo a ela por seu reducionismo. Os "shopping-malls não são panacéia. No máximo săo catalizadores do desenvolvimento..." e só podem ser bem sucedidos se as condições gerais do contexto forem abertas a isto (CUNNINGHAM 1977). Os casos bem sucedidos tem demonstrado isto na sua complexa mescla de componentes.

ou seja, as "âncoras" ou catalizadores, sejam eles centros comerciais ou não, só podem ser realmente entendidos como bem sucedidas se analisadas ao nivel dos objetivos do programa de intervencão como um todo. Para tanto, devem participar da verdadeira capacidade regenerativa da cidade e da área tratada, catalizando positivamente suas próprias potencialidades.

\section{6. Revitalizacăo de Areas Centrais e Novas Imagens}

Como diz CANTER (1977: 30) "se... uma conceituação comum do centro urbano (quais rotas conectam que edificacões, etc.) puder ser demonstrada, então é razoável pensar que qualquer proposta para sua modificaçăo deveria levar em conta esta conceituacão".

As ciências sociais jà estudaram muito os fenômenos gerados por mudanças súbitas, por vêzes violentas, de ambientes e de toda 
sorte de insatisfações causadas por renovação urbana e intervenções públicas "de cima para baixo". WHYTE (1977: 13) resumiu bem esta problemática em relaçăo á percepcăo ambiental afirmando que para os moradores antigos, os velhos bairros "...significam lugares familiares, encrustados de memórias significativas e confortando-os com estabilidade fisica e emociona1". Ela descreve como "new town blues" o sentimento de isolamento e desolação que a falta de familiaridade e as baixas densidades das novas áreas residenciais causam a seus novos moradores, problemas ligados á percepcões, valôres e alteracões súbitas de expectativas.

Por outro 1ado, para a revitalização de áreas centrais, um conceito, como vimos, abrangente e que integra diversas metodologias de intervencão, ficou evidente que os objetivos devem, acima de tudo, buscar a implantaçăo e popularizaçăo de novas imagens e atributos qualitativos. A percepcão pública da àrea revitalizada, através deste novo elenco de imagens, possibilitará uma avaliação diferenciada, positiva em relação ás anteriores á intervençăo. A partir disto, a consequente definicăo de novas condutas relativas á àrea irão viabilizar sua valorizaçăo em termos tão globais quanto forem os setores participantes das politicas publicas, tais como residenciais, ambientais, estéticos, de lazer, etc.

Atualmente, os casos a relatar de metrópoles mundiais que se utilizaram destas noções para a revitalização de suas àreas centrais seriam muitos e devemos remeter a alguns dos estudos existentes (APPLEYARD 1979, SANDERS 1980, HOME 1982, WRENN 1983) Nestes casos, os objetivos de revitalização estão sempre 
vinculados á promoça consciente de uma politica fisico-ambiental que promova novas imagens, consoantes com valores e expectativas da populacão usuária e dos potenciais investidores. Cabe ilustrar esta argumentação comentando brevemente os casos de são Francisco, Baltimore e Londres, com os quais somos mais familiares.

A cidade de Săo Francisco, na costa oeste dos E.U.A., famosa mundialmente pela beleza de sua topografia costeira e pelas caractertsticas de seu casario, foi uma das pioneiras em reconhecer a importância de uma politica de controle do desenvolvimento que pudesse priorizar a qualidade de patrimônio fisico-espacial (JACOBS 1980, SHIRVANI 1985). Para tanto, elaborou-se um plano especifico de desenho urbano, integrado ao plano diretor de 1970, com alguns objetivos explicitos relativos á percepção ambiental e á manutenção da imagem da cidade (Fig. 14). O objetivo primeiro, por exemplo, estabelecia "ênfase no padrão ("pattern") caracteristico que dá á cidade e aos seus bairros uma imagem, um senso de propósito e um meio de orientaçăo" (SFDCP 1970: 1.5ii), identificando os elementos fundamentais deste "padrăo" e ditando polfticas relativas a imagem, caráter e orientação.

Já mais recentemente, em complementação a este plano diretor original, a cldade de são Francisco aprovou um plano de desenvolvimento do seu distrito central, em que reconhecia-se os objetivos conflitantes entre "...o fomento a uma econômica vital e manutenção de padrões e estruturas urbanas que, coletivamente, conformam a essência física de são Francisco" (SFCDP 1984: 1). o plano previa a promocão da revitalizaçăo econômica em conjunto 
com o fortalecimento de valores historicos e o incentivo a novas formas arquitetônicas que pudessem gerar ambientes diferenciados e "..uma excitaçăo especial que reflita uma cidade mundial".

outra experiência recente de revitalizaçăo das mais importantes nos EUA, que inclusive comprova a importância do planejamento do desenvolvimento urbano de longo prazo, é a cidade de Baltimore, na costa leste dos E.U.A. Aqui, desde fins dos anos 50 o governo municipal vinha perseguindo objetivos e politicas de revitalizaçăo de sua àrea central, através de planos bastante flextreis quanto aos programas e projetos de imp rantação.

Sobre este caso, remetemos a uma análise mais pormenorizada (DEL RIO 1985, 1990). Entretanto, cabe dizer que o esforco maior sempre foi o de buscar que a populacăo e os empresários acreditassem na possibilidade de revitalizaçăo flsica, social e econômica da àrea central e, para isto, as intervençóes e o controle do desenho urbano foram vitais. A qualidade ambiental oferecida á populaçăo, seja estética seja de funçóes e atividades, foi componente fundamental para a formaçăo de novas imagens e atitudes em relação áquelas àreas e ás novas condutas estabelecidas: grande afluxo de investimentos, intenso uso pe1a população e visitaçăo de turistas, reversão do quadro de a ternativas habitacionais na área central, etc. (Fig. 15).

Jà em Londres, especificamente na àrea de controle do London Docklands Development corporation, mencionado anteriormente, deu-se fato bem diferente. De grandes dimensões e ao longo do rio Tâmisa, a área valorizou-se e é procurada para inúmeros empreendimentos diferenciados justamente pela postura do 

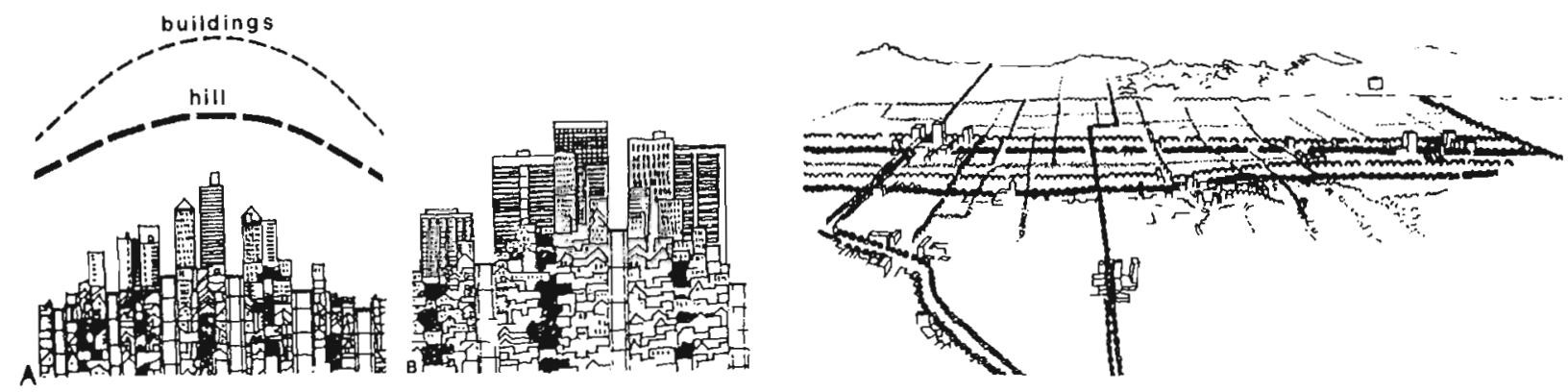

Fig. 14: Diretrizes do plano para São Francisco que buscam o fortalecimento das imagens conhecidas da cidade.

Fig. 15: Vista do Inner Harbor de Baltimore onde se distingue diversos elementos constituintes da nova imagem da cidade, como a torre World Trade Center e o aquário.

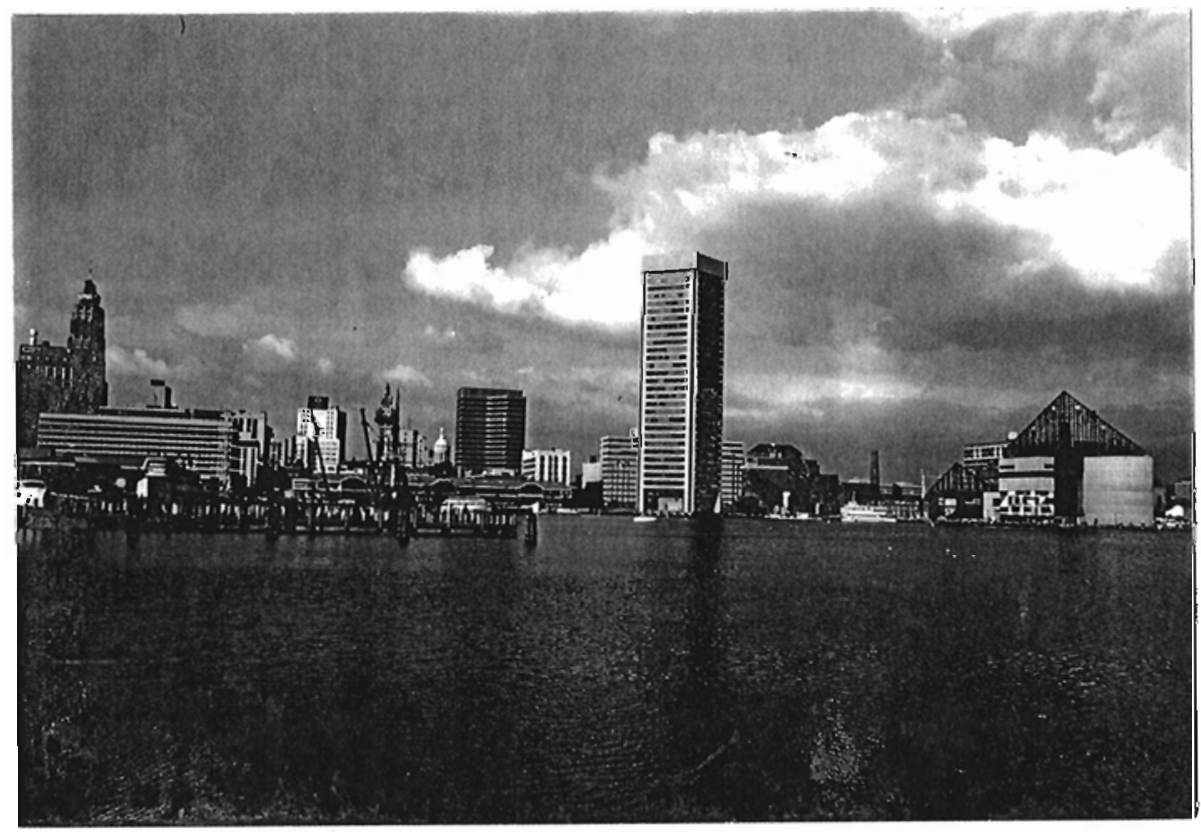


LDDC de năo pré-estabelecer um plano ou uma imagem ideal. A orientaçăo primordial era o "marketing" da área como onde se captaria a expansão de Londres, de valorizaçăo evidente e eminente, onde năo haveriam regras ou planos urbanisticos para "atrapalhar" o empresariado. A imagem global vendida ao público investidor, o que interessava á LDDC, era de uma àrea de fácil retorno do capita1 investido.

Atualmente, no entanto, passados alguns anos do inicio deste tipo de "revitalização" nas "docklands", em muito se critica a maioria dos resultados fisico-ambientais conseguidos, principalmente quanto á sua incapacidade de gerar um verdadeiro "caráter" urbano e uma imagem fisicamente satisfatória (DAVIES 1987, BUCHANAN 1989). Os próprios empresários já vinham exigindo algum tipo de planejamento fisico disciplinador por parte do poder púb1ico como uma garantia a seus próprios investimentos. E inevitável que, dentro do amplo espectro de possibilidades para o desenvolvimento de áreas centrais que se apresenta, um processo de planejamento urbano, integrado e integrador, assuma um papel fundamental na perseguicăo dos objetivos iniciais e na consequente promocăo de resultados que possam elevar o performance urbano, seja em termos de qualidade de vida, seja em termos de geração de capita1.

Por isto, o Desenho Urbano vai, por sua vez, também assumir importante função neste cenário de desenvolvimento integrado, uma vez que representa, como veremos no Capltulo seguinte, o nivel de atuaçăo responsàvel pela organizaçăo da dimensão fisico-ambiental das cidades. Ao dar destaque a sistemas de percepcão, vivências $\theta$ condutas, o desenho urbano é fundamental nos processos de 
intervençăo para revitalizaçăo de àreas centrais. Ele permite operacoóes urbanisticas concretas e, se tomado a partir de uma perspectiva da percepcăo ambiental, irà viabilizar a operacionalização consciente de percepcões públicas, imagens positivas e avaliaçåo ambiental, definindo atributos, compondo atitudes e expectativas, ou ideais, compartidos pela populacăo usuária existente e potencial. 
"Although attempts have been made to reduce design to completely explicit systems of search and synthesis, it remains an art, a peculiar mix of rationality and irrationality." (Kevin LYNCH 1981: 290)

A conceituaçăo de revitalizaçăo de àreas centrais, abordada no capttulo anterior, supunha uma perspectiva integrada $\theta$ integradora, onde a qualidade fisico-ambiental percebida e vivenciada pelos usuários e moradores da área è fundamental para - sucesso da intervençăo. A revitalizaçăo, como vimos, também diz respeito á um novo sistema de valores na busca de novas imagens e atributos ambientais para uma área, aspectos importantes na conformação de paradigmas e expectativas.

A crise ambiental e a crise das profissoes ocorridas a partir dos anos 60 , como veremos a seguir, foram antes de tudo reflexos de modificacoôes nestes sistemas de valóres e na consequente "crise de percepç̋es" (MACHADO 1988) da realidade e de conscientizaçăo das diferentes realidades co-existentes que compơem o mundo.

Neste Capitulo trataremos de comprovar que o desenho urbano trata um novo campo disciplinar para atuaçăo sobre a questăo da organizaçăo fisico-ambiental da cidade. E a partir as vivências, percepções e ações cotidianas da população, que ele vai permitir que se estabeleçam novas bases conceituais e instrumentais para a 
geraça de imagens e qualidades urbanas mais próximas dos ideais coletivos. Neste sentido, portanto, que o desenho urbano prova ser essencial para as intervençoses públicas que objetivam a revitalizaça de àreas centrais.

II. 1. Os Anos 60, Contexto Gerador de Novos Valores:

A compreensão de determinados aspectos geradores de novos valores durante a década de 60 ajuda a situar a consolidacão do Desenho Urbano e o seu desenvolvimento enquanto campo acadêmico e profissional espectfico. Naquela época surgiam as primeiras criticas e protestos generalizados sobre a qualidade do ambiente urbano que vinha sendo produzido, tanto pelo poder publico quanto pela iniciativa privada. Criticava-se tanto o impacto dos empreendimentos sobre o meio ambiente e a vida das comunidades, quanto a própria qualidade dos espacos urbanos e da arquitetura. Essas criticas partiam, principalmente, da própria populaçăo afetada, além de pesquisadores e académicos de ponta e da imprensa em geral.

A produçăo de conhecimento dos anos 60 e 70 caracterizou-se como um repensar das formas como o próprio desenvolvimento vinha ocorrendo atè então, num primeiro momento, nos palses do chamado Primeiro Mundo. Claro está que este "repensar humanistico" deuse, podemos dizer, em paralelo e independente ao desenvolvimento normal de campos de conhecimento ditos "cientificos", como a própria informática.

Isto levaria a novas ideologias, novas posturas e valores, fortalecendo, inclusive, as ciências sociais com enfoques mais humanisticos, e outras disciplinas com enfoques mais "pè no 
chão", conio a micro-economia e a educaçăo básica. Até mesmo novas disciplinas $\Theta$ campos de conhecimento viriam a ser abertos, facilitando o aparecimento de novas profissoes. Foi a partir destas atitudes criticas, dos novos valores surgidos e da necessidade de novas categorias de análise e de novos instrumentos para o controle do desenvolvimento urbano, que o Desenho Urbano se consolidaria enquanto campo de conhecimento $e$, para muitos, profissão especifica.

Cinco temáticas desta época, diretamente relacionadas á discussão sobre o meio ambiente construido, podem ser destacadas como as mais significativas para a consolidaça do Desenho Urbano. Esta compreensão è compartida por diversos autores e, não pretendendo fugir do escopo de nosso trabalho, remetemos ás publicaçós existentes (ATKINSON 1979, BARNETT 1982, APPLEYARD \& JACOBS 1982, DEL RIO 1990).

Primeiramente, apontariamos o inicio dos protestos populares, organizados por entidades comunitárias ou até mesmo por centros acadêmicos, contra as intervençôes urbanisticas nas cidades. As maiores criticas eram contra as intervencơes relacionadas com as politicas habitacionais daquela época, que traduziam-se em extensos programas de renovaçăo das åreas centrais "deterioradas", ocupadas por famt1ias de baixa-renda, e construção de conjuntos habitacionais modernistas, geralmente distantes do antigo lugar de moradia e trabalho das comunidades removidas. Diversos autores apontam, inclusive, o carater ideológico extremamente preconceituoso destas politicas publicas, ape1idadas de "urban removal" e "negro removal" -trocadilhos com a expressão "urban renewa1" (CASTELLS 1971, GOODMAN 1977). 
Os produtos destas politicas e programas perseguiam uma lógica funcionalista e elitista, revelando-se como impactos extremamente negativos, seja em sua qualidade fisico-ambiental propriamente dita, seja em sua real capacidade de resolver os problemas que se propunham. As novas áreas centrais revelavam-se impessoais, estéticamente pouco aceitas, limitadas em sua capacidade funcional, destituidas da animaça que caracteriza os centros urbanos e extremamente elitistas, provendo pouca habitação e, muito menos de baixa-renda. Por outro 1 ado, os programas habitacionais rompiam com toda rede social e econômica original dos moradores, obrigando-os a aceitarem uma nova estética modernista em ambientes insipidos e distantes. Nas palavras de Jane JACOBS, uma das criticas mais contundentes e influentes desta época:

"a pseudo-ciência do planejamento urbano e sua companheira, a arte do city design, ainda năo romperam o conforto superficial de desejos, supersticõos familiares, supersimplificaçoses, e simbolos, e não iniciaram a aventura de provar o mundo real" (JACOBS 1974: 23).

Em segundo lugar, apontariamos as mudancas intelectuais fomentadas pelo novo interesse despertado pelas culturas alternativas, pelo patrimônio histórico, pelos valores tradicionais e pelo produça vernacular. Vernacular visto como o a linguagem e prảtica arquitetônica nativas e tradicionais de um povo, ou seja, com pouca influência externa e passadas de geraçăo a geraçăo. Os trabalhos publicados e o publico em geral comecava a interessar-se pela qualidade estética da "paisagem" dos ambientes construidos espontâneos, como as cidades pitorescas do sul da França e da Itália, ou as cidades medievais. 
Os ambientes vernaculares de diversos cantos do mundo eram divulgados com sucesso, inspirando novos valores na populacão. Este foi o caso, por exemplo, da exposicăo e do livro "Arquitetura sem Arquitetos", promovidos em 1964 pelo Museu de Arte Moderna de Nova Iorque em 1964 (RUDOWSKY 1976).

Comecava-se a atentar para ambientes tradicionais $\theta$ populares por sua riqueza de mensagens visuais, significados complexos e respeito a sistemas culturais. Ampliava-se o conceito de patrimônio, passando-se a não só valorizar a edificação histórica como monumento, mas a resguardar conjuntos edificados por seu valor cultural global. Ampliavam-se as teorias e os métodos de projetacăo assim inspirados, como o "townscape" (CULLEN 1961), a "semiologia arquitetónica" (VENTURI 1966), a "morfologia urbana" e o "contextua1ismo" (ROSSI 1966, CASTEX \& PANERAI 1970).

Outra temática que destacariamos como importante nos anos 60 é a da participaçăo comunitária. O crescente descontentamento dos habitantes submetidos a ambientes modernistas e acões publicas tecnocráticas comecaria a despertar movimentos sociais urbanos que acabaram por forcar novos processos de tomadas de decisão, principalmente nos palses dos Primeiro Mundo. Evidenciava-se também a falência dos sistemas politicos tradicionais e sua falta de sustentaça de base (CASTELLS 1979, GOODEY 1981); era grande o distanciamento dos politicos e dos tecnocratas de gabinete das reais necessidades da sociedade.

Contestava-se, também, a própria nocăo de progresso e da utitizaçăo irracional de recursos năo-renováveis. Falava-se de "economia como se fosse as pessoas que importassem" (SCHUMACHER 
1973) e dos "usos da desordem" urbana (SENNETT 1970). o contexto urbano passava a ser visto como locus democrático por excelência e os governos locais passariam a incorporar sistemas e métodos participativos em vàrios niveis de gestão pública.

Uma quarta temática que apontartamos é relativa á falência do Movimento Moderno na arquitetura. Nos anos 60 começavam a ficar evidentes os diversos problemas inerentes aos próprios conceitos modernistas, tanto em termos estéticos quanto de conforto ambiental, ou mesmo, irônicamente, de funcionalidade. Os criticos mostravam que a arquitetura modernista teve grande parte da culpa no empobrecimento do meio-ambiente construido, principalmente através da exacerbada racionalizaçăo de tipologias e métodos construtivos, e por basear-se na premissa do Homem Universa1.

Diversas pesquisas iriam demonstrar que grande parte dos problemas de desajuste, ou de criminalidade, surgidos entre os usuários de ambientes modernistas derivavam dos próprios conceitos arquitetónicos geradores dos projetos (JACOBS 1974, NEWMAN 1972). A situação foi ironizada recentemente na obra de WOLFE, que fez o seguinte comentário sobre os operários moradores do conjunto de Pessac, projetado por Le Corbusier em 1925:

"Se os operários gostaram de sua habitacăo? Oh, eles reclamaram, o que era próprio de sua natureza neste momento historico. Em Pessac as pobres criaturas estavam desesperadamente virando os frios cubos de Corbu de dentro para fora tentando torna-los aconchegantes e coloridos. Mas isto era compreensive1. Como o próprio Corbu disse, eles tinham de ser reeducados para entender a beleza da cidade Radiosa ... não havia porque consulta-los diretamente pois, como Gropius havia dito, eles eram intelectualmente subdesenvolvidos." (WOLFE 1981: 32 ) 
Finalmente, a quinta temática a ser destacada é a relativa ao evidenciamento das dificuldades inerentes ás ideologias e métodos do planejamento urbano. No plano politico, a falha derivava dos proprios objetivos do planejamento urbano, politicamente determinados e distantes das necessidades do cotidiano das populaçóes. No plano técnico, os métodos eram exacerbadamente tecnocràticos e elitistas, moldados por visões profissionais elitistas dos planejadores, que deveriam responder ao paradoxo de justificar o seu papel social e, ao mesmo tempo, serem altrulstas e "neutros" (SIMMIE 1974).

Em geral os planos guardavam pouca relação com as expectativas reais da populaçăo atingida, sendo raramente implementados em sua totalidade, servindo de mera legitimaçăo de decisões aprioristicas. Conceitualmente, os métodos de planejamento revelavam-se muito rigidos, estáticos e ambiciosos. A falta de participaçăo efetiva da populaçăo, a pouca sensibilidade dos planos quanto á dimensăo temporal e continuidade administrativa e sua incapacidade de integraçăo dos diversos setores responsàveis pelo desenvolvimento urbano, foram fatores que tambèm contribuiriam para a falência do planejamento ás vistas do público e enquanto instrumento ágil de geståo administrativa.

II. 2. Planejamento Urbano $x$ Arquitetura: Desenho urbano

Este sub-titulo comporta propositalmente um falso conflito, que já tornou-se comum atualmente nos meios acadêmicos brasileiros. O que seria, no Brasi1, o Desenho Urbano? $E$ um novo substituto para o Planejamento Urbano? Ou seria para o 
Urbanismo? Alguns sustentam, ao contràrio, que não passa de "arquitetura grande", pois admitem o tratamento arquitetônico á escala urbana. Esclarecer como compreendemos esta questão è importante no ambito deste trabalho e, para tanto, trataremos a seguir do surgimento do Desenho Urbano para, em seguida, levantar algumas consideraçôs sobre suas definiçôes mais apropriadas, situando o desenho urbano como um campo disciplinar.

- estudo da situaçăo do Planejamento e da Arquitetura no contexto dos anos 60 nos paises do Primeiro Mundo, principalmente Gră-Bretanha e EUA situaçăo herdada também pelo Brasil, tanto em termos disciplinares quanto no ambito da prática profissional, nos ajudaria a compreender melhor as razôes do surgimento, o desenvolvimento e a consolidaçăo do Desenho Urbano como campo de conhecimentos especificos.

$\mathrm{Na}$ realidade, segundo diversos autores, parece que as preocupações com o ambiente fisico das cidades enquanto objeto de intervenções püblicas reguladoras, re-surgiu nos EUA após 0 perlodo do pós-guerra, época em que o planejamento havia assumido enorme importância instituciona1. Fundaram-se cursos de pósgraduação do que então se definiu "Civic Design", em Boston e na Filadelfia, respectivamente em 1953 e 1957. Parece que o de Boston demorou a "decolar", o que fez com que ambos fossem praticamente da mesma época. O "Civic Design" preocupava-se pelo projeto dos espaços públicos das cidades, concentrando-se em sua dimensăo fisico-espacial e sua monumentalidade.

Famoso áquela época por seu trabalho pioneiro no plano de renovação do centro de Filadelfia, Edmund BACON, foi um dos 
fundadores do curso daquela cidade e escreveu um dos livros mais influentes de sua geraçăo sobre o desenho das cidades (BACON 1967). Entretanto, nem a época ainda seria proplcia para tanto, nem a visăo abraçada pe 1o "Civic Design" u1trapassou a "grande arquitetura", restando sempre na tradicăo modernista e monumentalista como, aliàs, seu nome jả faz conotar.

A situação do Planejamento Urbano ao fim dos anos 50 e durante os anos 60 já foi heranca direta da II Grande Guerra, com os patses do Primeiro Mundo saindo de terrivel recessão, a demanda por planejadores pelo poder publico aumentou de forma consideráve1. Com o Estado envolvido nos esforços de reconstrucão e reestruturação económica, e com o desenvolvimento do sistema capitalista, necessitava-se de planos, principalmente econômicos e de investimentos. O planejamento regional e urbano passariam a assumir posicão de destaque neste processo de desenvolvimento, a fim de garantir sua racionalização e implementação de objetivos.

Por isto o Planejamento impunha-se como um "processo para determinar ações futuras através de uma sequência de opcões", no dizer de DAVIDOFF \& $\operatorname{REINER~(1973:~11),~e~como~"aplicacão~de~um~}$ método cientifico... ao processo de elaboração de poltticas", segundo Andreas FALUDI (1973: 1). Planejar não mais seria encarado como atitude "socialista", depois da guerra, mas como uma necessidade para integração de açôs e maximização dos investimentos, segundo opçós necessariamente pol1ticas.

- poder publico incentivaria, portanto, a criação e o desenvolvimento de cursos de Planejamento, inclusive em nivel de graduação. Fortaleciam-se os procedimentos "racionais" para a tomada de decisôes, auxiliado por vårias disciplinas, como a 
economia, a sociologia e a geografia (FALUDI 1973). A visão necessariamente globalizante e integrada buscada pelo Planejamento resultou em um tratamento da cidade como um sistema, ou conjunto de sistemas, racionalmente dispostos.

Os enfoques generalizantes advindos desta visão ignoravam muitas especificidades do urbano, tanto a nivel fisico-espacial, quanto sócio-cultura1, ou mesmo micro-econômico. Os planos urbanos eram elaborados a partir de estatisticas e dados ditos objetivos, os zoneamentos eram meras manchas coloridas com pouca ou nenhuma relacăo com o território do real, e as plantas seriam tratadas em escala de, no minimo, 1:20.000. Além disto, o planejador tornou-se um profissional basicamente preocupado com alocaçăo de recursos. Portanto "...no Planejamento Urbano as propostas fisico-espaciais săo formuladas a partir de diretrizes ou planos sócio-econômicos e institucionais... o espaço urbano $\theta$ pré-figurado através de outros campos disciplinares, quando não é totalmente omitido" (KOHLSDORF 1985: 41).

Enquanto isto, com a "descoberta" do Planejamento e o seu novo status acadêmico, ao fim dos anos 60 , os arquitetos, conturbados em sua identidade profissional, transformam-se em planejadores urbanos, "abandonando o ferramental básico de sua profissão, e buscando nas ciências soclais... novos instrumentos para intervir no tecido urbano sem entretanto, abandonar os

1: Compreensăo semelhante desta questão é compartida por diversos outros estudiosos (p.e. ATKINSON 1979, GOODEY 1979, BARNETT 1982, APPLEYARD \& JACOBS 1982, GOSLING \& MAITLAND 1985). 
preconceitos e o formalismo do Movimento Moderno da Arquitetura" (GASTAL 1984: 74). Os arquitetos-planejadores acabaram por levar ao planejamento os processos projetuais rigidos e paradigmáticos do modernismo, tratando a cidade praticamente como um problema arquitetônico, com uma diferença apenas de escala.

Tudo isto fez com que a dimensăo urbanistica e a escala vivencial do cotidiano dos cidadãos, aquilo que percebemos e vivemos diretamente, fosse totalmente ignorado pelos planos diretores e outros instrumentos do Planejamento Urbano. Os zoneamentos, por exemplo, eram manchas coloridas em um mapa, tratados as vezes até com preocupaçăo estética de uma pintura, sem qualquer relaçăo com as caracteristicas do 1oca1: morfológicas, topográficas, fundiárias ou sócio-culturais e politicas. As especificidades paisaglsticas ou ambientais, as identidades dos bairros, e o caráter das cidades năo eram objeto de preocupaçăo. os códigos de obra, ainda hoje, preveêm tipologias construtivas rigidas comuns a todo o territorio bem como zonas homogêneas independentemente das caracteristicas locais; uma sitaçăo fomentada até há pouco na grande maioria das cidades brasileiras, com Brasilia como paradigma.

Por sua vez, a Arquitetura tampouco mostrava-se com maiores preocupaçóes pelo cotidiano dos cidadăos ou pelas especificidades fisico-ambientais das cidades e seus sub-compartimentos. Por um 1ado, ainda como nos lembra KOHLSDORF (1985), a formaça profissionalizante, sem tradicăo de pesquisa, investigacăo e teorização, gerava uma ausência de reflexăo na produção arquitetônica. Pelo outro lado, o Modernismo em quase nada, ou 
nada, preconizava uma interrelaçăo biuntvoca entre a edificação e o seu contexto, formal ou socialmente.

são inumeros os exemplos desta problemática de distanciamento contextual da Arquitetura. Cidades repletas de boa arquitetura năo possuem, necessariamente, um bom Desenho Urbano geral: o resultado final não é a simples soma das partes (BARNETT 1982, GOODEY 1985). As preocupaçðes da Arquitetura em plenos anos 60 e intcio dos 70 , resumiam-se quase que exclusivamente a buscas formalistas e debates de estilo sobre a edificaça, vista como um objeto independente do contexto, ou a novas tecnologias e métodos construtivos.

Evidentemente, não se trata aqui de subestimar estas temáticas, mas de apontar a subestimaçăo da contextualidade da obra arquitetônica. Ainda assim, campos de pesquisa foram explorados neste sentido, como a participaçăo comunitária e a semiologia. A semiologia foi, inclusive, uma das fontes originadoras da Arquitetura Pós-Moderna no incentivo á utilizacăo de repertórios imagéticos de grande significado á cultura ou contexto das populaçōes.

Com a importância dada ao simbolo, enquanto transmissor de valores socio-culturais especificos, os estilos assumiram prioridade na produção arquitetónica, principalmente naquela 1igada a classe dominante e a burguesia ascendente, nos anos 70 . Uma postura, aliás, bastante coincidente com a situação então buscada pelo Modernismo e o Internacional style: muito diferente do engajamento social-democrático de suas origens. Prevaleciam os modelos formais ou de funcionalismo extremado, a "corporation image" e o "high tech" com as ultimas inovaçóes tecnicistas. 
o ensino e a prática da Arquitetura, como vimos, estavam jgnorando preocupaçôes tão vitais para a qualidade das cidades quanto a inserçăo da obra em seu contexto urbanistico: respeito a tipologias, a morfologias, á paisagem, ao sitio, e ás interrelaçoos entre os vărios elementos urbanos e seus usuários. A arquitetura, como o Planejamento, não conseguia uma perfeita integração de seu objeto de estudo e trabalho ao "genius loci"; expressão holistica popularizada por NORBERG-SCHULZ (1980) e que tão bem conota a força, o caráter e a identidade de um lugar.

Já no fim dos 70 , chamava-se a atenção para a importância de um novo redirecionamento da prática arquitetónica para a questão da "criação do Lugar", ou seja, para uma "redefinicăo critica porém criativa das qualidades concretas do dominio do construtdo" (FRAMPTON 1981: 10). Este tema conforma uma das preocupacóes principais do Desenho Urbano.

Vimos, portanto, o distanciamento das preocupaçoes do Planejamento daquelas da Arquitetura, e o quanto que as cidades ainda sofrem com o surgimento deste "gap" um verdadeiro abismo disciplinar no tratamento do urbano em sua dimensåo mais evidente para a população: o espaço vivencial público de seu cotidiano. Foi para responder á necessidade de complementar este "gap" que impôs-se o Desenho Urbano, com sus novas categorias de análise $\theta$ atuação sobre o urbano.

II. 3. Desenvolvimento Acadêmico e Desenho Urbano:

A situação acadêmica na Grá-Bretanha em 1970 foi analisada por importante relatório do Real Instituto Britânico de Arquitetura (RIBA) que admitia a necessidade de profissionais 
treinados em Desenho Urbano no mercado e no Poder Público (citado in GOSLING \& MAITLAND 1985: 7). Uma década depois, GOODEY (1982) relatava para o Conselho de Pesquisas em Ciências Sociais (Social Science Research Counci1, SSRC) como o Planejamento Urbano e a Arquitetura colaboravam na formacăo do campo disciplinar do Desenho Urbano.

Neste documento afirma-se que $\circ$ apoio de entidades oficiais, como o próprio SSRC e os Reais Institutos de Arquitetos e de Planejadores da Gră-Bretanha (RIBA e RITP), foi instrumental para o desenvolvimento dos cursos de Desenho Urbano e sua sobrevivência, em termos de alocaçăo de recursos. Da mesma forma, este apoio foi vital para a conquista do "espaço profissional" no mercado de trabalho. Neste ponto os graduados em Desenho Urbano, segundo o documento, encontravam poucas dificuldades em obter emprego, pois eram vistos como portadores de uma série especifica de conhecimentos, boas e novas idéias.

Portanto, já no inficio dos oitenta existiam nove cursos de pós-graduacão em Desenho Urbano na Grã-Bretanha captando, inclusive, grande clientela de alunos do exterior. Estes cursos, por convição, preocupavam-se em oferecer um treinamento pragmatico para seus estudantes, visto como essencial para o Desenho Urbano, uma disciplina de "design". Eram programas que geraimente situavam-se entre os departamentos de Planejamento Urbano e de Arquitetura das Faculdades, que percebiam sua atuacão também como uma espécie de "remédio": os inscritos, se planejadores, teriam que receber formaçăo em temas de natureza flsico-espaciais, de "design" e estetica, se arquitetos, teriam 
que passar a compreender e saber atuar sobre todo o entorno imediato de sua área e o contexto urbano como um todo.

Em relação a esta questão, estudos encomendados pelo SSRC ao seu Comitê de Planejamento concluiram que os cursos de Desenho Urbano deveriam ser multidisciplinares, incluindo diciplinas de Arquitetura, Paisagismo, Planejamento e disciplinas instrumentais, como Sociologia, Antropologia e Psicologia, em sua preocupação principal de relacionar os sistemas analfticos das Ciências sociais com possibilidades de compreender e desenhar a cidade e seus espaços. Entretanto, um nivel minimo de competência em desenho projetivo era exigido dos estudantes inscritos nos cursos a fim de que pudessem envolver-se na atividade projetual $\theta$ medir consequências fisico-espaciais.

Quanto a uma possivel definicão de Desenho Urbano, o Grupo de Trabalho do SSRC, em 1980, concluía que:

"Como Planejamento, o termo Desenho Urbano está aberto a uma serie de interpretaçós. Nós o entendemos, de uma maneira geral, como significando o projeto e gerenciamento do meio ambiente tridimensional, maior que a edificação individual. Consideramos que seu campo de interesse localizou-se na interface entre a arquitetura paisaglstica e o planejamento urbano, inspirando-se na tradicăo de projeto da arquitetura e da arquitetura paisaglstica, e na tradicăo de gerenciamento ambiental e de ciências sociais do Planejamento contemporâneo" (in B. GOODEY 1982: 13).

Também Kevin LYNCH (1979: 65) considerava o Desenho Urbano mais como uma atividade de planejamento do que de "arquitetura grande", pois lida com objetivos para perlodos de tempo consideravelmente grandes, tratados através de polfticas, programas e diretrizes, mais do que atraves de projetos especificos. Entretanto, enquanto fazia questão de frisar tratar-se mais de uma arte do que de uma ciência, afirmava que 
não è tarefa especifica de arquitetos. Este mesmo autor reafirmaria esta posicão em obra posterior, a ủtima antes do seu precoce falecimento, quando afirma que "o Desenho é uma arte... uma mistura peculiar de racionalidade é irracionalidade" (LYNCH 1981: 290).

Paralelo aos estudos do SSRC, nos EUA o ensino do Desenho Urbano era oferecido em diversos cursos, sendo que o seu primeiro programa, como o conhecemos hoje, parece ter sido iniciado em Harvard, por volta de 1960 (BARNETT 1982). A matéria foi objeto de importante seminário nos E.U.A. em 1979, na Universidade da California, em Berkeley, onde dava-se o tom da disciplina naquele Pał́s. Concluła-se na ocasiăo que o interesse do público no Desenho Urbano ultrapassa a questão de implantação de edificaçóes especificas ou de detalhes de projeto, dirigindo-se á questăo de qual vai ser o estilo de vida e a imagem da sua cidade, o seu "caráter" geral (FAREBEE 1982).

Portanto, poder-se-ia afirmar, segundo as conclusôes da conferência, que as comunidades estariam engajadas em lutas relativas á imagem de sua cidade, uma imagem da qual dependeriam para identidade propria e auto-respeito. O Desenho Urbano, portanto, é frequentemente utilizado para proteção ou instituicăo desta imagem urbana (LYNCH 1960 e 1976, GOODEY 1979).

Enquanto o Desenho Urbano se concentra, atualmente, em compreender as complexidades do processo de desenvolvimento urbano e em elaborar possibilidades para intervençóes a ntvel da qualidade flsico-ambiental, jà em sua institucionalização acadêmica inicial admitia-se que ele não poderia ignorar 
praticamente nenhuma àrea de conhecimento do ambiente urbano e da vida de seus habitantes. Assim, são utilizadas teorias, procedimentos e tècnicas de Arquitetura, Psicologia, Planejamento Ambienta1, Geografia, História, Paisagismo, Planejamento Teritorial, Ciência Politica, Engenharia, Transportes, Administração de Imóveis, Micro-Economia e tantas outras.

Por isto, em traba1ho recente, TURKIENICZ (1984) afirma a necessidade de atentarmos para as formas espaciais pois hoje jà admite-se que, uma vez gerada uma forma espacial particular, ela tende a institucionalizar e a determinar, em certos aspectos, o futuro desenvolvimento dos processos sociais. Segundo o autor, os arquitetos há muito teriam deixado de trabalhar a intersecăo entre os processos sociais e a morfologia urbana tendo "... ou estudado o espaço independentemente da sociedade real, ou discutido a sociedade real colocando em segundo plano a configuração dos espaços" (TURKIENICZ 1984: 10).

Concordamos, também, com SAMPAIO (1986: 36) quando afirma que "... a complexidade do fenômeno urbano induz a categorias de análise ao nivel interdisciplinar, inclusive para clarear as especificidades do próprio espaço fisico". Segundo ele, estas categorias em muito ajudam a definir o próprio sentido da forma, mas nunca antes estiveram instrumentadas para operaçóes de criação e de dar forma ao espaço.

- Desenho Urbano concentra-se, então, em algumas temáticas de desenvolvimento disciplinar, as quais podemos identificar como sendo:

- técnicas e instrumentos de controle do desenvolvimento do meio ambiente construido, 
- interpretação de valores e necessidades comportamentais individuais e de grupo,

- identificação de qualidades fisico-espaciais,

- desenvolvimento de técnicas operacionats do ambiente urbano,

- resoluçăo de problemas interdisciplinares,

- desenvolvimento de meios de implementaçăo.

Portanto, além da pesquisa fundamental em campos disciplinares diferentes, aplicados ao ambiente urbano, ás percepcões, ao comportamento e aos valores da populaçăo, é fundamental que o Desenho Urbano possa desenvolver programas e projetos operativos, com horizontes de médio e longo prazo de imp 1antação.

A marginalidade do Desenho Urbano em relaçăo aos campos acadêmicos e profissionais tradicionais vem fazendo com que ele atravesse uma intensa Timitaçăo de recursos e pesquisa para pesquisa, ou mesmo para o próprio funcionamento dos cursos (GOODEY 1982). Isto gera situaçăo dificil, indicando que as fronteiras profissionais estão se fortalecendo e que o Desenho Urbano corre o risco de se perder neste "jogo". Esta vem sendo, sem dủvida, a situação na Gră-Bretanha, principalmente face aos grandes cortes de subsidios promovidos pelo Governo Thatcher.

Já nos EUA a atuaça do Desenho Urbano sempre foi bastante forte, se năo conscientemente, ao menos em termos das práticas de governo e profissional. Lá, a dimensăo pủblica das cidades e dos bairros é motivo de grande interesse por parte da população, que dela participa ativamente. Os programas de Desenho Urbano vêm, inclusive, cedendo espaco acadêmico aos de "environmental design", ou desenho ambienta1, em que tenta-se um enfoque ainda 
mais amplo para a questão do meio ambiente. Talvez um dos motivos principais para esta modificacăo tenha sido a institucionalizaça dos relatórios de impacto ambiental e suas consequências para o planejamento e o projeto, bem como a importancia assumida pelos estudos de percepcăo e comportamento; em ambos casos assume-se definitivamente um caráter interdisciplinar á atuaçăo sobre o ambiente construido.

De qualquer forma, nos EUA o Desenho Urbano è visto como importante àrea profissional, onde a maioria dos atuantes são arquitetos ou "planners" (graduados em planejamento), tal qual o perfil encontrado na Gră-Bretanha. A diferenca é que no contexto de desenvolvimento norte-americano a queståo da qualidade da dimensăo fisico-espacial da cidade adquire importância fundamental para a reproduçăo do Capital e para a satisfação politica dos grupos de comunidade. Este contexto é, acredito, de especial interesse para nós, uma vez que o sistema capitalista norte-americano no que diz respeito á questão da ocupacão do solo urbano e dos empreendimentos imobiliários, possui situaçóes extremas e equiparàveis á situação das grandes metrópoles brasileiras.

Concordamos com BENTLEY (1979: 41) que afirma que deve-se cada vez mais entender o "desenhador urbano" como um promotor imobiliário consciente. Ele deve ser capaz de conquistar as habitidades para o controle do desenvolvimento urbano que o permitam engajar-se na negociaça em todos os niveis do processo, principalmente quanto ás implicaçôes financeiras e económicas das imagens e formas que està promovendo para um determinado ambiente. Com isto năo está se tentando minimizar a importância 
dos aspectos fisico-espaciais, mas atentar para fortes aspectos determinantes de sua implantação e seu sucesso real.

Sobre esta questão, destacamos importancia dos trabalhos e publicações de BARNETT (1974, 1982) um arquiteto que instituiu e 1iderou o departamento responsável pelo Desenho Urbano da prefeitura da cidade de Nova Iorque, EUA. Segundo BARNETT (1982: 241):

"O futuro do desenhador urbano està naquelas instituicões governamentais que detêm o poder sobre as decisôes de larga-escala no meio ambiente, e naqueles negócios e industrias cujas atividades tem um grande impacto em nosso entorno fisico.

Colocando em outras palavras, as mesmas instituicôes que ja foram consideradas os "caras maus" (bad guys) no desenho das cidades possuem a maior capacidade de serem os caras bons (good guys).

Ta1 transformação deve certamente começar no topo. 0 sucesso das atividades cotidianas depende de gente para fazer o trabalho, entretanto, as inovacões maiores são praticamente impossiveis em grandes instituicơes sem que as 1 iderancas estejam a favor da mudanca".

Este mesmo autor, assim como cada vez mais outros pesquisadores do Desenho Urbano, destaca o importante e crescente papel do investidor corporativo ("corporation investor") como crucial na qualidade emergente do nosso meio ambiente. Entretanto, seja qual for a àrea de pesquisa/atuaçåo apontada como a mais importante para o Desenho Urbano, nos diferentes contextos de traba1ho, destacamos a necessidade de atencăo especial deste tema dentro da complexidade das cidades modernas.

BARNETT (1982) também afirma que, para que possam produzir resultados significativos do ponto de vista prático ou artistico, os desenhadores urbanos devem se livrar da noção negativa de que seu trabalho ficaria "contaminado" se partissem para a compreensão dos processos decisórios politico e do mercado de 
capitais (BARNETT 1982: 12). Postura tradicional e ingênua entre arquitetos, ainda comum atualmente, que "tapam o sol com a peneira" quanto a processos imobiliários e especulativos, formação e reprodução do 7 ucro nos projetos urbanos, e que não pode mais ter vez no campo do Desenho Urbano, sob pena de distanciamento do real e dos consequentes riscos na capacidade de implementação dos objetivos.

Os pensamentos de CUTLER \& CUTLER (1983: 87) elucidam as tendências atuais deste campo profissional e acadêmico. Dizem os autores que o Desenho Urbano é onde negócios, desenvolvimentos, governo, planejamento e projeto convergem. Ainda, ele seria uma tentativa de substituir a especializaçăo por um compreençăo geral dos processos de produção e apropriação do espaço urbano, alcançada através da combinaçăo de alguns estudos em profundidade com uma maior consciência dos divesos campos disciplinares que possam contribuir para um enfoque mais correto do urbano.

II. 4. Definindo 0 Desenho Urbano:

Jà vimos como surgiu e se impôs a necessidade de desenvolver novas categorias de anàlise e atuaçăo sobre o urbano, e como ela expressou-se academicamente enquanto Desenho Urbano. Apresentaremos a seguir algumas consideraçoos para sua definicăo. E importante desenvolver esta questão pois ela năo se limita a filigranas semânticas mas trata de bem localizar o campo de atuação acadêmica e profissional do Desenho Urbano, e seu consequente papel no processo de controle do desenvolvimento.

No nosso entender, o Desenho Urbano es, antes de tudo, um campo disciplinar. Com nossas consideraçoses anteriores, pudemos 
verificar que seu surgimento deu-se no "preenchimento do vazio" entre as disciplinas de Arquitetura e Planejamento, cobrindo o campo vivencial mais próximo do usuàrio dos sistemas e estruturas urbanas. Suas duas caractertsticas principais são:

a) interdisciplinaridades nas categorias de anàise,

b) essencialmente fisico-ambienta1.

Acreditamos serem necessárias estas consideraçōes, principalmente no atual momento brasileiro de desenvolvimento acadêmico e profissional quando utiliza-se da expressão Desenho Urbano como "... bálsamo para as feridas abertas pela recente fase, da qual ainda năo saimos, do urbanismo e da arquitetura irresponsáveis" (DEL RIO 1987: 103). Em outras ocasiôes já discutimos definicơes de Desenho Urbano para o contexto brasileiro pois viamos o risco da expressão ser adotada irrestritamente por mero modismo, dos que nosso pals se vê seguidamente vitima (DEL RIO 1985b, 1990).

E importante entender, de inicio, que um dos problemas que enfrentamos é que o termo inglês "design" possui conotaçoses muito mais amplas do que seu correlato em nossa 1ingua. Significa muito mais do que desenho, uma atividade basicamente artistica, em português, e não é plenamente tradusivel para projeto, como querem muitos. Isto porque "design" possui toda uma conotacăo que engloba desenho, projeto, planejamento e processo: não è uma palavra limitadora e estática como desenho. O dicionário de Oxford traz toda uma série de definicões para "design", são pe lo menos oito entre as quais a de "adaptaça dos meios aos fins" (The Concise Oxford Dictionary, 6a. Edicão, 1976). Uma conotação, portanto, que embute a nocão de planejamento. 
Por outro lado, apesar de campo interdisciplinar por definicăo, o profissional que lida com Desenho Urbano deveria possuir um bom embasamento de formaçăo acadêmica na dimensão fisico-espacial, o que por vezes o confunde, limitada e errôneamente, ao arquiteto e ao engenheiro.

Por estas razôes, podemos tão somente estar sempre abertos ao debate quanto a esta questão, enquanto temos adotado, até mesmo por falta de melhor substituto, a palavra desenho como sua equivalente em inglês, conotando todos os significados daquela. Por isto também há referencias aos profissionais que atuam neste campo como "desenhistas urbanos". Como é o caso de outras disciplinas, como a própria Arquitetura e o Planejamento Urbano, as definicões são dificeis pois há margem para interpretacões diversas a partir dos contextos sócio-culturais ou até mesmo da formaçăo do pesquisador. Entretanto, o debate em torno ao assunto é positivo e só pode tender a um consenso. Por isto, o mais indicado parece ser a busca de definiços a partir do objeto em que se pretende atuar e dos objetivos a se alcancar, observando o contexto onde estarả inserido, no caso, o brasileiro.

Năo podemos, entretanto, concordar com o tratamento que alguns têem dando ao Desenho Urbano no Brasil. Existe uma certa confusão de definições aplicáveis: vem-se tratando o Desenho Urbano como um novo modismo. Como afirmamos em ocasião anterior, utiliza-se desta expressão inconsequentemente, apenas por que veêm nela uma nova roupagem para suas antigas práticas de "arquitetura grande" ou para substituir a jà impoputar expressão planejamento urbano. 
Há poucos anos passávamos por processo semelhante, quando da adoção da palavra "planejamento": sua institucionalização como uma nova disciplina cedeu a um aporte ang1o-saxăo, um modismo que muitas vêzes ignorava seus reais significados potenciais. A situçăo acadêmica e profissional tornou-se confusa no caso do "planejamento urbano" pois sua insercăo em nosso contexto ignorou o jà tradicional termo "urbanismo". Nos anos 70 muitas das escolas de Arquitetura até mesmo alteraram o nome da disciplina de Projeto por Planejamento de Arquitetura.

Como observado por GASTAL (1984: 74) "... nos anos 70 , a elite urbana buscava seus simbolos de progressão nas fontes da vertente cultural anglo-saxónica", a inventora do city ou urban planning. O mesmo autor ainda mostra como os processos de projetos urbanos áquela época eram voltados para a solucăo e não a interpretação dos problemas, gerando propostas baseadas em conceitos de eficiência, sob o ponto de vista etnocêntrico da elite cultural dominante. Realmente, constatamos que hoje em diversos casos, parece que o simples fato do profissional adotar a expressão Desenho Urbano como nova etiqueta classifica-o melhor para atuacão, mesmo que ela não difira em seu conteddo das anteriores, quanto á qualidade e legitimação de seus produtos finais.

Temos vivido situaçăo delicada no Brasil, tipica do estabelecimento de um novo campo de conhecimentos, quando ainda não se possui quadro conceitual prỏprio e espectfico, a definir sua àrea de atuação e suas preocupaçőes primordiais. Exemplo disto è a grande variedade de interpretações de desenho urbano, temas de estudo e enfoques adotados observáveis na literatura 
recente no pals, cujos exemplos mais significativos săo os anais dos Seminários de Desenho Urbano organizados pela Universidade de Brasi1ia (TURKIENICZ 1984, TURKIENICZ \& MALTA 1986). Em alguns trabalhos pode-se identificar a adoção da expressão desenho urbano por puro modismo, sua inconsistência teórica e falta de quadro conceitua 1; uma atitude irresponsảve1 que chega atè ser expllcita em alguns casos (RODRIGUES 1984).

o desenho urbano, a nosso ver, tampouco comporta definicões aplicadas a àreas geograficamente limitadas da cidade, como o bairro ou o espaço entre os ediflcios. No caso da importante obra de GOSLING \& MAITLAND (1984), por exemp1o, os autores certamente acertaram considerando que o Desenho Urbano lida com a dimensăo pública ("public rea1m") mas também afirmam que ele "... 1ida com a forma flsica da esfera pública em àrea limitada da cidade e, portanto situa-se entre as bem estabelecidas escalas da Arquitetura e do Planejamento..." (GOSLING \& MAITLAND 1984: 9). E evidente que a forma fisica das partes da cidade e aspecto importante na determinaçăo de sua qualidade ambienta1, mas o Desenho Urbano não se limita a isto, como veremos adiante.

E curioso relembrarmos o ponto de vista tradicionalista de BACON (1974), embora com restricões pois carregado de etnocentrismo, quando afirma que a forma da cidade è um indicador do estagio de uma civilização. Entretanto, podertamos aceitar tal afirmação se lembrarmos que, realmente, as relaçôes entre as formas urbanas e os processos socjais que as produzem e delas se apropriam săo, realmente, indicativos das caracteristicas de uma sociedade. Neste ponto concordamos com ROSSI (1966) e com LUCAIN 
(1981) quando afirmam que qualquer funçå só é visivel e possivel através de uma forma, e que é a forma que permite a existência do fato urbano.

Importante è frisar que as caracteristicas democráticas e pluralistas do Desenho Urbano constituem a própria essência de suas categorias de análise e da sua atuaçăo, identificàvis nos discursos dos mais importantes profissionais e pesquisadores, e em suas definiçôes para Desenho Urbano. Trata-se, aliás, como afirmam MACKIE \& METHUEN (1978), do que o publico mais identifica como Planejamento Urbano por sua evidência no cotidiano. Jà BACON (1974: 13) apresentava a interessante afirmaçăo que "... a partir de uma visão clara da idéia de desenho, a multiplicidade de vontades que constituem nosso processo democrático contemporâneo podem se fundir em ação positiva, unificada, em escala de tamanho tal que possa alterar substancialmente o caráter de uma cidade". Aqui, o autor nos transmitia otimismo talvez em demasia, mas certamente um cenário desejável enquanto produto continuo de um processo polftico democrático.

A "escola americana" nos ajuda a compreender o contexto de atuação e possiveis definicôes para Desenho Urbano. RAPOPORT (1977), por exemplo, diz que o Planejamento difere do Desenho Urbano, em parte, por uma questăo de escala pois não se pode desenhar uma cidade inteira mas organizá-1a e estruturà-1a: enquanto o Planejamento lida com decisões politicas e locacionais, o Desenho Urbano trata da natureza dos elementos urbanos e suas interrelaços, como experimentados e compreendidos pela populaçăo. Outra definicão eficiente é dada por CUTLER \& CUTLER (1983: 81) que afirma ser o Desenho Urbano "a disciplina 
que lida com o processo de dar forma e função a conjuntos de estruturas, bairros inteiros ou a cidade em gera1.

Mas no nosso entender, uma importante contribuiçao em termos de definiçăo vem da parte de um geógrafo; GOODEY (1979) destaca as seis caracterlsticas basicas que marcam seu campo de atuação, sem limitar-se a uma delas apenas:

a) Escala espacia1: o espaco entre os ediflcios, o bairro, locais das atividades do cotidiano;

b) Escala tempora 1: transformaçôes e evolução, meio ambiente como processo, programas e linhas de ação;

c) Interações Homem/Meio Ambiente: campo onde usuários e grupos sociais são identificáveis, análise de suas realizaçôes e das transformacões que promovem;

d) C1iente Múttiplo: negociações e conciliaçăo de interesses, o profissional como animador ou catalizador;

e) Multiprofissional: capaz de compreender as capacidades e os 1 imites de outras profissôes, poder coordenar suas aços em relação a dimensão fisico-espacial do urbano e suas funções;

f) Monitoraçăo/Orientaçăo: capacidade de controle do desenvo1vimento urbano, dirigir o processo de transformaçăo de uma àrea ou da cidade.

Por outro 1ado, Kevin LYNCH, o autor considerado como 0 mais influente no campo do Desenho Urbano e da percepcăo urbana, como veremos com mais detalhes nos capltulos seguintes, não se utilizava da expressão Desenho Urbano, mas "city Design" acreditando ser esta majs ampla e aplicável á atuaçăo em nossos contextos socioculturais ( LYNCH 1979, 1981). Esta expressåo, no entanto não "pegou", talvez por ter conotações muito limitadoras no passado, como jà vimos anteriormente, e pelo fato de "urban design" já estar sendo amplamente utilizada naquela época.

LYNCH sempre buscava inserir em suas preocupações de pesquisa e, consequentemente, nas definiçôes que apresentava para 
"City Design" ou Desenho Urbano tanto a dimensão fisico-espacial quanto a tempora1, a ideia do gerenciamento do Habitat, e os seus efeitos nos cotidianos e nas experiências individuais da população (LYNCH 1979). Em sua Ủttima e importante obra afirmava que o Desenho Urbano é:

"... a arte de criar possibilidades para o uso, gerenciamento e forma de assentamentos ou de suas partes significantes. Ele manipula padrós no tempo e no espaço, tendo sua justificativa na experiência humana cotidiana destes padrões. Năo 1ida exclusivamente com coisas grandes, mas também com polfticas para coisas pequenas -como bancos, àrvores e o sentar em pórticos de entradas- onde quer que estes aspectos afetem o performance do assentamento. o "City Design" preocupa-se com objetos, com atividades humanas, com instituicões de gerenciamento e com processos de transformaçăo" (LYNCH, 1981: 290 ).

Partindo, portanto, do campo de atuação do Desenho Urbano, podemos finalizar conceituando-o como o campo disciplinar que trata da organizacão da dimensão fisico-ambiental da cidade. A dimensão flsico-ambiental deve ser entendida como conjunto de sistemas fisico-espaciais e sistemas de atividades que interagem com a população através de suas vivências, percepcõos e ações cotidianas.

Como vimos, procura-se tratar da produçăo, da apropriacão e do controle do ambiente construido, processos estes que estão, necessariamente, permeados pela dimensão temporal e mediados pela percepcão na composicăo e perseguicăo de imagens ideais.

II. 5. Desenho Urbano e Percepcăo Ambiental:

Embora a partir do exposto tenha ficado evidente a importancia e o potencial do desenho urbano em 1 idar com imagens, 
avaliaçoses e atitudes ambientais, não podemos ser tăo enfâticos quanto ás possibilidades de efetividade do desenho urbano no que diz respeito a seu potencial decisório em padrốes de comportamento $\theta$ alterações nos sistemas de valores.

Existem limitaços evidentes devido á complexidade da questão da percepcão ambiental, senão mesmo devido á diferença entre "reagir" e "conhecer", uma vez que a atividade representativa é diferente de respostas comportamentais (MOORE \& GOOLEDGE 1976). Os resultados de estudos perceptivos não poderão garantir que os grupos populacionais assumirão as condutas provàveis definidas pelas cognicões e expectativas encontradas pe 10 pesquisador.

Entretanto, como veremos no Capitulo que se segue, existe um consenso teórico de que o conjunto homem-meio ambiente seja um sistema de interelações mútuas. Evidências empiricas sustentam esta noção e comprovam que a compreensão sistemática de "conjuntos de cognicores e de atitudes podem predizer alternativas de condutas" (BELL et al 1978).

Por isto, existe uma tendência epistemológica forte, em considerar o potencial da psicologia ambiental para o desenvolvimento de teorias de arquitetura, em contraposicão áquelas que apoiavam-se em paradigmas essencialmente estéticos (clássicos) ou simbólicos (modernos) (LANG et al 1974, CANTER 1977, LANG 1987).

DOWNS (in PIPKIN 1983: 56) tambẻm desenvolve a nocão que o enfoque buscado pelo estudo da conduta humana tem valorizado o papel do individuo por sobre a de massa, como unidade fundamental para o desenvolvimento de uma teoria do espaço. 
No Capitulo que se segue comentaremos com maiores detalhes sobre as correntes principais da psicologia e seu rebatimento no processo de conhecimento; LANG (1987: 100/101) destaca os consequentes reflexos deste debate sobre as posiçoses teóricas relativas ás interrelações entre ambiente construido e conduta. Quatro noçôes principais dominam nosso campo disciplinar: vontade 1ivre, possibilismo, probabilismo e determinismo.

$\mathrm{Na}$ noçăo de "vontade livre" năo se aceita o impacto do ambiente na comportamento humano, o que é insustentàvel se apenas pensarmos em nossas próprias condicionantes fisico-biológicas. A nocăo "possibilistica" diz apenas que o ambiente é pouco mais que um facilitador do comportamento, mas já se sabe que nossas opçôes e conduta dependem bem mais do ambiente do que isto.

- "probabilismo" é a noça que prevalece atualmente, a qual conceitualizamos suficientemente nas páginas anteriores. Nela, reconhece-se que o ambiente oferece possibilidades de comportamento, sendo que a sua percepcão e o seu uso acontece principalmente em função de necessidades e competências. E neste sentido que GIBSON (1966, 1979), por exemplo, desenvolveu o conceito de "affordances" (capacidades), dentro de sua teoria "ecológica" de percepcăo (LANG 1987), jà comentada anteriormente.

Por muito tempo, a nocão de "determinismo" dominou o pensamento arquitetônico considerando as relaçóes entre ambiente e comportamento como simples relaçóes de causa e efeito, segundo a linha da psicologia "behaviorista". Ambiente nesta nocăo é utilizado mais no sentido geográfico e fisico do termo. Toda a ideologia do Movimento Moderno, por exemplo, era baseada nesta visão: a1terando-se o ambiente construido necessariamente altera- 
se o Homem. Segundo LANG (1987), esta noção ainda è a que prevalece na prática geral da arquitetura e do urbanismo.

As ciências sociais durante dècadas abordaram as relaçôs entre ambiente construldo sobre o bem estar mental de seus usuários, segundo a nocăo behaviorista e deterministica. Este fato já foi comentado anteriormente, e destacamos que as "patologias" sociais eram muitas vezes explicadas a partir de fenômenos meramente flsicos, como, no caso do Rio de Janeiro e suas favelas, cujo mito de marginalidade patológica só foi desmentido a partir de trabalhos como de PERLMAN (1976) e LEEDS $(1977)$.

Embora o "determinismo arquitetônico" exacerbe a capacidade deterministica dos elementos fisico-espaciais como simples relações diretas de causa e efeito, independentemente de outras variáveis (sociais, económicos ou pol1ticos), não se pode negar que são elementos que possuem grande força como catalizadores de percepcões, condutas, reações e comportamentos especificos. Dependendo das condicores contextuais, os elementos fisicoespaciais podem realmente facilitar ou despertar as respostas sociais.

PARR ( 1964 in MERCER 1975: 81) sugeria dependência entre a monotonia ambiental, como o monofuncionalismo, e a delinquência juvenit por causa da pouca presenca de estimulos sensoriais para - bem estar cerebra1. Veremos no capttulo III que alguns tedricos defendem que o Homem necessita de um nivel minimo de excitacăo cerebral para seu equitibrio emocional (MERCER 1975, GOLD 1980). Também NEWMAN (1972) concluiu em seus estudos de conjunto 
habitacionais nos E.U.A. que o projeto acabaria por influenciar decisivamente nos niveis de satisfacão, delinquência e identidade ao năo gerar suficiente definiçăo e interelaçăo entre as dimensơes pủblica e privada.

Hoje o consenso teórico, baseado em evidências empiricas, assume a noçăo probabilistica nas relaçőes entre o Homem e o ambiente construido (RAPOPORT 1977, GOLD 1980, LANG 1987). Consequentemente, o Desenho Urbano é compreendido através de suas potencialidades de participar ativamente da percepcão e da conduta humana (LYNCH 1960, 1981; APPLEYARD 1976) e da organização do espaço, tempo, significado e comunicação (RAPOPORT 1977). Estas noçőes reforçam nossa definição conceitual de Desenho Urbano, já exposta anteriormente, como organização da dimensão fisico-ambiental da cidade, enquanto sistemas fisicoespaciais e de atividades.

II. 6. Desenho Urbano e Qualidade Ambiental:

A noção clássica de qualidade do ambiente construtdo pressupðe conceitos e categorias, sejam apenas estéticas sejam de fundo ideológico, com base em sistemas de valôres eruditos, oriundos de uma visăo ideossincrática e de classe do próprio teórico ou profissional de "design" (JACOBS 1961, GANS 1968, RAPOPORT 1969, LANG 1987).

Entretanto, no âmbito deste traba1ho, entendemos a questão da promocăo de qualidade no ambiente urbano como intimamente 1igada á sua percepcăo pela populaçăo em gera1, e pelos diferentes grupos de usuários em particular. As várias fases do processo de percepcăo, que comentaremos detalhadamente no 
capttulo que se segue, destacam-se por seu papel no processo de pensamento, e nossa conduta, inevitavelmente, baseia-se em avaliacão dos atributos que as imagens e memórias do ambiente nos permitem conceitualizar. Portanto, algumas destas imagens e seus atributos percebidos săo classificados pelo observador em sua avaliaça ambiental como aspectos qualitativos, positiva ou negativamente, participando de sistemas de valores, sociais e individuais.

Além disto, os atributos ambientais percebidos interrelacionam-se com as expectativas e as imagens ideais do observador, para que o quadro avaliativo seja complementado, definindo o que é entendido como qualidade ou năo. Como argumentou LYNCH no prólogo de sua ủtima obra, "sem algum senso do melhor, qualquer açăo é perversa", e è este senso que deve orientar o trabalho do "designer" (LYNCH 1980: 1). As expectativas e os ideais sempre formam a motivaçăo maior para a conduta humana (RAPOPORT 1977).

o estudo das imagens urbanas e seus atributos, da avaliacăo ambiental e da identificaçăo de suas qualidades, ajuda a entendermos a adequabilidade deste ambiente para os seus usuários e sugere uma base empirica nas intervençoes fisico-ambientais para sua reabilitação e melhoria (ZUBE 1984).

Talvez a conceituaça mais popularizada de qualidades ambientais 1igadas á percepcăo da cidade seja a sugerida no trabalho pioneiro de Kevin LYNCH (1960). Para ele "nada è experienciado por si propprio, mas sempre em relaçăo a seu entorno, á sequência de eventos que leva áquilo, ás memórias de experiências passadas" (LYNCH 1960: 1). 
A partir desta nocăo, ele desenvolveu o conceito de qualidade visual na cidade que chamou de "legibilidade", "...a facilidade com que suas partes podem ser reconhecidas e podem ser organizadas em um padrăo coerente" (LYNCH 1960: 2/3). Mais adiante em seu trabalho, ele especifica mais esta qualidade com um conceito complementar, a "imageabilidade" , definida como "a qualidade em um objeto flsico que the da alta probabilidade de evocar uma forte imagem em qualquer observador " (LYNCH 1960: 9). Embora ele reconheça que estas năo sejam as unicas qualidades a se destacar relativas á aparência da cidade, são vitais por possibilitar na população, entre outros efeitos: senso de seguranca emociona1, maior intensidade e aprofundamento da experiência humana, dominio de simbolos populares e memória coletiva. Neste sentido, elas permitiam mais fácil orientaçao dentro do todo e maior identidade das partes, fatores que com LYNCH assumiam posiçăo de destaque na utilizaçăo das cidades. o autor iria confirmar e desenvolver esta posicão em todos os seus trabalhos e consultorias posteriores.

Realmente, como observado por DOWNS \& STEA (1977: 252) "para que qualquer ambiente espacial seja humano e vivenciável (sic. "1ivable") ele deve ser legive1... temos de conviver com a escala e a complexidade do ambiente construldo reduzindo-o a um nive1 humano de compreensibitidade".

Sem dúvidas, LYNCH inspirou-se nas obras de PIAGET e GIBSON, o que será evidenciado por nossa discussão no capitulo III, do desenvolvimento do conhecimento humano através do dominio de estruturas progressivamente mais complexas em termos cognitivos. A "orientacăo", por exemplo, exige um esquema 
topográfico que se sobrepõe ao mundo visual pois nosso campo visual muda constantemente com o movimento e mudanças em nossa posicăo, portanto, nosso mundo visual infere uma "rede de ordenadas" entre os diversos campos visuais (GIBSON 1974). Veremos adiante que, a partir desta noção, uma das contribuiços mais importantes de LYNCH em seus estudos foi de como e através de que elementos nosso processo de cognicăo formaria esta rede de ordenadas na percepcão das cidades.

A identificaçăo e/ou implementaçăo de aspectos qualitativos na paisagem urbana iriam ainda orientar inumeros trabalhos posteriores, derivados da teoria de LYNCH, tanto no exterior (p.e. DE JONGE 1962, GOODEY et a1 1971, APPLEYARD 1976, NASSAR 1979, BAILLY 1979) quanto no Brasi1 (p.e. KOHLSDORF 1979, BLEY 1982, BAUZER 1983, TURKIENICZ \& MALTA 1986). Outros estudos abordam espectficamente a queståo das avaliaçoses e preferencias ambientais a partir, nåo de conceituaçós propostas pelo pesquisador como empiricamente evidentes, mas através de identificação dos atributos ambientais percebidos e avaliados como de qualidade (LOWENTAL 1972; KAPLAN in BELL et a1 1979: 49; SANOFF 1974, ZUBE 1984)

Estas pesquisas tentam, portanto, determinar as categorias qualitativas a partir das avaliaçós preferências dos entrevistados. Dentro desta tipologia, é exemplar o pioneiro de LOWENTAL (1972) que, através das impressōes e ju1gamentos de grupos percorrendo percursos urbanos pré-estabelecidos, pode inferir atributos ambientais e aspectos qualitativos para cada trecho estudado, tais como sossegado, limpo, bonito, 1 impo, caótico, mal cheiroso, etc. 
A nivel da avaliaçåo visual estética de ambientes, alguns pesquisadores chegaram a expor conjuntos fotos ou slides de determinados ambientes aos entrevistados para identificar os atributos mais significativos e sua avaliaço qualitativa a partir de uma 1 istagem deles organizados por pares semânticos opostos (SANOFF 1974, KAPLAN in BELL et a1 1979: 47). Atributos que os pesquisadores concluiram que significavam qualidade, por exemplo, foram os de coerência, textura, identidade, complexidade, sensualidade e novidade, enquanto não foram classificados como positivos, por exemplo, os de simplicidade, homogeneidade, simetria e universalidade.

Ao menos em termos visuais, esta linha de conclusores confirma a polêmica tese do arquiteto Robert VENTURI (1967), a respeito do valor da complexidade e da contradicăo de significados na arquitetura como valores estéticos, à qual jà nos referimos no Capttulo II, assim como as argumentaçóes de RAPOPORT \& KANTOR (1967) que defendem a complexidade $\theta$ ambiguidade como fatores de qualidade na forma urbana.

Outra àrea de interesse dos pesquisadores $\Theta \circ$ estudo de preferências e avaliação em ambientes exclusivamente residenciais. Especificamente dentro dos objetivos de nosso traba1ho, no capitulo I já destacamos porquê a percepcăo da dimensão residencial revela-se como uma das problemáticas mais importantes para a revitalização consequente e ampla das àreas centrais. Um dos atributos ambientais a nivel residencial que diversas pesquisas têm conclutdo como de grande importancia na avaliaçăo de uma área é o "status socia1" percebido (PRDCHANSKY \& ALTMAN 1979, NASAR 1979). Evidentemente, as avaliaços dos 
atributos percebidos dependem de sistemas de valores, o que leva muitos técnicos e leigos a conclusões apressadas quanto a qualidade de àreas populares ou antigas.

Mesmo sob um ponto de vista marxista, onde o espaco é visto como expressåo de poder e do conflito de classes, o sistema de valores da população em geral tende a ressaltar os bairros cujos atributos da imagem percebida (como qualidade de construcão, manutençăo e equipamentos urbanos) garantem seu "status social" (HOLANDA 1985, MACHADO 1985). A 1ógica de valorizaça do solo também se apoia nestes sistemas de valores.

Em suas pesquisas, PROCHANSKY \& ALTMAN (1979), por exemplo, observaram que as variàveis sỏcio-econômicas têm demonstrado ser mais importantes para as pessoas quando são perguntadas sobre "o que mais gostam" em um ambiente residencia1, ao contràrio do que respondem se perguntadas sobre "o que menos gostam", quando destacam fatores fisicos nas respostas.

No Brasil, este tipo de avaliacăo residencial é confirmado por algunas estudos. O "status social" era valorizado por moradores de copacabana, em detrimento de outros aspectos ambientais e na Selva de Pedra, em detrimento do "sentimento de comunidade" (SANTOS org.1981). MOCELLIN (1977) em seus estudo sobre as preferencias residenciais na regiăo do Grande Rio, também destacou o status sỏcio-econômico como principal fator diferenciador e agregador, contribuindo para o que chamou de forca e conteúdo da imagem.

A questão de avaliaça do espaço e preferências ambientais faz surgir conceitos de territorialidade a nivel de sua expressăo urbana, como o bairro percebido (BAILLY 1979); seja segundo noça 
nativista/hereditária ou socio/cultural (GOLD 1980). Ao destacar coincidências nas "configuraçôes totais" dotadas de qualidades formais e sociais na determinacăo de um bairro, LEE (1976: 147) certamente não estava subestimando a percepcăo do "status" socioeconômico como variável na definicăo de bairro.

Embora alguns pesquisadores destaquem a qualidade da unidade residencial em si (p.e. BAILLY 1979: 49), a imagem do bairro e os valores inerentes a ela parecem ser maiores definidores de julgamentos e condutas residenciais. TUAN (1974: 250) já reconhecia que "os moradores da cidade atribuem mais valor á qualidade do bairro do que ás vantagens da cidade ou á qualidade de sua casa", embora se equivoque ao afirmar que a acessibilidade da moradia também è secundária, fator comprovadamente importante para os grupos de baixa-renda (TURNER 1976, PERLMAN 1977, VALLADARES 1978).

A percepcão de alternativas e o sentimento de comunidade săo outras variáveis qualitativas, verificadas tanto nos grupos de baixa quanto nos de alta renda, que MEEKER ( in BAILLY 1979: 113) destaca em relaça á percepcăo ambiental e consequente satisfacão residencial.

Enfim, entendemos que a satisfação com o ambiente urbano è uma avaliação qualitativa positiva das imagens e atributos percebidos em uma área urbana, face a valores, concepcóes e expectativas. Portanto, mais uma vez frisamos a importância da compreensăo do processo de percepcão ambiental através da própria populaçăo, para direcionar eventuais intervençoos urbanisticas.

Em resposta ao quadro conceitual de "revitalizaçăo" definido no capttulo I, năo se pode prescindir da participacăo do 
Desenho Urbano em um processo de planejamento com que possua como objetivos a recuperação física, socio-cultural e econômica de uma àrea central decadente. As qualidades fisico-ambientais que ela possa revelar e vai permitir administrar são indissociáveis de nossas experiências e condutas cotidianas. E por isto que por sua própria conceituação e carateristicas metodológicas, o Desenho Urbano permite a flexibilidade necessaria para lidar com temáticas de percepcão inerentes aos objetivos da revitalizacăo.

Além disto, porque os resultados do Desenho Urbano são essencialmente visiveis e vivenciàveis em nosso dia-a-dia, destacando-se do processo de desenvolvimento e planejamento urbano, ele possui o papel de ser talvez o maior agenciador de percepções, imagens, significados e atitudes em relaçăo á cidade. 


\section{CAPITULO III:}

\section{PSICOLOGIA, PERCEPCAOO AMBIENTAL E IMAGENS MENTAIS}

"Oedipus, who has been called the greatest single individual in Greek tragedy, is primarily a man without a place" (WALTER 1988: 98)

Os três temas sugeridos no titulo deste Capitulo e que comentaremos nas linhas seguintes, por si próprios jà poderiam ser (como são) objeto de diversas teses especificas. No entanto, é necessário que, dentro dos objetivos pretendidos por este trabalho, possamos definir um quadro teórico-conceitual sobre estes três temas que nos possibilite sua correta aplicaça na problemática que nos dispusemos a enfrentar, a contribuicão da percepcăo ambiental na identificaçăo de diretrizes de desenho urbano para revitalizaça da Area Portuària do Rio de Janeiro.

Como jà frisamos na Introduçăo, è fundamental que no processo de geståo pủblica de àreas urbanas, compreendam-se as temáticas ligadas á percepçăo da cidade, de suas partes componentes e de suas imagens públicas, segundo os diferentes grupos sociais envolvidos neste processo.

Se, por um lado, o desenvolvimento da democracia na geståo pública tende cada vez mais á composiça de diferentes objetivos sociais e pol1ticos na definiça das alternativas viáveis para a revitalização, pelo outro, atualmente entende-se politica pública como a expressão de valores públicos que precisa 1idar com 
percepções, valôres e expectativas. Portanto, o desenho urbano que, como vimos, é parte integrante deste processo de planejamento e gestão publica no que diz respeito á organizacăo fisico-ambienta1, assume pape1 fundamenta1 nesta questão.

Dizia LYNCH (1981) que qualquer ação sem uma noçâo do ideal \& perversa; o Desenho Urbano lida portanto com a organização fisico-ambiental em nivel das expectativas coletivas e de imagem, ou imagens, ideais compartidas pela população.

Portanto, para a operacionalizaça de politicas públicas consequentes, será vital 1idar conscientemente com os elementos mais caracterlsticos naquelas imagens e com seus atributos percebidos, sua avaliaçăo pela populaçăo, as atitudes, expectativas e condutas resultantes.

Nas 1 inhas seguintes, trataremos de comentar este tema, a partir de conceitualizações sobre meio ambiente, desenvolvimento humano, psicologia ambiental e das diversas etapas de nossa inteligência que contribuem para a interaçăo ambienta1. Neste processo de interação ambienta1, destaca-se a importância das etapas de percepcão e de cognicão, por lidar com imagens mentais, e das de avaliaçăo e conduta. A formaçăo do conhecimento e o desenvolvimento cognitivo são, neste contexto, sempre entendidos como pressupostos á opinião e á ação.

III. 1. Meio Ambiente e Desenvolvimento Humano:

Antes de mais nada è necessàrio definir o conceito de meio ambiente que estarà determinando o nosso emprego do termo; toda categorização depende do propósito a que serve (LANG 1987). Para nossos fins, adotaremos um dos conceitos mais aceitos atualmente, 
originalmente defendido por GIBSON (1974), que entende 0 meio ambiente como tudo aquilo que nos rodeia no globo terrestre: seja natural, construldo, social ou cultural.

Na mesma 1 inha, SAARINEN (1976) menciona que meio ambiente e a combinação de condiçoses externas ou extrinsicas que afetam $\theta$ influenciam o crescimento e o desenvolvimento de organismos. E um conceito globalizante e altamente integralizado, onde linhas divisórias e classificatórias são dificeis de determinar. Da mesma forma, LEE (1977) e OLIVEIRA (1983) defendem que meio ambiente è tudo aquilo que rodeia o Homem como individuo ou grupo, e LANG (1987) vai mais alèm, frisando que qualquer descriçăo vàlida do meio ambiente humano deve sempre fazer referência ao comportamento humano.

A partir desta conceituação podemos derivar uma subclassificaçăo ủtị e relacionada diretamente com interesses de estudo em arquitetura e urbanismo. E a que identifica o "ambiente construldo" como o conjunto de adaptaçôs que o Homem promove em seu meio ambiente terrestre e cultural (LANG 1987: 81).

Em todas estas concep̧ões modernas, nenhuma das dimensões percebidas do meio ambiente esgota-se em si mesma, ao contrário, todas estão interagindo constantemente. como a interação è pressuposto para a existência de qualquer sistema, conclui-se que - meio ambiente deve ser considerado como um sistema. Portanto, é facil concordar que o nomem e suas relações sociais são influenciados pelo sistema ecológico do qual eles mesmos fazem parte. A psicologia hà algum tempo jà reconhece estas influências, principalmente a chamada corrente comportamentalista (behaviorist), como veremos adiante. 
Os resultados do processo cognitivo de processamento de informações, o nivel dos valores e imagens, passando pelo nivel de avaliaçăo e julgamento, leva inevitavelmente ao nivel de condutas e ações, que não podem ser explicados sem referência ao ambiente flsico e social que os contextualiza. Isto não é adotar postura deterministica, mas destacar a importancia de considerarmos a interrelação Homem/meio ambiente como bi-univoca, ou seja, ambas as partes afetam-se mutuamente, não havendo determinismos diretos (GOLD 1980). O ser humano transforma e è transformado pelo meio ambiente, objetiva ou fenomenologicamente, consciente ou inconscientemente. E, ao mesmo tempo, como afirma RAPOPORT (1977: 9), o meio ambiente constitui-se de uma série de relaçôes entre elementos e pessoas, relaçós estas que são ordenadas e possuem estruturas, ele năo è um conjunto de coisas dispostas ao azar.

Por outro lado, também notamos uma natural diferenciacão do mundo "objetivo" que cerca o individuo e o mundo "fenomenológico" que é percebido por ele, afetando consciente ou inconscientemente a sua conduta e respostas emocionais (TUAN 1980, LANG 1987). Foi neste sentido que GIBSON (1974) desenvolveu o conceito de "affordances" (capacidades) inerentes a um objeto ou ao ambiente, como as propriedades que os possibilitam serem usados de uma determinada maneira, por membros de uma determinada espécie. Ou seja, as capacidades ambientais, seu potencial de uso e de significado, são necessariamente dependentes dos sistemas sociais, particularmente, dos culturais.

Portanto, entende-se que o meio ambiente gera concepcôes subjetivas entre os diversos individuos, tão variadas quanto são 
os individuos, que as utilizam de formas diferenciadas (MOORE \& GOOLEDGE 1976). CARR (1970) comentava que qualquer interacăo com - meio ambiente se dá através de cinco fases: direta, de inteligência, de planejamento, de ação e de reavaliação. Embora achemos que a primeira fase apontada por CARR deveria ser complementada também com o conceito de processo de interação "indireta" (contacto com o meio ambiente sem estimulos diretos), estes parecem ser realmente os processos mentais båsicos de nossas interaçoos ambientais e que não podem ser entendidos como estanques e indepedentemente exclusivos.

Ao estudar a importancia do significado no ambiente construido, RAPOPORT (1977: 60) observa que "...a avaliação ambienta1...e mais uma queståo de resposta afetiva geral do que de uma anàlise detalhada de aspectos especificos, è mais questão de funcão latente do que manifesta, e é largamente afetada por imagens e ideais". Para ele, as pessoas reagem aos ambientes afetiva e globalmente antes de analisa-los de maneira mais especifica e objetiva; dai parte a sua conceituaçăo de qualidade ambienta1.

Portanto, para a compreensão da experiência humana e suas interações com o mundo, fecha-se o ciclo entre os dois sistemas interdependentes: o sistema social e o sistema ecológico (meio ambiente). "o comportamento humano não pode ser compreendido sem referência a um sistema social e uma cultura, nem tampouco sem referência a seu meio ambiente terrestre" (LANG 1987: 80). E por isto que pode-se afirmar que "a crise ecológica atual é crise de percepção, conhecimento e de afetividade (MACHADO 1988: V). Conceituação esta que, evidentemente, contraria a noção que o 
cientificismo tende a possuir, ao entender o meio ambiente como essencialmente composto de fatos fisicos, mensuráveis e controláveis.

E neste contexto que devemos considerar o processo de desenvolvimento da experiência humana. MOORE \& GOOLEDGE (1976) destacam três classes de teorias epistemológicas de base sobre como adquirimos experiência e conhecimento ambiental, que poderiam estar representadas em um continuum desde as teorias que defendem que a experiência e a conduta são inteiramente determinadas pelas forcas ambientais externas, até o outro extremo, em que os fatores comportamentais são vistos como hereditários.

Assim, num extremo do continuum, situa-se o empirismo dos filosofos britânicos do intcio do seculo XVIII, que propunha que nosso conhecimento da realidade era construido por sensaçoes a partir de uma "tábula-rasa" e que esta realidade pode ser medida cientificamente. Esta escola deu origem ao Positivismo e, mais tarde, ás teorias em psicologia de estimulo-resposta como do pavlovianismo clássico e do skinnerianismo, como veremos adiante.

No outro extremo, MOORE \& GOOLEDGE (1976) situam o racionalismo, derivado dos filósofos do século XVII como DESCARTES e LEIBNITZ, onde o conhecimento é entendido como inato, a-priortstico de qualquer experiência. Defendiam o pensamento puro, conceitos inatos que seriam manifestados em situaços particulares (como os conceitos de arquétipos de JUNG). "A existência de uma realidade externa è admitida, mas o conhecimento da forma da realidade é considerado como dado pela mente sob a forma de idéias inatas prévias á experiência" (MOORE 
\& GOOLEDGE 1976: 13). Existiria, portanto, uma total supremacia da mente mas uma negação do conhecimento empirico.

Numa posição mais intermediária neste continuum classificatório das bases epistemológicas, situa-se o transacionalismo, interacionalismo ou construtivismo, oriundo do filósofo alemão Immanue 1 KANT no sẻculo XIX. MOORE \& GOOLEDGE lembram que KANT estabeleceu uma distincăo fundamental entre matéria e o conteúdo do saber (que corresponderia ás sensaçóes) e a forma do saber (o que provoca com que a matéria seja arranjada de determinada maneira); o primeiro conceito é reminiscente do empirismo, enquanto o segundo do racionalismo. KANT dizia que o que tomamos por verdadeiro é produto do ato do saber, uma construção do pensamento. Esta escola filosófica prevalece sobre as outras e outros pensadores importantes, como CASSIRER e PIAGET extrapolaram e desenvolveram seus conceitos ainda mais. As transações entre o organismo e o meio ambiente são mediadas pelo conhecimento ou representaçôes mentais, numa nocăo de que estas estruturas evoluem no tempo.

Como um pensamento mais radical do transacionalismo, MOORE \& GOOLEDGE situam o enfoque fenomenológico, a compreensão holistica da relação nomem-ambiente. Situado como oriundo em 1935 do filósofo KOFFKA e mais tarde desenvolvido por Kurt LEWIN com sua teoria de homem-espaço (PROSHANSKY et a1.1970), este enfoque hoje conforma importante frente de estudos ambientais, bem desenvolvido no campo da geografia, com trabalhos como os de TUAN (1980), WALTER (1988) e, no Brasi1, OLIVEIRA (1978, 1983) e MACHADO (1988), ou, ainda, em arquitetura com NORBERG-SCHULZ (1971, 1979) e ALEXANDER (1969, 1977). 
TUAN (1980: 260) defende que "a experiência pode ser definida como o somatório dos meios através dos quais conhecemos a realidade e construtmos o mundo... inclui sensos, sensaçăo, percepçáo e concepção ou cogniçao". WALTER (1988: 2) diz que "...preocupaçóes com a lógica do espaço tendem a suprimir o sentimento do espaco..." e que só "... chegamos a conhecer um lugar quando participamos do imaginário local. A sintese completa da experiência localizada..."

Hoje, existe consenso entre os estudiosos em que o conhecimento é construldo a partir da interação entre sensação e pensamento, através de um organismo ativo (MOORE \& GOOLEDGE 1976). A conduta, portanto, só pode ser compreendida a partir de contexto especifico e um sistema socio-cultural e psicológico, também especifico ao individuo. A combinaça entre sensacões (estimulos externos) e razåo e sentimentos (estimulos internos) produz num organismo ativo o conhecimento, o saber, e gera as condutas e comportamentos.

Esta noção tem como uma de suas bases as teorias sobre o desenvolvimento mental e intelectual de PIAGET: o conhecimento do individuo desenvolve-se primeiro a partir de modos de funcionamento simples e reflexivos, através de funcionamento perceptivo $\theta$ orientado para a açăo, até modos mais complexos de mecanismos de funcionamento conceitual e abstrato (PIAGET 1963, GOLD 1980). Esta noçáo é comparti inada por outro famoso psicólogo transacionalista, BRUNNER (in LEE 1976) que explica o aprendizado como sucessão dos estágios ativo, icônico e simbólico.

outro ponto que também parece claro, è a importância da motivaçåo em uma crianca ou, de forma geral, no Homem, para o seu 
desenvolvimento enquanto individuo e enquanto espécie. o aprendizado é movido pela motivação e, consequentemente, dela depende o conhecimento. E o caso da teoria de MASLOW, dos degraus de motivacăo crescente em nossas conquistas, desde a luta pela sobrevivência até estàgios mais avançados de satisfação. Ou então, da noçăo de que somos motivados pelo desejo de ultrapassar 7 imites, ou mesmo pelo desejo de novidade, tensăo e neutralização de estimulos. Não existe conduta ambienta1, sem estimu1o, emocão, ou motivaçăo originária; dał a importancia de compreendermos as noçôs de psicologia do meio ambiente e de percepcăo.

Por outro 1ado, deve-se considerar as capacidades dos sistemas de socializaçăo e informaça simbolica, principalmente a linguagem. Se eles permitem transmitir idéias, conceitos e valores, tambem fazem com que a realidade percebida seja "filtrada" ou condicionada ás limitaçóes que eles mesmos impõem; assim conformam-se as diferentes "realidades culturais". Este é um dos objetos de estudo da semiologia, que toma todos os fenômenos culturais como fenômenos de comunicação ou sistemas de signos (ECO 1976). Este autor analisa a arquitetura, por exemplo, como sistema de signos portadores de dois niveis de significados, um diretamente ligado á sua função, outro á seu significado simbólico, ainda que ambos dependentes do código formado pelo sistema de expectativas e hábitos adquiridos, ou seja, em outras palavras, a cultura.

Esta importante noça é defendida por pensadores estruturalistas, em estudos linguisticos, sociais e antropológicos sobre comunicaçăo, o influente LEVI-STRAUSS (1955): por exemp10, foi o primeiro a desenvolver a tese do 
interrelacionamento entre sistema simbolico, rituais sociais e expressões espaciais.

Mais recentemente, RAPOPORT (1969, 1977, 1982) também apresenta estudos sobre a questão, analisando o significado do ambiente construldo, no sentido que nossos sistemas lógicos, de pensamento $\Theta$ de expressăo, estarem intimamente 1 igados com nossa capacidade de expressăo: são sistemas interdependentes. Os esquimós, por exemplo, possuem diversas palavras para conotar os vários tipos de neve, o qwu demonstra que seu correto reconhecimento e a relaçăo com o meio ambiente são vitais para sua própria sobrevivência; jà os japonêses possuem quatorze palavras diferentes para a chuva (TUAN 1980, GOLD 1980).

o pensamento de PIAGET (1969: 356) possui rebatimento claro nesta questão da 1 inguagem, pois afirmava que "todo conhecimento tem a ver com estruturas ... (que) podem ser figurativas, por exemplo percepcões e imagens mentais, ou operativas, por exemplo as estruturas de ação e operaçăo...". Ele entendia conhecimento como a capacidade de capturar ou compreender o mecanismo de uma determinada construção (objeto real). o aspecto figurativo do conhecimento representa os estados percebidos dos objetos ou eventos (configuraçoses), enquanto o aspecto operativo tem a haver com suas transformaços.

PIAGET mostrava que ambos aspectos são essenciais e integrados mas de maneira que as configurações subordinam-se ás transformacões. Ele propunha um "estruturalismo genético, onde cada estrutura é produto de uma gênese e cada gênese è a passagem de uma estrutura menos desenvolvida para uma mais complexa (PIAGET 1969, 1973). 
VURPILLOT (in OLIVEIRA 1978), discipula de PIAGET, também esclarece este ponto, referindo-se á noção de que vivemos mergulhados em um meio ambiente com o qual trocamos informaçóes e transformaçóes. Segundo esta autora, tomamos consciência do mundo flsico mediante informaçóes a nivel pràtico, orientando comportamentos imediatos, e a nivel representativo, construindo modelos do meio ambiente.

$\mathrm{Na}$ mesma 1 inha de raciocinio, KAMERON (1973), em estudo sobre as descricôes ambientais, ou seja, verbalizaçôes resultantes de processos de conhecimento, concluiu que elas podem ser "estruturais" (termos objetivos) ou "experienciais" (sentimentos e impressões), sugerindo complementaridade e interdependência entre as duas dimensões.

Enfim, è nesta concepção que o processo de desenvolvimento do conhecimento é tido como uma evoluça de estruturas cognitivas, baseada em processos perceptivos, da interaçăo do Homem com o seu meio. LEE (1977: 13) afirmava que "a experiência do meio ambiente através da sensacão e da percepcão deixa um restduo de conhecimento, ou de cognições, no sistema nervoso centra1... a pessoa nunca \& inteiramente a mesma em qualquer momento sucessivo de tempo..." .

Do exposto, fica evidenciado que o processo de conhecimento ambiental é conformado através da interaçăo de dois nłveis e de duas dimensões (Fig. 16). Os dois niveis que tratamos são os relativos á forma de conhecimento, se direto, resultante de insumos ambientais com a presença do observado, ou indireto, resultantes de processos de socializaçăo, como aprendizado, em que não è necessàrio a presença do objeto para formação de 
conhecimento. As duas dimensões são a objetiva, em que depreendese a natureza do observado e suas "leis de conformação" (PIAGET 1967), e a subjetiva, em que săo acionados fatores como emoção, sentimento ou "tonalidade afetiva" (LEE 1976: 13)

\section{2. Psicologia e Meio Ambiente:}

A psicologia ambiental ("environmental psychology") es uma expressão adotada em um congresso de 1946, tendo ganho reconhecimento institucional nos EUA em 1973 quando foi objeto de um capttulo no Annual Review of Psychology (PROCHANSKY \& ALTMAN 1979). Os pesquisadores comentam que ela è um campo de estudos nascido de necessidade social, que tomou corpo nos anos 60 e ainda năo possui uma estrutura teórica definida e de consenso (PROSCHANSKY et a1 1970, GOLD 1980). Em português, as traduçóes adotam indiferentemente as expressores psicologia ambiental ou do meio ambiente (OLIVEIRA 1978, 1983; MACHADO 1988); neste traba7ho estas expressões serão tratadas como sinônimos.

Entretanto, antes de tratarmos da psicologia ambiental ou do meio ambiente, fazem-se interessantes algumas consideraçóes a respeito das principais correntes de pensamento em psicologia, seguindo principalmente comentários de LEE (1977) e GOLD (1980), a fim de melhor conceituarmos o seu ramo que trata do meio ambiente e do espaço em gera1. Estes autores analisam cinco como as escolas de psicologia mais influentes:

O estruturalismo fundado por WUND na década de 1870 , tomava a consciência como a totalidade dos pensamentos e sentimentos do individuo; como vimos, em antropologia LEVI-STRAUSS foi um de seus expoentes. Jà o funcionalismo, desenvolvido na mesma época a 
partir do pensamento de DARWIN pe10 americano William JAMES, considerava a mente do individuo em função de sua adaptaçăo ao meio ambiente; segundo o seu expoente CARR (1925 in GOLD 1980: 8) a mente estaria orientada para a "aquisiçăo, fixaçăo, retençăo, organização e avaliação de experiências e em sua subsequente utilizaçăo na orientação da conduta".

A corrente do comportamentalismo (behaviorismo) foi uma reação ás anteriores, iniciada por WATSON, SKINNER e PAVLOV, nos principios deste século, e entendia a psicologia como estudo cientifico do comportamento; compreender seria questão de ser capaz de controlar e predizer fenômenos sociais (MERCER 1975). Apenas importava o que era mensuráve1, baseava a grande maioria de conclusões em experiências com animais controladas em laboratório e tratava o comportamento como simples respostas aos estimulos ambientais. Os criticos acusam que este enfoque destrói a nocão de livre arbitrio (LEE 1977).

Jà a teoria da gesta1t, desenvolvida por alemães no inicio do século, foi revolucionària na medida que entendia a percepcão como mediadora entre estimulos e respostas, ou seja, o comportamento mediado pelo mundo tal qual percebido. Assumia, entretanto, habilidades inatas organizando estimulos ambientais em padrós formais coerentes, segundo as chamadas "1eis da gestalt", tais como "similaridade" e "proximidade" (Fig. 17). Há algum tempo já se possui suficiente conhecimento empirico para demonstrar que o mais verdadeiro é assumir que determinadas estruturas coerentes săo formadas muito cedo no desenvolvimento de uma criança, e não inatas. PIAGET (1969) acusou esta teoria de "estruturalismo sem gênesis". 


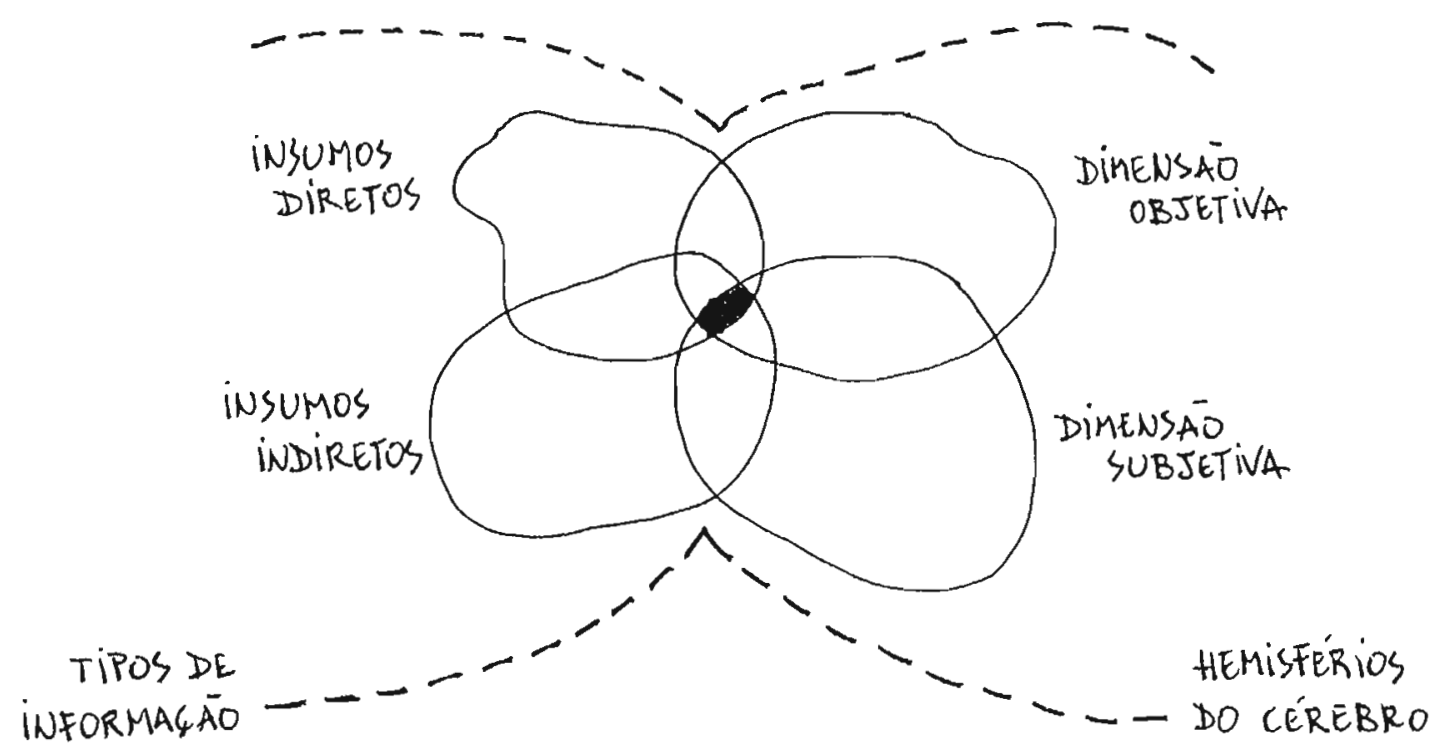

Fig. 16: Um esquema teórico do processo de conhecimento ambiental.
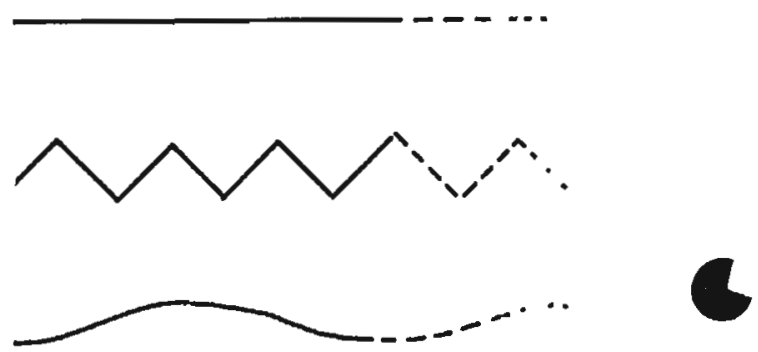

Fig. 17: Exemplo da Lei da Continuidade da Gestalt; a percepção tende a dar continuidade às linhas e figuras. (in PRAK 1977) 
Por fim, uma última escola de pensamento, e ainda pouco explorada no campo ambiental das relações humanas, è a da psicanálise, desenvolvida principalmente por FREUD no século XIX. Segundo esta escola, o meio ambiente seria conformado quase que exclusiva e decisivamente pelo contexto social familiar; o comportamento seria portanto determinado principalmente a partir de impulsos adquiridos na infância. A psicanálise também enfatiza - pape1 da motivaçăo inconsciente mas, dentro da temática ambiental, seus criticos apontam que ela retrata "o individuo como um ser não-racional cuja conduta reflete resoluções de conflitos internos." (GOLD 1980: 9).

Ao conceituar que um lugar deve ser entendido como localizaçåo de formas, poderes, sensaçoses, sentimentos e significados, WALTER (1988) tambèm faz uma anàlise sobre o rebatimento das teorias de FREUD para o estudo dos "1ugares". Diz WALTER (1988: 97) que "... a psicologia de FREUD nunca integrou a identidade pessoal com o senso de pertencer (a um 1ugar) e com o poder real dos lugares" ao deslocar sua teoria da experiência localizada, abstraindo o paciente do lugar das experiências. Ele faz uma interessante análise da dramaturgia de SOFOCLES e de Edipo, assim como FREUD o fêz, demonstrando, através da ủltima peca, em que Edipo volta e reestabelece a relaçăo com a sua cidade natal, que sua tragedia girava básicamente ao redor de ser um "homem sem 1ugar" (WALTER 1988: 98).

$\mathrm{Na}$ verdade, como observa GOLD (1980), estas escolas năo eram totalmente excludentes e a psicologia moderna, principalmente a norte-americana, por ser orientada para problemas espectficos (problem-oriented), guarda a visăo 
filosofica dos behavioristas, o positivismo, concentrando-se em fenômenos observáveis e no estudo das interelaçőes entre estes fenômenos através de métodos cientificos de análise e sintese. Estes estudos, entretanto, diferentemente da corrente behaviorista, não se baseiam em experiências de laboratório mas em ambientes reais, sob pena de esterilidade e irrelevância.

Dentro deste escopo, a psicologia ambiental ocupa-se, de uma maneira geral, dos vários conceitos que o Homem criou para representar o espaco e do estudo das respostas aos estimulos ambientais, sempre compreendidos em situaçoes reais (LEE 1977, CANTER 1977, GOLD 1980). O ambiente è entendido como fonte de variações do nosso comportamento e percepcões no cotidiano (MERCER 1975: 23) e, por isto, ele define nossa conduta e modela parcialmente nossas personalidades (LEE 1977: 27).

Diversos estudos mostram que a psicologia ambiental tomou, a principio, dois rumos de estudos, sem duvida influenciada, por um lado pela escola da Gesta1t, pelo outro pela escola comportamentalista e pela psicologia social.

o primeiro foi no sentido do desenvolvimento da chamada psicologia da percepcăo, em que estudava-se a influencia de determinados elementos fisico-espaciais na estética, valores inatos e, de forma geral, em nossa conduta. Este caminho era fácilmente aplicável ao estudo e ao projeto de arquitetura e urbanismo, até mesmo por heranca da escola BAUHAUS, que originou toda uma importante corrente de estudos e aplicações (CULLEN 1974, SMITH 1974, PRAK 1977, KOHLSDORF 1976 \& 1985). Até LYNCH iniciou-se nesta "escola" através de seu professor Gyorgy KEPES, oriundo da Bauhaus. 
Embora partindo de nocões importantes, como a que nosso mundo mental é mediado por nossas percepcões do real, como já observado anteriormente, e de determinadas "regras perceptivas" consensualmente verdadeiras para a cultura ocidental, alguns autores mostraram as 1 imitaçôes inerentes das teorias da Gesta1t para ap1icaçăo a situaçôes reais (BAILLY 1979, GOLD 1980). Primeiramente pela impossibilidade de universalizar estas regras perceptivas transculturalmente, ou mesmo entre grupos sociais diferentes de uma mesma cultura. Segundo porque fora de laboratório as regras apresentavam problemas, jà que suas variàveis não mais podiam ser estudadas independentemente.

- segundo rumo inicialmente tomado pela psicologia ambiental desenvolveu-se a partir de conceitos como territorialidade, espaco pessoal, densidade e privacidade. Este ramo de pesquisas gerou estudos que se intitulam psicologia comportamenta1, ou do comportamento, que muitos, principalmente nos EUA, hoje já adotam como a terminologia mais geral incluindo, inclusive, a percepcão ambienta1.

Muitos destes conceitos, atualmente clássicos em psicologia, derivaram de observações sobre animais em laboratório, dat nossa observaça de seu desenvolvimento a partir da escola behaviorista. Comprovou-se, por exemplo, que o conceito de território animal encontrava paralelo no comportamento humano, de necessidade de demarcaçăo de área espacial e controle de seu acesso a extranhos: esta seria uma "1inguagem" espacia1, manifestaçóes flsicas através das quais transmitirlamos nossas mensagens e nossa individualidade (HALL 1977). O mesmo pode-se dizer em relação aos gestos e sinais; SAARINEN (1976) menciona 
pesquisa em que se estimava que apenas 30 a $35 \%$ do significado social em uma transaçåo è transmitido verbalmente (SAARINEN 1976). Outro conceito importante nesta mesma linha, desenvolvido por SOMMER (1973), é o de "espaco pessoal", volume definido em volta de nosso corpo onde intrusos são indesejados e que é determinado por sistema socio-cultural e pelas instâncias contextuais. Interessante è que alguns destes conceitos, como o da territorialidade, aparentam ser inatos e resultantes de processos evolutivos mas ainda aparentes nas manifestaçôes humanas mais inconscientes (MERCER 1975, GOLD 1980).

Outra importante linha teórica desenvolvida a partir do comportamentalismo, é a de BARKER (1978) e sua psicologia ecológica, que se baseia na determinacăo de unidades de comportamento ("behavior settings"). Nestas unidades as acões, o espaço onde elas ocorrem e os seus elementos participantes, são vistos como um conjunto inseparáve1 e interdependente. Embora partindo de base comportamentalista, BARKER desenvolveu noços a1tamente pertinentes e imersas em situaços reais, revalorizando a observação, a categorizaçăo e a interpretação de fenômenos espaciais, principalmente os de escala arquitetônica (MERCER 1975, ZEISEL 1981, LANG 1987).

Os "behavior settings" chegam a ser considerados unidades geradoras de informação para o projeto arquitetônico e urbano pois conforma um conjunto estável entre atividade e 1ugar (LeCOMPTE 1974, LANG 1987). Muitos estudos, inclusive, frisam a concep̧ão de "congruência espacia1", quando mostram a necessidade de compatibilidade entre o ambiente construldo, o comportamento social e as atividades humanas para o significado das cidades e 
suas partes (LERUP 1972; LYNCH 1976, 1980).

Muito util para o propósito dos planejadores, também é o relevante conceito desenvolvido por LEE (1970, 1977) para o bairro. Ele demonstrou que a identificacão e delimitaça de bairros deveriam ser tratados atravès de um método fenomenológico, diretamente dependente da experiência dos moradores, pela imposstbilidade de distinguir-se relações flsicas das sociais. Em suas pesquisas, a partir de fatores julgados determinantes dentre aqueles mencionados pelos entrevistados (relaçóes de amizade e localização de comércio/serviços locais), LEE conceituou um "quociente de vizinhanca", dependente do grupo social e do tempo de moradia, na delimitacão dos bairros. Seus achados demostram que existem aspectos urbantsticos que são vitais para os moradores em sua percepcão do bairro, como o ntve1 de socialização e as caracteristicas morfológicas, enquanto outros, como a densidade, são secundảrios. Noções estas que, aliảs, confirmam as teses clássicas defendidas por clarence PERRY (por volta dos anos 1920) que um bairro com limites bem definidos e heterogêneos tendem a possuir alto nivel de participação socia1.

Depois desta primeira fase, a psicologia ambiental desenvolveu campo de estudos próprio, complementando as duas 1inhas de estudos mencionadas com outras mais abrangentes, que tratam a questão dos processos de formaça de conhecimento ambiental e formação de imagens, valores, expectativas, atitudes e condutas.

- psicólogo CANTER (1977) apontou que nesta temática o pioneirismo cabe ao geógrafo WRIGHT que, em 1947, já propunha que 
- mundo fosse estudado da forma como é percebido, para complementar os estudos convencionais do mundo dito "real"; hoje os gedgrafos britânicos fazem uso da expressão "geografia comportamenta1" (behavioral geography) (GOLD 1980, GOLD \& GOODEY 1986). Por outro 1ado, muitos pesquisadores usam a expressão "psicologia ambiental/do meio ambiente" (environmental psychology) como mais abrangente (PROSCHANSKY et a 1 1970, LEE 1977, BELL et a1 1978) ou, ainda, simplesmente "percepcăo do meio ambiente/ambienta1" (CANTER 1977, WHYTE 1977, BAILLY 1979, GOODEY \& GOLD 1987). Entre as disciplinas de "design" é comum empregarse a expressão "comportamento ambiental" (environmental behavior) como a mais geral (LANG et al 1974, LANG 1987).

Seja qual for a expressão empregada, o objetivo fina1 sempre revela-se o mesmo: compreender as relaçoos entre experiência e conduta humana e o meio ambiente (PROCHANSKY \& ALTMAN 1979). Mas sem duvidas pode-se afirmar que uma das grandes caracterlsticas deste campo de estudos é que ele não pode se classificar nos moldes clássicos que fazem distinça entre pesquisa "pura" (teórica) da "aplicada" e que os fenômenos estudados não podem ser explicados por simples relaçóes lineares de causa-efeito (BELL et a1 1978, PROSCHANSKY \& ALTMAN 1979). Neste sentido, estes autores observam que, na psicologia ambienta1, é comum a utilizaça conjunta de métodos de pesquisa diferenciados: experimentais (fenômenos controlados), de correlações (relaçôes causa-efeito) e descritivos (simples descricăo de fenômenos). E, finalmente, os estudos de psicologia ambiental são sempre orientados para solução de problemas e, portanto, a integridade entre os atores e o ambiente deve sempre 
ser mantida (PROSCHANSKY \& ALTMAN 1979).

Um ponto em que os pesquisadores parecem concordar è em destacar a psicologia ambiental como àrea de estudos interdisciplinares, por definicăo, e as temáticas estudadas têem comprovado isto. GOODEY (1974), por exemplo, em trabalho sobre qualidade ambiental elaborado para a UNESCO (programa homem/bioesfera), relacionou os temas mais estudados relativos á percepcão ambiental como territorialidade, espaço pessoal, percepça do ambiente visual, estética arquitetônica e riscos ambientais. Dentre as disciplinas ou profissões envolvidas nestes estudos relacionadas por GOODEY eståo: antropologia, arquitetura, psicologia, paisagismo, engenharia, sociologia, geografia, saúde pủblica, psiquiatria, etc.

Tambèm frisando a interdisciplinaridade, ALTMAN (in MERCER 1975) apontou três temas que poderiam ser considerados básicos em suas pesquisas: lugares (edificio, bairro ou cidade), fenômenos (territorialidade, privacidade, etc.) e processos (avaliacão, utilizaçăo, projeto, etc.). Enquanto por seu 1ado, CRAIG (in PROSHANSKY \& ALTMAN 1979: 25) identificava as seguintes sub-àreas de pesquisa como as principais: avaliacão ambiental (as dimensões que o público emprega), percepcăo ambiental (reaços e impressões; fatores culturais relacionados a fatores ambientais), representações cognitivas, atitudes públicas e qualidade do ambiente sensorial.

Uma das associaços mais importantes nesta área de estudos, a norte americana Environmental Design Research Association (EDRA), tratou o espaço púb1ico como tema de um de seus ủitimos congressos e de seus anais depreende-se que os principais temas 
de discussão foram, além da participacăo comunitària, os efeitos da cultura nos usos e percepçóes dos ambientes, orientacão espacial em relaçăo a interiores e exteriores de prédios púb1icos, e ava1iação pós-ocupação (HARVEY \& HENNING 1987).

Enfim, todas estas temáticas, é importante que se sublinhe, sempre partem do pressuposto que "qualquer ato é feito em relacăo ao contexto em que o individuo pensa (grifo nosso) que esta... o organismo reconhece, se conscientiza ou de alguma forma leva em consideraçăo o seu contexto, o que, se falhar, torna qualquer açăo difici1, e a ação apropriada, impossive1" (CANTER 1977: 1).

Disto tudo, depreende-se que a psicologia ambiental năo pode ser obsessiva quanto a metodologias estatisticas e generalizaçóes, que depois podem mostrar-se tendenciosas ou acabam por nåo se aplicar a nenhum individuo. Tenta-se compreender os problemas ou fenômenos como únicos, segundo variantes de tempo, ambiente e ator, para a elaboraça das teorias explicativas. Como observado por WHYTE (1977: 11), importa "a visão de dentro... caracterizada por familiaridade e longa experiência... vista como personalizada e subjetiva".

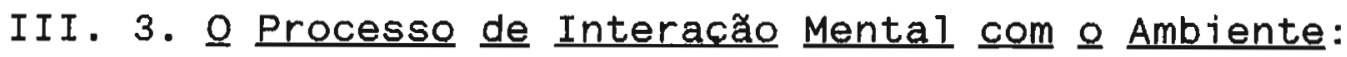

- processo de interação mental do Homem com o seu meio ambiente possui, como seu viabilizador exclusivo, a percepcão, que nåo deve nunca ser confundida com apenas a visual, como veremos. E por meio da percepcão que nossa mente se conscientiza e processa toda a informaçăo adquirida, seja através de meios diretos, os sentidos, seja através de meios indiretos, o imaginàrio, a socialização e o aprendizado. 
Conforme PIAGET (1969: 359) "as percepcões funcionam como conectores que estabelecem contactos locais e constantes entre, por um 1ado, açôs ou operaçôes e, pelo outro, objetos e eventos. As mensagens perceptivas săo transmitidas de uma forma figurativa, que é a única forma disponivel, e são decodificadas atravès de sua integração, tanto quanto possive1, no sistema de transformações".

Jà comentamos anteriormente que PIAGET entendia que este sistema de operaçôes correspondia a uma estruturaçăo progressiva e a uma dedução como coordenação de operaçôes, ao invés de um simples exerclcio de lógica: "funcionalmente falando existe apenas diferença de grau entre estruturas de experiência e constructos dedutivos" (PIAGET 1969: 358), onde "constructos" são os conjuntos mentais significantes. Existiria um continuum de atividade perceptiva entre a percepcão propriamente dita e a inteligência. Esta conceituaçăo introduz a importante noção de que o percebido năo apenas aumenta em quantidade com nossa idade e experiência, mas aumenta em qualidade.

Assim, segundo PIAGET (1969) existiria um saber figurativo, relativo a configuraçôes momentâneas através de contacto direto e imediato, e um saber operativo, relativo a operacões da inteligência com que transformamos partes do mundo em "esquemas" ou estruturas reconheciveis. A percepcăo visual è uma das formas do saber figurativo, enquanto a inteligência e a cognição se baseiam no modo operativo (MOORE \& GOOLEDGE 1976). Afirma OLIVEIRA (1978: 58) que em PIAGET a distinção entre espaco perceptivo e espaço cognitivo relaciona-se com suas proposiçóes sobre percepção e inteligência. 
A partir deste conceito e, principalmente baseando-nos nas obras de LANG et al (1974) e RAPOPORT (1977), podemos chegar a um quadro conceitual em nosso trabalho, onde o processo de interacão mental com o ambiente è entendido como composto de cinco componentes ou processos psicológicos básicos. Estes componentes săo sempre necessários e interagem de maneira integrada, em uma cadeia sucessiva; como em um moto perpetuo pois a cadeia é sempre realimentadora e define o continuum da inteligência (PIAGET 1969). Săo eles a motivaçăo, a percepcão, a cognicão, a avaliação ou julgamento e, finalmente, a conduta (Fig. 18).

o conceito de motivacão, já comentado anteriormente, é relativamente simples e está diretamente associado a nosso interesse, consciente ou inconsciente, de gerar o processo de interaçăo com o ambiente. Já vimos que sua importância está em que toda a percepcão é dependente de motivação, componente essencial de todo aprendizado. A motivaçăo è "...o processo de gerar a açăo, sustentar a atividade em curso e regular o padrão daque la atividade" (LANG et al 1974: 84). Além disto, estes autores relacionam a necessidade como a forca maior por traz da motivaçăo para interacão, de forma que os resultados transformem aquela necessidade inicial. Assim, a motivaça pode ser gerada com fins de superação de patamares de necessidades ou de atingir niveis de expectativas, como no conceito da escala de necessidades de MASLOW, comentada acima (RAPOPORT 1977).

Jà a avaliacão ou preferência ambiental é um componente do processo onde se expressam com mais intensidade nossos valores culturais, sociais e de grupo. E aqui que se expressa a identificaçăo de atributos ambientais e o julgamento da situaça 
especifica; è onde definem-se as categorias de qualidade ambientais em um processo de conhecimento (RAPOPORT 1977). Também é neste nive1 que podemos identificar a formacão de expectativas em funça de imagens ideais.

A conduta, é outro conceito interessante e o finalizador do processo de interaçăo ambienta1, uma vez que compõe-se das respostas que a mente processa, sejam elas manifestas, sob forma de açốs e comportamentos, ou não, sob a forma de novas imagens mentais, atitudes ou opiniões que realimentaråo imediatamente o sistema cerebra1. Evidentemente, devemos considerar também que a conduta gerarà uma re-alimentacăo no próprio processo de interação, causando alteracões em todos os seus niveis.

Seja como for, a conduta sempre reflete uma escolha ou opcão do individuo, seja mais ou menos independente, e è o componente final para a formação de opinião. Sobre a conduta expressam-se mais fortemente as influências individuais afetivas e temporais, tais como o "humor", que não são fortes o suficiente para a1terar os valores sociais ou de grupo expressos na preferência ambiental, mas podem originar atitudes e respostas temporariamente diferenciadas.

Entretanto, quanto aos componentes percepcão e cognicão, ainda existe bastante confusão no emprego destes termos e é conveniente que apresentemos a conceituaça que norteia este traba1ho.

Na noçăo clássica de percepcão, não mais aceita atualmente, os psicólogos experimentais consideravam-na como uma recepça passiva de estimulos ambientais, um resultado de excitaços fisiologicas dos receptores sensoriais que conota, portanto, 
imediatismo e dependência direta da existência dos estimulos (MOORE \& GOODLEDGE 1976, RAPOPORT 1977, CANTER 1977). Os individuos perceberiam sempre os mesmos objetos e elementos ambientais, independentemente de fatores culturais ou de personalidade, em uma massa de informaçoes ou estimulos, todos captados pelo cérebro, que em seguida os decodificaria.

Esta foi a orientaçăo dos estudos pioneiros de "psicologia da percepcão" aplicada ás artes ou á arquitetura, como as que fundamentaram-se nas teorias da gesta1t, quando viam na forma observada padrões coesivos inatos que, por definiqăo, subentendiam certos fatores, qualidades ou sentimentos, como ja observamos anteriormente. As reações ou condutas relativas a determinadas percepcóes seriam universais e sempre previstveis. Destacamos como exemplo o influente artigo de RAPOPORT \& KANTOR (1967), em que defendiam maiores niveis de complexidade e ambiguidade como fatores de qualidade universal para aumentar nosso interesse no espaco construido.

Nesta altura, devemos relembrar-nos dos conceitos relativos a este tema propostos por GIBSON (1966, 1974). Segundo ele, "as sensações são a matéria prima da experiência humana e as percepcões são o produto elaborado" (GIBSON 1974: 29). Ele parte de que os sentidos são como sistemas de percepcăo que se complementam, embora seja a visăo o que normalmente prevalece. Assim, considerados como sistemas, conceitua-se que os sentidos captam informaça do meio ambiente de uma maneira seletiva; a jà aparece uma distinção entre os "inputs" ao sistema nervoso que evocam sensacão daqueles que evocam percepça. 


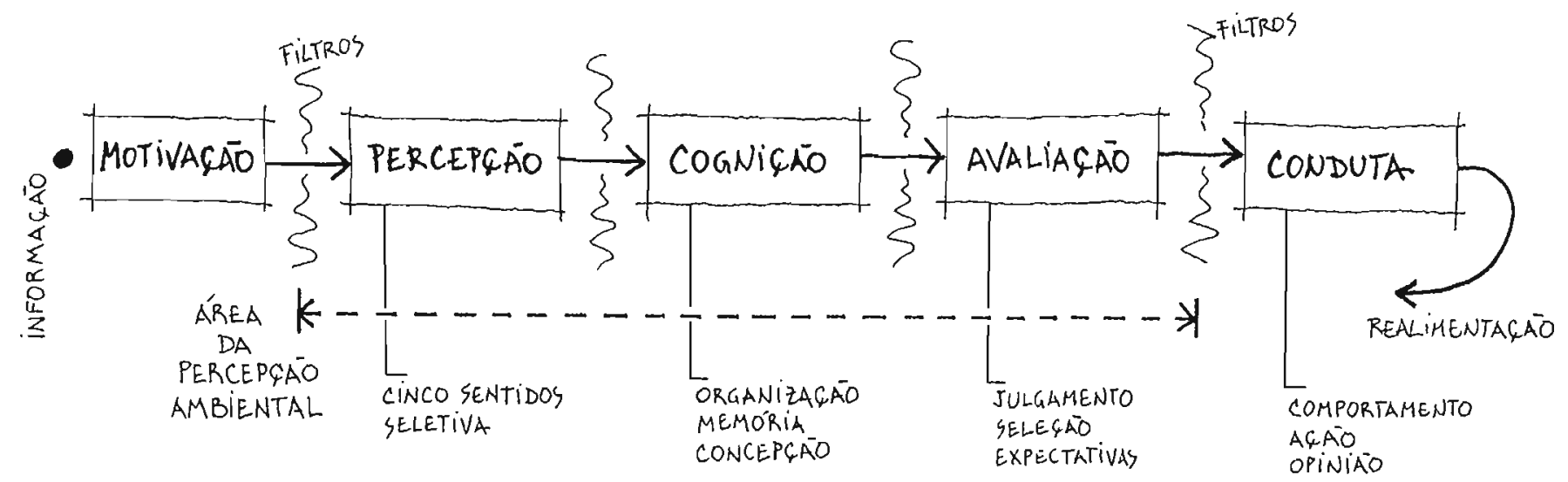

Fig. 18: Esquema teórico do processo de interação ambiental.
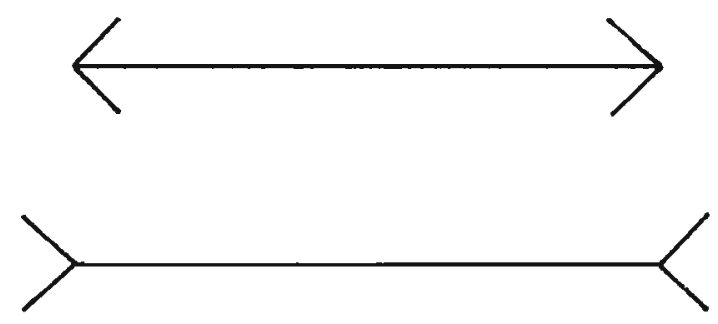

Fig. 19: Ilusão de Mueller-Lyer; exemplo de como a cultura influencia a percepção: algumas sociedades enfatizam a dimensão horizontal e outras a vertical, variando na conclusão sobre o tamanho das figuras idênticas. 
Segundo GIBSON, o que é percebido, o "percepto", è essencialmente subjetivo e depende de contribuiçoses do observador, através de peculiaridades e experiências anteriores. o processo mental que comanda as sensações visuais, diz GIBSON (1974) pode ser considerado como um processo de associaçóes e inferência.

Por isto ele desenvolve a importante distinção entre campo visual e mundo visual. Campo visual è o que alcançamos perceber da realidade através dos sentidos; o percebido está atrelado ás sensações e possui limites. Jả mundo visual refere-se ao percebido para além dos estímulos sensoriais diretos: sendo inferido, não possui limites fisicos objetivamente identificados.

Mas, mesmo que se aceite o pensamento de GOLD (1980) que a percepção é fundamentada no aprendizado, não podemos esquecer dois pontos importantes. Primeiro, que pesquisas experimentais sugerem que a percepcão de distância e de profundidade estão presentes nas crianças mais jovens e podem até ser habilidades inatas e possuirem caráter evolutivo. Segundo, que não podemos descartar os argumentos de que determinadas manifestaços espaciais são adquiridas hereditåriamente, como a territorialidade.

Por outro 1ado, a conceituaçăo aceita de cogniçăo a apresenta como o processo do saber operativo, que é reconhecidamente amplo, permitindo lidar, consciente $e$ inconscientemente, por um lado com a informacăo selecionada e apreendida, pelo outro com a sua organização em representaços simbólicas, conjuntos significativos, sistemas de valores $\theta$ tendências para determinados tipos de conduta. 
E interessante ilustrar a conceituação de cognição com um modelo operacional informático, que simula bem o trabalho da mente humana (LANG et al 1974: 91). Neste modelo, "inputs" de sensações e percepções competem com informaça interna para serem estocadas em uma pequena memória de vida curta. Esta memória de primeira fase filtra os "inputs" para uma memória intermediària chamada de aquisiçăo, que gera as funçôes, reconhece $e$ conceitualiza as informações em representacões. Esta memória pode ser vista como a de trabalho do pensamento naquele momento e guarda as representaçoses durante algumas horas atè serem transmitidas á memória chamada permanente, de tamanho ilimitado, onde são estocadas as imagens para uso futuro. DOWNS (1970 in SAARINEN 1976: 10) nos apresenta uma interessante descricão de um esquema conceitual que traduz o processo básico de percepcão ambienta1:

"O mundo real è tomado como ponto de partida e é representado como fonte de informacăo. 0 conteudo da informaçăo penetra no individuo através de um sistema de receptores perceptivos e o significado preciso da informaçåo e determinado pela interaçăo entre o sistema de valores do individuo e a sua imagem do mundo. O significado da informação è então incorporado á imagem. Com base nesta informacão, o individuo pode precisar se ajustar com relaçăo ao mundo real. Esta decisão é expressa como uma decisão que pode, evidentemente, não envolver nenhuma reação manifesta. Existem duas cadeias a partir do conceito de uma decisão (embora elas possam ser juntadas). A primeira é um processo de reciclagem, chamado busca, onde o individuo decide que suficiente informaçăo já foi adquirida, ou alguma limitaçăo de tempo ou custo atua como restricăo a mais uma busca. A decisăo é entăo tomada e pode ser expressada como um conjunto de comportamentos que, por sua vez, irà afetar o mundo rea1. Porque o mundo real muda, nova informaqăo podera resultar e o processo todo pode continuar. O esquema, portanto, permite que o processo de percep̧ão do espaco ocorra em um contexto tanto espacial quanto temporal". 
Evidencia-se que, dentro desta conceituaça de processo geral de percepcão, a cogniçăo é gerada por processos mentais especificos de categorizaça, organizaçăo e reconhecimento destes estimulos (CANTER 1977: 8). O processo cognitivo está, portanto, sujeito a "filtros" socio-culturais, categorias e sistemas resultantes do processo de socializaçăo do individuo, e a "filtros" psicológicos", dependentes do sistema interpretativo pessoal, de valores e expectativas de cada pessoa (Fig. 19).

RAPOPORT (1977: 38) tambèm reconhece a importância destes "filtros" para os processos cognitivos, definindo a diferenca entre "mundo real" e "mundo percebido" atraves de diversos filtros, como os de informą̧̃es (conhecimento) e o de atitudes (objetivos). Ele exemplifica isto com o classico estudo sobre o West End de Boston escrito por GANS (1971) em que o autor notava que quando mudou-se para aquele bairro, sua cogniçăo da área mudou dramáticamente, não mais vendo-a como deteriorada $e$ decadente como a imagem popular da maioria dos não-residentes, mas como local de intensas e significativas atividades humanas.

Ora, se as estruturas cognitivas pré-existentes influenciam a percepcăo, desde a motivação para iniciar o processo, selecão das sensaçôes processadas, em sua ava1iacăo e na prédisposicão á conduta, a percepção è subordinada á cognicăo que a pressupõe funcionalmente (PROSHANSKY 1974, MOORE \& GOODLEGE 1976).

O estudo da cognicăo ambienta1, portanto, 1ida com "...as informacõos subjetivas, imagens, impressőes e crenças que as pessoas possuem do meio ambiente, as maneiras com que estas concepções surgem com a experiência, e as maneiras como afetam a conduta subsequente em relacão ao meio ambiente" (MOORE \& 
GOOLEDGE 1976: 3). Para estes mesmos autores, as cogniçôes são "... a consciência, imagens, informaçăo, impressôes e crenças que individuos e grupos possuem sobre os aspectos elementares, estruturais, funcionais e simbolicos de ambientes reais e imaginários, sejam eles fisicos, sociais, culturais, econômicos e politicos" (MOORE \& GOOLEDGE 1976: 5)

Assim é que para muitos arquitetos, sociólogos e geógrafos, o significado do termo percepcăo ampliou-se, seguindo a conotação mais global e popular, incluindo percepcões, imagens, memórias, preferências e atitudes, ou seja, todos os fatores psicológicos que afetam o comportamento (MOORE \& GOODLEDGE 1976, RAPOPORT 1977, GOODEY \& GOLD 1987).

Adotaremos a visão que parece prevalecer, coincidente com a de RAPOPORT (1977) que trata a percepcão ambiental como um continuo dos seguintes processos: percepcão, propriamente dita, cogniçăo e avaliação. Nunca esquecendo que "toda percepçăo inclui julgamentos" (RAPOPORT 1982: 51). Portanto, a percepcão ambienta1 è definida pelo que você vê (realidade), pelo que você conhece (experiência) e pelo que você espera (expectativas).

Esta tambèm jà havia sido a postura de LYNCH (1961) ao analisar a percepcăo urbana, embora concentrando-se em aspectos puramente visuais. Na mesma 1inha, mas ampliando-a para incluir aspectos funcionais e sociais, APPLEYARD (1977) desenvolveu o seu famoso trabalho em ciudad Guayana. Nele abordava-se as diferentes percepçós que os grupos de usuários e planejadores tinham da cidade, no sentido em que estas permitiam diferentes interpretaçôes de significados e de utilizaçăo da cidade. 
SAARINEN (1976) tambèm adota esta conceituaçăo, referindose á Enciclopédia Internacional de Ciências Sociais para defender que percepcão depende, além do estimulo presente, das experiências passadas, valores, necessidades, expectativas, etc.

No Brasil está é a nocão de percepcão que prevalece, como quando MACHADO (1988), em seu estudo da Serra do Mar enquanto paisagem valorizada, apresenta-a como processo de atribuiçăo de significados ás informações sensoriais. Isto, na realidade, implica tanto no conhecimento direto e atual, quanto na atribuicăo de valôres pois subentende seleçao dos impulsos sensoriais recebidos, jà conformando atividade inteligente e 1 igada á cognicăo.

Portanto, como comentado por WHYTE (1977: 15), a expressão percepcăo ambiental hoje em dia é mais utilizada para significar a conscientização e compreensão humana do meio ambiente em um sentido geral" e, embora este seja o sentido popular adotado para "percepcão", ele fica mais próximo á "cognicão" em termos psicológicos estritos.

III. 4. A Formacão de Imagens Mentais:

Dentro do processo de interacão ambiental que descrevemos anteriormente, e do processo de percepcăo ambienta1 especificamente, våo nos interessar os conceitos de imagem mental e de avaliacão ambiental. A razão para destacarmos estes dois conceitos é por acreditarmos que é neles que se apoia fundamentalmente a conduta e, consequentemente, nossas opiniơes sobre o ambiente, construido e urbano em particular. Já apresentamos comentários suficientes para introduzir esta questão 
e sua importância no processo geral de interacão ambiental, mas traremos a seguir alguns comentarios mais especificos.

E sabido que a comunicacão humana foi iniciada através de sons e gestos, que alcançavam significados bastante limitados, para depois desenvolver-se através do desenho rupestre. WALTER (1988: 83) menciona que "vinte e cinco mil anos antes dos primeiros traços de linguagem, o Homem jà venerava animais, rezava á mãe-Terra, estabelecia locais sagrados... e expressava sua religiosidade através de desenhos que marcavam, pintavam ou modelavam nas paredes das cavernas".

Sem dủvida, o desenho foi dominado antes da escrita, uma vez que esta solicita uma maior sofisticaça de raciocinio, abstração e dominio de um sistema simbólico e, provavelmente, antes do desenvolvimento de uma linguagem falada (ECO 1976). A facilidade de comunicação do desenho, tomado como signo icônico, é por sua semelhança com o objeto que representa, deixando pouca margem para conotaçoes diferenciadas. O historiador Arnold HAUSER (1951: 21) chegou mesmo a sugerir que, em relação aos motivos de caça, a arte prẻ-histórica rupestre "...não era... uma funçăo simbólica, senăo uma ação objetivamente rea1..." antecipando o feito e assumindo função mágica ou mitológica.

Depois disto, em estágio de desenvolvimento mais avancado, - Homem pôde organizar sistemas de simbolos escritos, primeiramente iniciados por pictogramas e ideogramas justamente pela sua facilidade construtiva e semelhanca imagética com os objetos que representavam (MUNFORD 1961, MORRIS 1979). Vemos que - desenho e a imagem são constantes na cưtura das civilizaços, acompanhando o seu desenvolvimento. 
Por isto LANG et a1. afirmam que o pensamento sempre foi caracterizado pela habilidade de pensar visualmente e utilizar conscientemente imagens ambientais (LANG et a1 1974: 92). KAPLAN tambèm afirma que "conhecer è ser capaz de vê-10 em sua mente, pensar muito sobre ele, imaginá-10, senti-10. Algumas vezes conhecer algo è ser capaz de dizê-10..." (in STEA 1974: 187).

Portanto, nosso processo de cognição, anteriormente conceituado, tem por base informações mentais que nada mais são do que representacôes ou constructos hipotéticos que permitem evocação simbólica de realidades ausentes (MOORE \& GOOLEDGE 1976). Estas representações ou imagens assumem importante pape 1 na memória e nos processos de reconhecimento (LEE 1977) e podem ser adquiridas através de experiência direta ou através da indireta, na socialização, como vimos antes; o mais provável é que sejam um amảlgama de ambas. Segundo LYNCH (1960: 6):

"Imagens ambientais são resultado de um processo de dois sentidos entre o observador e seu ambiente. O ambiente sugere distinçōes e relaçóes, e o observador, com grande adaptabilidade e á luz de seus próprios propósitos, seleciona, organiza e presta significado áquilo que ele vê. A imagem assim desenvolvida agora limita e enfatiza o que é visto, enquanto a imagem propriamente dita vai sendo testada contra o input perceptivo filtrado em um processo interativo constante".

OLIVEIRA (1978: 55) ao analisar a obra de PIAGET e seus associados, comenta que a imagem mental é por eles definida como "...imitaça interiorizada, como uma especie de suporte do pensamento" e que fazem diferenciação desta para a imagem espacial em que "...destacam o problema do movimento e de suas relaçós com o elemento figural e sensive1". Também RAPOPORT (1977) diz que imagem em geral è vista como uma representação interna e que imagem ambiental è a representaçăo mental do 
individuo de partes da realidade externa conhecida por ele através de quaisquer tipos de experiência, inclusive indireta. A imagem mental supervaloriza alguns aspectos em detrimento de outros, segundo os filtros sociais e individuais (BAILLY 1979).

Além disto, se o percebido transforma-se qualitativamente com a experiência e o desenvolvimento intelectual, como estudado por PIAGET e já comentado anteriormente, estas representaçōes cognitivas ou imagens mentais văo tornando-se cada vez mais próximas das reais, embora nunca possam chegar a ter uma correspondência perfeita com a realidade (MOORE \& GOOLEDGE 1976).

Dizia PIAGET que:

"...a adequabilidade relativa de qualquer percepcăo em relaçăo a qualquer objeto depende no processo construtivo e năo de um contacto imediato... (quando) o sujeito tenta fazer uso de toda e qualquer informação que ele possui... e de construi-1a em um sistema que corresponda tanto quanto possivel ás propriedades do objeto. Ele apenas pode fazer isto através de um método que é simultaneamente cumulativo e corretivo..." (PIAGET 1969: 365).

Estas representações cognitivas são tratadas por nomes diferentes mas seguem básicamente a mesma conceituação, que é possibilitar o processo cognitivo, o raciocinio e o pensamento. Assim, encontramos: "percepto" (GIBSON 1974), representações ou imagem mental (PIAGET \& INHELDER 1967), imagens mentais (LYNCH 1960, APPLEYARD 1976, OLIVEIRA 1978, BAILLY 1979), constructo (LEE 1977) ou imagens cognitivas (PIPKIN 1983).

Como nos Tembra RAPOPORT (1977) até em marketing e publicidade utiliza-se do conceitos de imagem, onde ela é entendida como a capacidade do produto de satisfazer a determinadas expectativas, personalidades e sistemas de valores.

Sobre a consolidação do papel papel da imagem em nossa 
vida, diversas publicaços apontam a importancia dos trabalhos de Frederick BARTLETT, de 1932, e de Kenneth BOULDING, de 1956. O primeiro publicou um livro intitulado "Remembering" (Lembrando) onde defendia a existência de processos mentais direcionados á lembrança e ás imagens, mostrando a importância destas representaç̃es quando o individuo tenta reconstruir um quadro conceitual.

Com o livro "A Imagem", publicado em 1956, BOULDING é apontado como o responsável pelo estimulo aos estudos da imagem nas ciências sociais e na geografia em geral (RAPOPORT 1977, CANTER 1977, GOLD 1980). Ele defendia que toda nossa conduta è dependente da imagem, ou do que acreditamos ser verdadeiro, definindo imagem como todo conhecimento adquirido e acumulado. Dizia ainda que elas são muito resistentes á alteraçăo e rejeitam a principio todas as mensagens que as contrariam, num processo muito parecido com a noção de mudancas de paradigmas nas ciências (RAPOPORT 1977). BOULDING conceituou ainda dez tipos de imagens que RAPOPORT (1977: 43/47) resumiu a três: relativas a valores $\theta$ preferências, relativas a conhecimento factual, e relativas a estruturas e propriedades comuns.

Ainda sobre a questão da imagem, PIAGET (1969) propõe adotarmos dois tipos de representaçăo: a representacão cognitiva, ou conceitua1, (representação no sentido do saber) e a representacăo simbỏlica (re-apresentaçăo de realidades ausentes). Ele chama a combinaçăo destas representaçôs de "esquemas" ou estruturas de representacão, que possibilitam o processo de pensamento e a inteligência.

LEE foi aluno de BARTLETT e aplicou suas noçôes de formaça 
de imagens no contexto urbano (CANTER 1977), e em seu estudo sobre bairros, jà mencionado anteriormente, referiu-se a "schemata" sócio-espacial ou mapa cognitivo como o constructo hipotético do bairro da forma como ele è apreendido por seus habitantes (LEE 1974, 1977). Recentemente, LANG (1987) também se utilizou do termo "schemata" como as representacões cognitivas que viabilizam a experiência e o pensamento, concentrando informaçôes em padrões coerentes. Este autor diz ainda que as imagens ambientais que carregamos conosco săo um tipo de "schemata" e classifica-as como imagens icônicas (mapas cognitivos) ou associativas (simbolicas).

Segundo GOLD (1980), os "esquemas" săo um sistema de codificação que permite respostas apropriadas, são dinâmicos e incorporam seletivamente novo material; propõe ainda duas subcategorias para os "schemata" espaciais: 1ocacional e conhecimento de atributos.

Parece, portanto, que estes autores sugerem que os "schemata" săo uma versăo mais elaborada das imagens mentais, como estruturas mais complexas, que incluem simbolos e combinações operacionais entre eles. Entretanto, nåo nos importando neste estudo tanto o rigor acadêmico, sacrificando-o em prol de maior pragmatismo, trataremos os dois conceitos acima, de imagem mental e schemata, em relação á percepção ambienta1, como sub-categorias da imagem ambiental, a exemplo da maioria dos autores. Os proprios resultados das cognicôes posstveis se revelam, por si mesmos, mais ou menos complexos.

Finalmente, cabe mencionar que podemos falar da existência de "imagens públicas" ou "coletivas", comuns a determinados 
grupos sociais ou culturais (LYNCH 1960, APPLEYARD 1976, CANTER 1977, LEE 1977, GOLD 1980, OLIVEIRA 1983). Se aceitamos a hipótese de que valores, assim como determinados conhecimentos, săo compartidos e seguem determinados padrŏes, podemos falar em uma imagem pủblica como o amálgama de imagens individuais que possuem caracteristicas compartidas e comuns (Fig. 20).

Se existe uma hipótese básica comum aos inúmeros estudos e pesquisas sobre "imagem da cidade", constantes na 1iteratura especializada, ela resume-se á possibilidade de concluirmos imagens publicas a partir da composicăo de imagens individuais, onde pode-se inferir aspectos comuns a partir de cogniços comuns. Aspectos estes que poderiam ser tomados como conformadores de uma essência imagética da àrea estudada, um conjunto de imagens compartidas.

\section{5. Avaliacão Ambiental e Conduta:}

Em seguida destacaremos a importância da avaliacão ambiental e da consequente conduta, os dois estágios finais no processo de percepcão ambienta1. E na atividade de avaliacăo que nossa mente atribui valôres e forma julgamentos (TUAN 1980, MACHADO 1988). Já a definicăo da conduta, como vimos, pode ser formada por atitudes, formaçăo de opinião ou aça manifesta sobre uma drea ou bairro.

CANTER (1977: afirmava que qualquer menção a um lugar possui em si avaliação e expectativas diretamente relacionadas com a conduta considerada apropriada para eles. "A avaliaça è uma componente frequente e recorrente de nossas concepcóes dos 1ugares" (CANTER 1977: 163). 
Fig. 20: Imagens públicas são compartidas por todos em sua percepção sobre os lugares, como o Cristo Redentor no Rio e como explora o anúncio da SWISSAIR ao formar uma cidade ideal com as imagens públicas de diversas.
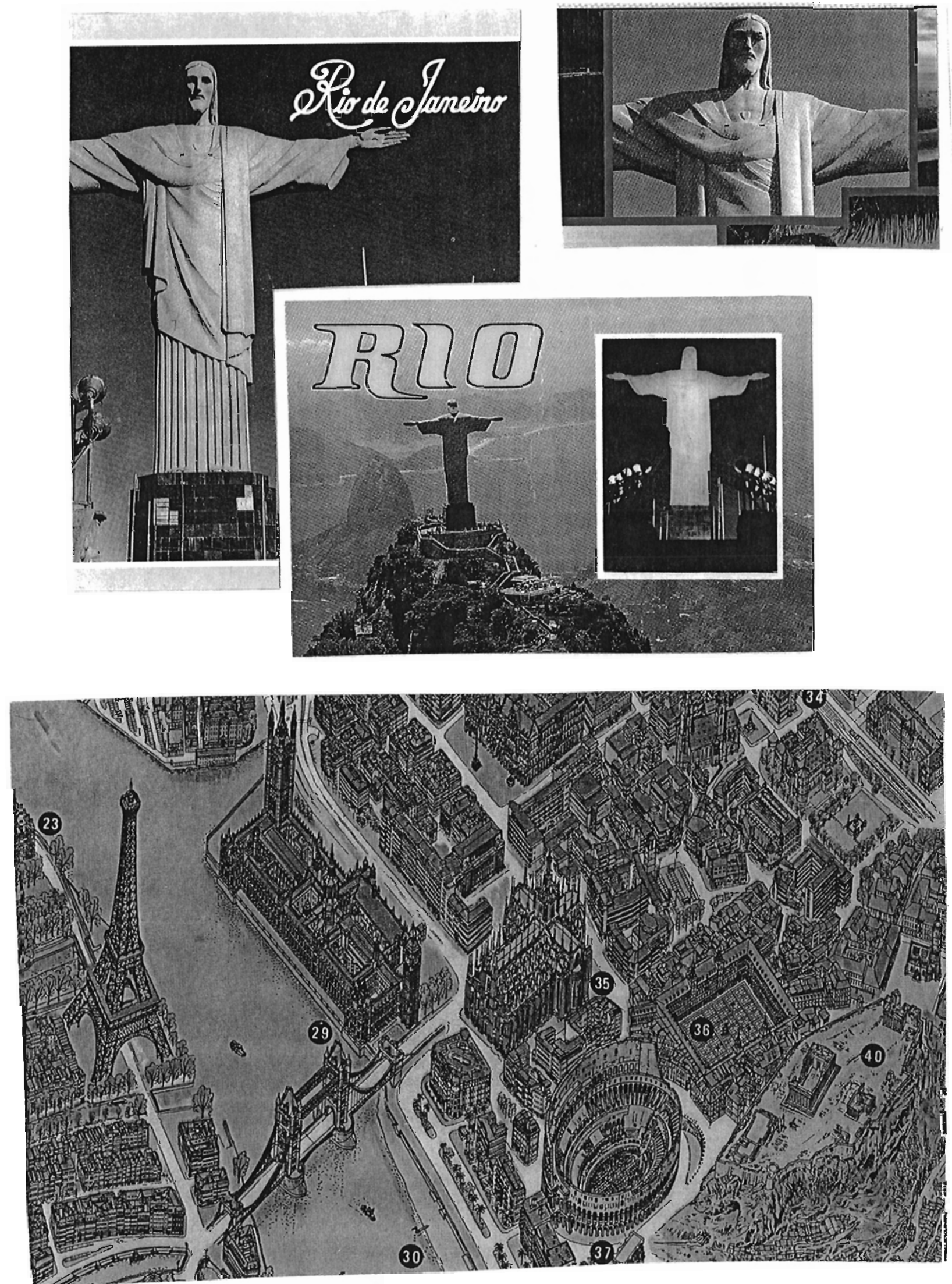
Como vimos antes, também RAPOPORT (1977: 60) chama atençăo para a avaliaça ambiental ser mais uma resposta afetiva e de funçăo latente, do que uma análise de detalhes especificos e de funções manifestas. Estas avaliações e preferências ambientais evidentemente săo fatores essenciais na definicăo do caráter de uma bairro em relaça á sua cidade, dos valores de mercado alcancados pelos seus imóveis, do seu prestigio social, sua fama ou "imagem" junto á populaçăo, se negativa ou positiva.

LEE (1977) reconhecia da mesma forma a importância dos estados de ânimo, predisposições, emoções e motivações para a complementacăo do processo perceptivo e sua consequente organização para a conduta, "...numa sintese organizada de sentimentos, cogniçóes e motivações que nos predispõem para o comportamento" (LEE 1977: 57 ).

Fica assim evidente a importancia dos processos de avaliação e de preferências ambientais para a tomada de decisões. Neste sentido, por exemplo, é que pesquisa-se a maneira como diferentes grupos sociais avaliam diferentemente os riscos ambientais ("hazards"), como as causadas por vulcôes ou pragas, e de como as consequentes percepcoes destas ameacas definem condutas opostas (DOWNS \& STEA 1977, WHYTE 1977, GOLD 1980, ZUBE 1984). Os valores e as expectativas de determinadas populações muitas vezes fazem-nas ignorar ameacas eminentes, seja por acharem que a possibilidade de outro desastre é "muito remoto" ou porque encontram-se "nas måos de Deus".

Os tipos de conduta adotados pelas populaçôes atingidas por estes riscos ambientais, segundo suas diferentes percepcões e julgamentos, podem ser a absorcão do risco, a aceitaçăo das 
perdas, a reduça dos prejulzos ou a mudança da àrea (WHYTE 1977, OLIVEIRA em aula 1988). A mesma noção de avaliação e conduta, a partir de diferentes percepcôes, pode ser aplicada á problemática do 1 ixo urbano e seu destino final (OLIVEIRA 1983).

Para uma avaliacão ambiental e definicăo de preferências é necessária a identificacão concomitante de seus atributos fisicoespaciais, sociais, etc, que contribuirão para o julgamento (CANTER 1977). Assim é que diversas pesquisas para estudar a avaliação de um lugar, relacionam atributos espaciais e fisicos, por exemplo, em escalas de pólos opostos, a fim de que os respondentes identifiquem uma gradaça, mais positiva ou negativa, para cada um (LOWENTHAL 1972, LOWENTHAL \& RIEL 1972, SANOFF 1974).

A lógica para uma análise avaliativa, segundo esta metodologia, pode ser justificada através de TUAN (1980), que mostra que ao longo da historia, dos rituais religiosos e práticas sociais, a mente do Homem tende a organizar fenómenos em pares opostos, refletindo uma tendência binaria, em um sistema lógico duatista, intuitivo e arquetipico.

A existência de expectativas ambientais, durante e na atividade de avaliação, tambèm nos prédispôe para a ação ou a conduta prevalecente, no sentido que conforma uma situaçăo ideal ou um conjunto de possibilidades assumidas como reais num contexto determinado. o processo de desenvolvimento do conhecimento adquirido, em conjunto como o de socializaçăo, tambèm ajuda a conformar estas possibilidades de expectativas. As expectativas podem ser tomadas como "imagens ideais" ou simbolos sociais a perseguir (RAPOPORT 1977). 
A atitude, componente do processo de conduta, pode ser também definida como uma tendência ou pré-disposicăo para responder a uma situaçăo de modo favorável ou não, assumindo-a como positiva ou não (BELL et a1 1978, GOLD 1980). Ela predispõe para determinadas condutas e è relativamente duradoura no tempo. A diferença entre expectativas e atitudes está em que atitude pode ser entendida como um resultado do processo de avaliacão na percepcão ambiental, em que a situação é medida e avaliada também face ás expectativas que possutmos.

BELL et a1. (1978) apontam os três tipos de formação de atitudes a partir do aprendizado: condicionamento clássico ou pavioviano (estimulo-resposta), condicionamento instrumental (atitude como funçăo das consequencias) e aprendizado social (teoria de desenvolvimento de PIAGET). Como vimos, este tipo de formaça de atitudes é o mais aceito se analisado face ao desenvolvimento das capacidades cognitivas do Homem.

TUAN (1980) e SAARINEN (1976), por exemp1o, comentaram como as atitudes em relaçăo á cidade eram negativas para a maioria dos pensadores norte-americanos desde Thomas Jefferson a Frank Lioyd Wright, arraigadas ao sistema de valores puritano. A vida urbana era associada a uma série de amoralidades e decadência, enquanto - campo era visto como o reduto da pureza. Já na Europa, o passado servia para situar o urbano além do bem $\theta$ do mal, embora não era esta a visão de muitos dos chamados socialistas utópicos como Robert OWEN e Charles FOURIER, que buscavam mudancas sociais instrumentadas por projetos fisico-espaciais (BENEVOLO 1971).

Ao analisar as diferentes percepçoses da serra do Mar Paulista, por exemp1o, MACHADO (1988: 252) descobriu que sua 
percepcăo geral é altamente positiva. Consoante com os valores afetivos e as atitudes dos diferentes grupos de respondentes, elas eram "...bastante positivas, coerentes e vigorosas, tanto em relacăo á proteçăo, preservaçăo e manutençăo das encostas serranas, como em relaçăo á consequencia da açăo sobre ela...".

E por isto que ZUBE (1984) descreve que a nocão de metas ou objetivos refere-se a uma estado final desejado ou idea1, expresso em termos de valores. Diz ainda que "os valores săo antecedentes essenciais para a avaliaçăo, pois ajudam a especificar as necessidades e os problemas, constituindo-se em um ponto de partida no processo de avaliaçăo" (ZUBE 1984: 3). Cada decisăo ou conduta relativa a um lugar, ainda segundo o mesmo autor, significa julgamento entre percepcões especificas e as projeções de nossas necessidades e valores pessoais.

Por seu 1ado, os sistemas de valôres dos grupos sociais já săo mais diftceis de se identificar através da pesquisa direta, uma vez que são sócio-culturalmente adquiridos, fazem parte inseparável dos sistemas lógicos e possuem maior constância no tempo. E muito mais diflcil a alteração dos valôres do que das atitudes. O racismo, por exemplo, è tido como um sistema de valores e, embora a atitude de uma pessoa racista possa modificar-se em relaçao a uma situaçăo especifica, seus valores năo necessariamente serăo alterados.

Em relação ao nosso estudo de caso, para a revitalizaçăo da Area Portuária do Rio de Janeiro, estará lidando-se com a identificaçăo de repertório de imagens, seus elementos conformadores, atributos e atitudes ambientais, e uma série de expectativas de desenvolvimento. Estes aspectos participam do 
processo de percepcão, mais especificamente da cognicão ambiental, e seu estudo deverà viabilizar o desenvolvimento de diretizes de desenho urbano mais consequentes no sentido de viabilizar a consolidaçăo de imagens e condutas positivas em relacăo aos investimentos e usuários da área. O Capitulo seguinte tratarà da operacionalizaçăo dos estudos de percepcăo ambiental. 
"... there are some significant and fundamental constancies in the experience of the same place by different people" (LYNCH 1981: 131)

Nos capitulos anteriores desenvolvemos um quadro teórico relativo aos conceitos e noçôes de percepçăo ambiental, desenho urbano e revitalização, integrados e capazes de nortear o desenvolvimento de nossa pesquisa. Agora, nas linhas que se seguem, comentaremos como os estudos da percepção ambiental podem vir a ser aplicados e operacionalizados dentro de um contexto de intervenção urbanistica de desenho urbano para revitalizaçăo.

Ficou claro que os objetivos de uma politica publica consciente no sentido de respostas ideais a anseios legitimos da população interessada, e que busque a revitalização de àreas centrais, devem 1 idar com o processo de percepcão ambiental destes grupos populacionais. Vimos que o estudo da percepcão pủblica da àrea em queståo deve evidenciar quais as imagens e atributos qualitativos positivos, assim como avaliaçoses e expectativas; isto dá ao pesquisador possibilidades de direcionar as diretrizes de desenho urbano no sentido de cognições publicas positivas, valorização e, consequentemente, de novas condutas dos usuários existentes e em potencial para com a área revitalizada. 
Resta-nos ainda comentar como os estudos da percepcăo ambiental podem vir a ser operacionalizados com estes objetivos, a fim de definir um quadro metodológico para nossa pesquisa. Para tanto, trataremos de algumas conceituaços operacionais e evidências emplricas publicadas na 1 iteratura especializada. Por operacionalizacão queremos dizer metodologias, instrumentos e técnicas aplicadas, suas vantagens e limitaçoes nos contextos apresentados.

Também é importante observar que a complexidade do tema da percepcão ambiental, bem como a sua relativa pouca idade em termos de pesquisa, fazem com que existam diversas dificuldades metodologicas reconhecidas (LANG et al. 1974, SAARINEN 1976, MOORE \& GOOLEDGE 1976, DOWNS \& STEA 1977, GOLD 1980, PIPKIN 1983). Tampouco existe um método tido consensualmente como "melhor" ou "mais valido" para estudar o tema, principalmente em se tratanto de estudos que, por definicăo, devem estar relacionados a contextos reais, não de laboratório, e em que importa mais a qualidade do que a quantidade de informaçóes (MACHADO 1988). No entanto, jà è posstvel identificar alguns métodos e criterios mais amplamente aceitos.

Estas dificuldades foram bem expressas em um exemplo de SAARINEN (1976: 9) quando, comentando a complexidade de se tentar generalizar o estudo de situaçôs reais, cita uma pesquisa em que se estudou apenas cento e dezenove crianças de uma cidade norteamericana e estimou-se que elas se engajavam em mais de 36 milhơes de episodios comportamentais ao longo de um ano! E isto foi uma pesquisa de cunho comportamenta1, supostamente mais simples que uma de cunho perceptivo, mais epistemológico. 
IV. 1. Pressupostos Para a Operacionalizacão da

Percepcão Ambiental para o Desenho Urbano:

No sentido da operacionalizaçăo dos conceitos e resultados de estudos de percepção ambiental para o desenho urbano e a revitalização, em termos de objetivos e diretrizes, é necessário que sejam aceitos quatro pressupostos básicos, que concluimos da discussão anterior e mais especificamente dos trabalhos de PROSHANSKY et al (1976), WHYTE (1977) e ZEISEL (1981). Inúmeras evidências empiricas publicadas comprovam a propriedade destas suposiç̃es na maioria dos casos.

Primeiramente, supõe-se que possam existir caracteristicas ambientais, elementos fisico-ambientais e/ou simbolos, suficientemente compartidos por parcelas significativas da população a ponto de contribuir para nossa afericão de imagens publicas ou coletivas. Esta possibilidade, dentro da temática da formação da imagem no processo cognitivo, jà foi discutida anteriormente, bem como a sua importância no desenvolvimento do conhecimento, raciocinio e socialização.

Em segundo lugar, supర̃e-se que a percepção e a consequente conduta humana em relação a um ambiente seja consistente e duradoura o suficiente para viabilizar mediç̃es, conceituaç̃es e generalizações. Consistência e durą̧ão no sentido de compreensão do fenômeno, sua manutenção em determinado pertodo de tempo, a probabilidade de sua repetição, a replicabilidade da situação e verificabilidade no mesmo grupo e contexto.

Em terceiro lugar, é necessário aceitar que alguns elementos, imagens, valores e expectativas, visuais ou não, podem ser identificados e a sua intensidade medida. Da mesma forma, a 
importância relativa e absoluta destes elementos no processo de percepção devem poder ser compreendidas, bem como a relação e os processos operativos entre eles.

Finalmente, o quarto pressuposto para a operacionalizaça dos estudos de percep̧ão ambiental è que seus fenômenos possam ser medidos e representados de forma que possibilitem a anàlise e as comparaç̃os. Evidentemente, para completar o processo de comunicação humana, as estruturas cognitivas e de avaliação internas devem poder assumir representaçסes externas, tomando a forma de algum dos sistemas simbólicos de comunicacão e socialização, como o desenho, a escrita ou a fala.

E apenas através destes quatro pressupostos que podemos partir da hipótese básica que os resultados de estudos de percepcão em principio serão sólidos o bastante como para viabilizar sua operacionalização em polfticas pủblicas e diretrizes fisico-ambientais consequentes.

Esses pressupostos conformam o quadro das metodologias mais populares no estudo da percepcão ambiental para o desenho urbano e que nortearão nossa pesquisa, segundo a definicão temática que traçamos nos Capttulos anteriores, e excetuando-se os enfoques comportamentalistas que possuem outras especificidades (LANG et a 1 1974, MICHELSON 1975, WHYTE 1977, GEHL 1980, ZEISEL 1981).

Sobre esta questão metodológica e de representatividade, è preciso frisar que a própria natureza dos estudos de percepcão ambiental coloca a qualidade da informação em primeiro lugar. o tamanho da mostra escolnida, por sua vez, ao contrário de sua representatividade enquanto sub-grupo, não possui muito 
significado pois se fôssemos determinar uma amostragem estatisticamente "vảiida" para representar a populaçăo envolvida, a questăo da qualidade de informaçăo fica necessariamente prejudicada e a pesquisa, geralmente, inexequivel (WHYTE 1977, BAILLY 1979, ZEISEL 1981).

Com base em MOORE \& GOOLEDGE (1976: 19), podemos dizer que existem duas àreas metodológicas bàsicas, essencialmente diferentes, para a pesquisa da percepça ambiental no desenho urbano: a que se utijiza de questionários, entrevistas e outros levantamentos de campo, e aquela que apoia-se em análises da 1 iteratura e outras fontes indiretas.

IV. 2. Operacionalizacão Através de Fontes Indiretas:

As fontes indiretas de pesquisa da percepcăo ambienta1 viabilizam principalmente o estudo e compreensão no conhecimento dito "indireto", conforme definido no capitulo III, no que diz respeito ao aprendizado e á socialização mais formalizada. Dentre estas fontes podemos destacar a literatura, a imprensa, os mapas e fotografias, os textos escolares, a música, a televisão. Algumas destas fontes fazem parte do que chama-se de "educaçăo forma1", como curriculos escolares, outras do que se pode chamar de "educação informal", que complementa o processo de socialização do individuo.

Năo săo muitos os exemplos de pesquisas ambientais que apoiam-se exclusivamente em fontes indiretas, que também podem ser chamadas de introspectivas. No Brasi1, por exemplo, temos conhecimento de apenas dois estudos que incluiram em seu desenvolvimento aspectos do conhecimento indireto do ambiente. 
OLIVEIRA (1978), ao estudar entre crianças como o mapa pode ser entendido enquanto meio de comunicacão espacial, sob ponto de vista cognitivo, abordou como ele pode ser visto como uma forma de representação de percepcão e de realidades geográficas.

MACHADO (1988) objetivando o estudo das atitudes e valores do público em relação á paisagem da Serra do Mar Paulista, chegou a avaliar as contribuiçoses do noticiário dos jornais a nivel de denúncia dos problemas ecológicos e sensibilização da opinião pública para a questão. Além do aspecto denunciador da terminologia adotada pela imprensa, esta autora destaca a grande afetividade revelada pelos usuários com maiores elos, como moradores e trabalhadores, neste seu cenário de vida cotidiana.

Evidentemente, uma das mais importantes fontes de pesquisas indiretas é a imprensa, os jornais e outros orgãos de divulgacão de noticias, tanto a escrita quanto a falada. E reconhecido o enorme potencial da imprensa e noticiários na divulgaçăo de imagens, avaliacỡes e na consequente formaçăo de opiniões e influência de condutas. A publicidade jà há muito estuda esta questão e dela utiliza-se em seus objetivos mercadológicos. Também o faz a politica e todos os regimes politicos autoritàrios necessariamente controlam estes vetculos pois sabe-se que na base de toda a democracia esta o acesso á informaça.

Năo nos cabe desenvolver aqui este tema, cuja especificidade foge aos objetivos de nosso trabalho. Apenas frisamos que a importancia dos velculos de informaçăo revela-se em relaçăo ao alcance que possuem na divulgaçăo de imagens e opiniões junto á populaçăo, constatado em dois niveis: penetracão e confiabi 1idade. 
Primeiramente, os jornais e órgãos afins possuem grande alcance junto á populaçăo por suas próprias caracteristicas como velculo: baixo preço relativo, imediatismo e diversidade de noticias, exposição de imagens fotográficas, praticidade e apelo popular; caracteristicas que evidentemente năo são encontradas nos veiculos literários e sim, em maior ou menor grau, nos jornais e na televisão ou no rádio. No caso da televisăo, inclusive, ressalte-se a forca da imagem "ancorada" pela palavra, que the tira as ambiguidades possiveis (ECO 1976: 161).

Em segundo Tugar, a imprensa escrita e falada possuem uma conotacăo de veracidade. As noticias são fiéis aos "fatos" que ocorreram ou estão ocorrendo, apenas relatados pelo noticiário. Este noticiário também é presumidamente "imparcial" para o leitor ou telespectador; um tipo de "vestimenta" adotada por alguns veiculos: quanto maior o tom de imparcialidade transmitido, maior a "veracidade" da informaçăo (vide telejornais como Jornal Nacional, da Rede G1obo).

Por outro 1ado, acreditamos que maior enfâse deveria ser dada á compreensão da contribuicăo da literatura em gerạ á percepcão ambiental, especialmente pelo desenho urbano tratar-se de uma atividade que visa á perseguicăo de "imagens ideais". Literatura que, segundo TUAN (1976), por um lado è uma evidência diagnóstica da cultura, pelo outro è uma forca criativa que direciona a cultura.

TUAN (1976) afirma ainda que não mais pergunta-se se a literatura revela valores comuns: jà se sabe que ela pode impor valores comuns. A efetividade dos meios de comunicacăo de massa, inclusive da literatura, em alterar nossa percepcăo ainda é 
menosprezada pelo pesquisador ambiental, embora hà muito seja reconhecida e usada por publicitàrios, politicos e pregadores.

E interessante fazer alusão ao grande escritor francês Victor HUGO, que jà entendia que "...se modificava-se a forma do pensamento humano, modificava-se também o seu modo de expressão..." (in CHOAY 1976: 499). No seu clássico "Notre Dame de Paris", publicado pela primeira vez em 1831, ele se mostrava fascinado pela noção de cidade como a metáfora de um livro, cujas pảginas são 1idas com a nossa vivência: "a arquitetura è o grande livro da humanidade, a expressão principal do Homem em seus diversos estágios de desenvolvimento... o pilar que é uma letra, - arco que é uma silaba, a pirâmide que é uma palavra" (in CHOAY 1976: 499/500).

As obras literárias vão escrevendo camadas sucessivas de histórias sobre os lugares, histórias que seguem as modificaçôes do pensamento social e cujas percepções săo consequentemente completadas e re-formadas. Em artigo em que aplicava noções semiológicas na leitura da cidade, Roland BARTHES (1970) concluiria que é necessário a multiplicaça de nossas leituras sobre a cidade, particularmente com os textos năo cientificos dos escritores. Mais tarde, BAILLY (1979: 161), fazendo um estudo da percepcão da cidade através da novela do século XIX, afirmaria que "os novelistas... ambicionaram apreender a cidade, reconstituindo-a mediante a descriçăo de uma imagem, esclarecem com seu discurso os valores e significados da sociedade, ao mesmo tempo que expressam melhor que ninguém os mitos coletivos".

Ao escrever sobre literatura, experiência e conhecimento ambienta1, TUAN (1976) observa que a 1 iteratura é cognição em um 
determinado nivel de sintese, possuindo o poder de clarificar e unificar a experiência, ao mesmo tempo que revela ambiguidades e discontinuidades profundas, possibilitando uma multiplicidade de significados. Ele aponta os tipos de informaçăo ambjental, sempre relativa a um tempo e um lugar determinados, que podem ser estudados através da 1iteratura: condiçóes materiais de vida, preocupaçós intelectuais do povo, esclarece a natureza da experiência, espelha e media as contradiçóes da sociedade.

Uma questão importante também abordada por TUAN (1976) è a da representatividade; o quanto a literatura é ideossincratica, refletindo percepçóes e valores do autor, e o quanto ela espelha fenômenos sócio-culturais ? Quanto a isto ele comenta que, quando bem sucedida, ela transcende estas limitaçoses; menciona, por exemplo, uma pesquisa sociológica de cunho estatistico que jà havia provado, nos anos 50, ser verdadeiro que os valores expressados em estórias para o consumo de massa representam perfeitamente aqueles do norte-americano de classe média.

IV. 3. Operacionalizacão Atravẻs de Fontes Diretas:

Como já comentado anteriormente, nesta área metodológica já existem métodos, técnicas e instrumentos cujo caráter têm sido aceitos consensualmente. As divergências e criticas existentes nestes casos, em sua maioria, săo relativas ao quadro conceitual ou a representatividade e tamanho da amostra escolnida, que limita a generalizaçăo dos resultados. Já existe um significativo corpo de literatura e de estudos especlficos sobre a questão metodológica, dentre eles destacamos os de LANG et al (1974), MICHELSON (1975), WHYTE (1977), GOLD (1980) e ZEISEL (1981). AS 
publicações e anais dos congressos anuais do Environmental Design Research Association-EDRA (Associação de Pesquisa em Desenho Ambienta1), que tem por base os E.U.A., também săo importantes instrumentos de acompanhamento deste "estado da arte".

BELL et a1 (1978) observam três métodos de pesquisa direta da percepcão ambiental. Os métodos experimentais são os únicos que permitem identificaça precisa de variáveis a partir da localização de seus efeitos. Os métodos de correlação partem da observacão das ocorrencias e dos efeitos, no ambiente, identificando as possiveis relaçôes. Os métodos descritivos, destacados como os mais utilizados atualmente, simplesmente descrevem as reações em uma dada situaçăo sem a necessidade de sempre inferir relações causais ou associações; estes seriam os mais comuns para pesquisas em "avaliaça de qualidade ambiental" e "estudos de satisfações dos usuários".

Para o estudo dos niveis cognitivo, avaliativo e de atitudes da percepcão ambiental (vide Capitulo III e Fig. 18) o cunho pragmático de nosso trabaiho solicita utilizaçăo de um misto de métodos: ao mesmo tempo que identificaremos imagens, atributos qualitativos e expectativas, através de métodos de levantamento descritivos, estaremos correlacionando estes fatores com possiveis efeitos ambientais no sentido das condutas e opiniơes possiveis.

IV. 3.1. Nive1 do Processo Cognitivo:

Do processo cognitivo que discutimos no Capltulo III, dois conceitos revelam-se particularmente instrumentais para o estudo e a operacionalizaça da percepcăo urbana em termos de 
planejamento e intervenção, as noções de imagem urbana e de mapa menta 1 .

Neste sentido, é interessante a concejtuaçăo proposta por TUAN (1980: 259) ao colocar que "a cidade grande é frequentemente conhecida em dois niveis: um de grande abstraçăo e outro de experiência especifica. Em um extremo, a cidade è um simbolo ou uma imagem... no outro è o bairro intimamente experienciado ("experienced")". Isto implica duas nocões: primeiramente, que nossa percepçåo ambiental é composta por um nivel simbólico e outro operacional; em segundo lugar que, quanto mais dificit a percepcão e apreensão de estruturas operativas, mais fácil a aferiçao de simbolos representativos.

Portanto, para a operacionalização do desenho urbano, podemos distinguir em nossa cognicăo do ambiente, dois tipos principais de imagens mentais. O primeiro, normalmente conhecido apenas por imagem, possui caráter altamente simbólico, figurativo e associativo (RAPOPORT 1977, LANG 1987). Esta imagem menta1 possui sentido por si mesma, numa representaçăo externalizada do real seja visual seja sob forma de palavras e sentimentos (Fig. 21). PIAGET \& INHELDER (in OLIVEIRA 1978: 55) a definiam como uma "imitaça interiorizada... uma espécie de suporte do pensamento". Neste caso, a imagem substitui a realidade, uma noçăo consonante com o conceito de signo, gerado a partir de uma relaça dinâmica entre objeto, significante e sigrificado (ECO 1976).

O segundo tipo cé imagem mental é o icônico, estrutura1, que corresponde a estruturas perceptivas mais complexas e, neste sentido, poderlamos tratá-las como "esquema", pois a sua retencão 
pela inteligência pressupõe uma estruturação de imagens simbolicas em algum esquema 1ógico operaciona1 (RAPOPORT 1977, BAILLY 1979, LANG 1987). Este tipo tambèm è vulgarmente conhecido como "mapa menta1", expressão popularizada a partir do trabalho pioneiro de LYNCH (1960) e outros (GOODEY et al 1971, GOULD \& WHITE 1974, DOWNS \& STEA 1977).

Este segundo tipo de imagem mental corresponde á noçăo de conhecimento operativo de um lugar, quando nosso pensamento jà possui a capacidade de re-construção do lugar, capturando seus mecanismos operativos e identificando logicas estruturais (PIAGET 1969, PIAGET \& INHELDER 1967, BELL et a1 1978) (Fig. 22). Como jả comentamos anteriormente, o desenvolvimento do nosso conhecimento e raciocinio tende a levar-nos a maiores capacidades de abstração, sintese e compreensăo de estruturas complexas; aumenta a quantidade e a qualidade de informações.

- mapa mental pode também ser compreendido como um "mapa cognitivo", e MOORE \& GOOLEDGE (1976: 5) definiram mapeamento cognitivo como "... processo pelo qual as pessoas adquirem, codificam, armazenam, relembram e decodificam informação sobre as localizaçóes relativas e os atributos de fenômenos no ambiente espacia1 do cotidiano". DOWNS \& STEA (1977) observam que o mapeamento cognitivo \& a habilidade que nos permite lidar com os problemas de compreender o ambiente espacial em que vivemos, ele è essencial para nossa sobrevivência; para eles esta habilidade è um pressuposto para o comportamento.

o conceito de mapa cognitivo do ambiente foi originalmente sugerido por TOLMAN em 1948, a partir de experiências com ratos em laboratório, ao defender que todos os organismos o possuem e 


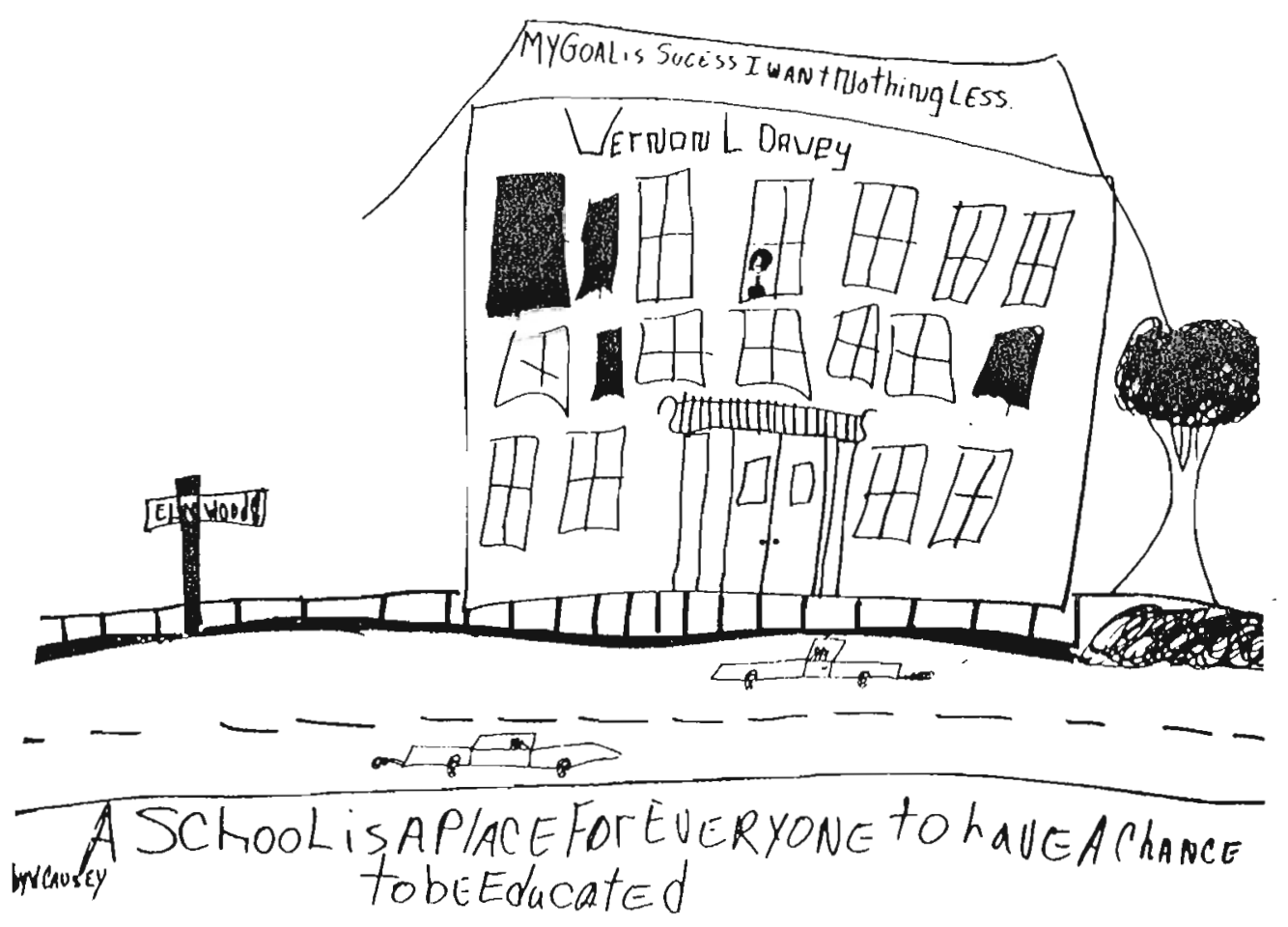

Fig. 21: Desenho de criança para sua escola ideal; imagem mental do tipo figurativo/simbólico/associativo.

Fig. 22: O bairro da Urca, Rio, por uma pescador de 22 anos; imagem mental do tipo estrutural/esquema operativo; um mapa cognitivo ou mental.

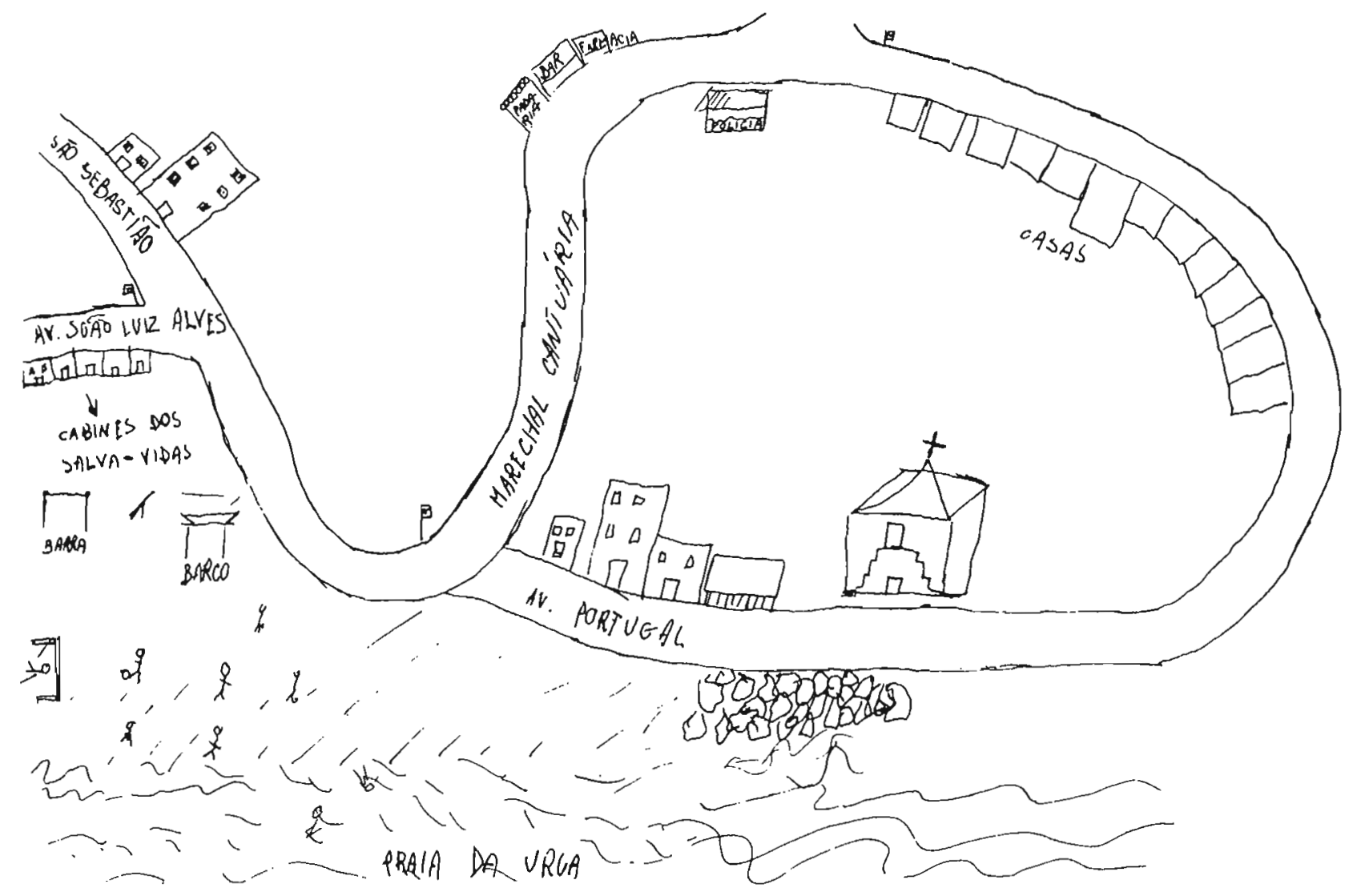


que o aprendizado è adquirido atraves de relacionamentos mais do que com fatos (RAPOPORT 1977, GOLD 1980).

No entanto, e importante que se atente para que o conceito de imagens mentais, sejam do tipo figurativo, sejam do tipo icônico ou mapas cognitivos, năo possue necessàriamente representaça gráfica especifica. Uma das criticas maiores aos métodos gràficos de obtencăo de imagens e mapas mentais è que eles acabam por tornar-se testes de habilidade grafica, traduzindo capacidades do entrevistado que não săo diretamente ligadas á cogniçăo ambiental, tais como abstraçăo e redução de esca1a.

Os métodos de pesquisa visam, portanto, a compreender o processo cognitivo: identificar quais são estas imagens, como elas são adquiridas, sua importancia relativa e como elas se interelacionam no processo de conhecimento e conduta ambiental.

a) Operacionalização de Imagens Mentais:

Ao contrário do que acontece no campo da arquitetura, os estudos que desenvolvem a noção especlfica de imagens mentais de ambientes e sua operacionalização ainda năo foram suficientemente desenvolvidos, principalmente devido a enorme influência exercida pelo trabalho de LYNCH (1960) que privilegiava "mapas mentais" para a obtenção da imagem da cidade.

Em arquitetura os ultimos trinta anos viu um grande desenvolvimento de teorias e metodologias que exploram a nocăo da imagem mental ou dos simbolos. Assim, vimos enfoques desenvolvidos a partir da psicologia da gestalt (SMITH 1974, PRAK 1977, CHING 1979), da semiologia (ECO 1976, VENTURI 1966 \& 1972 , 
BROADBENT 1970, JENCKS \& BAIRD 1975), da antropologia estrutura1 (RAPOPORT 1969, 1977), da psicanálise e da noçăo de arquétipos (BACHELARD 1969, COOPER 1974) ou da fenomenologia (NORBERG-SCHULZ $1971 \& 1980 ;$ ALEXANDER $1969 \& 1977$ ).

Ainda no nivel arquitetônico, mas fortemente relacionado com seus significado e papel na estruturacăo urbana, encontram-se os estudos de APPLEYARD de como as edificações são conhecidas (ou reconhecidas) pela populaçăo, derivados de suas pesquisas em Ciudad Guayana (APPLEYARD 1976). Seu principal pressuposto era que uma edificacão seria lembrada, ou seja a sua imagem seria formada, por uma combinação dos atributos de distinçăo de sua forma, sua visibilidade, seu papel nos sistemas de atividade e seu significado cultural. Em relação á construção da imagem em termos formais, supunha-se que os atributos mais significativos seriam os relativos á intensidade de sua intensidade e singularidade (movimento, tamanho, silhueta, superficie, qualidade, forma e signos). Suas conclusões apontaram os conflitos entre as imagens edilicias ideais da população e as dos "designers" e a relativa pouca importância da forma "per se" na construção da imagem dos ediflcios e, consequentemente, na estruturação dos mapas mentais; os maiores destaques das edificações ficavam por conta de seu significado social e sua visibilidade relativa.

$\mathrm{Na}$ escala territoria1, um dos autores que originaram a preocupação pelo estudo da percepcão em geografia e sua consequente determinaçăo de preferências ambientais foi GOULD (1966, GOULD \& WHITE 1974). Preocupado pela queståo da localizaçåo relativa, ele desenvolveu a noça de que as 
preferências residenciais, resultado de percepcốes dos diferentes grupos populacionais, poderiam ser traduzidas em uma versão de "mapas mentais". Assim, em seus estudos as respostas sobre desejabilidade residencial na Inglaterra, por exemplo, foram traduzidas através de técnicas estatisticas em curvas de intensidades de preferências, concluindo um mapa mental que reflete resultados com profunda influência dos sistemas de valores e emocional dos entrevistados (Fig. 23).

Outro exemplo interessante nesta área de pesquisa foi relatado por GOODEY (1974), que estudou a percepcão geogrảfica (geografia no sentido amplo) de estudantes norte-americanos em tôrno aos temas localizaçăo de cidades, preferências residenciais relativas ás diversas cidades, preferências para férias na Europa, julgamentos sobre nações e seus 1ideres. Inspirado no trabalho original de GOULD (GOULD \& WHITE 1974) sobre mapas mentais, a pesquisa constatou as diversas imagens compostas dos entrevistados e concluiu na importância educacional da discussão das imagens mentais e na queståo da influência da midia em sua formação.

Um outro método válido de estudar as imagens mentais foi utilizado por NASAR (1979), em pesquisa que já mencionamos anteriormente, para identificar o "mapa mental avaliativo" dos aspectos visuais de duas pequenas cidades norte-americanas. Entrevistas por telefone e face-a-face, a moradores e visitantes, permitiram-ihe identificar as àreas e aspectos fisicos que os entrevistados mais gostavam e desgostavam. As avaliações obtidas sugeriram cinco aspectos desejáveis na imagem avaliativa das 
cidades, e evidentemente relacionados á imagem ideal dos entrevistados, presença de natureza, conservação, àreas livres, ordem e significado histórico.

b) Operacionalizaçăo de Mapas Mentais:

Aponta-se que o principal problema desta noça é que ela tem sido interpretada errôneamente como uma analogia direta de representação cartográfica, como se carregássemos pequenos mapas na cabeça (CANTER 1977, GOLD 1980). Como afirmou DOWNS (1976) esta metáfora é confortável e perigosa pois nos leva a tratar o conhecimento espacial como se fosse um imenso "atlas" cognitivo; segundo ele deverlamos, portanto, enfatizar o processo e os mecanismos internos de elaboracão destes mapas mentais, não os mapas em si.

Para o estudo do mapa mental que uma populacão possui de uma àrea ou cidade, ainda hoje adota-se principalmente uma das técnicas desenvolvidas por $\mathrm{LYNCH}$ (1960), que se resume em solicitar ao entrevistado que desenhe de cabeca o mapa da área destacando todos os elementos que entende por importantes. Uma variação desta técnica é a elaboraçăo de um "mapa" esquemático a partir de respostas apenas verbais, chamado de "mapa mental indireto" por WHYTE (1977). De qualquer modo, o objetivo è sempre o pesquisador poder obter um mapa composto a partir do cruzamento de todas as informaçães "cognitivas", ou seja, obter um "schema" pủblico da àrea.

Segundo SAARINEN (1976) a pesquisa mais massiva de coleta de dados de mapeamento mental baseou-se em 1.118 entrevistas para delimitar o centro da cidade holandesa de Kartsruhe. Cada 


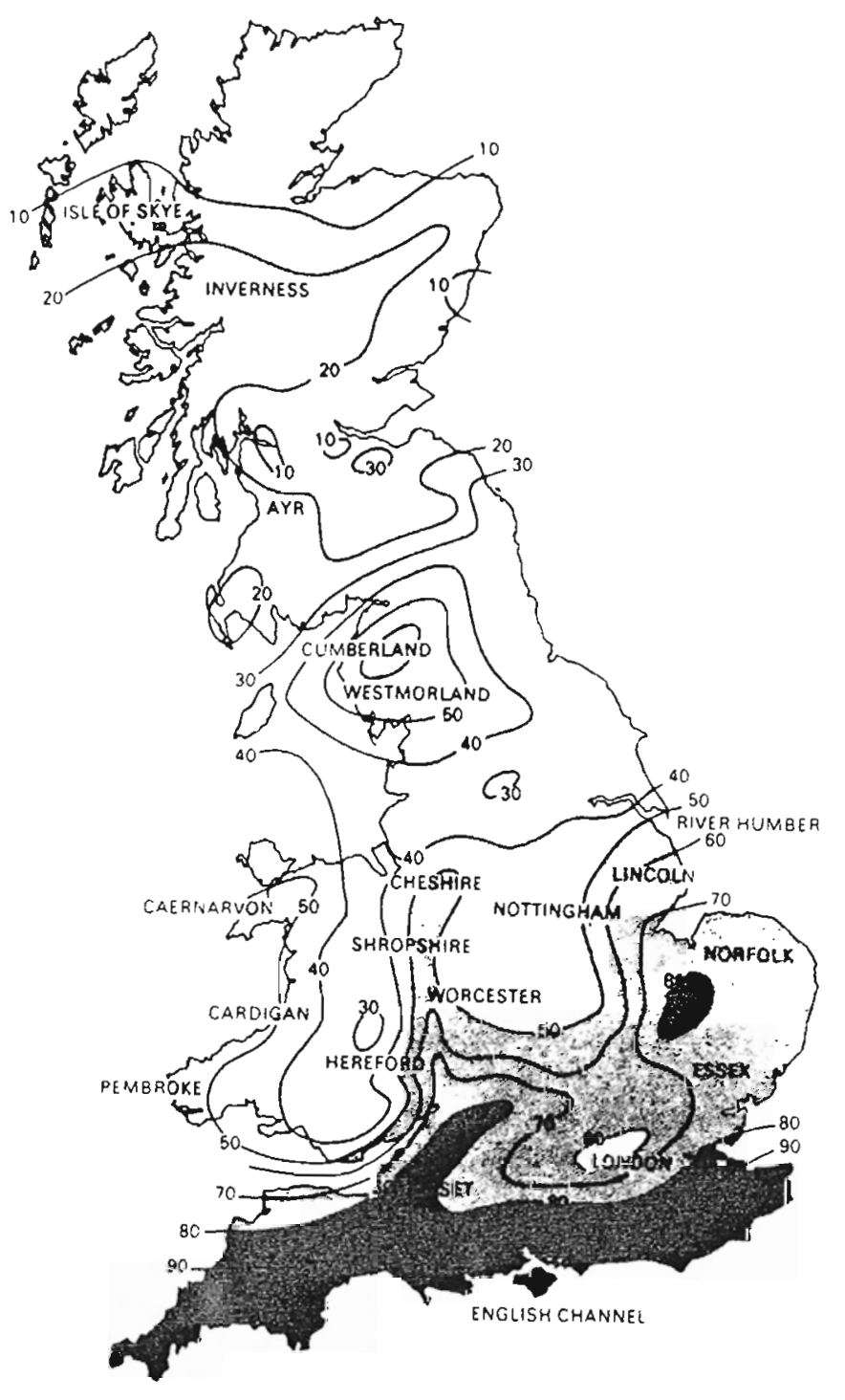

Fig. 23: Mapa mental de Gould; curvas de preferência na Grã Bretanha.

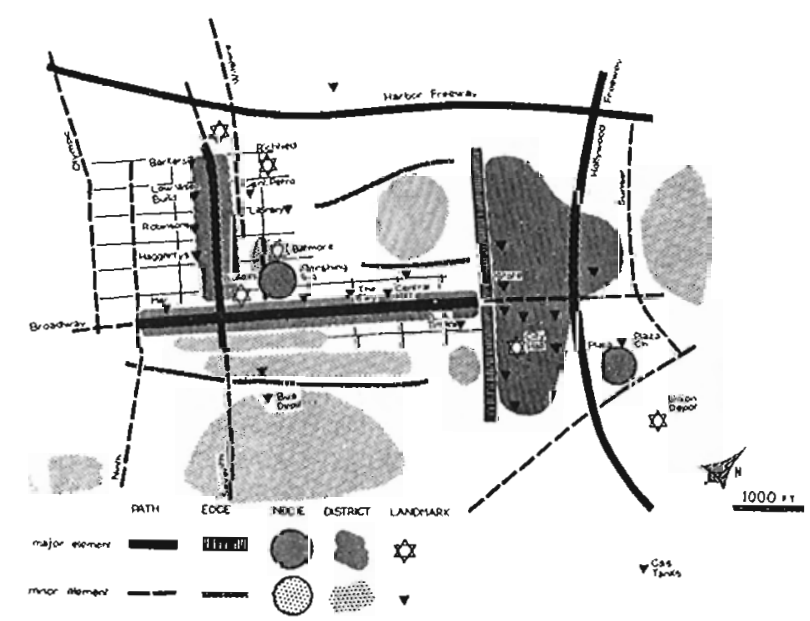

Fig. 24: Mapa composto de LYNCH da forma visual de Los Angeles.

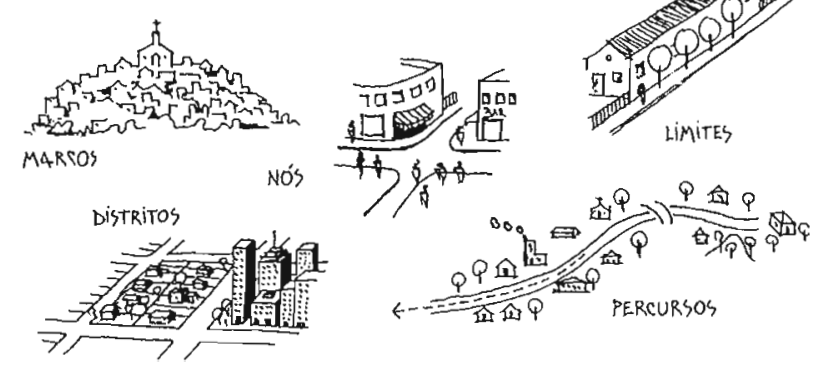

Fig. 25: Representação dos cinco elementos estruturadores da imagem da cidade de LYNCH. 
entrevistado tinha de escolher, de um jogo de cartões com imagens de lugares e ruas, quais os que consideravam no centro. As imagens obtidas foram relativamente coerentes, mas destacaram-se diferenças: residentes mais antigos incluiam àrea maior que os novos, o lugar de moradia influia nas tendências direcionais dos limites, o sexo e o nivel sócio-econômico geraram respostas diferenciadas.

E preciso reconhecer a importância e a prevalescência da dimensăo física e visual em nossa percep̧ão. Já comentávamos isto quando discutiamos a importancia da imagem visual em nossa cultura, no desenvolvimento do conhecimento e no processo de racioctnio. Mesmo as imagens mais elaboradas, com conotações sociais mais profundas, participantes de "schemata" mais complexos, formam-se a partir de evidencias visuais ou visualizadas, a partir do momento que o conhecimento està desenvolvido suficientemente para abstrair-se de denotacões diretamente funcionais e de conotaçóes puramente estéticas, e passa para estruturas operacionais e mais abstratas.

Esta prevalecência de fatores fisico-espaciais norteou o trabalho pioneiro em percepcăo ambiental de LYNCH, pois ele entendia a imagem urbana como essencialmente visual e interessava-se em saber "que formas geram imagens fortes" para a "imageabilidade" e o desenho urbano (LYNCH 1960: 14). Este continua constituindo um quadro conceitual básico e o ponto de partida para todos os trabalhos do gênero, apesar de diversas crtticas que identificam algumas de suas limitacões, inclusive pela pouca importância depositada nos fatores sociais que geram significados e as próprias imagens. E interessante que comentemos 
quais são as razões principais ou os criterios de cunho associativo que, segundo $\mathrm{LYNCH}$, levam nossa mente a distinguir determinados elementos, uma estrutura e um território em sua imagem mental de uma àrea.

LYNCH estudou a percepção de áreas centrais de três cidades norte-americanas, para identificaçăo de sua "imagem publica", atraves de dois tipos de andilise: um reconhecimento de campo por observadores treinados (mapeamento dos elementos urbanos, suas caracterlsticas, forca, visibilidade, interelaçốes) e uma longa entrevista, que tardava uma media de 1 1/2 hora, a grupo 1 imitado de moradores (evocando a imagem do ambiente fisico). Esta técnica e os instrumentos desta entrevista constituiram a parte mais original do trabalho; os entrevistados descreviam percursos, quais elementos consideravam de destaque na cidade e desenhavam o "mapa menta1" da área centra1. Os resultados conformavam um mapa composto da imagem da cidade, onde salientavam-se seus elementos estruturadores (Fig. 24).

Algumas criticas conceituais e, principalmente, metodológicas foram levantados quanto ao trabalho de LYNCH, como por sua excessiva obstinaça pelo aspecto visual (HARRISON \& HOWARD 1972, APPLEYARD 1976, GOLD 1980), fato já comentado anteriormente, ou pelo número de sujeitos ser exíguo e de pouca representatividade (LEE 1977: 142). A própria técnica e instrumento podem ser contestados pois dependiam de grande disponibilidade de tempo do entrevistado, de uma certa educaçăo de base para compreensão das perguntas e de capacidades de representaçăo gráfica. O prỏprio LYNCH (1960: 152/153), embora demonstrando a grande consistencia interna nos resultados que 
obteve, reconheceu limitaçoos relativas a: tamanho das amostras (não mais que trinta entrevistados em cada cidade), sua homogêneidade (quanto á idade, sexo e nivel sócio-econômico) e falta de distribuicão territorial mais randômica das entrevistas (quanto a locais de residência e traba1ho).

LYNCH (1960) partiu dos conceitos qualitativos de "legibilidade" e "imageabilidade", discutidos no capitulo II, para concluir a importância de imagens públicas urbanas evidentes e claras para o usuário da cidade. Ele estudou a imagem mental de três cidades norte-americanas atravès de mapas mentais e de entrevistas colnidos com um grupo de entrevistados. Embora contestada no âmbito metodológico, como vimos acima, os conceitos gerais de $\mathrm{LYNCH}$ e sua estratégia nunca foram totalmente desmentidos (GOODEY et al 1971, HARRISON \& HOWARD 1972, APPLEYARD 1976, BAILLY 1979, GOLD 1980).

Com as informaçoses das entrevistas e dos desenhos, LYNCH confeccionou mapas compostos da imagem da cidade e identificou sua conformaçăo estruturada básicamente a partir de cinco elementos fisicos: nós, percursos, setores, limites e marcos (Fig. 25).

Os nós (nodes) seriam locais estratégicos com forte funçăo, concentração de atividades, convergência fisica do tecido e onde o observador pode penetrar. Os percursos (paths) são os canais de movimento do observador e em muito influenciam na determinaça da imagem menta1. Os setores (districts) são as àreas da cidade que - observador identifica com uma certa clareza e que gera1mente possui limites e identidade bem definidos. Os limites (edges) săo 
elementos 1 ineares não utilizàveis como percursos que demarcam um setor ou uma área conhecida pelo observador, determinando uma interrup̧ão na continuidade urbana. Finalmente, os marcos (1andmarks) conformam referências externas, ou seja, destacam-se na paisagem como constância flsica observável.

Alguns autores discutem esta tipologia conciuida por LYNCH, como de aplicabilidade năo tão generalizável pois seus elementos se confundem entre si e ela tampouco é verificàvel em todas as situações (GOODEY et al 1971, GOLD 1980). Este ültimo autor, por exemplo, propõe como tipologia básica para os elementos conformadores dos mapas mentais: edificações (monumentos ou marcos), percursos e áreas (território reconhectvel).

Mas o que nos interessa de imediato, a nivel de operacionalização dos estudos de percepção ambiental, è uma definição de categorias cognitivas que permitam a compreensão do conceito de mapa mental enquanto imagem mental estruturada do ambiente urbano, ou seja, enquanto uma cognicão organizada, coerente e operativa para os usuários. Para estas estruturações mais complexas, os "schematas" ou mapas mentais, STEA (in KAMERON 1973) definiu o que chamou de "fatores" mais importantes para nossas concepcões sobre o ambiente são: hierarquias, 1igą̧̃os, localizações, relações entre pontos e coneções ou caminhos.

Sobre este mesmo tema, BAILLY (1979) faz interessante sugestão para resumir a três os criterios perceptivos mais importantes em sua formação: a escala, os esquemas lógicos e as referências. A percepção da escala é o que permite a ordenação e estruturação da paisagem, os esquemas lógicos preestabelecidos pela cultura e educaça permitem acesso á lógica de funcionamento 
esperada, e as referências evitam que nos desorientemos e são, com frequência, visuais.

Com base no quadro teórico traçado no capitulo II e nestas consideraçôes para operacionalizaçăo, sugerimos a seguinte categorização cognitiva na formação de mapas mentais ou cognitivos: escala/território, estrutura e referências. Nunca è demais relembrar que estas categorias serviråo apenas para facilitar a anàlise e a compreensăo do fenômeno cognitivo, nunca existindo independentemente uma das outras, mas sempre reforçando-se em suas funçôes significantes.

\section{a) Escala/Território:}

Esta categoria que inclui as variáveis de escala e território parecem ser das mais significativas na formaça de uma mapa mental de uma área ou bairro, segundo os achados de diversos pesquisadores (LYNCH 1960, LEE 1977, BAILLY 1979, MACHADO 1988). - tamanho da àrea e a clareza de sua delimitaçăo, ou seja a definicăo de seu território, estăo diretamente relacionados á nossa capacidade de abstração e apreensão do todo $e$ de suas estruturas operativas; ao mesmo tempo que permite o grau de familiaridade com os elementos constitutivos.

ou seja, enquanto é mais dificil captarmos uma imagem clara e operativa de uma àrea de escala muito grande, como uma regiăo ou pals, a indefinicão de seu território, principalmente se os limites năo săo precisos e significantes, também dificulta a cognicão. Por isto, as àreas reconhectveis, ou lugares, são destacadas por alguns pesquisadores, principaimente pelos geógrafos, como as unidades cognitivas básicas para a percepçăo 
ambienta1 (CANTER 1977, GOLD 1980). Esta noção, inclusive, confirma a importancia cognitiva do conceito fenomenológico jà discutido do "bairro" como unidade sócio-espacial (LEE 1974, 1977) e como expressăo de territorialidade, como visto.

Realmente, os limites dos bairros costumam ser alterados a partir de necessidades perceptivas. ALTMAN (1968 in MERCER 1975) observava que a territorialidade humana é muito mais passiva de ser expressa simbólicamente, dal o bairro-território tomado como stmbolo social, expressão ffsica de identidade (LEE 1974, BLEY 1982). Por exemplo, quando em áreas de fraca definicăo fisica de Timites demarcatorios de dois bairros, os moradores costumam declarar que moram no bairro com a "imagem" socialmente mais valorizada. Pelas mesmas razões, os moradores de favela só atingem "status" perante ás possibilidades de financiamento nas lojas de departamento e á sociedade em geral quando possuem um endereço formalizàve?.

Outro exemp1o conhecido de alteraçăo das percepçóes do bairro revela-se nas taticas adotadas pelo marketing da especulação imobiliảria que, quando o empreendimento está situado entre bairros distintos, "opta" por vendê-10 como do bairro de maior status socio-econômico e maiores qualidades percebidas, ampliando seus limites (Tijuca em oposiça a Andaral, Ipanema em oposiçăo a Copacabana, Lagoa a Jardim Botânico, etc.).

Os conflitos existentes relativos a percepcões dos bairros entre moradores ou usuários e o poder público è temática constante nos trabalhos de urbanismo. BLEY (1982) em seu estudo de percepcão do centro de curitiba, por exemplo, observou que das várias delimitaçoses citadas em entrevistas, nenhuma correspondeu 
^[ oficial. Na nossa àrea de estudo, Area Portuària do Rio de Janeiro, este tipo de conflito foi notado nas entrevistas que fizemos com usuários da àrea em campo, assim como especificamente expressa pelos membros de movimentos comunitários.

\section{b) Estrutura:}

Nesta categoria cognitiva da definiçăo de mapas mentais, ampliamos a noça classificatória proposta por BAILLY (1979) para - que chama de "esquemas 1ogicos". Por um lado os esquemas ou estruturas percebidas podem traduzir uma lógica operativa seja a nivel fisico quanto em nivel social. Por outro lado, a categoria tanto pode traduzir lógicas operativas em nivel geral (estrutura urbana) quanto em nivel operativo especifico (operação do Tugar ou do equipamento).

A nocão de esquemas 10 gicos lembra a de conhecimento operativo de PIAGET. Quanto a esta questão, perguntando-se o quanto podemos comparar o desenvolvimento de nosso mapa mental ao de nossos sistemas cognitivos, CANTER (1977: 77), tomando por base evidências empiricas, destacando inclusive pesquisas feitas com cegos aplicando mapas em brail1e, afirma que "... e o arranjo espacial dos lugares, não sua organização visual que è crucial" pois as imagens mentais estão longe de serem registros fotogråficos, mas sim conceituaçôs sumarizadas.

A maioria dos pesquisadores concluiram que a imagem que possuimos da cidade é parcialmente setorial (bairros conhecidos) e estas áreas se relacionam mediante fluxos visuais continuos correspondentes aos eixos de deslocamento; as partes mais claras săo as ligadas ás atividades cotidianas do individuo (TUAN 1980, 
RAPOPORT 1977, CANTER 1977, BAILLY 1979). Realmente, em termos de experiência e utilização funcional da cidade, impõe-se um conhecimento operativo de suas estruturas.

Dentro desta categoria de "estruturas", importância singular é assumida pela estrutura viária, ou as inter igaçós formais de deslocamento entre os diversos elementos e partes significantes. Neste sentido, BAILLY (1979: 129), por exemplo destaca que os eixos de deslocamento podem ser vistos como subsistema do meio urbano, em que cada individuo elabora uma geografia subjetiva e que è esta "geografia" que tende a estruturar as outras percepções.

Em suas entrevistas para composicão de mapas mentais, LYNCH (1960) jà observava que os percursos eram os elementos predominantes, embora sua importancia variasse de acordo com o grau de familiaridade com a cidade e a facilidade de sua legibilidade. Resultados semelhantes de predominância do sistema viàrio e articulação de outras imagens e referências ao longo dele, foram concluidos do estudo de mapas mentais nas pesquisas de DE JONGUE (1962), GOODEY (1968), CARR (1970), APPLEYARD (1976) e BAILLY (1979).

\section{c) Referências:}

Como "referências" classificamos todos os fenômenos particularizáveis como definidores das categorias anteriores de "estruturas" e "escala/ território". Portanto, nesta categoria cognitiva incluimos tanto as referencias fisicas, as mais popularizadas a partir de LYNCH e da prevalecência da percepção visual, quanto as referências sòcio-culturais. 
Para a navegaça e a orientaçăo na cidade, as referências fisicas assumem destaque evidente, como apontou LYNCH (1960), em sua conceituaçăo de "legibilidade". De JONGUE (1962) logo depois também concluiria que quando o plano da cidade é confuso, recorremos a maiores detalhes visuais e pontos de referência. RAPOPORT (1977: 142) tambèm observa que a orientação è de extrema importância e básica para o comportamento de todos os organismos, ligada á sobrevivência e á sanidade menta1.

Entretanto, uma das 1 imitações apontadas para o enfoque de LYNCH, principalmente em sua tipologia de elementos e, em especial da identificacăo dos marcos, é a de que ele teria se concentrado demasiado na dimensăo meramente flsico-espacial em detrimento do "significado" dos elementos imagéticos (HARRISON \& HOWARD 1972, RAPOPORT 1977, MOORE 1979, GOLD 1980, PIPKIN 1980). E $\circ$ argumento, por exemp 10, que "...as pessoas lembram das edificações primeiro e principalmente por seu significado de uso, não por suas caracteristicas arquitetônicas, e que lembram de objetos no ambiente mais facilmente se puderem encaixar-1hes uma etiqueta 1 ingulstica" (MOORE 1979).

APPLEYARD (1969: 153) afirmava que "a evidência aponta a nocăo de que todos os elementos do ambiente urbano... são conhecidos por alguma combinacão de sua forma, visibilidade, uso e significado". Mas observa que, especificamente no caso por ele estudado de Ciudad Guayana, revelou-se a grande importância da "visibilidade", ou o grau de exposicão das edificações em relaça ás rotas de transporte principais. Logo, em importante trabalho posterior, APPLEYARD ressaltaria a importância do ambiente como simbolo social e do significado na questão da imageabilidade: "o 
ambiente se torna simbolo social quando é concebido ou percebido como representativo de alguém ou de algum grupo social" (APPLEYARD 1979: 272).

Outras pesquisas apontam diferentes categorias e ordenamentos relativas ao significado e consequente destaque dos elementos estruturadores nos "schemata" ou mapas mentais. HARRISON \& HOWARD (1972) concTuem de sua pesquisa que as categorias mais importantes eram o significado, a 10calização, as componentes funcionais e, por último, a aparência físicoarquitetônica. Por sua vez, MOCELLIN (1977) aponta os aspectos funcionais, histórico/sociais e a dominância visual e ROZELLE \& BAXTER (in BAILLY 1979) sugerem as categorias construidas pelo homem, referências ao meio social e referências ao meio natural. Enfim, seja como for, BELL et a1 (1978) resumem bem toda esta discussão ao observar que "a capacidade de estimulo de um elemento fisico e o reconhecimento è função de fatores sociais (significado social, psicológico, etc.) e físicos (centralidade, distinção, visibilidade, etc.)". Assim, qualquer que seja o elemento destacado na imagem mental urbana pelo respondente, 0 destaque pode ser adquirido por seu significado, composto social e fisicamente. As estruturas mais complexas, traduzidas por mapas cognitivos, são conformadas pelo conjunto destes elementos, interelacionados, cujos significados possuem conotacões idênticas, apenas em dimensões cognitivas de ordem superior.

As referências cognitivas, com destaque para as visuais, são destacadas por todos os resultados de pesquisas aplicadas como importantes elementos estruturadores do espaco. A nivel flsico-espacial, sua capacidade estruturadora tem se verificado 
por fatores como visibilidade, localização e destaque no contexto. A nivel de significado, sua capacidade verifica-se por suas funções, usos e pape1 socio-cultura1.

IV. 3.2. Nivel dos Processos de Avaliaçăo e Conduta:

o segundo nivel de estudos ambientais a que nos referimos, abrange as atividades mentais de avaliação e conduta, do processo de percepcão e interação ambienta1, conforme explicitamos no Capitulo III. Conforme dissemos, a atividade de avaliaçăo engloba seleção e julgamento de atributos ambientais; a atividade de conduta comporta a organizacão de expectativas e a tomada de atitudes e opinióes, como preparaça para a acăo e o comportamento e realimentaça do processo interativo.

Neste nivel de estudos, é comum a utilização de entrevistas com perguntas cujas respostas apoiam-se em repertório de atributos, sentimentos ou a1ternativas de atitudes (WHYTE 1977 , ZEISEL 1981). Para tanto, muito utilizam-se questões cujas respostas são organizadas em escalas de diferenciais semânticos: pares de conceitos ou adjetivos opostos dispostos em uma escala linear de gradações de valôres onde o entrevistado deve manifestar sua preferência (do tipo "tenso $x$ relaxado"). Outros mètodos comuns săo o de complementação de afirmativas (do tipo "este ambiente é __ "), a manifestacăo frente a afirmativas ("este ambiente è bonito: sim/não") e o uso de cenários que representam possiveis alternativas de desenvolvimento.

Um dos mais interessantes estudos de âmbito geográfico no estudo da avaliação e preferências ambientais foi desenvolvido em 1966, coordenado por LOWENTHAL (1972), mencionado brevemente no 
Captulo III. Neste estudo, objetivava-se a compreensão das préconcepçôes e atitudes do pủblico em relação a uma série de estimulos ambientais em cinco cidades norte-americanas. o trabalho tinha por base solicitar, em cada uma das cidades, que um grupo escolhido de umas noventa pessoas andassem por percursos prédeterminado pelos pesquisadores. Instruçôes escritas esclareciam como os entrevistados deveriam registrar as suas impressões (atributos, sentimentos e preferências) durante estes percursos e fazer certos julgamentos: direcão do deslocamento, dia da semana e hora, deveriam fazer os percursos sozinhos, etc. As instruços evidentemente visavam que as condiçós das informações para a anải ise fossem relativamente uniformes.

A partir de uma 1 istagem de atributos em pares opostos os entrevistados tinham que classificar em uma escala de cinco pontos o que mais se aplicava em cada percurso (natural/artificial, feio/bonito, pobre/rico, etc). Depois deveriam destacar quais as cinco qualidades mais significativas do percurso e os sentimentos para com ele através de quatro palavras nåo existentes na listagem de atributos. Anàlises estatisticas, como de conteúdo, significância e variância, permitiram o grupamento de classes descritivas e concluir as diferentes avaliaçōes e preferências dos grupos entrevistados.

Por sua vez, BELL et al (1979: 47) descrevem pesquisa de KAPLAN em que foi constituido um modelo de preferências ambientais também a partir de classificação por pares opostos de atributos, cujos entrevistados responderam a partir de exposicão de slides dos ambientes. A anàlise dos resultados levou os pesquisadores a conclutrem as seguintes qualidades ambientais 
positivas: coerência, textura (quanto mais suave mais positivo), identidade, espaçoso, complexidade, mistério. Segundo os autores, parece que o modelo obtido enfatizava o conteủdo de informaçoses transmitido pelas cenas em slides, ou seja, quanto mais informaça, mais positiva a resposta.

Resultados coerentes aos de KAPLAN (in BELL 1979: 47) também obteve SANOFF (1974), que afirmou que existe relacăo entre a satisfaça visual e os atributos de complexidade, ambiguidade e novidade. Em experiência metodologicamente semelhante á de LOWENTHAL, ele comparou as respostas de dois grupos de entrevistados ("designers" e estudantes de planejamento) sobre uma sèrie de atributos, também ordenados por pares semânticos opostos, primeiro em relação a um ambiente ideal hipotético, depois com base em uma tipologia de quatro paisagens residenciais. As conclusóes apontaram as qualidades preferidas como "complexidade", "estimulos", "sensual", e "dinâmico", em oposicăo a "simplicidade", "universalidade" ou "simetria".

No Brasi1, já mencionamos que MACHADO (1988), estudou as manifestaçôes "topofllicas" relativas á Serra do Mar Paulista. Topofilia é um conceito desenvolvido por TUAN (1974) para definir - elo afetivo entre o individuo e o ambiente fisico incorporando percepcões, atitudes e valores, manifestacões cognitivas e afetivas. Estudando estes temas em campo, a partir de questionàrio com perguntas abertas distribuido a três grupos significativos da população (moradores/trabalhadores, técnicos e administradores/po11ticos), MACHADO aferiu tambèm considerações sobre atitudes e possibilidades de condutas relativas á ação ambiental e preservaçăo de determinados aspectos da Serra do Mar. 
IV. 4. Grupos Diferenciados, Percepcôes Diferenciadas:

A maioria das pesquisas aplicadas já concluiram que a cognição è função de cinco variàveis principais: ntvel sócioeconômico, sexo, idade, experiência pregressa e capacidades individuais (LYNCH 1960, APPLEYARD 1976, BELL et a1 1978, MOORE 1979, BAILLY 1979, GOLD 1980). Realmente, estes achados empiricos nos confirmam as suposiçðes teóricas jả comentadas, uma vez que o processo de percepça admite, principalmente em suas fases de seleção das informações, cognição e avaliação, condicionantes (os chamados "filtros") de grupo e individuais.

Se aceitamos que as percepç̃es, como vimos, săo dependentes da experiência e do universo de vida de cada observador, fica evidente que os diversos sub-grupos de uma sociedade, ou de usuários de uma àrea, tenham percepcões e atitudes diferenciadas em relação a ela. o que varia, no entanto, e não é tão simples de ser previsto para cada situação, é o quanto esta variância é significativa e em relacão a quê aspectos.

o desenvolvimento de um estudo de percepcão ambiental deve levar em conta todas estas variáveis, tanto em nivel do planejamento da pesquisa e dos questionàrios em si, quanto no da anàlise e correlação dos dados obtidos.

a) nivel sỏcio-econômico:

- nivel sócio-econômico manifesta-se principalmente pelo embasamento cultural que ele acarreta, ou seja, a quantidade de aprendizado via socializặão e experiências diretas pregressas. De uma maneira geral, quanto mais alto o ntve1, maior a área reconhecida pelos processos cognitivos, mais acurado este 
reconhecimento e mais objetivas as informaçoses representativas nas respostas colhidas pelos pesquisadores, além de maior a capacidade de inferir conhecimento (APPLEYARD 1976, BELL et a1 1978, MOORE 1979).

Por outro 1ado, MOORE (1979: 33) afirma que o que se está descobrindo é que "... a educaçăo geral per se, inteligência geral e raciocinio verbal năo estăo significantemente relacionados com a capacidade de mapeamento cognitivo por si próprios, enquanto determinadas habilidades cognitivas espectficas são possivelmente muito importantes, tais como operacões concretas, capacidade de lidar com relaçốes espaciais, coordenação de perspectivas, rotaçăo, abstraçăo e redução de escala".

Os niveis sócio-econômicos também pressupõem sistemas de valores diferenciados, que geram reflexos evidentes nas fases do processo de interecăo ambiental e percepcăo. Deve-se esperar que os grupos de renda mais baixa relacionem-se diferentemente com o ambiente, em suas motivaçŏes, avaliaçóes e expectativas, do que aqueles grupos cujos rendimentos já lhes garantem os confortos minimos da vida urbana.

Outra variável 1 igada ao nivel socio-econômico que não se deve subestimar es o tipo de meio de locomocão utilizado pelo entrevistado, na apreensăo de determinadas caracteristicas e atributos ambientais. Os possuidores de carro, por exemplo, têem maior 1 iberdade de locomoção e acessibilidade do que aqueles que necessitam utilizar-se dos transportes publicos (certamente os mais carentes em termos perceptivos neste caso são os usuảrios do metrô). De uma forma gera1, a atividade de caminhar é a que permite mais intimidade com o ambiente (LEE 1977, MOORE 1979). 
APPLEYARD (1976), por exemp10, em seu estudo sobre ciudad Guayana, registrou uma diferenca significativa entre os respondentes que se deslocavam de carro do que os de ônibus. Os primeiros representavam mapas mentais mais coerentes, com maior dominio espacial e capacidade inferencial, enquanto os segundos resumiam-se a representações lineares e pouco coerentes do sistema urbano. As mesmas caracteristicas foram encontradas entre os residentes com maior ou menor capacidades de desiocamento; entretanto, embora estes últimos tivessem apresentado menor capacidade para articular a cidade como um todo, eram capazes de perceber os seus bairros de maneira mais detalhada.

b) sexo:

Em segundo lugar, deve-se atentar para as eventuais diferencas em percepcão relativas ao sexo dos entrevistados. Uma vez que os papéis do homem e da muther na sociedade săo diferenciados, serão diferentes suas motivações, sistemas de valores e percepçôes.

A maioria das pesquisas mostram, por exemplo, que as esposas tendem a utilizar-se mais o lar como base de referência e tendem a produzir mapas mentais da àrea de entôrno imediato ao lar mais coerentes que os maridos, enquanto estes se utilizam de coordenadas mais abstratas e tem uma imagem composta mais completa da cidade, talvez porque se desloquem majs para o trabalho (MOORE 1979, BAILLY 1979, BELL et a1 1978).

Pesquisas citadas por MOORE (1979) demonstram que as habilidades de dominio espacial relativas ao sexo não săo de cunho biológico, mas derivadas da socializaçăo, estilo de vida e 
educacăo; assim, por exemplo, na maior parte dos grupos sociais, as meninas adolescentes, em relaça aos meninos, já apresentam menor dominio de território além do entôrno imediato á casa.

c) idade:

Quanto a esta variáve1, o consenso aponta para a nocão do desenvolvimento das capacidades cognitivas segundo as conceituaçóes de PIAGET, ja discutidas no capttulo II. Entretanto, como jà observado nas 1 inhas acima em relaçăo ao nivel de educaçăo, o nivel de desenvolvimento cognitivo, capacidades espaciais ou operaçóes concretas năo é depedendente da idade per se (MOORE 1979).

Portanto, a idade è fator que tende a fazer com que os mais jovens tendam a possuir percepcơos incompletas. Primeiro, pelas tendências desenvolvimentais demonstradas por PIAGET. Segundo devido ás próprias limitacões de locomoçăo e independência impostas pelas regras sociais e a seguranca real; evidentemente, esta segunda razåo se verifica diferentemente segundo a classe sócio-econômica, os mais pobres "ganhando a rua" mais cedo.

MOORE (1976), com base em PIAGET, propôs três niveis de desenvolvimento da ordenacăo de representaçós cognitivas, tanto para crianças quanto para adu1tos. O primeiro nivel chamou de "concreto egocêntrico" năo diferenciado, que inclui representações simbólicas primitivas. O segundo ntvel chamou de "diferenciado e parcialmente coordenado" em sub-grupos fixos, que incluem representaçoses simbólicas intermediárias. Finalmente, o terceiro nivel de desenvolvimento das representaçoes cognitivas seria o "operacional", que se vê hierarquicamente integrado. 
Algumas pesquisas corroboram este esquema geral de desenvolvimento de representaçôes cognitivas (APPLEYARD 1976). Entretanto, como apontado por GOLD (1980) deve-se aceitar apenas - principio conceitual mas de forma muito esquemática pois é duvidoso que o aprendizado de um adulto siga a mesma sequência do de uma criança uma vez que ele possui uma capacidade inferencial muito superior. Talvez esta mesma dúvida repita-se ao relativizarmos a escala do ambiente a representar, jà que em ambientes urbanos de grande àrea, por exemplo, também em muito aumenta nossa necessidade inferencial.

d) experiência pregressa:

Finalmente, como todo nosso quadro teórico anterior nos leva a pressupor, a evidência empirica demonstra que a experiência anterior dos entrevistados além daquela expressa na idade, em muito influenciam as percepcơes e cogniçóes.

Os padrôes de respostas das pesquisas existentes indicam que as áreas ou trajetos de uso cotidiano săo as mais conhecidas e seus mapas tendem a apresentar menos distorcőes e áreas "vazias" (LYNCH 1960, SAARINEN 1974, APPLEYARD 1976, NASAR 1979, BLEY 1982). O desenvolvimento de habilidades de mapeamento cognitivo mostram que mapas sequenciais se relacionam com pequeno tempo de residência no local, enquanto mapas espacialmente coerentes se relacionam com maior tempo de residência.

O aumento da familiaridade com a àrea pesquisada faz com que os mapas cognitivos e as respostas em geral sejam mais claras e apresentem maiores detalhes. A familiaridade com o ambiente é conseguida, geralmente, através de repetido uso ativo como, por 
exemp10, fazer compras (MOORE 1979). Esta especificidade também foj notada Por TUAN (1980: 74) quando observa que "a avaliação do meio ambiente pelo visitante é essencialmente estética".

Em seus achados sobre a pesquisa em Ciudad Guayana, APPLEYARD (1976: 219) tambèm confirma que "no primeiro encontro, a forma fisica da cidade tende a dominar as percepços de uma pessoa, mas a repeticão faz com que aspectos funcionais e sociais crescam crescer em importância. Com mais experiência, espera-se uma visão progressivamente mais ampla, mais complexa e mais profunda no conhecimento ambiental de uma pessoa e um aumento de conscientização das mudanças na estrutura urbana". Em termos de familiaridade espacial, ele observava que, em Ciudad Guayana, "existia uma tendência clara que o não-familiar dependia da visibilidade" dos elementos e edificaçóses (APPLEYARD 1976: 86).

Entretanto, este mesmo pesquisador concluiu que "em ambientes onde existe um a1to grau de congruência entre forma, visibilidade e significado, tanto extranhos quanto moradores possuiam imagem similar do assentamento" (APPLEYARD 1976: 85). Portanto, verifica-se uma tendência entre recém-chegados em uma àrea, que desconhecem os significados mais profundos relativos á cultura e história do lugar, de fazer prevalecer imagens visuais, tomadas primordialmente como leituras esteticas. Assim, por exemplo, para um visitante quando chega por primeira vez em uma praca em cidade desconhecida para ele, podemos esquematizar que seu processo de percepcăo e raciocinio provave1mente incluirà três fases principais, se pudermos dissecar o processo de interaçăo apenas para clareza de análise. 
Primeiramente, ele avaliarà o local segundo critérios meramente visuais e estéticos, que o possibilitarà a formaça de suas primeiras opiniões e condutas. Em um segundo momento o visitante compararà o seu repertório de imagens, valores e experiência, aos novos fatos, inferindo significados, o que novamente o levará a avaliaçoses e possibilidades de condutas. Finalmente, em uma terceira fase, com o tempo, ele terá conhecimentos suficientes sobre o contexto em que aquele 1ugar visitado está mergulhado para voltar a alimentar seu processo cognitivo, formando seus julgamentos e opiniões, agora mais duradouras. As imagens, progressivamente, vão recebendo componentes que não apenas visuais na complementação das representacões internas da realidade percebida.

e) capacidades individuais:

A variável das capacidades individuais representa a variabilidade ou a năo efetividade nas respostas segundo a interpretação que o entrevistado faz das perguntas ou das instruçoses, variações que refletem os fatores anteriores, mas tambèm introduz uma variável diretamente dependente do individuo.

Assim o seu humor, pressa para responder, correta compreensăo da pergunta, interpretaça das palavras e conceitos utilizados, capacidade de raciocinio, e tantas outras, sem dúvidas podem influenciar nos resultados obtidos. Algumas destas variáveis săo inevitáveis, como o humor, outras podem ser evitadas pelo pesquisador, como o tempo para responder.

Uma das maiores criticas ao instrumento de estudo ambiental conhecido por "mapa mental" em nivel de sua obtencăo por 
representação gráfica do entrevistado, é justamente a limitada capacidade deste tipo de expressão por parte de grupos da população e dos individuos. A representação gràfica pressupõe primeiro, uma grande capacidade de abstraçăo, segundo, as capacidades de orientaçăo, miniaturizaçăo, projecão e simbolização (CANTER 1977). Acaba-se confundindo capacidade de representacão gráfica com capacidade cognitiva em si, que independe dela.

Assim, como vimos, nosso quadro conceitual pôde ser finalizado com noções sobre a operacionalizaçăo dos estudos da percepção e cognição ambiental no sentido do desenho urbano e na revitalizaça de cidades. Embora ainda se esteja longe de poder utilizar conceitos, procedimentos metodológicos ou instrumentos de medida plena e universalmente aceitos, vimos que alguns obtêm consenso. Esta base conceitual nos permitirá a pesquisa de campo e o estudo desenvolvido nos dois ultimos capitulos.

Mas como nos lembra TUAN (1980), para se compreender as atitudes e preferências de um grupo, é necessário que conhecamos sua historia cultural e sua experiência ambiental. E isto que pretendemos com a Parte segunda deste trabalho. Trataremos de caracterizar o contexto ambiental da Area Portuåria do Rio de Janeiro, através da análise de sua evolução e dos aspectos principais de seu desenvolvimento. Veremos que o contexto que se revela è realmente propicio para açōes do poder pủblico no sentido de promover a revitalizaçăo da àrea, justificando, portanto, a própria aplicabilidade de nossa tese. 


\section{O Estudo de Caso: \\ A Area Portuária do Rio de Janeiro}

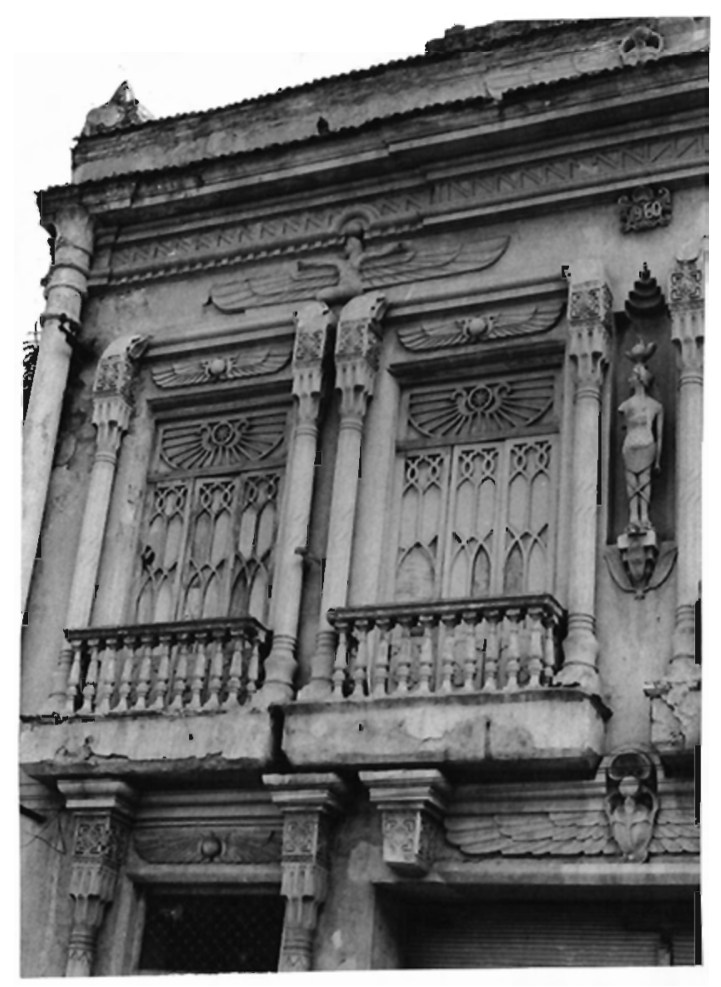

"A cidade... (é feita) das relacõos entre as medidas de seu espaço e os acontecimentos do passado... A cidade se embebe como uma esponja dessa onda que reflui das recordaçoses e se dilata... não conta o seu passado, ela o contèm como as linhas da mão, escrito nos ângulos das ruas, nas grades das janelas, nos corrimáos das escadas... cada segmento riscado por arranhơes..."

("As Cidades e a Memória" in CALVINo, Italo "As cidades Invistveis", Săo Pau1o: Companhia das Letras, 1990, pag. 14) 
CAPITULO V:

\section{A EVOLUÇÃO HISTORICA DA AREA PORTUARIA DO RIO DE JANEIRO}

Para a melhor compreensão de nosso objeto de estudo, sua caracterizaça e identificacão de seu pape1 no contexto da cidade do Rio de Janeiro, trazemos a seguir algumas consideraços sobre sua evolução histórica. A abordagem será a mais livre possivel, abordando os aspectos relevantes para o desenvolvimento urbano, como os geográficos, sociais, econômicos e urbanisticoarquitetônicos.

Esta análise está subdividida em diversos ciclos, entendidos como os principais momentos históricos na definição do desenvolvimento da área e de suas funções. Evidente que estes ciclos năo podem ser vistos como estanques e definitivos, apenas como uma maneira mais fácit de sistematizar as informações.

Entretanto, atravès das informações deste capitu1o, complementadas pelas do seguinte, veremos que a Area Portuária viveu quatro grandes momentos principais bastante caracteristicos (Fig. 26). o primeiro foj o momento de sua formaça e consolidação como lugar de atividades portuảrias, atracaçăo, armazéns e trapiches. O segundo momento foi o de fortalecimento e definicăo de seu papel como o principal porto brasileiro através das grandes obras urbanisticas de Rodrigues Alves e Pereira Passos. O terceiro viu a consolidação de suas funções econômicas e de sua àrea de influência para importaçớs e exportaçóes. 
Finalmente, o quarto grande momento da Area Portuảria, que como dissemos serà melhor explorado adiante, jà a mostra esvaziada de sua importância original, problemática em sua resposta ás funcões portuảrias e sofrendo diversas pressões oriundas de sua localização e do próprio desenvolvimento da cidade que ajudou a formar.

\section{1. Século XVIII: Consolidacăo da ocupacão}

Este periodo se destaca na evolução da cidade, marcado pela intensificaçăo do crescimento de sua funções e da ma lha urbana. Para isto, alguns fatores foram excenciais tais como a cotaça do açucar no mercado internacional e a expansăo da mineiração, cujo escoamento da produção dava-se pelo porto do Rio. A metrópole portuguesa passa, então, a cuidar mais da cidade, agora importante entreposto comercial e politico, principalmente após as tentativas de invasão dos franceses. Estes chegam, inclusive, a estabelecer um fortim no Morro da Conceição, em nossa área de interesse, junto ao Palácio Episcopal, nos primeiros anos do Século XVII. Depois, ali seria construido um ponto fortificado pelos portugueses. A cidade registrava aumento populacional de 12.000 habitantes em 1713 para $30.000 \mathrm{em} 1760$.

A malha urbana cresce para além das fronteiras originais definidas pelos morros do Castelo, săo Bento, da conceicăo e Santo Antonio. As obras de melhorias promovidas pelos portugueses a fim de acolher este crescimento, principalmente as de tratamento de àreas de mangues e lagoas, definiram dois vetores básicos de expansão urbana para o Norte. Um deles partindo do antigo Largo da Prainha, atual Praça Mauá, ao longo da Bała, 
encontraria dificuldades devido ás conformaçôs geo-morfológicas e ao trabalho da maré. Outro, buscava o interior pelo outro lado destas formações a partir da planicie central e do núcleo histórico. A expansão da malha através de grandes aterros viria a ser uma característica da cidade.

Existem indicios de ocupação em nossa área de estudo desde - Século XVI com pequenas casas de pescadores, chácaras e capelas nos morros. Entretanto, segundo os historiadores, esta ocupaça só torna-se significativa a partir do sèculo XVIII. As condicões geo-morfológicas da àrea tornavam seu acesso e sua ocupaça diffceis, entre o sopé dos morros, as àreas alagadicas e as àguas da Bala. Sua ocupação, portanto, justificaria-se apenas a partir da premencia de expansao do núcleo histórico e das suas funções portuarias ao Tongo da costa (Fig. 27).

A Cidade chegava até o Largo da Prainha, que já funcionava como complemento e extensão do Porto principal, localizado no Largo do Carmo, atual Praça XV. Já no inicio do século XVIII o entorno da Prainha havia recebido construç̃es significativas como a Forca, a Casa dos Presos, a Capela de Săo Francisco de Paula, trapiches e atracadouros. Da mesma forma, o Morro da Conceicăo jà possuia além de moradias de pescadores, duas vias públicas, entre elas a ladeira da Prainha (atual Joăo Homem), que levavam a capela e ao castelo fortificado, no topo do morro.

Um pouco mais tarde também iria se destacar a famosa Rua do Jogo de Bola (ver Fig. 61), que desembocava na Pedra do Sal, local onde se dava o comércio do sal, então monopólio da coroa. Atualmente a pedra encontra-se tombada pelo Patrimonio Histórico estadual como local significativo da cultura negra no Brasil. 

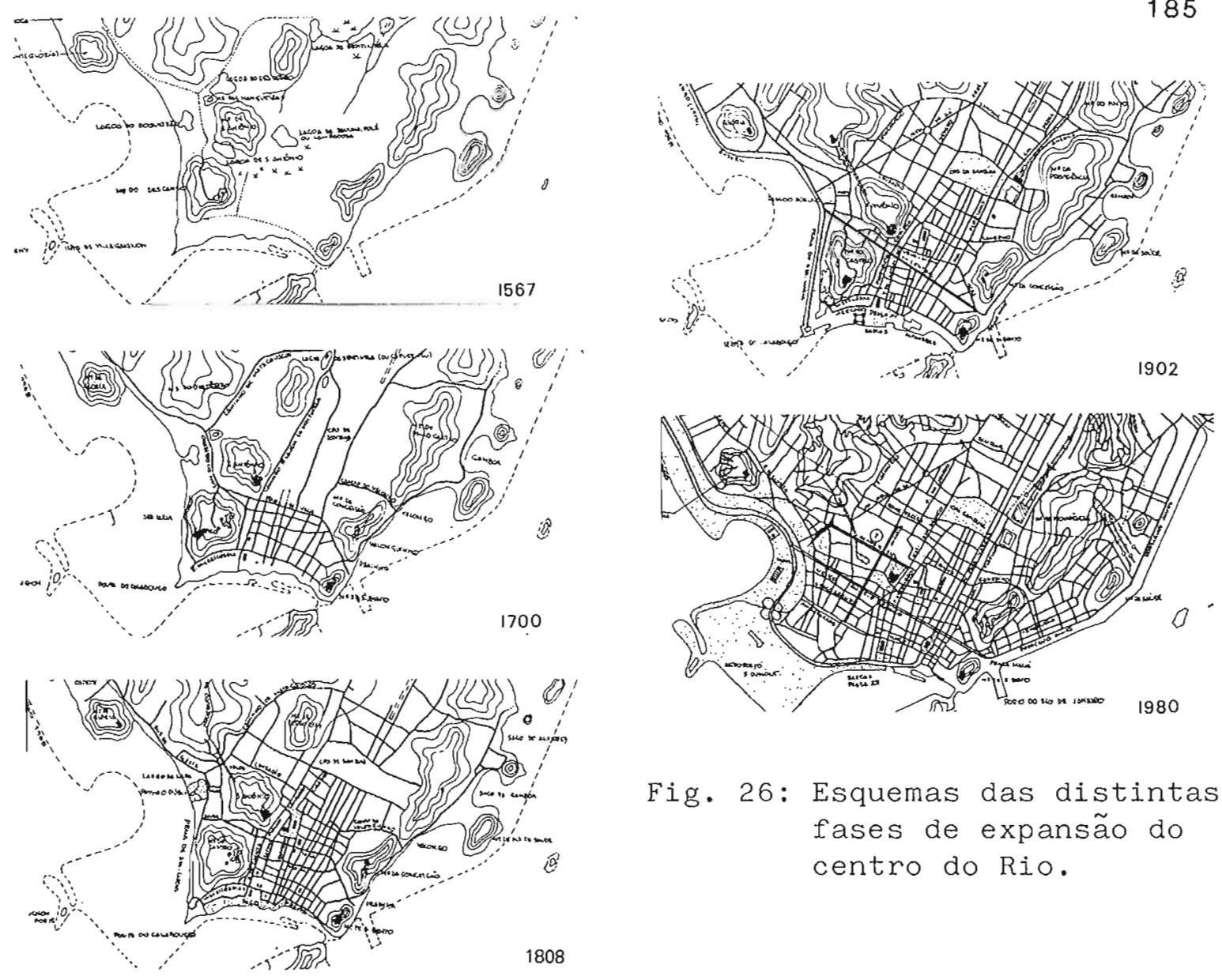

Fig. 26: Esquemas das distintas fases de expansão do centro do Rio.

Fig. 27: Croquis com os principais vetores e elementos do crescimento da Área Portuária e seu entôrno.

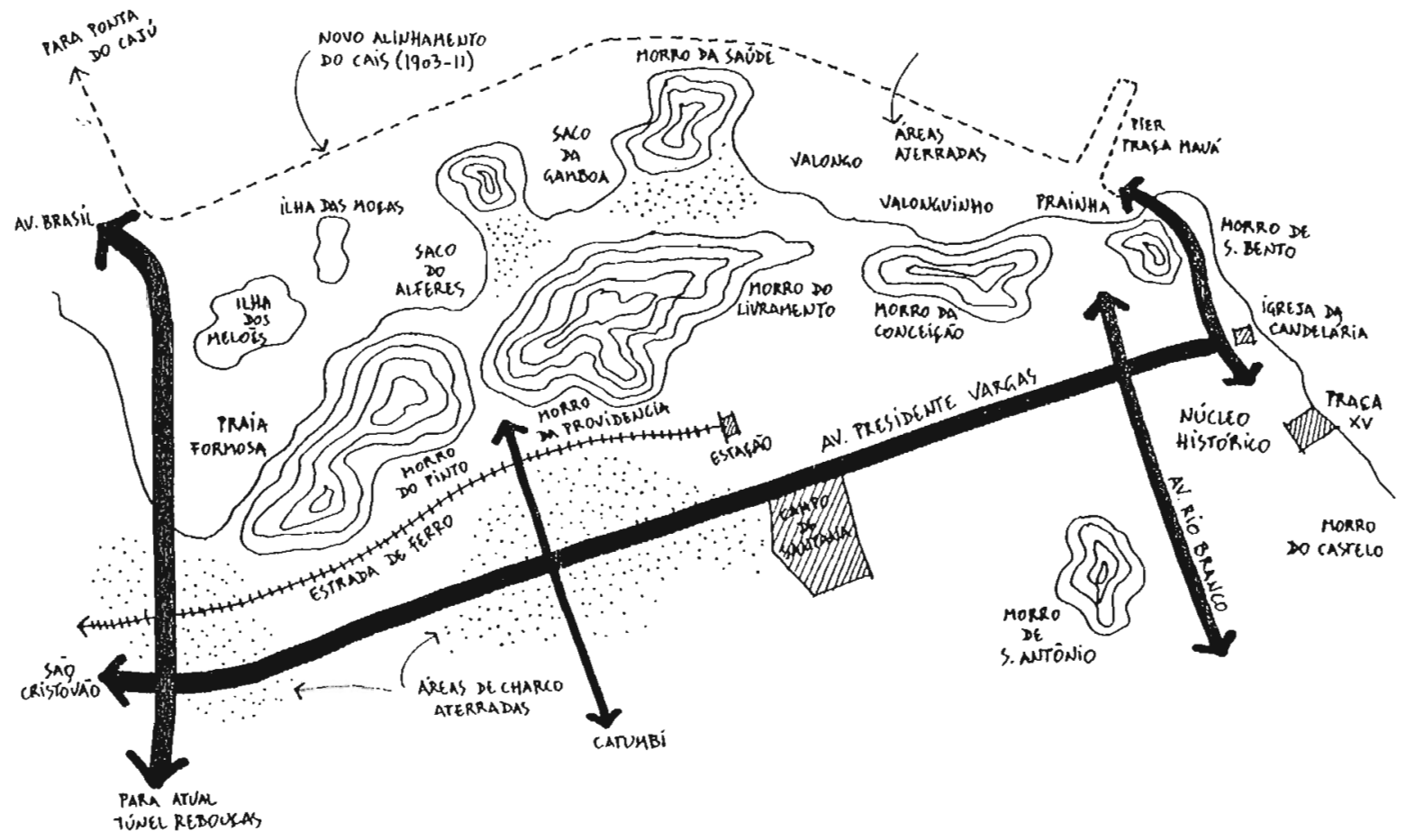


Alguns trapiches viriam a surgir também nesta época junto á Praça do Valongo, onde desembocava a Rua da Saúde, hoje conhecida por Rua Sacadura Cabra1, o que confirmava um dos vetores básicos de expansăo da cidade mencionados acima. Assim, tambèm o Morro da Saúde, um pouco mais longe do núcleo central, viria logo a receber a Igreja de Nossa Senhora da Saúde, por sua fama de local de bons ares marinhos.

Em 1831, a transferência do Mercado de Escravos do Largo do Carmo para o Valongo, por ato do Marquês do Lavradio, seria de grande importância como um primeiro indicio de "especialização espacial" da Cidade pois o núcleo central jà năo comportava este tipo de atividade (COARACY 1955, LAMARAO 1984). Dat talvez a origem de um processo de desvalorizaçăo da àrea que, junto com as próprias caractertsticas das funções portuảrias, trariam uma conotação bastante negativa que se mantém, de certa forma, como veremos em capitulos adiante, até os dias de hoje.

$\mathrm{Na}$ segunda metade deste século também se inicia a ocupação do Morro do Livramento, também por retalhamento das antigas chácaras, e surge o Cemiterio de Pretos Novos, no caminho da Gamboa entre o Saco e o Valongo, onde seriam enterrados os escravos e os negros recém chegados para o Mercado. Evidentemente que este local iria contribuir bastante para a imagem negativa da àrea. de qualquer forma, veria-se a consolidação da ocupação urbana das áreas junto aos morros da conceicão, saúde e Livramento, com novas estruturas geralmente voltadas para as funções portuárias tais como depósitos, armazéns, atracadouros, mercados, e afins (Fig. 28). 
V. 2. Secu10 XIX: Primeira Metade e consolidacåo de Funcốes

Neste século seria dado o grande impulso de expansão e consolidação de funções na área devido á chegada da Familia Rea1 em 1808 e á abertura dos portos a nações amigas. O comércio exportador também sentiria um grande crescimento com o inicio do ciclo do cafe, superando o acucar em valores e quantidades, vindo do Vale do Paralba e comercializado e exportado inteiramente pelo porto do Rio. A nivel global, a expansão do capitalismo e a cristalização do mercado internacional, com o desenvolvimento da navegaça, iriam gerar profundas mudanças nos sistemas sociais no Brasil e no resto do mundo (Fig. 29).

Como se sabe, a Inglaterra foi a principal beneficiària da Abertura dos Portos, em troca de proteção contra a expansão do bonapartismo na Europa e de empréstimos á Portugal. A mercadoria vinda da Inglaterra, por exemplo, pagava apenas $15 \%$ em tarifas alfandegária, enquanto as portuguesas pagavam $16 \%$ e as dos outros paises pagavam 24\%. LAMARAO (1984) registrou um aumento significativo do total de embarcaçós a se utilizarem do Porto do Rio neste periodo, de 778 em 1807 a 5000 , de várias nacionalidades, em 1811. A intensificacão do tráfico de escravos, um dos sustentàculos da economia, tambèm marcava a utilizaçăo do Porto do Rio com 53.000 escravos chegando á cidade apenas em 1829 (LAMARÁ 1984).

Estes fatores ajudaram no rompimento do equilibrio da cidade que em apenas duas décadas teria a sua população duplicada, chegando a 100.000 habitantes em 1822 (BENCHIMOL 1982). Calcula-se que apenas a vinda da corte contribuiu com 


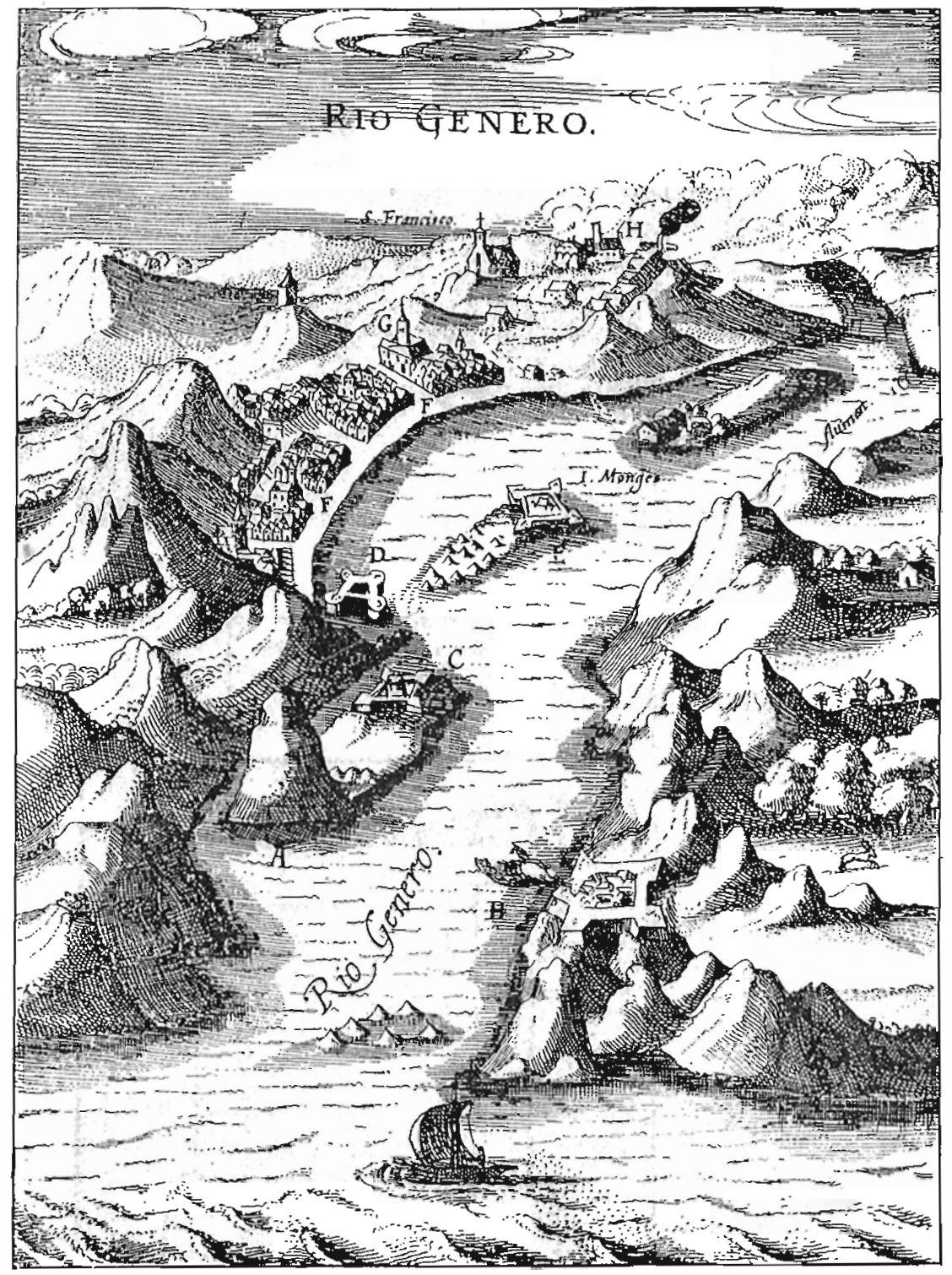

188

Fig. 28 : Aspecto geral do Rio em 1624, gravura de N. GEELKERKEN. Ao fundo, a letra $\mathrm{H}$ indica o Mosteiro de São Bento.

Fig. 29 : Carta topográfica da Cidade do Rio de Janeiro, pelo Capitão A. FIGUEIRA, 1775.

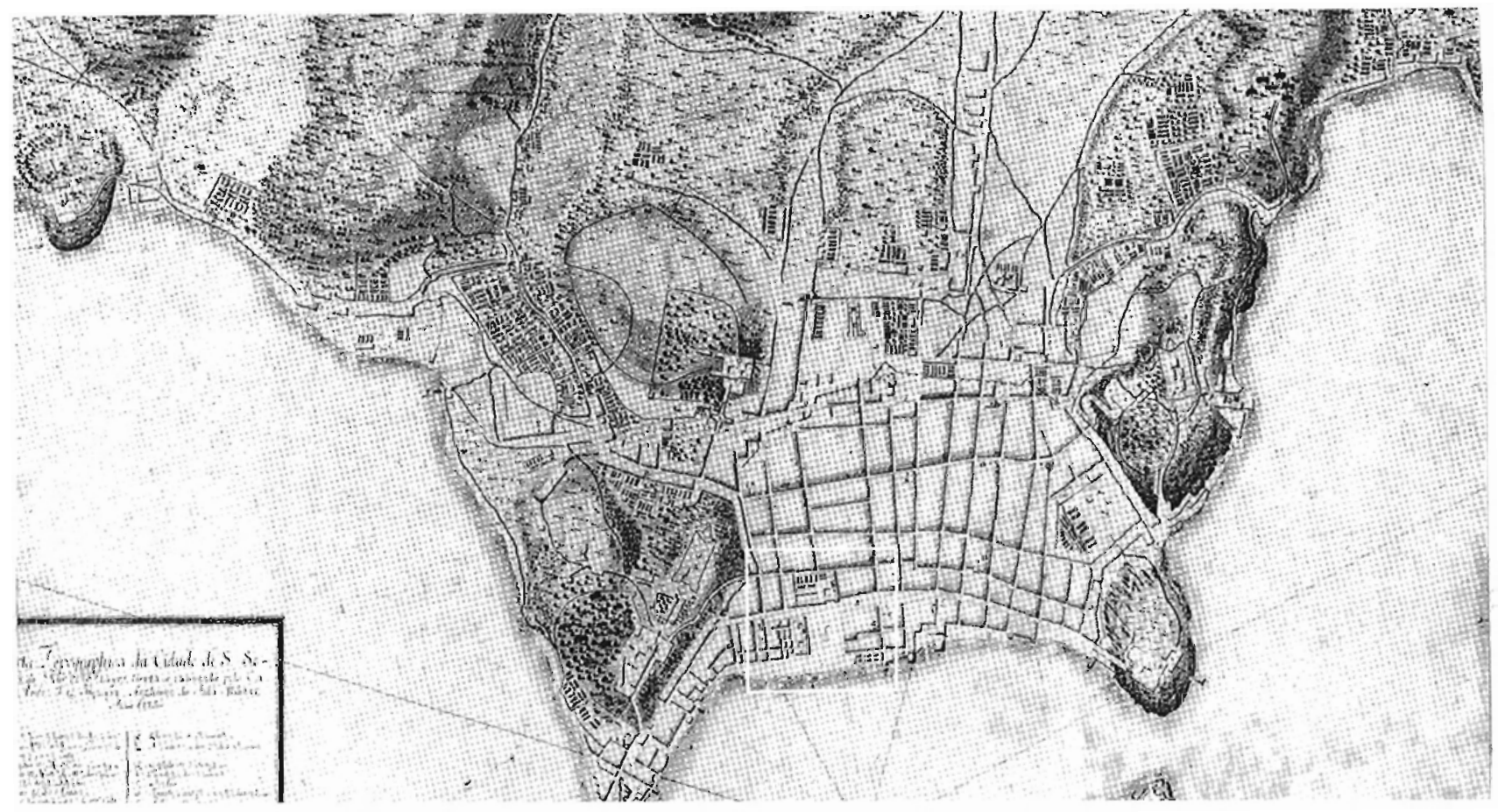


cerca de 15.000 novos habitantes. Tudo isto veio gerar novos valores e interesses, a intensificação dos vetores de crescimento, ampliaçăo dos tipos arquitetônicos praticados e uma ampliaçăo inusitada da demanda habitaciona1, concorrendo para a especializacão espacial e um inlcio de processos de valorizacăo do solo.

Incentivos fiscais apoiavam aterros de mangues e a ocupação de àreas como a Cidade Nova, ao longo do Canal do Mangue, confirmando o vetor de crescimento consolidado com a instalaçăo do palàcio real na Quinta da Boa vista, săo cristóvão. As obras de saneamento, melhorias e embelezamento representavam valores trazidos pela corte e confirmados pelas missões francesas, com o simbolismo e a monumentalidade transmitidos pelo estilo neo-clássico. o centro da cidade já iria sentir esta modificaçăo da dinâmica urbana e as residências mais nobres mudam para são Cristóvão e Flamengo, dando lugar ao surgimento de corticos e casas de cômodos, além de permitir a expansão das funções não habitacionais.

Por decreto de 1809 , D. João afora terrenos na Praia da Gamboa e no Saco do Alferes para trapiches, sendo favoràve1 å construção de um cais na Praia do Valongo. A Prainha, por esta época, tornava-se o principal entreposto para o comércio de madeiras e de café, advindos da região do Rio e do vale do Paraiba. As atividades portuárias fazem intensificar a ocupação da área de estudo que recebe uma série de pequenos aterros ao longo da Rua da Saude, atual Sacadura Cabra1, e geram o surgimento de novos parcelamentos das antigas chácaras nas encostas dos morros. 
A orla marltima comeca a especializar-se funcionalmente e a ser regulamentada com inumeros trapiches e atracadouros, atè o Valongo. Como resultado natura1, a1 também iriam surgir as primeiras atividades industriais, representadas por oficinas de fundicão, serralherias e pequenas fábricas de objetos 1 igados ás atividades portuárias. Segundo LAMARÃO (1984) a mais antiga fundicão, a Imperial, localizada no caminho do valongo, foi inaugurada em 1829. Isto se dava de forma ampla, mas sempre 1igada ao mar; o Cemitério dos Ingleses e seu cais, por exemp1o, tambem seriam construldos no saco da Gamboa, em 1811.

Os estudiosos consideram este periodo como critico na definicão do perfil socio-econômico e urbanistico que o Rio viria a ter. o centro tornava-se, entăo, "... cada vez mais o locus de um conjunto de realidades criticas, oriundas da crescente incompatibilidade entre a antiga estrutura material da cidade e as novas relaçoos econômićas capitalistas que nela se enraizavam" (BENCHIMOL 1985: 600). Esta preocupação crescente iria eclodir no pertodo Rodrigues Alves, já no intcio do século $x X$, como logo veremos. Os excedentes de capital da producăo agricola e extrativa comecavam a ser reinvestidos na cidade, o que se refletia em obras públicas, construcão residencial e expansão dos servicos púb1icos (Fig. 30).

A primeira obra urbanistica de vulto para intervencão na própria imagem da cidade foi a construcão da primeira praça monumental do Rio para celebrar a chegada da Princesa de Tereza Cristina em 1843, para o matrimônio com D. Pedro II. Projetada por Grandjean de Montigny e construtda no lugar do antigo Mercado de Escravos, ela era o intcio do percurso festivo que 1 igava o 
Fig. 30: A Cidade do Rio de Janeiro no início do Século XIX (in ABREU 1987)

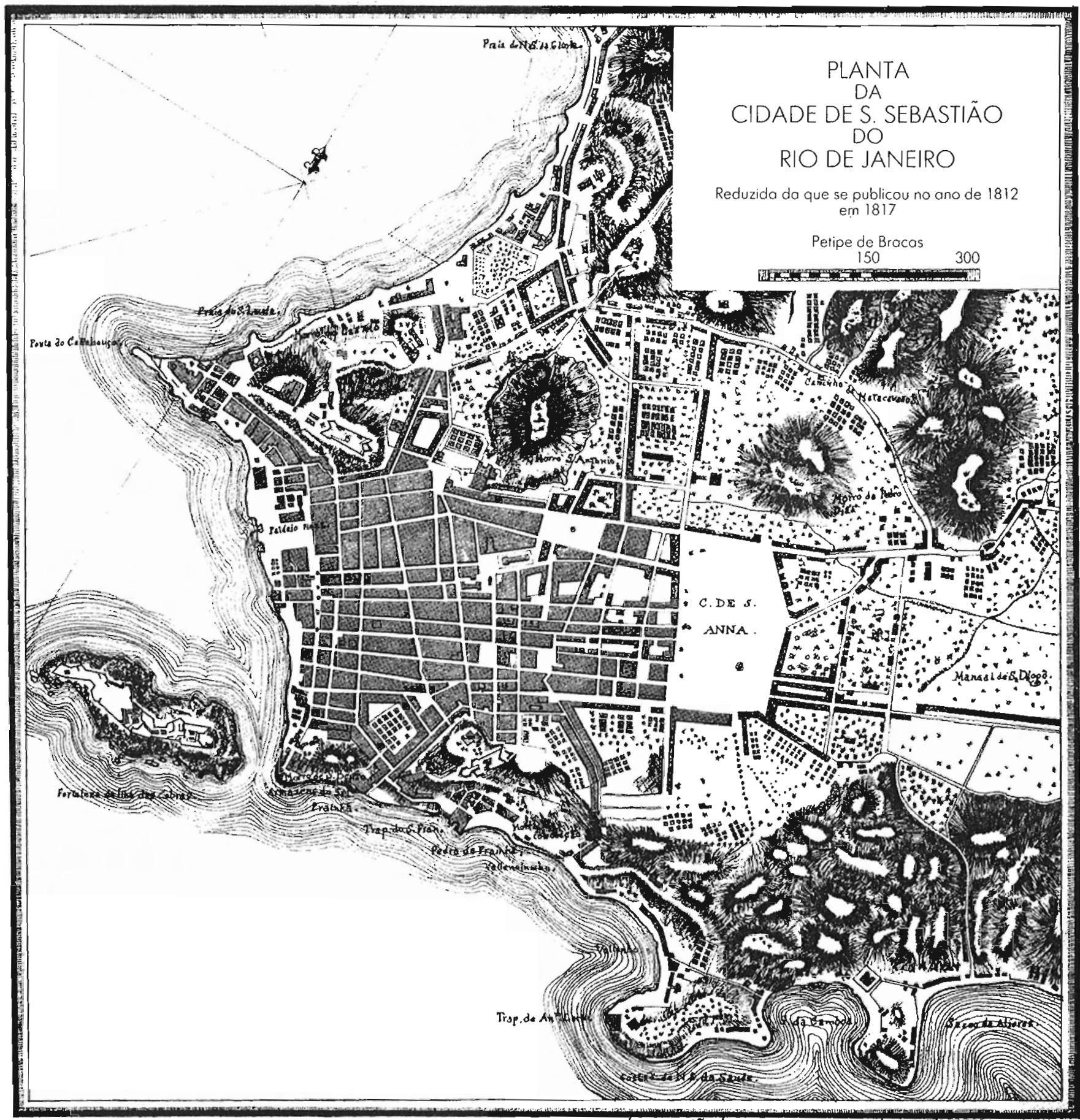

RIPRoducso a Mão do Mapa encorTrado va Blblotech Hacloral ARC 15.1 .2 por Jorbe Enriave Janke $H$. 
Porto ao Largo do Carmo, hoje Praça XV. Outras edificaços importantes tambèm estavam sendo construidas na àrea de estudo, consolidando suas funções, como a Escola Naval no Largo da Prainha, que funcionou de 1849 a 1867 , e o segundo maior mercado da cidade, no Largo da Harmonia, junto á Rua da Saúde em 1855 . No decorrer da segunda metade do século a àrea já estaria perfeitamente integrada ao resto da cidade.

Foi nos setores de servicos publicos urbanos que o capital estrangeiro seria investido, mostrando sua operacionalidade, principalmente no que diz respeito ao abastecimento e distribuição de água, linhas e companhias ferroviárias e de bonde, eletricidade, iluminaça pública, etc. As concessões iriam aumentar em muito durante a segunda metade do século, acompanhando a expansão do Capital e a maior inserção do pats no mercado internaciona1. O Rio, como a principal metrópole, representava papel primordial funcional e simbolicamente.

V. 3. Século XIX: Segunda Metade e Especializacăo Espacial

Os reflexos da Revolucăo Industrial nos palses centrais, a intensificaça das relacơoes capitalistas de produça e a internacionalização dos investimentos jà começavam a marcar profundamente o sistema urbano e o espaço das cidades no Brasil. Este, por exemplo, foi o caso dos impactos causados pela introducão da ferrovia, da energia a vapor e, logo depois, da eletricidade.

Com o crescente aumento das atividades portuárias, grandes interesses vão rebater-se na Area Portuảria, expectativas de sua modernização. Neste pertodo, até pelo menos 1870 , houve uma série 
de projetos propostos para estas obras, incluindo novas docas, inter 1 igação á ferrovia, novo maquinário a vapor, etc. (LAMARAO 1984). A maioria destes projetos incluia a Doca da Alfândega como principal preocupaçăo, ao longo do nủcleo histórico central da cidade, cujo intcio das obras de melhorias ocorreu em 1853 e se estenderiam ainda por quase toda a segunda metade do século.

A primeira ferrovia do Brasi1, inaugurada em 1854, foi iniciativa do Barão de Mauá e ligava o Porto de Mauá, no fundo da Bala onde hoje é o municipio de Magé, a Raiz da serra de Petrópolis. Para chegar 1á, tomava-se um barco na Prainha (Praça Mauá), cujos trapiches também haviam sido absorvidos pelo Barăo, ao Sopé do Morro de Săo Bento. Segundo LAMARAO (1984) jà nesta época pensava-se construir um terminal ferroviário de cargas entre o Porto e a Estação da Estrada de Ferro D. Pedro II, que seria inaugurada junto ao Campo de Santana em 1858.

Mas foi apenas após as sucessivas obras sanitårias e o aterro do Saco de Săo Diogo, em 1850 com a criação da Cidade Nova, e da consolidaçăo de såo cristóvão que a via férrea vaj passar a ditar o vetor de expansão da cidade para o Norte, os subúrbios e o Vale do Paralba (ABREU 1987). Acompanhando a orla maritma para o sul e os bairros mais elegantes, das mansões da alta burguesia e do casario de classe média, o vetor consolida-se com as linhas de bonde até Botafogo e o Jardim Botânico.

Este novo dinamismo econômico e social iria imprimir modificaçoses profundas no perfil da cidade, estabelecendo tendências de desenvolvimento determinantes de seu caráter atual. Diversos autores observam que è nesta época que vai se definir uma hierarquizaçăo social e funcional da cidade como um todo, 
ficando a àrea de estudo, entre os morros e a Bata, com os trapiches, oficinas, unidades de grande porte e bolsões residenciais de baixa renda junto aos bairros dos morros (BENCHIMOL 1982, RAHBA 1985, LAMARAO 1984, ABREU 1987).

Enquanto isto, o Morro do Pinto era loteado e ocupado em queståo de poucos anos no intcio da década de 1870. No Morro da Gamboa instalava-se uma das primeiras casas de saude do Rio, para doencas infecciosas, em 1853 e no Caminho da Gamboa (atual Rua Pedro Ernesto), um teatro de amadores em 1863, e a primeira escola pública do bairro, iniciativa de D. Pedro II, em 1877.

A dinamizaçăo do comércio exterior e das atividades portuárias levaria a intensa disputa entre grupos de interesses para o dominio das funções do Porto, conflitos detalhadamente descritos por LAMARAO (1984). As atividades de grupos privados no controle dos servicos urbanos e infraestrutura eram defendidas como de muito maior dinamismo e efetividade, em relaçăo aos gerenciados pelo Estado. Evidentemente, estes grupos privados possulam fortes alianças com o capital internacional, principalemnte o inglês. Finalmente, o Império iria conceder a criaçăo de duas companhias para exploração do Porto. A primeira delas, a Companhia Docas da Alfândega, objetivava o alinhamento do cais e melhoramento de seus servicos desde o Arsenal de Guerra ao da Marinha, ao longo do núcleo historico; o inicio de obras se deu em 1853, estendendo-se atribuladamente até o fim do século.

A outra companhia, a Docas D. Pedro II originou-se de um plano entregue ao governo pelo engenheiro Andrè REBOUCAS, em 1868, em que defendia um porto moderno, com estacão marttima diretamente 1 igada á Estaçăo D. Pedro II, 1 inhas férreas ao longo 
do cais, mais armazèns, estaleiros e diques, desde a Prainha á Saúde. O próprio REBOUCAS, que foi o primeiro diretor da Companhia Docas da Alfândega, apontava suas insuficiências mesmo após remodelado, no atendimento do movimento de carga e descarga. Ele destacava a necessidade de expansão do porto para além da Prainha, àguas de bom calado e áreas de um ntvel de consolicação não tão comprometedor quanto o entorno da Alfândega. LAMARÃO (1984) observa que a Companhia de D. Pedro II seria formada em $1870 \mathrm{e}$, cinco anos depois, inaugurava um cais de $160 \mathrm{~m}$ de extensăo entre a Pedra do Sal e a Praça Municipal (hoje Barão de Tefé) (Fig. 31).

Diversos empresários e casas comerciais se interessariam em investir na Companhia, que tinha o direito de desapropriar e indenizar, isençăo de impostos atè dez anos após o término das obras para compra de material, e cobrava taxas de atracacão por metro linear ocupado por embarcąão (LAMARÃO 1984). Embora o Imperador cedesse por decreto a criaça da companhia, como resultado das pressôes dos grupos de interesse, foi impedida a 1 igação do Porto com a Estação D. Pedro II. A competição entre estes grupos e entre as duas companhias formadas, que se tornariam quase rivais, viria a inviabilizar a Companhia Docas D. Pedro II, cujo arrendamento foi rescindido pelo Império em 1879. Entretanto, importante impulso representou para a cidade e, especificamente, para a área portuária a formação da comissão Melhoramentos da Cidade, em 1874. Esta Comissăo foi a primeira resposta do Estado para a crescente necessidade de adaptaça da cidade, suas funços e estrutura fisico-espacial, aos modos e relaçoses de producăo que se impunham. Dela participou o 
engenheiro Pereira Passos que depois viria a ser o atuante e controvertido Prefeito da cidade. A comissão propos onze pontos, que LAMARAO (1984) diria constituir-se, na verdade, o primeiro plano urbanistico da cidade, dentre os quais já se identificava a queståo portuária como uma das básicas, com o ramal ferroviário e o terminal.

Quando Pereira Passos assumiu gestão como Diretor da Estrada de Ferro D. Pedro II, em 1876, identificou o sitio da Gamboa como ideal para o terminal marttimo jà pensado havia anos, e logo iniciou obras de instalacão do ramal ferroviảrio,com extensão total de $989 \mathrm{~m}$ e dois tủneis através do Morro da Providência, um de $82 \mathrm{~m}$ e outro de $313 \mathrm{~m}$ de comprimento (LAMARÃo 1984). As obras do cais e do terminal marttimo terminariam no inicio dos anos 1880 e iriam ocupar de $9.575 \mathrm{~m} 2$. Este foi talvez - major aterro na nossa área de estudo até então registrado. Autores como BRASIL (1965) observam que o impacto do terminal foi importante dinamizador para a àrea portuária, fortalecendo suas modernas funções portuàrias (Fig. 31).

Toda a segunda metade do século foj marcada por sucessivos surtos epidêmicos. A primeira grande epidemia foi em 1850, de febre amarela, e teve seus pontos de irradiaça justamente na àrea da Prainha e da Saúde. Até 1891, com surtos de febre amarela, vartola, malària e influenza, a população morria aos milhares e a àrea portuária foi, seguidamente, a mais atingida. REIS (1977), por exemplo, destaca o principio de legislacăo obrigando conservaçăo de edificacões e a modernizaçăo do matadouro público a partir da criaçăo da Comissão de Saneamento em 1895. Aponta-se, inclusive, que a associação da àrea com as 
epidemias foi o motivo para bloqueio, durante muito tempo, de me1horias públicas na área.

Proclamada em 1889, a República já herda o pals endividado e compromissado com o Capital internacional. Autores vários observam que no fim do sèculo jà havia grave crise orcamentária e deficit na balanca de pagamentos da Prefeitura do Distrito Federa1, com dividas internas e externas (REIS 1977, CARVALHO 1985, ABREU 1987) devido principalmente á expansăo econômica e financeira dos palses centrais, o aumento das despesas do Estado Republicano, e á baixa de câmbio para facilitar as exportacões (FURTADO 1977). Por outro lado, chegava ao fim a era das concessões frente á incapacidade do poder privado de implantar grandes obras urbanisticas, como foi o caso das modernizações portuárias. A própria Proclamação da República parece ter resultado em um maior empenho dos homens publicos e do proprio Estado, na busca por identidade e legitimação.

V. 4. Seculo XX: Estruturas em crise

A virada do século traria ao Pals e á cidade tempos bastante conturbados, com mudanças sociais, politicas e econômicas. A mudança no regime politico iria precipitar grandes transformações econômicas e sociais que gestavam hà algum tempo, principalmente atravès de uma nova consciência politica ampliada da população, como observou CARVALHo (1985). Este autor tambèm destaca cinco alteracões bảsicas que afetariam o Rio profundamente: aumento demogrảfico (imigração e abolicão), surtos epidêmicos, déficit habitacional (quantidade e qualidade), inflação (emissão de moeda sem 1astro), e especulaçăo financeira. 
Mostra, tambèm, como os republicanos não conseguiram, contraditoriamente, a adesão das camadas populares, como os negros, que apoiavam a monarquia. Também, como forma de neutralizar o entåo Distrito Federal, com suas forcas mais progressistas, o Estado aliava-se ás oligarquias dos Estados.

Para o Rio, a situacăo mais explosiva era gerada, sem dủvida, pela intensa crise habitaciona1. o mercado não dispunha de habitaça suficiente para a crescente camada social de baixarenda, principalmente oriunda das áreas rurais: escravos 1 ibertos, camponeses europeus descontentes com as condicões do campo brasileiro, e todo tipo de gente atralda palo nascente setor industrial ou pelo setor informal de trabalho. Por outro lado, um problema talvez maior, com reflexos imprevisiveis, era o da qualidade da habitação dispontve1: edificaçóes precàrias, alta densidade, falta de saneamento e de higiene.

As estimativas mostram que a população do Distrito Federa1 superava os 680.000 habitantes em 1900. O recenseamento de 1906 jà acusava um crescimento para 811.443, e LAMARAO (1984) estima que a área portuária detia parcela significativa desta populacão pois abrangia quase toda a área das freguesias de Santa Rita e Santana (Gamboa), com 87.978 habitantes, dos quais $40 \%$ eram estrangeiros. Os corticos e estalagens eram os tipos residenciais mais comuns, com grande densidade e precárias condições de saúde, e a àrea portuảria concentrava muitos deles.

Também al1, no Morro da Providência, se formaria a primeira favela do Rio de que se tem noticia, por volta de 1897, com precários casebres dos soldados (e suas familias) que retornavam da Guerra dos Canudos, sob permissăo de seu quartel militar 
situado junto ao Campo de Santana (Fig. 32). Logo iria inchar-se com a população pobre expulsa do centro com o inicio da repressăo aos corticos, como o famoso "Cabeqa de Porco" (ABREU 1986, 1987; VAZ 1986). Para se ter idéia da gravidade da situação, VAZ estima que o "Cabeca de Porco", localizado na área do entorno a Estaçăo D. Pedro II, teria chegado a abrigar 4.000 pessoas.

Ao mesmo tempo que apresentava condicões precárias para as funções portuảria e residencial, a área portuária havia se tornado em importante concentracão de indústrias e oficinas, fundicôes e serralherias (Fig. 33). Desde o fim do século XIX, inclusive, jà abrigava duas grandes unidades fabris: o Moinho Inglês e o Fluminense, cujos prédios existem atè hoje, beneficiadores de trigo, que possuiam seus próprios cais e trapiches. A àrea tambèm seria servida por vàrias linhas de bonde, na virada do século, ligando-a ao Norte, através de são Cristóvão, e aos bairros do sul (LAMARÃo 1984).

Nesta época o Poder Púb1ico partiria, então, para tentar controlar o crescimento da cidade e "ordenar" as atividades urbanas. Ao lado das razôes sanitárias e de excesso demográfico já mencionados, duas outras revelam-se não menos importantes: a "explosividade potencial do centro... em caso de conflito social" (ABREU 1986: 51), e a importante imagem da capital do pais num mercado internacional em que tentava impor-se. surgiam os primeiros códigos de Posturas (1890) e outros regulamentos, edilicos e de atividades, que passaram a exercer forte controle na área do Distrito Federal, trazendo nitidas desvantagens á população pobre. Como observado por ABREU (1986), a estes só restavam duas alternativas: submeter-se ás precarissimas 

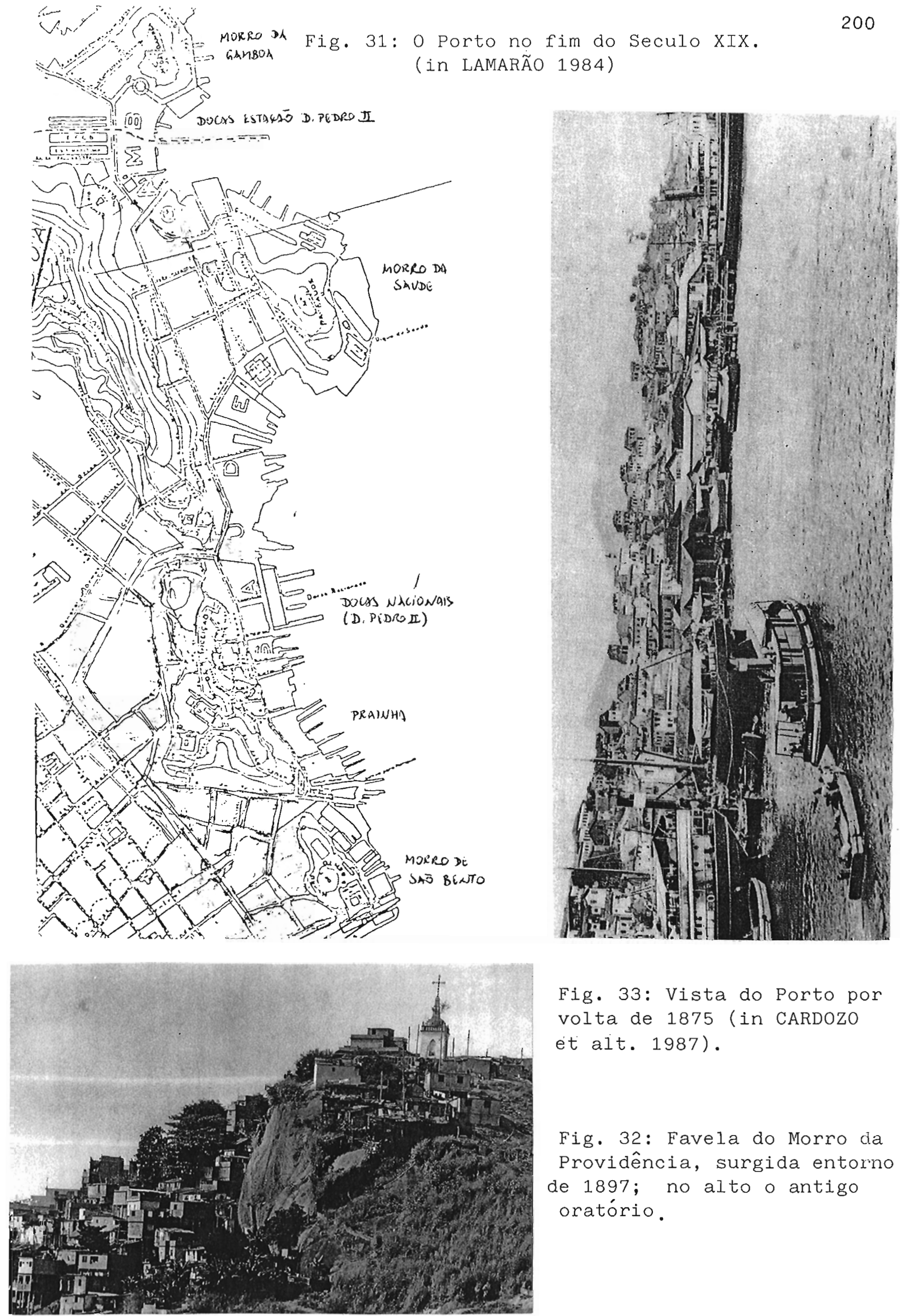

Fig. 33: Vista do Porto por volta de 1875 (in CARDOZO et alt. 1987).

Fig. 32: Favela do Morro da Providência, surgida entorno de 1897; no alto o antigo oratório. 
condicões das jà iniciadas favelas e nos densos corticos ou estalagens que sobravam, ou abrir mão da centralidade para habitar um longinquo subúrbio, onde năo havia o controle edflico do Distrito Federa1. Surge, a1, uma caracteristica de nossa cidade na dicotomia centro-periferia.

As novas relaçôes sociais estabelecidas e aquelas entre o Estado e o Capital descobrem os mecanismos para valorizaça do solo, a especulaçăo imobiliária, os requisitos da funcionalidade urbana, e a importância da queståo da imagem da cidade. Esta Ultima revelava-se cada vez mais determinante no comércio exterior e na atraçăo do capital estrangeiro; o Rio identificavase como o necessário cartão postal da naçăo emergente, local a receber investimentos e promocão. Portanto, junto com as ameacas sentidas pelas classes dominantes, pelas epidemias e pela expansåo da pobreza urbana, o Estado vaj ter razôes suficientes para promover uma sẻrie de açoos a fim de corrigir esta situação. Neste panorama, diz CHIAVARI (1985: 569), "a ação violenta, de destruir, desabrigar... transforma-se em conceito positivo de destruicão do mal". O mesmo nacionalismo e expansăo do sistema econômico já vinha ditando açơes pủblicas, como nos lembra a mesma autora, no sentido de conquista do interior, desenvolvimento e progresso: linhas férreas, novas regiões abertas e novas cidades implantadas, como Belo Horizonte.

A crescente preocupação social é resposta a uma situaça ameacadora, explosiva, e á incapacidade da cidade responder aos anseios da populaçăo, á novas relaçôes sociais e aos meios de producăo. Situacăo semelhante jà havia sido vivida no principio 
do Século XIX em palses da Europa, onde a Revoluça Industrial forneceu as bases para expansão do capitalismo (BENEVOLO 1963). Neste sentido é que as intervençôes urbanisticas promovidas por Rodrigues ALVES e Pereira PASSOS são comparadas com as ações do Barão von HAUSSMAN, em Paris (BENCHIMOL 1982, BRENNA 1985). No Rio, BENCHIMOL (1985) aponta, para tanto, três grandes agentes dinamizadores: o crescimento do comércio internacional á niveis sem precedentes, a exportaçăo de capital em termos de empréstimos e investimentos, e o desenvolvimento tecnológico. Tudo isso seria permeado pelo "progresso pela ciência" e por um "autoritarismo iluminado" do Estado, como analisado por CARVALHO (1985), num positivismo que caracteriza nossa cultura até hoje.

V. 5. Rodrigues Alves e Pereira Passos: Novas Relacôes e Novas Imagens para a Capital

o periodo do Presidente Rodrigues ALVES (1902-1906), foi de intensas mudanças na situação politico-econômica do País. o Estado, como vimos, encontrava-se necessitado de intervir drasticamente na Capital Federal a fim de resolver problemas de diversos niveis, que refletiam conflitos surgidos de uma só fonte: da expansão das relaçoos de produção capitalista. Estes problemas rebatiam-se particularmente na área portuária, entendendo-se prioritària.

Funcionalmente, as condiç̃es do porto e sua infraestrutura de apoio não davam vazão ao fluxo comercial, entrada e saída de mercadorias, e as embarcações costumavam ficar ancoradas ao largo da Bata por dias, aguardando a vez para atracar, ou se submetiam a dificil processo de desembarque das mercadorias por 
"baldeaçăo". Situação insustentável pois o Rio jà seria responsàve1, em 1906, por 45\% da receita da União oriunda de direitos alfandegários (LAMARAO 1984). Em paralelo a estas razões, tinhamos as necessidades das próprias casas comerciais e indústrias da àrea. que complementavam as atividades portuàrias e significavam importante setor econômico de pressão.

Em termos sociais, a àrea portuária não poderia possuir pior fama e piores condicões de vida que as verificadas na entrada do século. Em insalubres habjtaçōes coletivas, focos de epidemias, ao longo da Rua da saúde, junto a áreas alagadicas, nas encostas dos morros, ou misturadas ás atividades portuárias, a maioria da população era de baixa-renda. Conhecido "antro de malandragem", lá muita gente estava ligada á marginalidade (como os famosos grupos de capoeira, entåo fora-da-lei), á prostituicão, ou simplesmente eram ex-escravos não integrados ao mercado de trabalho forma1. A saúde era, inclusive, pejorativamente conhecida por Pequena Africa e é tida como o berco do samba, carnava1, capoeira, futebol e violão.

Ironicamente, no entanto, como observado por CARVALHO (1985), muitas destas manifestaços culturais e sociais, repudiadas áquela época, formariam a primeira identidade coletiva da cidade. A imagem da área, portanto, era das mais negativas, tanto no âmbito da sociedade carioca, quanto no exterior, através do comercio internacional.

- Estado jả vinha intervindo crescentemente na questão urbana, cristalizando as novas relaçoes sociais, viabilizando a reprodução e concentração do Capital. Em 1901 se iniciava o desmonte do Morro do Senado, no Centro, que gerou $125.000 \mathrm{~m} 2$ para 
aterros no Mangue e no saco de Săo Diogo (REIS 1977, LAMARÃo 1984). Em busca de investimentos estrangeiros, também se iniciava maciça campanha internacional para recuperação da imagem positiva do Rio, através de jornais, revistas, exposicões e feiras, descritas por BRENNA (1985). O novo "cartåo postal" da cidade seria no espirito "Belle Epóque", cujo auge foi na primeira dècada do século, e o Rio vaj tomar Paris como modelo urbanistico a perseguir (vide Fig. 1). As intervençós de HAUSSMAN eram os exemplos: funcionalidade, monumentalidade, elegância, controle social e valorização fundiària.

Com a posse de Rodrigues ALVES, o governo federal assume a coordenaça e implantaçăo dos projetos e obras para o porto, visto como pólo de extenso projeto de remodelação e saneamento da Capita1 (LAMARAO 1984, BENCHIMOL 1985). Como pré-requisito á ampla intervencão planejada na cidade, que não só restringiria aos seus aspectos físico-funcionais mas afetaria os próprios costumes da populąăo, foram aprovados decretos e promulgadas leis de excessăo que viabilizariam a arbitrariedade, a urgência e - dinamismo destas ações. Exemplo maior disto foi a própria indicacăo do novo Prefeito, o Engenheiro Pereira PAssos, empossado um dia após a suspensăo por seis meses do Conselho Municipal, o que the daria plenos poderes para promover arrocho fiscal, novos impostos, novos artiflcios para facilitar desapropriaços (BENCHIMOL 1982 \& 1985). Destes artificios destacam-se, por exemplo, venda e permuta de terrenos em hasta pủblica, não indenização da desapropriacăo de prédios considerados ruinosos, ou tomar por base o valor declarado dos imóveis para as indenizações. 
Os interesses poltticos e econômicos das naçós centrais, como a Inglaterra, e dos grupos internacionais fariam com que crescessem os investimentos no Brasi1. Os créditos e empréstimos externos seriam facilitados: tudo isto fomentado pelas reduç̃es cambiais que facilitavam nossas exportaçôes de café, açúcar e cacau (FURTADO 1977). A modernização do porto e as obras de methoramentos do Rio se deram graças a elevados endividamentos do Pals com, principalmente, o Banco Rotschild, num processo de progressiva dependência externa. O ciclo de produçăo dependente é estabelecido, onde todos os elos da cadeia dependem de insumos externos: financiamento/obras/producăo/exportaçăo. BRENNA (1985) menciona que no infcio de 1903, o Brasil conseguiu um empréstimo no valor de 8,5 milhões de 1 ibras esterlinas para a renovação do porto e obras complementares, incluindo at a implantaça da $A V$. Central (atual Rio Branco), considerada como obra complementar e artèria para distribuicão das mercadorias descarregadas.

Interessante acompanhar, na obra de BRENNA, as noticias e crtticas nos jornais da época, ao montante dos custos, á forma dos contratos e ao próprio endividamento externo (Fig. 34). 0 Jornal Avenida, de 8/8/03, por exemplo, dizia que os maiores interessados nas obras do Porto e da Avenida eram o Barão ROTHSCHILD e o Dr. Rodrigues ALVES (in BRENNA 1985: 90).

Neste ponto seria importante atentarmos até que ponto a dependência externa veio a ditar padrões diretamente no estabelecimento de novas morfologias urbanas. Acho que fica claro que muito pouco, ou quase nada, dos modelos e parâmetros urbanisticos de entåo eram originados em nossa própria cultura, muito pelo contrário, esta era reprimida ao máximo como 
manifestaçăo cultural sub-desenvolvida, como foi o caso com o samba e o violão. De forma talvez mais evidente, alguns tipos arquitetônicos, que respondiam a novas funçốes antes desconhecidas, eram diretamente importados como era o caso das fábricas e moinhos de beneficiamento, ou armazéns 1 igados aos novos processos de cabotagem e armazenamento.

Antes de mencionarmos as realizacooses urbanisticas mais significativas do Governo Federal no Rio e do Prefeito PEREIRA PASSOS, vale lembrar a sua forte atuaçăo no setor de higiene e saủde pública, o que iria interferir diretamente na vida da populacăo, jả estimada em mais de 800.000 pessoas, e ditar tantas obras. São as preocupações com as epidemias que iriam legitimar a ação pública, normas urbanisticas e edilicas, e códigos de postura. E neste periodo que atuou Oswaldo CRUZ, encarregado da saúde pública, no combate ás epidemias e seus focos.

Grandes problemas, entretanto, eram causados pela forma com que se dava esta atuaçăo, sempre autoritária e sem conscientização prévia da populacão. Os registros da época mostram que as "brigadas sanitarias" de CRUZ espalhavam verdadeiro terror nas comunidades, resultando, inclusive, na Revolta da Vacina de outubro de 1904. A populacão, principalmente aquela das habitaçóes coletivas no centro, revoltava-se violentamente à vacinaça compulsơria contra a variola e febre amare1a. A situaça gerou verdadeiras batalhas campais, com armamentos e barricadas, com importante foco de resistência nos bairros da saúde e Gamboa (LAMARAO 1984, BENCHIMOL 1982). Chegou-se a decretar Estado de sitio na Capital, em outubro de 1904, para facilitar a ação da policia. 

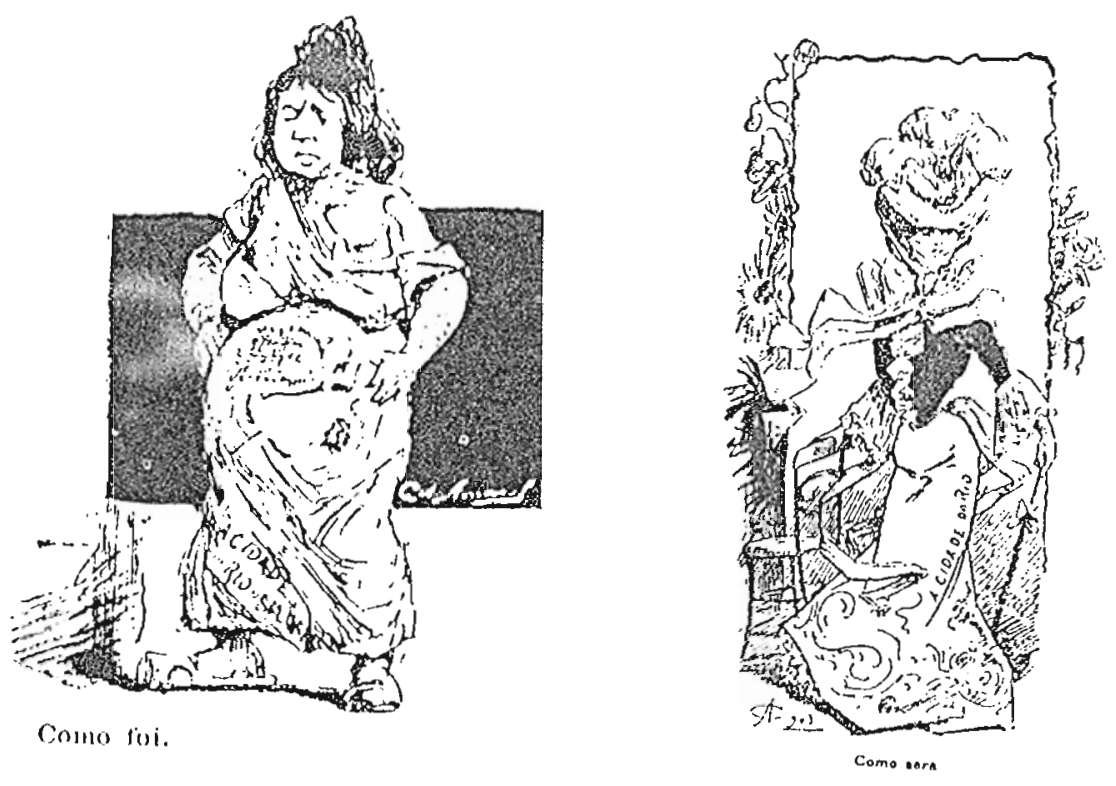

207

Fig. 34: Charge sobre o embelezamento da cidade promovido por P. PASSOS, revista "A Avenida" 8/1903). (in BRENNA 1985)

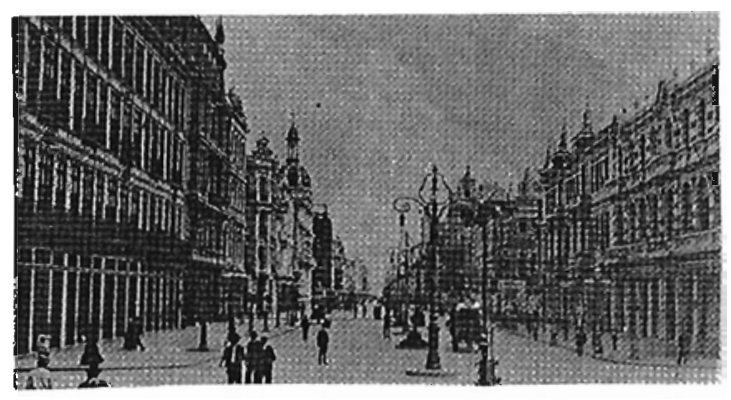

Fig. 35: Projeto da Av. Central e foto na sua inauguração. (in ABREU 1987)

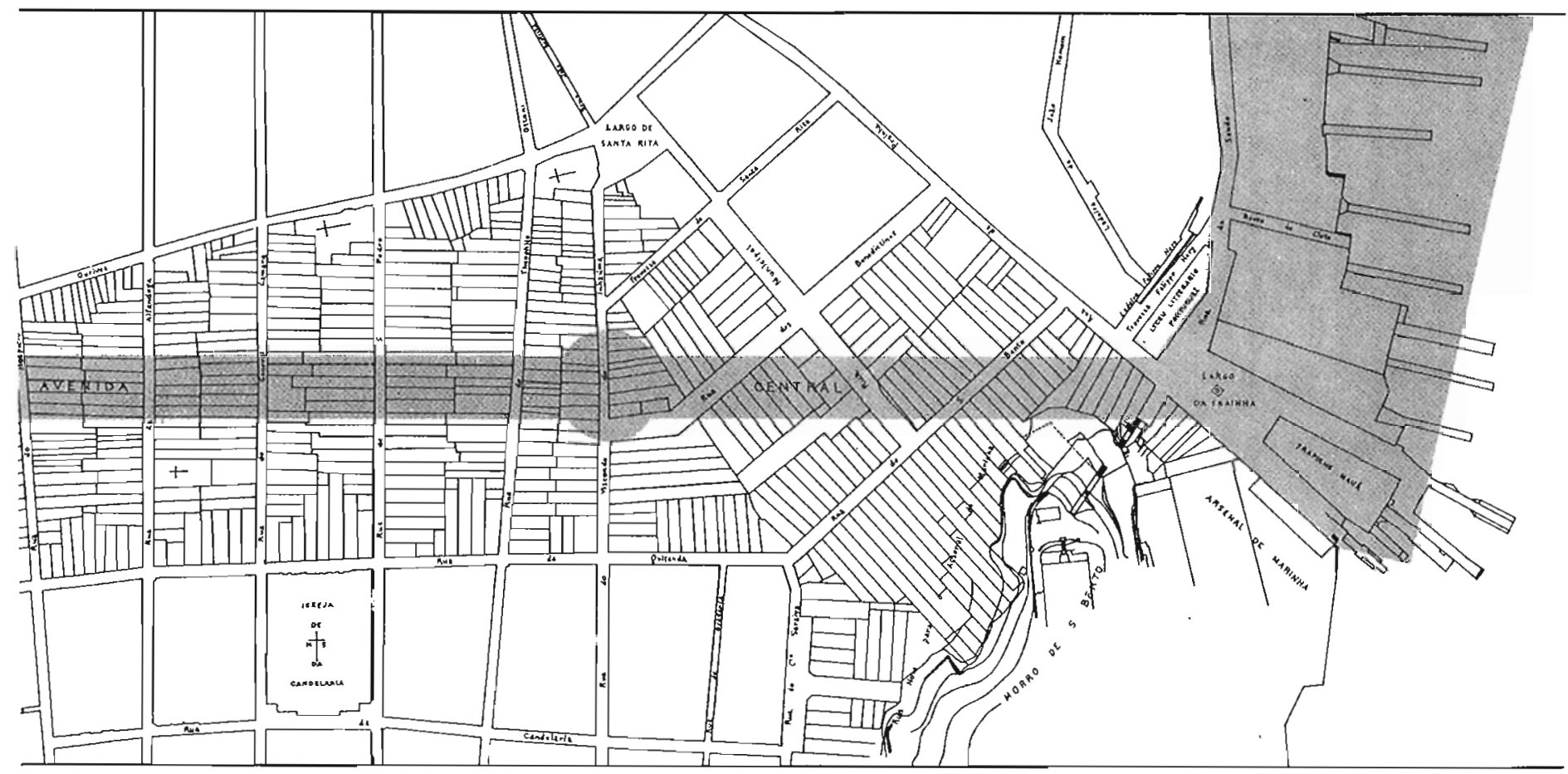


v. 6. As Intervencoes urbantsticas do Periodo Rodrigues Alves:

Estaria fora de nosso objetivo principal estudo detalhado de todas as intervençoes urbanisticas no Distrito Federal do perlodo ALVES (dez. 1902, nov. 1906). Foi um tempo pleno de realizaç̃os, numa escala e intensidade nunca vista no Brasil, e que leva autores como Paulo SANTOS (1981), famoso historiador de nossa arquitetura, a afirmar que a remodelaça da cidade promovida por ALVES e PASSOS foi o fato mais importante que assinalou a passagem do Impèrio á Republica. Jà outros autores, COMO BENCHIMOL (1982 \& 1985) e BRENNA (1985), comparam o Prefeito, implementador das açôs municipais, ao Barão HAUSSMAN, Prefeito da Paris napoleônica, com conotações negativas devido aos inumeros problemas sociais gerados a partir destas intervenç̃̃es. Sem querer tomar partido neste debate, abordaremos a seguir as principais realizacões urbanisticas do periodo, detendo-nos naquelas referentes á àrea portuària.

PASSOS iria promover uma série de intervençôes e obras públicas, diversas delas baseadas em planos de periodos anteriores, como os da Comissão de Melhoramentos da Cidade, da qual fez parte em 1874. Tendo estudado em Paris e grande admirador de HAUSSMAN, PASSOS iria ao encontro do objetivo de transformação da imagem do Rio e promoção dos simbolos "Belle Epóque". Baseando-se em uma sèrie de atos de excessão (a partir da suspensão da Câmara) e novos instrumentos de controle, PASSOS iria atingir "... áreas cuidadosamente selecionadas no centro, desarticulando uma trama de relaçoses econômicas e sociais cuja permanência ali se tornara incompativel com a cidade requerida 
pelo grande Capital e com a Capital requerida pelo Estado Repub1icano" (BENCHIMOL 1985: 604).

O Prefeito iria atuar abrangentemente nas melhorias urbanas e o "embelezamento" urbantstico enchia os olhos das classes mais favorecidas. Edificacões "ruinosas" seriam demolidas, vias seriam rasgadas e calcadas, criavam-se novos passeios á beira-mar, pracas e avenidas eram remodeladas, arborizadas e iluminadas. Dar-se-ia infcio, ainda, á pavimentaçăo asfáltica e á moda das calcadas em pedras portuguesas. Segundo SANTOS (1981), a atuação de PAssos seguiria três grandes eixos viários básicos: as Avenidas Mem de Sá, Beira Mar e Central (Rio Branco), obra do governo federa1. REIS (1977) destaca que 196 projetos seriam realizados, alem das vias citadas, entre eles: a importante remodelação do Canal do Mangue e sua continuação atè o mar pela nova Avenida Francisco Bicalho, o Túnel do Leme, as Avenidas salvador de Sá e Atlântica, as ruas da Assembleia, Carioca, Marechal Floriano, etc. (vide Figs. 1 \& 2 ).

Talvez a obra mais conhecida do periodo ALVES tenha sido a Avenida Central (hoje Rio Branco) que, além de importante artéria para a circulação do centro da cidade, tornar-se-ia local preferido para o "footing" vespertino. Entretanto, calcula-se que hajam sido demolidos 590 prédios para sua implantacão, num total de 1975 m desde o Largo da Prainha á Av. Beira Mar, e largura de $33 \mathrm{~m}$, considerada um exagero na época (SANTOS 1981) Alguns autores sustentam que esta intervença expulsou milhares de famtlias pobres que se aglomeravam nas inủmeras habitacôes coletivas existentes na faixa da nova avenida, que tiveram de ir aumentar a densidade de outros locais ou subir as favelas já 
numerosas (BENCHIMOL 1982, BRENNA 1985, LAMARAO 1984) (Fig. 35 ).

Embora apenas sua cabeceira seja situada fisicamente em nossa área de estudo, a construçăo da Av. Central nos interessa por haver sido parte integrante dos planos de modernizacăo do Porto do Rio. Estes destacariam a importância da Avenida, motivo para que o Ministro de Viaçăo nomeasse uma comissão construtora da Avenida Centra1, em fins de 1903. Como obra de impacto, nos lembra SANTOS (1981), alguns sustentavam que a Avenida deveria ser mais larga que a AV. de Mayo, em Buenos Aires, nossos principais rivais comerciais. Assim, seu tracado iniciou o desmonte do núcleo historico original de fundaçăo da cidade, o Morro do Castelo, totalmente arrasado nas décadas seguintes.

Em sua cabeceira foi totalmente remodelado o Largo da Prainha, então batizado Praça Barão de Mauả, que recebeu estátua aos moldes da de NELSON, em Trafalgar Square (SANTOS 1981). Realizou-se para as construçôes de toda a extensăo da Av. Central um concurso de fachadas, cuja marca foi o ecletismo. Outras edificações monumentais e de grande importância para a cidade foram construidas como o Teatro Municipal (objeto de outro concurso, organizado por PASSOS em 1904), a Escola Nacional de Belas Artes (obra iniciada em 1906), a Biblioteca Nacional (inaugurada em 1910), o Palácio Monroe (reconstruçăo do Pavi1hão Brasiteiro da Feira de st. Louis, em 1906, e demolido pelo METRO), entre outros.

V. 7. A Modernizacão do Porto e de seu Entôrno:

Em 1903, o Ministro da Viaça e Obras Públicas formou uma comissăo para estudar obras visando a modernização do porto do 
Distrito Federal que, como vimos, não acompanhava as necessidades da metrópole e do Pals. As dificuldades de funcionamento do porto vai causar sua perda da 1 ideranca nacional como exportador para Santos jà no inicio do século XX (LAMARAO 1984). O Rio continuaria, no entanto, a afirmar-se como principal porto importador e origem de mais de $45 \%$ das receitas da União relativas a tarifas alfandegárias, na primeira década do século. Um mês após sua formação, a Comissão apresentou relatório tomando por base, largamente, os planos da antiga Empresa de Melhoramentos do Porto, de 1890. Logo depois, levantar-se-ia um vultoso empréstimo com os banqueiros ROTHSCHILD, em Londres, e contratava-se firma inglesa para a empreitada iniciada em 1904. Tanto o montante do empréstimo de 8,5 milhơes de 1 ibras, equivalente á metade do orcamento da Uniăo para o ano, quanto o contrato da firma sem concorrência, foram motivo de fortes protestos por parte da imprensa e de vàrios grupos (LAMARÁO 1984, BRENNA 1985). Uma sẻrie de decretos federais tambèm viriam a facilitar o financiamento das obras, como estabelecimento de regime cambial especial, emissão de apólices, baixa dos valoresbase para desaproriaçăo, etc. (LAMARÃo 1984).

Os equipamentos mais expressivos da àrea em 1903, segundo GERSON (1965), eram: o Trapiche Mauá (Prainha), as Docas D. Pedro II, a Estação Marftima da Ferroviária, o Moinho Fluminense e o Inglês com seus cais, um dique do Lóide Brasileiro junto ao Morro da Saúde, e um cais de $160 \mathrm{~m}$ na Gamboa. Todos estavam na ảrea objeto das propostas da Comissão, 1 imitada pela Av. Centra1, com a remodelação do Largo da Prainha em Praça Barão de Mauá, e o Canal do Mangue, a ser finalizado até a Bata através a Avenida 
Francisco Bicalho. Os objetivos dos planos eram então três: o porto propriamente dito, a construcăo da Av. Central, e o remodelamento e finalização do Canal do Mangue.

Os planos previam uma linha continua de cais, com excessão de um dique na Saủde, de $3.500 \mathrm{~m}$ de extensão, com profundidade útil de $10 \mathrm{~m}$ por $2.500 \mathrm{~m}$ e $8 \mathrm{~m}$ por $1.000 \mathrm{~m}$. Previa-se que os $2.000 \mathrm{~m}$ restantes, desde a foz do Canal do Mangue á Ponto do Cajủ, seriam objeto de estudos espectficos e concessão futura. A Tinha do cais passaria a uma distancia relativamente grande da orla e liberaria grande espaço para a infraestrutura de servicos necessaria totalizando $175.000 \mathrm{~m} 2$ de área na primeira fase; 0 aterro resultaria de material procedente de dragagem, do desmonte final do Morro do Senado e de trecho do Morro do Castelo (retirado para construção da Av. Central). Citaçăo de época estimava o volume dos aterros em 25 milhơes m3 (in BRENNA 1985 ).

O novo espaco urbano ficaria, assim, determinado nos planos da Comissão como uma faixa de 100m, a partir do cais (REIS 1977, LAMARAO 1984). Os primeiros $25 \mathrm{~m}$ destinavam-se ao cais propriamente dito, á área de carga e descarga, e ás linhas férreas com os novos guindastes movidos á eletricidade. Depois, $35 \mathrm{~m}$ ocupados por 20 armazéns e casas de máquinas. Por ủtimo, $40 \mathrm{~m}$ servindo a uma Avenida de pista dupla e de $3.090 \mathrm{~m}$ de extensăo, que viria a ser chamada Av. Rodrigues Alves, com detalhes de passeios especiais para atendimento da carga e descarga. Após esta faixa "institucional" previu-se uma faixa para os particulares, constando de duas quadras separadas por três 1 inhas fèrreas, que serviam a 32 armazéns (Fig. 36 ). 
A primeira parte do primeiro trecho da obra, de $600 \mathrm{~m}$ de extensão de cais, entre a embocadura do Mangue e a Gamboa, seria iniciada em março de 1904, envolvendo mais de dois mil operários, e inaugurada em novembro de 1906 (LAMARAO 1984). Este autor observa que, jà em 1907, ficaria claro que os planos haviam subestimado o movimento comercial, que já superava o dobro das estimativas. Aprovou-se, então, a eliminação do dique na saúde com a retificaçăo do cais naquele trecho, bem como o projeto para - trecho entre o Mangue e o Cajú (só executado em 1924). Como é caracteristico na nossa cultura politica, estas obras foram objeto de vảrias inauguraçôes parciais, entretanto, registra-se que $3.500 \mathrm{~m}$ de cais do primeiro trecho (Mauá-Mangue) seriam definitivamente terminados em 1911. Calcula-se o custo total destas obras em 12,5 milhões de 1ibra-ouro (REIS 1977).

Complementando as intervençoses do governo Federa1 na àrea portuária, o Prefeito PASSOS melhorava as suas condicôes de acesso, alargando vias como a Rua Camerino, que também foi prolongada, e a do Acre. Ao mesmo tempo, implantava códigos de posturas e intervenções no entorno. Para a Prefeitura, tudo isto gerou grande peso financeiro e a administraçăo seguinte teve que tomar novo emprèstimo externo de 10 milhões de 1ibras, para fazer face ás dividas (REIS 1977).

Curiosamente, o entorno imediato á área portuária, ou seja, os bairros assentados nos morros desde o da conceicão até o do Săo Diogo, e alguns bolsões nas àreas planas, mantiveram-se relativamente estaveis, não apresentando muitas mudancas morfologicas, ou mesmo em sua tipologia arquitetônica. RABHA (1985) desenvolveu trabalho que versa sobre esta caractertstica, 
Fig. 36: A primeira página do jornal "O Paiz", de 1/6/1903, celebrando as novas obras do Porto. (in BRENNA 1987)

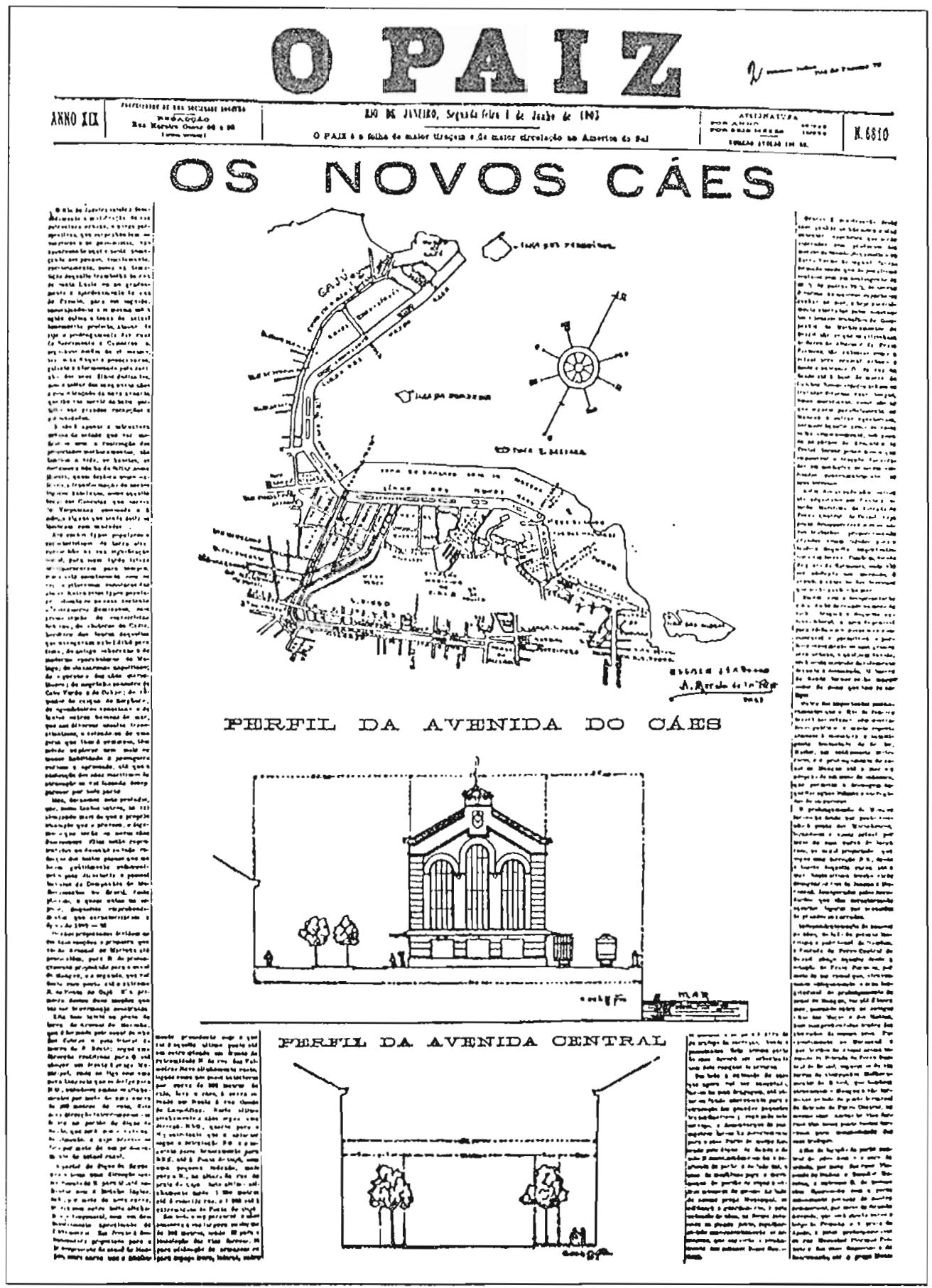


a que denomina "crista1izacão", e aponta algumas razơes para tanto: infraestrutura e condicões topogrảficas desvantajosas, incerteza do futuro devido aos Projetos Aprovados de Alinhamento de grandes eixos viários, os vetores de crescimento do centro que "by--passaram" a área, e o próprio complexo perfil fundiário dos pequenos lotes. A autora observa, ainda, que a populaçăo depende bastante das atividades do porto, até mesmo historicamente, ocupando um espaço estratégico e de forte identidade coletiva, pontilhando a sua evolucão com lutas comuns.

Como veremos com detalhe adiante, recentemente, em 1984, os Bairros do Santo cristo, saude e Gamboa, por estas suas caracteristicas fisico/ambientais tipicas de um importante perlodo evolutivo do Rio, foram objeto de protecão por decreto da Prefeitura (Fig. 37). Tambèm o Morro da conceicăo, á mesma época, foi protegido através de Portaria do Servico de Patrimônio Histórico e Artistico Nacional (SPHAN).

Finalmente, cabe observar que foi no perlodo ALVES, através das açôes diretas do governo Federal e daquelas complementares do Prefeito PASSOS, que firmaram definitivamente as funcões principais da àrea portuária e seu entrono imediato. A grande intervença do Estado, que aparecia por primeira vez como interventor racional da globalidade das acões capitalistas, tentava definir as funçoses daquele território e homogeneizar seu papel na economia urbana, vializando a divisăo social do espaço da cidade.

Isto representava grande carga ideologica na legitimaça do Estado, na consolidaça das forças dominantes e do sistema capitalista: finalmente o Rio era uma Capital digna de uma naço 
emergente, alinhada com os melhores valores da cultura dos palses centrais, e possula um porto moderno e funcional. Em termos da área portuária, não muito será modificado do Projeto abordado nos periodos posteriores e as referências consideram que já se encontrava totalmente implantado por volta de 1911.

V. 8. Consolidacăo da Area Portuaria:

Além da frágil situação financeira da Prefeitura no fim da primeira década do século, a cidade apresentava grave problema de déficit de moradia para a populacão mais carente. Com a implantacão de rigidas normas de controle da construça, inclusive nos subúrbios, esta populaçăo seria expulsa para áreas mais distantes fora do Distrito Federal, originando novo surto de loteamentos e novas ruas ou, se dispunha de menos recursos, localizar-se-ia nas favelas (REIS 1977, ABREU 1986 \& 1987). As condicões habitacionais iriam deteriorar-se progressivamente, enquanto a falta de "unidade de elaboracão" caracteriza os projetos urbanos até o Plano Agache, em 1930 (REIS 1977: 54).

Em 1915 aprovava-se projeto para a Rua da America, alargando o seu dominio para $30 \mathrm{~m}$, aumentando a acessibilidade ao Porto pela sua área centra1, através da garganta entre os Morros da Providência e o do Pinto, desde o Catumbi. Já previa-se sua 1igacão, através de túne1, ao bairro das Laranjeiras e Zona Sul. Em 1919 perfura-se o Túnel Joăo Ricardo, durante a gestăo do Prefeito PauTo de FRONTIN, que conectaria a Rua Bento Ribeiro á Rua Rivadávia Correia, antiga Rua da Gamboa.

Nos anos seguintes nada fez-se especificamente em relaçăo a nossa àrea de estudo. Ações determinantes na estrutura urbana, 
no entanto, aconteceriam no intcio dos anos 20 . Preparava-se a cidade para o 10. Centenário da Independência com a continuação do desmonte do Núcleo Histórico original, o Morro do Castelo, construção de cais e enrocamento até a Glória, saneamento da Lagoa Rodrigo de Freitas, construcăo de diversos edificios comemorativos, etc. Logo. em 1927, inaugurava-se a estação de passageiros, que recebia os navios, um elegante prédio localizado na Praça Mauá, que depois seria ocupado pelo TOURING Clube atẻ 1983 quando teve suas funcõoes de recepç̃o reforçadas e foi transformado em Museu do Porto (Fig. 38).

E interessante notar que o Morro do Castelo teve seu desmonte iniciado com as obras da Av. Centra1 em 1903, mas só seria finalmente arrasado em 1938 e 1959, com a implantaça de projeto do Plano Agache para a área. REIS (1977) alerta que, logo após a Semana de 1922, a cidade vai se notar novamente no "buraco" financeiro, confirmando os ciclos "grandes obrasfalência-empréstimos externos" que nossos pollticos tåo bem sabem assumir.

Nesta mesma época, o Prefeito de então convidou o urbanista francês ALFRED AGACHE, internacionalmente conhecido e expoente do movimento "city beautiful", para uma série de palestras. Acabou contratado, com aval da câmara Municipa1, para elaboraça do chamado "10. Plano de Remodelaçăo, Extensão e Embelezamento da cidade", publicado em 1930. A cidade jà possuia, então, quase 2,5 mi Thơes de habitantes.

O plano respondia ás expectativas da burguesia urbana, que perseguia o modelo progressista francês, e tratava apenas os aspectos fisico-territoriais (REZENDE 1982). Fazia, entretanto, 

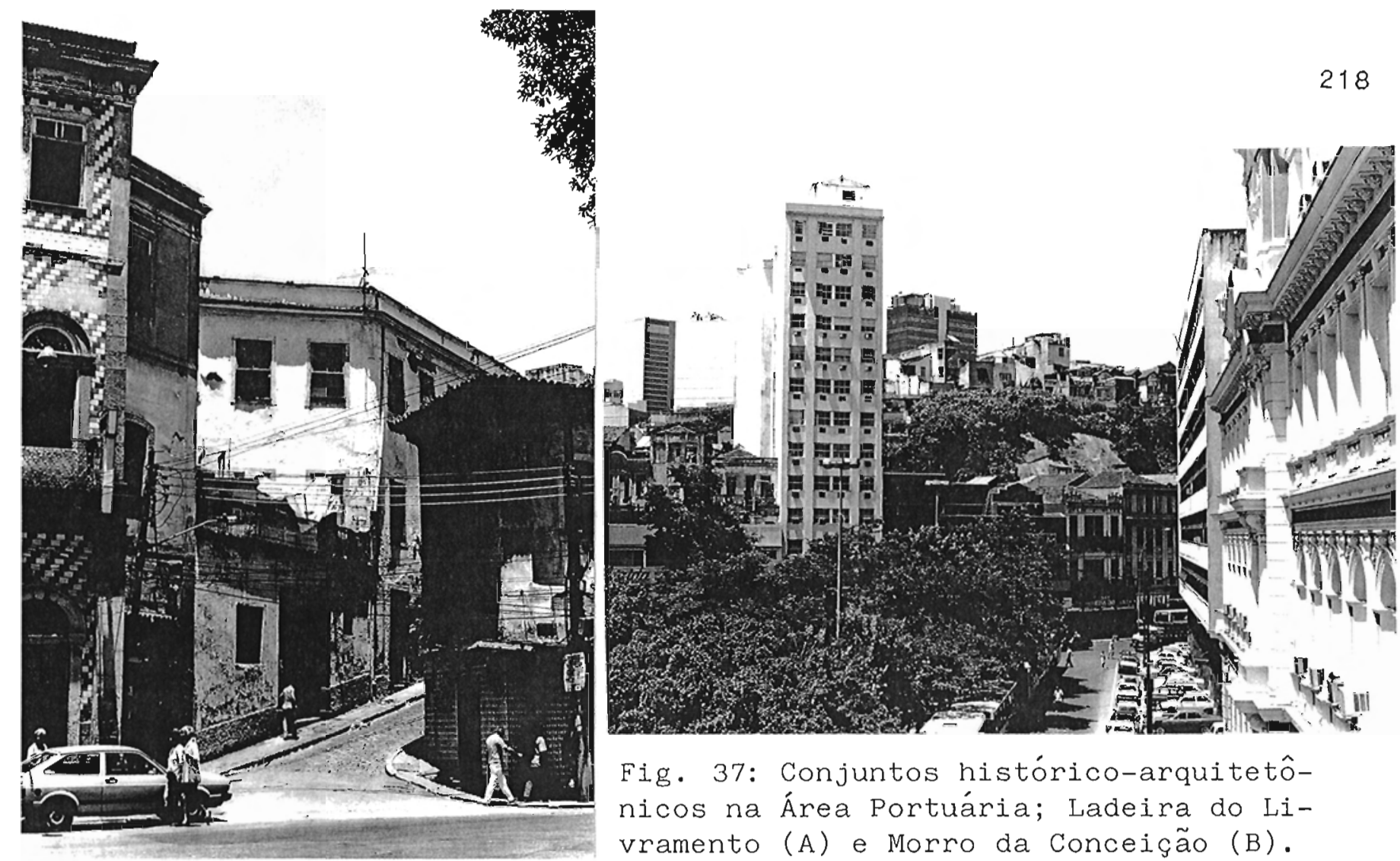

Fig. 37: Conjuntos histórico-arquitetônicos na Área Portuária; Ladeira do Livramento (A) e Morro da Conceição (B).

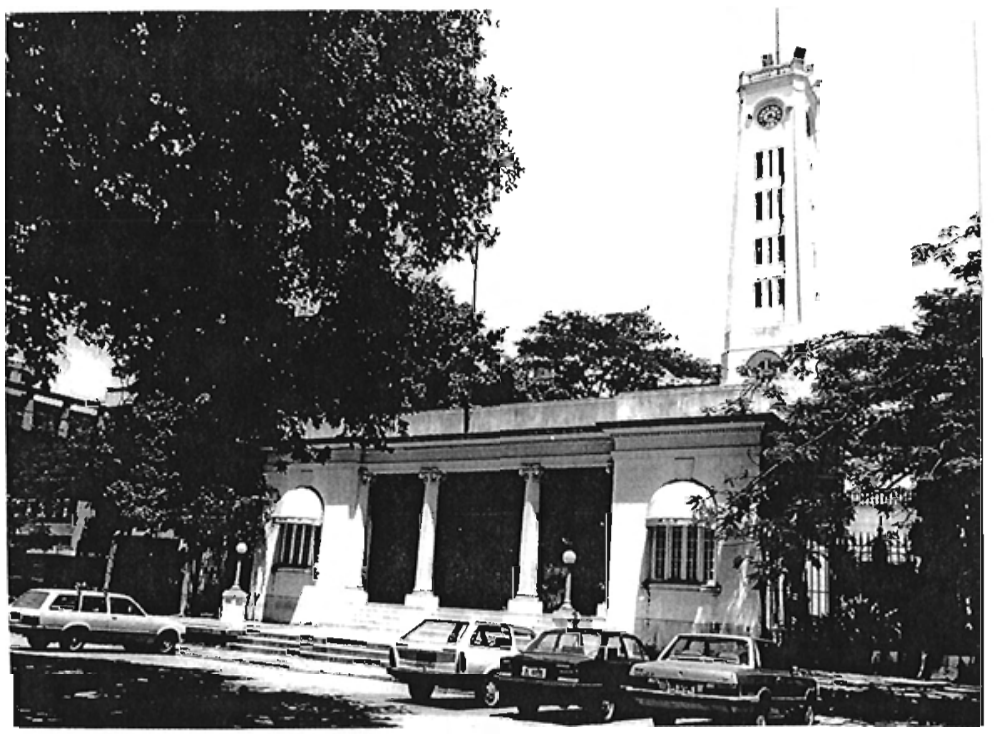

Fig. 38: O antigo prédio do Touring, estação de passageiros do Porto, Praça Mauá.

Fig. 39: O Conjunto dos Portuários, a favela e o velho oratório no Morro da Providência.

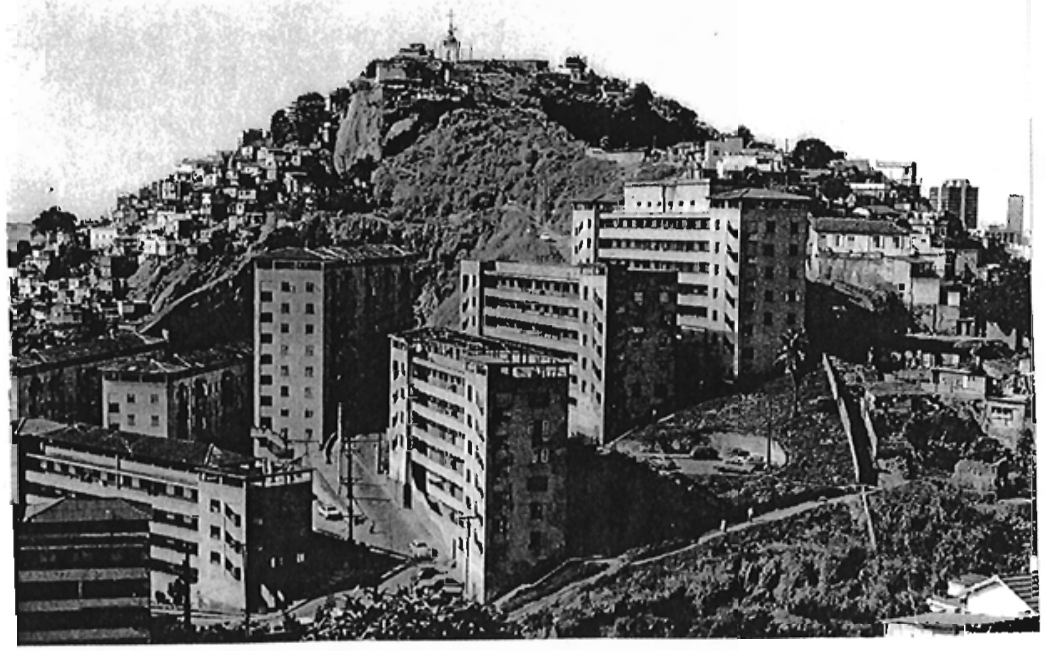


considerações a respeito da engenharia urbana, tráfego e saneamento, que completavam os objetivos de remodelacão fisicoterritorial na busca por funcionalidade e beleza. Tratava de zoneamento, hierarquização viária, regulamentos de edificaça e cidades-satèlite para o operariado. As imagens resultantes eram as das grandes perspectivas, blocos de quarteirão compactos e páteo central, portais de entrada á cidade, pracas monumentais, "rond-points", galerias cobertas para pedestres, etc. Alguns destes elementos, como as galerias e o setor conhecido por Castelo, no centro do Rio, foram realmente implantados.

Também em 1930, um movimento revolucionário que deslocou as oligarquias cafeeiras das classes dominantes, tendo por base diversos levantes militares e a populaça urbana, principaimente as classes mèdias (REZENDE 1982, FURTADO 1977). Ascendem ao poder as classes industriais e fortalece-se o sistema capitalista industria1, devido a grande depressão e decréscimo das exportaçôes agricolas brasileiras. Com isto o pats acabaria crescendo economicamente através de uma expansão do mercado interno e da substituicão das importaçós, fato que depois, quando da 2a. Guerra Mundial, vai ser ainda mais vantajoso pois terá novo impuiso com o estimulo ás exportacões de produtos primários pelos paises centrais envoltos no conflito.

Na área de estudo é construido, no injoio dos anos 30, um pequeno conjunto habitacional na Gamboa, ao sopé do Morro da Providência junto ao Largo de Santo cristo. Realização da Caixa de Peculios dos Portuários, è importante por ser exemplo de uma das primeiras tentativas do Movimento Moderno, autoria de Lúcio 
COSTA e Gregory WARCHAVSKI, com interessantes resultados em suas relaçoses com a rua.

Logo, com a ascençăo de VARGAS, criava-se a comissão Plano da cidade, aliás uma antiga recomendaçăo do próprio $A G A C H E$, que teria por objetivo investrigar o Plano do urbanista francês (REIS 1977). Acabam por aconselhar sua adoçăo e regulamentaça, bem como a criação de comissão permanente. Na gestão seguinte, entretanto, o Plano seria revogado oficialmente e, em 1937, o famoso Primeiro código de Obras era publicado para a cidade. O seguinte Prefeito retoma, por sua vez, o Plano Agache, criando uma comissão para sua revisão e acompanhamento.

E nesta gestão de Henrique DODSWORTH (1937-1945) que vai se construir a AV. Presidente Vargas, de $72 \mathrm{~m}$ de largura, "boulevard" monumental com o Canal do Mangue ao centro, desde a Igreja da Candelária á Ponte dos Marinheiros. Calcula-se que cerca de 526 prédios foram demolidos, em uma faixa de três quarteirôes por uma extensão de $2 \mathrm{~km}$. Como observado por REIS (1977), a intervençåo tratou-se de novo conceito pois, após desapropriar os imóveis, traçou novos lotes ás margens da avenida, que foram vendidos em hasta publica como parte do pagamento ao financiamento obtido. A tipologia arquitetônica gerada ao longo, foi ditada pelo máximo aproveitamento da testada e da área com 100\% de ocupaçăo.

Acreditamos que o intenso fortalecimento deste antigo vetor de expansão do centro da cidade tenha sido um dos fatores primordiais no desvio dos interesses econômicos (especulacão imobiliària e expansão das atividades de negócios) da àrea portuária. Curiosamente, por diversos motivos dentre os quais o próprio perfil fundiário, a localizaça de vários equipamentos 
estatais, e as caracteristicas do mercado imobiliário do centro do Rio, a Av. Presidente Vargas encontra-se até hoje sub-ocupada em mais de $2 / 3$ de sua extensão.

Com a queda de Getulio VARGAS em 1946, o Prefeito interventor do Rio elevou a comissăo e o Servico Técnico do Plano a Departamento de Urbanismo, na Secretaria de Viaçăo e obras Púb1icas. O arquiteto Afonso REIDY seria um dos primeiros diretores deste Departamento, e responsável por grandes projetos de intervença urbana como o da renovaça da Esplanada de Santo Antonio (1950) e, depois, o do Parque do Flamengo (1960). Na Area Portuária foi inaugurado importante equipamento regiona1, em 1948, que é muito atuante até hoje: o Hospital dos Servidores do Estado, á Rua Sacadura Cabra1, mandado construir ainda por Vargas (REIS 1977). No mesmo ano, na Gamboa, inaugurava-se um grande conjunto habitacional de ediflcios, do Instituto de Pensóes dos Portuários, na encosta do Morro da Providência (Fig. 39).

Jà no inicio dos anos 50 a cidade iria ver um anteprojeto para Metrô, contratado a firma de consultoria francesa, e a realizaçăo de um grande projeto viário, a Avenida Perimetral, que só seria plenamente implantado no infcio dos anos 70 . Neste projeto estava incluido grande trecho em elevado, cortando a cidade, inclusive por sobre toda a extensão da Av. Rodruigues Alves, na área portuária. Vindo em elevado desde o Aeroporto Santos Dumont por sobre o centro, a Perimetral faria a 1igaçăo de trảfego expresso desde a Zona sul à Av. Brasil e Zona Norte.

No fim dos anos 50 è criada a superintendência de Urbanismo e Saneamento para gerir fundo especial do Governo da Capita1. Em 1960 estaria terminado o Túnel Santa Bảrbara, 1igando o Catumbi a 
Laranjeiras, complementando importante eixo viàrio de acesso ao centro da área portuária, interligada por entre os Morros da Providência e do Pinto, á altura do Santo Cristo (Fig. 40).

o impacto desta intervencăo nos bajrros do catumbi e de Fátima foi extremamente negativo, sob a égide da renovação urbana, expulsando milhares de familias de baixa-renda. No Catumbi, as as residências deram lugar á implantaçăo dos aneis do novo sistema viàrio que interligava Laranjeiras á Rodrigues Atves e á Perimetral (este trecho nunca implantado; o contexto urbanistico tradicional e as lutas da comunidade foram registrados por SANTOS (1981) e SANTOS (org.1981). Já o bairro de Fatima foi afetado pelo projeto Cidade Nova, misto de ediflcios administrativos do governo municipal e de alguns edificios para habitação de classe mèdia-baixa pelo sistema $\mathrm{BNH}$, alèm de uma estaça de metrô. Este projeto modernista impunha-se inclusive como alternativa moralizadora contra a maior área de prostituição da cidade, a "zona do Mangue", mas ainda não foi totalmente implantado, apenas umas poucas edificaçoses em a tura contrastam com a àrea arrasada, á margem da AV. Presidente Vargas. Recentemente, construiu-se o controvertido sambỏdromo, no Catumbi, quase em paralelo ao eixo viàrio Santo cristoLaranjeiras, como que para coroar o desrespeito áquela população. No intcio dos 60 foi construlda a Rodoviária Novo Rio, para ônibus interurbanos, em antigo terreno pertencente ao corpo de Bombeiros, no extremo de nossa área de estudo junto á foz do Canal do Mangue (Fig. 41). Tal equipamento, ampliado no final dos anos 70 com um terminal de chegada e outro, urbano, em nova àrea fronteirica, causou bastante impacto na circulacăo e gerou 
Fig. 40: Plano geral da cidade e do sistema viário básico, onde se pode notar a localização estratégica da Área Portuária.

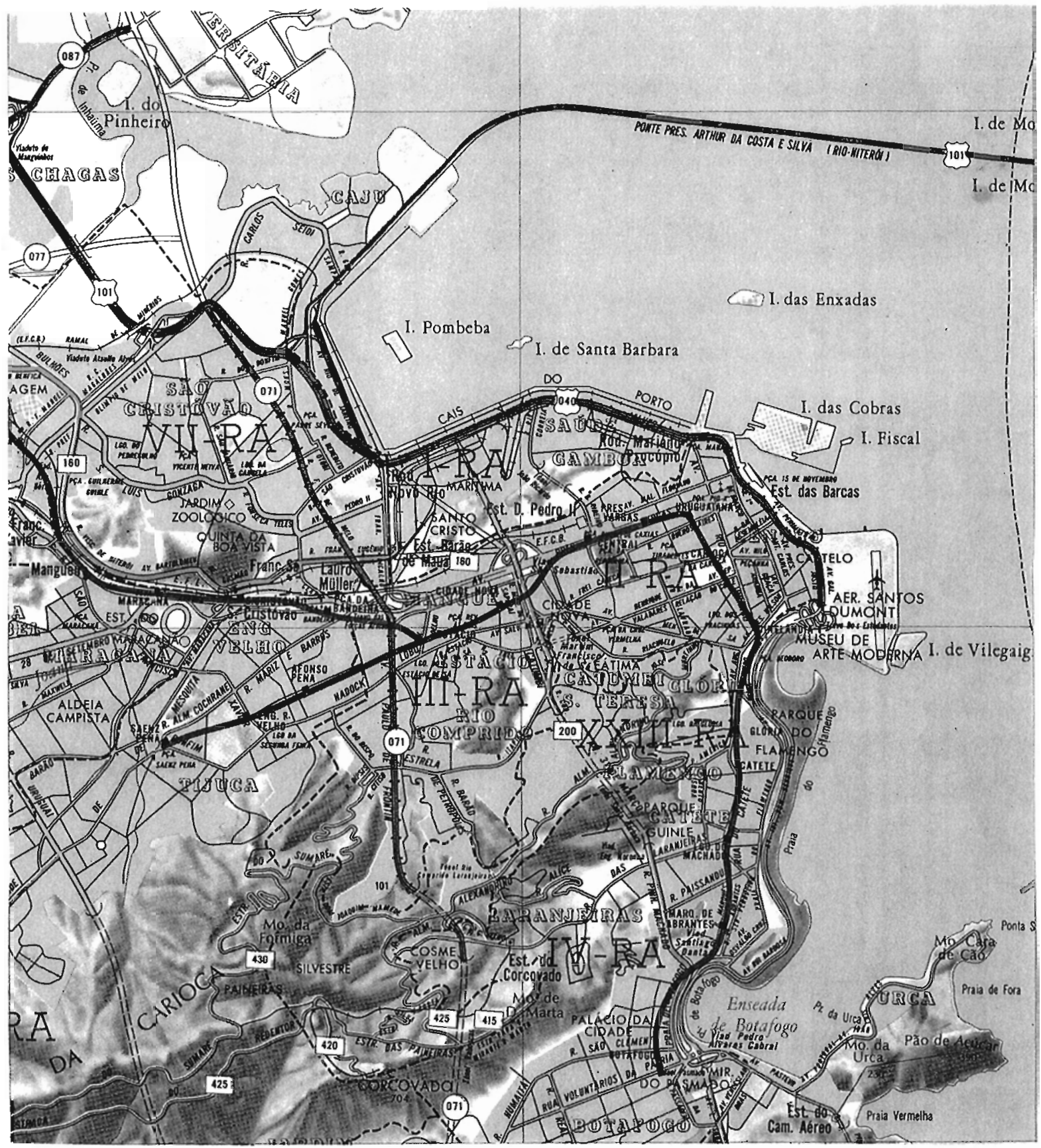


utilizaçăo constante da àrea, embora não tenha acarretado muitas alterações de uso. Com a implantação deste novo pỏlo de tráfego e a continuidade da antiga rodoviària junto á Praça Mauà, agora utilizada como terminal metropolitano, em muito se intensificou o tráfego de passagem de ônibus pela área de estudos, principalmente na Avenida Rodrigues Alves.

Também no intcio da década de 60 , o principal produto importado pelo porto passou a ser o petróleo e inaugurou-se as refinarias de Duque de Caxias e Manguinhos. Em 1962 concluiam-se as obras do cais do Parque de Minério e Carvăo, ampliando o porto em direção ao cajú. Em 1967 extinguia-se a autarquia Administraçăo do Porto do Rio de Janeiro e autorizava-se a formacão da Companhia Docas da Guanabara; com a fusão seria transformada em do Rio de Janeiro (CDRJ) em 1975, que passava a administrar todos os portos do estado.

No fim dos anos 60 as exportaçoes do porto concentravam-se em café e minério, e as importacões continuavam lideradas pelo petróleo, carvão e trigo. O Rio era porto tipicamente importador, perfil só alterado a partir de 1983, como veremos adiante.

Sem dúvidas um dos majores impactos na àrea de estudo nestas ultimas dẻcadas, depois da construção da ligaçăo Santo Cristo/Laranjeiras, deu-se na segunda metade dos anos 70 com a construção do elevado da Perimetra1, sobre a Av. Rodrigues Alves, um forte bloqueio para a continuidade do espaco em altura equivalente a cinco pavimentos (Fig. 42). o viaduto possui rampas de acesso e saida, inclusive junto á Praça Mauá, mas o projeto ainda carece da coneccão ao sistema viario santo cristol Laranjeiras, passando direto por todo o resto da área portuária. 


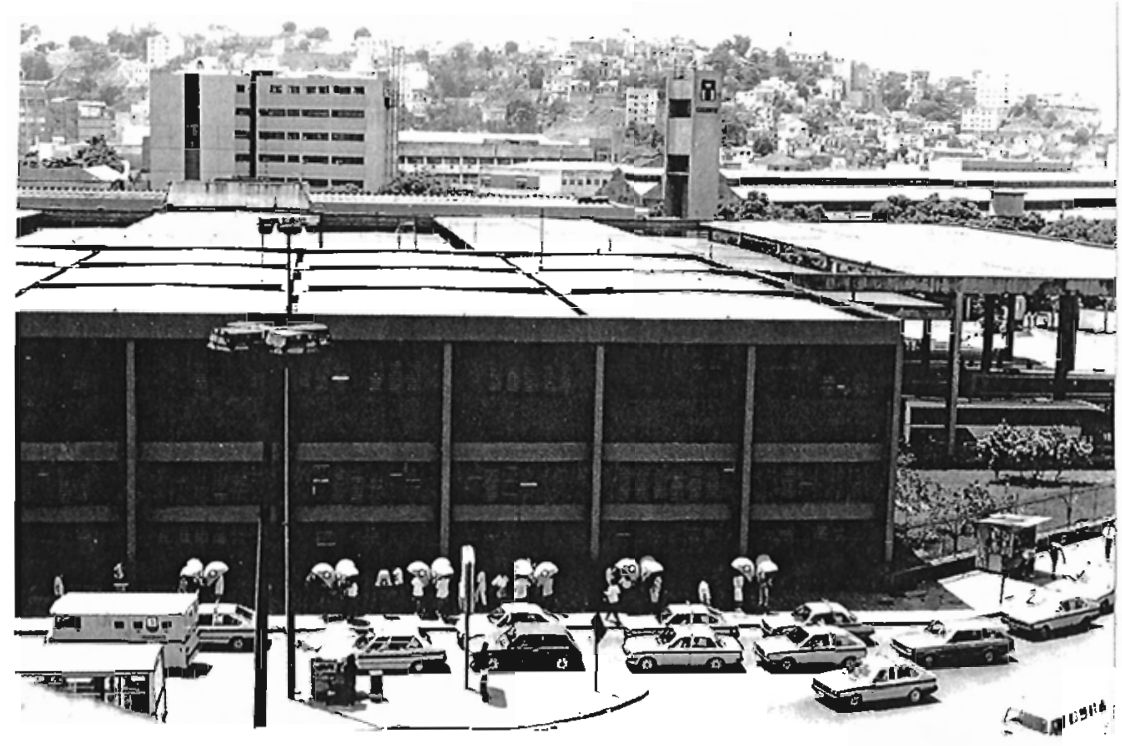

Fig. 41: A Rodoviária Novo Rio, no limite da Área Portuária junto ao Mangue; ao longe o Morro da Providência.

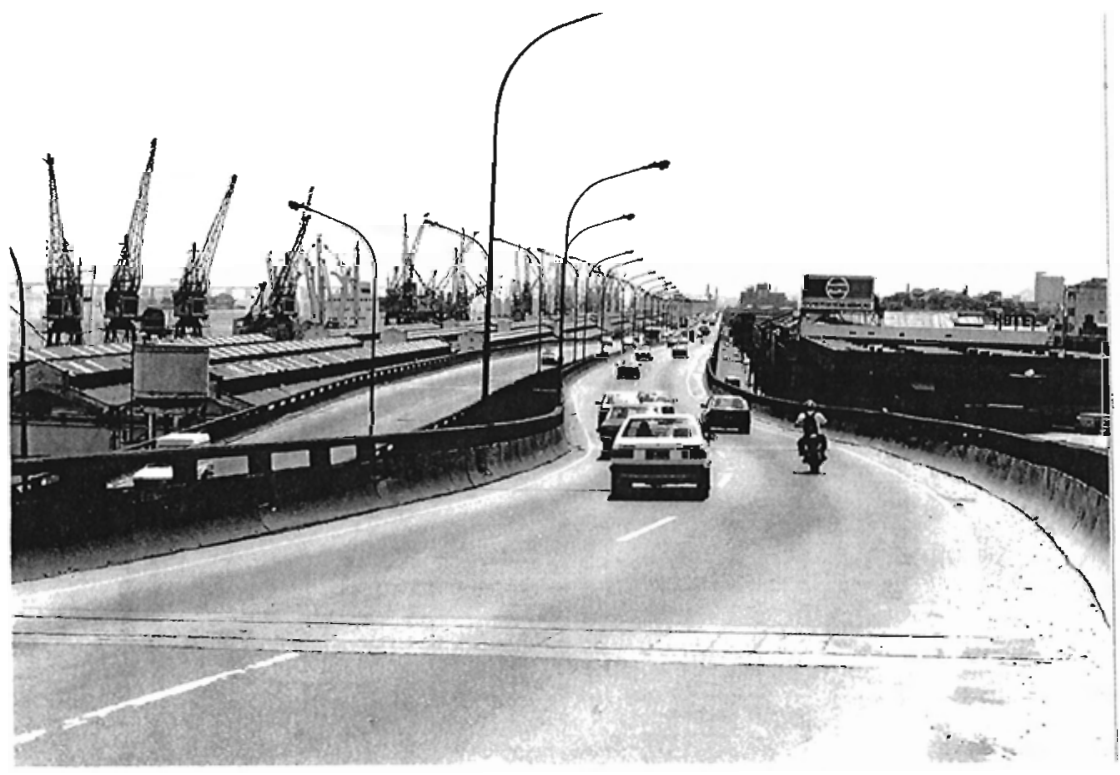

Fig. 42: O Viaduto da Perimetral visto de cima, junto à Rodoviária, e de baixo, junto a uma das rampas de descida na Av. Rodrigues Alves.

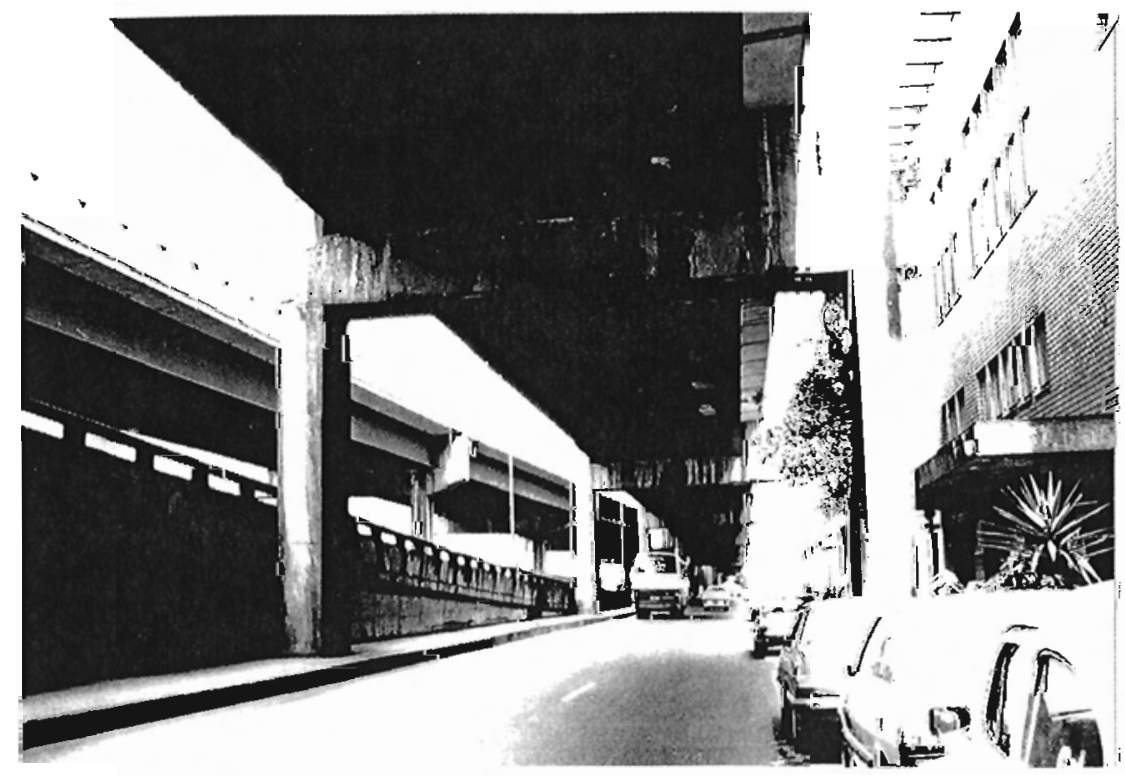


Em relação ás operaç̃es do porto propriamente ditas, o grande impacto esteve por conta da inauguração do Porto de sepetiba, que passou a concentrar os terminais de carvão e minérios. Isto veio a liberar uma grande área no cais do porto do Rio, para que se firmassem ainda mais suas operações conteinerizadas e de exportação de velculos; mas esta temática serà abordada com maiores detalhes a seguir. 


\section{CAPITULO VI:}

\section{TENDENCIAS OPERACIONAIS DO PORTO DO RIO DE JANEIRO}

Por sua evidente importância na determinação do desenvolvimento em nossa àrea de interesse, impõe-se a compreensåo do papel do Porto do Rio de Janeiro na rede estadual portuária, seu papel na economia da regiåo de sua influência, bem como as suas caracteristicas principais de movimentaçăo de carga e de instalações físicas e tendências para o futuro.

Desde 1976 o Porto de Rio de Janeiro integra rede estadual administrada pela Companhia Docas do Rio de Janeiro (CDRJ), sociedade de economia mista com maioria acionária da PORTOBRAS, empresa vinculada ao Ministério dos Transportes $\theta$ responsável pelo sistema portuàrio nacional.

Passando por várias transformações ao longo de sua existência, como vimos, o Porto do Rio sempre marcou a economia nacional e, especialmente, a da sua cidade e de sua área de influência econômica (hinterlandia). Atualmente ele insere-se na diversidade da produção brasileira e em suas necessidades de consumo. Entretanto, a própria lógica de mercado e a racionalização das atividades econômicas a nivel naciona 7 fazem com que a antiga variedade de cargas venha se traduzindo em crescente especializacăo. 
Em obediência ao planejamento desenvolvido pela PORTOBRAS, a CDRJ opera com uma polftica de racionalizaçăo de atividades, tão intensa quanto permitem as 1 imitaçóes impostas por fatores conjunturais e politicos. A CDRJ vem se esforcando na implantaça de especialização nos movimentos de seus portos, buscando compatibilizar os tipos de cargas com as instalaçós e caracteristicas de cada porto, fato não so demonstrado pelos relatórios e declarações oficiais, como também pela opinião de especialistas em publicacỗes especializadas.

Entende-se por condições das instalaçôes a capacidade dos piers e armazéns, as condicões de navegabilidade dos canais de acesso e atracaçăo, a capacidade operativa dos guindastes e maquinário, atè a funcionalidade da retroárea. A retroárea, também chamada retaguarda, é constitulda pela área envolvente ao porto propriamente dito e que presta-se como apoio ás atividades portuárias, com patios de estocagem e manobras, terminais de carga, rodoviários e ferroviários, pátios de containeres, etc.

Evidentemente, a localizacăo de um porto revela-se como uma de suas caracteristicas mais importantes pela capacidade de acessibilidade e facilidade de escoamento dos produtos, boa integraçăo aos sistemas ferroviário e rodoviário, e por suas interrelações com a hinterlândia e o sistema portuărio naciona1. Estas duas ủltimas caractertsticas são essenciais para o bom rendimento operacional de qualquer porto e estão presentes em grau bastante satisfatório, como veremos, no Porto do Rio.

Além do Porto do Rio, a rede portuária administrada pela CDRJ è integrada pelos portos de Niteroi, Angra dos Reis, Arraial do Cabo e Sepetiba (Fig. 43). 
Fig. 43: Hinterlândia do Porto do Rio de Janeiro (A), rêde da CDRJ e acessibilidade (B).

("Plano Diretor Portuário do Brasil 1979/83", Portobrás)

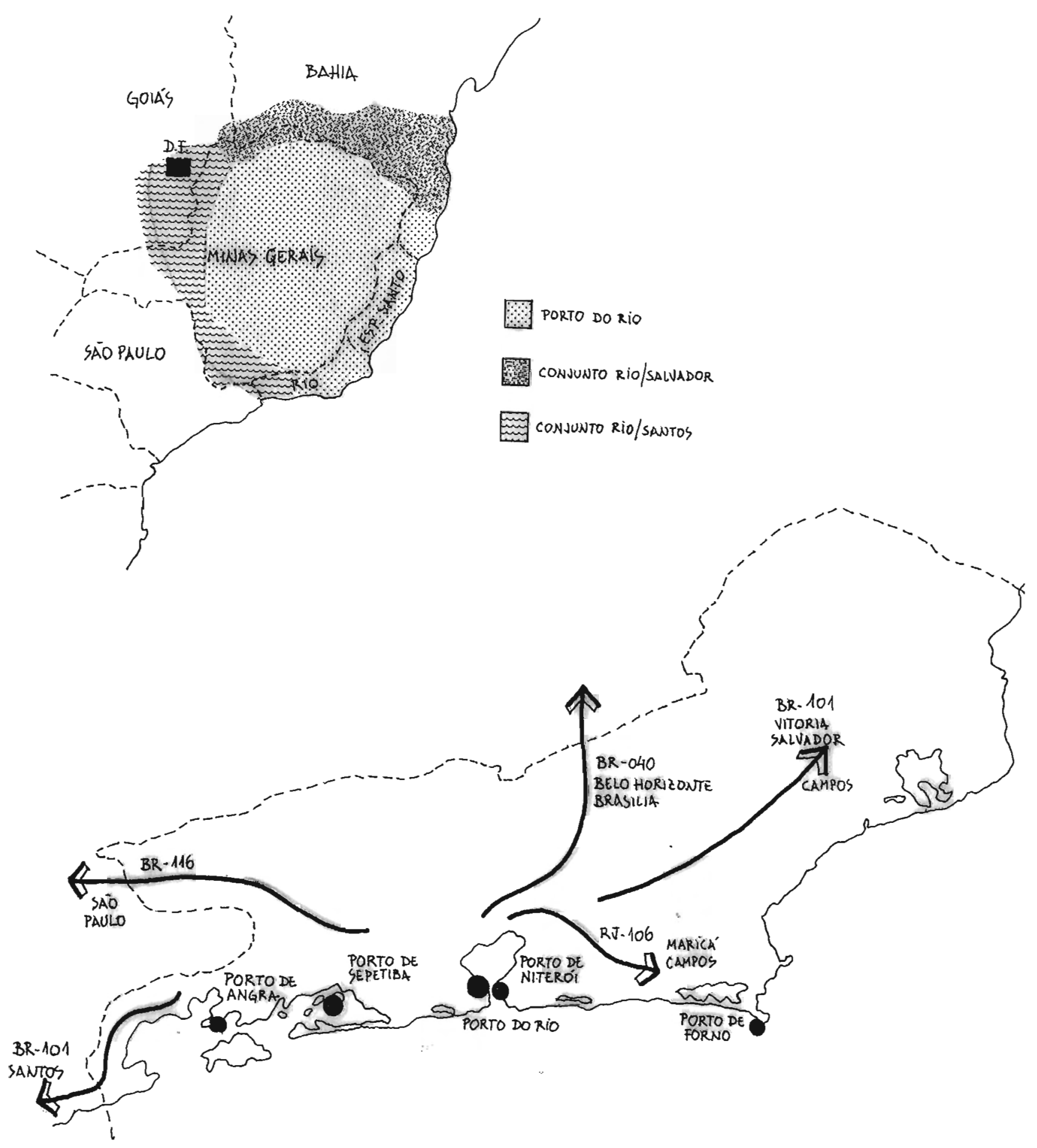


O Porto de Niterói, na Bala de Guanabara, movimenta principalmente o trigo, exerce forte vocacăo de terminal pesqueiro e vem tornando-se importante centro de reparacão naval e apoio ás atividades "off-shore" das plataformas de petróleo na Bacia de Campos, norte fluminense. Embora os seus 420 metros de cais com profundidade média de 8.5 metros tenha sido fisicamente interrompidos pela Ponte Rio-Niterói, ao contrário do que muitos previam na época de sua construção, isto veio a facilitar e reforçar as funçôes portuárias, aumentando sua integração com o Rio e o escoamento das cargas.

No Munictpio de Angra dos Reis, o Porto segue uma operaça a partir de pequenos terminais especializados, com um total de 340 metros de cais e 9 metros de calado médio. Concentra suas operações na exportação dos produtos siderúrgicos da CSN de Volta Redonda, movimentando mais da metade de sua produção, além da importaçăo do trigo e do petróleo, este principalmente através do terminal exclusivo da PETROBRAS em ITha Grande. Tem se destacado como um dos maiores importadores de petróleo bruto, juntamente com São Sebastião, em são Paulo.

Já o Porto do Forno, em Arraial do Cabo, Municipio de Cabo Frio, possui apenas 100 metros de cais acostável com calado de 10 metros, e tornou-se, quase exclusivamente, terminal salineiro e recebedor de óleo combustivel, atendendo ás industrias da regiăo dos Lagos, particularmente a Companhia Nacional de Alcalis.

Finalmente, o Porto de Sepetiba fica no Municipio de Itaguat, nas costas da I ha da Madeira e banhado pelas águas da bala de sepetiba. E o mais novo integrante da rede estadua1, inaugurado em principios de 1983. Possui um cais acostável de 
mais de 540 metros de extensão e calado de 18 metros, o que revela sua capacidade para atracaçăo e movimentação de carga. Segundo o II Plano Nacional de Desenvolvimento, Sepetiba torna-se o terminal graneleiro da rede estadual e está 1 igado diretamente á Ferrovia do Aço. Atualmente jà concentra as operaçóes com o carvåo para a indústria siderúrgica e da alumina de Volta Redonda e do resto do Estado e de parte de Minas para, futuramente, centralizar as exportações de minèrios e operações com outras cargas compativeis. Parece que uma das funçós principais de Sepetiba será eventualmente implantada, após estar suspensa durante anos, que é integrar um complexo portuário-industrial de porte planejado para o Municipio de Itagual, o que incluiria uma nova usina da Companhia Siderúrgica Nacional com capacidade bem superior á de Volta Redonda.

Recebendo a movimentaçăo de minerios e de carvăo, o Porto de sepetiba deverá possibilitar funcores antes só possiveis no Porto do Rio, de maneira limitada, melhorando seu desempenho operacional especifico pelas caracteristicas fisicas e de equipamento. Outro produto que tambem tem concentrado sua movimentacão em sepetiba è a soja (em farelo ou torta) que vem sendo um dos principais itens da exportaça brasileira.

1: Esta foi, aliás, a razăo que levou a Fundaçăo para o Desenvolvimento da Regiăo Metropolitana (FUNDREM) a elaborar seu primeiro P1ano Diretor, em 1977/78, para o Municipio de Itagual, receosa dos impactos que o súbito desenvolvimento industrial traria á vida municipal e metropolitana. 
Podemos afirmar que a àrea de influência econômica direta, a hinterlândia da rede portuária fluminense abrange os estados do Rio, Minas Gerais, sul do espirito Santo e da Bahia, e sudoeste de Goiás (vide Fig. 43). Pela extensão deste território e sua evidente importância na economia nacional, a partir do pape1 estratégico da rede portuária da CDRJ, torna-se evidente que $\circ$ Porto do Rio continuará a exercer funções vitais que excedem o simples interelacionamento com a cidade e seu território metropolitano.

VI. 1. $\underline{\text { Porto do }}$ Rio de Janeiro:

E necessário fazer notar que as excelentes condicões geográficas e as caracterlsticas do Porto do Rio possibilitam que assuma cinco funcões principais, como demonstrado por MAGALHAES (1968). E porto distribuidor, recebendo navios para redistribuir a sua carga para outros portos por cabotagem ou longo curso, e para a sua hinterlândia. E porto consumidor, destinando carga para o parque industrial e comercial da própria cidade. Mostrase como porto de trânsito por ser depositàrio de cargas para futuro translado. Os atrativos do Rio e da região o fazem porto turtstico e a sua posicão estratégica no território nacional impơe sua funcão de porto militar.

Os especialistas afirmam que a importância do Porto do Rio de Janeiro deu-se a principio pelos determinantes históricos, consolidando-se por suas 1 igações com os meios de transporte e por sua integração com o interior e o sudeste do pals. Logo após a sua fase inical de exportandor do acucar cultivado na região, passou a movimentar o ouro que, vindo das Minas Gerais, embarcava 
em seus navios. O outro porto mais próximo das minas era Parati que revelava-se muito exposto aos piratas e ataques estrangeiros. Como vimos no capitulo anterior, a cidade e seu porto se consolidaram economicamente a partir de meados do século XVIII e, a partir desta data as funçoes urbanas iriam se multiplicar e o seu porto teria de corresponder a este dinamismo.

- aumento da importância da produção do café no vale do Paraiba e sul de Minas, somado á instalaça da famflia Real no Rio de Janeiro, foram fatores primordiais para a economia e o estabelecimento da hinterlândia do porto. o advento das estradas de ferro deram grande impulso a este processo e realcou a capacidade de integraçăo do porto. Mesmo com a queda da produção de café na região, ele manteria seu papel na economia como importador de produtos básicos para o nascente processo de industrialização e continuariam as importaçós de algodão, trigo e carvão. o movimento destes produtos, como vimos, já era facilitado pelas obras de ampliaça das instalacões portuárias promovidas na administracăo Rodrigues Alves, durante a primeira década do século.

As importações intensas feitas através do Porto do Rio eram destinadas principalmente ás indústrias têxteis, atè 1930. Já as indústrias de base e os produtos para o seu processamento, como cimento e as siderúrgicas, assumiriam a ponta das importaços apenas a partir de 1940. Já no inicio dos 60 , fato reforcado com a inauguração das refinarias de Manguinhos e Duque de caxias, 0 petroleo tornou-se o principal produto importado através do Rio. No fim dos 60 , as estatisticas nos mostram que este ainda era 0 principal produto importado, seguido do carvăo para volta Redonda 
e do trigo para os moinhos do Rio de Janeiro, enquanto o café e o minerio de ferro eram os principais exportados.

- Porto do Rio iria caracterizar-se como porto importador até 1983, quando voltou a ser um dos maiores exportadores do pais, registrando que $85 \%$ da carga movimentada destinava-se á exportação, tendo por base o incremento da produçăo siderúrgica. Estes produtos representavam aproximadamente $50 \%$ da tonelagem total daquele ano, oriundos basicamente de Volta Redonda (CSN, $33 \%$ ) e do Rio (COsIGUA, 20\%).

Os relatórios do movimento de cargas da rede portuária mostram que, na ultima década, os três produtos que 1 ideraram as importaçóes no Rio foram o óleo bruto, o carvão mineral (energético e para as cimenteiras) e o trigo, diferenciando-se apenas na disputa pelo primeiro lugar. Os dados mostram que no intercâmbio comercia1 com o exterior, o porto do Rio manteve-se em quarto lugar em valor total importado no periodo 1981 a 1987 , e em terceiro em 1988 (Tab. 1).

As exportaçós também mostram um quadro pouco variado nestes ütimos dez anos, com o minério de ferro, o bleo combustivel e as pecas de aço apresentando sempre a maior movimentação de longo curso, e os automóveis assumindo importante posicăo. A evolução do intercâmbio comercial com o exterior mostra o Rio mantendo uma média de terceiro colocado entre os portos brasileiros, mais constante de 1985 a 1988 (Fig. 44).

o Rio é importante centro de navegação de cabotagem, em que movimenta principalmente o petróleo, o àlcool hitratado carburante e o carvão energético. Em relaça ao embarque para cabotagem, também se destacaram os produtos genéricamente 
Tab 1: Evolução do Intercâmbio Comercial com o exterior nos quatro principais portos brasileiros; 1984/88

IMPORTACAO (em US $\$ 1000$ FOB)

\begin{tabular}{|c|c|c|c|c|c|}
\hline COLOCACAO & 1984 & 1985 & 1986 & 1987 & 1988 \\
\hline 10. & $\begin{array}{c}\text { Angra } \\
3.810 .589\end{array}$ & $\begin{array}{c}\text { Angra } \\
3.325 .276\end{array}$ & $\begin{array}{c}\text { Angra } \\
3.560 .520\end{array}$ & $\begin{array}{c}\text { Angra } \\
3.571 .822\end{array}$ & $\begin{array}{c}\text { Santos } \\
3.388 .022\end{array}$ \\
\hline 20. & $\begin{array}{c}\text { Santos } \\
2.398 .753\end{array}$ & $\begin{array}{c}\text { Santos } \\
2.479 .994\end{array}$ & $\begin{array}{c}\text { Santos } \\
2.655 .439\end{array}$ & $\begin{array}{c}\text { Santos } \\
2.366 .175\end{array}$ & $\begin{array}{c}\text { Angra } \\
1.877 .814\end{array}$ \\
\hline 30. & $\begin{array}{l}\text { S. Sebast. } \\
2.362 .730\end{array}$ & $\begin{array}{l}\text { S. Sebast. } \\
1.911 .942\end{array}$ & $\begin{array}{l}\text { S.Sebast. } \\
2.047 .201\end{array}$ & $\begin{array}{l}\text { S. Sebast. } \\
1.302 .342\end{array}$ & $\begin{array}{c}\text { Rio } \\
1.110 .835\end{array}$ \\
\hline 40. & $\begin{array}{c}\text { Rio } \\
1.002 .652\end{array}$ & $\begin{array}{c}\text { Rio } \\
871.388\end{array}$ & $\begin{array}{c}\text { Rio } \\
933.034\end{array}$ & $\begin{array}{c}\text { Rio } \\
990.542\end{array}$ & $\begin{array}{l}\text { S.Sebast. } \\
1.075 .607\end{array}$ \\
\hline
\end{tabular}

EXPORTACAO (em US $\$ 1000$ FOB)

\begin{tabular}{|c|c|c|c|c|c|}
\hline COLOCACAO & 1984 & 1985 & 1986 & 1987 & 1988 \\
\hline 10. & $\begin{array}{l}\text { Santos } \\
9.898 .467\end{array}$ & $\begin{array}{l}\text { Santas } \\
8.932 .350\end{array}$ & $\begin{array}{c}\text { Santos } \\
8.089 .677\end{array}$ & $\begin{array}{c}\text { Santos } \\
9.000 .759\end{array}$ & $\begin{array}{c}\text { Santos } \\
11.189 .409\end{array}$ \\
\hline 20. & $\begin{array}{c}\text { Rio } \\
2.820 .170\end{array}$ & $\begin{array}{c}\text { Vitoria } \\
2.964 .003\end{array}$ & $\begin{array}{c}\text { Vitoria } \\
2.882 .284\end{array}$ & $\begin{array}{c}\text { Vitoria } \\
2.746 .556\end{array}$ & $\begin{array}{l}\text { Vitoria } \\
3.726 .700\end{array}$ \\
\hline 30. & $\begin{array}{l}\text { Vitoria } \\
2.682 .521\end{array}$ & $\begin{array}{c}\text { Rio } \\
2.508 .615\end{array}$ & $\begin{array}{c}\text { Rio } \\
1.937 .811\end{array}$ & $\begin{array}{c}\text { Rio } \\
2.208 .943\end{array}$ & $\begin{array}{c}\text { Rio } \\
2.794 .257\end{array}$ \\
\hline 40. & $\begin{array}{l}\text { Paranagua } \\
2.500 .397\end{array}$ & $\begin{array}{l}\text { Paranagua } \\
2.448 .319\end{array}$ & $\begin{array}{l}\text { Rio Grande } \\
1.786 .370\end{array}$ & $\begin{array}{l}\text { Rio Grande } \\
2.076 .366\end{array}$ & $\begin{array}{l}\text { Rio Grande } \\
2.573 .685\end{array}$ \\
\hline
\end{tabular}

Fonte: CACEX/Banco do Brasi1, CIEF/Ministerio da Fazenda PORTOBRAS 1988 


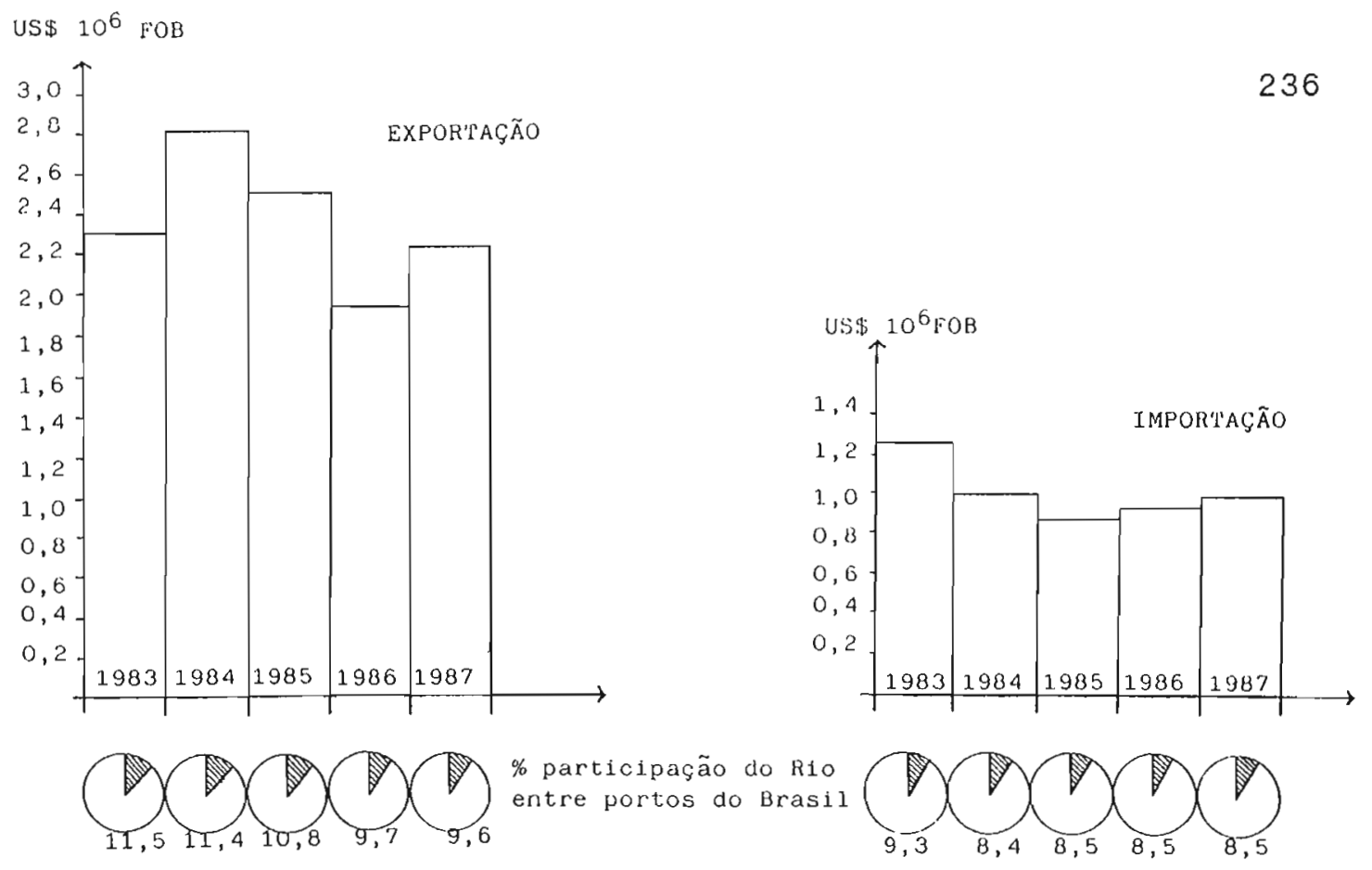

Fig. 44: Histogramas da movimentação de valôres no Porto do Rio de Janeiro, 1983/87.

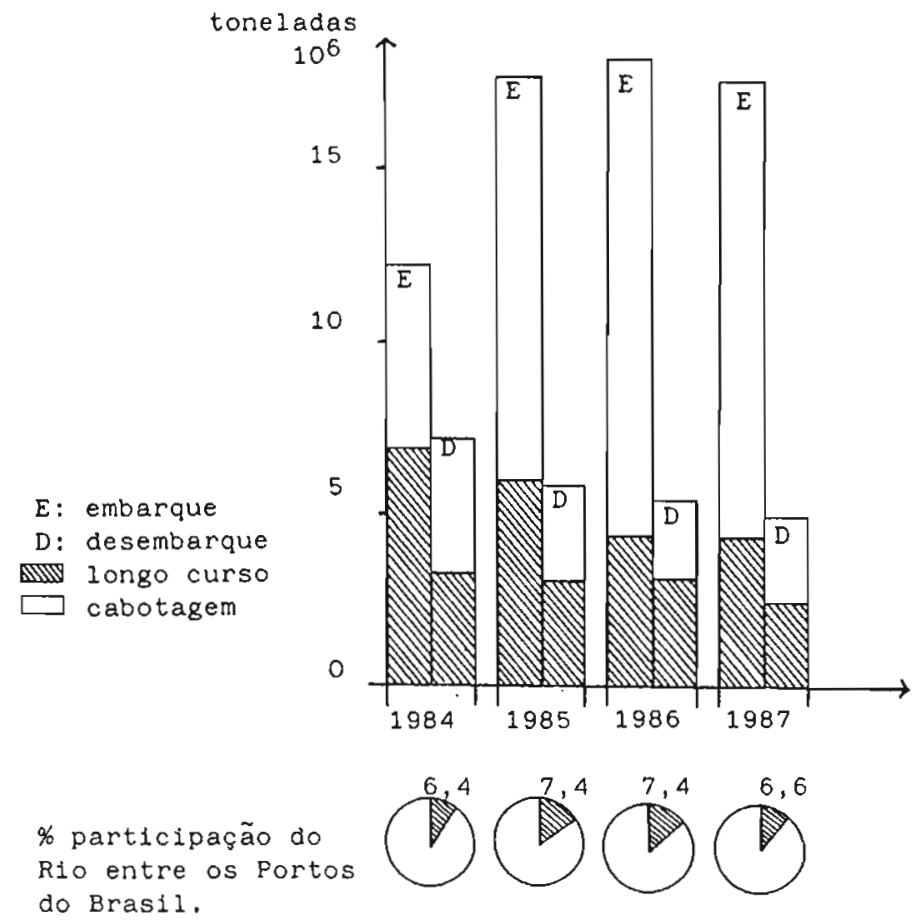

Fig. 45: Histograma da evolução anual das tonelagens em embarque/desembarque por tipo de navegação, no Porto do Rio. 
classificados como graneis 1tquidos: petroleo, dleo combustivele diese1, nafta e gasolina. Sua tendência de firmar importância maior como originàrio da cabotagem (Fig. 45). Em 1986, o Porto do Rio foi registrado como tendo apresentado o maior movimento de cabotagem em àguas brasileiras.

Se observarmos a movimentaçăo geral de mercadorias no pais, em total de cargas no periodo 1982/5, ủitimos dados disponiveis nesta data, veremos que o Porto do Rio vem se mantendo no quarto lugar da rede nacional. Entretanto, é significativo que dados da CDRJ para o mesmo periodo mostram que o seu movimento de desembarque em tonelagem caiu em 50\%, enquanto o total de embarque permaneceu práticamente inalterado. Dados sobre o intercambio comercial em valores monetários mostram que para o pertodo $1981 / 85$, o valor total importado caiu em $50 \%$ enquanto que o exportado manteve-se práticamente estável.

Atualmente, o Rio tende a tornar-se um grande porto de carga geral limpa, com ênfase na exportaçăo em produtos siderúrgicos, velculos e acessórios, produtos quimicos, café solúvel e carne de gado vacuum. A tendência é da movimentação ser containerizada, por suas evidentes vantagens operacionais, ou através do sistema "roll on/roll off" ("ro-ro"), que utiliza-se de navios especiais com rampas.

Para importaçoses o Porto do Rio deverá continuar a concentrar-se em óleo bruto, trigo e outros produtos a 7 menticios. Interessante que notemos a efetividade da politica de desenvolvimento do Governo Federal nesta área, a partir do II PND, pois enquanto até 1976 o Rio era apenas grande recebedor de produtos siderúrgicos importados pelo Brasil, já no inicio dos 
anos 80 ele passaria a grande exportador deles.

Em 1986, um ano bastante atipico pelas medidas econômicas do Plano Cruzado, houve sobrecarga no trabalho portuário pelo incremento das importaçoses de produtos alimenticios. o cais permanceu lotado por alguns meses, tendo navios ancorados ao largo esperando espaço para desembarque por diversas vezes. Mesmo assim, o petróleo e seus derivados foram os responsáveis pela maior parte da movimentaçăo de importaçăo, registrando até $77.8 \%$ do total em setembro de 1986. Também foi grande o movimento de exportação dos produtos siderúrgicos, minério de ferro, sal e o terminal "rolt on/rol1 off".

Finalmente lembramos, ainda quanto a questão da funcionalidade e economia portuárias, da importância do Porto do Rio na geração de empregos diretos, possuindo um quadro de aproximadamente 3600 empregados. Quanto ao total de empregos indiretos, è imposstvel precisarmos a populaçăo exata envolvida nos setores formal e informal, mas supondo um indice de 4 empregos indiretos para cada direto, chegamos a uma estimativa de 14.400 pessoas dependentes da economia portuária. Evidentemente, boa parte desta população ainda encontra sua habitação nos bairros do entôrno imediato, conformados pelo próprio desenvolvimento do porto, como vimos.

VI. 2. Condicôes Fisicas e Operacionais:

Para atividades portuárias, a Bala de Guanabara realmente oferece condiçoes excepcionais não sỏ por sua localização no territorio nacional, como por suas caracteristicas próprias como porto natura1. Possui uma barra de acesso com 1600 metros de 
largura e suas profundidades variam até 50 metros, oferecendo condições seguras para o fundamento de navios em seus $412 \mathrm{~km} 2$ e $160 \mathrm{~km}$ de perimetro. Várias ilhas em seu interior são utilizadas por funções portuàrias, com tanques de óleo combustivel ou estaleiros navais. Além disto, o Porto do Rio, por suas profundidades mèdias, não está sujeito a contingências da maré, cuja mèdia é de 2.40 metros.

As condiqões de acessibilidade por terra săo bastante boas, dentro das limitações geomorfológicas da regiăo. Este fato, aliás, foi primordial para o processo de consolidaçăo econômica e politica da antiga capital federal. E o porto brasileiro que oferece as maiores facilidades viárias, com acesso relativamente fácil ás principais rodovias e diretamentre ligado ás ferrovias Leopoldina e Central do Brasil (RFFSA), com bitolas estreita e Targa, possuindo três terminais rodoviários (vide Fig. 40). Internamente, o Porto conta com um sistema ferroviário próprio ao longo de toda extensão de seu cais, com três 1 inhas fèrreas de bitola mista.

Estas instalaçôs são complementadas pelo equipamento de apoio: guindastes sobre trithos e pneus, empilhadeiras, frota de caminhões e carretas, frota de locomotivas e vagões, etc. Tudo isto viabiliza não só o movimento de cargas como também a atracaça de navios em áreas dispontveis mas que estejam distantes do ponto mais adequado para o embarque, desembarque ou armazenagem. E caso, por exemplo, dos containeres, que podem ser movimentados por toda a faixa do cais, embora o seu terminal especifico esteja no cajú. 
As informações dispontveis nos revelam que a area total de armazenagem do Porto é de aproximadamente 1 mi 1hão de $\mathrm{m} 2$, entre cobertas e descobertas. Estas instalaçôes de armazenagem dividemse entre os pátios descobertos, 22 armazéns de 1a. 1 inha situados junto ao cais, chamados internos, e 9 armazéns de $2 \mathrm{a}$. e $3 a$. linhas, chamados externos, inseridos na malha urbana. Muitos destes funcionam apenas como reserva para os maiores piques de carga, como aconteceu durante o Plano cruzado com o excesso de importações. Os armazéns internos perfazem àrea total de 93.600 $\mathrm{m} 2$. e os externos $66.274 \mathrm{~m} 2$. Evidentemente, as condicões de acessibilidade e disponibilidade destes armazèns são das maiores responsáveis pelas vantagens operacionais ao Porto.

A CDRJ também possui instalaçoes externas para abrigar servicos auxiliares e de apoio ás instalacõos do porto, como oficinas de manutenção, almoxarifados, servicos da Receita Federa1, guarda de cargas apreendidas ou abandonadas, depósitos variados, etc. Como diversas destas instalações e armazéns externos, inseridos á malha urbana, encontram-se arrendados a empresas privadas ou simplesmente desativados, a CDRJ vem encontrando ałguns problemas quanto á sua utilização. No recente episodio do Plano cruzado, a Companhia teve de expulsar de seus armazéns algumas escolas de samba para quem os havia emprestado como depósito de alegorias utilizadas nos desfiles de carnaval.

o Porto possui um cais acostável de $8.0 \mathrm{~km}$, estendendo-se desde a Praça Mauá, onde está limitado pelas instalacóes da Marinha no sopé do Morro de såo Bento, até o Cajú (Fig. 46). o cais comercial é composto por 41 bercos (sem contar os terminais privados) e està subdividido em cinco segmentos principais com 


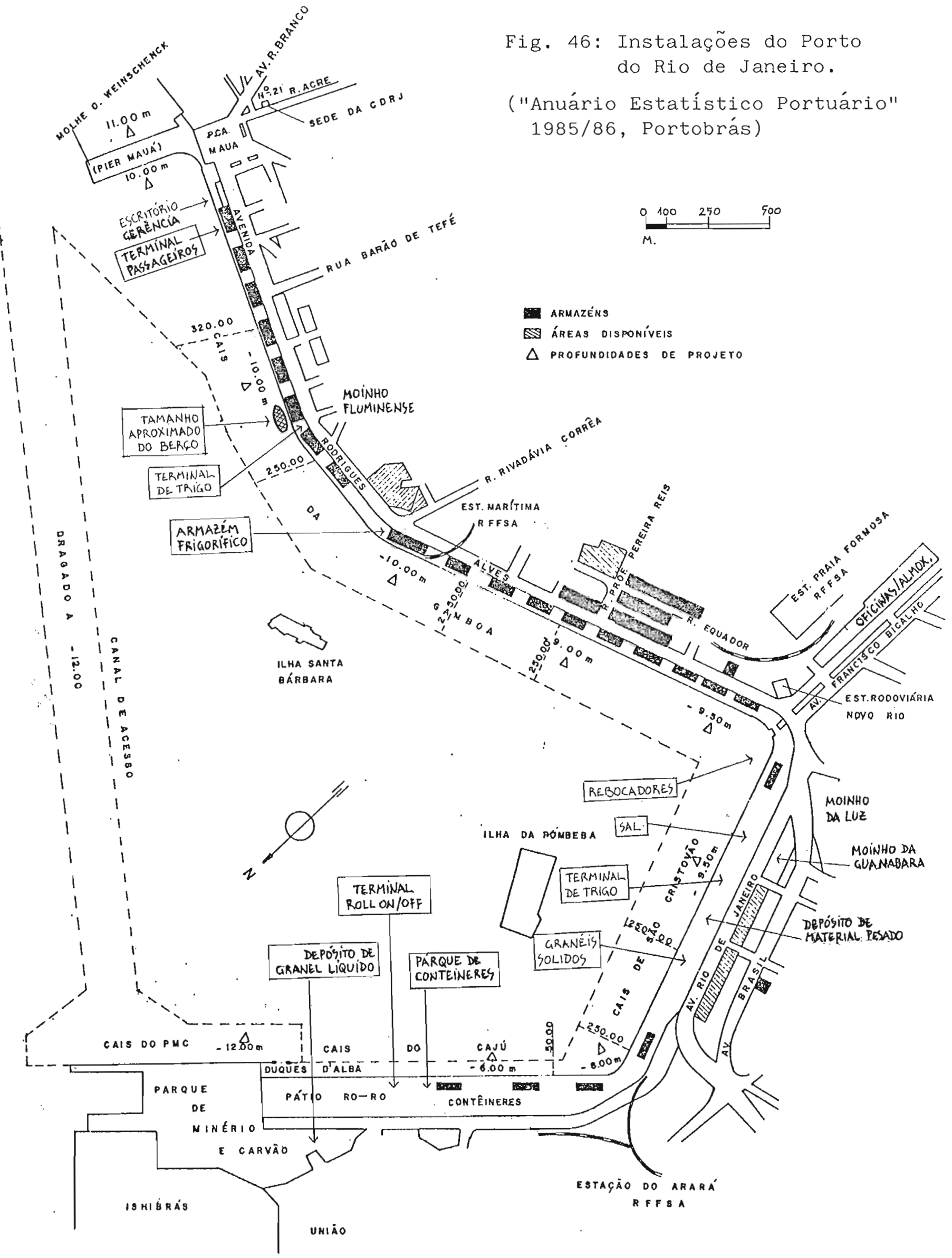


diferentes finalidades. Estudos especializados mostraram que, em 1987, 17 destes bercos estavam especializados em carga geral, 2 em trigo e 14 encontravam-se sub-uti1izados (PLANAVE 1987).

A seguir, descrevemos suscintamente as caracteristicas e as condiçôes dos trechos do cais comercial:

Pier Mauá:

E o trecho mais versatil do cais por seu calado ( 7 a 10 metros) e pela área disponivel de $38.512 \mathrm{~m} 2$, dos quais 20.000 podem ser utilizados para armazenagem, com seus 880 metros de cais acostàve1 e 80 metros de largura.

Este pier é utilizado principalmente para movimentaça de produtos siderúrgicos e carregamentos de velculos por "ro-ro", e eventualmente para atracacăo de navios da Marinha e de passageiros. E junto deste pier que encontra-se o elegante prèdio da antiga Estaçåo de Passageiros (1927), hoje recuperado para suas funções originais e Museu do Porto (exposicões, biblioteca e pesquisa).

Apresenta problemas de retroàrea pois suas condições de acessibilidade para o sistema viário são limitadas por sua localizaça junto á Praça Mauá e o intcio da Avenida Presidente Vargas.

Cais da Gamboa:

Estende-se da Praca Mauá ao Canal do Mangue, com 3.175 metros de extensão e calado variando de 7,20 a 10,30 metros. Ao longo deste cais, que tem capacidade para uns vinte navios de porte médio, encontram-se a unidade de entrada de passageiros, a administraçăo centra1, a 1ém dos armazéns internos de no. 1 ao 18 , com as seguintes destinações de uso: 
- Armazèm 1: embarque e desembarque de passageiros, instalacões do setor de exportação;

- Armazém 2 a 5: carga geral de longo curso, importacão e exportação;

- Armazém 6: movimentacão de trigo importado para o Moinho Fluminense, cujo transporte è feito por sugadores de grăos por sob a Av. Rodrigues Alves até os silos do Moinho;

- Armazéns 7 e 8: carga geral de 1ongo curso; entre os dois hà um tune1 com esteiras para transportar carga congelada até o frigorifico da CIBRAZEM, do outro Tado da Avenida;

- Armazém 9: frigorifico para carga geral perecive1, de quatro andares e capacidade de estocagem para até 15.600 toneladas em 56 câmaras;

- Armazéns 10 a 15: carga geral de 1ongo curso;

- Armazéns 16 a 18: carga gera1 de cabotagem;

o trecho inicial deste cais è muito antigo e não admite sobrecargas maiores que $4 \mathrm{t} / \mathrm{m} 2$, năo aceitando, portanto, carga pesada. A partir do berco 314, ele apresenta problemas de calado devido ao assoreamento causado pelo Canal do Mangue, cujos mau cheiro e má qualidade da água também afetam os sistemas de refrigeraça dos navios. Outro fator que restringe a operacionalidade do cais da Gamboa é a sua estreita faixa de retaguarda de apenas $30 \mathrm{~m}$, que impede servicos de embarque/desembarque mais flexiveis e intensos. Finalmente, o armazém frigorifico é hoje utilizado muito aquém de suas capacidades originais de armazenagem de frutas pela paralizaçăo quase que total desta movimentacăo e por não adaptar-se facilmente a outras operações.

cais de são cristóvão:

Com 1.350 metros de cais acostável e profundidades de 6.00 a 8.50 metros. Ao longo deste cais, além de pátios para o 
armazenagem e carga e descarga e atracacão de rebocadores junto á embocadura do Canal do Mangue, situam-se os seguintes armazens:

- Armazém 22: carga gera1 de longo curso ou cabotagem;

- Armazém 30: carga gera1 de cabotagem e produtos siderúrgicos para longo curso.

Junto ao Armazém 22 situa-se a trigueira e sugadores para transporte do trigo aos Moinhos da Guanabara e da Luz. O terminal de sal possui pátio com aproximadamente $2.200 \mathrm{~m} 2$. de capacidade de armazenagem. Neste segmento de cais também existem instalaçoos especiais para recepcão de sleo cru e derivados de petróleo, oleodutos diretos para as refinarias e para as empresas distribuidoras.

- Cais de são cristóvão apresenta problemas quanto a insuficiência de energia eletrica e dos efeitos gerados pela embocadura do Cana1 do Mangue, mencionados acima.

Cais do Cajü:

os seus 1.300 metros de extensão de cais e calado máximo de 6.00 metros destinam-se principalmente á operação de "containers" de navegação de longo curso e cabotagem e operaç̃es com barcaças. Após descarregados, os containeres são transportados por vagões e caminhões para seu grande pátio e os adjacentes Armazéns 32 e 33 .

Em uma de suas extremidades foi recentemente implantado o Termina1 "Ro11 On-Ro11 Off" com área de cerca de $30.000 \mathrm{~m} 2$, entre - Armazém 33 e 0 Parque de Minèrio e Carvăo. Segundo o planejamento da CDRJ, futuramente este constituirá um terminal intermoda1, principalmenter após a construção da Linha Vermelha (variante da Av. Brasi1), facilitanto a movimentação da crescente exportacão de velculos. 
Parque de Minèrio e Carvão/Terminal de Containeres (TECON) Inicia-se logo após o cais do Cajú, atè o caís da ISHIKAWAGIMA. Originalmente dimensionado para alcançar exportacão anual de 4.5 milhões de toneladas de minèrio de ferro e um movimento de 3 milhões de toneladas de carvăo, em seu cais de 765 metros e profundidades de 11,50 a 12,00 metros.

Com a inauguração do Porto de Sepetiba em 1983, o termina1 de carvão foi desativado e o de minério, embora ainda se encontre em funcionamento, com área de estocagem de 250.000 toneladas, também terà suas funcóes encerradas em breve.

Nestas àreas 1 iberadas, um cais de dois bercos e $450 \mathrm{~m}$. , implantou-se um terminal de containeres (TECONT) em $50.000 \mathrm{~m} 2$, cuja capacidade deverá ser ainda dobrada em uma segunda fase de implantaçăo. Este novo terminal significou aumento da capacidade portuária de 50\% pois anteriormente estas operacões estavam espalhadas ao longo de todo o porto.

Finalmente, hà um trecho do cais do Cajủ tambèm ocupado por $12.081 \mathrm{~m} 2$ de terminal "ro-ro", para movimentacăo de veiculos, mas encontra-se hoje sub-utilizado para este tipo de operacăo.

VI. 3. Tendências de Funcionamento do Porto:

O Porto do Rio chegou a apresentar um gradativo decilnio de movimento apesar de apresentar aspectos favoráveis de funcionamento e acessibilidade. O volume total de carga movimentada relativa á navegaçăo de longo curso, por exemplo, registrou significativo decréscimo real no periodo 1976/85: no desembarque, de 17.101.242 t/ano a $3.135 .906 \mathrm{t} / \mathrm{ano}$, no embarque, de 13.246 .142 t/ano para 5.902.478 t/ano. Na última década 
registrou-se uma queda de $50 \%$ do movimento de importacões.

Entretanto, o Porto do Rio continuará a representar importante papel na economia urbana e regional do Rio de Janeiro, assim como funçôes especificas na rede portuária nacional. Sua recuperacão parece estar bem representada pelos numeros recentemente divulgados: a CDRJ informou que o volume de carga movimentado pelo Porto do Rio foi de 19,3 milhôes de toneladas em 1989, resultado que supera os do ano anterior em cerca de $2 \%$ (O GLOBO: 12/4/90). Estes totais foram atingidos devido á estabilidade de suas exportacões e ao aumento da cabotagem (vide Figs. 44 \& 45). Os crescimentos significativos neste perlodo foram da movimentaçăo de containers que totalizaram 784,7 mi1 ton., um acréscimo de 12\% em relaçăo a 1988, e das operaçóes de "ro11-on-ro11-off", que cresceram em $15 \%$ no mesmo perfodo.

Portanto, o Rio tende a firmar-se como porto de carga gera1 movimentada, principalmente, por containeres, de exportacăo de produtos siderúrgicos, vefculos e acessórios, e importacão de alimentos como o trigo. Embora os estudos indiquem que o indice de containerizaçăo ainda esteja baixo (na ordem dos $15 \%$ do tota1 movimentado em 1988) devido á grande participação de produtos năo-containerizáveis, como os siderúrgicos, a tendência é que este tipo de processo de movimentacăo aumente sua participacão (PORTOBRAS 1988).

- desembarque de álcool carburante e a importação de produtos derivados do petróleo e o óleo bruto, cuja movimentacão se dá fora do cais comercial e em cais privados como os da PETROBRAS, deverà manter sua importancia pela proximidade das grandes refinarias e distribuidoras. 
A liderança como porto central na navegação de cabotagem também deverà ser mantida: como embarque de cargas o porto do Rio tem seguidamente se apresentado como o 11 der brasileiro desde 1986, tendo triplicado o seu movimento nos ủltimos dez anos; como destino de carga manteve a média de movimento neste mesmo pertodo.

Entretanto, a possibilidade do crescimento de sua importância e especialização nestas funcões parece estar 1imitada por diversos fatores que extrapolam a simples atuaçăo de sua administração, derivados diretamente de suas próprias caracteristicas. As dificuldades que neste sentido podem ser agrupadas em quatro classes de fatores distintas.

Primeiramente, independente mesmo das próprias especificidades do porto, a atual situaça é um reflexo das tendências mundiais de diminuicão do transporte marttimo em detrimento do rodoviário e aéreo, mais flextveis e rápidos. Esta tendência tambèm se reflete a nivel interno no Brasil e o transporte rodoviario é, indubitave1mente, o responsável pelo maior movimento de cargas no territorio nacional.

A segunda classe de fatores é gerada pelo papel definido para o Porto do Rio no desenvolvimento nacional, na sua rede portuaria e nas especificidades de sua hinterlândia. Tanto os dados disponiveis quanto as evidências expressas na politica nacional de desenvolvimento, apontam para uma significativa diminuicăo no total de carga importada contra uma relativa manutencão do total exportado. com o pais tendendo a aumentar suas exportacões, o movimento de cargas no Rio deverá evidencia10 crescentemente. 
o Rio vem mantendo-se entre a quarta e a quinta posiça em importância na rede portuảria nacional, quanto á navegação de Tongo curso. As poltticas do Ministerio dos Transportes e da PORTOBRAS que maximizam as potencialidades de outros portos, num planejamento de especificidades, irăo sem dưvidas se refletir na distribuição da movimentação portuária por todo o território nacional. Se, por um 1ado, a especialização almejada è funcionalmente positiva, pelo outro isto significarà diminuicão da importância relativa do Porto do Rio. Foi o que aconteceu, por exemp1o, após a inauguração do porto de sepetiba e sua concentraçăo de movimentos de carvão e minério.

A terceira classe de fatores que identificamos refere-se a 1 imitada capacidade de suas àreas de retaguarda, ou seja, a àrea de apoio ás atividades portuàrias que devem não apenas estar fisicamente bem interrelacionadas com ele, como possuir caracteristicas e capacidade próprias para o bom desempenho. Neste sentido, podemos destacar o ordenamento fisico-espacial, o sistema viário compative1, edificacơos próprias em bom estado, areas dispontveis para flexibilidade e crescimento, facilidades no deslocamento de equipamentos, entre outros fatores. Atualmente, como a anàlise dos dados cadastrais e dos mapas de caracterizaça da Area Portuária vai comprovar mais adiante, as atividades do Porto encontram-se limitadas pelo próprio desenvolvimento da cidade e pela ocupação de seu entôrno imediato por funções não diretamente 1 igadas a elas.

Finalmente, o próprio valor do solo e as pressões de desenvolvimento exercidas, principalmente, pelas funços centrais fazem com que a situaçăo da àrea em situação de exercer funcões 
de retro-porto estejam comprometidas com ocupacăo ou irreversivelmente á espera da realizaça de uma mais-valia semelhante ás da àrea central; as soluções para reverter esta situação seriam evidentemente complexas e extremamente onerosas.

Além desta questão da retro-área, a capacidade operacional da Area Portuária também encontra-se relativamente limitada, particularmente no trecho ao longo dos Armazens 1 a 18 , pelo intenso tráfego de velculos pesados e ônibus na Avenida Rodrigues A1ves -principal via de escoamento de inúmeras linhas Centro/subúrbios, e pelo próprio acesso á Avenida Brasil, bastante complicado. Os atrasos causados ás operações portuàrias são comuns e uma medida a ser implementada, segundo os planos oficiais do governo do Estado, que deverá minorar este problema serà a criaçăo de uma variante á Avenida Brasil a partir da altura do Armazém 22. A transferência gradual dos granéis sỏitos para sepetiba também vem colaborando no altvio de operações que envolvem tráfego viàrio.

Por suas caracteristicas morfologicas, o Porto do Rio tende a desenvolver e ampliar as suas atividades e instalaçoos de forma longitudinal ao longo da orla e, necessariamente, em direção Noroeste, para o fundo da Bała. As informacões existentes relativas ás funçôes desempenhadas pelo Porto nos permite concordar com a opiniăo de especialistas (entrevista a Pedro Batouli, ex-presidente da CDRJ) e estudos existentes (PLANAVE 1987, 1989) que apontam o Cais de são Cristóvão e a àrea do cajủ como as que apresentam condicões mais proptcias para a consolidaçăo e expansão das atividades portuárias. Devido a seu calado relativamente 1 imitado, entretanto, sua plena utilizaça 
deverà contar com obras de dragagem de canais navegáveis. Note-se que, mesmo sendo esta àrea a mais proplcia para consolidaçăo de novas instalacões, ela também è limitada ao crescimento no sentido Noroeste pela própria malha urbana consolidada e pelos dificilmente contornáveis problemas de assoreamento. A soluçăo alternativa seria a onerosa construção de piers e canais de profundidade na forma de costelas, perpendiculares á atual linha de cais; o que, aliảs, seria uma retomada dos projetos do intcio do século.

Além disto, atualmente, o bairro do Cajú possui uma confusa configuracão urbanistica, fruto de sucessivos aterros e do intenso uso industrial e de servicos de porte, mesclando-se a nabitações de baixa renda. A superintendência para o Desenvolvimento da Pesca (SUDEPE) tambèm possui planos de ali instalar uma colônia de pesca e seus escritórios, mudando-se das atuais instalaçóes na Praça XV. Mesmo assim, dentre as opcôes disponiveis no entorno do Porto, o Cajú ainda possui àreas para melhor instalaçăo de atividades de retro-porto.

Os estudos existentes sobre o Porto do Rio de Janeiro, indicam que o aproveitamento de suas àreas está inferior aos padrões internacionais, com baixa utilizaçăo em relaçăo á área bruta dispontve1; estima-se em $1 / 3$ de bercos acostáveis com

2: Neste área existe uma antiga colônia de pescadores, instalada desde fins do século XIX e errôeamente classificada como favela (vide SA 1985), habitaçôes faveladas que a ela se aglutinaram, uma favela urbanizada nos anos 70 , um pequeno conjunto de prèdios da COHAB, e inumeras edificaços residenciais populares. 
ocupacão ociosa (PLANAVE 1989). Detecta-se também que o porto necessita evoluir no que diz respeito \& movimentaçáo de carga geral e, para isto, o "lay-out" territorial mostra-se incompativel com esta demanda e suas exigências. Some-se a isto, as pressôes para expansăo de outros usos urbanos de seu entôrno. Portanto, as 1 imitações da retro-área e as tendências expostas, de containerizaçăo de suas operações e de consolidação e crescimento da exportaçăo de velculos, mantendo-se os atuais niveis de importaçăo de alimentos, farão com que o Porto do Rio procure a fixaçăo de suas operaçôes ao longo dos segmentos de são Cristóvão e, particulamente, do Cajú (Fig. 47). Por outro 1ado, a movimentaçăo de passageiros registra significativos decréscimos e a concentraçăo de suas operaçoses è quase insignificante em relaça ao tota1, verificando-se apenas na Praca Mauá.

Em termos operacionais, os dados e os comentários expostos demonstram que todo o cais e as instalações portuàrias de sua retaguarda imediata, desde a Praça Mauá até o Canal do Mangue, mantidas as mesmas tendências de desenvolvimento do comèrcio marttimo, deverão continuar apresentando trechos com significativa diminuição de uti1izaçăo. 


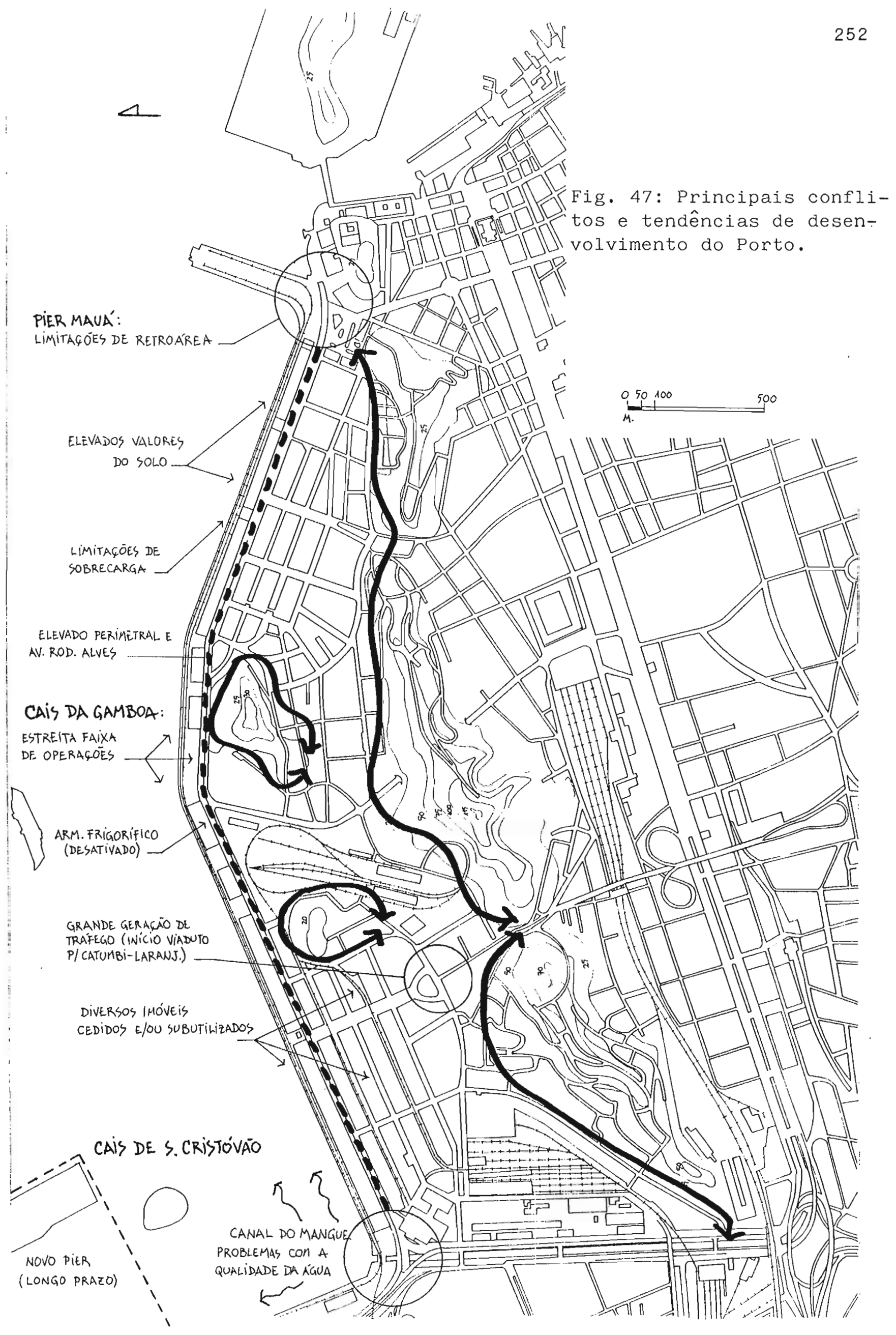


CAPITULO VII:

CARACTERIZAÇAO E DINAMICA RECENTE DA AREA DE ESTUDO

Jà vimos como as atividades de atracação e portuárias em geral davam-se ao longo de todo o litoral da área central, em maior ou menor grau, desde a formação da cidade, apenas deixando de fazê-10 desta forma quando na consolidação de determinadas funçðes centrais, econômicas e poltticas, a partir do intcio deste século. No capitulo anterior vimos também como a especialização funcional do território e as necessidades de operacionalidade econômica vieram a concentrar atividades portuárias em uma área determinada, conhecidada como Porto do Rio de Janeiro, e todas as operaçós e funçóes de apoio vieram a localizar-se em seu entorno imediato.

Atualmente, a Area Portuảria do Rio de Janeiro propriamente dita, estende-se por significativa àrea litorânea da Bata de Guanabara, desde os 1 imites do Aeroporto Santos Dumont e as propriedades da Aeronáutica, até o bairro do Cajú, onde a pequena profundidade da Bala já impossibilita maiores operaç̃es (vide Fig. 46). Como vimos, as funçôes portuárias comerciais, administradas pela Companhia Docas do Rio de Janeiro em seu Porto, localizam-se a partir do limite noroeste das propriedades utilizadas pela Marinha. 
Portanto, a àrea objeto deste estudo, a que denominamos simplesmente Area Portuária do Rio de Janeiro, representa apenas parcela do território da cidade dedicado a esta funçăo. Nossa área de interesse direto é 1 imitada ao Norte pelo Porto e a Baia, ao sul pelos bairros da saude, Gamboa e Santo cristo e os Morros da Conceiçăo, Livramento e Pinto, ao Oeste pela Avenida Francisco Bicalho e o Canal do Mangue, ao Leste pela Praca Mauá e - Morro de São Bento (Figs. 48 a 50).

Com àrea total que se aproxima dos $1,85 \mathrm{~km} 2$, estes 1 imites foram adotados levando-se em consideração quatro fatores básicos, que serăo analisados com mais vagar adiante, a saber:

a) A concentraçăo de atividades e de operações portuárias, reforcada pelas caracterlsticas morfológicas e geográficas, bem como por sua proximidade ao centro, fazem com que a Area de Estudo seja natural e tradicionalmente percebida pela populaçăo como a "área portuária";

b) A sub-utilização de seus espaços e patrimônio construido, situação causada pela própria dinâmica das funçoos portuárias e econômicas, conjuntamente com a sua situação estrategica e potencialidades para o desenvolvimento junto ao centro da cidade, geraram a formação de interesses politicoeconômicos espectficos que se refletem sobre o seu territorio;

c) A implantação de uma zona de proteçå ambiental pelo governo municipal, com limites bem definidos e que protege o patrimônio e as funçôes residenciais existentes nos bairros da Saude, Gamboa e Santo Cristo com todo o apoio das comunidades 1ocais; 
d) A evidente importância econômica da continuidade e consolidaçăo de determinadas operacões portuárias no patrimônio jà instalado fará com que grande parte das áreas sob o controle da Companhia Docas do Rio de Janeiro, principalmente aquelas ao longo do 1 itoral, permaneçam com as funcơes atuais.

Assim sendo, "nossa" Area Portuària possui limites precisos, com compartimentadores ambientais bastante claros, sejam eles geográficos (canal, morros), morfológicos (perfil fundiário, volumetria e tipologia das edificaçóes) ou funcionais.

Os comentários que se seguem complementam as informaçóes trazidas em forma de mapas e tabelas, e caracterizam a àrea segundo diversas tematicas usualmente abordadas pelo Planejamento (ocupação do solo, transportes e circulação, condições de suas edificações e áreas 1ivres, aspectos sociais, perfit fundiàrio, condicionantes legais e dinamica imobiliária). Com estes comentários, poderemos verificar a crescente estagnação de seu desenvolvimento nos ulutimos anos e como è verdadeiro o potencial existente para sua revitalizaçăo como àrea integrada e complementar ás funçooses centrais da cidade.

VII. 1. Caracteristicas Urbanisticas da Area:

Fatores geográficos e locacionais foram os primordiais na determinaçăo dos usos e das caracteristicas de ocupacão do solo na nossa área de estudo, uma vez determinada a consolidação da funçăo portuária oficialmente no século XIX, como vimos na análise de sua evoluçăo. Assim, básicamente definiram-se dois "territórios de uso" complementares: as partes baixas e 


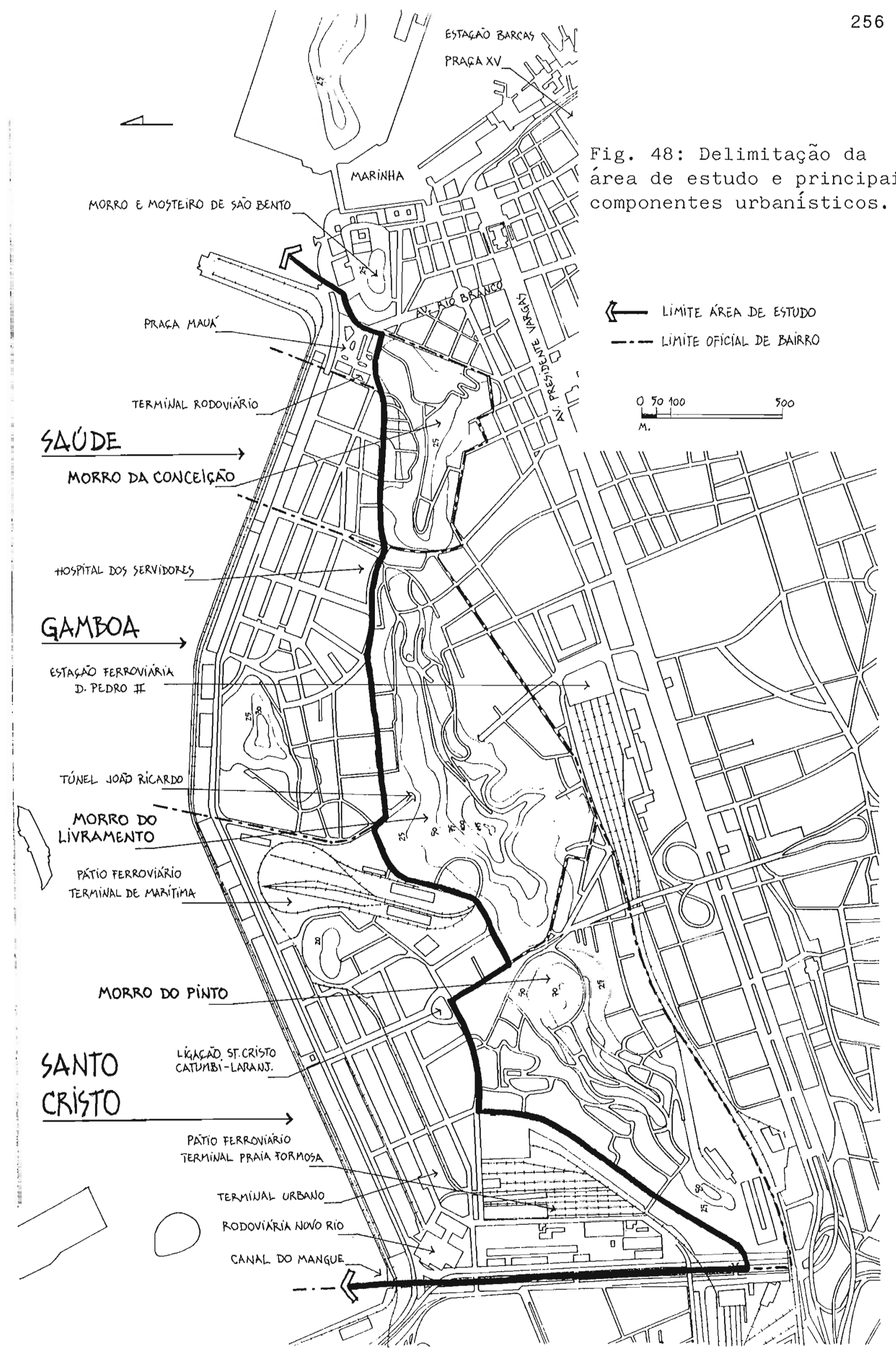




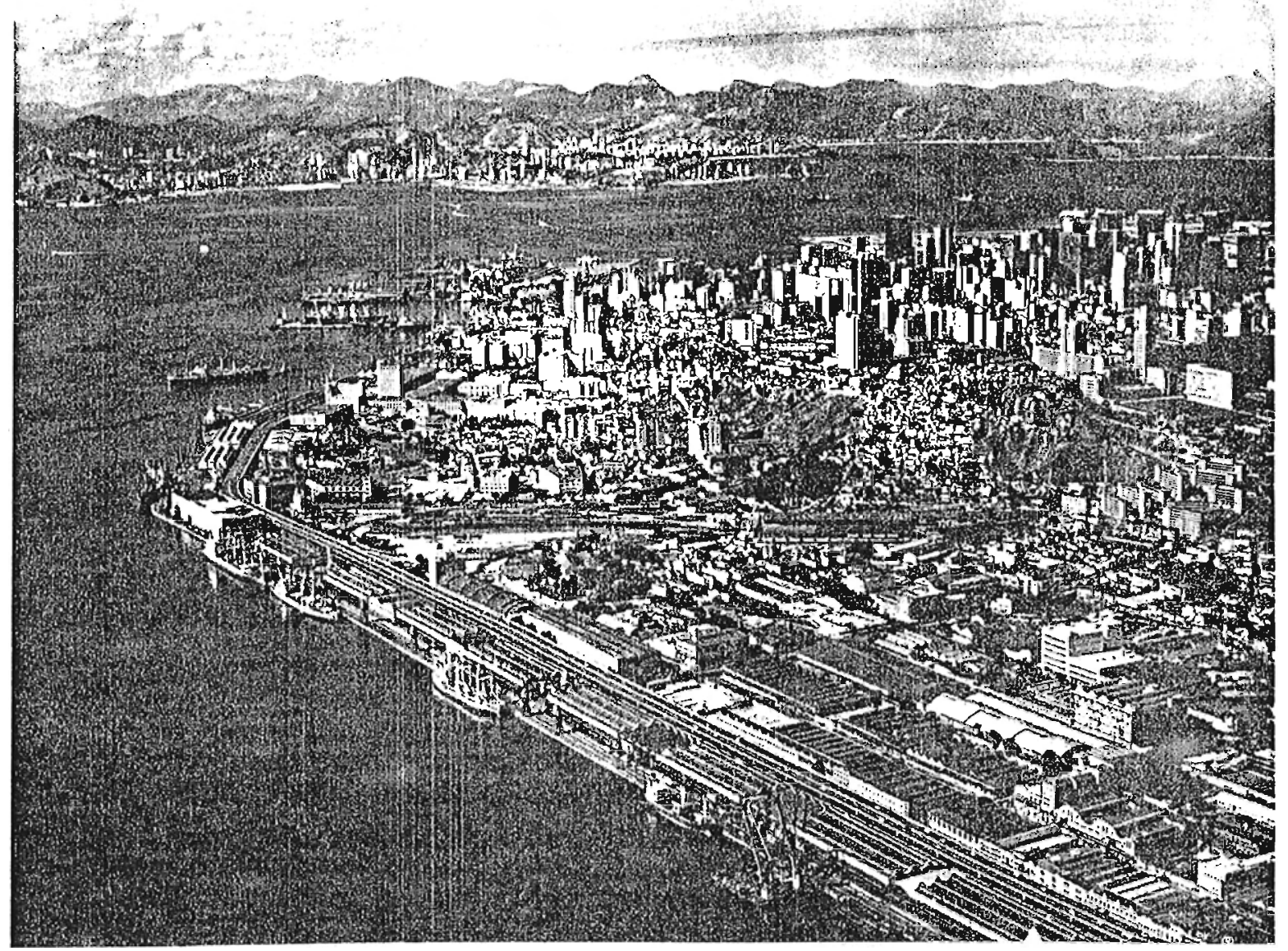

Fig. 49: Vistas aéreas gerais da Área Portuária. Acima, no meio da tomada, o pátio da RFFSA; abaixo em primeiro plano a Rodoviária e a Av. F. Bicalho.

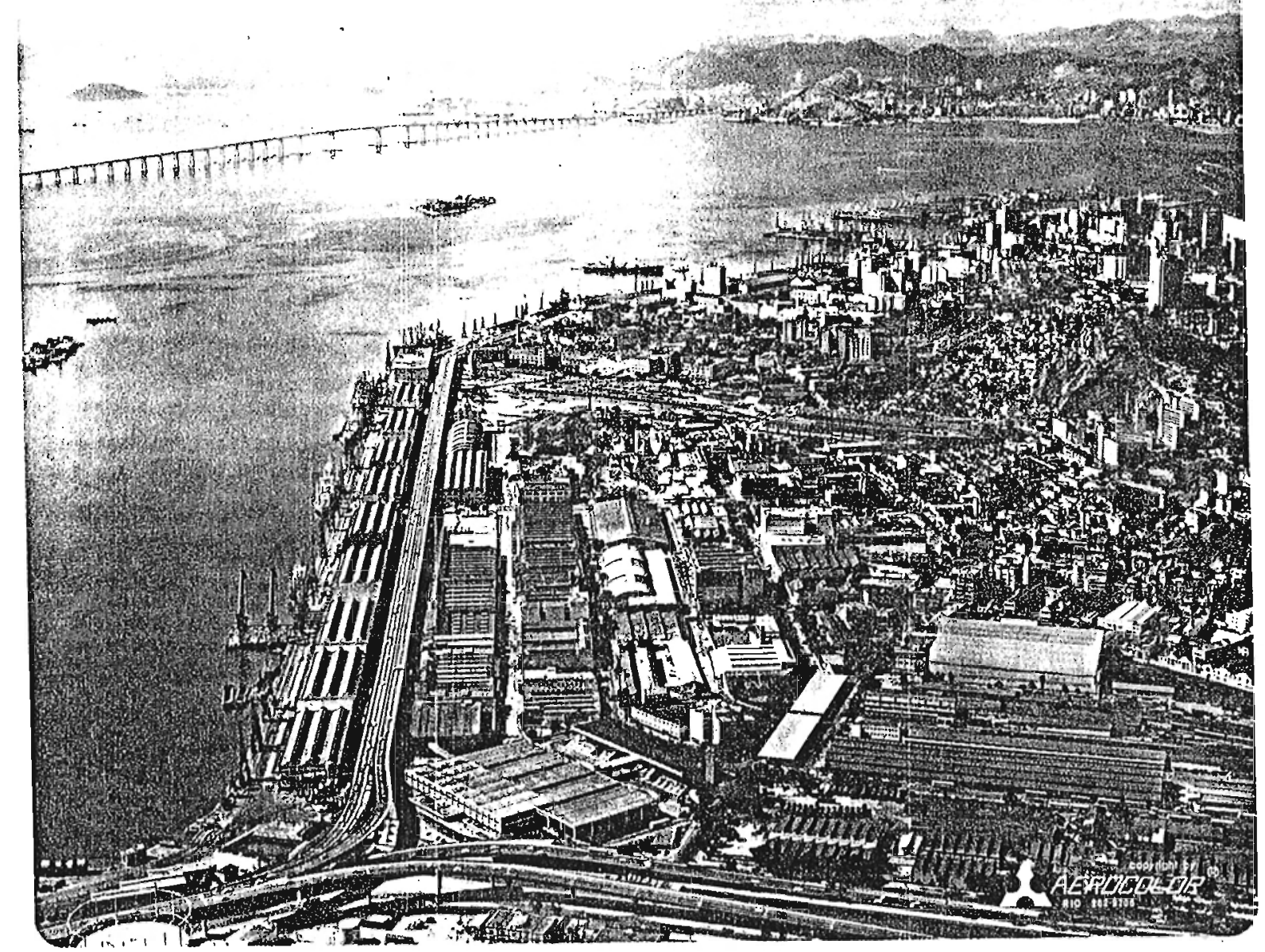




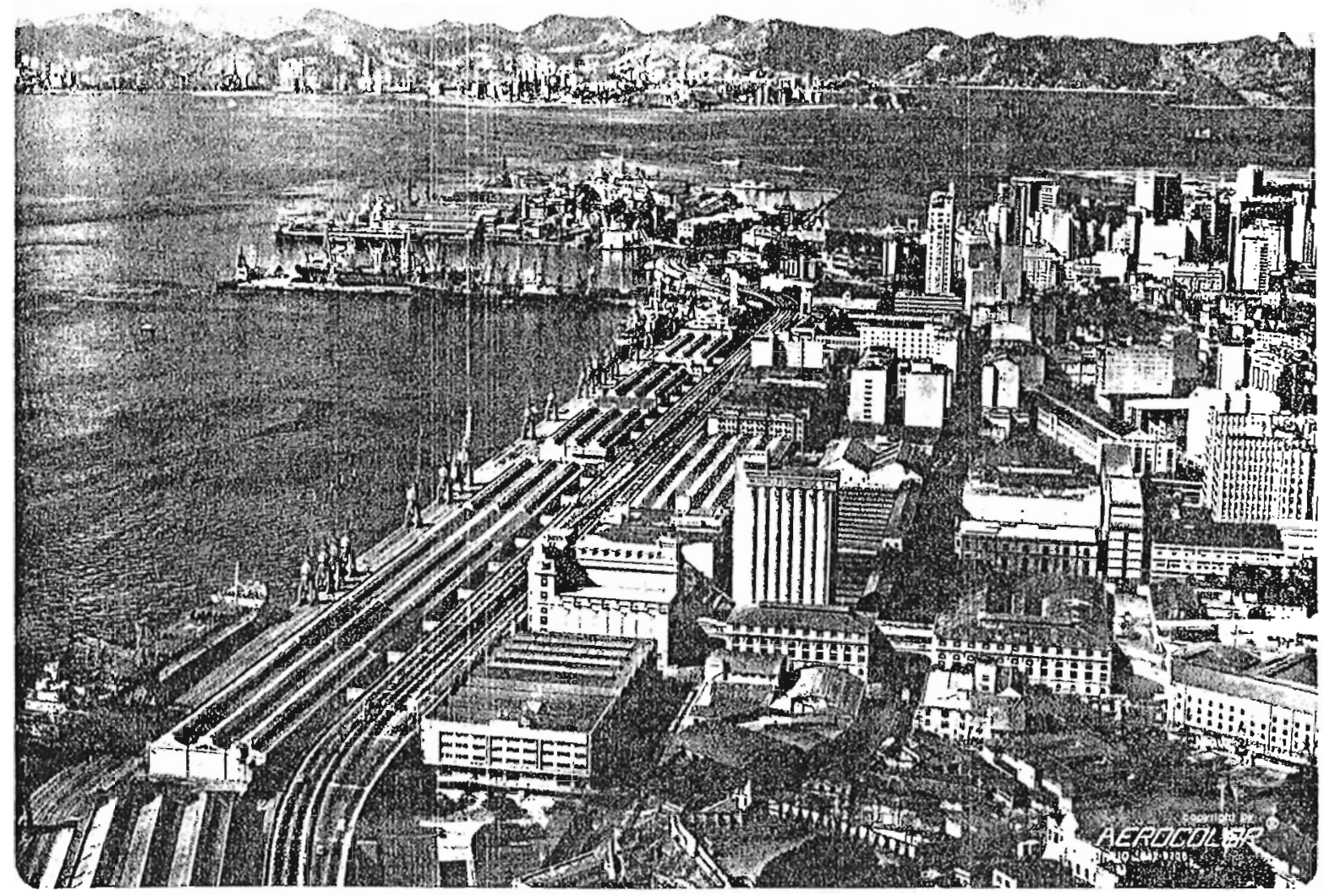

Fig. 50: Vistas aéreas da Área de Estudo. Acima, em primeiro plano, o Morro da Saúde e o Moinho Fluminense, ao fundo, o Morro de São Bento. Abaixo, a área do antigo Moinho Inglês e o pátio da RFFSA.

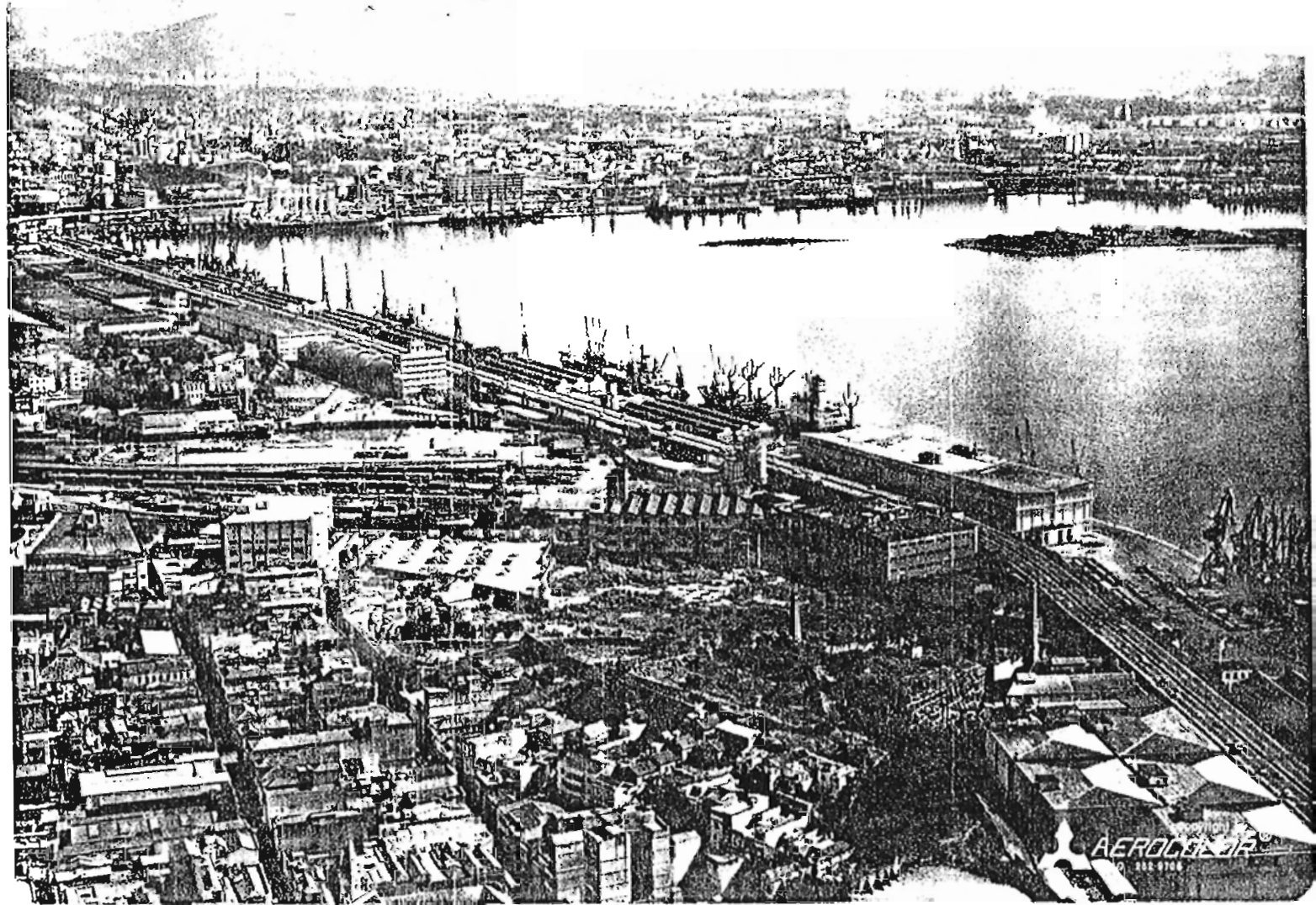


resultantes dos aterros para construcão do porto no inicio do século, e as partes altas e morros cujas condiçóes de ocupacăo já haviam sido anteriormente determinadas pelo uso residencial. As operaçôs portuárias, a proximidade do centro funcional da cidade foi relativizada pelos compartimentadores existentes, e o complicado perfil fundiàrio da àrea, que comentaremos adiante, fizeram com que as funçôes centrais nunca viessem a causar séria ameaca; seu desenvolvimento passou ao largo da Area Portuária durante muito tempo.

As principais funçoes na Area Portuária podem ser identificadas como se segue (Fig. 51):

I. portuária: ocupa toda a orla e a maioria das áreas administradas pela CDRJ e pela CIBRAZEM. Diversos armazéns e àreas de sua propriedade de segunda e terceira linha, originalmente engajados neste tipo funcional encontram-se arrendados a terceiros ou foram vendidos para usos diversos.

II. servicos: diversos imóveis e áreas săo utilizados para usos direta ou indiretamente complementares ás atividades portuárias, por particulares ou órgãos públicos. Assim, destacamse os pátios ferroviários da Rede Ferroviária Federa1, principalmente o Terminal de Marttima, que ainda apoia a função portuària, e $o$ complexo edificado de silos, armazéns e escritórios do Moinho Fluminense. Existem vàrios imóveis que são utilizados para servicos de apoio a grandes empresas, como PETROBRAS, BANERJ e CSN, a maioria utilizada como depósitos e garagens, e alguns utilizados como sede de suas empresas, como a XEROX e a MICHELIN. 
III. comércio: esta funcăo è bastante incipiente se analisada em relação á escala e situaçăo urbana de nossa área de estudo. o comércio atacadista é de ocupaçăo linear e verifica-se em dois pólos; um com predominância de produtos alimentares e bebidas, outro com venda de papel e artigos de escritório. o uso residencial deu origem a comércio varejista mas bem aquém das necessidades da população local, fato confirmado junto ás associaçôes de moradores. No eixo que liga a Praça Mauá á Praça Barão de Tefé, verifica-se um comércio mais intenso complementar a funçôes espectficas, como aos hospitais dos servidores e o do INAMPS, á Pollcia Federal, ao terminal rodoviário ou a escritórios da CEDAE, PORTOBRAS e Ministério da Fazenda. Já no entorno da Praça Mauá há um conjunto de lojas, bares e casas noturnas oriundo do antigo movimento de passagejros, marinheiros estacionados no porto e de portuários.

IV. industria: a maioria das indústrias que haviam se instalado na área no inlcio do século, como metalúrgicas e serrarias, afastaram-se por causa das limitaçoes do zoneamento e da valorização da àrea para outros usos e em busca de maiores terrenos, algumas para o Santo cristo e são cristóvão. Pequenas indústrias de caracterlsticas urbanas instalaram-se na àrea, como as de cunho editorial, pequenas gráficas e confeccões de texteis. As unidades fabris mais importantes săo o Moinho Fluminense, a industria de chocolates Bhering, no santo cristo, a companhia Usinas Nacionais e a Almar de aluminios.

V. instituciona 1: funçăo identificada nas àreas militares, nas entidades governamentais e nos servicos de interesse publico. o uso militar està presente principalmente no Arsenal de Marinha, 
mas também no Servico Geográfico do Exẻrcito e Observatório do Valongo, na Pollcia Marttima, na sede do 5o Batalhão de Poltcia e na Companhia de Apoio de Material Bẻlico. o uso governamental expressa-se em diversos prédios dos ministèrios da Fazenda, Saủde, Agricultura, e instituições como a Portobràs, sunamam e Instituto Nacional de Tecnologia. Servicos de interesse publico incluem os hospitais dos Servidores do Estado, INAMPS, de Oncologia e Nossa Senhora da Saude, além de escolas e igrejas.

VI. residencial: funçăo pouco presente em nossa área de estudo mas dominante em larga faixa limitrofe, nos bairros populares tradicionais da saude, Gamboa e santo Cristo, principalmente nos morros da conceicão, Livramento, Providencia e do Pinto. A tipologia é de pequenas edificações, de ocupação térrea ou assobradada, principalmente remanescente do século passado. Além destes bairros, existem ainda três favelas, a maior representada pela da Providência, reconhecida como a primeira favela do Rio de Janeiro, como vimos anteriormente.

Em termos de circulação e transportes, a área de estudo è bastante singular pois os seus eixos principais comportam inúmeras linhas de ônibus que servem á cidade como um todo e deles se utilizam, principalmente as oriundas nos dois terminais rodoviários situados em suas extremidades, o da Praça Mauá, que comporta as principais linhas para os suburbios e região metropolitana, e o de Santo cristo, complementar á Rodoviària Interestadual Novo Rio (vide Fig. 48), por onde passaram, por exemplo, quase 2 mi hoôes de passageiros em 1980.

A Av. Rodrigues Alves, com sua 1igaça á Avenida Brasi1, principal eixo de entrada/salda do Rio, e outros eixos principais 

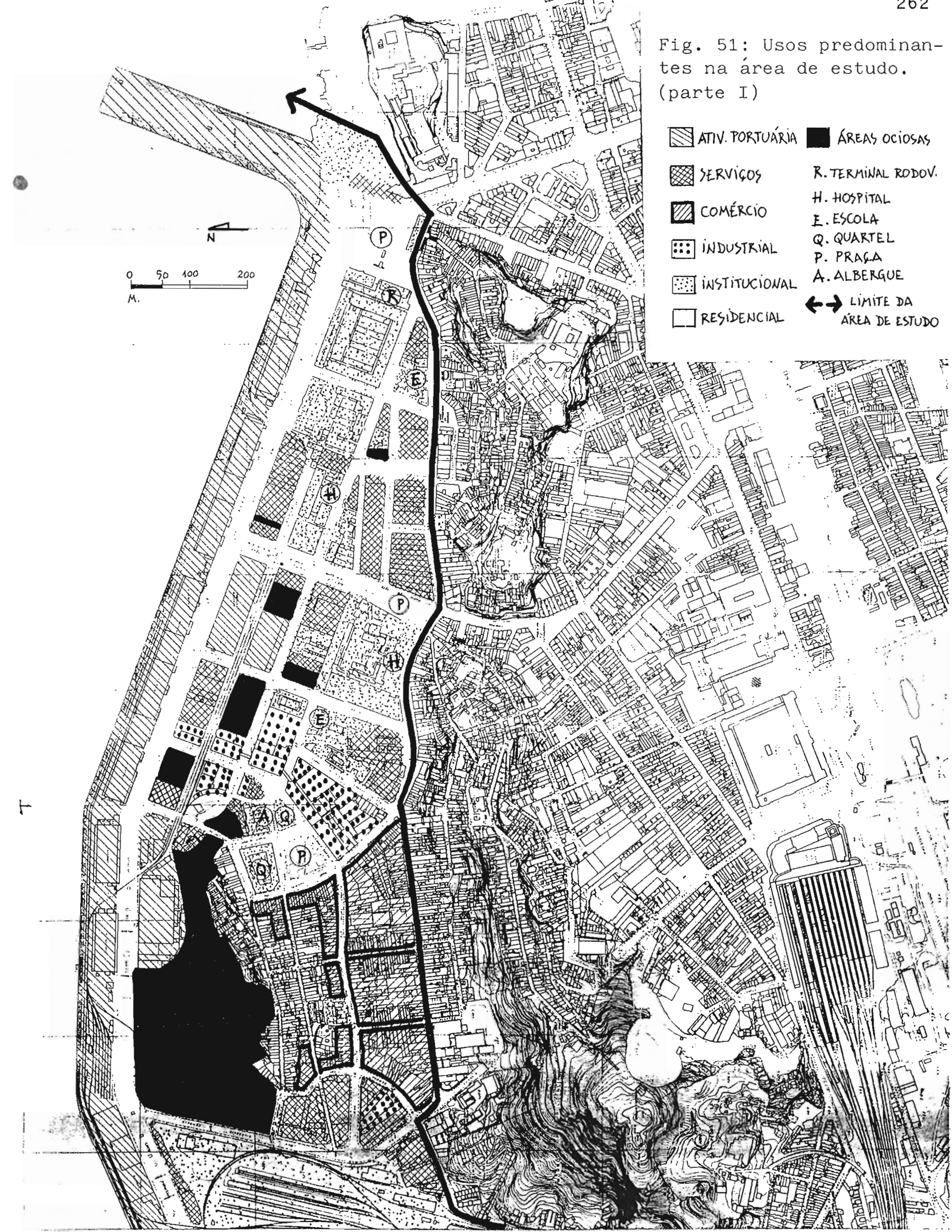


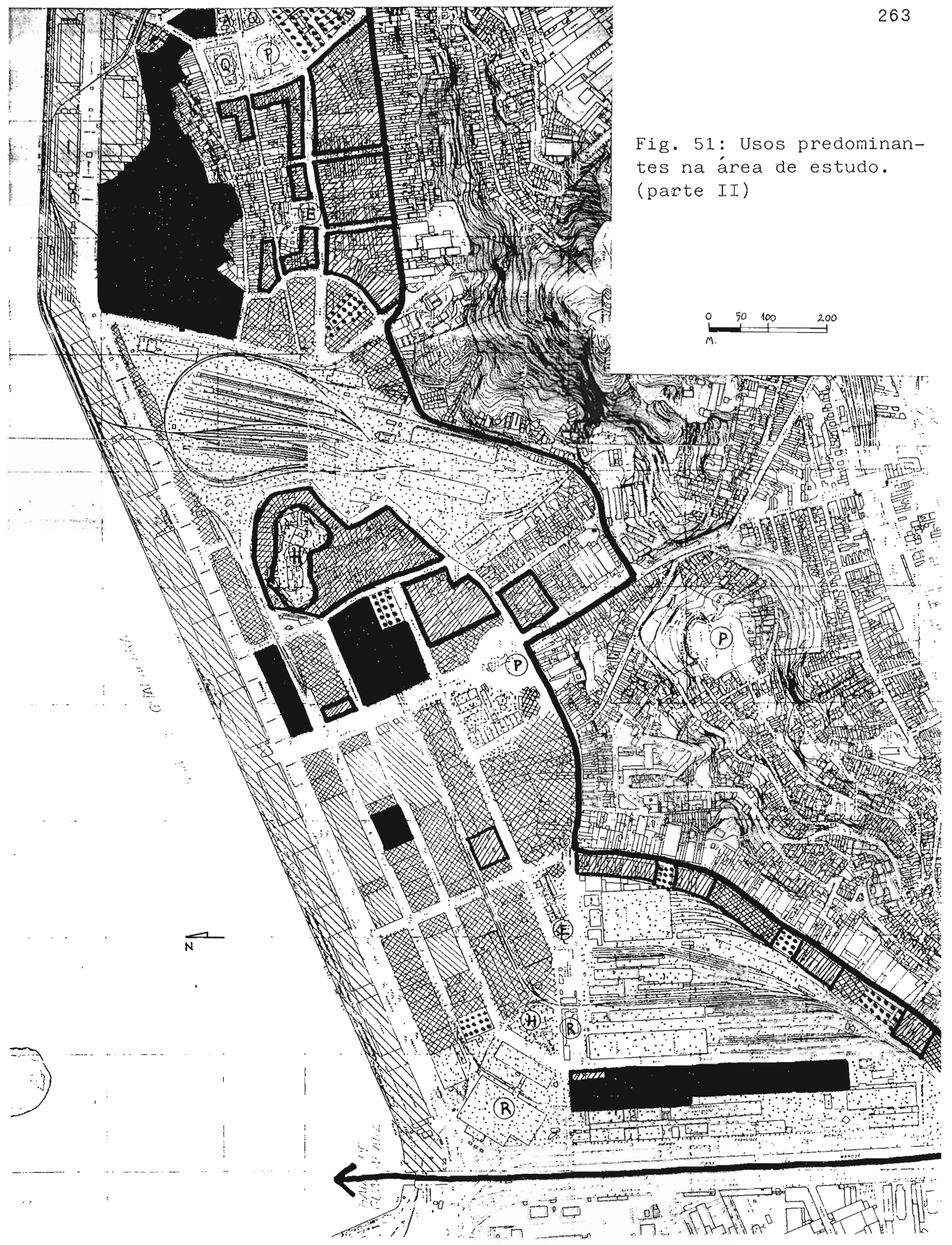


integrantes deste sistema na área comportam assim mais de 130 linhas de ônibus. Através do túnel Joăo Ricardo sente-se, ainda, os reflexos das linhas de ônibus originadas na estaçăo ferroviària Pedro II, cujos ramais fazem importante ligação aos suburbios cariocas; em 1980 foram transportados mais de 34 mịhơes de passageiros pelas 1 inhas ferroviảrias. Muitos destes passageiros fazem baldeação e tomam linhas de ônibus para o Centro, Praça Mauá ou á Av. Brasi1, através da Area Portuária.

Servindo aos movimentos pendulares da populaça trabalhadora do Grande Rio, a grande maioria destas linhas diminuem significativamente os seus servicos á noite e não servem diretamente os interesses da populacão residente nos bairros junto á nossa àrea de estudo. Os usuảrios dos servicos localizados na àrea servem-se destas linhas, como para os hospitais e instituiçoses governamentais existentes junto a Praça Mauá. A área tambèm comporta dois eixos viários importantes para circulaçăo de velculos á escala metropolitana, o eixo Santo Cristo-Catumbi-Laranjeiras e o Viaduto Perimetra1, que 1iga o sistema periférico do Aterro do Flamengo á AV. Brasil e possui um acesso e uma salda na Praça Mauá.

o perfil fundiàrio que a área apresenta, ou seja, a tipologia dos terrenos e seus proprietarios, è um dos maiores inibidores de desenvolvimento. Evidente que nas àreas residenciais, por sua formação histórica, o perfil delineia-se em sua maioria como pequenos e estreitos lotes, de uma mirtade de proprietários. Os dados relativos á Região Administrativa Portuária, indicam que em 1980, de um total de 12.177 domicilios registrados na àrea, 58,6\% eram alugados, fato que inverte o 
perfil tipico médio encontrado na cidade (Tab. 2). Sem dúvidas, isto concorda com o perfil sócio-econômico tipico encontrado e com as próprias condicôes de evolucăo da àrea, principalmente relativo aos bairros residenciais dos morros, e mostra a fragilidade da populaçăo residente á eventuais programas de intervenção inconsequentes.

Jà na maioria das àreas planas e oriundas das grandes obras de aterro e construcaao do porto no inicio do século são consideradas "terreno de marinha", cujo dominio pode ser direto (Uniăo) ou indireto (contratos de aforamento) (Fig. 52). Muitas săo as àreas cujos proprietários possuem cartas de aforamento. Mas um facilitador para a intervenção na área, è um decreto presidencial recentemente publicado (decreto 97.101 de 06/12/88) que estabelece procedimentos para a execucăo de programa de "desimobilizaçao" de bens das empresas públicas e sociedades de economia mista, como a CDRJ. A partir deste decreto, os imóveis considerados não vinculados ás atividades operacionais do porto, ou seja, aqueles sub-utilizados, podem ser alienados para outros proprietários e usos que não portuários.

Isto è importante quando se verifica que a maioria das propriedades na área de interesse direto para intervenção săo de porte e a maioria dos maiores proprietários são governamentais. Esta àrea de estudo, que se aproxima dos 1,85 km2 està composta assim de grandes proprietários, o maior sendo a CDRJ seguido da RFFSA, com respectivamente $443.793 \mathrm{~m} 2(24,1 \%)$ e $289.487 \mathrm{~m} 2$ $(15,7 \%)$ da área total (Tab. 3). Estes guardam ampla margem em relacão ao terceiro maior proprietario, a União, com apenas $57.557 \mathrm{~m} 2(3,1 \%)$ da àrea. 
Tab. 2: Domicílios particulares segundo condição de ocupação por Região Administrativa (R.A.). 1980.

\begin{tabular}{|l|rrrrrrr|}
\hline \multicolumn{1}{|c|}{ R.A. } & Proprio & A.7ugado & Cedido & Outros & Total \\
\hline I. Portuaria & 4.205 & 7.130 & 513 & 329 & 12.117 \\
\hline II. Centro & 5.701 & 13.437 & 749 & 131 & 20.018 \\
\hline IV. Botafogo & 41.570 & 33.421 & 4.808 & 432 & 80.231 \\
\hline V. Copacabana & 39.431 & 30.326 & 5.748 & 386 & 75.891 \\
\hline VI. Lagoa & 36.073 & 17.294 & 5.394 & 342 & 59.103 \\
\hline XII. Meier & 60.197 & 38.631 & 5.989 & 871 & 105.688 \\
\hline XV. Madureira & 33.131 & 32.301 & 5.762 & 752 & 71.946 \\
\hline XVI. Jacarepagua & 47.565 & 20.511 & 6.261 & 1.845 & 76.182 \\
\hline XXIV. Barra & 6.726 & 2.117 & 2.139 & 404 & 11.386 \\
\hline TOTAL & 737.738 & 449.624 & 89.6523 & 24.119 & 1.301 .104 \\
\hline
\end{tabular}

(Fonte: IBGE/IPLAN-Rio)

Tab. 3: Os maiores proprietários na Área de Estudo.

\begin{tabular}{|lccc|}
\hline \multicolumn{1}{|c}{ Proprietario } & $\begin{array}{c}\text { area (m2) } \\
\text { aproximada }\end{array}$ & $\%$ do tota \\
\hline 1. Companhia Docas do R.J. & 443.793 & $24,1 \%$ \\
\hline 2. Rede Ferroviaria Federal & 289.487 & $15,7 \%$ \\
\hline 3. Uniao & 57.557 & $3,1 \%$ \\
\hline 4. INAMPS & 29.340 & $1,6 \%$ \\
\hline 5. CIBRAZEM & 29.075 & 1,6 \\
\hline 6. ESSO & 28.193 & $1,5 \%$ \\
\hline 7. CODERTE & 27.015 & $1,5 \%$ \\
\hline 8. Moinho Fluminense & 19.396 & $1,1 \%$ \\
\hline 9. Municipio do R.J. & 13.286 & $0,7 \%$ \\
\hline
\end{tabular}




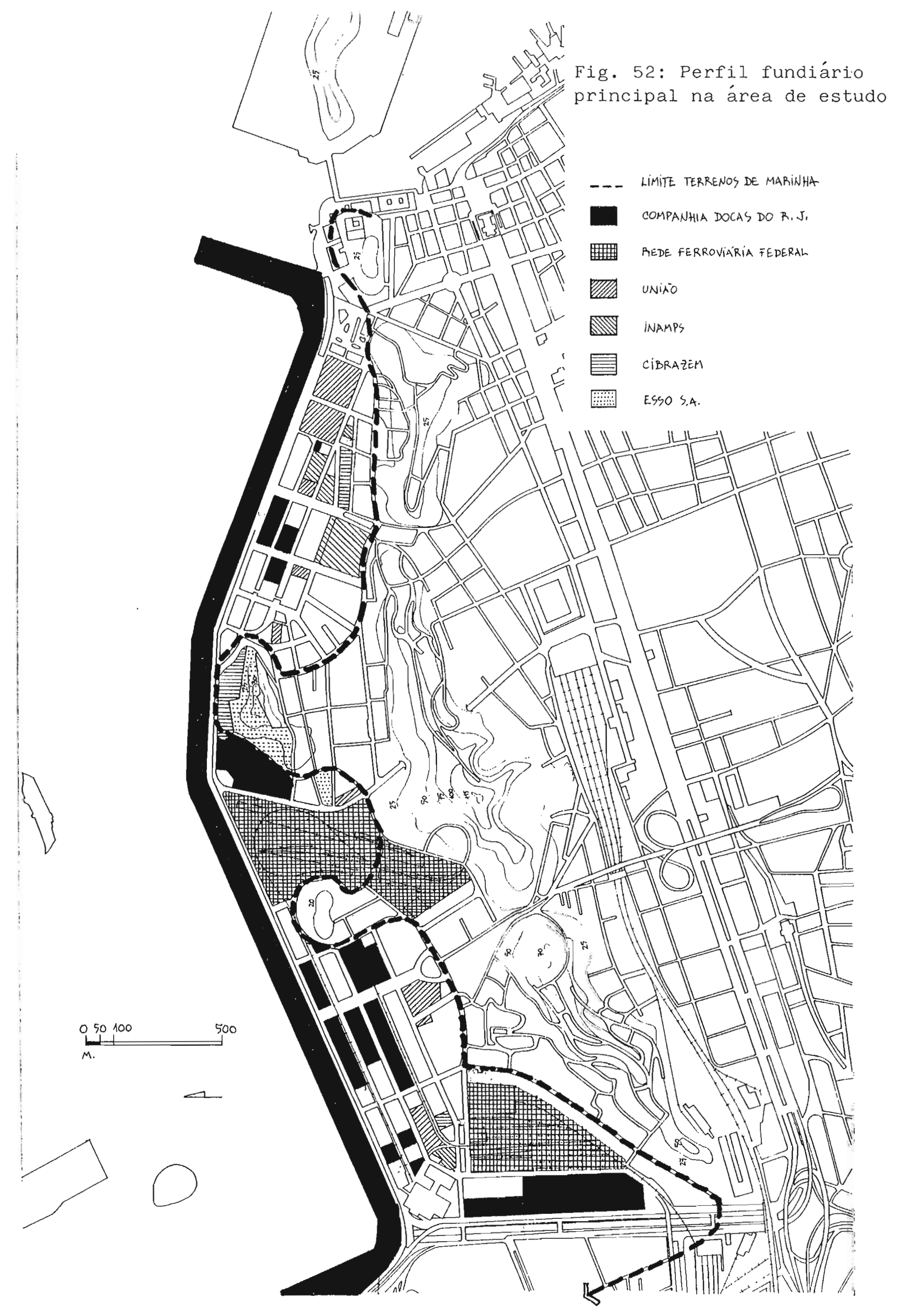


Em termos do estado de conservação dos imóveis da àrea são inủmeras as àreas e edificaços sub-utilizados, vazios e abandonados ou em precário estado de conservação, conferindo á àrea de estudo uma impressão de abandono (Fig. 53). Os estudos da RIO-PART (1983) indicavam um total de $77.500 \mathrm{~m} 2$ de terrenos e armazens abandonados e ociosos; destaca-se af o terreno do antigo Moinho Inglês, junto à AV. Rodrigues Alves, com $42.000 \mathrm{~m} 2$. A estes somem-se os imóveis e àreas pertencentes á órgãos pủblicos que encontram-se em evidente estado de sub-utilização de seu potencia1, principalmente por alterąões nas funçoes originais que Thes deram origem, como è o caso dos pátios ferroviários de Marttima e da Praia Formosa e de diversos armazéns originalmente dedicados á funções portuàrias, como o Armazèm Frigortfico, hoje largamente desativado, e outros. Alguns dos armazéns de segunda linha servem, inclusive, de depósitos "provisorios" emprestados a terceiros, como è o caso de alguns cedidos á escolas de samba para a guarda de alegorias utilizadas durante os desfiles de carnava1 (Fig. 54 a 56 ).

Segundo maior proprietário na àrea, com $15,7 \%$ do total, a RFFSA controla dois pátios ferroviários de porte, citados acima, e diversas faixas de dominio, muitas já desativadas. O potencial de transformação destas àreas è imenso e de grande importância por situarem-se em locais estratégicos no tecido urbano, tanto em termos de localizacão, quanto em termos de capacitar maior acessibilidade (vide Fig. 52).

Note-se que muitos dos imóveis em mau estado pertencem aos grandes proprietários, principalmente a órgãos governamentais. Esta situacão è sintomática de nosso poder público, que prefere 


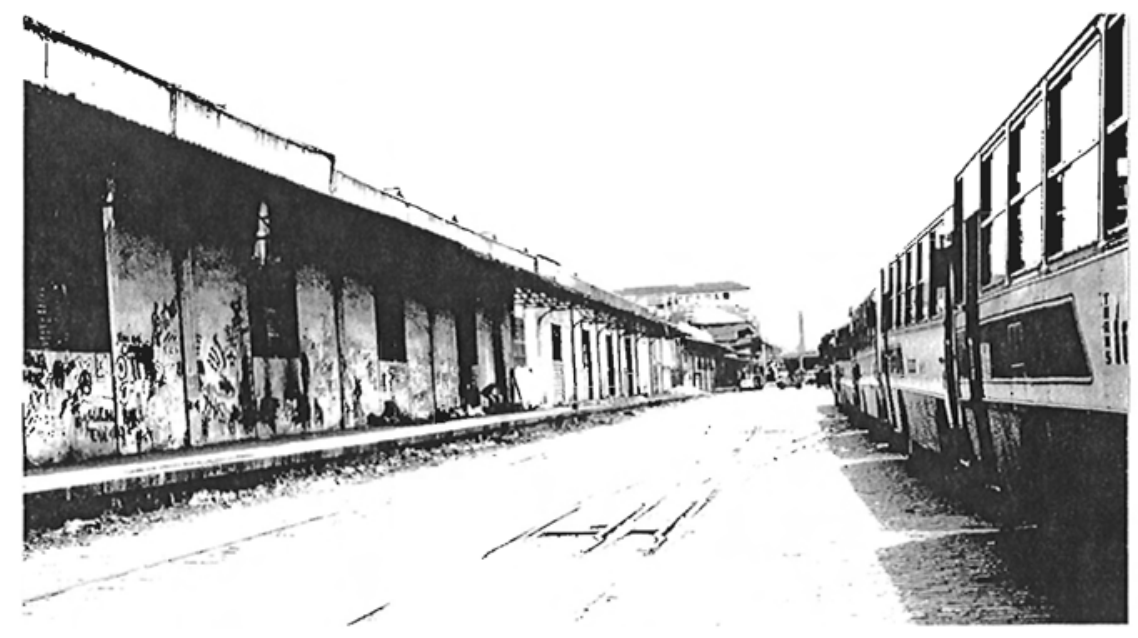

Fig. 54: Imóveis abandonados e mau conservados, a rua como estacionamento de ônibus, o leito da RFFSA inutilizado. Um dos aspectos da Área de Estudo no Santo Cristo.

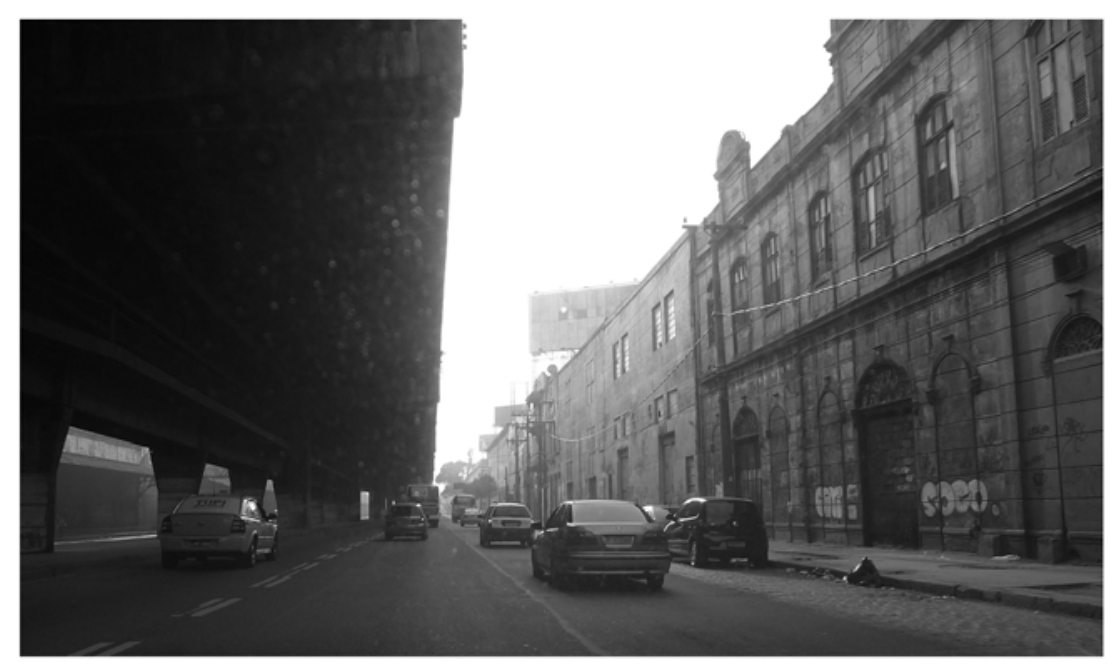

Fig. 55: Imóvel abandonado na Av. Rodrigues Alves; o trecho escurecido em cima da foto é o Viaduto Perimetral.

Fig. 56: Aspecto do pátio da RFFSA e sua baixa utilização.

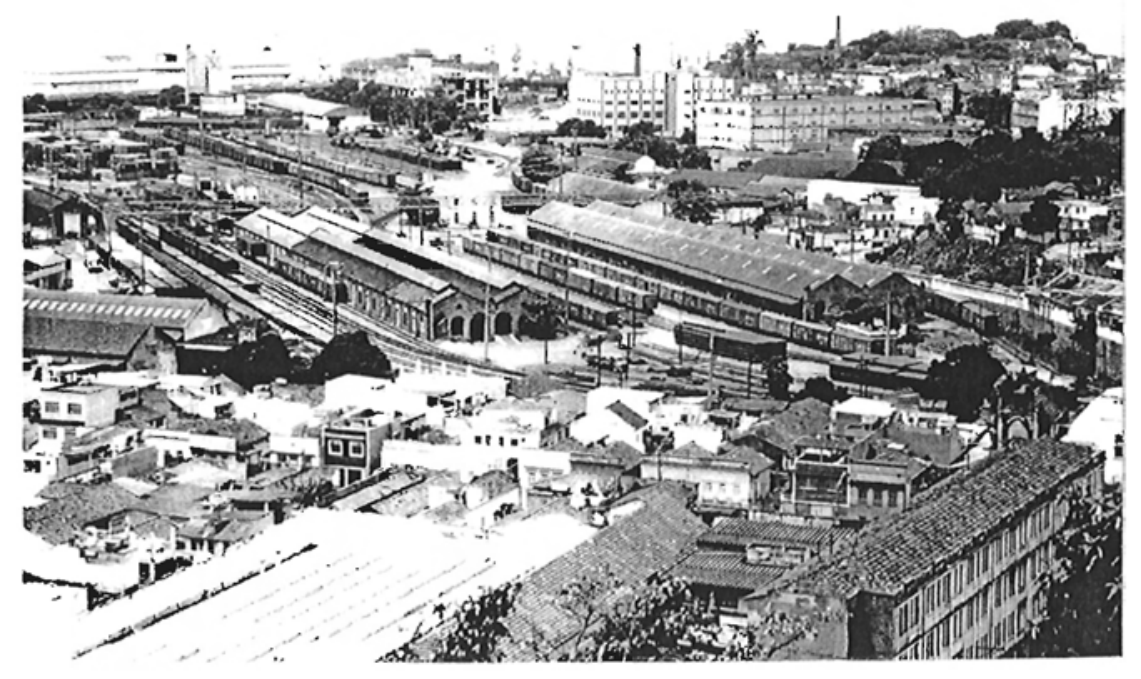


manter no que chama de "reservas técnicas" imóveis para os quais não possui utilizacão prevista, e que tampouco investe em sua conservacão. Evidentemente, esta situacão está 1igada a uma complexa queståo pol1tica, em que por um lado as administracões não compreendem o verdadeiro significado de patrimônio pủblico, e pelo outro compreendem como "perda de poder" ceder propriedades sob o seu controle para outros usos ou outros órgãos.

Apresentamos na Fig. 57 uma aproximação composta com estes fatores de sub-utilizaçăo e estado de conservaça; uma imagem bastante fiel da situaça $10 c a 1$ e seu potencial.

\section{2. Caractertsticas Populacionais e Sociais:}

Os aspectos populacionais e sociais referentes á nossa àrea de interesse mostram-se como de diflcil anàlise pois apresentamse agrupados segundo unidades de planejamento, cujas definiç̃es variam segundo o órgão. Assim por exemp1o, existem territórios como Regiós Administrativas, Unidade Espacial de Planejamento, Area de Planejamento, Divisôes de Licenciamento e Fiscalizaçăo, Setores de Educaçăo, etc. E mais, os órgăos nem sempre adotam as mesmas fronteiras para os bairros. Portanto, agrupar e compatibilizar os dados nem sempre è tarefa fácil.

Além disto, também existem significativas discordancias de dados entre as fontes, ou, ás vezes, de uma mesma fonte! Tentamos, no entanto, apresentar os dados mais confiáveis e com o menor número possivel de extrapolações para a presente caracterizaçăo. Lembramos, a este respeito, que a unidade I\& Região Administrativa, utilizada por diversas fontes, inclui alem de nossa área de estudo, parte do Centro e do bairro do Cajú. 


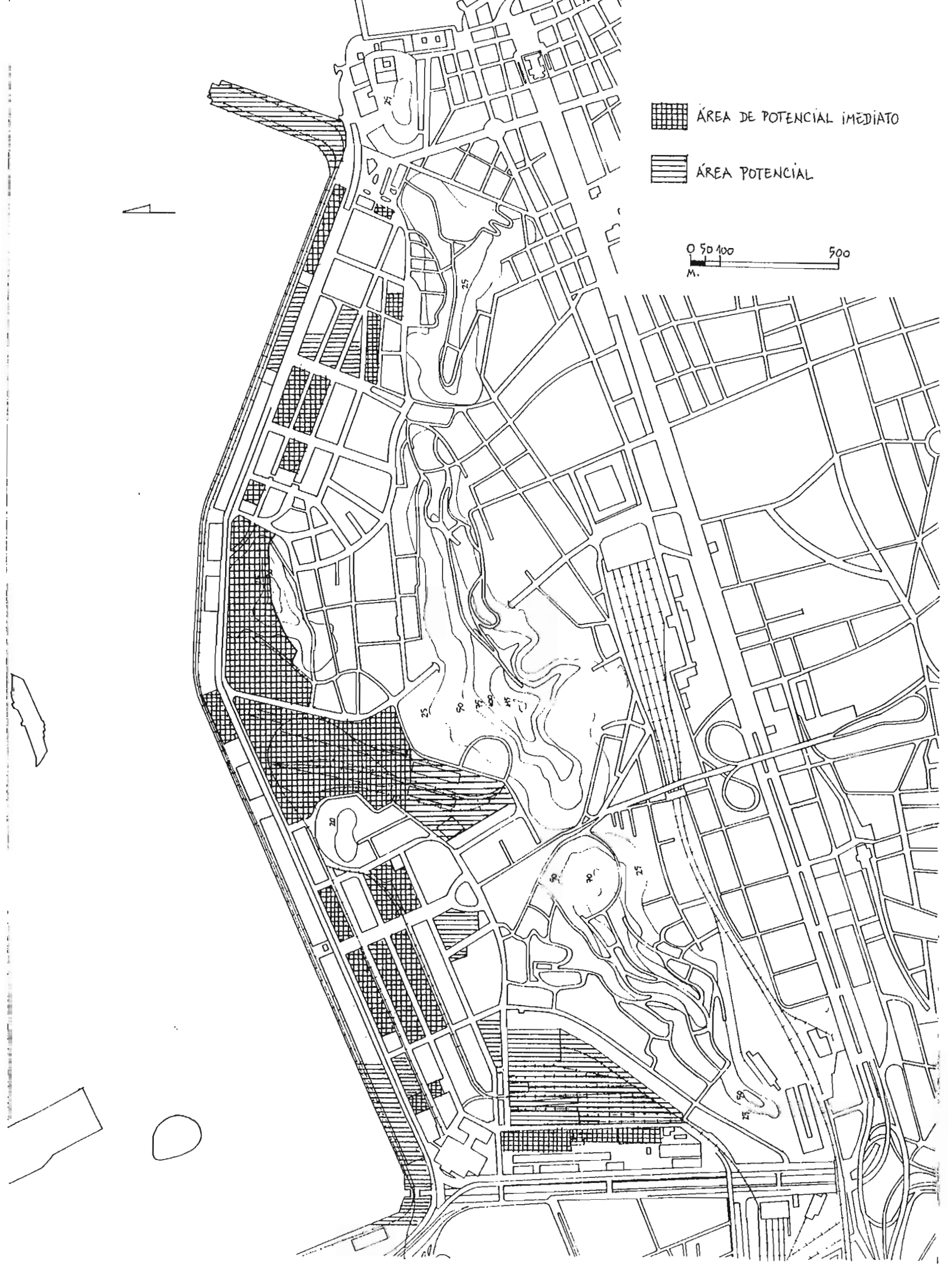


Embora a grande maioria da populaça da Area Portuária a que nos referimos resida ás margens do território definido pelos grupos de interesse como passivel de uma intervencăo direta, como veremos adiante, è evidente que o conhecimento de suas caracteristicas é primordial para nossa atuacão. Isto porque, como jà afirmamos antes, uma intervenção para revitalizaça da àrea, integrada ás potencialidades e aspectos sociais locais, deverá reconhecer as interelações politicas e econômicas com esta população, respondendo ás suas necessidades.

A taxa geométrica de crescimento anual da populaça da Ia RA foi de - 1,02, segundo os dados dos censos de 70 e 80 , de 51.052 para 46.113, mostrando um decrescimo significativo da populacão residente. Pela Tabela 4, podemos verificar que esta diminuiçåo reflete certamente uma problemática 1oca1, comparandose os dados de outras RAs do Municlpio que registrou uma taxa de crescimento de $1,8 \%$. A I \& RA apresenta decréscimo populacional semelhante a outras àreas como o Centro e Copacabana, enquanto o municipio como um todo mostra acréscimo populacional significativo, principalmente em suas áreas mais dinâmicas como os subúrbios do Méer e Madureira, ou as àreas novas de expansăo em Jacarepaguá e Barra da Tijuca. Podemos utilizar este raciocinio para trabalhar projeçoses dos dados dos bairros de nossa área de estudo, extrapolados a partir de dados agrupados pe 10 IPLAN-RIO para 1980 (Tab. 5).

Seguindo a mesma 1ógica, a Tabela 6 nos mostra estimativas para o perlodo $1980 / 88$ em que a população favelada da àrea apresentou incremento insignificante nos ủitimos anos (não existem dados sobre a populaçăo favelada na área em 1970). A 
variacăo $1980 / 88$ foi apontada tomando por base o número de novos domictlios registrados através das 1 igaçoóes novas de eletricidade no pertodo. Isto faz sentido, uma vez que as favelas existentes na àrea são de encosta, bastante antigas e extremamente densas.

Todo este perfil populaciona 1 é, sem dủvida, decorrente de quatro fatores principais, a saber:

- inibicão do uso residencial pela legislaçăo de zoneamento em trechos da Area Portuária;

- impossibilidade de adensamento nas áreas controladas por regulamentaçôses de preservaçă

- complexa situaçăo fundiária em lotes pequenos e problemas de sucessão e/ou propriedade;

-. inibicões causadas pela própria indefinicăo governamental quanto a suas politicas para a àrea (conhecido por "planning b1ight") e fatores inerciais de inibicão da entrada de outros grupos de renda.

Entretanto, è interessante verificar através da Tabe1a 7 , que embora a população total da I\& RA tenha sofrido decrèscimo no periodo 1970/80, a População Econômicamente Ativa (PEA) registrada aumentou de 19.618 para 20.167 , com o maior aumento para o setor Terciário, o mais expressivo na àrea. Os outros apresentados, relativos a distribuicăo de faixas etàrias, renda média e educaçăo, apresentados nas Tabelas 8 e 9 , nos indicam que nossa populaçăo não se difere da média municipal e naciona1.

As Tabelas 2 e 10, respectivamente de condicốes de ocupaçăo dos imóveis na I\& Região Administrativa e de distribuiçăo de renda, săo fortes indicativos sociais do nivel da 
Tab. 4: Pópulação por principais Regiões Administrativas (R.A.) incluida a Portuária; $1970 / 1990$.

\begin{tabular}{|c|c|c|c|c|}
\hline R.A. & 1970 & 1980 & 1990 & $\operatorname{taxa}$ \\
\hline I. Portuaria & 51.052 & 46.113 & 41.652 & -1.02 \\
\hline II. Centro & 59.457 & 55.108 & 51.077 & -0.76 \\
\hline IV. Botafogo & 256.250 & 267.760 & 279.787 & $0 . \overline{44}$ \\
\hline V. Copacabana & 239.256 & 228.252 & 217.754 & -0.47 \\
\hline VI. Lagoa & 175.586 & 216.352 & 266.583 & 2.11 \\
\hline XII. Meier & 364.796 & $411.6 \overline{41}$ & 464.502 & 1.22 \\
\hline XV. Madureira & 267.321 & 277.353 & 287.761 & 0.37 \\
\hline XVI. Jacarepagua & 216.748 & 326.594 & 492.109 & 4.19 \\
\hline XXIV. Barra & 24.269 & 50.061 & 103.264 & 7.51 \\
\hline TOTAL MUNICIPIO & 4.251 .918 & 5.090 .700 & 6.094 .950 & 1.8 \\
\hline
\end{tabular}

Fonte: IBGE (censos 1970/80); IPLANRIO (estimativas c/projecao da taxa geometrica anual de crescimento)

Tab. 5: Projeções da população na Área Portuária por bairros.

\begin{tabular}{|l|r:c|c|}
\hline & 1970 & 1980 & 1990 \\
\cline { 2 - 4 } & 3.357 & 3.323 & 3.289 \\
\hline Saude & 18.763 & 18.572 & 18.383 \\
\hline Santo Cristo & 13.739 & 13.599 & 13.460 \\
\hline TOTAL & 35.859 & 35.494 & 35.132 \\
\hline
\end{tabular}

Fonte: IBGE (censo 80); projecao da taxa geometrica anual de crescimento $(-1.02 \%)$

Tab. 6: Projeções da população favelada na Área Portuária.

\begin{tabular}{|l|rrrrr|}
\hline fave la & 1980 & domicilios & 1988 & domicilios \\
\cline { 2 - 5 } & & 4.720 & 1.120 & 4.720 & 1.120 \\
\hline Morro da Providencia Lisa & 1.057 & 256 & 1.057 & 256 \\
\hline Moreira Pinto & 175 & 40 & 258 & 59 \\
\hline TOTAL & 5.952 & 1.416 & 6.035 & 1.435 \\
\hline
\end{tabular}

Fonte: IBGE (censo 80); Projecoes IPLAN-Rio/LIGHT. 
Tab. 7: População Economicamente Ativa (PEA) da I Q Região Administrativa. 1970/80.

\begin{tabular}{|l|c|ccccc|}
\hline 1970 & populacao & PEA & primario & secundario & terciario \\
\hline 191.052 & 19.618 & 533 & 4.543 & 14.542 \\
\hline 1980 & 46.113 & 20.167 & 405 & 4.573 & 15.189 \\
\hline
\end{tabular}

Tab. 8: População por Idade e Sexo na Io Região Administrativa.

\begin{tabular}{|l|c|ccc|c:cccc|}
\cline { 2 - 9 } \multicolumn{1}{c|}{} & 0 a 14 & 15 a 20 & 21 a 30 & 31 a 40 & 41 a 50 & +50 & TOTAL \\
\hline $\mathrm{H}$ & 5.932 & 2.371 & 5.350 & 3.520 & 2.665 & 3.954 & 23.792 \\
\hline $\mathrm{M}$ & 5.617 & 2.107 & 4.530 & 3.011 & 2.644 & 4.679 & 22.588 \\
\hline $\mathrm{T}$ & 11.549 & 4.478 & 9.880 & 6.531 & 5.309 & 8.633 & 46.380 \\
\hline
\end{tabular}

Tab. 9: Escolaridade da População da Io Região Administrativa; 1980.

\begin{tabular}{|c:c:c:c:c|}
\hline Elementar & 10. Grau & 20. Grau & Superior & Total \\
\hline 15.531 & 6.181 & 3.385 & 536 & 25.633 \\
\hline
\end{tabular}

Tab. 10: Rendimento Médio Mensal em Salários Mínimos da População da I a Região Administrativa; 1980

\begin{tabular}{|c|c|c|c|c|c|c|}
\hline 0 & $\overline{\text { ate }} 1 \mathrm{SM}$ & +1 a 2 & +2 a 5 & +5 a 10 & +10 a 20 & 20 \\
\hline 13.069 & 4.372 & 9.209 & 8.431 & 2.343 & 467 & 60 \\
\hline
\end{tabular}

Fonte: IBGE (censo 1980)/IPLAN-Rio 
populaçăo residente. Em 1980, por exemplo, identificou-se um total de 7.130 imóveis alugados, contra apenas 4.205 imóveis próprios, enquanto a média da cidade invertia esta proporçăo. Evidentemente, esta populaçáo inquilina será a mais propensa a receber impactos negativos gerados por eventuais intervencões urbanas que possam vir a gerar uma valorizacăo da àrea e consequentes pressões no mercado para aumento dos alugueis. A populaçăo favelada, que chegava a quase 6.000 pessoas em 1980 , deverà também sofrer este tipo de impacto, embora em proporçôs bem menores do que as áreas mais "formais" do tecido urbano.

Em termos de equipamentos urbanos para o atendimento da populacão Tocal, a área apresenta diversas carências que, no entanto, săo relativamente fáceis de resolucão pelo Poder Publico. O ensino de 1'Grau, por exemplo, apresenta otima relacão espacial com as comunidades a que serve e tambèm è boa a situacão em termos quantitativos (Fig. 58). Estudos realizados pela PLANAVE (1986, 1988) consideravam, por exemplo, que na Area de Planejamento 1 (AP-1, sub-divisão do municipio que engloba a Area Portuária) a populacăo escolarizável de 10 grau seria de 34.122 pessoas, enquanto o total matriculado è 37.252 alunos, revelando um superavit de ofertas.

Realmente, durante nossas entrevistas com as associacões de moradores e pessoas 1 igadas aos movimentos de bairro, não foram expressadas queixas quanto ao atendimento escolar de 10 Grau, mas sim quanto ao de 2' Grau e falta de opcões de ensino profissionalizante e supletivo. Segundo os mesmos estudos da PLANAVE (1988), calculava-se um deficit de 243 vagas de 2' Grau para a populacăo da Ia Regiăo Administrativa. 
Também pode-se dizer que a populacăo local possui um bom atendimento médico pois existem na área dois hospitais com servicos de ambulatório, assim como pode-se utilizar o Hospital Souza Aguiar, nas imediacões, um dos mais completos centros de atendimento municipal. No entanto, um equipamento social instalado na Praca da Harmonia, na Saúde, que foi unanimemente censurado pelos entrevistados é o albergue administrado pela Fundacăo Leão XIII, devido á alta concentraçăo de mendigos e indigentes que atrai para a distribuicăo de comida e abrigo noturno.

Finalmente, devemos comentar a situacão local em relacão a equipamentos e possibilidades de lazer recreativo e cultura1. Neste sentido a área é muito carente e quanto a esta temática todos os entrevistados se manifestaram negativamente. o maior equipamento de lazer de toda a Area Portuária é um parque situado no topo do Morro do Pinto, no santo cristo, uma iniciativa municipal do intcio dos anos 80 (Fig. 58). Com dimensões e localizacão que garantem a preservacão do topo do morro, o parque possui excelente desenho e arborizacão, sendo equipado com três quadras poliesportivas, iluminacăo e mobiliário. Entretanto, seu acesso é diflcit para a populacão de outras áreas e, hoje, encontra-se sub-utilizado apresentando sèrios problemas de manutencão e de invasão por grupos de contravenção.

o restante do território estudado năo possui equipamentos de lazer, excetuando-se as pracas municipais, como a antiga Praca da Harmonia e a do Santo Cristo, que não possuem dimensões suficientes e nem estão equipadas para um correto atendimento. Uma das tentativas municipais de suprir estes espacos è a 


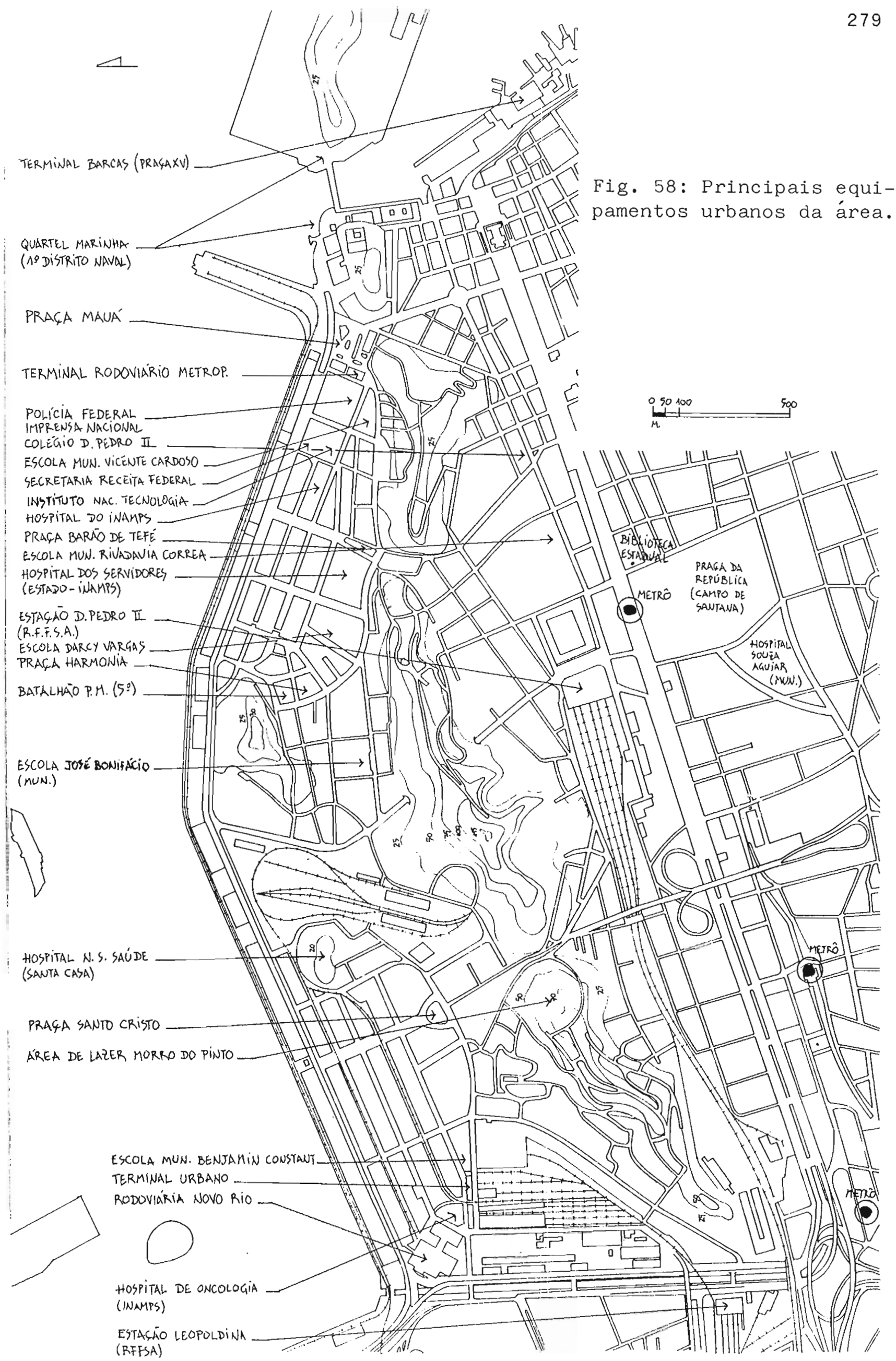


pedestrianizacão de trecho da Rua Sacadura Cabral aos domingos, que è ocupada de forma bastante intensa pela populacão. A comunidade do Morro da Conceicăo, por exemplo, havia conquistado uma área non-edificandi no morro, para lazer, mas que no entanto foi apropriada para uso como quadra de futebol do quartel do Exército lá situado (Servico Geográfico) e é, 1argamente subut i 1 izada.

Hà grande carência de lazer cultural, que é parcialmente suprido por dois centros culturais, um localizado em antigo armazém reciclado junto á praca do santo cristo, outro na antiga escola Darcy Vargas, na saude, onde instalou-se também a associacão de moradores do bairro e o escritório técnico do Projeto SAGAS, como veremos adiante.

VII. 3. Condicionantes de Legislacăo Urbanistica:

Dos condicionantes legais que se expressam em nossa àrea, aqueles que mais dizem respeito a seu potencial e caracteristicas de desenvolvimento são o zoneamento e as normas relativas ao patrimônio histórico e bens tombados. No Rio de Janeiro o Zoneamento era, com raras excessóes, definido em forma de decreto-lej pelo Executivo até recentemente, com a promulgação da Lei Orgânica no inicio de 1990, que levou esta prerrogativa de volta ao Legislativo Municipal. Além disto, o Executivo ainda fixa, em paralelo ao zoneamento, os chamados Projetos de Alinhamento (PA) dos logradouros, que determinam as faixas de dominio, recuos e gabaritos; estes PA prevalecem sobre o zonamento decretado. Comentários detalhados a respeito desta questão fogem de nossos objetivos principais, mas è importante 
atentarmos para a natureza e de evolucão da legislação urbanistica incidente em nossa àrea de estudo para a melhor compreensăo da situaçăo atual (Fig. 59).

No caso da Area Portuária, o decreto 322 de 1976 estabelecia a adequabilidade e intensidade de usos, bem como o tipo, as condições e os gabaritos das edificações. Este decreto definia para a àrea uma Zona Portuária (ZP), Areas Centrais ( $A C$ ) tipo 1 e 2, Zona Residencial (ZR) 5, e dois centros de Bairro (CB) tipos 2 e 3. Dentre as diversas diretrizes, destacamos que a ZR-5 è uma das zonas residenciais menos restritivas da tipologia municipal, possibilitanto grande incidência de atividades terciảrias e secundảrias. Além disto, na ZP o uso residencial, embora tolerado, era na prática bastante desestimulado pelas condiçôes de edificação; as atividades permitidas na ZP aproximam-na á uma zona industrial, excluidos os usos industriais pesados. Os Centros de Bairro possibilitam ocupaça mais intensa do solo e usos mais voltados para o setor secundario e terciário.

o decreto 322 ainda representa um dos maiores inibidores de desenvolvimento na Area Portuária, principalmente aquele relativo a usos residenciais. A ele foi sobreposto outro decreto, em 1978, de protecão ambiental para as partes de encosta apenas. Entretanto, como apenas atentava para a volumetria das edificaçôes, năo impedia a descaracterização cultural e social dos bairros; era posslvel a substituicăo do uso residencial por outros, nem que imóveis de valor cultural fossem destruldos.

A partir da preocupação manifestada por setores da população, comunidades locais e órgãos governamentais como o Instituto Municipal de Arte e Cultura, a Diretoria de Patrimônio 
Cultural da Secretaria Municipal de Educaçăo e cultura, e o SPHAN, em 1983 foi formado um grupo de trabalho com representantes de todos estes setores, para desenvolvimento de estudos do inventário dos bens culturais existentes e proposta de nova regulamentação urbanistica. Denominado Projeto SAGAS (Santo Cristo, Gamboa e Saúde), este relatório veio apoiar a promulgaça de um decreto em novembro de 1985 regulamentando a ocupação da área com fins de proteçăo ambiental. Em maio de 1987 foi promulgada uma Lei Municipal definindo-a como de protecăo ambienta1, tendo sido regulamentada e detalhada por novo decreto do executivo em janeiro de 1988 (Fig. 59).

Atualmente, o decreto vigente redefine as zonas mencionadas anteriormente e acrescenta uma outra Zona Residencia1, a ZR-3. Dentre as diversas normas detalhadas para preservaçăo ambiental, - uso residencial é tornado adequado para toda a àrea, diversos dos antigos Projetos de Alinhamento modernistas existentes foram revogados e as novas construções passaram a ter de obedecer os alinhamentos tradicionais. As alturas das edificaçoes foram definidas rua por rua com altura máxima de 11,00 metros, e quatro sub-àreas especificas de proteçăo ambiental foram definidas. Nestas ảreas (Morros da Conceicão e Saủde, e rua Barão de São Felix), proibiu-se modificaços de fachadas e obras de transformação de uso; as novas construções agora devem ser submetidas ao servico de patrimônio municipal.

Em fins de 1989, a Prefeitura instituiu o Escritório Técnico do Projeto SAGAS, localizado em uma antiga escola municipal no bairro da Saúde, cujo coordenador além de ser funcionário municipal, foi presidente da associaça de moradores 
deste bairro, e que conta ainda com dois arquitetos. Com isto objetiva-se um trabalho conjunto com a comunidade e uma maior dinamização e efetividade do contrôle do desenvolvimento na área. As regulamentações municipais de uso e ocupação do solo atualmente incidente sobre os bairros da Saúde, Santo cristo e Gamboa, decorrentes destes decretos, visam nitidamente a preservacăo das caracterlsticas históricas e culturais da àrea, buscando também a atenuaçăo dos impactos sociais das transformaçôs posstveis.

Enquanto isto a SPHAN desenvolvia e aprovava projeto de proteção de entornos de bens tombados, defindo quatro àreas em torno a pólos, um dos quais engloba o Morro da Conceicão, na Area Portuária. Entendiam seus técnicos que esta era "provavelmente, a ultima área que ainda guarda caracteristicas da espontaneidae de sua ocupaçăo iniciada no século XVII... ( )... manteve-se, de certa forma, imune á especulação imobiliária" (ARNAUT 1984: 98).

A àrea que encontra-se na Area Portuária, denominada "A" pelo SPHAN, definiu-se a partir dos polos compostos pelo conjunto arquitetónico do Morro da Conceiça: observatório e jardins do Valongo, Igreja Nossa Senhora da Prainha, Palảcio Episcopal e Fortaleza da conceicão. As demais áreas e seus respectivos pólos, encontram-se mais próximos á Avenida Presidente Vargas (Fig. 60). Assim, a atuação da Prefeitura e do patrimônio federa1 complementam-se e fortalecem-se na proteça das caracteristicas morfológicas e tipológicas do Morro da conceicăo. Quanto á preservação do patrimônio histórico-arquitetônico através da figura do tombamento, um instrumento mais radical e de carater pontua1, a Area Portuária e os bairros limitrofes possuem 
diversos imóveis tombados a niveis federal (secretaria de Patrimônio Histórico e Artistico Naciona1-SPHAN), estadual (Secretaria de Estado de Educaqåo e Cultura/Instituto Estadual de Patrimônio Cultura1- INEPAC) e municipal (Conselho Municipal de Patrimônio Cultural/ Secretaria Municipal de cultura).

Os imóveis tombados por estas várias esferas constituem importantes testemunhos da evolucăo histórico-arquitetônica e, portanto, indiscutivel patrimônio cultural (Fig. 60 e Anexo II). Infelizmente, apenas recentemente esses conceitos de patrimônio cultural ampliaram-se para incluir os valôres não necessariamente ligados á "história oficial", e definidos monumentos por critèrios de gabinete, mas também aqueles relacionados á vivência cotidiana das comunidades, refletindo um pouco das imagens populares dos bairros e da cidade (Fig. 61).

Os próprios trabalhos dos órgãos publicos, principalmente do municipio, que apoiam-se em unidades territoriais chamadas de "bairro", adotam abairramentos estranhos ao repertório e a percepção das comunidades. A Associaça de Moradores da Saúde, por exemplo, reclama que o bairro da Saúde foi sub-dimensionado pela prefeitura e que o chamado bairro da Gamboa năo existiria por falta mesmo de uma comunidade residente, segundo as tradicões aceitas na àrea e, portanto, ás imagens poputares.

Assim, como vimos, o contexto legal resultante para o desenvolvimento urbano é bastante confuso e restritivo. Duas subáreas principais foram geradas, uma que abrange os morros e demais trechos de ocupaça mais antiga, de pequenos proprietários e de tipologias assobradadas; nesta sub-àrea aplica-se uma regulamentação de carảter preservacionista. Outra que abrange 


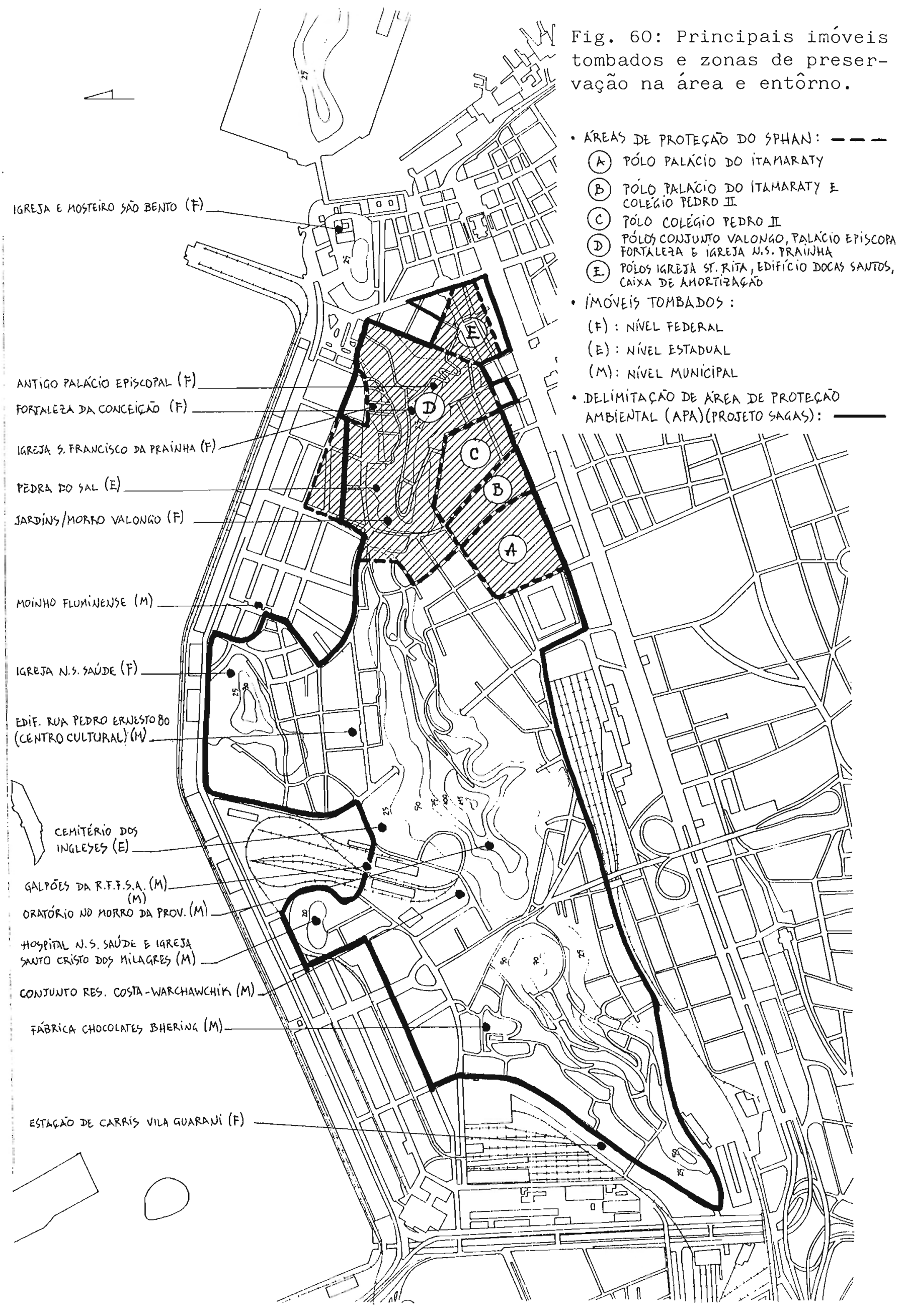




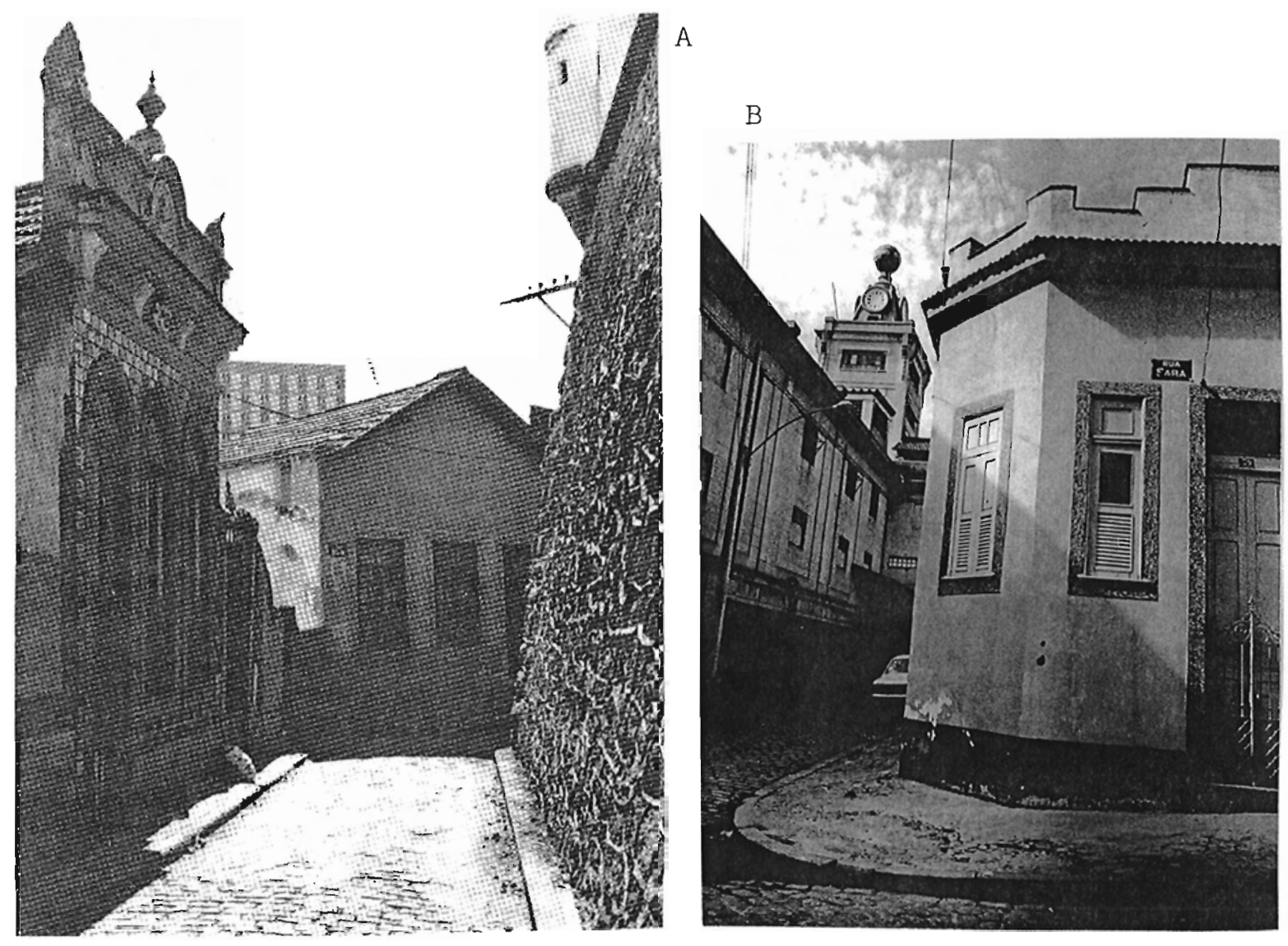

Fig. 61: Detalhe da Rua do Jogo da Bola e fortaleza do Morro da Conceição (proteção SPHAN) (A); aspecto da Rua Sara e Fábrica Bhering, Morro do Pinto (B) e detalhe de prédio do Moinho Fluminense, Saúde (C) (ambos proteção municipal).

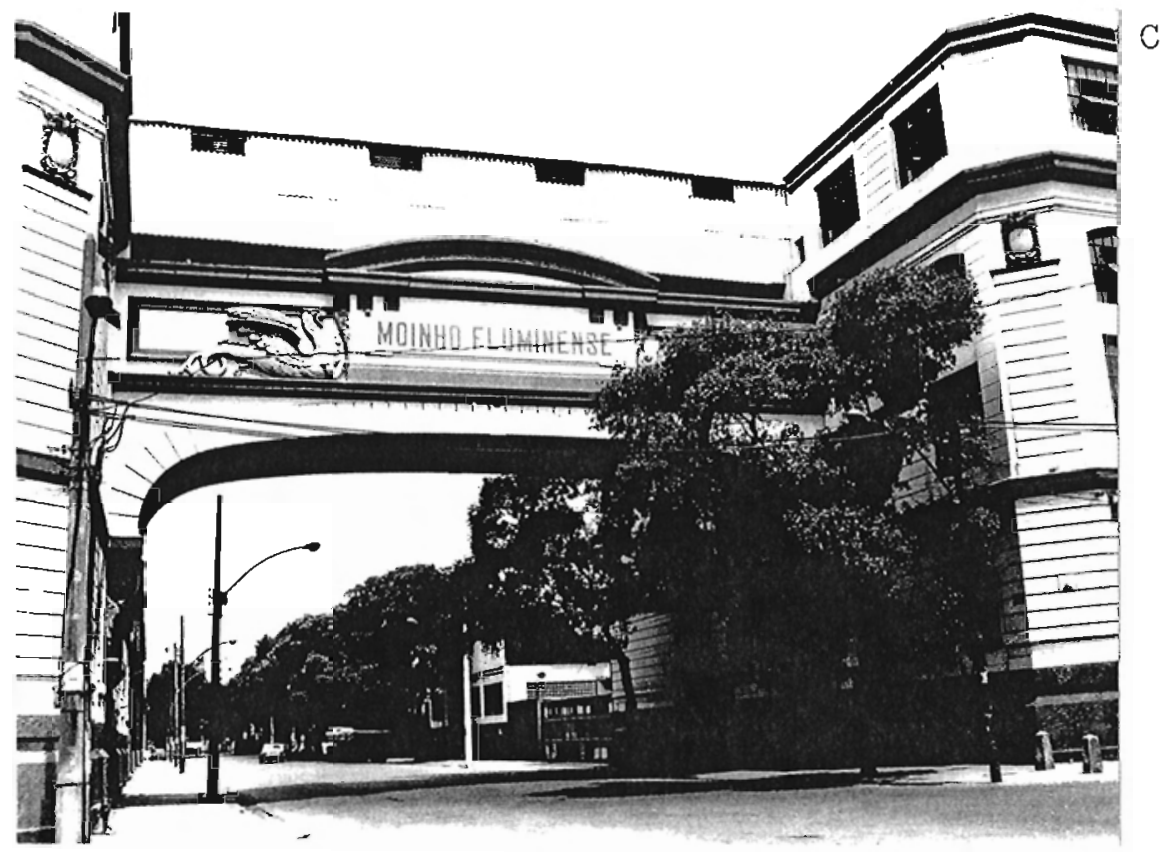


básicamente os trechos planos e resultantes dos antigos aterros promovidos pelo Governo Rodrigues Alves na década de 1900, onde a regulamentaça é direcionada para o uso portuário e de servicos de grande porte, inibindo a funcăo residencial e outras afins.

Se, por um lado a atitude preservacionista tende manter o "status quo" e, principalmente, as estruturas fisicas, embora a dimensão social continue ameaçada pela valorizaça do solo, pelo outro a manutencão da regulamentacăo para usos portuários por si só não garante o drnamismo da área e acaba por gerar decadência ambiental ao inibir a possibilidade de outros usos.

VII. 4. Dinâmica de Desenvolvimento Recente:

Um dos melhores indicadores do dinamismo no desenvolvimento formal de áreas urbanas, é o setor da construçăo civil. Para tanto podemos utilizar-nos de alguns indicadores confiaveis quanto a registros de novas construcões, 1 icenças de obra, projetos aprovados e lançamentos imobiliários.

Infelizmente, existem dificuldades significativas pois o referencial tradiciona1, o IBGE, năo dispõe destes dados especificos. Apresenta, no entanto, o total de domictios registrados para a Area Portuária como um todo que, em 1970 era

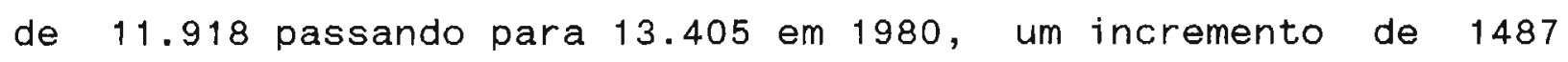
domiclitios. A mesma fonte registrou no perlodo um decréscimo de edificaçôes de 10.573 para 9.478 , indicando um claro processo de adensamento das remanescentes com maior numero de domicilios.

Por outro 1ado, a coleta deste tipo de dados pela prefeitura é feita por distritos de licenciamento e fiscalização 
que, para os nossos propositos, revelam-se totalmente inuteis pois a nossa àrea de estudo é agregada com diversos outros bairros, resultanto em território muito mais amplo.

Portanto, primeiramente, utilizamo-nos dos dados fornecidos pela Pesquisa de Acompanhamento e Análise do Mercado Imobiliàrio do Rio de Janeiro, realizada pelo Instituto de Desenvolvimento Econômico e Gerencial por encomenda da Associaçăo dos Dirigentes e Empresários do Mercado Imobiliário (ADEMI). Estes săo relativos apenas a imóveis novos registrados pelo Departamento de Edificações da Secretaria Municipal de Desenvolvimento Urbano, e năo incluem reformas ou ampliações de imóveis existentes. Săo estes dados que maior se aproximam de um indicador do setor formal imobitiário.

Os dados revelam que no perlodo relativo aos últimos dez anos, de 1980 a 1989, não houve sequer um projeto 1 icenciado ou lançamento imobiliário na área portuária, com excessão do prédio comercial da Joåo Fortes Engenharia situado na Praça Mauá (que serà especificamente comentado no capitulo seguinte). O centro como um todo apresentou também um indice baixissimo de dinamismo formal no setor imobiliário, revelando apenas um total de seis imóveis novos no perfodo, dos quais cinco eram exclusivamente comerciais. De certa forma, estes indices refletem e ampliam, pelas caracteristicas contextuais especificas da àrea, o perfit de desenvolvimento apresentado pela cidade que, de 14.000 lançamentos imoblliários em 1982, registrou apenas 4.000 em 1987; e os 27.0001 icenciamentos de obra viram-se resumidos a 14.000 . Outro tipo de indicador do qual poderlamos nos utilizar, que apresenta um carater mais abrangente e inclui indistintamente 
os setores formal e informa1, são projeções com base no nummero de novas ligaçós de eletricidade registradas pela LIGHT. Em relaçăo aos dados de favelas; para o pertodo 1980/88, jà vimos na Tab. 6 que estimava-se um incremento de apenas 59 domiclitios, todos na favela Moreira Pinto. De qualquer forma, mesmo não podendo considerar os eventuais "gatos" ou ligaç̃es. ilegais, è muito baixo o Indice de ligaçóes revelando um setor favelado pouco dinâmico.

Evidentemente, a dinâmica do setor dito mais informa1 não pode ser corretamente avaliada por dados deste tipo, apenas cabendo exaustivos levantamentos expeditos, o que fugiria totalmente de nosso escopo. Os bairros históricos de encosta, quase que totalmente ocupados, como vimos, por grupos populacionais de renda média-baixa e baixa, e os assentamentos favelados da área, certamente apresentam este tipo de dinâmica, principaimente a referente a reformas internas e pequenas ampliações das unidades.

Entretanto, è verdade também que, em um setor urbano como o estudado, de ótima localizaçăo e acessibilidade em relaça ao Centro e ao resto da cidade, condicôes normais de desenvolvimento fariam com que apresentasse um setor formal tăo dinâmico quanto, ao menos, a média da cidade. 
CAPITULO VIII:

GRUPOS DE INTERESSE E PROPOSTAS PARA A AREA

Finalmente, para completar o quadro de caracterizacăo de nossa àrea de estudo, cabe traçar algumas considerações sobre as pressões socio-pol1ticas que vêm se expressando sobre nossa àrea de estudo, uma vez que elas serão sempre fatôres determinantes nos possiveis perfis de desenvolvimento. Baseamos nossos comentàrios nas publicações existentes, principalmente jornais, em nossos próprios contactos profissionais e de desenvolvimento da pesquisa, além de entrevistas com diversas pessoas envolvidas nesta questão ( $v i d e$ istagem no Anexo I).

As pressões no sentido de renovacăo ou revitalizaçăo da Area Portuária ou de partes dela foram iniciadas a partir de 1982, e já foram propostos vảrios projetos neste sentido, a grande maioria de caráter localizado, que comentaremos adiante e representamos na Fig. 62. Os interesses que se expressam sobre a àrea, quer para sua revitalização, quer para sua preservaçă, podem ser agrupados em torno a três grupos básicos: o setor privado, o setor público e a comunidade.

VIII. 1. 으 Setor Privado:

Representado pelas companhias de caràter privado e associaç̃es delas, cujo interesse principal è o da reprodução 


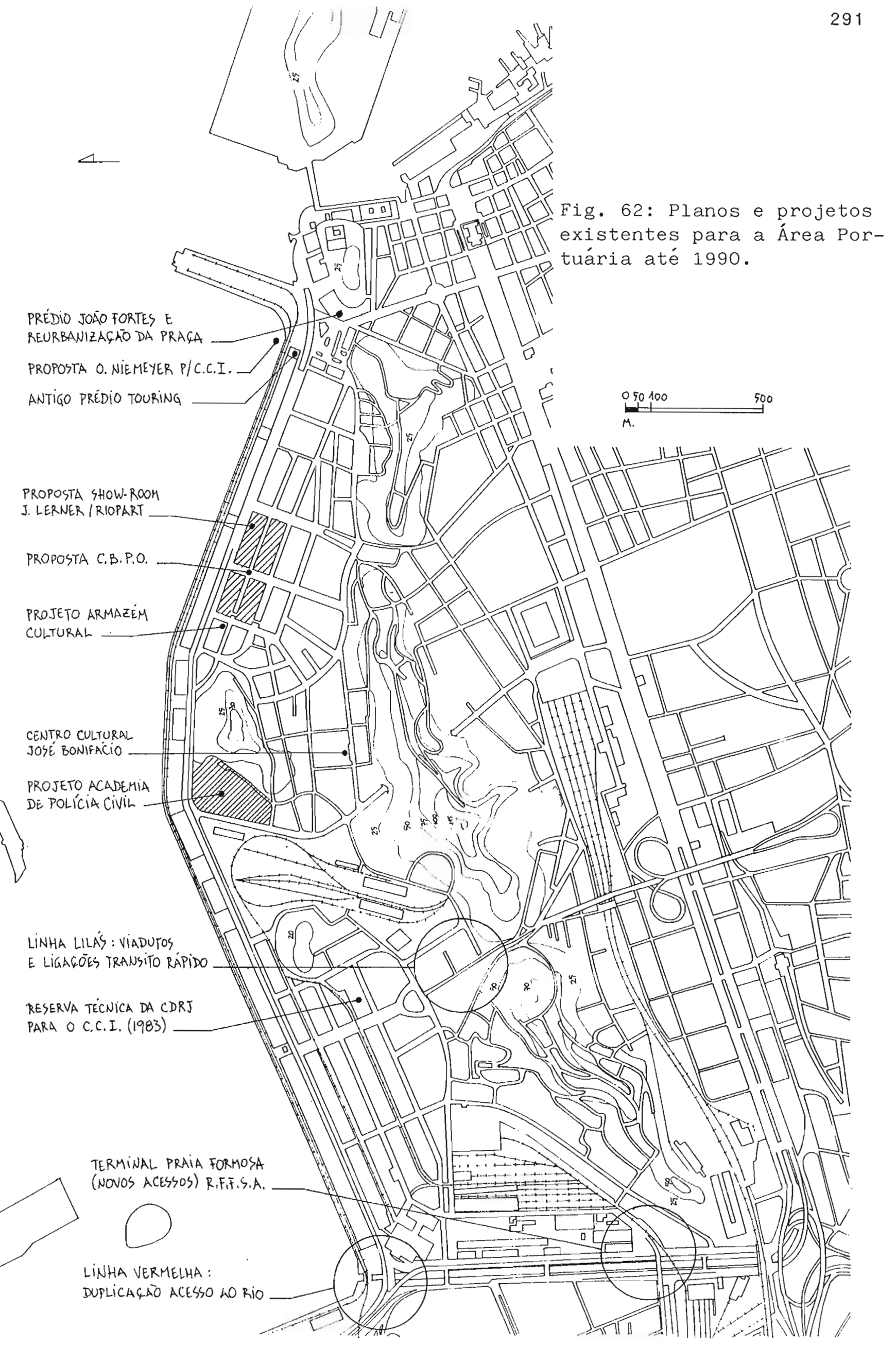


ampliada de seu capital investido. Os interesses neste lucro sobrepassam quaisquer outros interesses sociais ou culturais, que só săo reconhecidos enquanto fortalecem os primeiros. Historicamente, è o grupo mais forte pelo peso politico que alcanca o seu capital, pela agilidade de seus movimentos e por sua capacidade tècnica.

Seus representantes de maior peso são, sem dúvidas, a RIOPART Participações e Empreendimentos S.A. e a Associação Comercial do Rio de Janeiro. Formada em 1983, a RIOPART è uma empresa constituida por 100 cotistas com o objetivo de promover e apoiar a promocão do comércio internacional no Rio de Janeiro. Ela, na realidade, poderia ser considerada como um braco da Associacão Comercial uma vez que todos os seus cotistas participam tambèm desta, possuem objetivos complementares e seus diretores-presidente vêm intercambiando-se desde sua criaçăo. Assim, não há nem pode haver conflito de interesse entre as duas. Em outubro de 1982, a RIOPART e a Associacăo Comercial promoviam a I Semana Rio Internaciona1, com apoio do Instituto de Arquitetos do Brasil (IAB-RJ), para discutir as possibilidades de incremento do comércio exportador no Rio de Janeiro. Um dos diversos eventos foi o seminário Desenvolvimento da Area Portuária do Rio de Janeiro, que buscava debater as possibilidades para a renovaça e valorizacăo da área. Neste seminário discutiram-se as iniciativas bem sucedidas de outros paises, a problemática brasileira e a potencialidade do Rio de Janeiro, acabando por identificar-se as seguintes conclusões bàsicas: 
a) exportaçåo como uma "necessidade imperiosa" para nossa economia; prioridade nacional para equilibrio da balanca de pagamentos e dinamizaçăo do mercado interno;

b) a vocaçăo "natural" da cidade do Rio de Janeiro (localizaçăo no território nacional, existencia do porto, possuidor dos principais agentes, apelo de marketing internacional) como "Tocus" para ações coordenadas no sentido do mercado internacional e implantaçăo de um centro de negócios.

c) um Centro de Comércio Internacional -CCI (World Irade Center), è peça fundamental para a dinamizaçăo destas operacões, facilitando-as e concentrando-as geográficamente, oferecendo ao mesmo tempo toda uma serie de servicos complementares de apoio e amenidades aos usuários em um cenário atrativo. Concentrar-se-iam servicos como da CACEX e de bancos, salas e servicos de apoio ás empresas, salas para convenções e show-rooms, etc. A implantaçăo de um CCI è o maior objetivo da RIOPART.

d) a Area Portuária do Rio de Janeiro já oferece diversos atrativos neste sentido: edificaçoses e áreas sub-utilizadas, facil acessibilidade, potencial turistico e histórico, proximidade ao centro, conjugaça com o Porto, proximidade da àgua e toda a série de conotacões simbólicas e possibilidades recreativas que ela permite.

e) implantação de uma Zona Industrial Livre de impostos, capaz de promover a agregação de componentes obtidos no exterior em producăo local para exportaçăo; principalmente se estiver conjugada a patios industriais na região do Porto de Sepetiba e dos distritos industriais ligados a ela. 
f) reciclagem do comércio atacadista, atravès de métodos e processos de armazenagem e distribuicăo modernos em novas bases fisicas, assim como dinamização do Porto do Rio de Janeiro através do investimento na melhoria de sua operacionalidade.

g) exploraça das potencialidades turisticas internas e externas destas iniciativas complementares. As novas atividades e melhorias fisicas promovidas, como rede hoteleira e de servicos de apoio, causariam efeitos multiplicadores, além de fixar bases para promocăo de outros atrativos recreacionais como conjuntos de lojas, atividades maritimas, recuperaçăo e valorização do patrimônio arquitetônico existente, etc.

Algumas destas conclusões citavam especificamente exemplos de outros palses para demonstrar o alcance do empreendimento, mas è verdade que a maioria é bastante evidente. A atividade de exportaçăo no Brasil tem sido sempre iniciativa aventureira $e$ individualista dos empresários e a implementaça de um centro de negócios ágil e facilitador seria um grande passo para o aumento das exportaçoos. o grande problema que reconhecia-se nas entrelinhas dos documentos e que ainda persiste até hoje è a incapacidade do poder público brasileiro, e o carioca em particular, de gerir processo e iniciativa tão ampla tendo como base instituicôes tåo pouco sỏlidas e conflitantes. Por isto, defendia-se que o poder privado deveria assumir papel prioritário no processo.

Enquanto acontecia este Seminário, a RIOPART encomendava ao Centro de Apoio á Pequena e Média Empresa do Rio de Janeiro 
(CEAG-Rio) um estudo intitulado "Cadastro Fisico da Area Portuária do Rio de Janeiro" (RIOPART 1983). Bastante completo, este trabalho teve por objetivo um amplo levantamento fisico da àrea com vistas a sua avaliacão para o desenvolvimento. Foram descritos aspectos funcionais, de uso do solo, condicionantes legais e condições de propriedade dos imóveis. O setor privado disporia assim de um importante documento para embasar suas reivindicaçôes. Desta forma, apontava-se os principais conflitos flsico-ambientais e funcionais e comprovava-se empiricamente a potencialidade da área portuária para o desenvolvimento.

Desde entåo, têem surgido projetos para intervençăo na àrea, propondo ou apostando em sua renovaçăo. Evidentemente, a RIOPART e a Associacão comercial apoiam estas iniciativas, sempre que contemplem seus interesses ou, pelo menos, não interfiram com eles. Lutando sempre para implementaça do CCI, sua maior reivindicaçăo, a RIOPART e a Associacão comercial filiaram-se á International Association of world Trade centers (Associação Internacional dos centros de Comércio Internacionais). Esta iniciativa, antes mesmo de qualquer definicão de real implantaçăo institucional ou flsica do centro, comprova a confianca dos empresàrios no sucesso eventual do empreendimento e sua penetraçăo nas esferas do poder. Mais adiante, no capłtulo XI, veremos a forca que este "lobby" reflete através de matérias e coberturas jornalisticas sobre a questão.

A própria RIOPART quando na tentativa de buscar capital extrangeiro, particularmente o japonês, para a implantaçăo de um Centro de comércio Internaciona1, atraiu a execucão de uma projeto preliminar de reurbanizaça oferecido pela firma NIPPON 
TELEGRAPH \& TELEPHONE. Interessada em vender tecnologia de fibras óticas e "ediflcios inteligentes" (plenamente computadorizados), a NTT apresentou projeto totalmente alheio ás realidades locais, com o objetivo evidente de manipular as possibitidades de máximo desenvolvimento (Fig. 63). Fisicamente, os cenários apresentados eram radicais e "internacionalistas", com muita demoliçăo, desrespeito ao patrimônio local e prèdios altos. O pouco do que se veiculou da proposta foj mujto criticado, principalmente pelas associaçóes de moradores locais, receiosas de seus efeitos. A RIOPART engavetou o projeto, classificando-o como "apenas uma oferta para a discussão".

Ainda em relacăo ás tentativas de discutir possibilidades para o CCI, no inicio de 1985 a RIOPART contratou ao escritório Jaime LERNER um estudo preliminar para reciclagem de um antigo armazém da CDRJ. A edificąăo histórica estava localizada na I inha 2 de armazéns e deveria ser destinada para "show-room" de exportaçăo. Uma estrutura tubular de acrilico transparente serviria de passarela sobre a AV. Rodrigues Alves 1igando as novas funções à um restaurante mirador construido sobre o cais entre dois armazéns (vide Fig. 62).

Em 1986, o secretário de Desenvolvimento Urbano do Municipio do Rio de Janeiro recebeu pessoalmente um projeto preliminar da Companhia Brasileira de Projetos e Obras (CBPO), empresa do grupo ODEBRECHT, para a Area Portuària. A proposta, que totalizava $370.000 \mathrm{~m} 2$ construldos, previa a construção de um entablamento unificando a àrea de quatro quarteirões, um conjunto de edificios "inteligentes", encimados por um de quarenta pavimentos ( $v i d e$ Fig. 62). O embasamento constituiria uma "massa" 
construlda abrigando um "shopping center" de caráter regiona1, auditórios, zonas de servico e um estacionamento com capacidade para 6000 veiculos. Embora tendo impressionado o então secretário Municipa1, por seu caráter "progressista", a proposta não possuia nenhum fundamento, revelando-se apenas como uma tentativa especulativa do grupo que, se obtivesse um aval preliminar do poder municipal, partiria para tentativas de incorporaça .

Finalmente, talvez o mais importante empreendimento de caráter privado que está realmente sendo implementado em nossa área de estudo seja o edificio comercial da Joăo Fortes Engenharia, situado no infcio da Avenida Rio Branco, Praça Mauá (vide Fig. 62; Fig. 64). O prèdio foi incorporado em conjunto com a ordem dos beneditinos, proprietária do terreno de $2.934 \mathrm{~m} 2$ no sopé do Morro de são Bento que, como vimos, è um dos importantes redutos históricos do Rio de Janeiro. O projeto, de autoria do escritório Edison MUSA, é pretenso representante da arquitetura pós-moderna tardia, mas sem dủvida já representa, por sua altura e caracteristicas estéticas, um novo marco no centro cidade. Com seus 32 pavimentos a torre oferece andares corridos, galerias comerciais no tẻrreo, restaurante, pequeno centro de convenções e garagem de 10 pavimentos com 750 vagas.

Como toda iniciativa deste calibre, ainda mais por situarse em local de "reputação duvidosa" ás vistas da populaçăo e junto á Area Portuåria "decadente", o empreendimento da João Fortes precisava apostar na revitalizaçăo da àrea. Portanto, a estratégia de marketing da empresa apoiou-se em que o prédio era, na verdade, o primeiro da importante Avenida Rio Branco ( o nome do edificio é Rio Branco 1) e que este era o "endereco interna- 

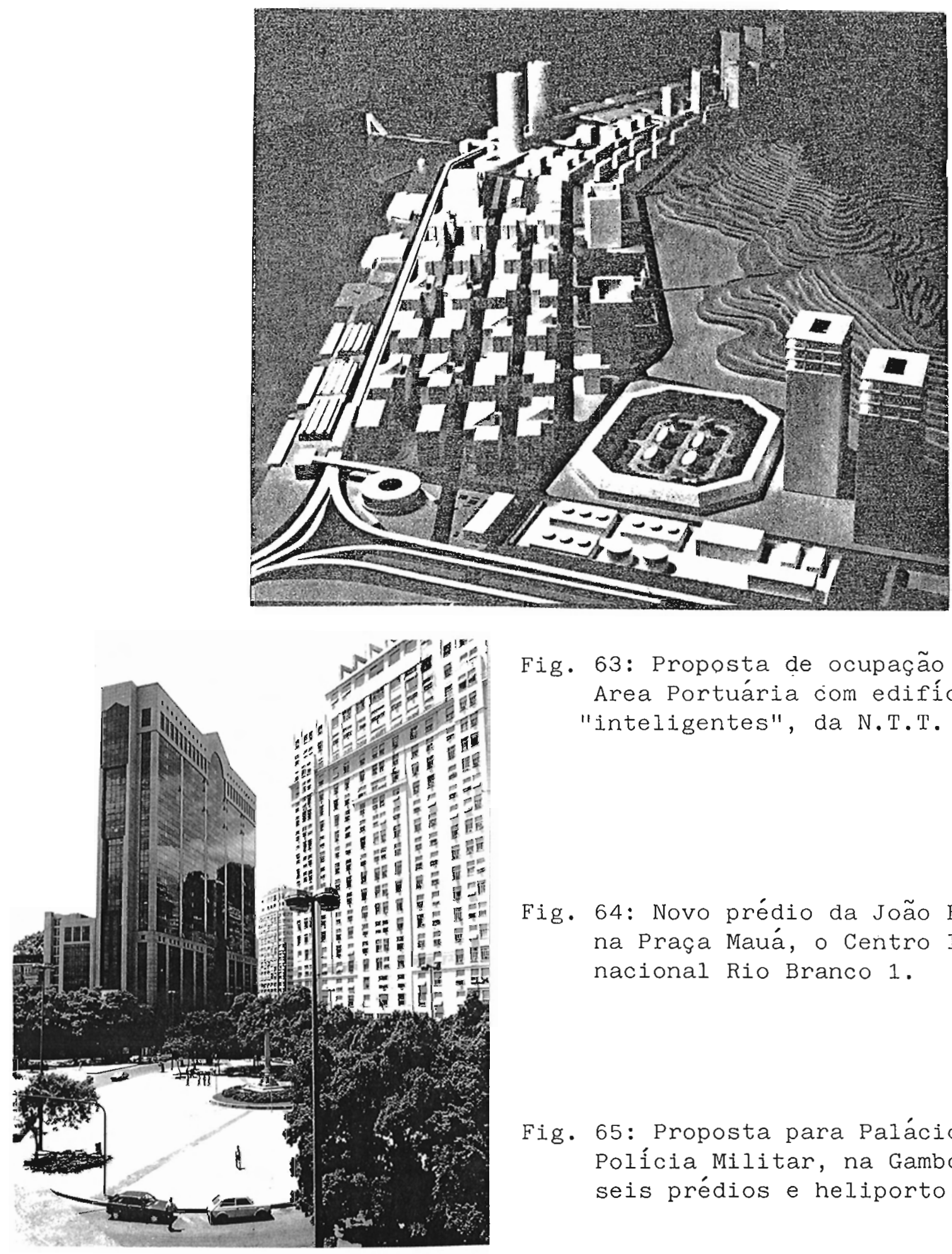

Fig. 63: Proposta de ocupação da Area Portuária com edifícios "inteligentes", da N.T.T.

Fig. 64: Novo prédio da João Fortes na Praça Mauá, o Centro Internacional Rio Branco 1.

Fig. 65: Proposta para Palácio da Polícia Militar, na Gamboa, seis prédios e heliporto.

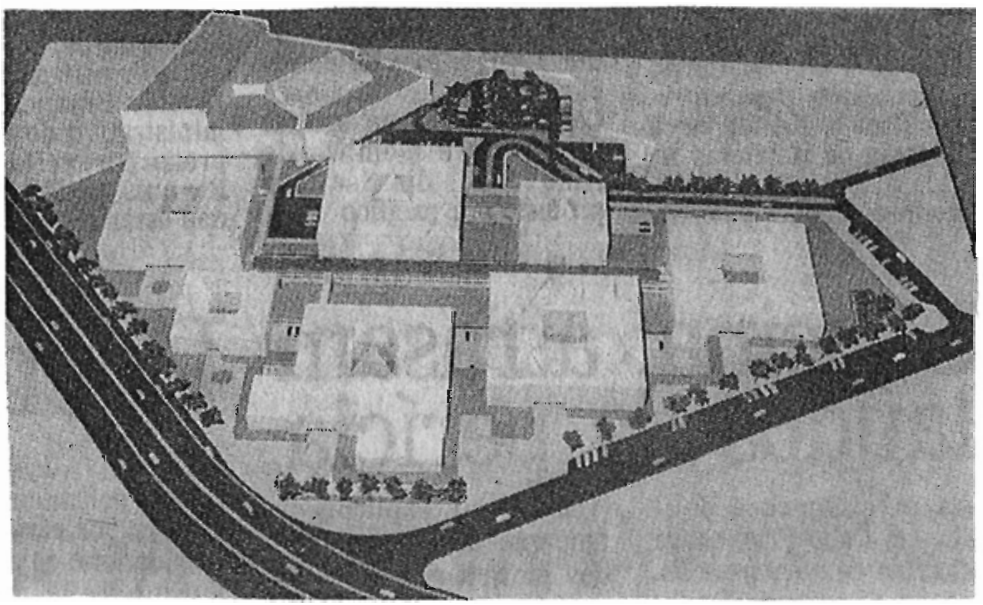


cional do Brasil" e lugar perfeito para um centro de comércio internaciona1. Vende-se a idéia de que o empreendimento serà um póto irradiador da revitalizaçăo da àrea, e a empresa està investindo no remodelamento da Praça Mauá e na publicaçăo de dois 1ivros históricos sobre a Area Portuária e a praça. Interessante é que o "projeto de fachada" do prèdio foi a 1 terado para "pósmoderno", quando a estrutura jà estava terminada, pois a João Fortes buscava uma imagem mais engajada na contemporaneidade internaciona1. Espera-se a complementaça da obra e seu tota1 1 ancamento para 1990 .

Vemos, portanto, que as ações e pressões do setor Privado săo bastante coincidentes, todas buscando possibilidades no sentido de lucrar com a "revitalizacăo" e a utilizaçăo de áreas ociosas, para o que em muito de inspiram nos exemplos bem sucedidos do exterior. E tambèm coincidente a busca pela implementação de facilitadores para o mercado internacional, comércio de importacão e exportaçăo, e zona de negócios, principalmente através de um centro de Comércio Internacional e toda a modernidade implicita neste empreendimento. $E$ neste contexto que permite-se falar em preservaça histórica, lazer, recreaçăo e patrimônio turistico.

VIII. 2. 으 Setor Púb7ico:

A participação do setor Público na questão da revitalizacão da Area Portuária tem sido multi-facetada e, como típicamente acontece em nosso pais, reflete interesses pessoais, conflitos de poderes e fuga de responsabilidades. Como setor Publico queremos dizer não apenas as instituicões diretamente responsàveis pela 
gestão do território e seu desenvolvimento, mas tambèm as empresas de capital misto, de responsabilidades especificas, e os órgãos setoriais.

Assim, em um primeiro grupo de problemas, encontram-se os conflitos entre os diferentes niveis de poder, que não se expressam exclusivamente em nossa área de estudos mas a 1 i encontram veio fértil. Os imóveis, como vimos, pertencem a diferentes esferas de governo e de empresas públicas. Os poderes federa1, estadual e municipal, por nå pertencerem ao mesmo partido polltico, nunca acordaram sobre os destinos da àrea e de seu patrimônio e, a nosso ver, dificilmente chegarão, dadas as atuais circunstâncias politicas. Os interesses eleitoreiros e suas diferentes visões de desenvolvimento dificultam imensamente que os podêres publicos tomem iniciativas conjuntas.

Em segundo lugar, encontram-se os conflitos de poder que se expressam espacialmente quando, ás vistas do funcionalismo brasileiro, perder "espaço flsico" é perder poder polftico. Portanto, as instituicŏes raramente admitem a sub-utilização de seus imóveis, preferindo tratá-10s como "temporariamente pouco utilizados" ou como "reservas técnicas". Isto ficou bem claro na anảlise dos mapas e identificaçao de sub-utilização de imóveis e seu estado de conservação.

Por ültimo, está o grupo de problemas composto pelo imobilismo tipico do setor publico, que prefere sempre deixar para amanhã uma decisão que pode tomar hoje, atuando quase que exclusivamente em questões de caràter emergencial. E bem verdade que existem 1 imitações reais na atuaçăo pủblica, como prioridades de planos de governo e limitacơos de recursos e pessoal. 
Entretanto, a intensa pressåo do setor Privado sobre a àrea de estudos e sua evidente importância para o desenvolvimento da cidade jà deveriam ter gerado uma atuą̧ão mais consequente, ao menos por parte do poder municipal.

De qualquer forma, vejamos quais têm sido as principais expressões do setor Pủblico em relação á área, desde o surgimento da discussão sobre a sua revitalizaça, em 1982. O que caracteriza estas diferentes expressôes é, sem dủvida, a não tomada de decisôes abrangentes, ou mesmo uma politica de desenvolvimento para a área. O máximo que se conseguiu foi a instituicăo de àreas de preservaçăo ambiental nos bairros residenciais adjacentes, como ja vimos no Capitulo anterior. Nem mesmo as proposicôes de preservação e controle de desenvolvimento constantes nas politicas relativas ao projeto corredor cultural, que abrange significativa àrea do centro do Rio, principalmente na Rua da Carioca, Praça XV e adjacências, geraram estudos que as estendessem á Area Portuária como um todo.

Evidentemente que toda esta situaça relativa á administraçăo pủblica è fruto de interesses particulares, do casuismo eleitoreiro e da grita das associaçôes de moradores. Mas năo nos cabe aqui desenvolver esta abrangente temática já abordada por muitos estudos competentes (SANTOS 1981, REZENDE 1982). Basta dizer que, também em relaçăo á nossa área de estudos, as propostas e projetos pủblicos são, sintomáticamente, pontuais, setoriais e desintegradas, o que veremos a seguir.

Dentro do grupo de atores pertencentes ao setor Público e de maior rebatimento sobre a Area Portuaria, destaca-se a autoridade portuária, a CDRJ. A época do seminário patrocinado 
pela RIOPART e Associação Comercia1, o então presidente da CDRJ era pessoalmente concordante com a implantacăo de um CCI na Area Portuária, declarando-se receptivo á qualquer sugestão que possa valorizar o Porto (Jornal O GLOBO 13/10/83). Declarava ele que o antigo prédio da estação de passageiros, localizado na Praça Mauá, sendo recuperado pela CDRJ poderia servir de embrião ao CCI. O arquiteto Oscar NIEMEYER teria sido contratado pela CDRJ para um projeto de CCI a ser localizado sobre a àgua, em frente á Praca Maua; infelizmente, jamais pudemos comprovar esta noticia e parece não se ter saldo do plano das idéias. Mas a antiga estaçăo de passageiros e prédio-sede do Touring club do Brasil, foi totalmente recuperado e agora também abriga um centro de exposiçôes e a biblioteca da CDRJ, que não revela grande impacto público na Praça Maud, onde se localiza (vide Fig. 62).

Depois disto, as administrações da CDRJ vêm alternando-se em suas posiçoes relativas ao destino das áreas de retaguarda do porto e sua eventual revitalizacăo com outros usos. A cada novo presidente, apoiava-se ou não as iniciativas da RIOPART e da Associação Comercia1. Era sintomático e bastante respeitoso da moda, o apoio da CDRJ a iniciativas culturais, como em 1988, para a implantação pela Secretaria de Educação do Estado, em conjunto com a RIOPART, de um "armazém cultural" no antigo Armazém Interno A, destivado havia oito anos. o prédio reciclado abrigaria escritórios culturais, teatro, cinema, auditório, biblioteca e um restaurante. Apesar da declarada 1 iberacăo de verbas estaduais para inicio dos trabalhos, o projeto não saiu do papel.

Recentemente, em 1987, a PLANAVE, empresa de consultoria encarregada pela PORTOBRAS do desenvolvimento de um plano diretor 
portuário, como jà vimos no capitulo VI, iniciou o desenvolvimento de estudos para a retaguarda imediata do porto onde parte-se da premissa que seus indices de produtividade poderiam melhorar sensivelmente sua conceituação de operacionalidade e desitribuicăo espacial fosse repensada. Para tanto pensa-se básicamente na concentraçăo e melhoria operacional de suas atividades, conduzindo á liberação de retro-àreas e á condução de aproveitamentos múltiplos de suas possibilidades de uso e comercialização de seus imóveis; com isto pretende-se gerar recursos para reinvestimentos nas próprias operaçôs portuàrias. As proposicões finais destes estudos, que teriam grande alcance caso aprovadas, no momento da elaboraça deste trabalho, ainda encontram-se sob carater sigiloso.

Em nossas entrevistas, um ex e o atual diretor-presidente da CDRJ, oprimeiro bem mais enfaticamente, chegaram a admitir a possibilidade de destinacão de propriedades controladas pela companhia para outros usos que não os portuários, segundo um programa de revitalizacão. Este, evidentemente segundo eles, deveria também contemplar possibilidades de melhoria operacional e concentracão de atividades portuárias em áreas mais próximas ao Cajủ. Segundo o seu depoimento, estes investimentos deveriam preceder á Tiberacão das àreas mais centrais.

Outro importante agente de desenvolvimento na Area Portuária è a Rede Ferroviária Federal, que ali controla os

1: Este ex-diretor presidente, o engenheiro Pedro BATOULI foi, inclusive, um dos promotores, junto da RIOPART $e$ Associacão Comercial, do seminário sobre o desenvolvimento da Area Portuária em 1983, jà comentado anteriormente. 
terminais de Praia Formosa e Marttima. O Plano Diretor de Modernização e Ampliaçáo do Sistema de Trens Urbanos do Rio de Janeiro, de 1986, mencionava a previsăo de desativar o Termina1 de Marttima principalmente pelas crescentes dificuldades de convivência entre os trens metropolitanos de passageiros e os de carga, pois utilizam-se de 1 inhas comuns. O terminal de Formosa teria o mesmo problema, agravado por maiores dificuldades de acesso e de limitaçăo de àrea. Entretanto, já em um estudo posterior encarregado pela CBTU á METROCONSULT/DUCTOR (1988), as anàlises não foram tão coincidentes, negando sua desativaçăo e indicando os dois terminais como de grande importancia para a funcåo retro-portuária e com potencial de utilizacăo intermodal para distribuicão e recebimento de carga.

Ao que tudo indica, parece-nos que esta possibjlidade não é tåo real, ao ser analisada em conjunto com as próprias tendências portuárias que jå expusemos acima e com os elevados custos relativos as adaptaçoos necessárias dos acessos ferroviários. Conclusôes deste tipo devem ser cuidadosamente analisadas face a objetivos integrados de um plano de desenvolvimento local mais amp10 e, necessàriamente, em conjunto com a autoridade portuảria. Em relaça a outros planos setoriais que possam rebater-se na àrea de estudo, parece ainda existir ameaça por parte de dois planos viários de responsabilidade do Departamento de Estradas de Rodagem do Estado (DER-RJ). O primeiro, mais antigo e datando dos anos 50 como vimos em nossas consideraçós históricas de capttulo anterior, determinava complexos anéis viários para continuidade do sistema Catumbi-Santo cristo (chamada Linha Lilàs) conectando- ao resto do sistema viário municipal e estadual, inclusive ao 
elevado da Perimetral; isto acarretaria substantivas demoliçốes e intervençôes viárias no bairro do santo cristo e adjacências (vide Fig. 40 \& 62). Embora esquecido atualmente, sem duvida por sua grandiosidade, a ameaça deste plano ainda persiste.

o segundo plano viário de importância para a Area Portuária è o da Linha Vermetha, antiga intença de duplicar a possibilidade de acesso ao Rio através de uma via paralela a Avenida Brasil. Ainda com os projetos vagarosamente em desenvolvimento, ao que tudo indica o seu inicio seria na Avenida Rodrigues Alves, á altura do Cajú e recebendo uma aba de acesso vinda do Elevado da Perimetra1, continuando pela margem da bala. Embora os posstveis reflexos em nossa àrea de estudo parecam ser apenas marginais devido á localizaçăo desta via planejada e seus acessos, quando no detalhamento dos projetos deveriam ser previstos estudos aprofundados relativos aos eventuais impactos na àrea e seu funcionamento, principalmente oriundos da geracăo de tráfego do centro e do catumbi.

A Ultima novidade em termos de proposicóes para a área partiu do governo estadua1, atraves de um decreto de desapropriação em setembro de 1989, para construcão do complexo da Pollcia Civil em uma área de $46.000 \mathrm{~m} 2$ (vide Figs. 62 \& 65). De autoria do arquiteto Mauricio ROBERTO, o complexo terá 77.000 m2 de área construida, em terreno do antigo Moinho Inglês junto á Avenida Rodrigues Alves, e abrigaria uma academia, setores de microfilmagem e policia cientifica, além dos institutos fèlix Pacheco (identificaçăo civil), de criminalistica e médico-legal. A CDRJ censurou a iniciativa pois pretendia para ali a instalação de um pátio de atividades portuárias pela iniciativa privada. As 
associacões de moradores locais, através dos jornais e em suas entrevistas, tambèm têm protestando contra o que entendem và ter impacto negativo na àrea, principalmente temerosos com o eventual mau cheiro que possa ser produzido pela manipulação dos cadáveres no IML, a exemplo do que acontece com o atual e o seu entorno, também no centro do Rio.

VIII. 3. A comunidade:

Entendemos aqui por comunidade aquela representada pelas associações formais de moradores da àrea e que têm demonstrado uma atuaçăo constante na defesa de seus direitos civis e de reivindicacões relativas á qualidade de vida junto ao poder público (CASTELLS 1971, SANTOS 1981). Encontramos apenas três grupos que enquadram-se nesta definição, sendo que um deles, a Associação de Moradores e Amigos da Praça Mauà na realidade nunca teve existência prolongada; o grupo foi formado por alguns moradores apenas em funçăo de uma reivindicaça especifica e logo di 1uiu-se.

Optamos por não considerar as reivindicacões provenientes dos sindicatos de estivadores e outros portuarios, uma vez que são grupos representativos que não caem em nossa classificacão; suas reivindicações são exclusivamente relativas a situações trabalhistas e extremamente contràrias a qualquer possibilidade de mudança, entendida por eles como ameaca a sua fonte de renda. Como comentado anteriormente, o total empregado diretamente pelo porto do Rio é de 3.600 pessoas, e o total estimado de empregos indiretos pode ser fixado em pelo menos 14.400 . 
Embora nåo sejam totais precisos, evidenciam a importância econômica das atividades portuárias para significativa parcela da população, principalmente residente nas àreas de entorno ao porto. Portanto podemos concluir que os trabaihadores do porto que habitam na àrea eståo perfeitamente representados pelas associações de moradores, em suas preocupaçoes por uma me1hor qualidade de vida. Históricamente, como já vimos anteriormente, estas populações são oriundas e descendentes, em sua maioria, da estiva ou de atividades com ela relacionadas.

A preocupacão imediata destes grupos de trabalhadores, segundo nossas fontes e entrevistas, é com a sua fonte de renda e, em segundo lugar, com seu local de moradia; estes fatores fazem com que sejam extremamente avessos a possibilidades de mudancas, cujos resultados quase nunca são conhecidos e dominados. Demonstram-se preocupados com as possibitidades de decilinio do movimento de operaçôes portuárias e com quaisquer projetos especificos que ameacem diretamente o seu mercado de trabalho. Portanto, eventuais alteracôes com a tipologia de oferta de trabalho, resultado de politicas de revitalizacão, por exemp10, ou transferência de operaçós portuàrias, deveriam considerar o futuro desta população.

Veremos a seguir quais as principais preocupacões e reivindicacốes das associaçôes de moradores. Cabe comentar que, enquanto muitas das informações relativas aos setores Privado e Publico eram constantemente veiculadas pelos jornais, como veremos adiante no Capttulo XI, aquelas relativas ás associaçoses de moradores apenas raramente alcancavam as manchetes publicas e, portanto, nossos comentários serão baseados principalmente nas 
entrevistas mantidas com, sempre que possivel, três representantes membros da diretoria, de cada uma delas.

Estes, de uma forma gera1, revelaram-se extremamente conscientes e orgulhosos do caráter histórico de seus bairros e da manutencão do patrimônio arquitetônico. Talvez esta seja a maior razåo de caràter flsico-espacial expressa pela maioria, em seu receio relativo ás propostas de intervencão urbanistica na Area Portuária. A seguir uma declaraça que obtivemos do presidente da associação de moradores do Santo cristo, Manoel de Sà Rodrigues, o Neca, sobre o Morro do Livramento:

"..tem coisas que é bom uma pessoa dar uma volta lá por cima... aquele tracado, aquela rua... acho aquilo superinteressante, como que aqueles homens antigos conseguiam fazer um tracado de uma rua daquelas com os poucos recursos que tinham naquela ocasiăo... hoje em dia se faz uma avenida que é uma régua, uma reta, e eles fizeram aquilo cheio de curvas e nós vamos ter là em cima na capela, no monumento para a santa... eu acho aquilo sensaciona $1 . . . "$

Outra temática de que estão plenamente conscientes, è da existência de inúmeras àreas e edificacões ociosas na Area Portuária, e defendem uma atitude oficial a respeito, seja porque eståo conscientes dos inumeros reflexos negativos que geram sobre o seu entorno, seja pelo potencial de sua utilizacão suprindo a escassez de áreas públicas para o atendimento de diversas de suas reivindicacões, como novas áreas de 1 azer.

A Associação de Moradores e Amigos da Praça Mauá (AMAMauá) foi formada quase que exclusivamente por moradores do Morro da Conceicão, a partir da vontade de proceder a um levantamento das necessidades da àrea, em 1986. Alguns representantes preocupados com os possiveis impactus da expansão do centro de negócios e a consequente valorizaçăo dos imóveis e expulsão de 
moradores, já haviam colaborado com o trabalho do SPHAN e do Projeto SAGAS, comentados anteriormente, para preservação do patrimônio histórico-arquitetônico. Entretanto, a AMA-Mauá jamais alcançou grande expressão, não obteve o apoio dos comerciantes do bairroe, pouco tempo depois, desestruturou-se desmotivada. Hoje a comunidade empenha-se apenas em organizar festas religiosas junto á Igreja santa Rita, no alto do morro, como a quermesse e festa de Nata1.

As preocupacões principais reveladas pelos entrevistados, antigos participantes da AMA-Mauá, foram por um lado com as condicões de habitabilidade do bairro, tais como a carência no abastecimento de água, o comércio de primeiras necessidades deficiente, a falta de áreas de lazer, estacionamento de velculos alheios ao bairro durante o horário comercial, e o descaso geral do poder municipal na conservação. Pelo outro, sua preocupacão com os possiveis impactos do desenvolvimento sobre suas vidas é consciente e primordial; enquanto não negam as eventuais vantagens de um projeto de revitalizacăo para a Area Portuária, receiam seus impactos sobre o patrimônio histỏrico-arquitetônico do bairro, além da intrusão de novos usos em detrimento do residencial.

A Associação de Moradores e Amigos do Santo Cristo (AMASto. Cristo) revelou-se mais interessada em manter a constância de certas atuacões relacionadas a carências báscas dos moradores, como a distribuicão de tiquetes de leite. O seu presidente, comerciante com humilde oficina de metais loca1, foi candidato a vereador pelo PMDB e possui transito fácil entre alguns politicos municipais. Os entrevistados 1 igados á AMA-SC mostraram-se muito 
conscientes da importância do patrimônio histórico da área, da necessidade e da funcăo social de novas áreas de lazer (principalmente direcionada para "a mocidade ter o que fazer nos dias de domingo), da carência de comércio loca1, do ensino do 20 grau e profissiona1izante. Quanto a equipamentos para suprir a estas demandas, o presidente defende sua localizacăo no parque situado no alto Morro do Pinto, em seu bairro, como uma das maneiras de livrar-se da marginalidade que hoje lá impera. Ele também alega desrespeito a leis municipais que proibem expansão do uso industrial em santo cristo e cita os impactos negativos dos grandes armazéns e da circulacão de grandes carretas.

Recentemente a associacåo foj parcialmente vitoriosa em suas reivindicacões relativas a uma antiga estação de carris, situada na rua Pedro Alves e tombada pelo SPHAN. Queriam que o prédio fosse destinado a usos comunitários, como um novo centro de saúde, mas o máximo que conseguiram foi obter uma obra para sua recuperacão por seu proprietário, a empresa de ônibus ủti1, que o utiliza como dormitório eventual para empregados.

Finalmente, a Associacão de Moradores e Amigos da Saúde (AMA-Saúde) deve ser destacada como a mais atuante e organizada dentre as analisadas. Ativistas do Projeto SAGAS (vide Capitulo VII), atualmente o seu ex-presidente, um funcionário da prefeitura, è coordenador do recém criado escritório técnico para análise de projetos na zona definida como de protecão ambiental. Outra grande conquista da comunidade foi a transformacăo da antiga escola municipal José Bonifacio, um bonito palacete republiciano, em centro cultural administrado pela prefeitura em conjunto com a associacão de moradores. Neste centro estão 
instalados a sede da associacão, o escritório técnico, cursos de dança, música, exposicões, dentre outras atividades comunitárias. Os membros da AMA-Saúde que entrevistamos reclamaram da falta de critérios de base social local para definicão dos limites dos bairros, censurando a atuacão da prefeitura que "inventou" o bairro da Gamboa artificialmente. Foram também muito criticos quanto ao albergue da Fundação Leão XIII localizado na principal praca do bairro, Corone 1 Assumpção (antiga Harmonia), com os planos viários ainda existentes que prevêem a demolicão de muitas áreas dos bairros, e comércio "nocivo" aos moradores, como os grandes armazens de atacado. Um de seus grande motivos de preocupacão atual è o projetado complexo estadual de pollcia, já comentado anteriormente, e os impactos negativos que temem causarà no entôrno. 
CAPITULO IX:

TENDENCIAS DE DESENVOLVIMENTO DA AREA PORTUARIA

A partir da análise das informacõos e dados contidos nos capitulos anteriores, apresentamos alguns comentários conclusivos relativos ás tendências de desenvolvimento verificadas na Area Portuária, objeto de nosso estudo.

Pudemos observar que os indicios revelados pelos dados e aqueles observáveis diretamente em campo nos levam a concluir que, realmente, a Area Portuária apresenta características tipicas de área urbana em deterioraçăo. Vimos, no entanto, que ao mesmo tempo ela tambèm oferece condicôes favoráveis á intervenções urbantsticas com vias á sua revitalizaçăo econômica e socia1. Estas intervenções deverão, como visto, procurar o objetivo maior de reintegrar a área á vida da cidade, participando de forma singular no desenvolvimento urbano.

Históricamente, a área perdeu importância e muitas de suas funções, mas vimos que toda uma sèrie de fatôres existentes ainda permitem que uma recuperação seja possive1, viável e desejảve1, em um tempo relativamente curto. Politicamente, nossos comentarios anteriores sobre os grupos de interesse na àrea mostraram que estes objetivos tambèm săo viàveis e compativeis, atravès da 1iderança e monitoraçăo do poder municipa1. 
Assim, resumindo, verificamos que:

I. Existe um perfil tendencial de transformaços na própria natureza das movimentações portuàrias. O Porto do Rio revelase como concentrando suas operaç̃es de exportação em produtos siderúrgicos e de automóveis, as de importação em graneis sólidos, e a movimentação geral em operaç̃es containerizadas.

Esta especializaça faz com que a estrutura portuária existente, ainda originária da época em que o porto era tipicamente importador e as mercadorias permaneciam muito tempo nos armazéns, revele entraves operacionais. Estes entraves, inclusive, já originaram a implantação de alteraçoos conceituais nos próprios métodos e sistemas operativos. Grande número de armazèns, oriundos das épocas de farta importaçăo encontram-se atualmente sub-utilizados.

II. As operações portuàrias atuais e as ałteraçós previstas encontram condiçơes negativas nas próprias condiçôes fisicoespaciais das instalações portuárias. As operações estão espaihadas longitudinalmente por quase três quilômetros de cais, em uma restrita faixa de 30 metros, e por diversos armazéns e áreas espalhadas em meio ao tecido urbano.

As faixas ligadas diretamente ao cais encontram-se saturadas, uma situaçăo que diminui a operacionalidade. Năo hả ảreas de retaguarda suficientes, nem corretamente dispostas, para o apoio eficiente ás atividades de embarque/desembarque, ou mesmo de estocagem estratégica.

III. A evoluçăo normal da cidade e do entorno da Area Portuária, em conjunto com sua localização estratégica central, gerou uma invasão de usos extranhos ás pràticas portuảrias, inibiu o 
desenvolvimento de outros que poderiam a elas estar integrados (como o uso industria1, por exemplo) e causa outros inibidores significativos em termos de circulaçăo e transportes. Ao mesmo tempo, o tecido urbano existente e destinado á vida normal da cidade atrapalha as operações portuárias que por ele permeiam.

IV. Por estas razőes existem diversas áreas sub-utilizadas e edificações abandonadas. Mais áreas poderiam ser ainda 1 iberadas atravès da implantacăo do novo 1ay-out reorganizativo do Porto, defendido pelos técnicos especializados. Neste novo lay-out, objetiva-se a eficiência e a concentraçăo das operaçôs portuárias, utilizando-se das capacidades instaladas e do potencial existente de àreas mais proplcias para tanto que oferecem retaguardas compativeis, junto aos cais de são cristóvão e do Cajủ.

V. As pressões de expansão do desenvolvimento do centro do Rio, assim como o regime juridico e o perfi1 de proprietários de grande parte destes imóveis facilitam sua incorporação a um plano integrado de intervenção urbanjistica para revita1izaçăo. A viabilização da utilização de imóveis de empresas e sociedades controladas pela união, como a CDRJ, jà foi instituida por decreto presidencial que permite a alienacăo de imóveis não vinculados ás suas atividades operacionais.

VI. As operações portuárias, suas instalações e sua administraçåo, encontram-se carentes de recursos. A participação do setor privado nesta temática é essencial, assim como a implementaçăo de meios diferenciados de geraça de recursos, como através do próprio desenvolvimento urbano 
das áreas de retaguarda e outras, identificadas como desnecessárias pelo novo lay-out portuário que se pretende.

VII. E real a necessidade de implantaçăo de um organismo centralizador e viabilizador de exportações, concentrando facilidades e servicos, que se convencionou chamar de centro de Comércio Internacional (CCI). Isto seria facilitado através de instalaçôes fisicamente concentradas e complementadas com servicos diversos de apoio. Este CCI apresenta fatores que o identificam como um catalizador urbano positivo para a revitalizaçåo de àreas centrais, simbólica e socialmente. Simbólicamente, este CCI deve localizar-se no Rio, utilizando-se das evidências de que a imagem da cidade já participa do repertório internacional cognitivo sobre o Brasi1; uma estratégia de marketing para exportaçăo, o Rio ainda é simbolo do Brasil.

VIII. O centro da Cidade do Rio de Janeiro está carente de novas àreas de expansão, que estejam a ele integradas e que apresentem potencial instalado para transformar-se facilmente em catalizadores de atração e animação pủblica, novos usos complementares ao de centro de negócios. A Area Portuária oferece diversas vantagens a este respeito como patrimônio histórico-arquitetônico, ótima acessibilidade metropolitana, facilitadores de lazer como a bala e as vistas, etc.

IX. As legislacões e regulamentacões urbanisticas existentes na àrea revelam-se grandes inibidores do desenvolvimento nas áreas planas, não atingidas pela regulamentặăo de preservacăo ambiental, principalmente em relacăo ao uso residencial e aqueles ditos mais "nobres". Por outro lado, a àrea ja 
protegida apenas através de seus aspectos fisico-espaciais, pode vir a receber um impacto de valorização do solo que atingirà os moradores de renda mèdia-baixa.

Tambèm è negativo o fato da permanência sobre este território de conflitos entre vàrios projetos e planos antigos e destrutivos. Portanto, também através deste fator, é possivel identificar o fenômeno conhecido por "planning blight" (vazio de planejamento), em que a indefinicăo do poder público sobre uma àrea gera um crescente processo de deterioraça sobre suas condiçoes flsicas e sociais.

X. A cidade do Rio de Janeiro vem perdendo sua capacidade econômica e de captação de novos recursos. A implementação de um programa de revitalizaçăo urbana, integrado á implantacão do CCI e reorganização das operações portuárias, seria capaz de gerar centenas de novos empregos e amplos recursos econômicos a nivel de impostos e atividades econômicas; restabelecer-se-ia, tambe̊m, a imagem simbólica.

Todos estes fatores nos apontam uma realidade que justifica uma tomada de consciência do poder público, particularmente o municipal e o representado pela CDRJ, por seu evidente peso especifico na área e no desenvolvimento da cidade, a fim de gerar um processo de planejamento e gerenciamento urbano com vistas á revitalizaçăo deste importante patrimônio instalado.

Caso isto năo seja viabilizado em tempo útil, por um lado, determinadas pressões, que não necessàriamente as mais positivas para a cidade, prevalecerão ás expensas de outras e, por outro se perderà uma oportunidade única no sentido de um aproveitamento ideal de potenciais e respostas á carências. 
Como vimos, os próprios estudos de desenvolvimento portuário e abordam a questão das possibilidades de utilização das áreas de retaguarda do Porto para o desenvolvimento urbano. A partir do perfil tendencial do sistema portuario e de novas concepçôes de operaçôes portuàrias, principalmente o cais da Gamboa deverà apresentar alta ociosidade. o valor comercial desta retro-área, ainda segundo estes estudos, torna questionáve1 a manutenção de seus usos portuários esporádicos e pulverizados e aponta para sua possive1 reciclagem.

Portanto, a partir da análise das informaçoos cometadas, principalmente aquelas transmitidas pelos mapas das figuras 52 e 53, 57 a 60, é possiver identificarmos um perfit tendencial de potencial para intervencăo na Area Portuária do Rio de Janeiro que se nos apresenta com duas sub-àreas e três pólos principais (Fig. 66).

A primeira sub-àrea, que convencionamos chamar de ârea de potencial imediato para intervencăo, è a que apresenta condiçoses propłcias para a implementaça a curto prazo de uma politica de intervencăo expressa por programas e projetos de revitalizacăo. As condicơes sociais, fundiarias e funcionais já expostas poderiam ser consideradas como os principais fatores catalizadores deste novo desenvolvimento. Como vimos, os grupos externos de interesse que geram as diferentes pressões para o redesenvolvimento da àrea expressam-se territorialmente justamente nesta sub-àrea.

Por seu 1ado, a sub-área que convencionamos chamar de área de potencial mediato para intervencão, compõe-se dos trechos da Area Portuária em que uma politica de intervençăo encontraria 


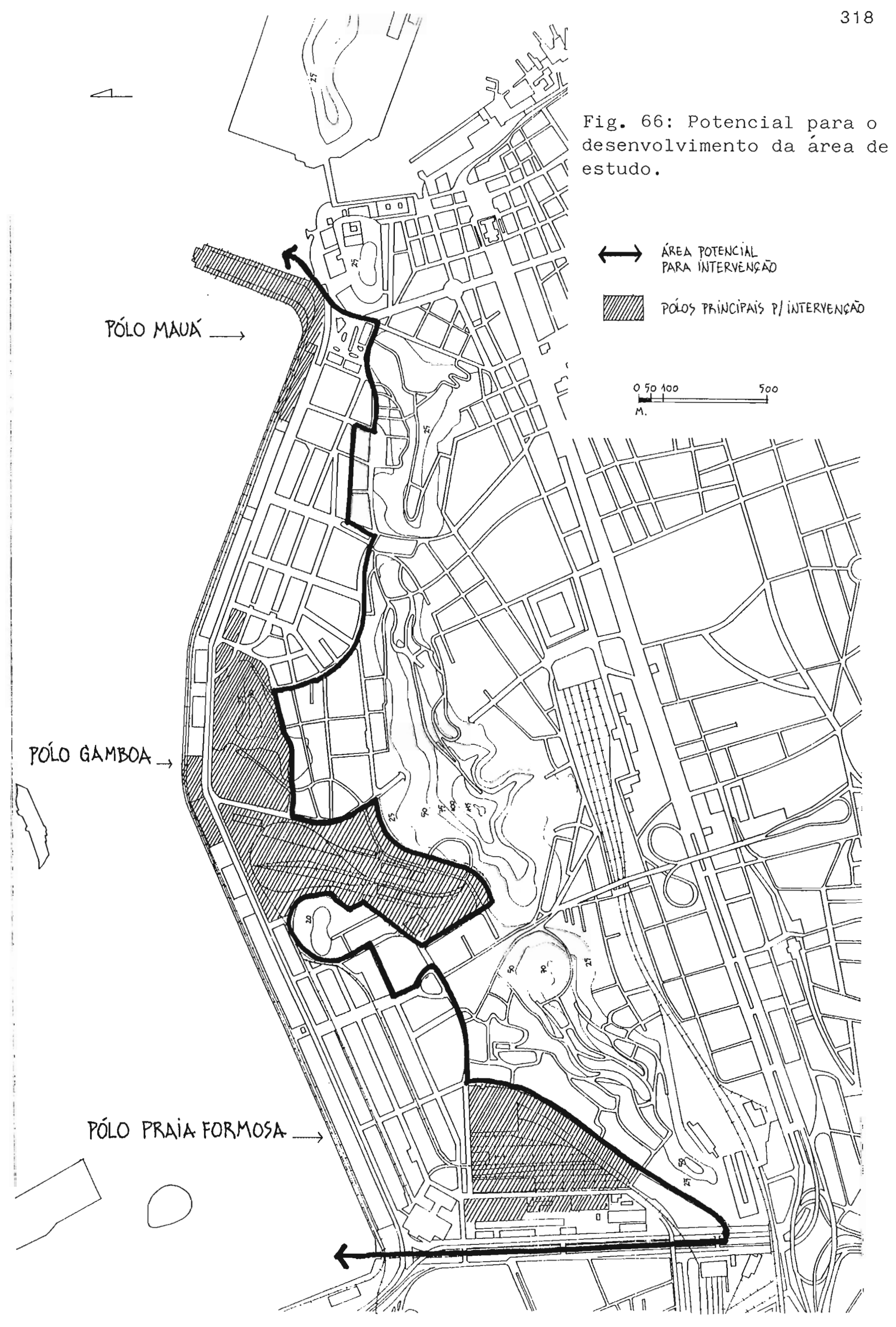


maiores dificuldades para expressar seus programas e projetos. São as areas residencias, principalmente de encosta $e$ inclutdas como de protecão ambiental pela municipalidade, onde os programas de revitalizacăo, inclusive, deveriam assumir cuidados especiais e espectficos.

Enfim, è evidente que neste processo de pianejamento, 0. desenho urbano possuira importante papel a desempenhar, na busca por condicões fisico-ambientais ideais para a consecucăo dos objetivos da revitalizacão. O estudo da percepcão ambiental desempenhard funcão primordial nesta papel pois orientará a acão no sentido dos verdadeiros valores, expectativas e imagens coletivas. 
A Realização da Pesquisa

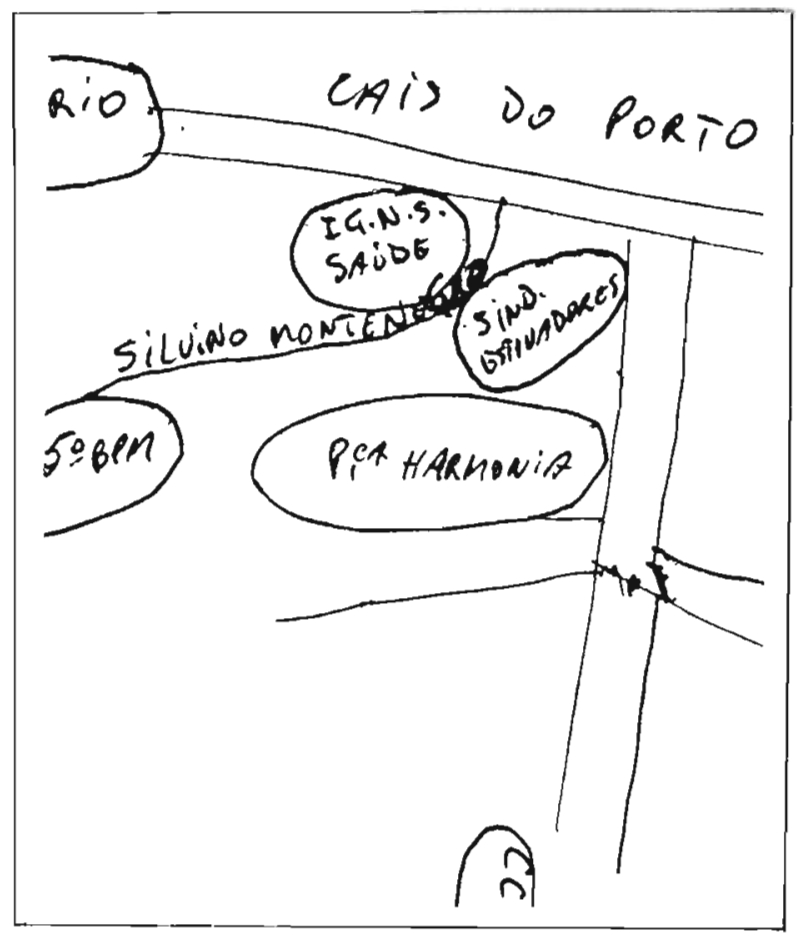

"... construt na minha mente um modelo de cidade do qual extrair todas as cidades possiveis... Ele contem tudo o que vai de acordo com as normas. Uma vez que as cidades que existem se afastam da norma em diferentes graus, basta prever as excessões á regra e calcular as combinacões mais prováveis."

(Kublai Khan a Marco Polo in CALVINo, Italo "As cidades Invistveis", Såo Pauto: Companhia das Letras, 1990, pag. 67) 


\title{
CAPITULO $X$ :
}

\section{A REALIZACAO DA PESQUISA: OBJETIVOS E METODOLOGIA}

\begin{abstract}
"A Place is a matrix of energies, generating representations and causing changes in awareness." (WALTER 1988: 131)
\end{abstract}

Nossa pesquisa, a ser comentada nos próximos capłtulos, teve o propósito de compreender uma das facetas da interaçăo ambiental entre a populaçăo e Area Portuária do Rio de Janeiro, no que diz respeito á percepcăo. o quadro teórico inicial jà conceituou a percepcão ambiental e a sua importância para intervenções de desenho urbano e revitalização de áreas centrais, assim como o papel dos niveis do processo perceptivo que definimos por cognitivo, de avaliaçåo e de conduta.

Especificamente, irá nos interessar o estudo de elementos conformadores destes niveis, respectivamente as imagens, os atributos ambientais que possam ser interpretatos como atitudes e as preferências/expectativas ambientais.

Jả observamos anteriormente que, pelas caracteristicas do campo de estudos da percepcão ambienta1, principalmente por sua pouca idade, sua interdisciplinaridade e a especificidade do estudo, não existe uma metodologia ou sequer instrumento destacável como mais proplcio de uma maneira gera1; frequentemente utiliza-se de diversas estratégias de pesquisa, métodos e instrumentos (MANDEL 1978, GOLD 1980). A pesquisa teve como quadro metodológico básico aquele definido através dos comentários sobre operacionalizaçăo que fizemos no capitulo IV. 
Este tipo de investigaçăo, ou mesmo esta temática, aplicada á Area Portuária do Rio de Janeiro ainda não havia sido objeto de estudos, não dispondo-se de nenhum dado espectfico anterior que pudesse nos auxiliar. Os resultados obtidos pela investigaçăo e a sua anàlise viabilizarão algumas consideracões em forma de diretrizes de desenho urbano para revitalização da àrea, que apresentaremos mais adiante, e poderăo contribuir efetivamente para o corpo de conhecimentos que venham a viabilizar intervençooses mais conscientes em àreas centrais e, especificamente, na área objeto de nossos estudos.

Utilizaremo-nos de uma metodologia formada por dois niveis de investigação: um definido pela anảilise de fontes de dados indiretos, através de elementos de literatura e velculos de imprensa; o outro definido pela análise de dados diretos, obtidos por uma pesquisa de campo. Em ambos casos, os métodos empregados serăo "descritivos", onde não existe o rigor das infericões causais, ou nem sempre pode-se atribuir correlações diretas entre fenômenos (MANDEL 1978).

X. 1. Objetivos da Pesquisa da Literatura e Imprensa:

Nossa investigaçăo por fontes indiretas considerou a literatura e a imprensa, como velculos contribuidores á percepcão indireta e à construçăo do conhecimento. Interessava-nos identificar:

I) quais os atributos da área e suas imagens ambientais transmitidas pelos velculos analisados a seus leitores, relativas ao "espaco social", "espaco natural" e "espaco fisico-cultural"; 
II) quais as avaliaços e atitudes, segundo a dicotomia "positivo/negativo", que representa campos perceptivos opostos, que os textos transmitem implicita ou exp11citamente;

Quanto á primeira questão colocada, as três categorias de espaco que nortearão a nossa análise conformam as primeiras categorias perceptivas em qua classificamos o espaco na atividade cognitiva, pois refletem as dimensões das relacões sociais, da natureza e da geografia natural percebida, e do ambiente edificado; conforma os aspectos principais do "sentido do lugar" ( LYNCH 1980).

Em relação à segunda questão, evidentemente que as avaliaçoes destas imagens e as consequentes atitudes serão sempre bastante consoantes com aquelas dos autores dos textos analisados, em relação á Area Portuária. Espera-se que a transmissão destas avaliações, que podem ser implicitas ou explicitas, seja exatamente o que o autor quer fazer crer ao seus leitores; este é afinal o fim mesmo de todo processo de socialização indireto, como comentamos no capitulo IV. As imagens e avaliações transmitidas pela imprensa, particularmente, assumem importante pape1 neste processo.

Como método de investigaça adotaremos a leitura de obras de 1 iteratura prè-selecionadas por sua penetraçăo e importância 1iterária, e dos principais jornais da cidade publicados em um periodo recente de cinco anos, identificando e analisando trechos e artigos que referiam-se á Area Portuária do Rio de Janeiro. 
X. 2. Objetivos da Pesquisa de Campo:

A pesquisa de campo a ser apresentada visou a permitir a investigacăo da percepcão da Area Portuária por fontes diretas. Estes dados foram obtidos através da aplicação de questionário (constante do Anexo III) a um determinado número de respondentes, total este definido por nós. Este total foi considerado como subdivisive1 em três sub-grupos cujas percepçôes entendiamos ser das mais importantes para os objetivos de intervencão para revitalização: os moradores da Area Portuária, os que là trabalham e os usuários eventuais.

o questionário foi organizado em quatro partes distintas, sendo que a primeira destinava-se à caracterizaça do respondente. As outras refletiam três categorias distintas de perguntas relativas á percepcăo ambiental, correspondentes a diferentes niveis do processo cognitivo e cujos objetivos eram identificar:

I) imagens e mapas mentais:

a) Em nivel das imagens mentais, verificaremos a percepçåo dos respondentes relativas ao bairro onde eram abordados pelo pesquisador, alem das diferentes imagens ambientais que compõem sua percepcão de bairro e da Area Portuaria como um todo.

b) Em nive1 de obtenção de mapas mentais dos respondentes, assim como de suas caracteristicas e elementos constitutivos, utilizaremos o método de "mapeamento indireto", atravès de questões sobre quais os elementos mais significativos no bairro e na Area Portuária. 


\section{I) atitudes/atributos:}

objetivaremos a identificacão de atributos ambientais e atitudes para com o ambiente vivenciado do respondente, através da aferição de pesos na avaliação de uma 1ista de afirmativas aplicadas, tanto a nivel de bairro quanto da Area Portuária como um todo.

\section{II ) preferências/expectativas:}

As preferências e expectativas dos respondentes relativas ao futuro da área serăo identificadas através da exposicão comparada de três cenários possiveis de desenvolvimento, acompanhados de listagens de possibitidades ambientais.

Evidentemente, o objetivo geral do questionário cujos resultados de aplicação analisaremos a seguir, consoante com os próprios objetivos da pesquisa como um todo, era o de possibilitar a obtencăo de dados percetivos que pudessem mostrarse operacionalizáveis a nivel de desenho urbano para revitalizaçăo. Entretanto, é necessário lembrar que os próprios métodos utilizados, assim como as técnicas e instrumentos, estarão inevitavelmente revestidos do caràter experimental que ainda caracteriza a pesquisa ambiental. 


\title{
CAPITULO XI:
}

\section{PERCEPCCAO DA AREA PORTUARIA}

ATRAVES DA LITERATURA E DA IMPRENSA

\begin{abstract}
"Dej uma caminhada grande; mas, sim, senhor, isto aqui é bonito, é curioso; aquelas praias, aquelas ruas, é diferente dos outros bairros. Gosto disso. Hei de vir mais vezes." (Personagem Rubião, após passeio á Gamboa e Saude, in MACHADO DE ASSIS "Quincas Borba", 1892)
\end{abstract}

A realizaça desta pesquisa tomou por base as possibilidades definidas no quadro conceitual e metodológico já evidenciado anteriormente, no sentido da importância do conhecimento ambiental indireto veiculado através da 1 iteratura e da imprensa. Evidentemente, este tipo de conhecimento se faz mais importante para aquelas pessoas que nunca foram ou pouco conhecem pessoalmente da àrea de estudo, mas tambèm serve para complementar o conhecimento direto dos usuários mais assiduos.

A àrea tradicionalmente conhecida por portuària abrange os bairros da Saúde, Gamboa e Santo Cristo e seu território jà foi definido na segunda Parte; è neste segmento que concentramos nossa pesquisa de fontes indiretas. Como interessava apenas 0 estudo de obras literárias e de veiculos de imprensa cuja importância e penetração junto á populaça carioca são indubitavelmente significativos, nossa estratégia metodológica fez-nos proceder á pré-seleção do material estudado. 
XI. 1: Método de Pesquisa:

A escolna dos romances, contos e crônicas analisados tomou por base a relevância do autor para a história literária brasileira, e carioca em particular, assim como a repercussão da própria obra junto ao público leitor. As diversas reedições das obras clássicas de até 1950 comprovam a sua permanência e o seu significado, permitindo nosso estudo. No pertodo posterior, a incidência de obras que tratam da Area Portuária é muito menor e fixamo-nos em três delas por seu caràter popular e representativo Da mesma forma, em relacão ás imagens, atributos e expectativas transmitidos pela imprensa, interessou-nos apenas as matérias publicadas nos dois maiores jornais da cidade nos U1timos quatro anos, periodo que reporta-se aproximadamente ao infcio da veiculaçăo da idéia de intervenção na área para a implantação de um centro de comércio Internacional, jà comentado no capłtulo VIII. Isto corresponde, veremos, á divulgação de imagens e atributos cuja avaliacăo do pủblico leitor tende a ser negativa, em relação ao ambiente construido e aos aspectos sociais da área. Ao mesmo tempo, estas matérias jornalisticas expunham a possibilidade de melhorias através de intervença urbana, criando diversas expectativas e perseguindo imagens ideais geradas através da veiculaça de experiências internacionais.

XI. 2. As Imagens Iransmitidas pelas obras Literárias Ana1isadas:

Cometaremos uma a uma cada obra literária analisada, destacando seus aspectos principais no que diz respeito a imagens 
ambientais, sua avaliação pelo autor e a consequente atitude transmitida ao leitor.

"Memórias de um Sargento de Milicias", de Manuel A. Almeida Publicado pela primeiravez em 1852, em fasclculos do jornal semanal "A Pacotitha", este romance foi lancado em dois volumes em 1854. Seu autor utilizava-se do codinome "Um Brasileiro" para assina-1o e ambientava-o basicamente no centro do Rio, fazendo referências claras á conceicăo e ao valongo, dois dos bairros que compõem a Area Portuària.

Retomado diversas vezes no texto, o Morro da Conceicăo apresenta-se como local para onde o protagonista deveria ser enviado para que aprendesse um oficio. A referência ao local como onde havia uma escola primária e de oficios confirma menções em pesquisas históricas, bem como no livro de GERSON (1965) a ser em seguida anatisado, da existência da primeira escola da Gamboa, bem próxima ao Morro da Conceição. Aqui existe uma imagem positiva, se tomarmos a lógica burguesa da educação como ascensão socia1, tema que è insistentemente abordado no romance.

Por outro 1ado, ainda sobre o Morro da Conceição, é 1á que - escritor localiza uma casa utilizada como refúgio constante de "gaiatos" e onde se cantava cantigas e fados em roda, referência clara de cantos religiosos de umbanda ou candomblé. Esta poderia ser tomada como uma imagem socialmente negativa da àrea.

Existe ainda uma passagem narrativa ambientada no valongo, onde recebia-se comboios de comércio de escravos. Por ser obra de carater romântico, folhetinesco, da linhagem dos de aventuras, a imagem do Valongo pode parecer um tanto superficial ao leitor, 
mas isto vai de acordo com as intenções do autor. Dizemos "superficial" pois, embora o Rio fosse á época repleto de escravos, năo hà praticamente nenhuma referência á escravidão em todo o romance, e o mercado de escravos do valongo está obviamente 1igado á questão. As cenas que deviam ocorrer neste mercado não estão bem descritas ou mencionadas; o autor parece apenas querer mencionar o Mercado sem referir-se á "mercadoria". Como esta obra constitui-se num folhetim, dedicado ao entretenimento, as passagens constituem episódios engraçados, em que não caberiam imagens que propusessem reflexões sèrias por parte do leitor. Por isto, os espacos da Area Portuária que aparecem na obra consistem apenas em cenários para o desenvolvimento das ações narrativas.

"As MuTheres de Mantilha", de Joaquim M. de Macedo.

Este popular autor também escreveu o famoso "A Moreninha", de 1845, e embora a obra analisada não tenha tido o mesmo sucesso, figura dentre os romances brasileiros mais reeditados desde sua primeira edicão em 1871. A estória é ambientada a partir de 1766 e segue a 1 inhagem dos romances históricos, reconstituindo fatos e personagens reais, citando edificios públicos e pormenorizando a vida e a fisionomia da cidade aquela época.

- romance menciona costume da época dos negociantes e homens ricos possutrem chácaras nas vizinhancas do outeiro da Glória, da Gamboa e do Saco do Alferes, estes dois na Area Portuária. Segundo o narrador "essas chácaras, porém, serviam só para o gozo dos domingos e dos dias santificados". Um dos 
personagens, pai das moças mais belas da época, "negociante de grosso tráfico, de bem merecida fama de probidade e de austeros costumes", morava com a famplia em chácara na Gamboa. Provavelmente "pelo justo receio da insalubridade e das moléstias contagiosas que com frequência eram o flagelo da cidade".

A imagem que o autor faz da Gamboa na época que se passa o romance não condiz com a que passaria ter a àrea no século XIX. $O$ mercado de escravos, dos mais fortes elementos para esta mudanca de percepcão, ainda se situava no centro da cidade, de onde seria transferido apenas por volta de 1780. O próprio autor faz a ele a referência de que "o tráfico de escravos já era então muito importante: os miseros filhos dAfrica, guardados em multidão, em depósitos, dentro da cidade, propagando nela suas moléstias...". A Gamboa, O Saco do Alferes e a Rua do Valongo são apresentados ao leitor como àreas quase que totalmente rurais, suspeitas de maus encontros, sendo conveniente andar armado e em companhia de pagens. Ele não apresenta imagens de negros, escravos ou pessoas de classe socio-economicamente inferior, que viriam a conotar a área de estudo posteriormente.

"Memórias Póstumas de Brás Cubas", "Quincas Borbas" e "Dom Casmurro", de Machado de Assis.

Estes três romances foram ana1isados principalmente atravès do traba7ho "O Mundo de Machado de Assis", de autoria de Miécio TATI, que trata das paisagens e costumes do Rio de Janeiro retratados na obra do famoso escritor. Apesar de não termos recorrido diretamente ás obras originais, o estudo de TATI é de reconhecida qualidade e facilita nossa pesquisa, no que diz respeito ás referências á área de estudo. 
Segundo MESQUITA (1986), a cidade adquire uma enorme importância na obra de Machado de Assis pois, tratando-a como espaço vivido, ela assume a mesma importância que o tempo como fator estruturante de significados. Ele a trata como uma arquipersonagem e "nesta função, ora se relaciona harmoniosamente com as personagens, principalmente com as que pertencem ãs classes dominantes, ora 1hes è hosti1, quando năo esfinge devoradora, para aqueles que não the souberem decifrar o enigma crucia1" (MESQUITA 1986: 84)

Em uma das passagens de "Quincas Borba", publicado em 1892, o personagem Rubiăo "... prosseguiria, saindo dos Cajueiros, pela Rua Larga de São Joaquim (atual Marechal Floriano), dobrando á esquerda pela Rua da Imperatriz, antiga do Valongo (hoje Camerino), ultrapassando o Largo da Imperatriz (Praça dos Estivadores), nas proximidades da Ladeira do Livramento, e atingindo a saúde, para de lá perambular pelos bairros de praia que se estendiam do Largo da Prainha (Praça Mauá) a são Cristóvăo: Praia Formosa, Saco do Alferes, Gamboa, Valongo e Saúde".

O autor continua na narrativa: "Viu ruas esguias, outras em ladeira, casas apinhadas ao longe e no alto dos morros, becos, muita casa antiga, algumas do tempo do Rei, comidas gretadas, estripadas, o caio encardido e a vida la dentro. E tudo isso the dava uma sensaçăo de nostalgia... Nostalgia do farrapo, da vida escassa, acalcanhada e sem vexame. Era bom não ser pobre!". Apesar disto, o narrador de "Quincas Borba" conclui que o lugar era bonito, diferentemente de outros bairros: "...gosto disso. Hei de vir mais vezes". 
As imagens narrativas apresentadas nestes e em outros trechos da fição machadiana nos levam a concluir que esses bairros năo serviriam de domicilio a pessoas mais bem colocadas social e economicamente, pois tratava-se de locais de gente numilde e adequados para romances clandestinos, como o do protagonista de "Memórias Póstumas de Bràs cubas". A passagem relatada acima nos permite concluir, inclusive, a existencia de favelas nas encostas do Morro do Livramento e de corticos, o que è confirmado pelos historiadores da época. Apesar disto, o Valongo, a Saúde e a Gamboa nos são apresentados pelas obras como locais apraziveis, principalmente numa referência \& paisagem natura1. Os valores socio-econômicos das classes sociais parecem ser o que caracteriza a aparente contradicăo em considerar-se os bairros da Area Portuária como bons ou não; mas eles são efetivamente locais fora dos projetos sociais dos que aspiravam á realidade da vida burguesa.

Imprimindo insistentemente a relatividade dos fatos humanos, Machado de Assis faz desta temática uma das situaçoos narrativas mais representativas de sua obra. As imagens dos bairros portuários transmitidas corroboram esta relatividade no sentido que mudam de conotaçăo de acordo com quem os olha. A tendência do leitor, no entanto, e de compreender o espaco social descrito como negativo e o espaco geográfico como positivo.

"A A Tma Encantadora das Ruas", de João do Rio.

Esta obra è riquissima em passagens descritivas carregadas de significados, definindo imagens claras do autor sobre elementos e práticas sociais urbanas, em particular, sobre a àrea 
de estudo. Em "A Rua", crônica de abertura deste livro, escrita em 1905, o autor, definindo um "flaneur", discorre "..flanar è ir por at, de manhå, de dia, á noite, meter-se nas rodas da populaça... conversar com os cantores de modinha das alfurgas da Saủde". Entenda-se por "alfurgas" ruas estreitas ou qualquer área onde se atira o despejo das casas e, em sentido figurado, pocilga ou antro.

Esta crônica trata também de costumes difundidos na época e menciona que, do mesmo modo que, em tempos antigos, os homens somavam a seus nomes o nome da cidade onde haviam nascido, "os chefes da capadoçagem juntam hoje ao nome de batismo o nome de sua rua", fazendo alusăo a Cardosinho e Carlitos da saude, sujeitos muito temidos. Isto é ainda mais significativo para o autor que entende por rua muito mais do que um conceito topo/geográfico simples.

Discorre o autor que a rua è muito mais que "...um a 1 inhavo das fachadas por onde se anda nas povoaços... a rua faz - individuo... e as pedras săo a courą̧a da rua, a resistência que elas apresentam ao novo transeunte. Refleti nessas coisas que a vida cria e haveis de compreender então a razăo por que os humi1des 1 imitam todo o seu mundo \& rua onde moram".

Em seguida, estabelere textualmente uma analogia entre o Beco da Música, su Beco da Fidalguia, e as ruas de Nápoles, Florença, Portugal e Africa, porque, explica, "são ruas da proximidade do mar, ruas viajadas, com a visão de outros horizontes... chinêses bebados de ópio, marinheiros embrutecidos pelo àlcool... a estranha vida dos portos do mar... esses becos, essas betesgas têm a perfidia dos oceanos, a misèria das 
imigraç̃es e o vicio, o grande vicio do mar e das colônias".

A partir desta crônica de Joăo do RIO é que as imagens referentes a portos, associadas áquelas especificas da saúde, transmitem idéias de vícios, vagabundos, marginais. A parte em que se refere ás ruas reforça a idéia unindo conceitos por ele definidos: se afirma que "os humildes limitam todo o seu mundo á rua onde moram" e se os que moram em regiăo portuária são, mesmo que de forma indireta, definidos com impressōes negativas, podemos concluir que a populacăo residente na área de estudo è socialmente negativa.

Em "Pequenas Profissões ou Profissões sem Academia", o narrador da crônica fala-nos ricamente de algumas profissões pequenas, de miséria: "resultado dos que não se integraram no corpo de trabalhadores das fabricas importantes e que acabam por viver do lixo, do que cai nas sarjetas, dos ratos, dos magros gatos dos telhados, são os heróis da utilidade, os que apanham o inútil para viver, os inconscientes aplicadores a vida das cidades daquele axioma de Lavoisier: nada se perde na Natureza".

Ainda nesta crônica, faz referência direta á Area Portuária na passagem "do cais via-se para os lados do mar o desenho multiforme das ilhas verdejantes, dos navios, das fortalezas. Pelos boulevards sucessivos que vão dar ao cais, a vida tumultuària da cidade... era ainda mais intensa, mais bruta1, mais gritada, naquele trecho do mercado, naquele pedaço da rampa, viscoso de imundicie e de vicios". Jà em "Tres Aspectos da Miséria", segunda parte do livro, apresenta a crônica "Os Trabalhadores da Estiva", um dado significativo de como a àrea é entendida pelo cronista. 
o repertório imagético das crônicas que se referem á Area Portuária (misèria, infelizes, pobres, gatuno, gentalha, vagabundos, ralé, mulambeiro, malandros, birbante) não deixa dủvidas á respeito da avaliaçăo que o autor nos passa sobre a área, de enorme impacto social negativo e, ao contrário de Machado de Assis, sem qualquer juizo de valor quanto ás paisagens naturais.

"Recordacões do Escrivão Isaias Caminha", de Lima Barreto.

Nesta obra, publicada em 1909, o autor faz alusăo, no Capltulo $x$, á Revolta da Vacina de 1904, uma das metas do saneamento e renovacão do Rio de Janeiro durante o periodo Rodrigues Alves, como já vimos anteriormente. Isto porque o local de maior resistência popular á vacinação obrigatória foi o bairro da saủde.

E significativo abordar esta parte da narrativa, embora o episódio seja tratado alegoricamente por Lima BARRETO como, por exemplo, tratando-o como "nascera a questão dos sapatos obrigatorios". Mesmo estando a saúde implicita, o texto trata da questão muitas vezes em tom irônico, mas sempre de maneira defensora em relação aos moradores, como quando fala sobre a "morte de... cidadăos nas barracas improvisadas". As imagens que - texto nos permite construir sobre a área são, sem dúvida, positivas, mostrando o autor ser bastante engajado nas questões sociais do seu tempo.

"Vida e Morte de M. J. Gonzaga de Sa", de Lima Barreto.

Este romance diferencia-se muito das outras obras do autor, principalmente no que diz respeito á sua estrutura, pois mais 
parece um pretexto narrativo a justificar dialogos entre os dois personagens a respeito de temas e fatos sociais tipicamente brasileiros. Publicado em 1919, seus personagens, um rapaz de uns vinte anos e um sexagenårio, passeando pelas ruas ou sentados num banco do Passeio Público, trocam idéias sobre a cidade.

A obra produzida, sem dúvida, pode ser chamada de "engajada" e, para alguns, tratar-se-ia de autobiografia. Mulato e funcionário público, Lima BARRETO dissertou repetidas vezes, principalmente em seus romances mais significativos, sobre a discriminação racial, a marginalização social e a burocracia das reparticões públicas, desmoralizando-as com razăo e ironia. Estes fatos permitem-nos interpretar com a correta significacão algumas das cenas da Area Portuária recorridas pelo autor.

Ao afirmar que "o tráfico de escravos imprimiu ao valongo e aos morros da saủde alguma coisa de aringa africana", o autor retira destes locais qualquer imagem negativa pois "aringa" era o reduto de grandes chefes tribais africanos em campos fortificados. Desta forma, a metafora empregada faz com que o Valongo e a saủde incorporem em sua imagem resistência, forca e 1uta. Jà no trecho que diz "a melancolia do Cais dos Mineiros é saudade das ricas faluas (embarcacõos) pejadas de mercadorias, que năo the chegam mais de Inhomerin e da Estrela", explicita a situacão do pałs que tem $4 / 5$ de sua história marcados pela condicão de colônia exportadora. A Area Portuária, dentro da narrativa, tem o seu eixo espacial deslocado de Rio/Rio para Rio/Europa.

Em relação á topografia da cidade, argumentando que "as montanhas e as colinas afastam e separam as partes componentes da 
cidade", Lima Barreto escreve que " a Saude, a Gamboa, a Prainhagraças aquele delgado cordão de colinas graniticas- Providência, Pinto, Nheco-ficam muito distantes do Campo de Santana". Esta forma poética e cheia de imagens positivas ao referir-se aos morros, já á época redutos de diversas favelas, demonstra bem a postura do autor frente á estigmatizacão destes lugares e de seus habitantes. Ele era um apreciador das pessoas, das paisagens e da geografia da Area Portuåria.

"O Rio de Janeiro do Meu Tempo", de Luts Edmundo.

O segundo capitulo desta obra, de 1938, sobre fatos e costumes da cidade, trata também da "Rua do Ouvidor pela alvorada do século, da elegância da grande artéria" e de como se transformava á medida que corria em direção ao mar. De acordo com - autor "a rua, que a Municipalidade de então chamava Moreira Cezar e o povo, como sempre, rua do Ouvidor, era a artèria principal da cidade, a mais elegante, a mais limpa". Dizia, tambèm, que se tratava da rua com menos aspecto colonial pois reproduzia com perfeicåo um ambiente de boulevard parisiense.

A Rua do Ouvidor, passando pelo Largo de São Francisco, Rua do Ourives, Uruguaiana e Goncalves Dias, possuia a imagem urbana onde a vida elegante do Rio mais sobressaia, trecho de trânsito obrigatório para os que chegassem á ao coração da cidade. Entretanto, dizia: "descendo-se mais um pouco, atravessando a Rua Primeiro de Março, em caminho do mar, Santo Deus! Em vez de vitrines ou de lojas, mesmo de aparência regular, o que se vê è o armazém mal arranjado e sujo, com as rèstias de cebola dependuradas pelos tectos, mantas de carne seca enodoando 
portaes, o toucinho defumeiro, á mostra o bacalhau da Noruega, o polvo seco..."

As palavras com que o autor descreve a parte da Rua do Ouvidor próxima á Area Portuaria podem ser incluidas no campo semântico de "sujeira", "desagradabilidade", "obscenidade", "palavrões", "cheirando em demasia ao pouco amável tempo da colônia". Completa o capłtu1o, entretanto, afirmando que "ao tradicionalista, porém, o trecho sujo e barulhento interessa, porque è o Rio de há cem annos atraz". As imagens fundamentais transmitidas pe1o texto ficam sendo, por um lado, a de ambiente sujo e ubsceno, pelo outro, a de área tradicional da cidade que manteve presentes as estruturas fisicas e, talvez, as sociais do passado.

"Aparência do Rio de Janeiro", de Gastão Cruls.

Este clássico, publicado em 1949, è de reconhecido valor nistórico e co-literário, tratando da aparência do Rio, seus usos e costumes do comeco do século. Como era de se esperar, a obra faz diversas referências á nossa área de estudo. Junto com a "História das Ruas do Rio", de Brasil GERSON publicada por primeira vez em 1965 e que analisaremos a seguir, è obra de referência obrigatória nos trabalhos que estudam o deserivolvimento da cidade.

Uma nota de rodapé, no segmento do livro intitulado "Ermidas", faz referência á origem do nome do bairro do Valongo, "àrea compreendida entre o Morro de São Francisco da Prainha e a Ponte da Saúde". Explica que o nome é abreviatura de "vale 1ongo", trazida de Portugal onde, no Porto, há localidade de 
igual denominação. A palavra designa, ainda, local proptcio para chácaras, o que o autor irà confirmar mais adiante no segmento "A cidade cresce".

Em "O Marquês do Lavradio", trata dos feitos politicoadministrativos do periodo 1769 a 1779 "em beneficio" da capital. o Marquês, como administrador do Rio, teria se preocupado com a defesa e tambèm em cuidar-1he da aparência, dando-lhe casas, regularizando as ruas, etc. Diz o autor que "para o Valongo... toda a zona compreendida entre a Saúde e a Gamboa- transferiu o aviltante (grifo nosso) mercado de escravos, que até ali fora feito no centro da cidade, principalmente na Rua Direita (atua1 Primeiro de Marco)". Uma vez que todo o fragmento referente ao Marquês do Lavradio é em tom elogioso e aprovador, pode-se concluir que a transferência do mercado para o valongo foi, segundo o texto, atitude feliz e passa a carregar de imagens negativas o bairro portuario, pois, capaz de receber tal equipamento.

Abordando o tema da expansão da cidade em "A Cidade cresce", CRULS afirma que do que relatou até então "pode-se concluir que o século XVIII aparece como um grande século para a nossa cidade, principalmente depois que a capital se sediou no Rio e passamos a ser governados pelos vice-reis". A cidade comeqava a delimitar melhor suas zonas centro, sul e norte, definindo como região de chácaras e sitios o que hoje conhecemos por Area Portuária. Já em outro segmento do livro, o autor diz que o intendente da cidade, em 1809, fez construir o cais do Valongo, onde Dom João mandara demarcar terrenos para novos trapiches e armazéns. Confirma, portanto, a mudança de funcões 
básicas da årea neste curto perlodo histórico, premida pela expansăo das atividades centrais.

Sabe--se que, devido ao Tratado da Amizade entre Inglaterra e Portuga1, os ingleses passaram a gozar de diversas regalias em território brasileiro. Afirma o autor que "do Principe Regente tudo conseguiam. O tratado da amizade concedera-1hes privilégios excepcionais no comércio. Podiam também ter 1 iberdade de culto e sepultar os seus mortos em cemitèrios particulares", como o cemitério protestante construldo no Morro da Gamboa em 1809.

Alguns viajantes citados por CRULS deslumbravam-se com a beleza do sitio, como a inglesa Maria Graham que escreveu em 1822 ser "aquele um dos lugares mais bonitos por ela já vistos". Entretanto, o autor nos dá suas impressões colhidas no 1ocal jả na época de elaboraçăo do seu livro e diz que "o cemitério perdeu muito do que The dava a situacăo privilegiada. A frente, as construç̃es do cais do Porto e outras minguaram-1he a vista sobre a bala e, ao fundo, onde, outrora, deviam desdobrar-se vastos planejamentos de verdura, uma horrivel favela agarra-se ao morro acima (grifo nosso)".

o autor descreve a saude como um dos vales criados pelo relevo urbano dos principais macicos a compor a paisagem carioca. Dedica também um sub-capitulo a este bairro e as imagens narrativas que transmite não são nada positivas, quando diz, por exemp10, que "a Saúde era a antitese do seu nome. Densamente habitada e sem condicões higiênicas, a vida promiscua que por a 1 i se fazia em grandes cabecas de porco e infectas baiúcas, trazia em constante preocupacão as autoridades sanitárias... Não menor trabalho dava o mesmo bairro á policia, pois que em tais 
pardieiros a rafaméia do crime e da desordem encontrava homizio seguro". Trata-se de imagens estigmatizadoras que marcam estes lugares como ocupados por classe social menos favorecida economicamente, associando-as, quase que numa conclusão, á criminalidade e marginalidade.

No capitulo "Favelas", CRULS lembra que o nome haveria de estar ligado á volta dos soldados que lutaram na campanha dos Canudos, na Bahia, e que instalaram-se com suas familias em barracos nas encosta do Morro da Providência, como relatamos anteriormente. Sua permanência, ainda segundo cruls, haveria de dar origem á favela, nome herdado da Bahia e que passou a ser utilizado para este tipo de assentamento. Refere-se também, neste segmento, à Favela da saúde, que classificou como uma das "favelas famosas" da cidade.

Interessante que, em relação á arborização da cidade, o autor admite que apenas depois da construcão de largas avenidas e amplas pracas foi que a cidade precisou preocupar-se com o sombreamento, pois antes este era resolvido pela própria proximidade do casario. Vários jardins pủblicos foram então construldos, como o Jardim do Valongo, no Morro da Saúde.

De acordo com as imagens narrativas mais fortes que CRULS constrój neste livro sobre o valongo e a saude, os dois bairros de nossa área de estudo que aborda, o leitor os associa ao mercado de escravos, cemitérios, favelas e marginalidade. Embora em alguns trechos ressalte as antigas chácaras e o Jardim do Valongo com conotacăo positiva, é muito provável que o leitor forme uma imagen bastante negativa sobre a área, principalmente no que diz respeito ao seu uso social. 
"Historia das Ruas do Rio", de Brasil Gerson.

Publicado em 1965, trata-se de excelente livro de registro histórico e, como dissemos, junto com o de cruls, jà analisado, è leitura obrigatória para todo pesquisador da história da cidade. Nesta análise 1 iterária iremos deter-nos nos fragmentos "Santa Rita e Saúde" e "Valongo e Gamboa".

o texto é extremamente rico de registros históricos, e o autor mantém uma Tinha narrativa em que descreve os fatos e os locais de forma que passa muito pouco julzo de valores, talvez numa tentativa de construir um texto historico "neutro". Mas algumas de suas observacões deixam transparecer que aqueles locais que analisamos não eram frequentados por pessoas de classe social mais favorecida, como quando diz que o ilustre paulista Alcântara Machado provavelmente nunca teria pisado ou sequer visto a rua que leva o seu nome. Ou, ainda, quando fala do a1jube (prisåo) e do "pequeno e imundo depósito de cadáveres improvisado em necrotèrio" na Ladeira da Conceicão perto do que hoje è a Rua Acre, deixando uma imagem que a àrea năo deveria ser realmente das mais agradåveis.

Entretanto, o leitor tem a melhor impressão do Morro da Conceicăo quando o autor menciona a decisăo do Bispo de fixar em seu topo casa própria, afirmando que "protegida por uma cerca de limoeiros, dela se desconcertava o mais belo dos panoramas - no mais saudável dos lugares, batido pelos ventos frescos do mar". GERSON faz também referêricias culturais bastante positivas a determinados lugares que foram berco de práticas sociais tipicamente brasileiras, como o futebol praticado na Rua do Jogo da Bola, para onde afluiam "... todas as tardes centenas de 
cariocas..." e que "... mais tarde seria o principal reduto da capoeiragem na zona da Saúde".

Por volta de 1845, afirma, junto á Pedra do sa1, também naquela àrea e recentemente tombada por seu significado na nossa cultura negra, surgia o nosso primeiro "rancho carnavalesco", o das Sereias, fundado por negros moradores do bairro da Saúde. Portanto, definitivamente, embora associe estes espacos urbanos a uma ocupaçăo por classes menos favorecidas, não se furta a associa-los tamberm a fatos culturais importantes, marcando sua tradição.

A Saude, segundo o autor, foi se convertendo em nosso principal entreposto para o comécio de madeiras e, posteriormente, de café. A partir de 1910, após as obras de construcão do novo porto, iniciativa do governo Rodrigues Alves e do prefeito Pereira Passos, o Largo da Prainha recebeu monumento a Mauà e teve seu nome alterado (atual Praça Mauà), transformando-se na "... nova sala de visita ou porta de entrada da cidade depois que os navios, ao invès de ficarem ao largo como antes, passaram a atracar no cais". Là também, no elegante ediftcio da estação de passageiros, instalou-se a sede do Touring Club do Brasil, sendo substituldo, no fim dos anos 80, por instalaçoses turisticas mais modernas e por biblioteca e museu do Porto. A praca ainda conformava importante espaco politico pois, como destaca o autor, era lá que se reuniam comunistas e anarquistas entre 1920 e 1936.

Quanto á área do Valongo, GERSON tambèm a associa ao mercado de escravos, reafirmando imagens narrativas de outros autores, como cRULS e transcreve descricões de viajantes 
estrangeiros a este respeito. Estas são sempre negativas e elaboradas a partir da "...violenta transformacăo em suas (dos escravos) vidas" e da "...sordidez das casas em que ficavam os homens, as mulheres e crianças separadas por completo, as feridas, disfarcadas com unguentos...". o autor também contrapões em seu texto o cemitério dos ingleses, o British Burial Ground na Gamboa, com o cemitério de valas comuns improvisado para os negros no 1oca1. Todas esta área, o Valongo e a Gamboa, após a ilegalidade do mercado de escravos, "...depressa adquiriram as mesmas caracteristicas da Prainha, com seus armazéns e trapiches de exportação e importacão".

Admitindo como fato peculiar a "...circunstância tão curiosa, rartssima em outros bairros da mesma gente humilde" de que quase todas as ruas modestissimas tragam nomes de pessoas expressivas na Historia oficial da cidade, GERSON talvez esteja admitindo uma tentativa daquela populacão de formalizar ou "aburguezar" simbólicamente o seu espaço para melhor aceitaçăo na sociedade.

"Rio de Janeiro em Prosa e verso", de Manuel Bandeira e carlos Drummond de Andrade (organizadores).

Esta obra foi organizada para o quinto volume da coleçăo "Rio Quatro Séculos", editada em comemoraçăo ao quartocentenário do Rio de Janeiro. Destacamos a crônica de J. B. DEBRET intitulada "Valongo: Mercado de Vidas", escrita entre 1834 e 1839. A apresentação do texto assemelha-o a um trecho de diário de viagem que parece ter a intencão de registro histórico.

Neste sentido, DEBRET se imbute do que é, ou seja, um estrangeiro possuidor de certa condicăo social que the permite 
certos ares especificos. O curioso, talvez triste, é lembrarmos que tambèm os negros escravos eram "estrangeiros" e que, portanto, deveriam ser possuidores das mesmas regalias. A crônica transparece uma visão de surpresa, curiosidade e excentricidade, próprias das narrativas "de fora para dentro", do colonizador para o colonizado.

São mencionados ainda os rituais negros e o fingimento de alguns em situaçôs especificas, como quando narra o estratagema de um vendedor para conseguir que um de seus escravos, defeituoso flsicamente, fosse também vendido por bom preco, de tal forma que - leitor è levado a interpretar como fingido o escravo, e năo o próprio vendedor. Muito embora tenhamos de levar em conta que o texto é de uma época em que a mentalidade social não permitia a incorporação do negro á sociedade, as imagens por ele transmitidas são preconceituosas e negativas, tanto as que se referem ao ambiente analisado quanto aos negros em si.

"Quatro Dias de Rebeliăo", de Joel Rufino dos Santos.

Publicado em 1980, o romance parte da rea1idade histórica da revolta contra a vacina do começo do século para trabalhar sua fiçăo, utilizando personagens reais, como Rodrigues Alves e Oswaldo cruz. O autor admite que "...nunca disseram, talvez, as palavras que eu os fiz dizer", mas justifica-se afirmando que "o processo 1 iterário em que se atribuem palavras e gestos irreais a pessoas reais è velho e consagrado".

Ambientado na saúde, o texto faz referências diretas a elementos arquitetônicos e urbanos, como as hospedarias e a Travessa da Pouca Vergonha, atual Rua do Senado. Sobre esta, 
delimita, através de seu personagem, o leque de interpretaços do leitor afirmando que "um nome assim, contudo, não faz juz á sociedade dos moradores da nossa rua. Honestos e trabalhadores são a maioria dos viventes da Pouca Vergonha". Com isto faz alusão direta aos que insistem em confundir pobreza com marginalidade. Adiante, o autor trata o cenário básico do protagonista, o acougue Transmontano, classificando-o de sujo e seboso, suas carnes de magras e secas, como a sua clientela moradora do bairro.

Quanto á construcão dos personagens moradores nos bairros portuários, o autor imprimiu-ihes a caracterisitca significativa de odjio em relaça ao poder intitucionalizado, á lei e aos seus representantes. O bairro da saude é tratado como o principal foco de resistência popular contra a vacinaça obrigatória, fato históricamente comprovado, com destaque ao Morro da concejção e adjacências. A rebelião seria também insuflada pelo "bota-abaixo" promovido por todo o velho centro da cidade, sob ordens do prefeito Pereira Passos em sua lógica de modernizaçăo das estruturas urbanas da capita1, prejudicando principalmente os moradores pobres.

"Manter a saude em poder do povo" ou "história de amor e morte" são frases recorrentes no romance e as principais imagens que contribuem para a formatacão da narrativa. A Saúde è reconstrulda na fiçăo pelo autor como um lugar em que se luta contra o poder institucionalizado e pelo povo. Seus moradores são apresentados como heróis, sem conotacões panfletảrias. Estas talvez sejam as principais imagens transmitidas pelo texto, que 
resgata toda a dimensăo social da àrea em estudo como positiva e, até mesmo, exemplar em sua ingenuidade.

"Historia dos Bajrros: Saude, Gamboa e Santo cristo: Zona Portuária" de Elizabeth Cardoso, Lilian Vaz, Maria Paula Albernaz, Mario Aizen e Roberto Pechman.

Este livro, de autoria de grupo de pesquisadores 1 igados ao Instituto de Pesquisas em Planejamento Urbano da UFRJ, foi publicado por iniciativa da João Fortes Engenharia, em fins de 1987. Talvez seja a publicação que 1 ida mais especificamente com nossa àrea de estudo em relaçáo á questão de seu patrimônio instalado, embora trate com maior propriedade das àreas residenciais localizadas nos morros 1 imitrofes ao que definimos inicialmente como àrea portuária em nosso trabalho.

Na apresentação do 1ivro, o empresário João Augusto Fortes, um dos diretores da empresa patrocinadora, esclarece que com sua publicacăo gostariam de "...contribuir com a valorizaça histórica de uma região que tende a receber interesses de desenvolvimento urbano por estar dentro da àrea centra1 da cidade -com toda a infraestrutura realizada, e próxima á necessidade de evolucăo natural do pólo principal de comércio e servicos que é o centro da cidade". Ainda segundo Fortes, "em todo o mundo vem crescendo o interesse de uso das antigas áreas portuárias como novas áreas de cultura, lazer, negócios e habitaçăo".

o objetivo principal da pesquisa dos autores è bem transmitido ao público leitor, logo em sua introdução, quando dizem que "só atravès do conhecimento do seu passado serà possivel a discussão sobre o seu futuro ainda incerto, pois novas reformas eståo sendo planejadas para a área que abrange 0 
porto...". Este é o tom que vai caracterizar todo o desenvolvimento do 1ivro, um resgate da evolução histórica da àrea, tocando em seus aspectos sociais, econômicos, e arquitetônicos. O texto e fartamente ilustrado com gravuras, mapas e fotos de época, acompanhados de densas referências.

Pelo seu conteúdo e caracteristicas, indubitavelmente teridertamos classificar este como o livro com potencial para gerar as majores influências no campo da produção de imagens em seus leitores. Entretanto, seu elevado preco e sua restrita circulação -publicado em ediçăo 1 imitada e como brinde de fim de ano da empresa patrocinadora, deverão restringir a sua penetraça junto ao grande público.

XI.3. As Imagens Transmitidas pela Imprensa:

Foram pesquisados os jornais cariocas O GLOBO e JORNAL DO BRASIL do pertodo 1980 a meados de 1988, perfazendo um total de 110 reportagens. O periodo adotado para este estudo levou em conta a incidência de assuntos relativos a Area Portuaria a partir de sua identificação como local apropriado para implementação de açóes voltadas ao incremento do comércio exportador, tanto quanto a partir da conscientizacão de seu estado de subutilizaçăo e deterioraçăo. Apenas os dois jornais for am estudados por terem sido considerados como suficientemente representativos, tanto por sua penetração regional e nacional, quanto por seu carater de ponta.

Em outubro de 1982, como vimos no capitulo VIII, foi promovido um evento chave em toda esta questão sobre a àrea portuária, a I Semana Rio Internacional, iniciativa da Associaça 
Comercial do Rio de Janeiro e da RIO-PART. Segundo reportagem publicada $\left(J B, 18 / 10 / 8 c^{\prime}\right)$, em meio aos mais de trinta eventos destacou-se um seminário cujo tema foi a "valorizaçăo e melhor aproveitamento do Porto do Rio de Janeiro".

A partir deste evento, nota-se uma maior incidência de reportayens sobre a àrea, destacando a necessidade de sua renovação e o lançamento do centro de comércio Internaciona1, dando ampla repercussão sobre a questão junto aos leitores e á populaçăo em geral.

Quanto á posicão do setor publico, tem-se mencão de que a Companhia Docas do Rio de Janeiro estaria "receptiva a qualquer sugestão que possa valorizar o Porto... inclusive á idéa de instalação de um centro de comércio internacional na zona portuária" (O GLOBO, 13/10/83). Fato este comprovado mais tarde pela declaração do presidente da Companhia, Pedro Batouli, quando afirmou que "o prédio da Praça Maua, de propriedade da Companhia Docas, que já foi ocupado pe10 Touring, poderáabrigar o embrião do centro de comercio Internacional no Rio" (JB, 09/11/84). Posicão esta que seria, entretanto, revista pelo economista $A$. Theodoro, que passaria a presidir a companhia em 1985, o que reflete o nivel contraditório tipico do posicionamento oficial de nossos órgãos pủblicos frente a questões complexas e de longo a 1 cance.

As matérias publicadas na imprensa apresentaram semelhancas entre si em relação ao conteudo dos assuntos abordados. Isto permitiu a identificação de quatro grupos temáticos afins, a saber: incremento do comécio exterior (instalacão de porto franco e de centro de comércio internaciona1), a existência de 
ociosidade nas edificacões e terrenos, referências culturais e históricas, e, finalmente, as de assuntos espectficos á Companhia Docas do Rio de Janeiro.

A grande majoria das matérias, 65 das 110 ana 1 isadas, trata de propostas e assuntos relativos ao primeiro grupo, incremento do comércio exterior. Mais recentemente, aumentou a incidencia de matérias que 1 idam com o potencial cultural da àrea, através da ocupacão de armazéns ociosos, e algumas poucas que 1idam com visôes folclóricas das áreas residenciais na Area Portuária. As matérias sobre assuntos especificos da CDRJ não nos interessou mais que marginalmente.

As caracteristicas dos três primeiros grupos de reportagens, sem dúvidas os mais importante para nossos estudos, como também no panorama de desenvolvimento da cidade, se resumem a seguir.

I) As matèrias classificadas neste grupo refletem principalmente a postura do empresariado carioca, interessado em incrementar o potencial exportador de suas industrias, gozando de vantagens crediticias e locacionais, expandindo o mercado exterior e, consequentemente, aumentando suas margens de 1 ucro.

Menciona-se as grandes dificuldades de exportar das empresas nacionais que não possuem os servicos exportadores centralizados, o que se resolveria através da implantacão de um centro de comécio internacional. Ele iria congregar instalações fisicas para negócios e exposicões, ao mesmo tempo que concentraria a burocracia institucional para os servicos de exportação. De modo a facilitar tudo isto, algumas matérias 
defendem o dinamismo e as vantagens economico-financeiras da instituição de uma zona (ou porto) franca no Rio.

Alguns exemplos das matérias do primeiro grupo săo:

"...no Porto Franco do Rio, exportadores e importadores vão movimentar, comercializar e industrializar mercadorias gozando de todos os beneficios e isencões do comércio exterior" (JB $28 / 2 / 85$ ).

"O Brasil precisa exportar mais e pode comercializar produtos de parceiros latino-americanos e africanos, oferecendo oportunidades crescentres para empresas voltadas para o comércio exterior. E o Rio deve ser base destas operações, saindo na frente de outras cidades, em termos de infraestrutura..." (empresàrio Amaury Tempora1, Presidente da RIO-PART e Vice-Presidente da Associacão comercial, in BARROS, Romualdo "Rio discute novo Centro de Comércio Internacional" in JB pg.13,4/3/85)

". . esta bateria de armazensi servirá para apoiar a exportacão brasileira, facilitando a concentração de produtos do Nordeste e do Su1, de forma a baratear o frete, que representa mais de 10\% do valor final na Europa ou nos Estados Unidos" (idem)

"O Brasil precisa passar da fase de pals exportador de mão de obra barata para a de vendedor eficiente" (JB 29/3/85).

"... Centro de Comércio Internacional do RJ, embrião de um Porto Franco e de uma Zona Franca de Comércio fluminense..." (in JB 28/10/85)

"O a 1emão, o americano ou o francês vêm hoje ao Brasil fechar negócios em São Paulo, mas não deixam de dar uma passadinha no Rio..." (empresário João A. FORTES in THYS, Bruno "Na Beira do Futuro", Caderno Cidade pag.1, JB 14/3/88)

"Esta àrea vai se transformar inevitavelmente um shoppingcenter da exportaçåo" (Marcio Macedo, presidente da CDRJ in Bruno THYS op cit.)

I) Neste grupo classificamos as materias que apresentam argumentos baseados na constatação da existência de muitas edificacões, armazèns e terrenos ociosos. Segundo matèria publicada no Jornal O GLOBO (05/7/83) estas àreas totalizariam $77.500 \mathrm{~m} 2$ ociosos e a sua subutilização é criticada e ligada diretamente ao seu potencial para receber empreendimentos 
voltados ao comércio exterior, ao lazer-cultural e ao turismo. Estas materias trazem explicitas ou implicitas as intencões de re-valorização ou revitalização da àreas portuária.

As seguintes citaçôes são exemplos representativos do grupo:

"Exportaçăo, turismo e lazer -eis a forma carioca de desenvolvimento que ... vai dar vida nova ao centro das cidade, principalmente á regiăo portuária..." ( BARROS, Romualdo "Rio discute novo centro de Comércio Internacional" in JB py.13, 4/3/85).

"Quanto ao aproveitamento da área portuária carioca, que vem se deteriorando do ponto de vista urbanistico, com velhos armazéns deteriorados, a RIOPART... produziu um cadastro Fisico... indicando terrenos e armazens ociosos que somam 77 mi1 500 metros quadrados" (idem)

"o arquiteto Oscar Niemeyer aceitou o convite para trabalhar no projeto de revitalização da área portuária carioca e vai projetar um conjunto de edificios de escritórios e centro de convenções..." ( JB 28/10/85)

"...areas disponiveis junto aos portos de Rio e de sepetiba" (JB 28/10/85)

"Hoje, existem alguns projetos de reaproveitamento da área... - mais ambicioso deles, certamente, é o de utilizar espaços ociosos das instalaçōes portuárias -o chamado retro-porto, que são galpões e armazèns tornados obsuletos pela modernização das técnicas de carga e descarga dos navios..." (THYS, Bruno "Rio comeca a redescobrir seu passado" in caderno Cidade pag.5, JB $03 / 11 / 85$ ).

"Suas (do porto) instalações, adequadas a uma época em que a própria sobrevivência do pałs dependia de importações ... eståo agora subutilizadas. Sem ter o que armazenar, desde que - pals virou para a exportaça, os depositos são usados como estacionamentos, estúdios de cinema e até barracão de escola de samba" (THYS, Bruno op cit. 14/3/88)

III) Quanto ao grupo das matèrias com referências culturais e históricas, elas geralmente permeiam as dos grupos acima desde o aparecimento do debate sobre a questão da área portuária. Mais recentemente, com o crescimento dos movimentos populares preservacionistas na cidade, veio á tona a necessidade de resgatar o patrimônio das àreas centrais cariocas, valorizando e 
divulgando o que ainda resta.

Neste sentido, as influências são as cidades européias e seus movimentos de recuperacão de centros históricos e funções residenciais e culturais. As imagens lidadas pelas matérias pressupõem sempre que os espacos urbanos são democráticos na medida em que mesclam funçóes básicamente sociais, ou seja, culturais, de lazer e residencial. E neste grupo que se inserem as referências sobre potencialidades turisticas da àrea, expressas no patrimônio e no folclore urbano existente.

Assim, são representativos deste terceiro grupo:

"Morar no centro. Por que não? Quem mora, não quer outra vida" ( $t$ 1 tulo de matéria de MEDEIROS, Alexandre in JB 19/10/86)

"Rio começa a redescobrir seu passado: Saude, Gamboa e Santo cristo só agora văo entrar no século XX" (tiłulo de matéria de THYS, Bruno in Caderno Cidade, JB pag.5, 03/11/87)

"O Moinho Fluminense comecara... o trabalho de recuperacăo da Praça da Harmonia, na Gamboa, onde está instalado, devolvendo ao local o mesmo desenho que apresentava no final do século passado. Uma iniciativa aplaudida pela comunidade e considerada extremamente simpática pelos administradores publicos que vêem no projeto um exemplo a ser seguido..." (THYS in idem)

"Carioca tem sua Ouro Preto" (THYS in idem)

"Cais do Porto vira centro Cultural" (titulo de matéria sobre transfurmaçăo de armazèns da CDRJ em complexo de 1azer/cultura1, JB pag.7, 29/1/88.

"A cultura atraca no cais: comecaram as obras no velho armazem escolhido para centro de arte" (titulo de materia in Revista de Domingo JB, $31 / 1 / 88$.

"...a própria população redescobrirá a área, porque, revitalizada, atrairá hoteleiros, donos de restaurantes, de casas de espetáculos... a secretaria Municipal de cultura recupera um velho armazém para abrigar um centro cultura1..." (THYS, Bruno "Na beira do futuro" in Caderno Cidade pag 1, JB $14 / 3 / 88)$

Todas estas matérias, não importa o grupo em que estejem classificadas, não raro fazem comparações com experiências afins 
bem sucedidas em outros palses cujas àreas portuárias tambèm sofriam de problemática semelhante, questão já por nós abordada anteriormente. As imagens apresentadas săo extremamente positivas, relatando os casos de Baltimore, Boston, Londres, Singapura, Nova Iorque, e outras metrópoles:

"A reciclagem de áreas portuárias è uma tendência mundial e o Rio não pode ficar de fora" (Amaury Tempora1, presidente da Associaçăo comercial do RJ, in THYS, Bruno "Na beira do futuro" Caderno Cidade pag. 1, JB 14/3/88)

"...utilizar espacos ociosos das instalacões portuarias... para criação de um centro de comercio internacional, a exemplo do que vem sendo feito em cidades como Londres, Nova York e Baltimore." (in THYS, Bruno "Rio comeqa a redescobrir o seu passado", Caderno cidade pag.5, JB $03 / 11 / 87$ )

"PYO exemplo de Baltimore: Cidade deve recuperacão \& ousadia de empresarios que investiram e se uniram aos politicos... uma visita que é obrigatória para os turistas" (FERRAz, sylvio in JB, Caderno Cidade pag. 6, JB 14/3/88)

Chamava-se a atença do leitor para o fato que a maioria destas experiências previam intima ligação entre a implantação de um Wor 1d Trade Center (Centro de Comércio Internaciona1) e à revitalização ou renovação da àrea de seu entôrno.

Durante todo $\circ$ perlodo pesquisado, os periddicos mantiveram aceso o interesse do público leitor pela problemática, na maioria das vezes, sem dúvidas, como recurso de "marketing" utilizado pelos fortes interesses empresariais neste sentido. A própria entrada dos grupos RIO-PART e Associação comercial na Associacão Internacional de centros de Comercio (International Association of Wor 1d Trade Centers), antes de qualquer definicăo de real implantaçăo deste centro comprova a intensidade do "1obby" e sua penetracăo nas esferas do poder publico com vistas para o futuro. 
Em termos visuais propriamente ditos, além das eventuais fotos das condiçôes atuais das edificaçôes na àrea e de imagens dos projetos no exterior, as materias parece ter tido potencial de causar maior impacto foram as que inclutram imagens de projeto de renovação oferecido pela empresa japonêsa Nippon Telegraph and Telephone (NTT). Como jà vimos no Capttulo VIII, convidada pela RIO-PART e interessada em investimentos no Brasi1, a NTT ofereceu um ante-projeto urbanistico preliminar, com maquete, para, segundo estas empresas, fomentar o debate sobre a questão. Já haviamos visto também, que a proposta era extremamente radical e modernista e causou um protesto bastante intenso dos grupos comunitários envolvidos, receiosos de que a proposta fosse imp 1 antada.

Recentemente, embora o assunto não venha sendo apresentado com a mesma intensidade pelos periódicos, ele foi retomado diversas vezes a partir da construçăo de um grande edificio de escritórios pela João Fortes Engenharia, a ser finalizado em 1990. Localizado na Praça Mauá, junto ao Morro de são Bento, no nascimento da Avenida Rio Branco, a antiga porta de entrada simbólica da capita1, o prédio pretensamente pós-moderno luxuoso tem levado a empresa a investir na recuperacão estético-espacial da Praça. O marketing do empreendimento è direcionado no sentido de captar a imagem de centro internacional de negócios e, ao mesmo tempo, "vender" a idéia de que, com a sua implantaçăo, estaria-se dando intcio a uma processo de revitalização da própria Area Portuària.

Como parte deste "marketing" a João Fortes patrocinou o lancamento de um livro que trata da evolução dos bairrus da 
residenciais da Saude, Santo cristo e Gamboa, quarto integrante de uma colecăo que vem patrocinando sobre a história dos bairros do Rio de Janeiro, anteriormente analisado (CARDoso, E. et alt. 1987). A empresa tambèm jà prepara um novo livro nesta linha, este apenas sobre a evolução da Praça Maua.

\section{4. Consideracôs Sobre as Imagens Iransmitidas ao Publico:}

Este estudo nos expôs uma ampla diversidade de imagens geradas sobre a Area Portuária carioca. Intuitivamente, uma pessoa que nåo a conheça apenas possui sobre ela imagens estereotipadas, formadas pelo folclore, pré-estabelecidas a partir de todo um conjunto de experiências indiretas que dizem respeito a outros contextos: leituras, contos, filmes, viagens, etc. Ou seja, imagens que conotam ambientes fisicos deteriorados, sujos e malcheirosos, frequentados pela prostituição e pela marginalidade, que em nossas fantasias (e na vida real até certo ponto) misturam-se muito bem com a populaçăo frequentadora de portos e suas atividades.

Entretanto, com o aprofundamento do conhecimento indireto especifico, com a leitura das obras e dos periódicos aqui analisados, por exemplo, o público leitor vai percebendo uma diversidade imagética e interpretativa, ás vezes contraditória, que The possibilita formar a sua própria interpretação daquela realidade que the es apresentada.

Evidentemente, nem todos experienciam a leitura de todas as fontes aqui apresentadas, pelo contrário, mas sem dúvida a fonte mais influente săo os periodicos. Estes possuem prevalencia na formaçăo das imagens pủblicas pois, alèm de sua facil acesso e 
"[bvia facilidade de leitura, possuem uma "aura" de imparcialidade de informação, ou de, ao menos, estar comunicando a "verdade". $\mathrm{Na}$ percepcão indireta e formaçăo de imagens sobre um tema, seja ele pessoa, fato ou lugar, é esta "imparcialidade" jornalistica que, em ủitima instância, adquirirà grande importância para o leitor. Os romances e crônicas, mesmos que muitas vezes baseados em fatos reais, são sempre entendidos como mundos construldos ao bel prazer de seus autores. Evidentemente isto será ainda mais verdadeiro se os veiculos jornalisticos são reconhecidos como "sérios", como o são O GLOBO e o JORNAL DO BRASIL; O mesmo poderia afirmar..se dos jornalistas e seu estilo.

Em nosso caso, tomando os textos analisados em sua totalidade, livros e periódicos, somente para facilitar nossos estudos, poderiamos classifica-los através da identificacão de três grupus significativos básicos de "espaços", segundo as referências principais dos textos. São eles o espaço social, o espaco fisico natural e o cultural. Por espaco social entendemos um referêncial semântico que 1ida basicamente com as relacões sociais ocorridas dentro ou relacionadas ao palco da aça. 0 espaco fisico natural diz respeito ás referências geográficas propriamente ditas, e espaco fisico cultural ás referências arquitetônicas.

A obra literária, assim como as outras manifestacões culturais humanas, é incomensurável e, por isto, porta dimensões que sempre sabem superar quaisquer esquemas em que possamos tentar classifica-las (TUAN 1976). Entretanto, neste caso, delimitamos a nossa análise e tratamos de abordar especificamente - conteudo das mensagens a partir, principalmente, da adjetivacão 
estabelecida socio-culturalmente no campo de valores positivo $x$ negativo, representando o nosso objeto de estudo. Vimos no Capitu1o IV, que é da natureza humana a reduzir os fenômenos e as percepcões a pares pólos opostos, e que esta tendência pode refletir a própria mente humana (TUAN 1980).

Esta dualidade de valores está formada a partir dos campos semânticos adotados nos textos e em suas conotaços imagéticas. Dentro deste campo de valores, a classificacăo das obras e periodicos segundo os três grupos de espaços referênciais està representada esquemàticamente atravès do Quadro 1.

No caso da obra de Manuel de MACEDO, devertamos obsorvar que a grande positividade de suas inagens narrativas com certeza se deve au fato de estar ambientado na Gamboa do século XVIII, quando sua ocupaçăo ainda era bastante rarefeita e a cidade airida ião havia sentido intensos crescimentos nopulacionais. Por outro Tado, a grande positividade também é transmitida pelo 1ivro de CARDOSO et a1. (1987) por seu próprio caráter histórico e preservacionista.

Concluindo o resultado de nossas investigações, podemos constatar que:

-. a major parte das imagens sobre a Area Portuária de nossa cidade pertence ao campo NEGATIVO, no que diz respeito ao seu espaco social e estado geral fisico-ambiental, tanto aquelas formadas a partir das obras literárias analisadas quanto, principalmente, as derivadas dos periódicos contemporâneos;

- as imagens que percebemos no campo POSITIVo referem-se, na maioria dos casos, ao espaço arquitetônico e cultural da área, os textos mais antigos evidenciando a concepcão de espaco 
tropical ou exclusivamente "natural", grande qualidade de nossa posição "abaixo do Equador".

Assim, vimos que algumas temáticas são constantemente veiculadas, influenciam o público para as imagens posstveis e, sem dúvida, colaboram para a formaçăo das imagens coletivas da Area Portuaria. Algumas destas temáticas imagéticas possiveis são: desenvolvimento da Area Portuária, dinamização da Praça Maua, o patrimônio culturâ e ambiental dos bairros residenciais (Saude, santo cristo e Gámboa), possibilidade de convivência harmoniosa entre o comércio a ser implantado e estas áreas residenciais, necessidade de intercâmbio de informações entre os diversos centros de comércio internaciona1, o incremento do lazer e do turismo na àrea centra1, etc.

As imagens existentes atualmente em torno a estas tematicas, segundo a leitura dos jornais, estão em estado latente e, como vimos, as vezei; aparecem de forma atè negativa. Entretanto, a partir do momento que se recorre a outro grupo temático, como condição prèvia, como a abertura do porto franco, renovaça da estrutura urbana e, principalmente, implantaçăo do centro de Comercio Internacional, formam-se unicamente imagens possiveis positivas.

Tudo leva o leitor a dissociar o espaco fisico cultural e natura1 do social, como se estas não fossem dimensões complementares e interdependentes de um ambiente. Assim, certas obras e matèrias jornalisticas nos são apresentadas como se o verdadeiro problema da Area Portuária fossem os grupos sociais que là habitam ou frequentam e as atividades econômicas 1 igadas ao porto, com todas as suas consequencias de marginalidade. 
Quadro 1: Avaliações ambientais segundo campos de valores por referências imagéticas nas obras e Periódicos.

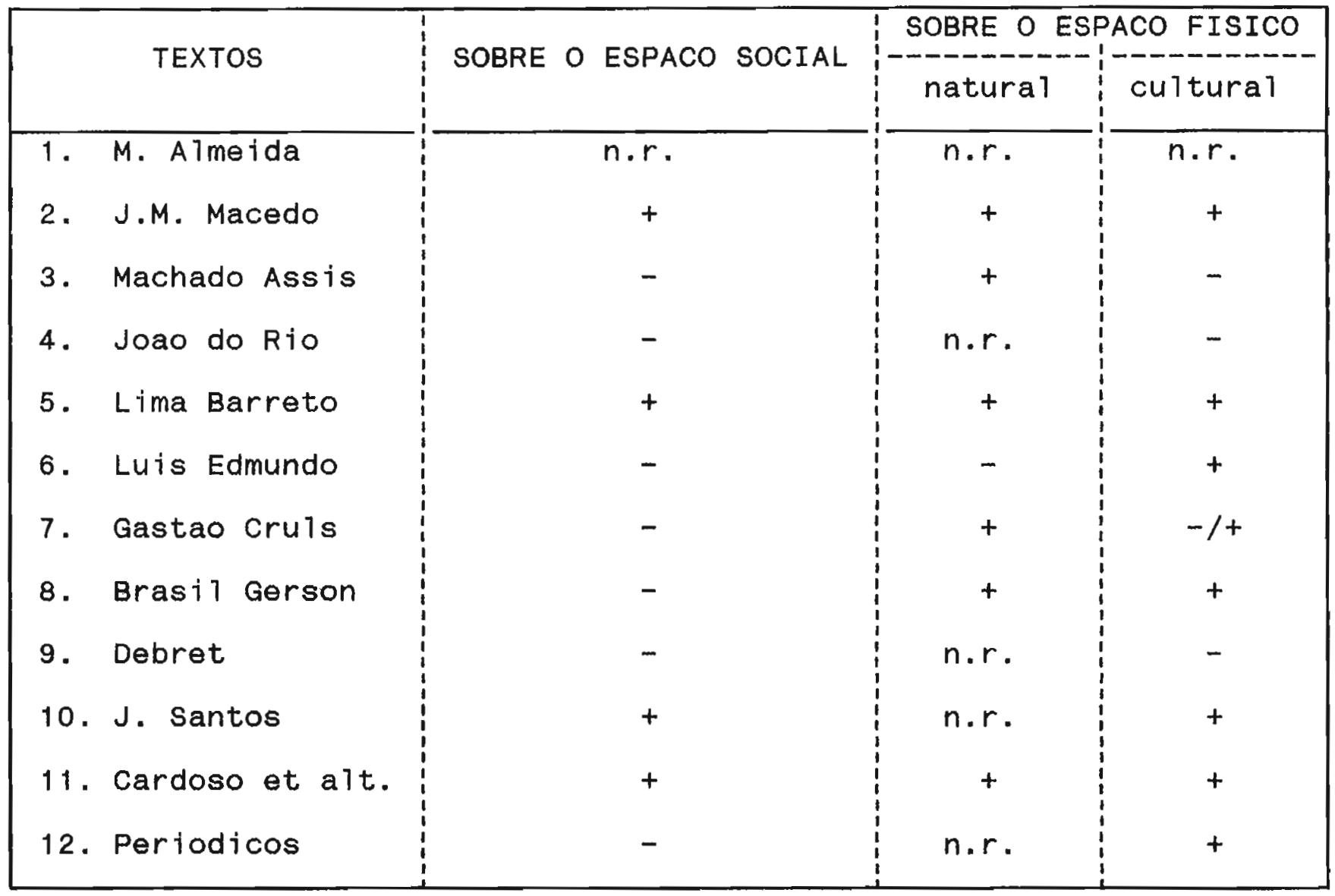

Obs.: nao faz referencia $=n \cdot r$. 
o patrimônio flsico-espacial "per se" è apresentado como atraente e historicamente importante. Seus elementos deteriorados deveriam dar vez á renovação e expansão da área central de negócios, segundo as interpretações explicitas e implicitas dos jornais atuais; seu ambiente tipico e até sua população poderiam (e deveriam) ser explorados pelo turismo e por novos empreendimentos comerciais e culturais.

A este respeito, é a multiplicidade de significados que a 1 iteratura permite, enquanto ao mesmo tempo clarifica e unifica a experiência humana, como afirma TUAN (1976). Sem dủvida, hoje compreende-se que as formas e os elementos formadores das cidades perfazem um fenômeno único com suas funcões, as idéias, conceitos, valôres e condutas associadas. As imagens transmitidas pela 1 iterátura possuem papel primordial na experiência urbana. 


\section{CAPITULO XII :}

\section{PERCEPCAO DA AREA PORTUARIA}

\section{ATRAVES DA PESQUISA DE CAMPO}

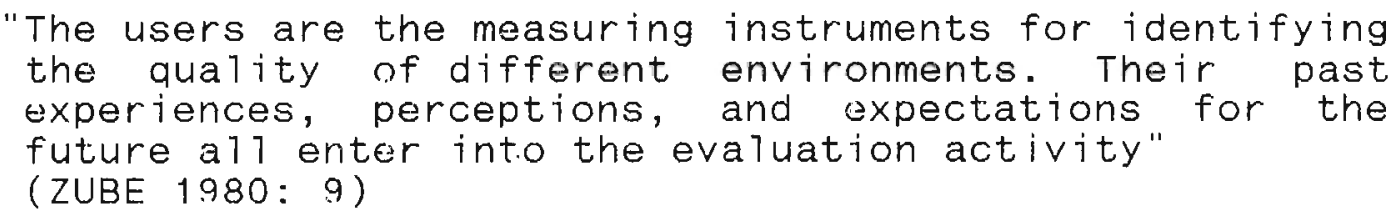

A seguir, apresentamos como foi realizada pesquisa direta sobre a percep̧ão da Area Portuária, no que diz respeito á metodologia e instrumentos empregados, caracterizaça das pessoas que responderam aos questionảrios aplicados, descricăo e anàlise dos dados obtidos. Veremos que muitos dos conceitos desenvolvidos nos capitulos IV foram identificados e confirmados, sendo o suporte para as consideracốes que faremos no próximo e ultimo Capitulo, sobre aplicabilidade dos achados para o desenho urbano e a revitalização da Area Portuària.

XII. 1. Definicões Operacionais e Instrumento de Medida:

As consideraç̃es que se seguem estarão apoiadas no quadro teórico definido na Parte I, mas principalmente no capttulo IV, relativo a operacionalizaçăo do estudo da percepcão ambiental direta para os nossos objetivos especificos. Para tanto, concentramos o nosso estudo em dois niveis do processo perceptivo: "cognitivo" e de "avaliacão/conduta". Este quadro, não só definiu os conceitos a serem aplicados e verificados, como a própria construção do instrumento de medida, o questionário ap 1 icado em campo que, será comentado em seguida. 
Segundo a conceituaça de processo perceptivo exposta em nosso quadro teórico, è ao nivel da cognicão onde se dá a formacão, estruturacăo e organizaçăo de imagens mentais. Foi neste nivel que também pudemos fazer uma distinção entre dois tipos de imagens ou representacões mentais, a que convencionou-se chamar de "imagem mental" e a denominada "mapa mental".

Primeira a ser abordada, lembramos que a imagem mental a que nos referimos, e que anteriormente já classificamos simplesmente de "imagem mental", è a do tipo simbólico, figurativo ou associativo. Já vimos também que, como esta imagem possui sentido em si mesma, ela se revela como substituicăo da realidade, ou simbolo.

o "mapa menta1" constituem a segunda categoria principal que distinguimos dentre as "imagens mentais", com o intuito de ajudar na operacionalização dos estudos da percepcão ambiental. Como dissemos no Capttu1o IV, os "mapas mentais" (tambèm chamados "cognitivos") são imagens icônicas, guardam em si algum tipo de estruturação interna entre os seus elementos formadores, e remotam a uma 10 gica operacional. F através dessas imagens, ou "mapas mentais", que nossa cognicăo é capaz de re-construir um lugar.

Já o nivel que definimos como de "avaliacăo/conduta", é onde se dà a seleça, o julgamento, a formaça de expectativas e atitudes, que possibilitam diferentes tipos de conduta final. E aqui que aparece a oposicão qualitativa "positivo/negativo" e a definicăo das preferências e expectativas ambientais.

Seguindo este quadro conceitual, portanto, definimos o instrumento de medida como um questionàrio composto por quatro 
partes complementares (veja Anexo III). Para sua definicăo foram feitos dois pré-testes no sentido de estabelecer seu desenho fina1, atentando principalmente para sua logica interna, clareza e tempo de ap1icação (ANASTASSI 1976, WHYTE 1977, MANDEL 1978, BELL 1987). Também interessava-nos atingir o maximo de confiabilidade e validade com o questionário. o tipo de questôes e opçôes de afirmativas utilizadas no questionàrio foram bastante especificas á problemática e á àrea de estudo, embora possamos afirmar que a estratégia básica de sua composicão possa ser generalizada.

As quatro partes que compuseram o questionário aplicado, os seus objetivos especificos e as suas caracteristicas, estão descritas a seguir (veja Anexo III):

Parte I do Questionário: Caracterizacão do sujeito

A primeira parte do questionário visava a simples caracterizaçăo do sujeito respondente, e buscava dados como nome, sexo, idade, ocupacão, escolaridade, domicłlio, etc (questões 1 a 9). Nesta parte também buscávamos a identificação da frequência do sujeito ao local da entrevista, bem como o motivo para a sua presenca naquele local (Questós 11 e 12).

Parte II do Questionário: Nivel da Cognicão

(Imagens e Mapa Menta 1 )

A segunda parte do questionário visou á avaliação do repertório de IMAGENS e dos elementos fisicos mais significativos dos MAPAS MENTAIS. Ambos săo componentes da cognicăo do respondente sobre a área em estudo, tanto em nivel do bairro onde se encontrava o local de aplicacão do questionário, quanto 
em nivel da Area Portuaria como um todo. Impunha-se, portanto, que as questões dirigidas a este objetivo especifico fossem do tipo com respostas 1 ivres.

A questão "Em que Bairro nós estamos?" (Questão 10) visava principalmente a verificar o conhecimento das pessoas quanto sua localizacåo, a compatibilidade de sua imagem de bairro com a delimitaçăo oficial e a forca da imagem do bairro.

As Questões 13 e 14, "Diga a primeira coisa que vem â sua cabeca quando você pensa neste Bairro" e "... quando você pensa na Area Portuária como um todo", visavam a identificar e avaliar o repertório de imagens ambientais dos respondentes.

Jà as Questões 15 e 16, "Diga quais os cinco prédios, lugares ou ruas que você mais lembra aqui do Bairro" e "... da Area Portuaria como um todo" visavam a identificar os elementos urbanisticos mais significativos da imagem mental dos respondentes em sua cognicăo definidora de "mapas mentais".

Parte III do Questionário: Nivel de Avaliacão/Conduta (Atitudes e Atributos)

Com a terceira parte do questionário, Questões 17 e 18 , visamos á compreensão das atitudes ambientais dos respondentes e dos atributos percebidos por eles, tanto em nivel do Bairro da entrevista quanto em nivel da Area Portuária como um todo.

Estas questões relacionaram dez impressões ambientais, ou seja, afirmativas onde o respondente deveria expressar a sua opinião segundo uma escala de gradação de sete pontos, desde "não concorda" (ponto -3 ) até "concorda muito" (ponto +3), passando por "indiferente" (ponto 0). Esta construçăo seguiu os modelos de escalas de atitude de LIKERT (codificacăo ordenada; no caso de -3 
$a+3$ ) e de diferencial semântico (campos de valores opostos; no caso "positivo $x$ negativo).

Foi nossa intenção utilizar impressões ambientais que, ao serem interpretadas pelas afirmativas utilizadas, pudessem estar relacionadas a aspectos de desenho urbano, ou seja, operacionalizáveis segundo nossos objetivos de trabalho.

As impressões ambientais expostas ao respondente deveriam ser entendidas segundo os campos perceptivos "positivo" ou "negativo" suscitado; portanto, as respostas puderam ser interpretadas como traduzindo visões do Bairro e da Area Portuảria, conforme os campos de concentração das respostas. Entretanto, para năo gerar uma tendência inconsciente do respondente de "escolher" sempre o mesmo lado da escala de respostas do questionário, construimos as afirmativas de maneira que fossem ás vezes positivas, ás vezes negativas, obrigando a uma maior racionalizaçăo e consciência pela resposta escolhida.

Sobre a questão da utilizacão de valôres negativos no questionário, na aplicaão năo deparamos com problemas por parte dos respondentes por incluirmos numeros negativos nestas escalas; o sistema lógico de valores das pessoas abordadas aceitavam a abstração dos números negativos como significando rejeicão.

Parte IV do Questionário: Nive1 de Ava1jacăo/Conduta (Preferências e Expectativas)

Finalmente, a quarta parte do questionàrio (Questão 19) visava a identificar as preferências ambientais dos respondentes, em termos do cenário de desenvolvimentio que Thes era preferivel e de suas expectativas ambientais. 
Aqui, novamente, utilizamos cenårios e afirmativas referentes a aspectos diretamente relacionados a possiveis intervenções em nivel de desenho urbano, perseguindo a operacionalização de nossa pesquisa.

Em um primeiro momento o aplicador expunha ao respondente os três cenários alternativos de desenvolvimento $(A, B \in C)$, que deveriam ser numerados segundo sua ordem de preferência. Definimos estes cenàrios segundo as três classes paradigmáticas de atitudes institucionais para com as åreas centrais: renovacão, revitalização e manutençăo da situaça: segundo a conceituação desenvolvida no capttulo I.

Logo depois, cinco afirmativas para cada cenário abordavam possibilidades ambientais, para que o respondente definisse a intensidade de suas expectativas relativas a cada uma, segundo uma escala de gradaçăo de três pontos, desde "menos intensa" ( $\cdots 1$ ) até "mais intensa" $(+1)$. Definimos estas possibilidades ambientais considerando as caracteristicas mais comuns que via de regra acontecem nos diferentes cenários expostos inicialmente ao respondente.

XII.2. Definicăo dos Respondentes e Técnica de Pesquisa:

como mencionamos anteriormente, a pesquisa de campo teve como método básico a aplicacão de um questionário estruturado a um total que fixamos em 250 respondentes (Anexo III). Consideramos esta número como suficiente para nossos objetivos, viabilizando estratégicamente o experimento e possibilitando uma maior qualidade no nivel da informação obtida e sua análise. 
Subdividimos este grupo populacional em três categorias distintas pois supunhamos que as pessoas que os formavam possuiam interacôes ambientais diferenciadas com a Area Portuária:

a) seus moradores,

b) os que là trabalham e

c) os que a frequentam esporadicamente.

Assim, embora tudos os respondentes possam ser considerados "usuários da área", a discussão que desenvolvemos nos Capitulos III e IV nos fazia supor que seus papeis sociais relativos á área poderiam gerar percepcões, avaliacões e condutas diferenciadas.

Portanto, alỏm da análise de quantificacões estatisticas descritivas, interessava-nos comparar os resultados e verificar possiveis semelhancas ou discrepâncias entre as percepcôes dos três grupos populacionais, sempre no sentido da operacionalização dos resultados da pesquisa para o desenho urbano.

o questionário não era simplesmente entregue ás pessoas para que o respondessem por si mas, enquanto o respondente tinha uma cópia em suas mãos, o aplicador lia as questơes e ia marcando em sua propria cópia as respostas obtidas. Esta técnica, que poderia ser considerada como próxima a uma entrevista estruturada, tentou evitar uma série de dificuldades, tanto em nivel da simples leitura e interpretacăo das solicitaçoes, quanto em nivel da facilidade de aplicaăo, receptividade do sujeito e do tempo de aplicação. Durante este processo o aplicador cuidou o máximo para não direcionar ou sugerir as respostas, através de medidas tais como não citar suas próprias impressões ou elementos fisicos como exemplos, dentre outras (ZEISEL 1981, BELL 1987). 
o tipo de escolha dos respondentes para a aplicacáo do questionário seguiu um método aleatório simples, onde pessoas foram abordadas compondo grupos de 50 sujeitos, em cinco locais da Area Portuaria, totalizando 250 pessoas entrevistadas. Definimos os locais de aplicacăo segundo um critério que partiu de sua popularidade na área e de respeito pela morfologia do tecido urbano, o que poderia identifica los como pólos ou "nós", segundo a tipologia de LYNCH (1960), quais sejam: Praça Mauà, Praça Baråo de Tefé, Praca da Harmonia, Praca Santo cristo e Rodoviária Novo Rio (Fig. 67).

Como critério para escolha dos respondentes nos utilizamos de um simples método de tentativa a cada cinco passantes, em horários e dias da semana variados, durante um periodo total de aplicacăo de quatro meses. O pesquisador, com ajuda de um auxiliar de pesquisa, procurou evitar tendências no sentido de pré-seleção inconsciente dos sujeitos. Evidentemente, houve momentos em que năo podiamos nos limitar a esperar pessoas que se prontificassem a responder o questionário apenas em um ponto especifico da àrea prè-definida para a aplicacão, mas sempre nos limitamos a percorre-1as, ou o seu entôrno mais imediato, na busca por sujeitos que se prontificassem a participar do estudo. Aproximadamente 10 a $15 \%$ das pessoas que responderam 0 questionario estavam utilizando-se de algum modo das funçoses localizadas nos pontos de coleta (bancos de praca, pontos de ônibus ou táxi, etc.).

Aliás, desta técnica podemos concluir que, em nossa pesquisa especifica, a questão da receptividade ou do interesse dos respondentes não dependiam do seu nivel sócio-econômico 


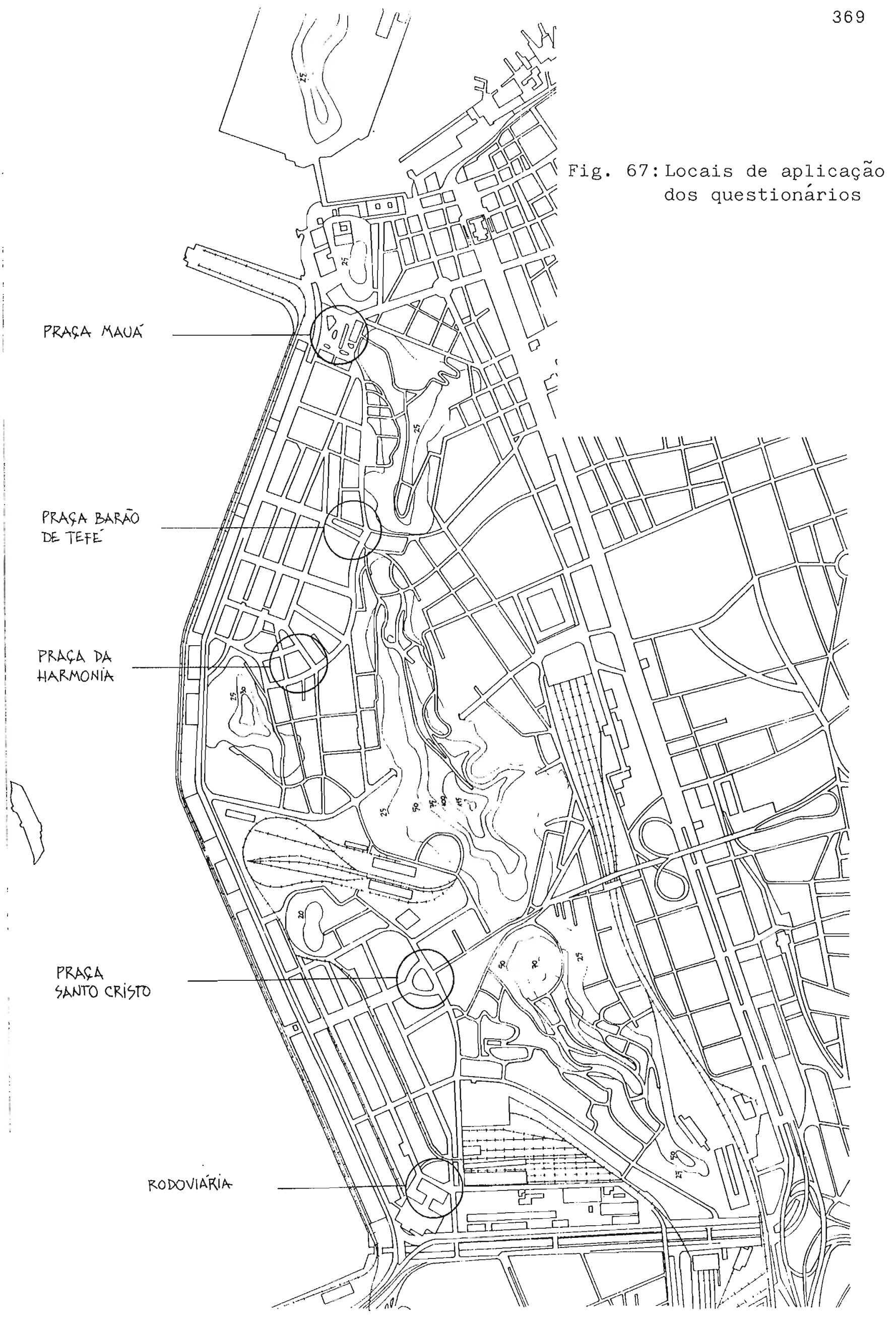


percebido mas muito mais da conscientizaça que possuiam sobre a importância do meio ambiente enquanto tema de estudo (tema exposto inicialmente pelo pesquisador em sua tentativa de aproximação).

XII. 3. Sobre a Descricăo e a Análise dos Dados:

Para sistematização dos nossos dados, obtidos dos questionários, foi inevitável recorrer a métodos estatisticos e, portanto, apresentar inumeras tabelas de dados, mesmo com o risco de tornar enfadonha a leitura do trabaiho. Mas, como já comentamos com relação a operacionalização dos estudos de percepcão, nåo nos interessava jigidez conceitual em nivel estatitico, como por exemplo, en definir o numero de respondentes de modo que ele fosse significativo em relacăo ao conjunto populacional carioca ou mesino ao conjunto de bairros envolvido diretamente nos estudos. A qualidade da informaçăo, em termos de sua profundidade, validez e aplicabilidade mostravam-se como os aspectos mais impurtantes para nossos objetivos especificos.

Por isto, além das caracterlsticas metodológicas definidas e ja comentamos acima, rolativas ao tamanho da amostra e técnica de aplicação, resolvemos nos limitar a lidar apenas com aná1ises estatisticas descritivas; mesmo porque estas próprias caracterlsticas metodológicas fazem com que a utilizacão da estatistica inferencial seja questionàvel.

A análise descritiva partiu de duas grandes classes dos dados obtidos: a primeira classe relativa aos dados gerais obtidos para o conjunto de respondentes; a segunda classe de dados respeitava a subdivisăo dos grupos populacionais principais 
que pré-selecionamos paia anảise (moradores, trabalhadores e usuários). Optamos por não continuar a subdivisăo dos grupos populacionais possiveis, como em relacăo a sexo, idade e escolaridade, pois as caracteristicas do questionário e o numero de respondentes fazem com que a criacão de muitos sub-grupos por um lado inviabilizasse as anảlises estatisticas, e pelo outro dificultasse a própria verificacão visual de diferenças significativas nas respostas.

A partir das questôes relativas a domicilio e local de trabalho, os respondentes puderam ser classificados segundo os grupos principais para análise dos dados. Os que moravam no bairro da entrevista ou em outro no local da Area Portuária foram classificados como "moradores". Os que apenas trabalhavam na àrea de estudo foram classificados no grupo "trabalham". Os demais respondentes foram classificados simplesmente de "usuários".

Como jà afirmamos, esta metodologia buscava viabilizar maior riqueza de análiso dos dados perceptivos a partir de eventuais diferenciacões significativas no perfil das respostas destes grupos e, consequentemente, em suas percepcões dos bairros e da Area Portuària. Nossas consideracões teónicas precedentes, desenvolvidas no Capttulo III e IV, nos faziam supor que isto seria verdadeiro ou que, ao menos, era o caso de verificarmos esta hipótese.

A seguir, mostraremos a descricăo e a aná1ise destes dados, apresentando primeiramente a caracterizaçăo dos sujeitos da pesquisa, seguindo-se os dados relativos ás outras partes do questionảrio: IMAGEM e MAPAS MENTAIS, ATRIBUTOS e ATITUDES, PREFERENCIAS • FXPECTATIVAS. Lembramos que em relaçăo a estas 
três últimas partes do questionario, sempré que possivel e desejáve1, analisaremos os dados segundo um enfoque global (a totalidade das rospostas obtidas), segundo o local da aplicacăo (total das inspostas espectficas a cada um dos cinco locais) e segundo os três grupos populacionais definidos.

Todas as Tabelas construldas a partir da análise dos dados obtidos em nossa pesquisa de campo, através da aplicaça dos questionários, eståo destacaddas no Anexo IV, pois consideramos que a sua insercão no corpo do trabatho interromperia em demasia a fluidez de sua leitura.

XII. 4. Caracterizacăo dos Respondentes:

A Tabela 11 mostra a distribuicão dos 250 respondentes por sexo e faixas etarias; 188 (75.2\% da mostra) eram homens e 62 (24.2\%) mutheres. A faixa etaria de 21 a 30 anos revelou-se ser a de maior incidência de sujeitos, com um total de 85 (34.0\%), seguida da de 31 a 40 anos com 75 (30.0\%); a faixa que menos sujeitos apresentou foi a de 15 a 20 anos de idade, com 19 $(7.6 \%)$.

Resolvemos näo utilizar como respondentes sujeitos com idade inferior a 15 anos pois, conforme conceituads em nosso quadro tedrico dos capttulos III e IV, julgamos esta como idade limite onde a percepcåo, principalmente a formaça de atitudes e preferências, jà se encontra mais consolidada.

o cruzamento entre as categorias de sexo e escolaridade encontra-se na Tabela 12, onde a maior incidência de respondentes revelou-se como com o Primeiro Grau completo, totalizando 56 (22.4\%) pessoas. Estes totais foram seguidos de perto pelos 
relativos a sujeitos com o Terceiro Grau completo ( 52 sujeitos; 20.8\%) e Primeiro Grau Incompleto (51 sujeitos; 20.4\%). Quanto ao Segundo Grau, 31 respondentes (12.4\%) o tinham completo e 26 $(10.4 \%)$ incomp 1eto.

A Tabela 13 mostra a distribuicão de sujeitos segundo domictlio e tempo de moradia, revelando que a maior incidência foi dos que moravam em outras partes do Rio, num total de 158 respondentes $(63.2 \%)$. O tota 1 de moradores da Area Portuaria foi de 60 (24\%), dos quais 36 sujeitos (14.4\%) moravam no próprio bairro da entrevista. Quanto a sujeitos moradores fora do Rio, a incidência foi de $31(12.4 \%)$.

os locais de aplicação de questionàrios uue se revelaram com maior incidência de respondentes de fora do Rio foram a Rodoviária Novo Rio e a Praca Mauá, resultados estes que eram esperados uma vez que junto a estes locais encontram-se, respectivamente, os terminais rodoviàrios interurbano e o metropolitano, como vimos no capitulo VII.

Parä os objetivos do nosso estudo, agrupamos estas categorias em apenas três, como afirmado anteriormente, e do total de 250 respondentes, cada uma apresentou os seguintes totais: 60 pessoas ( $24 \%$ ) que "moram" na Area Portuaria, 107 que $1 a ́$ "trabalham" (12.8\%) e 83 (33.2\%) "usuários" (frequentam eventua 1 mente)

Quanto ao tempo de moradia e trabatho dos respondentes na Area Portuaria, as Tabelas 13 e 14 nos revelam que houve uma distribuicăo bastante equitativa de moradores do bairro da aplicacão ou da Area Portuária, com 1 igeira acentuacão nos grupos mais antigos. Ao contrário, a maioria dos respondentes que 
trabalhavam na Area Portuária pertenciam aos suh-grupos com menos de 10 anos de 1 igação com a área.

A Tabela 15 revela a frequência dos grupos: de respondentes aos locais da entrevista, dividida em semanal, mensal e raramente/de ve? em quando. Dos 250 respondentes, 158 frequentam - $10 c a 1$ onde responderam ao questionario semanalmente (a maioria com frequências superiores a 5 vezes), revelando uma relaça bastante intensa com o lugar, tanto pela própria frequência, como por ter escolnido a alternativa de relacão semanal do questionário para responder, em detrimento das outras categorias existentes de frequência. Os respondentes que revelaram uma relaça mensal com o lugar foram 34, dos quais o maior grupo o frequenta pouco ( 14 pessoas, uma vez por mês), embora de forma cunstante. Uin total de 42 pessoas revelou uma relacåo pequena com - 7ugar, ao optar por definir sua frequência como "de vez em quando" ou "rara" (a menos intensa).

A razão de encontrar-se no local da aplicacăo foi definida atravès da Questăo 12 e a Tabe la 16 nos revela alguns dados:. Um tota1 de 125 respondentes (50\%), a maioria, justificaram ostar no $10 c a 1$ por "trabalhar perto", enquanto a segunda maior incidência foi de motivo foi "passagem" pelo local, respondido por 52 pessoas (20.80\%). Ora, ambas as categorias são semelhantes, o que revela certa dificuldade do respondente em assumir uma razão especlfica. No local de aplicacão mais inserido ao centro de Negócios da cidade, a Praça Maua, a incidência de justificativas de frequênuia por "trabaihai peito" foi de 58\%, enquanto na Rodoviária, a maioria das pessoas (80\%) admitiu estar ali "de passagem" . 
Previsivelmente, a maioria do grupo dos "moradores" da Area Portuária responderam que estavam naquele local por "morar perto", a maioria do grupo dos que "trabalham" estavam 1à por "trabalhar perto", enquanto a maioria do grupo de "usuários" responderam que estavam 1à de "passagem".

Como conclusão, podemos dizer que os dados quantificados através das respostas dos questionários aplicados, nos revelam que as caracterlsticas dos respondentes correspondem ao que seria esperado como referindo-ise a transeuntes médios de uma área urbana com os aspectos revelados no Capttulo VII. Básicamente vimos uma incidência três vezos superior de sujeitos do sexo masculino, com uma concentracão de respondentes nas faixas etarias intermediárias. A distribuicăo relativa da escolaridade também mostrou um perfit semelhante, exceto pela incidência de um numero significativo de respondentes que responderam 'ser universitarios; um fato talvez explicado pela proximidade do Centro e o caráter de $10 \mathrm{ca} 1$ de passagem dos pontos de aplicacão. A relacăo dos respondentes com a Area Portuária também revelou-se bastante intensa, tanto em termos do tempo de moradia ou trabalho na Area Portuária, como em relaçăo á intensidade da frequencia ao $10 \mathrm{a} 1$ da aplicaçăo.

XII. 5. Imagens e Mapas Mentais:

A Parte I do questionário buscava, como vimos, identificar imagens e mapas mentais. Para tanto, incluia as Questões 10 ("em que bairro iós estamos?"), as Questões 13 e 14 ("a primeira coisa que vem â cabeca quando pensa..." respectivamente no bairro e na Area Portuaria) e as Questões 15 e 16 ("os cinco elementos 
flíicos que mais lembia..." respectivamente no bairro e na Area Portuária) (vide Anexo III).

As respostas á Questão 10, sobre em que hairro o respondente se encontrava no momento da aplicacão do questionário, foram classificadas segundo categorias que incluem não só os nomes populares pelos quais alguns dos locais da área de estudo são conhecidos, mas também os nomes dos bairros oficialmente definidos pelo poder municipal assim como as categorias "não sabe" e "zona portuária". A distribuicão destas respostas encontra-.se na Tabela 17 .

As respostas obtidas ás Questões 13 e 14 (Tabelas 18 e 19), relativas ás primeiras imagens recorrentes do bairro de aplicação e da Area Portuária, furam classificadas segundo dez categorias imagéticas diferentes: nove relativas a aspectos fisicoambientais gerais e uma relativa a elementos fisicos.

As categorias relativas a aspectos fisico-ambientais foram consideradas como dentro dos campos perceptivos explicitamente "positivo", "negativo" ou "neutro". Esta definição operaciona1 baseia-se nos conceitos de dualidade perceptiva da mesma forma que ofizemos para a análise de publicações no cap1tulo XI.

Assim, as categorias adotadas para classificação das respostas do questionârio ás Questões 13 e 14 sobre "primeiras imagens", e os seus campos perceptivos, foram:

- abandonado (‥): respostas sugerindo estado de abandono da área

- inseguranca $(-\cdot)$ : respostas sugerindo sentimento de inseguranca ou presenças indesejàveis na área;

- falta infraestrutura (--): respostas sugerindo descaso das autoridades e/ou mal funcionamento de servicos urbanos; 
- mà impressăo (-): resposta refletindo um sentimento negativo geral mas sem ter expressado especificidade;

- gosta (+): resposta sugerindo sentimento positivo geral mas sem ter expressado especificidade;

- passagem/comercio (neutro): resposta relativa ao uso para passagem em percurso ou para compras/servicos.

- traba1ho/escola (neutro): resposta relativa ao trabalho/escola ou local de trabalho/estudo do respondente;

-. atividades portuarias (neutro): relativa a motivos portuários

- motivo da visita (neutro): resposta diretamente relativa á razăo do respondente estar naquele local, caso diferente das anteriores ou eminentemente pessoal (como pessoas, noiva, etc)

-.. elemento flsico (neutro): resposta como um elemento fisico segundo a tipologia "rua", "edificacão" e "lugar".

Tambèm inclutmos as categorias de "não respondeu" e "não vảilda", esta ủltima para respostas inconsequentes, não localizadas ou fora da àrea de estudo.

Para trabalharmos com dados relativos a elementos fisicos nesta parte do questionário, foi composta uma 1 istagem daqueles citados nas respostas as Questões 13, 14, 15 e 16, o que revelou um total de 107 elementos vàlidos, isto é, que se encontravam dentro dos limites de nossa área de estudo (Anexo $V$ ). classificamos estes elementos em três categorias tipológicas imageticas: "ruas", "edificacões" e "1ugares".

A identificacão de cada tipo de elemento fisico năo faz merecer nenhuma observaçăo especlfica, exceto no que diz respeito ao elevado da Perimetral, classificado como "via", e no que diz respeito a ter considerado respostas do tipo "as boites da Praca Mauà", a serem classificadas como citando um "lugar", e nåo uma edificacăo especifica. Esta listagem nos serviu para identificar a tipologia de todos elementos citados nas respostas (Anexo $V$ ). 
As Questôes 15 e 16 exploraram os cinco elementos fisicos que os respondentes mais lembravam do Bairro da aplicaçăo do questionário e da Area Portuảria. Neste caso interessava-nos, a 1ém do conjunto dos elementos citados, aquele citado em primeiro lugar, uma vez que supunhamos que esta ordenaçã equivalia da "intensidade" cognitiva do elemento para o respondente.

XII. 5.1. Territórios dos Bairros:

Com a Questão 10, "Em Que Bairro Nòs Estamos?", objetivavamos obter dados que possibilitassem anàlisar: o quanto - 10ca1 de aplicação era percebido como um "Bairro", a margem de acertos das respostas e a compatibilidade desta percepcáo com os limites oficiais dos bairros. Atraves da Tabela 17 e da interpretação espacial de sua anàlise (Fig. 68), podemos verificar alguns aspectos interessantes das imagens dos bairros segundo os respondentes.

A Praça Mauá, embora nåo constitua oficialmente um bairro, obteve um dos grandes indices de respostas: a maioria das pessoas naquele local (48) a reconheciam como "bairro" (mesmo todos os moradores das redondezas); o mesmo tendo acontecido na na Praça Barão de Tefé, jà distante dali, onde a grande maioria (37) respondeu que se encontrava no "bairro" Praça Mauá. Segundo a delimitação oficial da Prefeitura, ambos os locais de coleta encontram-se no bairro Saude (vide Figs. 48 e 67 ).

Outra incompatibilidade de percepcăo de território de bairro transmitida pelas respostas foi encontrada no ponto de coleta Praça da Harmonia, oficialmente localizada no bairro da Gamboa. Ali apenas duas pessoas, ambas do grupo dos que 
Fig. 68: Mapa indicativo das percepções relativas aos territórios dos Bairros (Questão 12).

LoCAL de APHicáä́ DE QUESTIONÁRIOS

RECONHECDDO UM BAIRRO

"PRAGA MAVÁ" QUE SE EXTENDE

iS IMEDIRGOES DA PRAGA

baráo de tiEE"

(oficialmento bairro saúde)
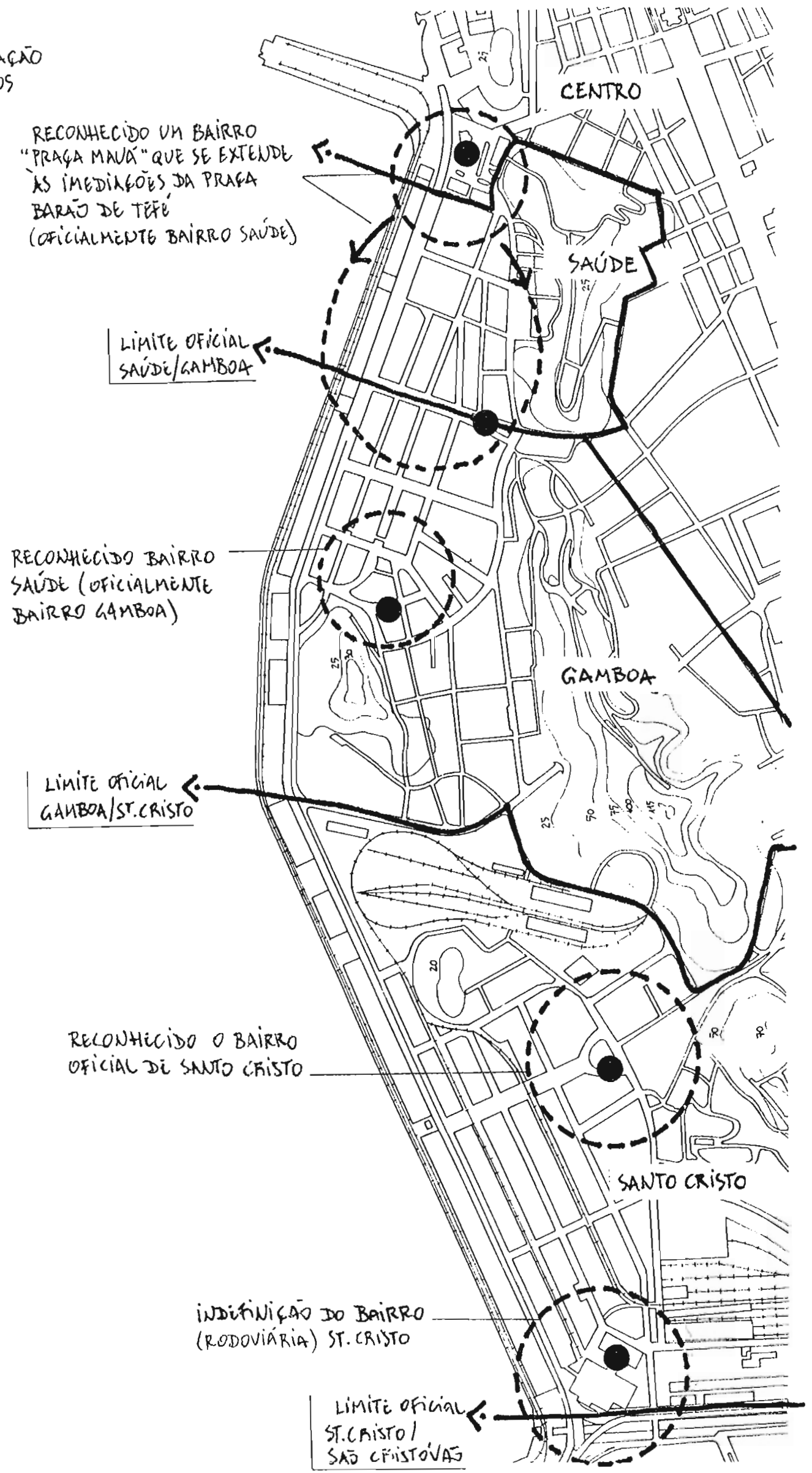
"traba1ham" na Alea Portuária, responderam o nome oficial. A grande maioria (33) respondeu que encontrava-se no bairro da Saủde; com uma única excessão, os respondentes "moradores" neste local também o classificaram como no bairro da saúde.

os maiores indices de coincidência das respostas com as delimitaços oficiais deu-se, indubitavelmente, na Praç Santo cristo, localizada no bairro de Santo cristo. Neste ponto de coleta, os 50 respondentes daquele local de aplicaça acertaram em que bairro se encontravam.

Enquanto isto, como se previa devido á grande presenca de respondentes apenas "usuàrios" dos pontos de aplicaçăo, o maior Indice de respostas "não sabe" aconteceu na Rodoviária (31), embora o número de respostas certas (Santo cristo, 11) haja sido superior ao que esperávamos.

Quanto a diferenciacooses entre percepcões de bairros nos 1ocais de aplicaçăo pelos três grupos populacionais, a Tabela 17 também nos permite verificar que nåo aconteceram grandes heterogeneidades. Encontramos apenas pequena diferença de percepcões destes grupos na Praça Barão de Tefé (maioria a identificava como no "bairro" Praca Maua), onde dentre o grupo "trabalham" alguns (5) acertaram o nome do bairio; um número significativo de moradores errou nas respostas.

XII. 5.2. Sobre os Territórios dos Bairros:

A análise dos dados possibilitou constatar fortes incompatibilidades entre bairros percebidos pelos respondentes e as delimitaçoses oficiais da Prefeitura. A Praca Maua mostrou-se muito presente na percepcăo como bairro e foi uma referência 
constante nas respostas do questionário, extrapolando limites e imporido-se como um "bairro" na percepcăo dos respondentes; fato registrado com intensidade até nas respostas obtidas na Praca Barão de Tefé. A percepçăo dos respondentes também mostrou incompatibilidade com a denominação oficial na Praça da Harmonia, onde a maioria das respostas identificava o bairro como saúde, embora oficialmente seja denominado Gamboa.

O Indice de respostas erradas ou de respondentes "usuarios" que ignoravam em que bairro se encontravam mostrou-se muito elevado na Rodoviária, localizada no bairro do Santo cristo, como poderia se supor a partir de sua utilizacão como equipamento de uso temporário e comutacião.

o unico local de aplicacao de questionarios onde houve uma srande compatibilidade, aliás obtendo indice máximo de acertos, entirn as respostas e a denominaço oficial foi na Praca de Santo Cristo.

Os achados nos permitem concluir da validade de dois conceitos básicos dentro da yuestão da percepcão dos territórios dos bairros e já desenvolvidos no quadro teórico dos capttulos IIJ o IV. Primeiramente, o conceito de "imageabilidade" (LYNCH 1960), que como vimos refere--se basicamente á importância de uma forte constância de alguma àrea ou elemento físico na percepcão e cognicão ambiental dos seus usuảrios.

Em segundo lugar, as evidências também parecem reforcar os achados de $\operatorname{LEE}(1974,1976)$ que, como vimos, definia o bairro coino unidade socio-espacial, no sentido de uma percepcão de imagem funcional mais ou menos homogênea uujo território è definido socio-espacialmente. 
Neste sentido, acreditamos que devemos destacar a importância da funcionalidade, relativa ao cotidiano dos respondentes dos locais de aplicacăo dos questionários, na formaçåo e constância da imagem dos bairros. Esta funcionalidade pode se expressai pelo uso do espaco em si, como percurso entre origem e destino, de seus equipamentos especificos, como é o caso do mobiliàrio das praças, ou dos equipamentos e edificações á sua volta.

Finalmente, a percepcăo dos respondentes exposta por nossos dados nos permitem concluir a predominância de três áreas-bairros no tierritorio da Area Portuaria por nós estudado. são eles a Praça Mauá, a Saúde e o santo Cristo.

XII. 5.3. Imagens dos Bairros:

Em seguida, a Questão 13 buscava identificar a "primeira coisa que vinha á cabeca "quando o respondente pensava no bairro onde se encontrava no momento da aplicação do questionário; estes dados estão expostos na Tabelá 18 e 19

A Tabela 18 apresenta a distribuicăo de respostas por categorias imageticas, as quais jà comentamos acima, segundo os bairros e grupos de respondentes. A Tabela 19 apresenta a distribuicăo das respostas que fizeram uso da categoría imagètica "elemento fisico", segurido a tipologia classificatoria de: "ruas", "edificacões" e "lugares". Primeiro faremos a análise dos dados segundo os totais gerais de respostas obtidas e, depois, segundo os totais obtidos para cada local de aplicação.

No gera1, entre as categorias imageticas destacou-se "inseguranca" como a mais citada com 24\% das respostas (60 
respondentes) socuido da categoria "elemento ftsico" com $21.2 \%$ (53 respostás), e dos aspectos "abandonado" (18. 8\%), "trabalho/ escola" (12.8\%), "motivo da visita" (8\%) e "falta de infraestrutura" (8\%). Entretanto se atentarmos, algumas destas categorias podem ser ainda agrupadas por suas semelhancas: "trabalho/escola" e "de passagem ou utilizar comercio" podem ser aglutinados a "motivo da visita" (por serem relativos ao motivo do respondente encontrar-se no 1oca1) e "abandonado" pode ser aglutinado a "falta infraestrutura" (por serem lelativos a administraça ambienta1). Turlamos assim os resultados ordenados: "abandonado/falta infraestrutura" (67 respostas), "inseguranca" (60), "trabalho/escola/motivo da visita/passagem/comercio" (57) c "elemento flsico" (53).

Pela grande incidência de respostas em categorias imageticas consideradas no campo perceptivo negativo, ficou ovidenciado que a imagem dos bairros da Arca Portuária, segundo a totalidade dos respondentes, è "negativa".

Apenas $1.8 \%$ do total de respondentes, ou seja oito pessoas, năo responderam a esta questăo, sendo metade delas "usuárias". As respostas classificadas como " não và1 idass" também se reduziram a três. os resultados destas categorias não permitem que reprosentem maiores consequências para nossa andi ise.

A categoria "atividades portuárias", ao contrário do que se poderia esperar, não se mostrou como imagem presente na porcep̧ão des bairros. Notawse que, alóm dos numeros terem sido extremamente baixos, rienhum dos que a citaram era "morador".

Quanto aos dados especificos relativos aos cinco pontos de coleta, houve concordância quasse que total quanto ao aspecto 
"inseguranca" em primeiro lugar, exceto na Harmonia, onde a primeira imagem mais citada foi "abandonado". De qualquer forma, também a nivel das respostas nos diversos pontos de coleta, podemos repetir o raciocinio que fizemos mais acima, quando mostrávamos que as respostas revelaram uma tendência dos respondentes de perceberem os bajrros das áreas de aplicacão como sofrendo de conservação e de questõos ligadas á administração municipal do espacio público.

Apenas em relaçăo ao santo cristo verificou-se respostas na categoria especfficamente "positiva", onde 6 respostas conotavam imagen: classificáveis na categoria resumida a "gostam". Tambem foi no santo cristo que pode--se notar uma distribuicão mais equitativa das respostas nas categorlas imagéticas. Aqui, o elemento fisiou mais sitado foi a Praca do santo cristo, com 3 votos, sondo o unico elemento com mais de um voto dos citados neste $10 \mathrm{ca} 1$.

Em todos os locais de aplicaça notamos uma média significativa de respondentes que citavam a própria razăo de 1 a estar cumo a primeira imagem recorrente, elegendo as categorias "motivo visita", "passagem/comercio" e "trabalho/escola". Este fato acontece mais intensamente no sub-girupo populacioiral dos que "trabalham" na area portuária, onde 36 pessoas $(33,98 \%)$ apresentaram estas três categorias de imagein.

Quanto ao conjunto da totalidade de pessoas entrevistadas, a percepcáo de bairros da Area Purtuaria revolou que 131 delas, ou seja $: 2,40 \%$ do total, responderam dentro do campo imagético negativo. 
Aprofundando um pouco mais a anàise da mesma rabela 18 em relacăo aos três diferentes grupos populacionais, outros resultados ainda podem ser destacados. Pelos dados gerais, nota.. se que do total de 83 "usuários", 51 (61,45\%) tiveram como sua primeira imagem recorrente uma imagem "negativa". A cateyoria imayética de maior incidência foł "inseguranca", com 23 respostas $(27,7 \%)$.

Podemos observar um campo perceptivo 1 imitado e bastante negativo que se destaca nos respondentes do grupo "usuários" na Rodoviária, que totalizaram 40. Destes, 28 possuem primeiras imagens dentro das categorias de respostas classificadas como "negativas". Da mesma forma, todos ostes "usuàrios" que citarain elemento fisico como prinoira imagem neste local de coleta, uti 1 izaram o próprio prédio da Rodoviária como referência.

Fato similar ocorre com o grupo dos 107 respondentes que "trabaiham" na Area Portuária, pois a maior incidência de respostas e destacada nas categorias "inseguranca" (21), "abandonado" (14) e "falta infraestrutura" (9). Entretanto, ainda maior è a incidência de respostas neste grupo relativas a imagens de seu proprio trabalho que totalizam 32: categorias "traba1ho/escola" (27) e "motivo da visitáa" (0).

Quanto ao grupo de "moradores", 60 no tota1, o campo perceptivo também è bastante negativo no geral, a maior incidência de respostas na categorias "inseguranca" (16) e "abandonado" (19). Não consideramos "abandonado" cumo a primeira entre os moradores pois o resultado final foi "puxado" pela alta incidência desta categoria nos respondentes moradores na Praça da Harmonia $(12 ; 20 \%)$. Por outro lado também pode-se afirmar que os 
"moradores" possuem uma imagem "negativa" de seus bairros pois 36 respostas, ou seja, $60,6 \%$ foram relativas a categorias negativas. Finalmente, no que diz respeito á categoria inagética de elementos fisicos, a Tabela 18 apresenta os 3 mais votados pe10 conjunto de respondentes, em cada Bairro, desde que a soma total fosse difaronte de 01 (um): como foram poucos, não faria sentido subdividf.los ainda mais identificando os três mais votados em cada uma das três categorias populacionais.

Jà a Tabela 19 apresenta a distribuicăo de respostas de primeira imagem "elementos flsicos" segundo a sua tipologia imagética: "ruas", "edificacôes" e "lugares". Pode-se notar a incidência da tipologia de "edificacôes" (26 respostas) seguida pela de "lugares" (14), tanto no conjunto de rospondentos quanto dentre os diferentes grupos e locais de coleta de entrevista.

Dos grupos dos que "trabalhain" na àrea e seus "usuários", respectivamente $20.6 \%$ e $20.5 \%$ das pessoas recorreram a "elementos fisicos" como primeira imagem, enquanto entre os "moradores" o total foi de $16,7 \%$. Resultados semelhantes em termos relativos aos $21.3 \%$ obtidos para a totalidade dos respondentes que recolreram a esta categoria, como observamos anteriormente.

Os resultados relativos a esta categoria imagética parecem indicar que os elementos flsicos que se destacaram como primeira imagem mostraram ser aqueles de forte "imageabilidade" devido a seu USO e, 10 caso de Ruas, por sua importância como elemento de 1 igacăo/circulaça (que também refere-se a uso), mais do que scus aspectos unicamente visuais: Rodoviária (9), Rua Sacadura Cabra1 (5), Hospital dos Servidores (5) Quartel da Pollcia Mi1itar (4) e as Pracas Mauà (4), Harmonia (3) e Santo cristo (3́). Destes, os 
$\hat{\wedge}$ nicos que podemos dizer apresentam aspectos visuais mais destacados são o Quartel (estilo neo-medieval), a Praça da Hainonia (em frente ao quartel, com coreto e forte preserica historica) e a Piraca Santo Cristo (Igreja e àrea arborizada com mesas de jogos: .

Os resultados parciais de dois pontos de coleta especificos também parecem confirmar esta conclusão. Na Rodoviària, para todos os respondentes cuja "primeira imagem" era elemento fisico, a unica roferência citada foi a própria Rodoviària, elevando-a com isto á categoria de mais votada. Sem dúvida este resultado devo-se a que a majoria dos respondentes naquele local eram "usuarrios", cuja referência ftisica mais facil era a da própria edificąăo onde se encontravam. Na Praça Barão de Tefé foi onde se registrou mais respostas nesta categoria e onde maior variedade de elementos foram citados. observamos que este local de aplicacăo é importante foco de atividades (ponto de taxi, passagem, etc), junto do Hospital dos servidores e a importantes vias de penetraçă, como a Rua Sacadura Cabra1.

- mapa constante da Figura 69 apresenta um resumo indicativo dos principais achadus relativos ás primeiras imagens mais recorrentes ras iespostas á Questão 13 , em nive1 de percepcão de bairro, relacionados com cada local de aplicação de questionarios.

XII. 5.3. Sobre as Imagems dos Bairrus:

Nossa investigacão leva-nos a concluir que o campo perceptivo das primeiras imagens recorrentes relativas aos bairros da Area Portuária, tanto para a totalidade dos 
Fig. 69: Primeiras imagens referentes a Bairros (questão 13) mostrando categorias imagéticas principais e os elementos físicos mais citados.

[N] ELEMENTO FISICO

(N) LOCAL DE APLICAGÃO A QUE SE REFERE

(D) CATEGORILS IMAGETTICAS
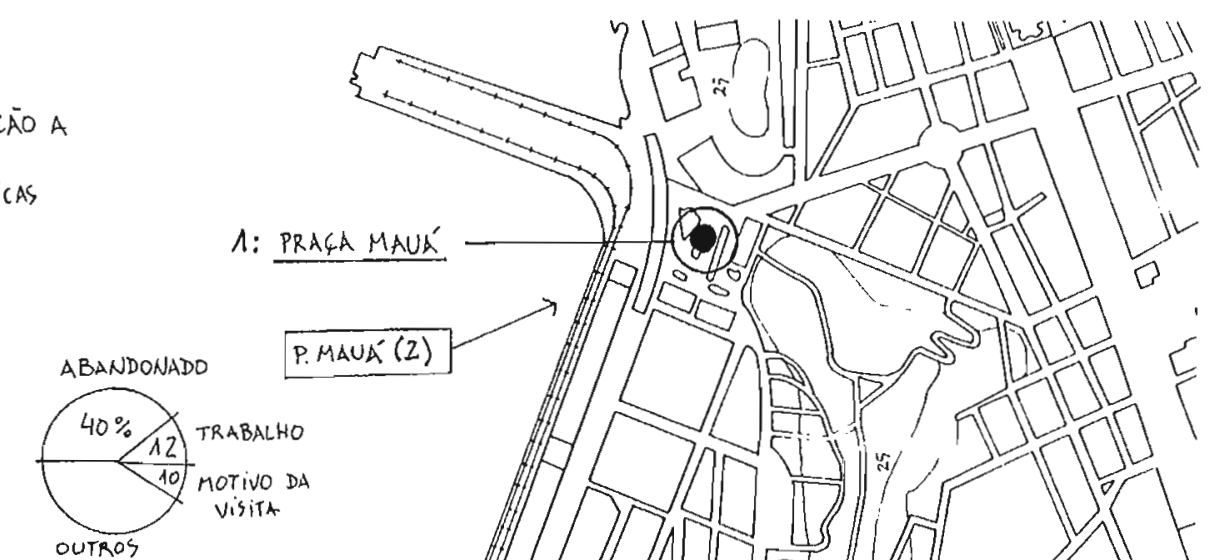
OUTRAS
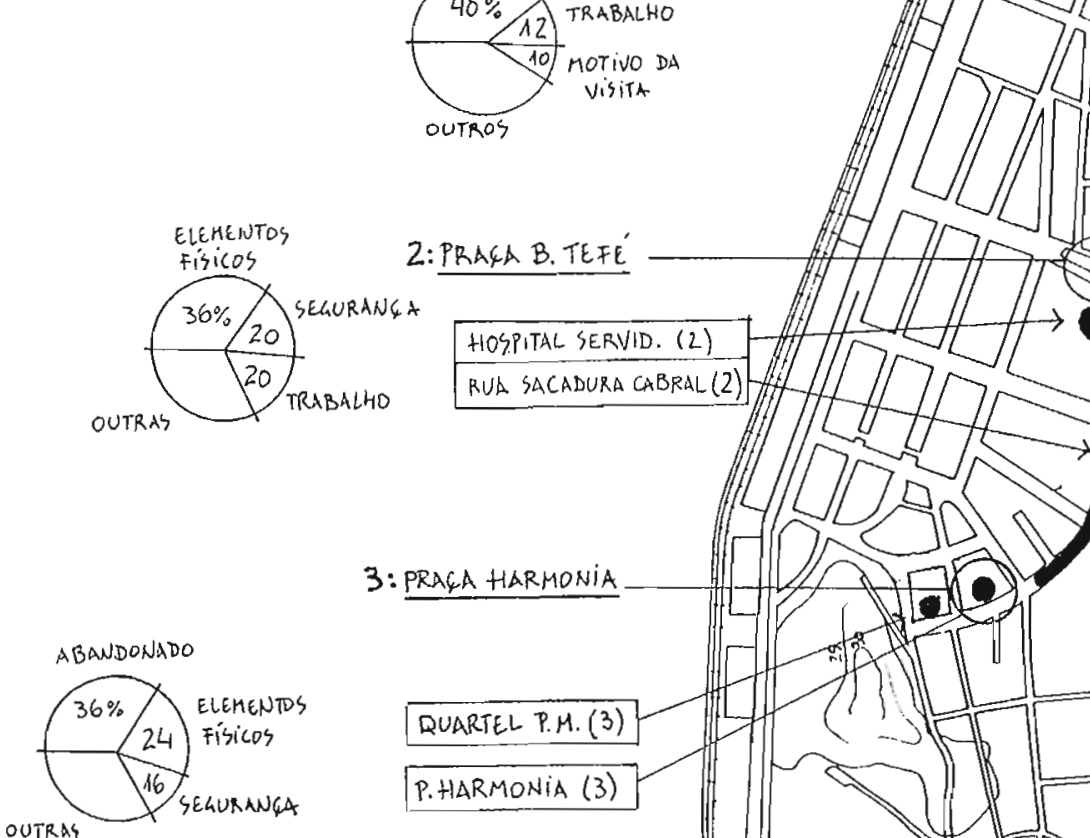

3: PRAGA HARMONIA OUTRAS
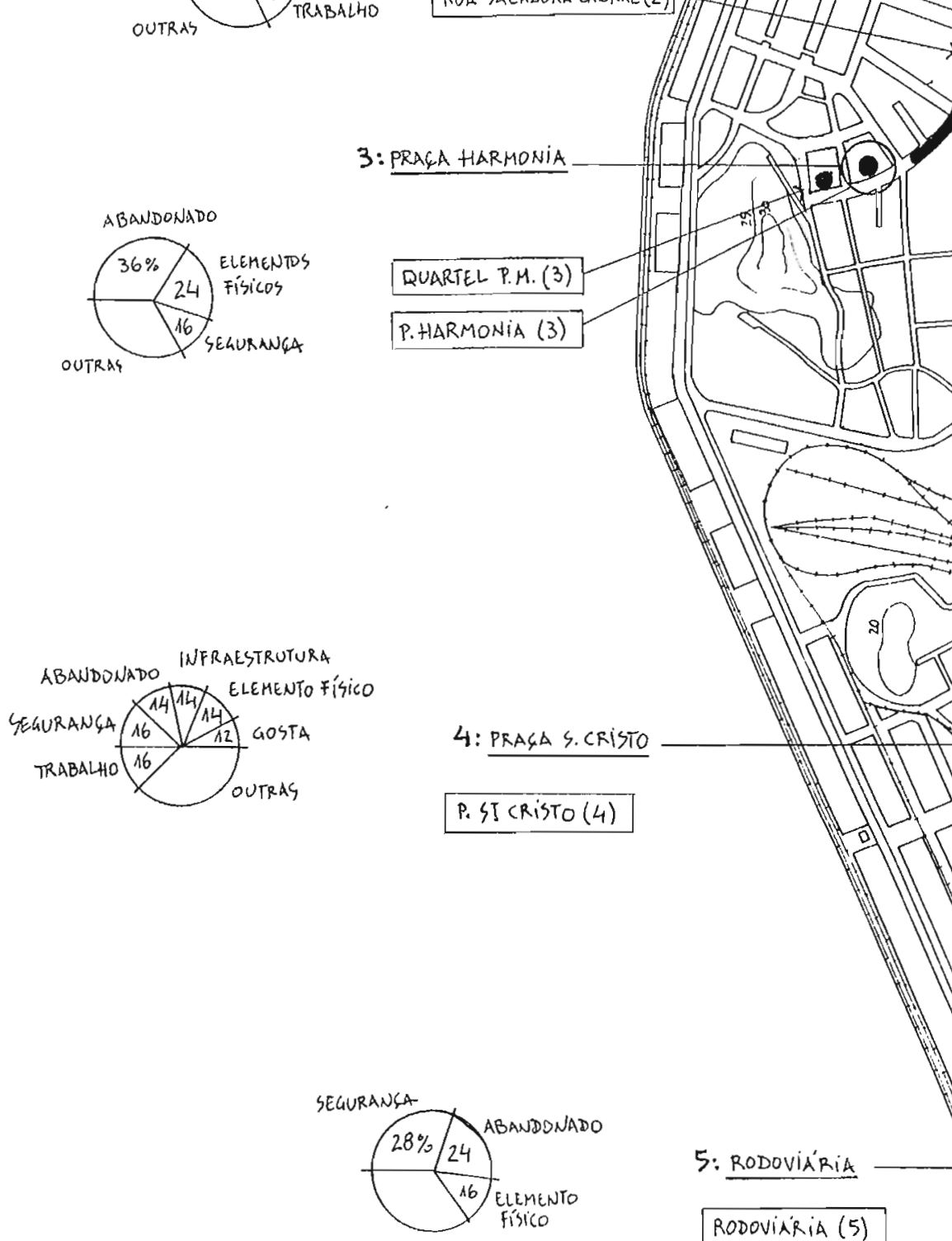
respondentes, quanto para todos os seus sub-grupos $\Theta$ locais de aplicacão. Em todos os casos, as categorias imageticas negativas recoridas nas respostas ultrapassou a casa dos $52 \%$.

As imaguns que sobrossaem nesta impressão negativa dos bairros são sempre ligadas a questôes relativas á administracăo urbana em geral, principalmente insegurança, aspectos de conservacăo e do nivel dos servicos oferecidos. Dos bairros que compõem o territorio estudado, Indices menos negativos foram alcançados apenas no Santo cristo e na Prạ̧a Barão de Tefé.

nutro resultado com incidencia bastante acentuada, como vimos, foi relativo a respostas segundo categorias que nåo destacavain nenluin aspecto imagético especlfico, mas 1 imitavam-se a expressar como primeira imagem o seu motivo de se encontrar no 10ca1 da aplicacão ou no bairro. Estes respondentes mostraram uma percepqão majs atenta para a atividade-fim do que para o meio onde $01 e$ acontece.

Três: resultados foram bastante surpreendentes para o pesquisador. Primeiramente a incidência quase nula de imagens de bairros que remetessem ás atividades portuárias, inclusive dentre os moradores respondentes. Em segundo lugar a forte presença de elementos fisicos como uma das mais recorrentes categorias de primeira imagem. Em terceiro lugar a fraca evidência dos "1ugares" nas respostas, uma categoria que os arquitetos citam como a mais importante, pois sua percepcão realca valores historicos e paisagioticos dos conjuntos adificados.

os totajs de citaçôes de elementos fisicos foi semelhante entre os três sub-grupos populacionais, em média $20 \%$ das respostas. Os elementos mais. citados foram sempre aqueles mais 
intensamente relacionados a um uso localizado, facilinente destacáve1 como peitencente ao bairro. Os destaques foram para as "edificacões" e os "lugares"; as "ruas" citadas tambèm apresentam forte caracteristica de uso, quer seja por seu carater comercial, quer seja por ser itineràrio dos ônibus.

Não notamos grandes destaques visual ou estetico na majoria dos elementos mais citados, com poucas excessões, como mostramos no capitulo anterior e dentro de um critério que evidentemente è personalista do autor. Ou seja, quando utilizando se de um olemento fisico como a imagem "simbolo" de seus bairros, os sujeitos tendiam a utilizar-se de algo que melhor representasse a sua rolaçăo de USo com o bairro; esta tendência pareceu se acentuar nos sujeitos pertencentes a grupos com menos intimidade com os baijros. Fista tendência vê-so acentuada se notarmos que a maioria dos elementos recorrentes para os bairros são de carater oxtra-10cal e, ás vezes até metropolitanos, como é o caso do Hospital dos Servidores do Estado.

Os "usuários", por exemp 10, concentraram mais de $70 \%$ de suas respostas na categoria de "edificaçes", em especial no elemento Rodoviária, um equipamento de uso intenso. Nas imagens de bairros, a categoria "rua" foi mais recorrente dos sujeitos "moradores" (mesmo assim "empatada" com "edificacôes"), o que parece indicar que, em nossa área especifica, esta categoria não

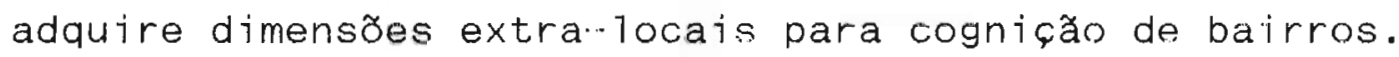

Finalmente, embora o questionário năo tenha explorado as razões para que os respondentes citassem elementos fisicos como primeira imagem, as evidências nos levam a concluir a importância la dimensăo utilitảia na percepcăo urbana. Pelas caracteristicas 
das categorias imagéticas incidentes, o uso cotidiano das areas urbanas pesquisadas e seus elementos formadores parece ser aspecto fundamental em sua "imageabilidade", para os três grupos populacionais indiferentemente.

XII. 5.4. Imagens da Area Portuária:

Os dados sobre as primeiras imagens recorrentes em relacão á Area Portuária, possibilitados pelas respostas á Questå 14, encontram-se na Tabela 20, assim como na jà apresentada Tabela 19.. A Tabela 20 apresenta a distribuigão das respostas segundo categorias imageticas por ponto de aplicacão e cada grupo de respondentes. A Tabela 19 apresentava esta distribuicão em relaçăo á tipologias imagéticas de "elementos flsicos" citados: "ruas", "edificacoges" e "lugares".

Em relaça ao conjunto de 250 respondentes, a categoria imagètica de maior incidência de respostas foi, de uma forma destacada, "abandono", obtendo um total de $107(42,8 \%)$ de respostas. Este resultado refletiu-se em todos os três grupos populacionais, que guardaram aproximadamente a mesma média percentual em relação a seus totais: "moram" (50\%), "trabalham" $(39,25 \%)$ e "usuários" (42,17\%).

"Inseguranca" foi a segunda categoria imagética mais citada, com o total de $49(19.6 \%)$. Os percentuais desta categoria relativos aos tirês grupos populacionais também não mostraram diferencas significativas, ficando perto do percentual global.

A terceira categoria mais citada foi a de "elementos ftsicos", com um total de 36 , representando $14.4 \%$ das respostas, um total inferior ao obtido na questå anterior, relativa a 
primeira imagem do bairro da entrevista. Esta diferenca se deu aperias pelo fato do grupo "usuarios:" haver rocorrido bem menos a esta categoria; apenas 4 deles, ou seja, $4.9 \%$ do grupo (Tab. 20 ). Os resultados referentes á tipologia dos "elementos fisicos" foi bastante diferente do obtido para os bairros. Aqui, a categoria imagética mais citada foi a dos "lugares" (16), seguida pela de "ruas" (12) e de "edificacões" (8) (Tab. 20 ). Interessante notar o baixo numero de respostas com "elementos ffsicos" na Praca Mauá e na Rodoviària.

Em relacăo a respostas de "elementos fisicos" dos diferontes grupos, nutamos que houve uma maior incidência de respondentes do grupo "trabalham" recorrendo a elementos "ruas".

No yera1, segundo o corijunto de respondentes, os elementos fisicos mais citadus foram: Prasa Mauá (8), Av. Rodrigues Alves (7), Porto/Cais e Avenida Perimetral (3). Na resposta a esta queståo, notou-se alèm de um total de citaçós fisicas inferior em comparacão coin aquelas relativas a Bairros, uma concentração de: respostas em um número menor de elementos fisicos.

Destaca-se o fato que apenas duas pessoas na Rodoviária citaram "elementusi fisicos", ambos do grupo dos que "trabalham" na Area Portuária, tendo citado diferentes elementos; resultado não explicito na Tabela 20 onde, leinbramos, apenas apontamos os elementos fisicos com mais de uma citacăo. Observa-se, portanto, uma total ignorância do grupo "usuários" na Rodoviària relativa á

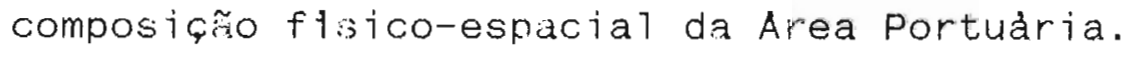

No que diz respeito á categoria "atividades portuárias", ao contrario dos resultados obtidos na questão anterior relativa a hairros, aqui encontramos uma maior incidência de respostas. Um 
total de 2.3, sendo que os "usuàrios" tiveram uma incidência um pouco maior, principalmonte nis respondentes na Rodoviária. Portanto, verifica.'se uma importancia significativa nas imagens relativas ao próprio porto e seu funcionamento, como primeira imagem recorrente á área de estudo.

Repetindo-se o raciocinio sobre as categorias imagéticas que fizemos anteriormente, aglutinando-as por suas semelhancas, os resultados obtidos apresentam ordem de importância não muito diferentes: "abandonado/falta infraestrutura" $(116)$, "inseguranca" (49) e "elemento fisico" (37), "trabalho ou escola/motivo da visita/passagem/comércio" (20).

Quanto aos resultados obtidos para cada um dos locais de aplicacăo, repete-se u mesmo perfil obtido para o global. ou seja, nostes locais as percepcões primeiras da Area Portuária seguem o padrăo do obtido no conjunto de dados: "abandonado" e "inseguranca", com "atividades portuarias" e "elementos flsicos" alternando-se como terceira categoria mais citada.

Quanto a outras possiveis diferencas entre as percepcóes dos: três grupos populacionais, ao contrário, nota-se a homogeneidade da imagem da Area Portuária entre eles, bastante "negativa", pois as categorias imageticas negativas concentraram as respostas de: 42 (60\%) dos "moradores", $69(65,1 \%)$ dos que "trabalham" e $57(68,7 \%)$ dos "usuários". Totais estes que, aliás, guardam a média da impressão gera1 que somou 168 respostas nas categorias negativas, ou seja, $67,2 \%$ do total de questionários.

O mapa apresentado na Figura 70 resume indicativamente a distribuigåo de dadois relativos as pitimeiras imagons recorrentes aos respondentis: em relaçăo \& Area Poituária. 
Fig. 70: Primeiras imagens da Área Portuária (Questão 14) mostrando categorias imagéticas principais e os elementos físicos mais citados.

N ELEMENTO FISTiCO

(D) caterorias imagkíticas
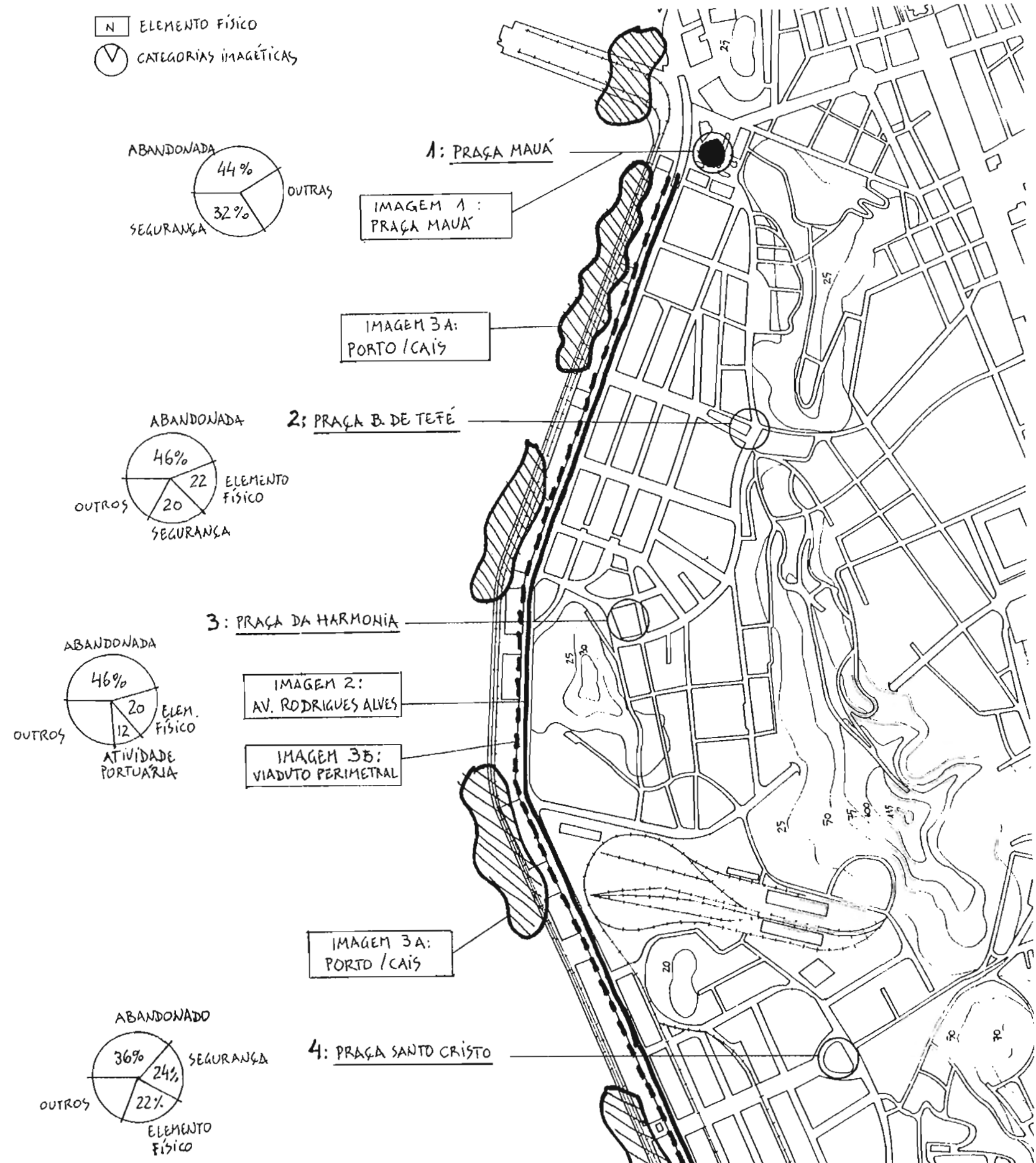

4: PRAGA SANTO CRISTO

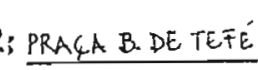

IMAGEM 3 A: PORTO/CAIS
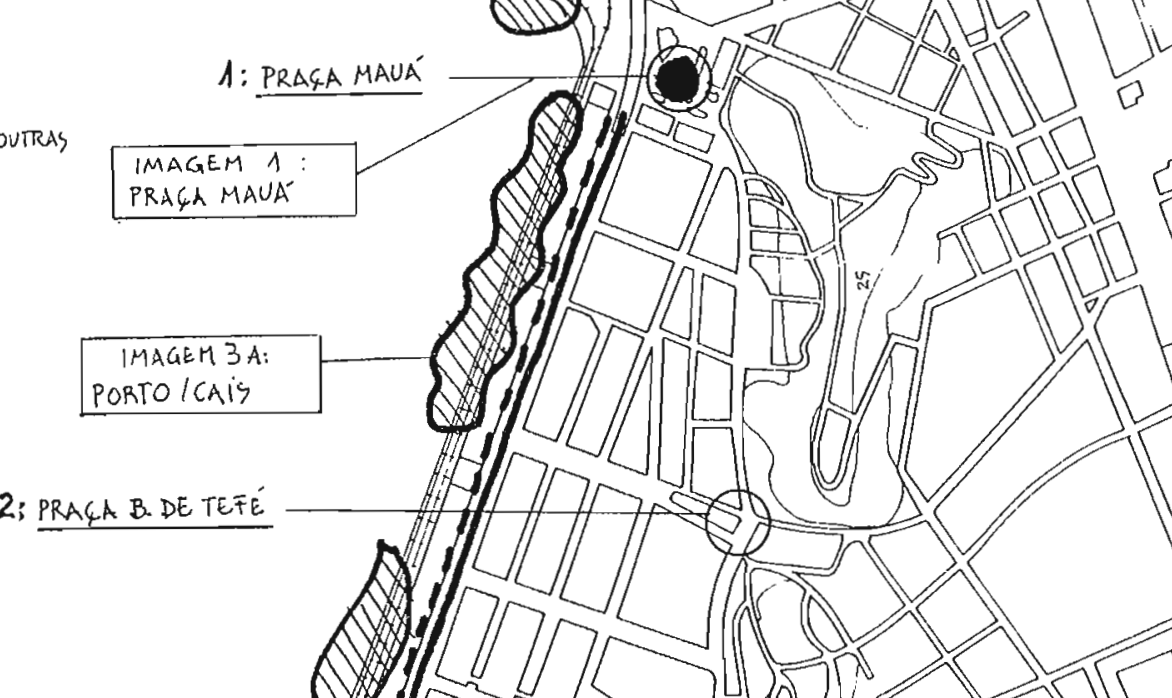
XII. 5.4. Sobre as Imagens da Area Portuária:

Os resultados obtidos com as respostas sobre primeira imagem recorrida para a Area Portuária såo semelhantes aqusles obtidos para a questão anterior, relativa a bairros. Tampouco houve grandes diferencas entre as percepcões dos três sub-grupos populacionais.

Novamente, a incidênciá de categorias imagéticas negativas foì muito grande, ainda superior á dos bairros, representada por mais de $67 \%$ do total das respostas, como vimos. De novo as questões relativas á administrạ̧ão urbana prevalesceram nestas imagens negativas.

A categorias de elementus flisicos foi a terceira mais citada, mas o resultado em termos absolutos de citacões foi inferior áquele relativo a bairios. Isto evidencia que os respondentes possuein um conhecimerito expiresso menor da Area Portuaria, fato expresso de forma mials forte entre os respondentes "usuarios" e nos lociais de coletia com mais pessoas "de passagem" ( Hraça Maua e Fodoviária).

Tambèm €iil relaçăo á Area Portuária, us elamentos físicos mais citados possueiii dimennsäo de uso muito acerituada, o que parece ser a razão maior de sua "imageabilidade"

XII. 5.5. Os Cinco Elementos Flsicos Citados para os Bairros:

Na Questão 15 solicitava-se que o respondente mencionasse "os cinco elementos que mais lembra" do bairro, dentre ruas, edificacões e lugares. Como afirmamos anteriormente, nossa principa intenção era a obtenção de dados que viabilizassem a construcão de "mapas mentais" indiretos, alèm de identificar os 
elementos flsicos mais significativos na cognicão do território dos diversos bairros, suas referências. A 1 istagem dos 107 elementos fisicos vàiidos para a àrea de estudo, citados nas respostas dos 250 questionàrios, encontra-se no Anexo $V$.

Iniciaremos nossos cometários analisando os dados obtidos com os resultados referentes aos elementos flsicos que foram citados em primeiro lugar nestás respostas, pois consideramos que, por terem sido lembrados: nesta oidem, assuinem uma posicão mais importante em sua cognicão.

Através da Tabela 21 nota-se o total de elementios físicos citados ein niimeiro lugar é de 244 (6 respondantes não rosponderain á questão), dos quais 12.7 ellain "iuas", 93 "enificacões" $€ 24$ "lugares", qut correspondem respectivamente a $52.05 \%, 38.11 \% ; 9.6 \%$. Guanto a distipuica das respostas vàitidas ohtidas a esta questão, dos respondentes 57 eram "moradores", 102 "trabalhavam" e 75 eram "usuários" da Area Portuária.

Tmprossiona o destaque obtido pela categoria "ruas" na poircepcåa de bairro, que não apenas foi o elemento mais citado em primeiro lugar no total, como dissemos acima, mas também 0 primeiro em todos os locais de aplicacão dos questionários e dentre o: três grupos populacionais.

Os dados obtidos da totalidade das respostas nos permitem ver que of cinco elementos mais mencionacios em primeiro lugar, foram, em ordem: Rua Sacadura Cabra1 (24), Rua santo iristo (16), Rodoviuria (14) e Hospital dos servidores (11). Os dois primeiros for:an "ruas" a os outros dois "edificacôes"; note-se que estas "edificacões" são tortemente marcantes pelo seu intenso uso, em 
detrimento de sous aspectos meramente visuaic, que nåo são especialmente sionificativos. Estes dados ustáo parcialmente revelados peía Tab. 22 que, no entanto, só leva em conta os cinco elementos fisicosi mais citados.

Podemos notar uma tendência de, se o respondente näo conhecia bem o local (usuários ou trabalhadores), as respostas concentram-se mais em aspectos mais "vinkis" (categorias "edificacão" ol "lugar"), como pode ser verificado através dos dados referentess á Praça Mauá e Rodoviária, locaja com maior quantidade de "usuários". Os "moradores" parece que se referiram mais intensamente á categoria "ruas".

Em relação aos diferentes pontos de roleta cie entrevistas, a média de 14 elementos distintos citados foi mantida ein todos eles: A major coincidência de respostas em primeiro lugar foi obtida pela Rua Sacadura Cabra1, com 20 votos obtidos na Praça Barão de Tefé; seguido da Rua Santo Cristo com 15, obtidos no Santo Cristo.

Agora, passaremos a analisar a distribuiqüo de dados relativa á totalidade das respostas a Questão 15, ou s: os cinco elementos fisicos citados pelos respondentes para os bajirros. Adui ututive-se uin total de 927 citações, sendo 507 (54.59\%) referentes a "ruas", $339(36.57 \%)$ a "edificacões" e 81 (8.74\%) a "lugares" (Tah. 23). Novamente notaremos a predominância da categoria "ruas" na cognicão dos respondentes em relaça ao bairro da aplicação do questionàrio, o com a ủnica excessão na Praça Mauá.

Também aqui, os dados nos levam confirmar que em locais de maior incidência de pessoas com menor conhecimento do bairro, 
na Praça Mauá e na Rodoviária, z tendência parece ser do respondente se reportar mais a elementos mais "visuais", representados pelas "edificacões", categoria que no primeiro caso foi a mais citada e, no segundo, esteve bem perto da mais citada. $\mathrm{Na}$ quantificacão geral destes cinco elementos dentre o total de respondentes, foi o seguinte o ordenamento: Rua Sacadura Cabral com 66 citacões, Hospital servidores (44), Rua santo Cristo (43) e Policia federal (36). Verificamos que dois doles são "ruas", dentre eles o primeiro e o terceiro lugares, ᄅ dois são "edificacôes". Estes resultados aparecem parcialmente na Tabe 1a 24.

Se, por um 1ado, a categoria "rua" é seguidainente reforida em relação ás cognições dos bairros, pelo outro nota-se quo a categoria "lugar" é sempre a menos mencionada.

Na Rodoviária, o baixo número de elementos fleicos citados no total das respostas (111) reflete $n$ pouco conhecimonto dos respondentes sobre a àrea, poi̊ a maior parte deles :são do grupo "usuários". Podemos dizer que outro indicador deste "desconhecimento" es a coincidencia de olementos mencionadow e concentração nos primeiros lugares, tambem verificado na Rodoviària e na Praça Mauá.

Ainda na Rodoviária, a tabulaça dos questionários nos mostrou que apenas três pessoas foram capazes de citar os cinco elementos solicitados, enquanto que nove pessoas rião furam capazes de citar nenhum ou citaram elementos irrolovantes d questão.

Dentre as três categorias populacionais, não notamos grandes diferenças no cômputo geral das categorias dos cinco 
elementos fisicos citados, sendo que as "ruas" sempre martiveram a primazia (média de 15 em cada grupo populacional), seguido de "edificacőes" (média de 7) e "1ugares" (vide Tab. 23).

XII. E.5. Sobre o: Mapa; Mentais Indiretos dos Bairros:

A andise da distíibuicão dos dados nos leva a uma primeira conclusão da importância major assumida pelo elemento "rua" na formacão dos mapas nentrais "indiretos" dos Bairros. Na tipologia dos elementos fisicos citados, tanto no que diz respeito ás citaçoses de primeiro lugar, quanto ao total dos cinco elomencos citados por cada respondente, verificou-se a prepondorâricia das "ruas" sobre as "edificacões" e "lugares", nesta ordfm, que: repetiu-se entre o:s três sub-grupos populacionais e em todos os locais de aplicação de questionários. Se houvé uma tendência especifica dentre os sub-grupo, foi uma aparente maior intensidade de citaçoses de "ruas" entre os "moradores", sem que isto resultasse em inversão dos resultados.

Ao analisaimos os elementos ospecificos que assumiram destaque, verificamos sua importância relaitiva a seu uso no cotidiano dos respondentes em relacão ans distintos beirros abordados, ou de fuicionalidade expressa. Observação dsta que e valida para todos us tipos elementos citados; os seus aspectos simplesmente visuais nos pareceram relegados a segurdo plano de importancia face sua intensa funcionalidade.

A distribuicão das respostas tambèm confirinou que, em locais de maior incidência de respondintes "usuärios", como na Rodoviària e Praça Mauà, o nummero de elementos fisicos citacios diminui em quantidade e em abrangência. 


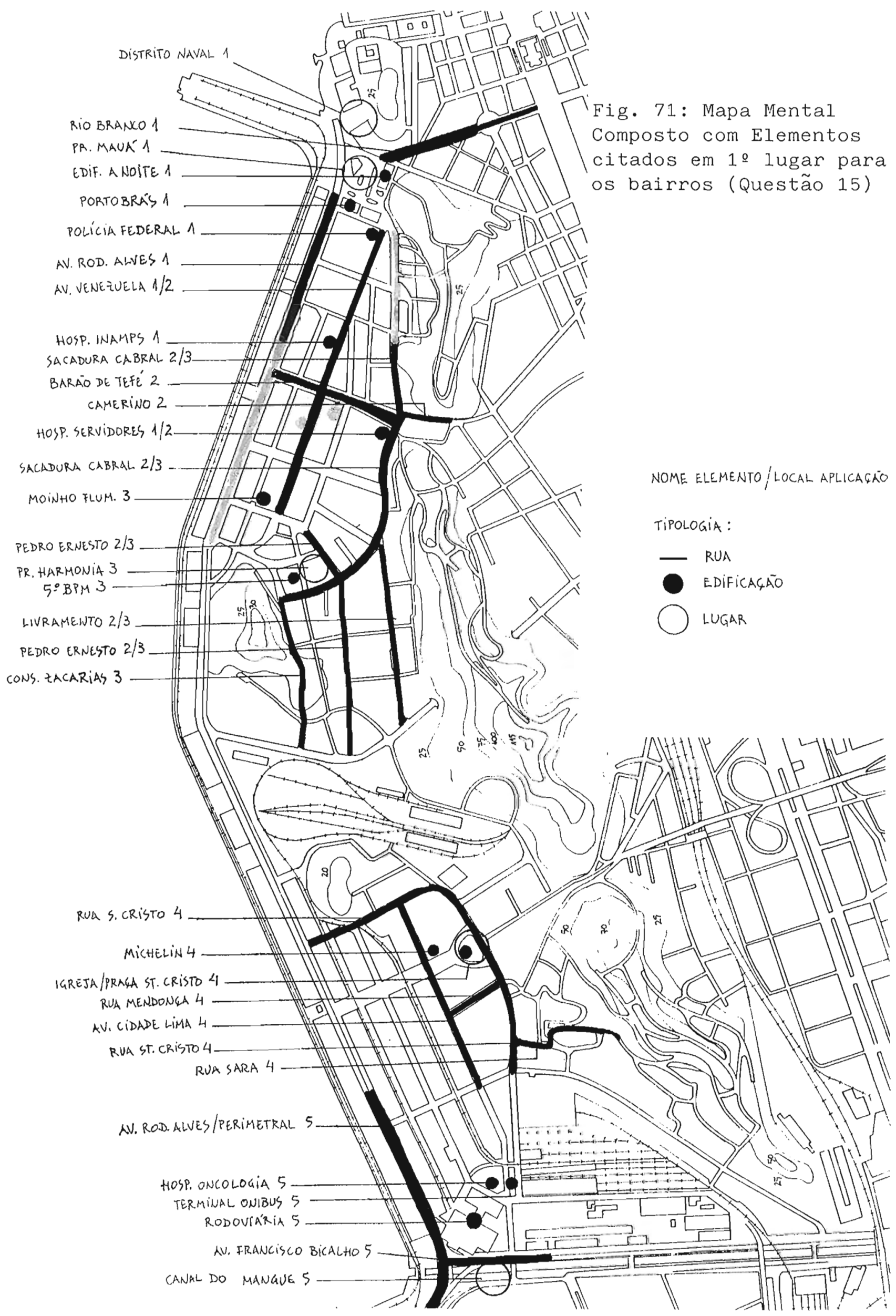




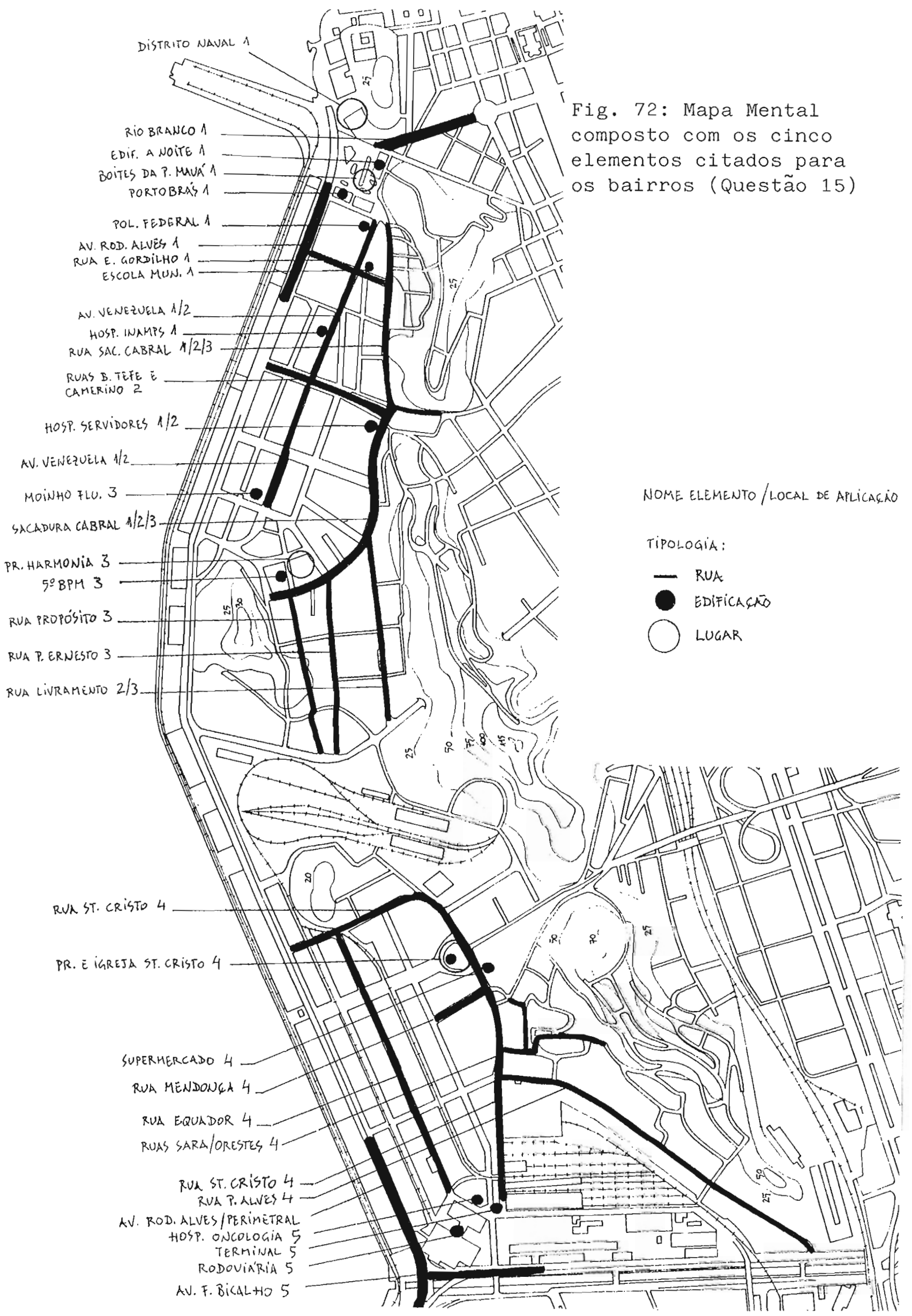


As 1 istagens constantes nas: Tabelas $22 \odot 24$ possibilitarain a elaboração dos mapas mentais compostos das figuras 71 e 72 , que respectivamente destacam os elementos ciiados em primeiro lugar e os cinco citados para os bairros da area de estudo. Através de sua comparação, pode-se verificar que ambas as percepcões dos respondentes são bastante semelirantes, ou seja, a cognição revelada pelos primeiros elementos citados 2 apenas reforqada pela citaça dos outros quatro.

Nestes mapas mentais compostos (Fig. 71 \& 7?) alguns aspectos gerais chamam a atencão:

- proximidade entre as "edificacões" e "Iugares" com as "ruas", - distribuicão dos elementos acentua a caractertstice de "compatimentos", àreas bem definidas, no território estudadu,

- incidência de elementos que compartimentam estas percepcões, como vias, àreas : morros;

- importância das vias de 1 igąão;

- todos elementos citados situam-se fioicamerite no território estudado, ou seja, nenhum elemento distante, iresmo com presença visual no local, assumiu destaque.

XT.T. 5.6. Os Sinco Elementos Fisicos citados para Area portuária: similarmente ao que fizemus em relação ao ponto discutido anteriormunte, na anàise da distribuicão de respostas á Questão 16, os cinco elementos fisicos citados para a Area Portuária, destacamos inicialmente o elemento citado ein primeiro lugar pelos rospondentes.

Nos 250 questionários aplicados, as respostas obtidas rovelaram um total de 233 elementos citados em primeiro luyar, isto è, dezesete pessoas deixaram de responder a questão, um ilimero pequeno em relação ao total. Deste total 103 (41.2\%) das 
citacões foram "Iuas", 75 (30\%) "edificacões" e 55 (22\%) "Iugares:" (vide Tab. 21). Perfil de respostas que, alias, repetiumse nos três grupos populacionais.

Entretanto, tomados em relaçăo a cada um dos sub-grupos populacionais ou a cada um dos locais de aplicação individualmente, o destaque para as "ruas" como elemento de primeira citaçăo não è tãc acentuado quanto o foi ria listribuicão da Questao anterior. Na fraca da Harmonia, pur exemplo, o destaque no conjunto de dados ficou com a categoria "edificacão" assim como nos sub-grupos dos "moradores" e dos que "trabalham".

Um indicativo evidente de relacionamenio e conherimento da Area Portuária são os totais do elemontos fisicos ditados e as Tahelas 23 e 20 mostram uma 1 igeira tendência dos respondentes em locais, maje rahitacinnais. (Praçs Barãu do Tofe, Haimonia e Santo Cristo) de iresponderem a questão coln mäis citacões, o que podeinos interpreciar como um repertório mais vasto de elementos cognitivos de seu "mapa menta1".

Na Rodoviaria, o tabulaineito nos mostrou que apenas duas pessoas for am capazes de mencionar os cirico elementos solicitados na questão, enquanto dezenove não foram capazes de citar sequer um elemento ou citaram respostá irrelevante.

No computo geral de respostas, a distribuicăo das primeiras citações de elementos fisicos para a Area foi: Av. Rodrigues Alves (com 39 citações), a Rudoviária (36), a Praça Mauà (35) e as ruas Sacadura Cabra (13) e Santo Cristo (9) (Tab. 25). A quantificaça utilizada para gerar a coluna "total" foi obtida na 1istagem gera1 de respostas, portanto apenas parcialmente representada pelo somatório das outras colunas que só incluem os 
Ginco mais citados om cade locálidade.

Quatro lemeitos aparecem entre os cinco mais citados dos três subligrupos populacionais: Av. Rodrigues A1ves, com 39 citaçoos, a Rodoviária, com 36, a Praca Mauá, com 35, e a Rua Sacadura Cabra1, com 35. Estes são os elementos físicos mais fortes no mapa mental indireto da Area Portuária, segundo a primeira lembranca de todos respondentes.

Interessante notar que do total de 75 citacôes de "edificaçoss" em primeiro lugar, 35 são Rodoviària, e das 55 relativas a "lugares", 35 são relativas á Praça Mauá, totais a lcancados principalmente pelas citacões de pessoas com menor identif'icaço com nossa àrea de estudo, os "udisurios", exatamente nos locais de aulicagău de inesmon nome (vide Tab. 21). Isto parece indicar que o repertório imagético dos "usuários" relativo á Area Portuária è extrellamente reduzido $\Theta$ concenira-se nos elementos de maior "contato" com a cidade e con seu cotidiano.

Em relacão a todos os cinco elementos flsicos da Area Poriuaria, citados nas respostas, as respostas revelaram 81 elemento: diferentes em 898 citaços: 446 "ruas" (49.67\%), 267 "edificacões" (29.73\%) e 185 "lugares" (20,60\%) (Tab. 23).

Dentre o: cinco primeiros culocados entire os cinco elementos físicos más citados para a Area Portuária, no cômputo gera1, a distribuicăo foi: Av. Rodrigues Alves (94 citiçõos), Rodoviária (85), Praca Mauá (79), Rua Sacadura Cabra7 (47) e Rua do I.ivraintonto ( 37 ) (Tab. 2.6). Tivemos, portanto, três "ruas", uma "edificacán" e um "Iuyai" cumo os cinco mais citados.

Pela Tabela 23 , pudemos observar que, neste caso, as "ruas" foram os elementos mais citados nos cinco pontos de coleta. Note- 
se, também, como o total de "ruas" citados na Rodoviária, onde hà o maior numero de respondentes "usuários", è bern menor relativamente ás outras categorias, que nos outros poritos.

Se analisarmos o total de elomentos diferentes citados para us bairros (107), que jà mencionamos na discussão sobre o ponto ancerioi, com o total citado para a Area Portuaria (81), $e$ Tombraimos que por diversas vezos conclutinos a observacão de quanto menor conhecinento da área do responderite, maio: a tendência de citar um elemento fisico "visual" que possa conotar uma funcionalidade para o respondente (edificacão ou lugar, mais do que rua), verificamos que o relativamente pequeno perceritual de "ruas" sobre as demais categorias citadas para a Area Portuária parece também comprovar um conhecimento fraco da àrea pelos respondentes como um todo.

Masmo assim, ume análise do conjunto de dados obtidos relativa a tipologia dos elementos fisicos entre os cinco mais citados nos mostra: 14 ruas, 7 lugares e 6 edificacões (Tab. 24). Comparando este resultado global com a distribuicão revelada pela Tabela 23, em relação a cada grupo populaciona1, os dados mostram um perfil idêntico de respostas, ou seja, proponderância significativa de "ruaㅗㅗ. .

A Tabela 2.6 nos permite verificar que dentre os cinco elementos flsious inais mencionados nas listagens gerais de rospostas, relacionados na coluna "total", três deles são comuns a todos os sub-grunos populacionais: Av. Rodrigues Alves, com um tntal do 94 citaçóes, a Rodoviária, com 85 citaçoses, e a praca Mauá, com 79. l.embrom-se que a coluna "total" da Tabela 26, dorivada da 1 istagen total de respostas (assim como jà observamos 
para a Tab. ?4), so representa parcialmente a totalizacăo das outras colunas pois nolas só aparecem os cinco mais votados. Note-se que os mesmos três elementos e segurido a mesma ordenaçăo, revelaram-se como os mais fortes tanto na primeira citacão quarto na constmicão global dos mapas mentais indiretos para a Area Portuária de todos os respondentes.

A mesma Tabela 26, entretanto, permite uma outra leitura ana11tica. Se verificarmos a distribuicão das respostas para cada local de coleta individualmente, os elementos mais citados passam a ser: @m primeiro lugar a Praca Mauá (em três locajs: Praça dá Harmonia, Santo cristo e Rodoviária), en segundo lugar a Rodoviària (em dois locais: Praça Mauà e Barão de Tefé). Note-se como o grupo "usuarios" teve um significativo peso nestes totais. Desta forma, novamente, identificamos a tendência de que a categoria "rua" adquire maior importância imagética para o grupo populacional que maior relação mantém com a Area Portuária, os "moradores", o que tambéin traduz uma forte relacăo de uso coin aquele tipo de elemento.

XII. 5.7. Sobre os Mapas Mentajs da Areá Portuària:

A distribuịão das respostas relativas aos cinco eleinentos citados para a Area Portuaria, assim como ao primeiro deles, corrstante na coluna "total" das Tabelas 25 e 26 , puderam gerar us mapas compostos expostos nas figuras 73 e 74 . Julgamos que os rosultados aparentes nesta coluna transmitem bem as percopcôes resumidas das diftentes localidades.

Uma análise global dos resultados nos permite concluir que a percepcão da Area Portuária como um todo é mais pobre do que a 
percepcão de seus bäirros componentes. Não só o inúmero de diferentes elementos fisicos citadns pulos respondantes toi inferior, como também o foi o total de citaçøs: ou seja, a capacidade de cogricăo foi menos intensa.

Através da coincidência de resultados dos elementos fúsicos mais votados em primeiro lugar e na globalidade das citaçes, verificamos a forte tendência de que os elementos fleicos citados em Niineiro lugar para a Area Portuaria realinente representem os meis significativos na formacăo dos mapas mentais dos respondentes. Ou seja, caso fi:esssemos tentativa de gerar um mapa menta1 composto apenas com os respondentos citando um único lemento fisico, o resultado soria bastante somethairte a obtido utilizando-se cinco citacões por respondente.

Pará a formacão dus mápas mentais da Area Portuária, nossa anảitise perintiu verificar novainente a importância para os: respondentes da funcionalidade percebida dos eloriento:; que forain capazess de citar. As "ruas" adquiriram primaria, ombora menos: intensa que quando relacionadas á percepcz̃o de bairros, como vimos antoriomento, snquanto elementos funcionais no cotidiano Lins respondentes.

Assim, respondentes com menor relacáo com a Area Portuária, tendiam a citar outros elementos que, por sua funcionalidade percebida, compunham o seu mapa mental da área. Evidentemente, exatamente por este seu menor relacionamento com á àrea, tendiam a citar menos elementos fisicos em suas respostas, e o exemplo extremo foi obtido pelos responderices na Rodoviária.

Interessante observarmos que, mesino quando tinham dificuldades de citar elementos para a Area Portuaria, ou não o 


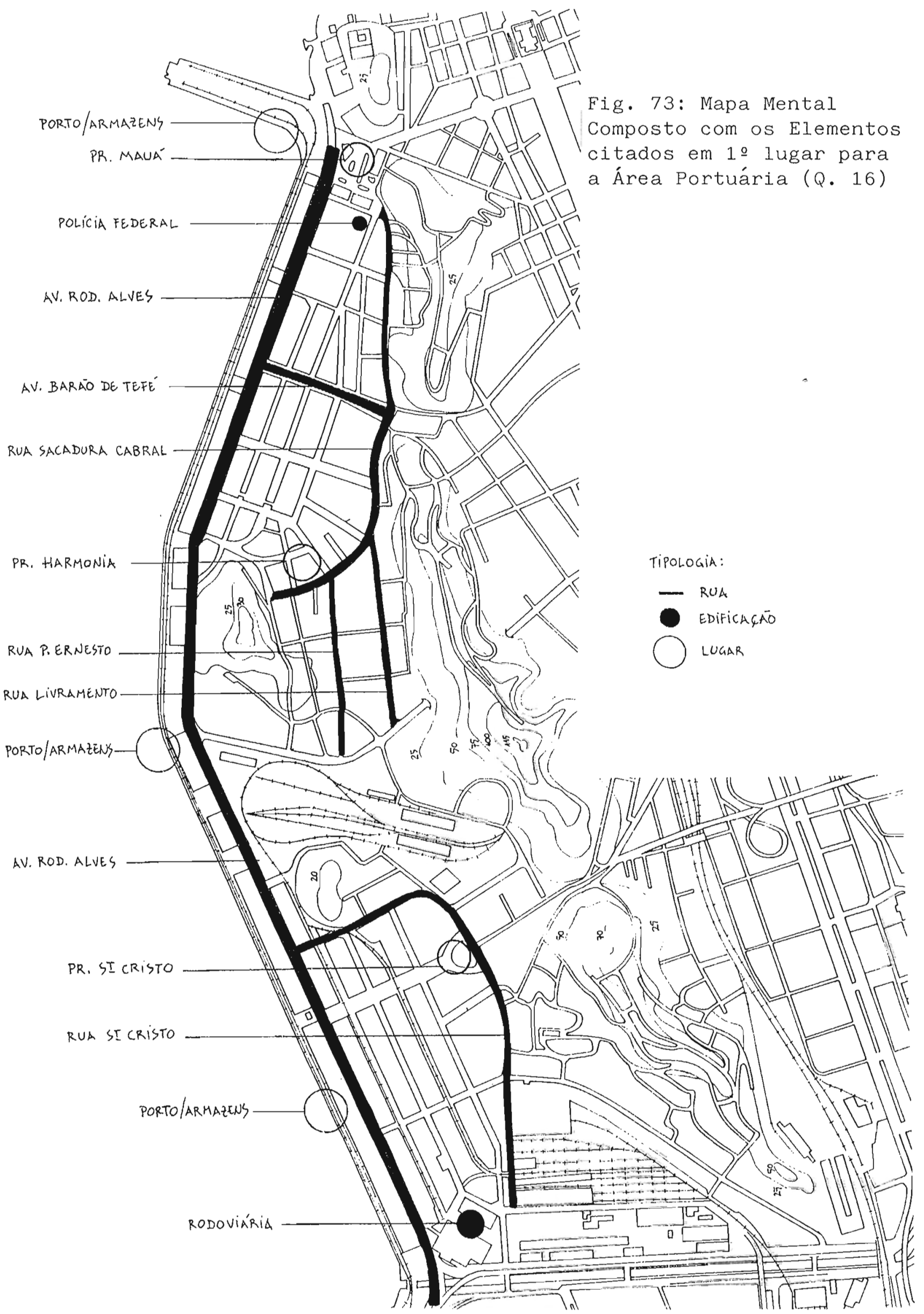




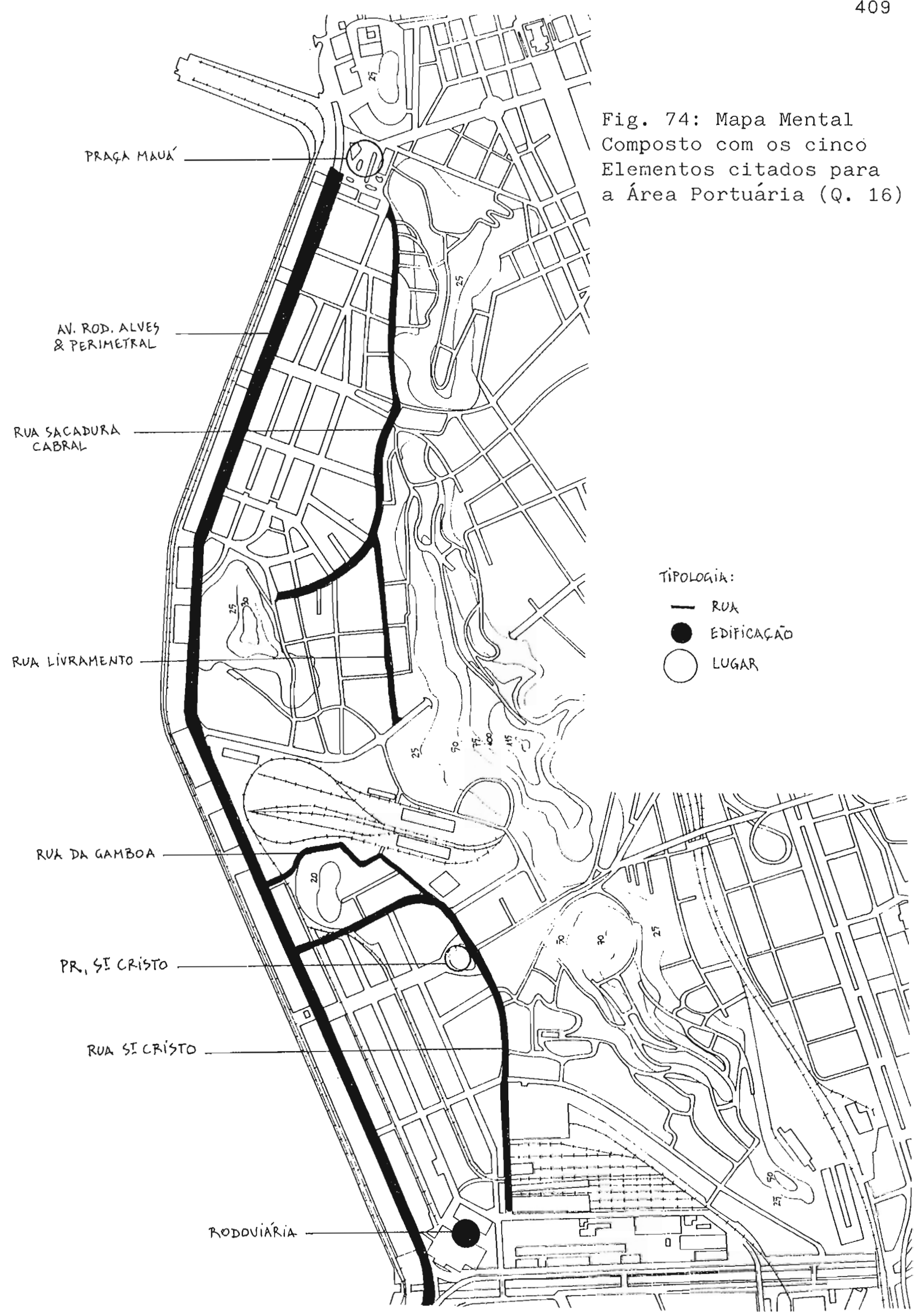


conseguiam, os respondentes não eram capazes de simplesmente repetir aqueles citados em suas resposta para o bairro que, afina1, faz parte da Area Portuária.

Finalmente, os mapas compostos resuitantes dos dados relativos a elementos fisicos citados, constantes nas Figuras 73 \& 74, também nos permitem as seguintes observacões:

- tendência á estruturação espaciil a partir de dois polos (Praca Mauà e Rodoviária) e eixos de ligaçăo limitados ás vias de transporte coletivo.

- proximidade entre as "edificacoes" e "lugares" com as "ruas";

- importância das vias de 1 igação;

- todos elementos citados situali-se fisiciamente no territóito estudado, ou seja, nenhum elemento distante, mesmo com presencia visual no local, assumiu destaque.

- năo aparece nenhume elemento de 1 igaça com as áreas de entoino (centro da cidade, etc.), exceto pela continuidade da via Perimetra1.

\section{6. Atitudes e Atributos Percebidos:}

Buscando, como destacamos acima, o estudo do nivel da avaliacão/conduta do processo perceptivo, a Parte III do questionảrio trazia as Questôes 17 e 18 onde relacionamos o que podemos chamar de "impressões ambientais": afirinativas que poderiam revelar as "atitudes" dos respondentes ou o seu julgamento de "atributos" ambientais dos bairros de aplicação e da Area Portuária. Elas eram sempre relativas a questõos ambientais que pudessem posteriormente auxiliar em consideracõus para o firocesso de desenho urbano e revitalizacão.

o respondente tinha de manifestar-se sobre cada afirmativa do Acordo com uma escala de valores, de "não concorda" (-3) a "concorda muito" $(+3)$, passando por "indiferente" $(0)$. Como jà 
observamos anteriormente em relaça á construção destas questões, as. impressões que utilizamos variavam de conotação, para que o respondente não tendesse sempre a optar inconscientemente o mesmo campo de escala (direita ou esquerda); ou seja, ele tinha de pensar se concordava ou discordava de cada uma delas e o quanto.

Estas impressores ou afirmativas possuem conotaços que renetem a campos perceptivos opostos e octa interpretacăo foi a adotada para a tabulaçăo e construcăo dos grâficos analiticos. Asoim, as interpretações das respostas geraram campos perceptivos "positivo" (direita) e "negativo" (esqueida), facilitando a análise visual e gráfica das tendêricias cognitivas. Por exemplo, se o respondente optava por "concorda muito" com a afirmativa "gustaria de mudar do Bairro", isto revelava uma atitude "regativa" para com o Bairro. Da mesma maneira, respostas positivas para as afirmativas que a Area Portuaria "deveria ter mais uso turlstico" e "mais habitacões" foram tomadas como indicativae de campo cognitivo "positivo", ou seja, atitudes favoraveis. As interpretacões de cada afirmativa neste sentido serão colocadas a seguir.

As iniras afirmativas que nå seguiram este raciocinio foram as que visavam á atitude dos respondentes relativas á participąão da comunidade no planejamento dos Bairros e da Area Portuária, respectivamente as afirmativas 3 e 10 das Questões 17 e 18; estes resultados apresentados em separado (Tab. 27). Assim, nas Tabelas 28 , relativa á uma visão global, e 29 a 32, espectficas de cada ponto de coleta, as interpretações das Afirmativas segundo os campos perceptivos opostos foram: 
1: Este Bairro é bom para morar: Indica uma atitude e pode ser interpretada como resultado final da avaliação dos atributos dos bairros em relaça a moradia. Resposta afirmativa indica campo perceptivo positivo.

2: Ele è bom para trabalhar: Aqui o mesmo raciocinio acima foi aplicado o resposta positiva indica campo perceptivo positivo

4: @ Báirro é mal frequentado e perigoso: Representa uina percepção diretamente relacionada com a questão da insegurança, jà tão presente nas respostas relativas á "primeiras imagens". As respostas afirmativas indicam campo perceptivo negativo.

5: Tem muita sujeira e mau cheiro: Percepcão de atributos relativos a manutenção da àrea, mas que pode ser interpretada tambèm como uma atitude final qualitativa. As respostas afirmativas indicam campo perceptivo negativo.

6: EE agradàvel com casas e paisagens bonitas: Com esta afirmativa, buscávamos explorar as atitudes dos respondentes perante os aspectos paisagisticos estéticos gerais do patrimônio construido. Resposta afirmativa indica campo perceptivo positivo.

7: O bairro tem pouco comércio: Impressão ambientaí que diz rospejto a um atributo percebido do Bairro, mais do que simplesmente uma atitude para com ele, assim como o nivel de satisfaçăo/carência por servicos de primeira necessidade. Resposta positiva indica campo perceptivo negativo.

8: Tem poucas opcoses para lazer: Outra afirmativa que conota atrihutos percobidos dos bairros mais do que atitudes perante esta temática. Resposta positiva indica campo negativo.

9. O Bairro precisa de um ponto social central: Impressão ambiental sobre um atributo do Bairro mas, ao mesmo tempo, uma atitude do respondente perante as potencialidades de sua vida socia1. Respostas positivas indicam campo perceptivo negativo.

10: Gostaria de mudar de Bairro: Represunta uma atitude que quertamos explorar, principalmente pelos "moradores", a respeito de possibilidades futuras. Por outro lado, dentre o grupo dos que "trabalhain" na área, ela pode ser interpretada como mudança de local de trabalho. Entretanto, em ambos os casos, as respostas positivas indicam campo perceptivo negativo.

$\mathrm{Na}$ Tahela 34 , relativa á Questão 18 sobre atitudes/atributos da Area Portuária, as interpretaçóes das afirmativas foram:

1: A Aroa Portuária tem lugares e paisagens muito bonitos: conota atributos percebidos e uma atitude positiva; as respostas positivas indicam campo perceptivo positivo. 
2: Està mal corlservada e cheia de lixo: Afirmativa que: transmite conotaçăo acentuada de atributos percebidos relativos a manutenção. Resposta positiva indica campo perceptivo negativo.

3: As casas e armazens antigos deveriam ser preservados: Afirmativa que sugere atributos percebidos na área, enquanto tambem conotia uma necessaria atitude para com eles por parte do respondente. A resposta positiva indica campo positivo.

4: Maior integracão com o centro e mais escritórios: Novamente, afirmativa que conota atributos da àrea assim como uma nocessaria atjtude do sujeito para com eles, no momento em que inserimos adverbios. Respostas positivas indicam campo neyativo.

5: Deveria ter mais lazer: corresponde a atributos purcebidos pelo respondente mas também pode conotar uma atitude quanto ás potencialidades da área. A resposta positiva indica campo perceptivo negativo.

6: Deveria ter mais uso turistico: Afirinativa 1igada a atributos percebidos na àrea e que pode ser conpreendida como bastante relacionada á Afirmativa 1 , ao menos no que diz respeito a percepça do do potencial do patrimônio arquitetôrico e paisagistico. Resposta positiva indica campo perceptivo pusitivo.

7: As atividades portuárias deveriam ser transferidas para lunge: Denotando claramente o que talvez seja o maior atributo da hrea, esta afirintiva buscava principalmente dados sobre as diferencas de atitudes entre os grupos populacionais respondintes no que claramente ainda é uma das atividades econômicas mais importantes para significativa parcela deles. Respostas positivas indicam campo perceptivo negativo.

8: 을iaduto da Perimetral es muito feio: com esta afirmativa propunhamos medir a atitude dos sujeitos peiante o Viaduto da Perimetral cuja construcăo, na opiniăo unânime dos técnicos respondentes, e caracterlsticas inseriram impactos nogativos na área, principalmente quanto ás continuidades visual $\epsilon$ morfológica, além de dificuldades para o funcionamento das atividades portuárias. Resposta nositiva indica campo negativo.

9: Deveris haver mais habitasões: conota atributos da área, no sentido da existência, ou não, de suficientes habilições para seu potencial, enquanto tambem conota a atitude do sujeito em relacoúca á adequabilidade da área para a moradia. Resposta positiva indica campo perceptivo positivo.

As tauelas relativas a atitudes e atributos (Tab. 28 a 34 ) apresentam a distribuigão de respostas relativas as diversas impressões ambientais, segundo cada girupo pupulacional e cada ponto de coleta, bem como a média ponderada de cada uma. 
A média ponderada sera indice importante na análise dos resultidos e em sua interpretacão gráfica (F゙igs. 75 a 81 ). Listes graficus iriterpretativos foram construldos mentendo- se no eixo horizontal a média ponderada entre os valores - 3 a +3 , de maneira a facilitar as comparacơes das proporcōes de resultados entre os grupos populacionais, explicitando os campos perceptivos "negativo" e "positivo".

Um fato evidenciado pela distribuicăo das respostas, foi a tendência dos respondentes de evitarem marcar o valor o na escala de concordancia com as afirmativas, ou seja, evitavam se mostrar "indiferentes". Isto poderia ser explicado como sendo uma caracteristica do próprio desenho do questionário, mas nâo acreditamos que ele tonha gerado uma tendência inconsciente ao respondente de avitar o zero, ao contrário, quorlamos que "indiferente" tambéin fosse uma opcão viàve1, e não forcando a ver-se obrigado a optar por um dos campos perceptivos se assim não o desejasse.

Cabe alertar que, principalmente no caso desta Parte III $\epsilon$ : da Parte IV do nosso questionário, devemos sempre relativizár alguns dos rosultados gerais obtidos na anàise dos dados, segundo os três grupos populacionais. Estatisticamente, a diferenciação nos totais de respondentes em cada um dos grupos, se individualmente inuito acentuadas, podom influenciar em demasia a média pondorada, eventualmente, gerando interpretacóes equivocadas. Este fato foi levado em conta durante toda nossa análise dos dados gerais e atiavés da utilizacăo de gráficos comparativos lado a lado nas figuras, facilitando a análise visual das distribuicơes. 
Antes de analisarmos os dado: relativos, primeiramente, \& percepcáo de bajrros e, pusteriormente, da Araa Portuária, cabe adiantar a anàijse da distribuicão de respostas coristante á Tabela 27, da atitude dos respondentes relativa á participacão comunitária. Isto norque por um 1ado, como vimos, esta afirmativa não consta dos procedimentos normais de nossa análise, não tendo sido incluida llas outras tabelas $€$ gráficos. Pelo oucro, devido á obviedade dos seus resultados conuns aos dois niveis de percepcão, que deixaram evidente que o nusso conjunto de respondentes possui uma atitude extremamente positiva em relacão ¿ participaçăo em planos e no planejamunto tanto a nivel dos Bairros quanto á nivel da Area Portuária (Tab. 27).

Em relação á participaça comunitária no planejarnento do bairro, o percentual de respostas com inteneidade $\div 3$ supera $35 \%$ em todos os grupos populacionais, se verificado em relaqżo aos dados globais, e mesmo em relaço aos diferentes locais de aplicacáo de questionarios e aos três sub-grupos populacionais, este percentual nunca foi inferior a $72 \%$, atingindo poi vezes picos máximos de 100\%. No caso das respostas relativas á participaçåo em plano para a Area Portuaria, os percentuais revelados pelas respostas dos trêsi grupos populacionais foram ainda maiores, superiores a $95 \%$.

XII. 6.1. Atitudes e Atributos Relativos aos Bairros:

Por uma queståo de facilidade, desenvolveremos os comentários seguintes ordenados segundo cada uma das afirmativas, representativas de atitudes e de atributos ambientais sobre os bairros (oueståo 17), a partir dos dados gerais a todos os locais 
de aplicacão de questionáíos (Tab. 28 e Fig. 75) para, em seguida abordarmos os relativos a cada uma destas localidades (Tabs. 29 a 33 e Figs. 76 a 80 ). As Figuras estão todas localizadas ao fim do presente ponto.

Lembramos, mais uma vez, que nas tabelas e figuras mencionadis, as intensidades marcadas correspoindem, não ás respostas dirotas, mas à sua interpretacão seyundo campos perceptivos opostos (Positivo X Negativo), de maneira a facilitar a análise e possibilitar uma melhor visualizacăo das percep̧ôses encontradas.

- Afirmativa 1: "Este Bairro é bom para morar"

Os dados gerais nos mostram que a atitude mèdia em relação ¿ afirmativa e "negativa", com média pondeiada de .1 .12 . Embora deva-se considerar que o giupo do "rioradores" sempre teve uma atitude positiva, do média geral to.4?, este resultido năo foi forte o suficiente em nenhum local de aplicação para reverter a média punderada geral, embora no Santo cristo ela tenha atingido o pique de +0.85.

Quanto aos dados relativos aos 1ocais de aplicacão, tomados individualmente, nota-se atitudes semelhantes ás médias: globais, bastante "negativas", exceto na Praca da Haimonia, onde a media negativa foi cerca do valor zero, influenciada pelas respostas positivas dos "usuálios".

o hairro que ohteve a menor média ponderada, ou seja, gerou a atitude mäs "iegativa" dentre os respondentos foi - correspondente á Rodoviaria. Interessante é como a percepcãu das precàrias condiçoses ambientais deste 1ocal determinam esta atitude negativa, embora tenhamos visto que 
11 dos respondentes neste local acertaram que o bairro é Santo Cristo (como vimos na análise das respostas á Questão 10, Tab. 17), um dos bairros que gerou mais atitudes positivas.

Portanto, dentre os respondentes, mesmo "moradores", os bairros da Area Portuária, nas condições existentes, não evocam suficientes atitudes positivas para moradia.

- Afirmativa 2: "Ele è bom para trabalhar"

Ao analisarmos os dados relativos á totalidade de respondentes, chama a atenção a atitude "positiva" perante esta afirmativa, quando em relacão a todas as outras impressões ambientais fica patente a forte tendência a atitudes "negativas" dos grupos de usuários.

Neste caso a média ponderada para os valores da escala atingiu to.98 no geral. o pique máximo foi obtidos nas respostas do grupo dos que "trabalham" na Area Portuária, cuja mèdia ponderada foi de +1.66 . As médias ponderadas sobre esta impressão ambiental, espectficas a cada local de aplicação, também foram em sua maioria positivas, com exceqăo da impressăo dos "usuários" na Barăo de Tefé $(-0.20)$ e de todos os grupos na Rodoviària, onde a média ponderada geral fot de -2.60 .

Pode-se dizer que estas impressões demonstram que, com a excessão da àrea da Rodoviària, todas as outras, enquanto bairros, são vistas positivamente para trabalhar, com variacoóes apenas quanto á intensidade destas atitudes, mas sempre mantendo valores mèdios. 
- Afirmativa 4: "Q Bairro é mal frequentado e perigoso"

Afirmativa que conota percepcão diretamente relacionada com a questão da "segurancia", jà tão presente como vimos nas primeiras imagens recorrentes aos bairros.

A média ponderada relativa á totalidade de respondentes foi uma das mais negativas, de -2.54 , traduzindo bem as atitudes dos três grupos populacionais em todos os pontos de coleta, que percebem os bairros da Area Portuária cumo "mal frequentado e perigoso". O pico minimo de 3.00 foi atingido nas respostas dos "usuários" na Pracia Mauà e da Barão de Tefé, e entre os "moradores" ná Rodoviaria.

- Afirmativa 5: "Tem muita sujeira e mau cheiro"

Tampouco huuve discrepancias nas mèdias gerais em reląão aos grupos populacionais e os distintos pontos de coleta. Soble eista impressão ambiental, a atitude das pessoas perante so bairros foi "negativa", com intensidade média geral de $-2,66$, atingindo o minimo de: $-2,94$ entre os respondentes na Praça Mauà.

Afirmativa 6: "E agradảvel, com casas e paisagens: bonitas Pelos dados gerais, a atitude perante esta afirmativa é "negativa" tanto no conjunto dos sujeitos $(-1.07)$ quanto em cara um de seus grupos. Entretanto, o grupo de "moradores" tendeu em todos os locais a manter uma atitude menos negativa, enquanto os "usuários", ao contrário, tendiam a atitudes inais negativas. 
A única exceça foi traduzida pela media ponderada de +0.69 obtida entre os "moradores" no Santo cristo, o que revela uma atitude positiva bastante significativa (senåo em valores absolutos, por destoar dos demais resultados) para com os aspectos paisagisticos daquele bajrro.

- Afirnativa 7. "@ Bairro tem pouco comércio"

Os dados: tabulados e o gráfico de atitudes pela média poriderada nåo revelam grandes discrepancias entre as percepcones dos diversos grupos $\Leftrightarrow$ pontos de coleta, os rosultados siempro se mantendo "negativo".

Poderlamos, entretanto, interpretar mais detalradamente os dados no sentido de obstrvar que na Barão de "efe, os grupos dos "moradores" e "usuários" registraram médias ponderadas significativamente mais negativas do que - grupo dos que "trabaiham". Na Harmonia foram us "usuários" que responderam mais iegativamente, enquanto na Rodoviaria foram os que 1 á "trabalnam".

- Afirmativa 8: "Tem poucas opcões para lazer"

sob o aspecto geral, os dados nos revelam aqui um dos Indices (média ponderada) mais negativos de -1.38 .

Embora a percepcão desta questão dentre os três diversos grupos mantenha-se em mèdia semelhante, os dados sugerem que quanto menor a familiaridade com a área, meis carente de lazer ela parece ser para o respondente. Assim, as médias ponderadas na anàlise geral foram: "moradores", -1.80 , "trabalham", -2.00 , "usuàrios", -2.10. 
Este raciocinio serve também para a analise dos dados referentes a bairros nos diferentes locais de aplicação. As médias foram sempre muito negativas coin o grupo de "moradores" tendendo a demonstrar uma peicepcăo menos "negativa" do que os outros grupos.

Foi surpreendente a alta média riegativa nu santo Cristo, uma vez que o Bairro possui da area de lacer inais equipada das redondezas, no Morro do Pinto, como vimos no Capitulo VII. Até o grupo dos "moradoies" apresentaram média ponderada de -2.00 . Na Rodoviaria foi onde aparoceram as peircepcôes mais "negativas" da questão, nos três grupos poputacionais.

- Afirmativa 9: "O Bairro precisa de ponto social central" Segundo os dados gerais, esta questão tambèm sugeriu uma das percepcôes mais "negativas" do conjunto de pontos de coleta, atingindo média ponderada de $-2,14$, com o grupo de "moradores" da Area Portuária definindo a percep̧ão mais negativa.

Ein relaçăo a cada uiin dos pontos de coletia individualmente, o grupo "moradores" despontou como apresentando as percepços mais negativas, com pique previsivel na Rodoviária, onde a inèdia ponderada desto grupo atingiu -3.00 . As outras percepcôes muito negativas dos "moradores" foram na Praca Mauá, do $-2,78$, e no santo cristo, de -2.38 . Neste último caso o resultado surpreende um pouco já que a àrea possui uma praça bastante central no que diz respeito an tecido urbailo \& \& poopria distribuicão 
de funçoses e circulaça do bairro, visto no capttulo VII. Interessante notai qus, mesmo nos locais de alicaão que constituiam-se de praças bastante frequentadas por atividades que não apenas de passagem, com importância inclusive na evolucão o identidade dos bairros, as percepcões dos "moradores" foram muito negativas, sugerindo que estes locais talva: não estejari sendo devidamente utilizados e reconhecidos coino centros de encontro.

- Afirmativa 10: "Gostaria de Mudar do Bairro"

Os dados gerais nos mostiam uina atitude não muito "negativa", de média punderáda -0.39, média geirai esta que reflete bem aquelas relativas a cada um dos grupos populacionais do conjunto de respondentes.

Embora a interpretacao \& as respostas a esta afirmativa remeta a percepcôes pertencentes ao mesino tipo de campo imagético (conotaçôes idênticas), sua natureza é diferente entre os três grupos de sujeitos. Entre "moradores" da Area Portuária ela diz respeito a uma real mudança de moradia.

No caso do grupo dos "moradores", a média ponderada geral foi de -0.20 , atitude algo "negativa" mas que não se repete em todos os resultados $f \in$ lativos a cada um dos pontos de coleta. Exceçós deram-sie na Praça Mauá (+1.22) e, Tigeiramente, no santo cristo (+o.08), percepcăo esta que ainda pode ser entendida como reforcada pelas atitudes do ginpo de "moradores" que foram respondentes na Rodoviaria, local oficialmente no bairro de santo cristo. 
Foi outro lado, a Afirmativa 10 em relaça ao grupo de sujuitos que "trabalham" nä Area Pultudiia deve sei vista apenas como referindo-se a possibilidade de eventual mudanca de local de trabalho.

Analisados comparativamente com aqueles obtidos com as respostas á Afirmativa 2. (se o bairu era "bom para trabalhar"), os resultados da percepcáo desie grupo em relação aos bairros parece mostrar atitudos contraditórias. Enquanto a anàise da Afirmativa 2 mostrou uma atitude muito "positiva" para com trabalhar no bairro (indice médio de +1.66$)$, o mesmo năo pode sor dito com as atitudes concluidas da Afirmativa 10, cuja média ponderada geral foi de -0.43 ; ou seja, que um percentual significativo de sujeitos gostaria de mudar de $100 \mathrm{l}$ de tiráalro. Analisador individualmente segundo locais de coleta, os resultados se mostram atitude "positiva" do grupo "trabalham" na praca Maud, com, mèdia de +0.47.

Entre os "usuários" a conotacầo da Af i inativa 10 é semelhante aquela dos que "trabalham", remetendo a possibilidades de mudanças relativas As razões por quo encontram-se no loca1. A média ponderada dos resultados gerais deste grupo mostra atitude negativa ds -0.37 . No entanto, os "usuários" respondentes na Praca Mauá, na Práá da Harmonia, coin indices respectivos de +0.21 e t0.67, mostraram atitude "positiva" a este respeito. Curiosamente, - Indice mais negativo não foi obtido entre os "usuários" da Rodoviaria, mas no santo cristo $(-0.91)$. 
Fig. 75: Gráfico de Intensidade de Atitudes e Atributos segundo Campos Perceptivos, relativos a bairros, no conjunto de respondentes (Questão 17).
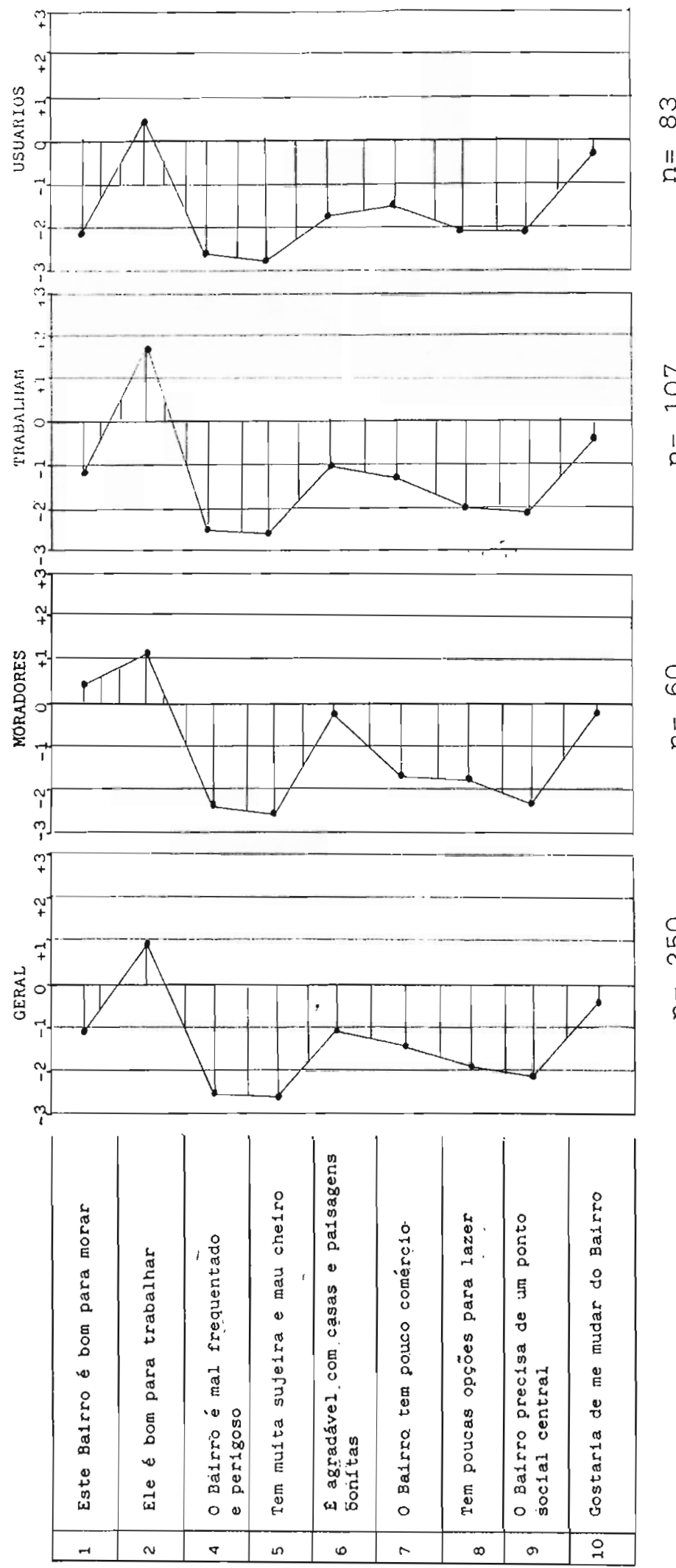
Fig. 76: Gráfico de Intensidade de Atitudes e Atributos segundo Campos Perceptivos, relativos a bairro; local de aplicação: Praça Mauá (Questão 17).
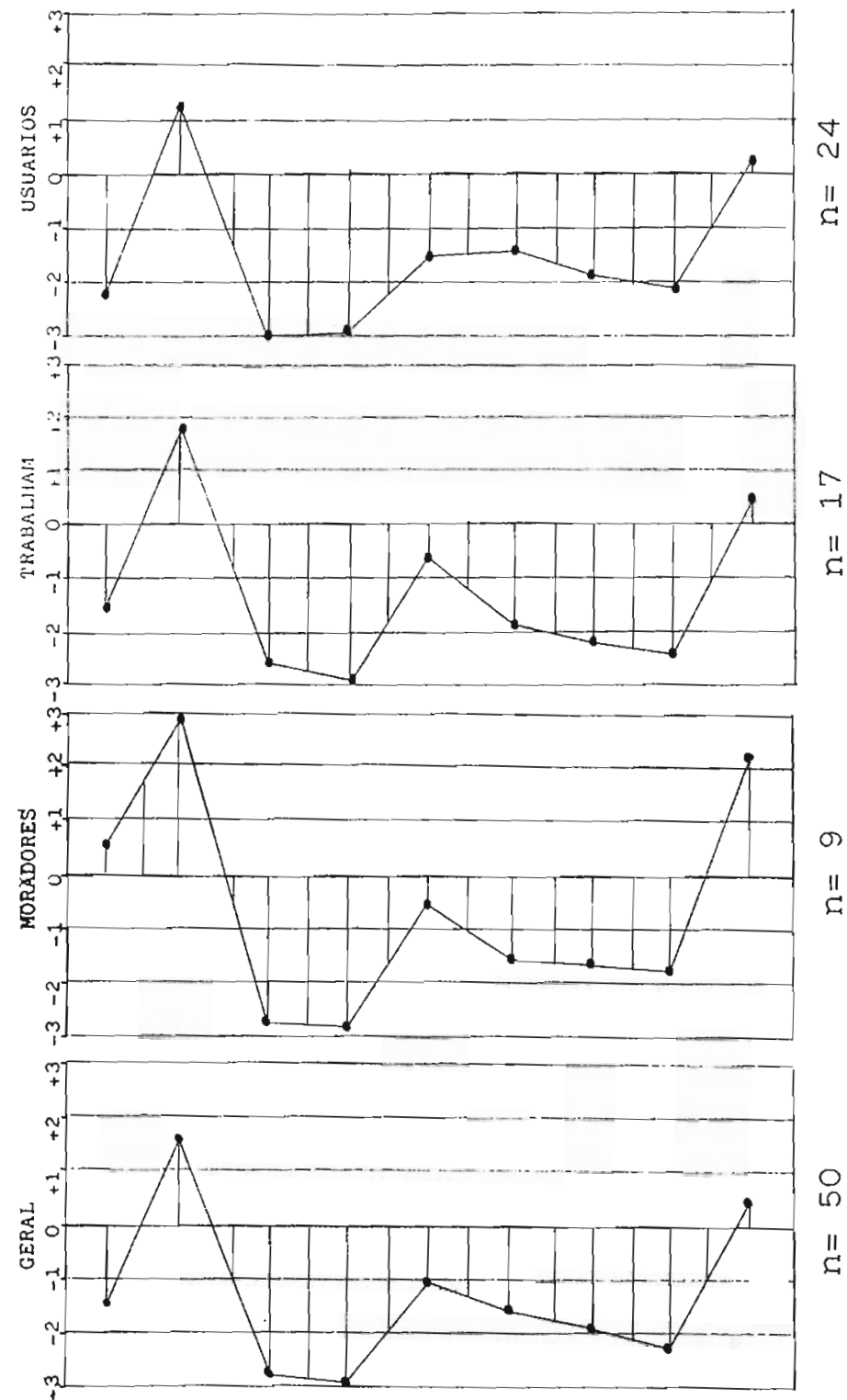

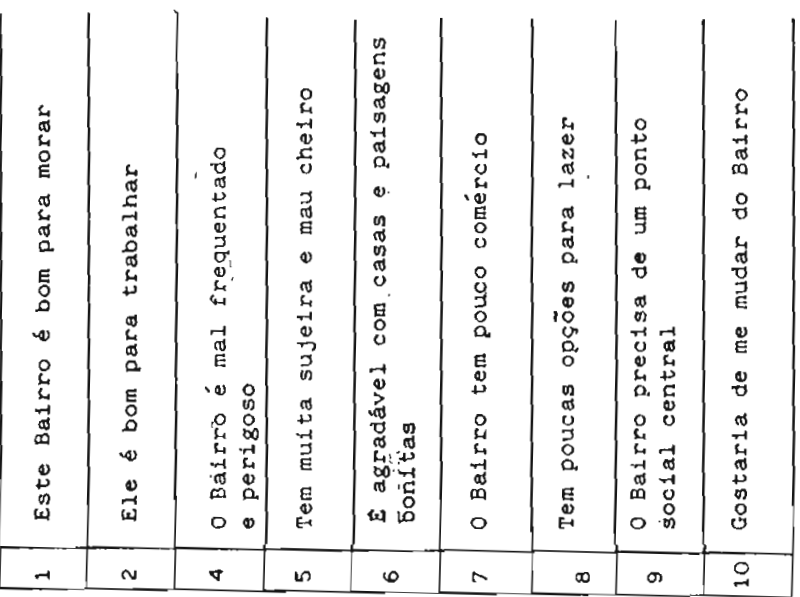


Fig. 77: Gráfico de Intensidade de Atitudes e Atributos segundo Campos Perceptivos, relativos a bairro; local de aplicação; Praça B. Tefé (Questão 17).
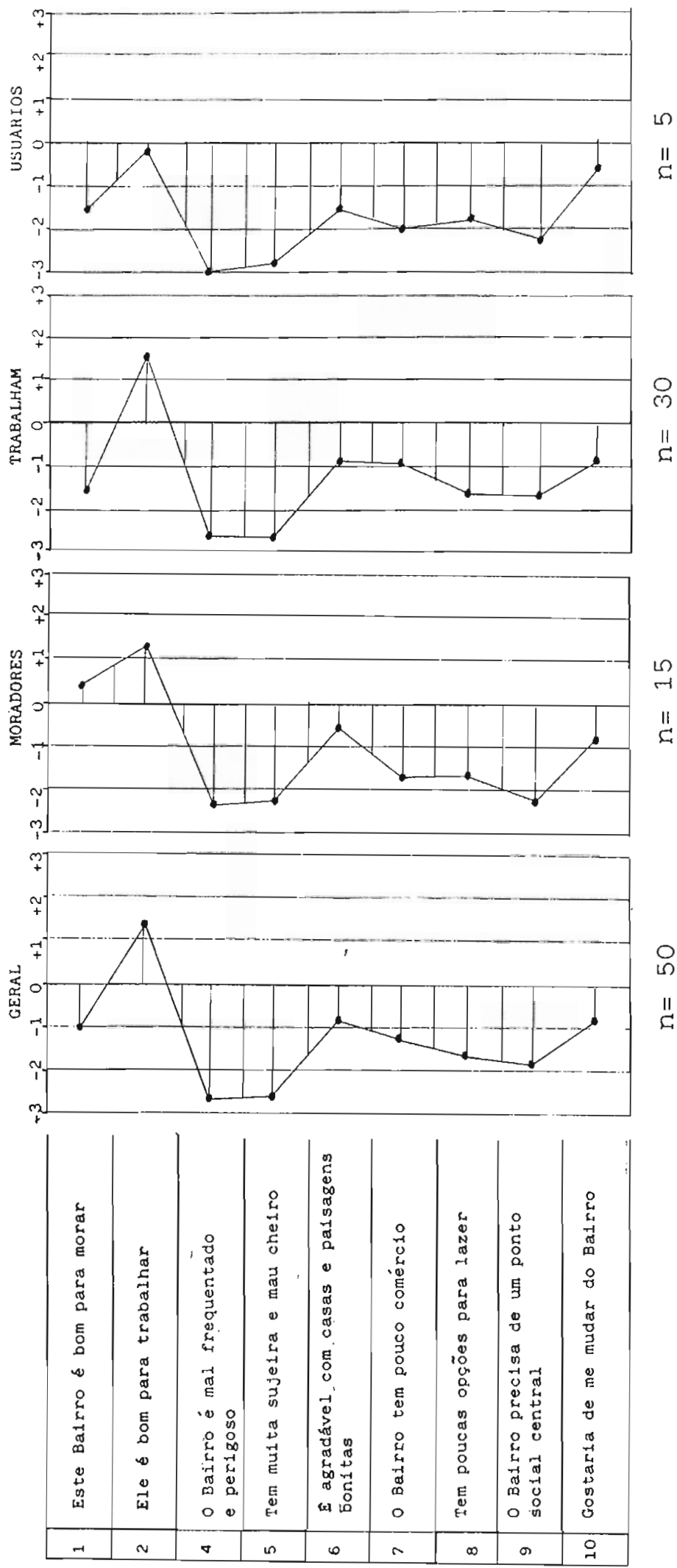

옹 II 
Fig. 78: Gráfico de Intensidade de Atitudes e Atributos segundo Campos Perceptivos, relativos a bairro; local de aplicação: Praça da Harmonia (Questão 17).
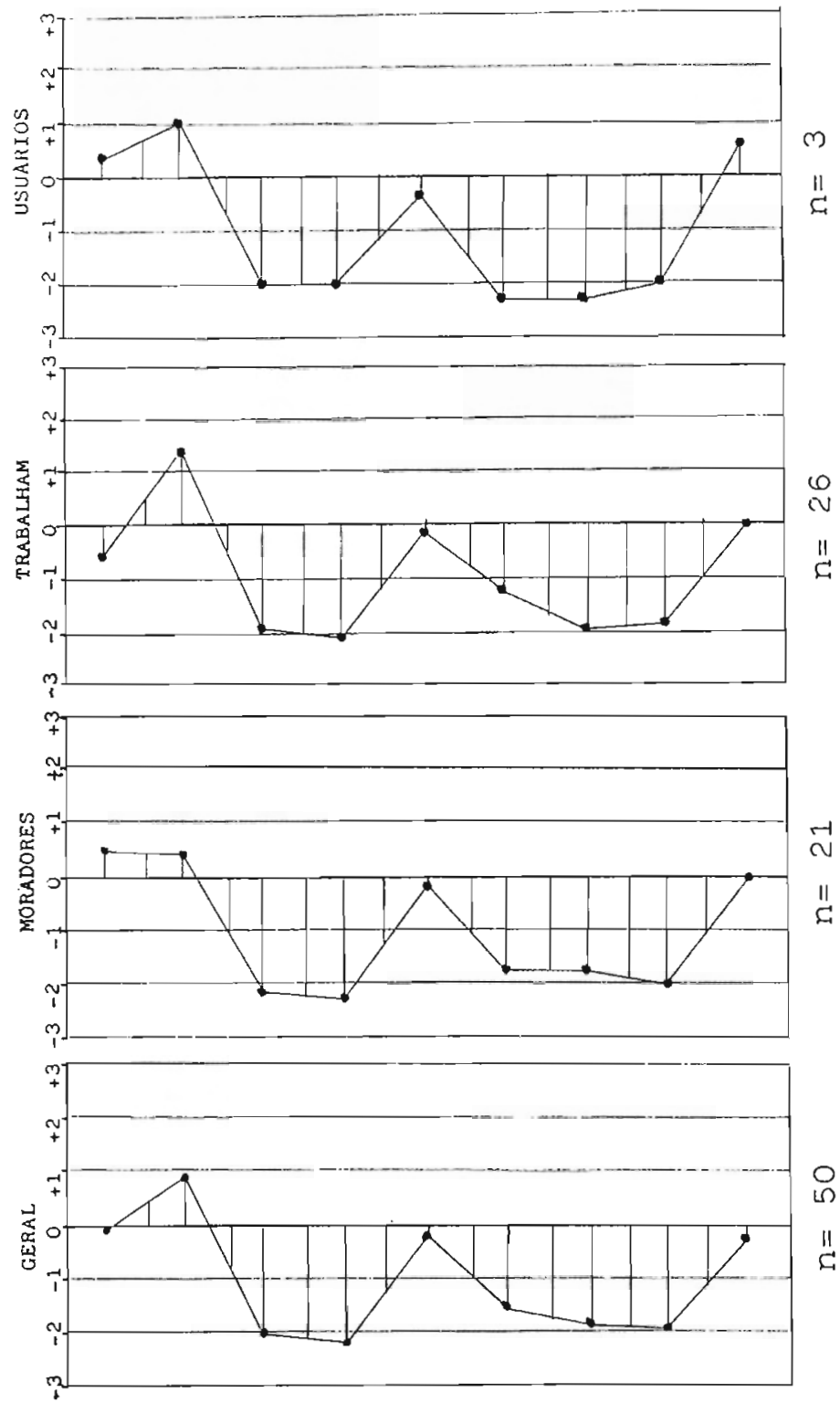

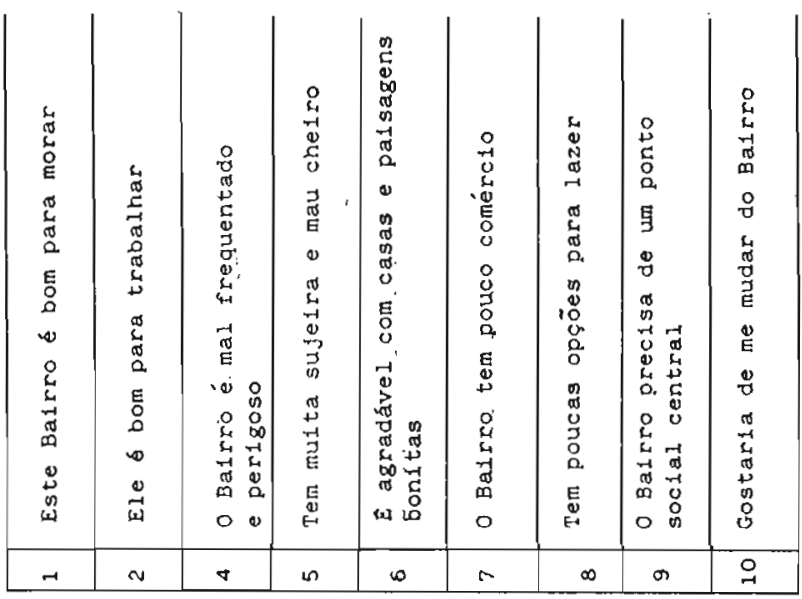


Fig. 79: Gráfico de Intensidade de Atitudes e Atributos segundo Campos Perceptivos, relativos a bairro; local de aplicação; Praça Sto Cristo (Questão 17).
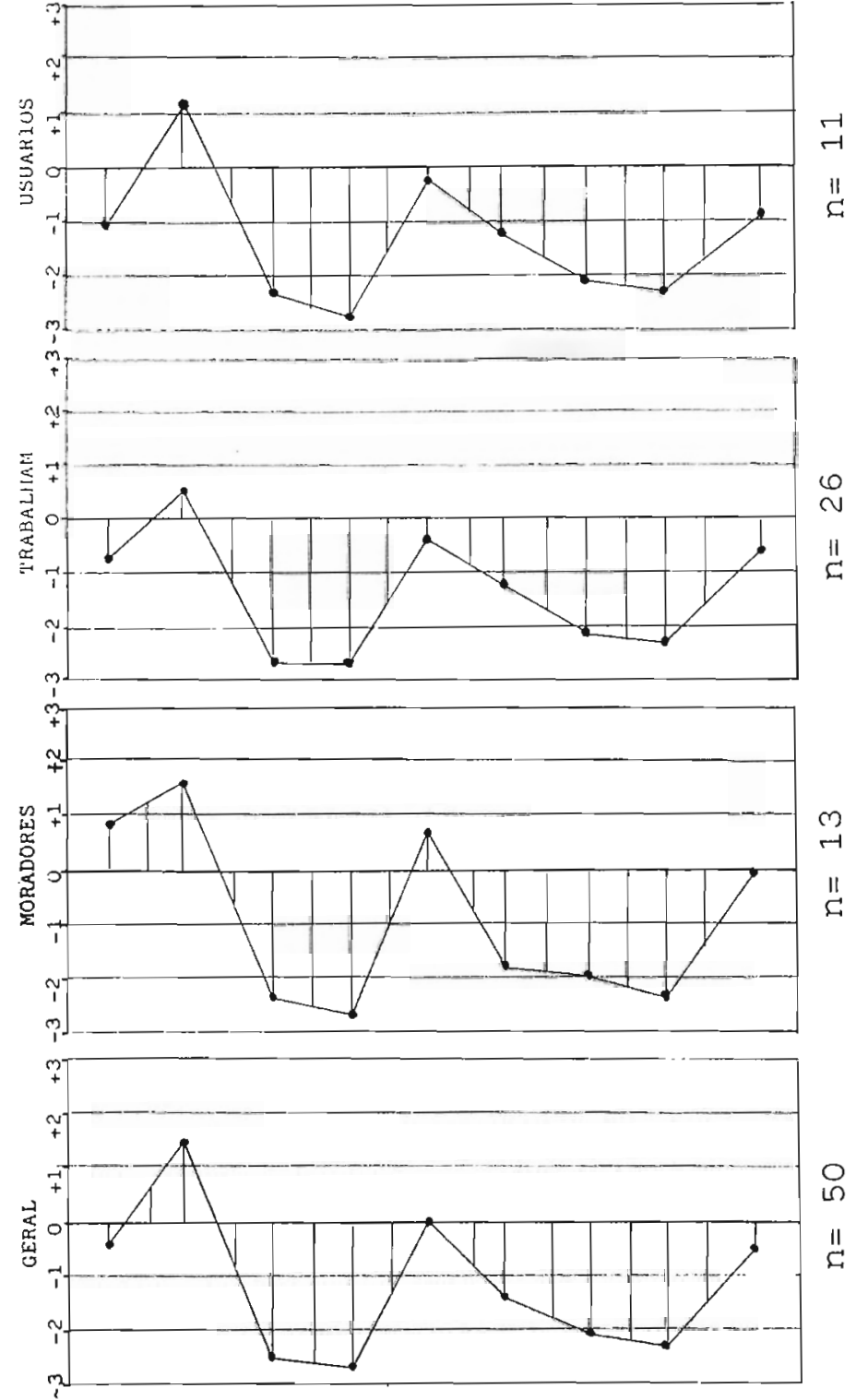

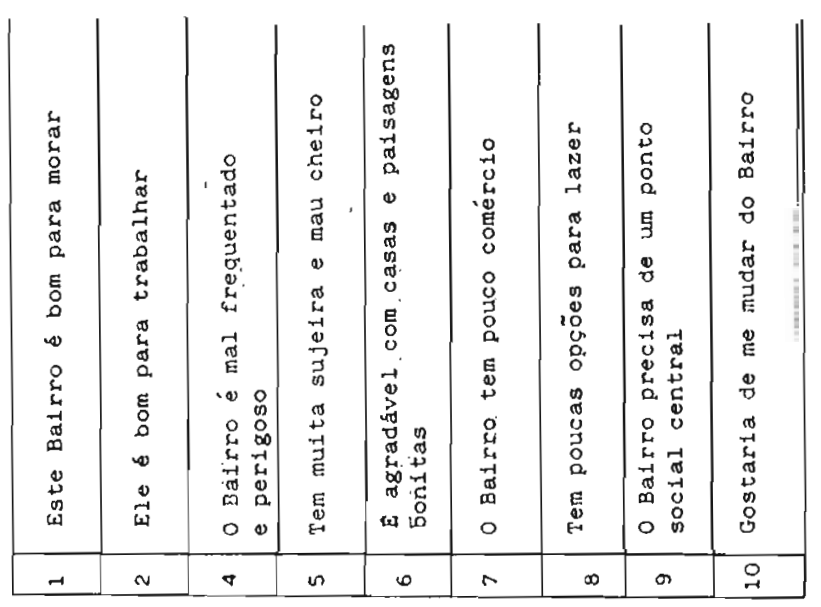


Fig. 80: Gráfico de Intensidade de Atitudes e Atributos segundo Campos Perceptivos, relativos a bairro; local de aplicação: Rodoviária (Questão 17).

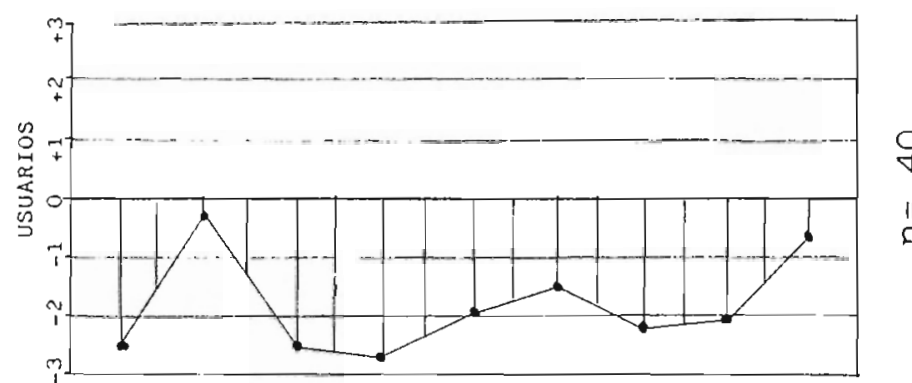

웅
ㅁ
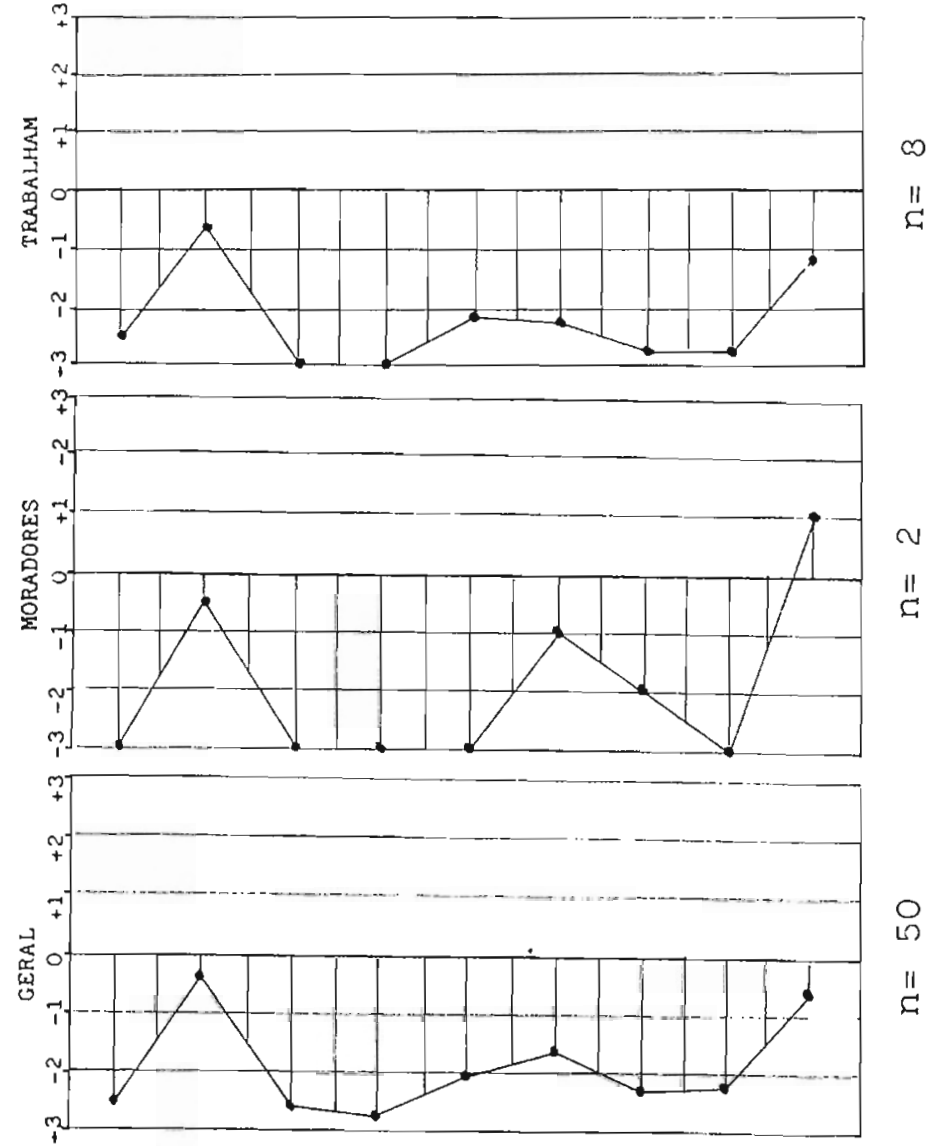

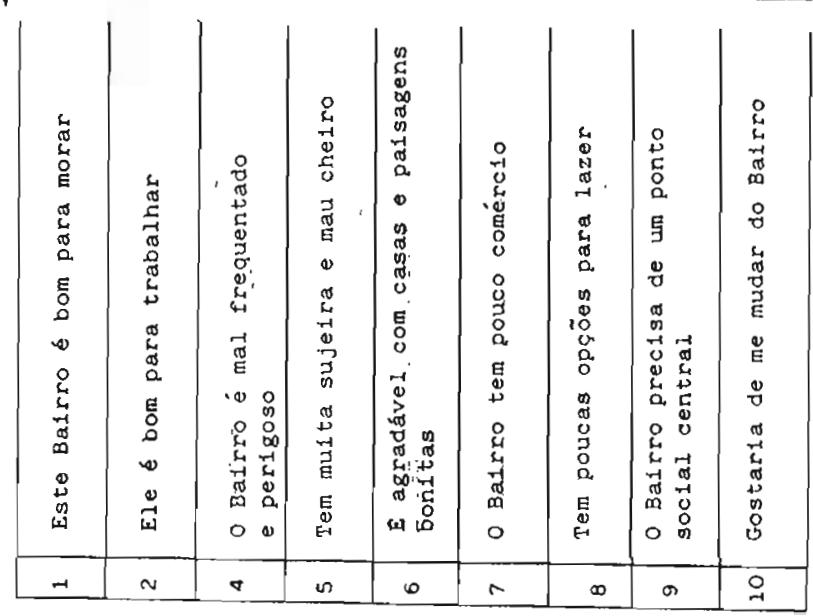


XII. 6.2. Subre Atitudes e Atributos Relativos a Bairros:

A análise quo realizamos sobre as atitudes dos respondentes perante os baiiros e os seus atributos, percebidos, desenvolvida acima, hos permice um recunio conclusivo através dos seguintes pontus:

- em termos medios do conjunto de respondentes, os bairros não são percobidos como bons lugares para morar, cmbora as respostas dos "moradores" mostrem atitudes ligeiramente positivas, principalmente em rolaça ao santo cristo.

- a afirmativa sobre atributos, cuja interpretacão teve a major concordância no campo positivo por todos os grupos respondentes foi a de todas os bairros serom bons locais para se trabalhar, com ủnica excessão da àrea da Rodoviária.

- foram das inais negativas as percepcôes de todos os grupos de respondentes rla interpretaça das afirmativas 4 e 5 , relativas aos aspectos mais obviamente percebidos da administraça ambientä : seguranca e limpeza.

- apenas o grupo de "moradores" do santo cristo manifestaram percepcão positiva em relação a atributos paisagisticos e arquitetônicos de seu bairro.

- de uma forma geral, os respondentes possuem percepcão negativa de atriliutos nos bairros diretamente responsaveis por condicões de habitabilidade complementares á propria habitaça, como comercio, lazer e ponto social central (Afirmativas 7, 8 \& 9). A percepcăo de atributos ligados a lazer e ponto social centra1, inclusive, foram dos que atingiram indices mais negativos na totalidade das respostas. Ein relacão a comércio e ponto central os "moradores" e os que "trabalham" na àrea foram os mais ressentidos, enquanto ques em relacão ao lazer, a familiaridade do respondente com o bairro pareceu aumentar-ihe a satisfacăo.

- em relaça a possibilidade de mudar de bairro, exposta pela atitude representada na afirmativa 10, os indices revelam que os três grupos possuem percepcỗes negativas dos bairros. Entretanto, algumas excessões foram registradas como percepções positivas: todos os sub-grupos na Praça Mauà, os "usuảrios" na Praça da Harmonia, e os "moradores" na Rodoviária.

Cabe destacar que as respostas dos ruspondontes na

Rodoviária expressam uma forte rejeicå por aquele local, us campos negativos prevalesceram muito se comparados aos outros 
locais de aplicagáo de questionários. Este resultado vem de encontro ao obtido em relação ás primeiras imagens recorrentes, quando a1ton grau de rejeição foi detectado neste local.

A apkrente contradicão entre as percepções dos "muradores" quanto ás Afirmativas 1 (bairro bom de morar) e 10 (gostaria de mudar de bairro), pode ser interpretada como un recunrecimento dos atributos positivos da area o seu potencial, mas uma insatisfação com o estado das coisas.

XIT. 6.3. Atitudes e Atributos Relativos á Area Portuária:

Para o desenvolvimento da análise rulativa a este ápocto da percepcão dos sujeitos respondeiltes, seguiremus a inesina sistematica do item anterior, segundo o order das afirmativas. apresentadas no questionario.

O grafico de intensidade de atitudes e atributos percebidos: par"a a Airea Portuária, segundo campos perceptivos, constiuido a partir das médias ponderadas das respostas encontra-se no firat deste porto (Fig. 81).

Afirmativa 1: "A Area Portuaria tem lugares e paisagens muito bonitos":

A atiude geral transmitida pelos resultados foi "negativa", com mèdia ponderada de -0.79 . O grupo de "moradores" apresentou uma atitude um pouco melhor, de -0.13 , enquanto os que "tiabalham" e os "usuários" demonstrárám Indices de $-0.60 €-1.49$, respectivamente, o que indica porcepcões progressivamente neyativas com a diminuicão de intimidade com a ąrea. 
- Afirmativa 2: "Está mau conservada e cheia de 1ixo"

Tanto na avaliacão geral de dados, quanto em relação aos três diferentes grupos de respondentes, foi a afirmativa de impressåo ambiental que mostrou atitudes mais negativas em relaça á Area Portuària. Apenas duas pessoas responderam no campo positivo, mesmo assim, dispondo o menor valor dispontvel.

No conjunto total de respondentes o indice foi de 2.60 , enquanto entre os "moradores" de -2.55 , antre os que "trabalham" de -2.50 e entre os "usuarios" de -2.78. Estes resultados indicam, novamente, uma ampliacăo das percepcras negativas dos individuos segundo a diminuicáo do sua intímidade com a àrea.

- Afirmativa 3: "Casas e armazèns antigos devem ser preservados":

A média geral de respostas foi no campo positivo, alcancando o Indice bastante elevado de +1.86 . Neste caso, curiosamente, foi o grupo de "usuários" que apresentou a porcepcão mais positivá, de +2.33 , enquanto o de "moradores" apresentou o mais baixo, de +1.75 .

- Afirmativa 4: "Major integracão com o centro da cidade e mais escritorios":

Oe dados gerais mostram indico muito baixo, de $-?, 13$, indicando que indica que us rospordentes percebem a área como possuindo pouca integracão com o centro $a$ necessitando de mais escritorios. Previsivelinente, quanto inenor a intimidade do respondete, mais negativa esta visăo, culminando com os "usuarios" com indice de $\cdots 2.20$. 
- Afirmativa 5: "Deveria ter mais 1azer"

Certamente o lazer não se encontra entre os atributos da área, como vimos, mas interessava tambem medirmos a intensidade das atitudes negativas a este respeito. No âlibitio sera1, foi o segundo indice mais negativo obtido no conjunto de afirmativas $(-2.26)$. Também um relação a cada um dos grupos populacionais manteve-se sempre como o seguido indice mais negativo entre "moradores" (-2.27), "trabalham" (-2.17) e "usuários" (-2.39).

- Afirmativa 6: "Deveria ter mais uso turistico"

Puderia ser entendida como relacionada com a Afirinativa 1, eriquarito potencial do patrimômio construido. Mas, "riquarito aquela foi "negativa", esta afirmativa gerou percepcăo "positiva" qụe, embora năo muito elevada, polos dados do conjunto atingiu indice de +0.6.3. Novamonte aqui, a maior intimidade dos sujeitos com a área determinou uma maior atitude positiva nas respostas e os: "moradores" atingiram o Indice t0.92.

- Afirmativa 7: "As atividades portuarias deveriam ser transferidas para longe".

O Indice geral médio foi "positivo" de +1.54 , serido que para ogrupo de "moradores" foi de +1.03 , para os que "tiabalham" de +1.71 e para os "usuarios" de +1.25. Os resultados demonstram que a grande maioria dos respondentes possui uma percepcăo positiva das atividades portuàrias na área e sua atitude è de que elas não sejam transferidas daquela àrea. 
- Afirmativa 8: "O viaduto da Perimetral é muito feio"

o indice geral médio foj "negativo", de -0.80 , muito influenciado pelas atitudes expressas pelo grupo de "moradores", cuja média ponderada fol de ..1.05; isto demonstra o impacto relativamente forto do viaduto em sua percepcão da àrea. Por outro 1ado, os qua 1à "trabalham" e os "usuários" não demonstraram indices tac negutivos, de $\omega 0.40$ e -0.29 respectivamente. De qualquer maneira, pode-se concluir que o impacto do Viaduto da Perimotral sobre os três grupos populacionais gera percepcôes com atitudes negativas.

- Afirmativa 9: "Deveria ter mais habitacões"

A média ponderada atingida pelos dados gerais mostrou uma percepcão bastante positiva $d e+1.70 .0$ grupo de "moradores" novamente "puxou" O resultauo com o lindice de +2.07, onde apenas uma pessoas respondeu no campo negativo. O grupo dos que "trabalham" na Area Portuária geraram ambos indices de +1.59 . Portanto, os grupos de respondentes såo concordantes em que deveria haver mais habitações, discordando apenas na intensidade com que defendem esta temática.

XII. 6.4. Sobre Atitudes e Atributos Relativos á Area Portuaria:

A seguir, alguns pontos que refletem um resumo conclusivo de nossa análise sobre atitudes e atributos percebidns pelos respondentes em reliąăo á Area Portuária como um todo. Năo houve difeirenças de percepcôec antre sub-grupos que pudesse comprometor os Indices sugeridos pelas médias ponderadas (veja Fig. a1). 
- a paisagem da área é percebida negativamente entre os três grupos, sendo que os Indices ficam mais intensos á medida que diminui a intinidade do iespondentes com a área.

- o Indice mais negativo foi relativo da administracão ambiental e servicos, no que tange a conservação e 1 impeza.

- a atitude de preservacão dos imóveis antigos foi percebida como muito positiva por todos os sub-grupos. Interessantemente, os "usuarios" parecem perceber maior potencial nesta questão, uma vêz que suas respostas atingiram o indice mais alto, enquanto o mais baixo ficou com os "moradores".

- os Indices atingidos e a distribuicão de respostas entre os três grupos de respondentes indicam que, segundo sua percepção: a área deveria possuir mais integraçăo com o centro, mais possibilidades de lazer, mais uso turistico e mais habitaçoes.

- a percepcão dos respondentes é bastante positiva quanto á manutenção das atividades portuárias na área.

- todos os sub-grupos mostraram percepcão negativa do viaduto da Perimetral, resultado mais acentuado entre "moradores".

us indices atingidoe pelis respostas relativas á possibilidade de mais habitacôes foram muito positivos, indicando nos rospondentes uma clara percepcão de atributos positivos na avaliaça do potencial dá área.

De uma maneira gera1, o resultado do julgamento das afirmativas de atitudes e aiributos, tanto relativas a bairros quanto á Area Portuária, confirmaram os resultados obtidos com as "primeiras imagens", no sentido dos respondentes possuirem percepcão negativa quanto a temas que digam respeito á administração pública e servicos urbanos. Neste caso tampouco encuntromos diferencas expressivas entre as manifestacões dos diferentes grupos nem entre os diferentes locais de coleta de informação; ou seja, não houveram drásticas mudanças de campos cugnitivos, como vimos.

Pode-so também dizer que a área desperta percepcồes positivas iriquestionàveis em relaçăo á seu potencial como local de trabalho, moradia e á possibilidade de preservacão de imóveis. 
Fig. 81: Gráfico de Intensidade de Atitudes e Atributos segundo Campos Perceptivos, relativos a Área Portuária (Questão 18).
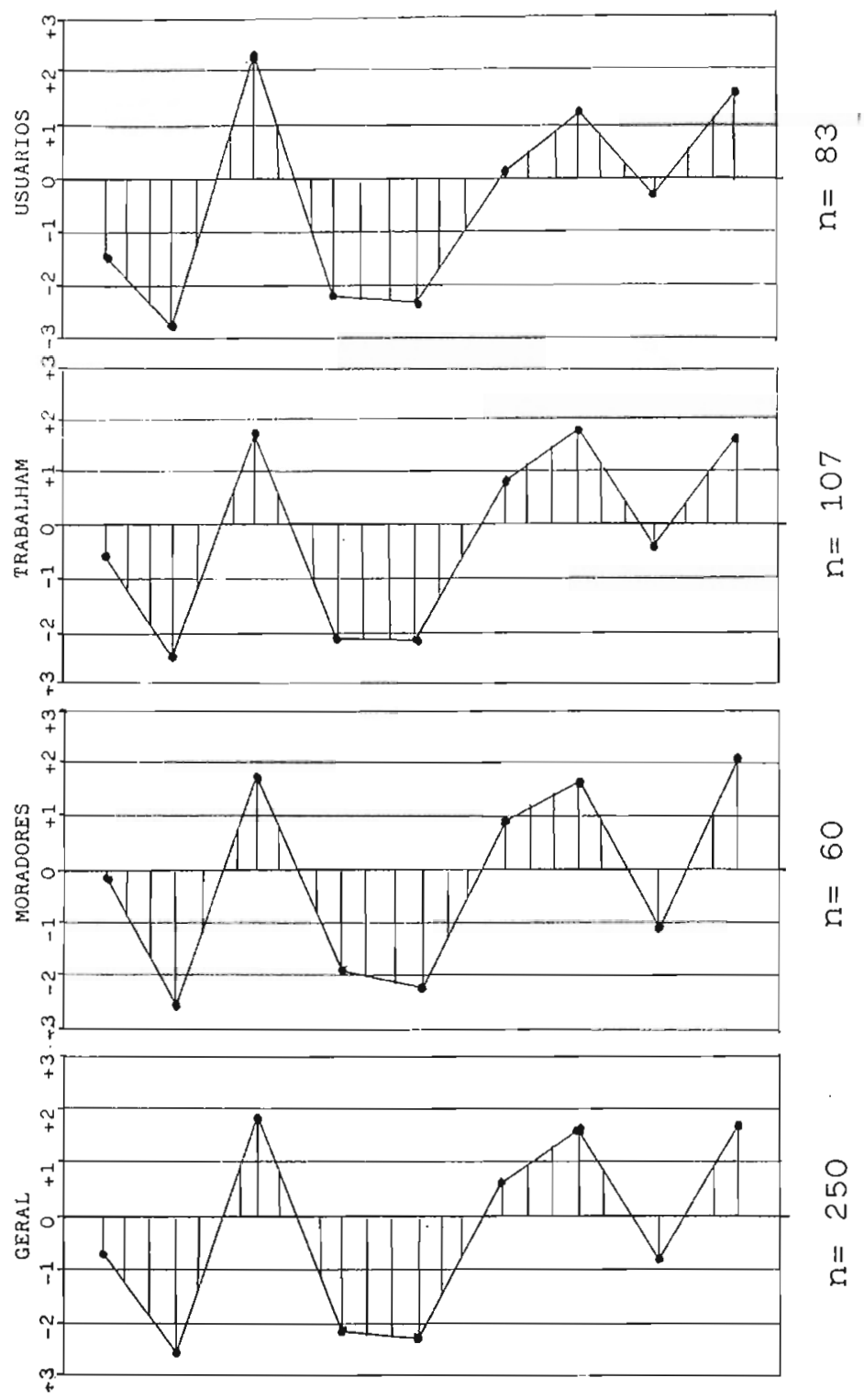

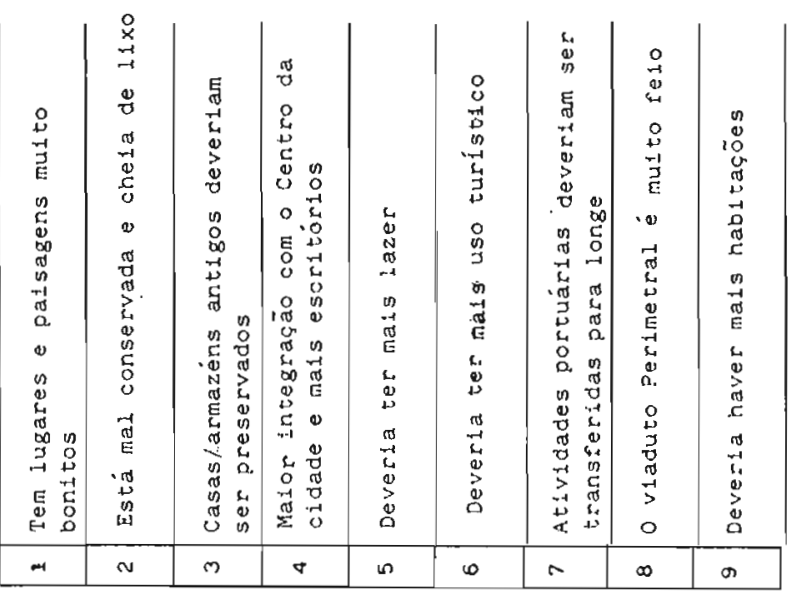


XII. 7. Preferências e Expectativas Ambientais:

L.embramos que esta quarta e lit tima parte do questionario tinha o objetivo de identificar as preferências e expectativas ambientais dos respondentes em relaça a possibilidades de desenvolvimento da Area Portuária, possibilitando a sua avaliação com vistas aos processos de desenho urbano e revitalizacão.

Neste sentido, a Questão 19 expunha o respondente a trêis cenarios; alternativos de desenvolvimento, que ele deveria ordenar segundo a sua preferência. Logo depois, o respondente definia a interisidade de sua expectativa frente a grupos de cinco possibilidades ambientais, cada grupo com afirmativas tipicas de cada cenário exposto, através de escala com valores de -1 (rejejcăo), 0 (indiferente) e+1 (acejtaça) (Tabs. 350 .36; Figs. 82 e 83 ).

XII. 7.1. Preferências Frente a cenários de Desenvolvimento:

Os três cenários de desenvolvimento apresentados na Questão 19, e sobre os quais as pessoas tinham que se expressar eram (vide questionàrio, Anexo III):

- Alternativa A: o mais radical, conotando processo de renovacão "Tudo mudaria muito pois a prefeitura, aliada aos Empresarios, resolveria fazer um plano moderno para renovacão total."

- Alternativa B: maior equilibrio, conotarido revitalizacão

"Tudo mudaria bastante pois a Prefeitura, os Empresários e a comunidade elaborariam juntos um Plano de Desenvolvimento. integrado e envolvendo todos os aspectos da àrea."

- Alternativa $\underline{c}$ : de maior inércia, sugerindo manutencão do estado "Mudaria mujto pouco pois a prefeitura não tem interesse politico ou recursos. Nem a Comunidade nem os Empresarios conseguem convencê-la a fazer muitos investimentos no local. 
A anàlise da distribuição das respostas segundo o conjunto de sua totalidade, nos permite concluir que a preferência ambiental dominante è aquela representada pela Alternativa $\underline{B}$, ou seja, a que promoveria um processo de desenvolvimento mais equilibrado, de consenso, no sentido de uma revitalizacão ampla (Tab. 35).

Esta foi a primeira opcão de $193(77,2 \%)$ dos respundentes e, aliás, ela tampouco foj registrada como terceira opção em nenhuma das respostas. Este resultado também se verificou entre os três grupos de respondentes, individualmente, com percentuais de primeira opção de $71.7 \%$ entre os sujeitos do grupo "moradores", 84.1\% do grupo "traba1ham" e $72.3 \%$ dos "usuarios".

A opcăo do desenvolvimento tipo "revitalizacão", dados mostram que os respondentes demonstraram preferência a A1ternativa A, "renovacão" mais radical. A primeira vista podemos ser levados a acreditar que năo, pois em numeros absolutos a Alternativa $\mathrm{C}$, "dejxar tudo como está", parece ser a segunda op̧ão pois 105 respondentes (42\%) votaram nela em segundo 1ugar.

Entretanto, matemáticamente, pela média ponderada das respostas e seus valores, chegamos á conclusăo que o fato de um número significativo de respondentes terem optado pela Alternativa A em primeiro e em segundo lugar, enquanto apenas um sujeito optou pela Alternativa c em primeiro, influi na avaliaça final ponderada. O mesmo raciocinio e resultados se aplicam a todos os três grupos populacionais respondentes.

Portanto, os dados indicam que a alternativa de revitalizacão é a preferência de todos. A não se fazer nada, mantendo-se a situaçăo atua1, a larga majoria dos respondentes optaram pelo cenário de renovacão mais radical. 
Fig. 82: Gráfico de Preferências face a três Cenários de Desenvolvimento, segundo sua ordenação (Questão 19)
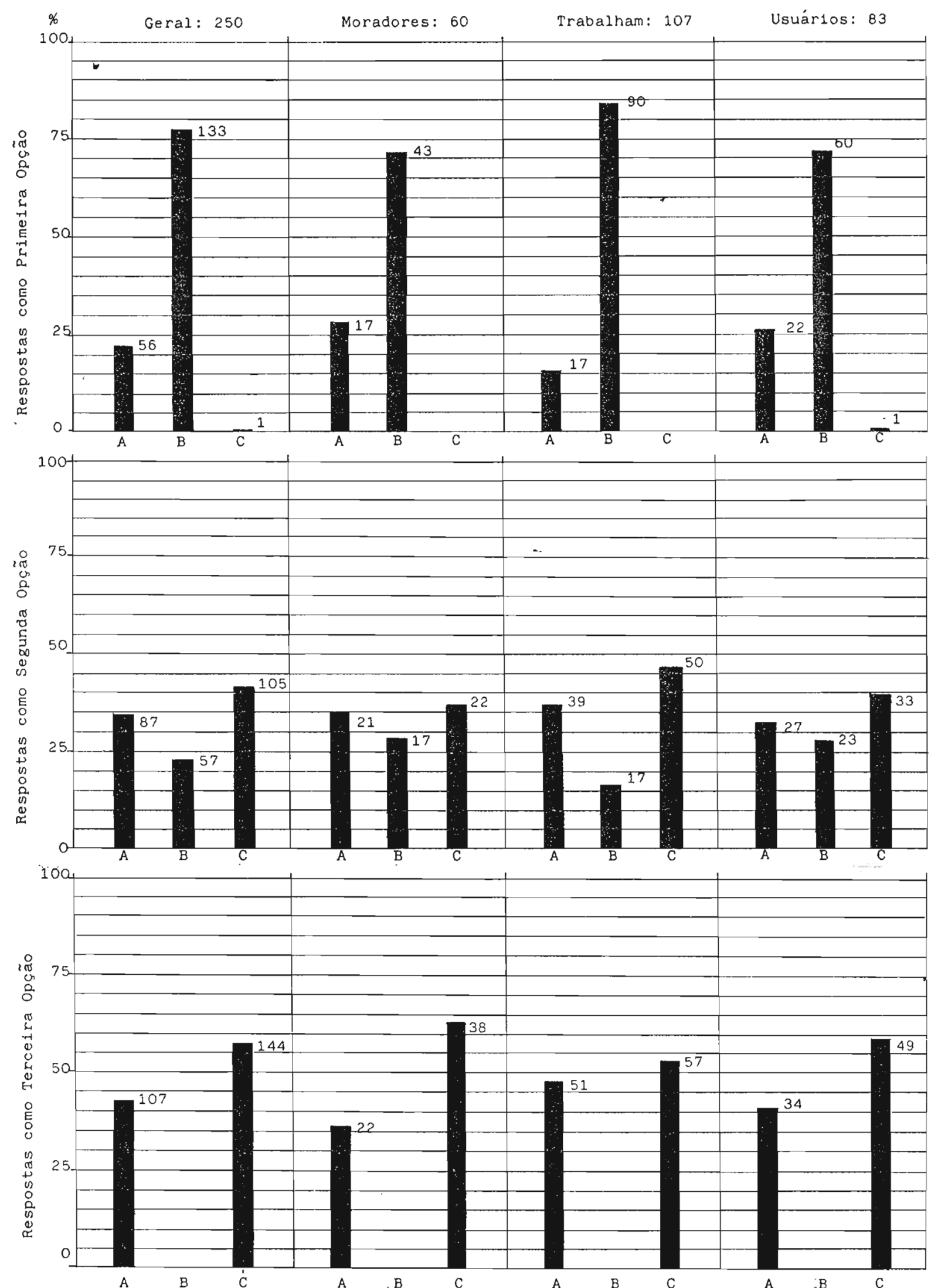
XII. 7.2. Expectativas para o Desenvolvimento:

Em seguida, comentaremos os dados resultantes relativos á intensidade de expectativas ambientais paia os cenários de desenvolvimento (Tab. 36, Fig. 83). Wnvament., nosso raciocinio apoiou-se no calculo das médias ponderadas, iomadas como tindices de aceitaçăo (valor positivo), rejeicão (valor negativo) ou indiferenca perante a afirmativa apresentada.

Individualmente e em conjunto, as expectivas expressas nas respostas ás afirmativas sugeridas nos permitem diferentes tipos de análise. Inicialmente faremos comentários individualmente.

Das afirmativas constantes na Alternativa $\underline{A}$ (renovaç̃o) podemos fazer as seguintes observaçós:

- 1: "Os ediftcios velhos seriam demolidos dando lugar a modernas construcôes, lojas e escritórios.

obtave baixo indice de aprovacăo $(+0,07)$ segundo o conjunt.o de dados mas "moradores" e "usuários" a aprovaram, ambos com $+0,18$; os que "trabalham" na área rejeitaram a opção com $-0,08$.

..2. "은 residencial serja desencorajado"

Rejeitada pela maioria segundo o cunjunto de dados, con Indice de -0,62. Fnire os "moiadores" obteve indice de rejeiça quase máximo (-0 93), bon acima dos obtidos entre os que 1à "trabalham" $(-0,50)$ e os "usuários" (... (i, 54), que mostraram-se semelhantes.

- 3: "Seriam constiuidos shopping centers"

Raixo indice de aurovaça de forma geral $(10,10)$, sendo que os resultados individuais para os diferentes grupos tampouco foram muito expressivos. o grupo los que 
"trabalham" na àrea apresentaram, inclusive uma ligeira rejeiçăo á idéia com indice de $-0,06$.

- 4: "O Porto continuaria funcionando na area, fortalecendo as suas funcôes"

Toriado o conjunto de respondentes, esta foi a afirmativa que obteve maior indice positivo, de tu,78. Obteve tambem valores altos, cerca desta midia, em cada um dos grupos de respondentes, sendo que entre os moradores obteve um indice ligeiramente natior do que os outros, igual a +0,83.

5: "A Area seris uma continuacăo do centro somo ele è atualmento"

o segundo Indice de aprovaçăo mais alto vesta Alternativa com to,6n. Os "moradoros" aprovaram com $\therefore 0,75$, os que "trabalhari" coil to,65, c os "usilarios" com $+0,19$

Em relação ao desenvolvimento sugerido pela Alternativa $\underline{B}$ (revitalizecâon), as afirmativas apresentadas trazem as seguintes expectativas:

- 6: "As áreas residenciais existentes seriam mantidas e novas residências seriam construtdas"

obteve o segundo major indice de aprovaçáo entre os "moradores" com +0.97 e Indices altos também entre os que 1 a "trabalham", to,70, e os "usuários", +0,67. A mèdia ponderada geral refletiu estas expectativas com o valor $+0,76$.

- 7: "As casas e armazéns antigos seriam preservados obteve o segundo maior indice de aprovaça no conjunto de 
sujeitos, com +0,97. Foi tambèm quase mảxima a aprovaçăo entre os "moradores", com to,98. Atingiu o valor ináximo de aprovação entre os que "trabalham" 1á, +1,00.

- 8: "Novos usos comerciais seriam promovidos"

o Indice máximo de aprovação no conjunto de sujeitos, com +0,98. Indica bem os elevados indices de cada grupo individual; os "moradores" expressaram sua expectativa màxima $(+1,00)$ apenas nesta afirmativa.

- 9: "Novos usos de lazer e turismo seriam promovidos" Indice médio de aprovação segundo o conjunto de dados $(+0,47)$ e mantendo-se com comportamento semelhante entre os três grupos de sujeitos, com os "usuarios" expressando preferência ligeiramente superior.

... 10: "Em alguns trechos do Porto seria permitido o acesso à àqua para o lazer"

Foi significativo o indice de rejeicão geral, de .0,20, puxado muito pelas expectativas negativas do grupo do "usuarios" cujo indice fol de $-0,29$, contra o de 0,23 dos que "trabalham" e apenas -0,02 dos "moradores".

Entretanto, devemos observar que talve: a compreensão desta afirmativa tenha eido prejudicada, pois muitos dos sujeitos consideraram "acesso a agua para o lazer" como possibilidade do banho, conforme a observacão de alguns durante a entrevista.

o desenvolvimento sugerido pela Alternativa $\underline{\mathrm{C}}$ (manutencão) gerou respostas ás expectativas que permitem os seguintes comentários: 
- 11: Novos prédios comerciais seriam construldos raramente No conjunto de dados foi a expectativa que mais se aproximou do Indice "indiferente", com o valor de $0,06$. Obteve rejeicão significativa de $-0,23$ entre os "moradores", 1igeiramente positiva entre os que "traba1ham" 1á, de +0,01, e negativa entre "usuários", com $-0,04$.

- 12: "은 uso residencial năo seria encorajado"

Indice negativo de $-0,40$ no conjunto de sl!jeitos e com acentuada rejeicăo entre o grupo de "moradores" $(-0,70)$, seguido dos "usuarios" $(-0,41)$ o dos que "trabalham" ($0,21)$.

- 13: "O Porto continuaria a utjlizar as suas instalacôes da mesma forma como o faz hoje"

Alto indice de aprovaçăo de $+0,63$ no conjunto de cados, refletinds o du to,67 obtido entre os "moradores", de $\div 0,70$ entre 03 que "trabalham" $e+0,51$ entre os "usuários".

- 14: "A àrea continuaria pouco integrada ao centro e ao resto da cidade"

Fsta afirmativa obteve o segundo maior indice de rejejcão no conjurito de sujeitos, com 0,80 . O grupo de "moradores" tambeir deinonstrou sua grande rejejç̃o, com .. 0,87 , terceiro major indice de rejeicão deste grupo.

- 15: "Mujtos prédios continuariam abandonados"

Af́rinativa qus gerou o maior indice de rejeicão ino conjurito do sujoitos, -0,98. Também roi a maior rejeicão untre os três grupos individulamente, com médias muito equivalentes. 
Fig. 83: Gráfico da Intensidade de Expectativas Ambientais em cada Cenário de Desenvolvimento (Questão 19).
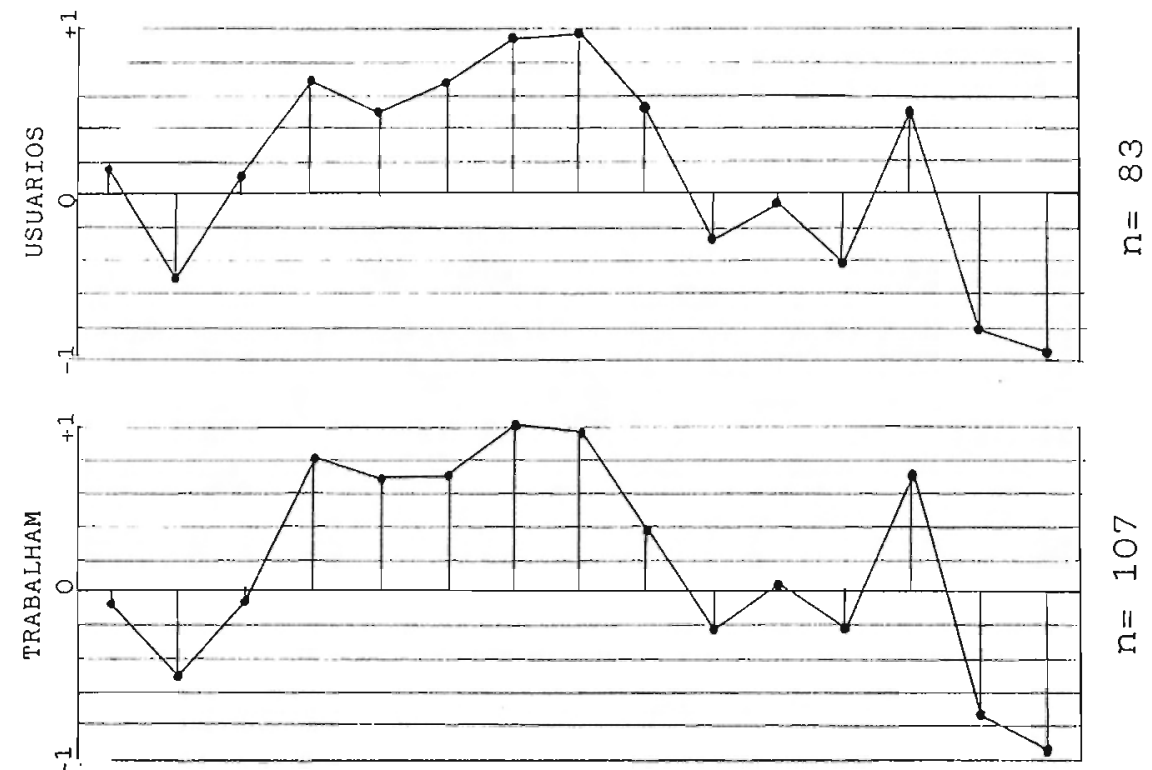

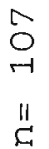

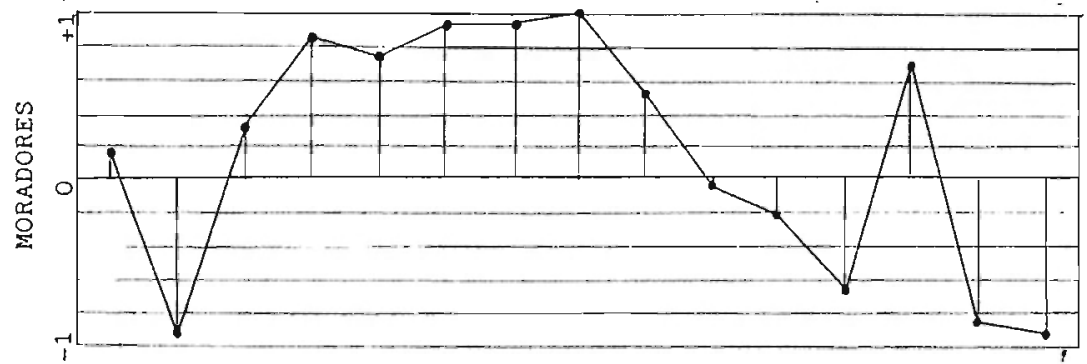

$\circ$
6
$\stackrel{4}{C}$

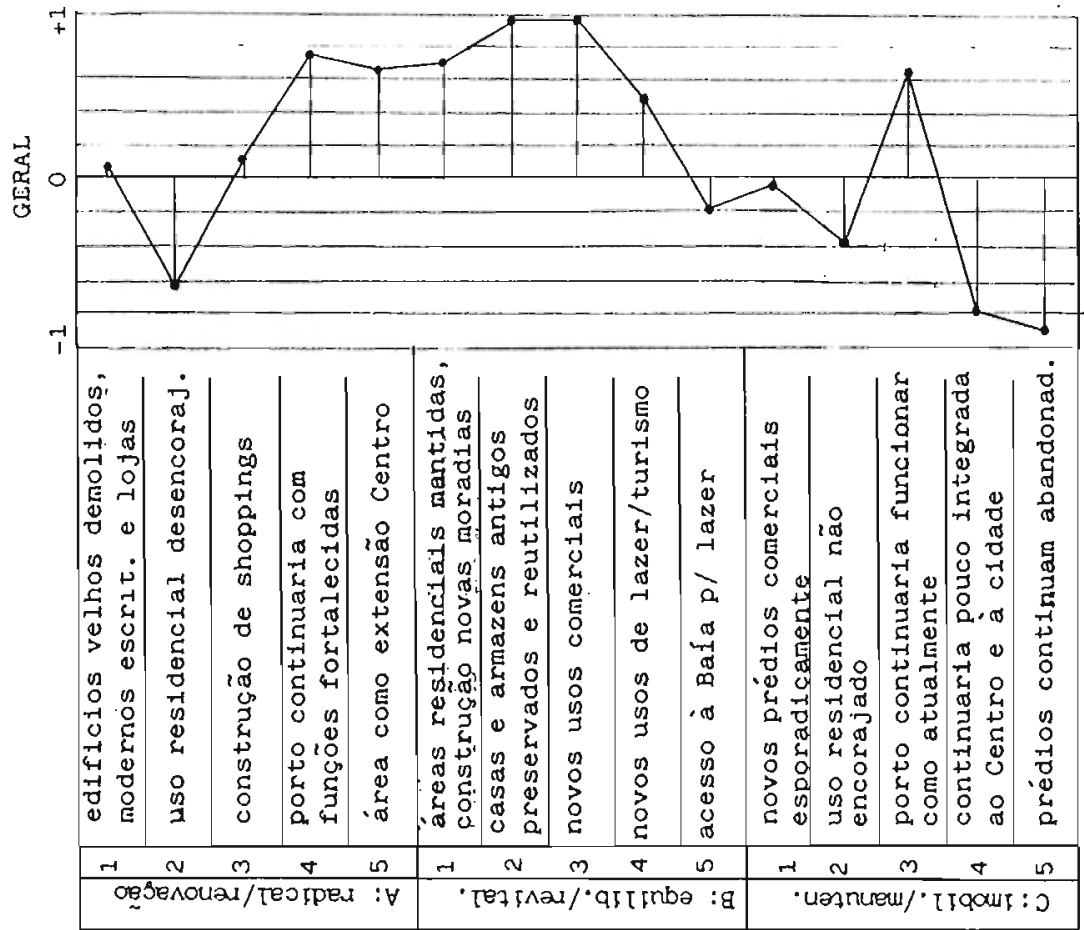

$\stackrel{\circ}{\circ}$ 
Ein conjunto, as expectativas expressas em relação as afirmativas apresentadas aos sujeitos permitem ainda duas obsorvacões. Primeiramente, devemos lembrar que aos sujeitos era podido escolher as Alternativas de Desenvolvimento segundo aus orderil de preferência para, en seguida, marcar a intensidade de axpectativa de cada afirmativa segundo o cenário em que se encontirava. Neste scntido, devertamos considerar apenas as afilinativas constantes no cenario de: desenvolvimento preferido em primeiro lugar pelos sujeitos, ou seja, a Alternativa B de revitalizaçăo.

Por outro lado, podemos raciocinar que os três cenários ds desenvolvimento podem ter apresentado afirmativas cujas expectativas såo igualmente vảilidas para os sujeitos independentemente do cenário em que se apresentam. Assim, tudas as possibilidades de desenvolvimento sugeridas pelas afirmativás seriam objeto de uma consideraçãu conjunta e integrada.

XII.7.3. Sobre Preferências e Expectativas para a Area Portuaria:

A preferênciá para cenário de desenvolvimento cxplessa por todos os sub-grupos de respondentes, como vimos, è a que prevô um piocesso di revitalização. Em segundo lugar, os respondontes preferian a alternativa da renovacão, demonstrando uma vontade bastante intensa de superaçăo da situaçăo de decadência f: imohilismo que vom caracterizando a àrea, sugerida como a terceira opção da questão.

Dentro das expectativas ambientais sugoridas para que os resporidentes se manifestassem em cada cenario de desenvolvimeritu, podemo shegar ds seguintes conclusões. Como observarios 
anteriormente, consideraremos o jl.1 gainonto pelo; respondentes das expectativas expostas independentemente de seus cenarios, ou seja, qualquer uma das expectativas poderia vir a integrar possibilidades de desenvolvimento co-existentos no cenirio mais votado pelos respondentes. Como na maioria das percepcões consideradas nas questões anteriores, não encontiamos muitas hetegogeneidades nos resultados obtidos entre os três sub-grupos populacioncis, como mostia claramente a Figura 83.

Interessaite: notar que, embora tenhamos nos utilizadn de expressões semelhantes, ás vêzes com sentido invertido, para diversas das expectativas que caracterizam os cenarios exposios nesta questão, os resuliados obtidos não foram contraditórios, revelando uma porfeita compieensão da temática e uma constânoia de percepç̃cic dus poporideites. Assim, por exemplo, as interpretacões dadas a afirinativas como "área como extensăo do Centro" (5\& da opção A) e "continuaria pouco integrada á cidade" (4\& da opqão $c$ ), atingindo campos perceptivos opostos, obtiveram interpretação correta e idêntica pelos respondentes.

As expectativas ambientais qus olutiveram os majores indices de aprovação foram as relacionadas com o uso residencial, a integração com o centro, e a utilizaçăo dos prédios abandonados. ou seja, as expectativas dos respondentes indicam fortemente que eles gostariam que o uso residencial fosse consolidado e incrementado, que a área estivesse melhor integrada e que os predios vazios fossem re-utilizados.

Alèm destes resultados, como indicativos para o desenvolvimento da Area Portuária, tambèm identificamos forte expectativa dos respondentes quanto a: fortalecimento das funç̃os 
portuárias, preservaçăo dos imóveis antigus t: incremento de novos usos comerciais. Com menos intensidade apareceram as expectativas relativas a incremento de usos turisticus e, bem menor, a possibilidade de construcăo de shopping-centers. A possibilidade de acesso á Baía para o lazer năo foi percebida coino expectativa válida pelos respondentes.

De uma forma geral, podemos afirmar que os resultados cullidos relativos a preferências e expectativas confirmam aqueles obtidos nas questões anteriores, relativos á percepcão que os respondentes expressaram sobre a Area Portuária. 


\title{
CAPITULO XIII:
}

\section{DESENHO URBANO E REVITALIZAÇAO \\ NA AREA PORTUARIA DO RIO DE JANEIRO}

\begin{abstract}
"Decisions about urban policy... must use norms about good and bad... Without some sense of better,
\end{abstract} any action is perverse." (LYNCH 1981: 1)

Iniciamos aste trabalho nos colocando uma hipótese básica, complementiada com duas hipóteses secundàrias que, ao mesmo tempo, a precediam. Interessavá-nos comprovar a importancia dos estudos da percepcão ambiental para o desenho urbano e a revitalização de àroas centrais. Podemos evocar a figura do triângulo isósceles para simbolizar nossa situaça teórica: o vértice voltado para o alto (percepcăo ambiental) anoiado na base dos vèrtices inferiores (desenho urbano e revitalizaçăo). A base do quadro todrico dependia da conceituacão tanto do desenho urbaro quanto da revitalizacão; so a partir dał pudemos concojtuar a percepcão ambienta1, definir sua operacionalização e as relações entre os trềs "vèrtices".

Ao tomar a Area Portuária do Rio de Janeiro como estudo de caso, fomos capazes de demonstrar o estado de sub-utilização do seu potencial, a ociosidade e má conservacáo de muitos de seus imóveis. Por outro 1ado, comprovou-se também que a àrea possuj limitacões especificas á expansão das atividades portuárias, as quais, além disto, tendem a concentrar-se em territorios 
especializados o a liberal" ainda mais terrenos e edificaços, pela propria transformaçăo e agilizaça dos sistemas portuái ios. A cidade do Rio de laneiro pode, portanto, tirar partido de vantagens locacionais e das estruturas instaladas expandindo-.se neste sentido, consolidando funçôes centrais e, mais importante, promovendo diversas outras que possam revitalizar a atuai Area Portuária, ou seja, dar - 1he nova vida, implementando um novo e completo setor urbano.

- estudo da evolucão e das caracteristicas da Area Portuária nos serviu para mostrar que là também existe um potencial cultural instalado muito forte, en sua maior parte ainda latente, inexplorado. Potencial quo se expressa em uma rica ambiência ainda preservada social e arquitetónicamente. Os grupos moradores, em sua maioria, são representantes destas fortes tradicôes o guardam estas memórias ainda hoje. E o território da Pedra do Sal, do mercado e cemitério de escravos, onde é forte a cultura negra, da primeira favela do Brasi1, do berço da capoeira e do carnaval, da famosa Revolta da Vacina, da estiva, dos marinheiros $€$ suas astórias, dos armarèns e molhes, da indústria nascente no antigo Distrito Federal. Muitas testemunhas arquitetônicas de tudo isto ainda resistem, algumas institucionalmente protegidas, outras mais dependentes das reviravoltas da historia urbana.

Entretanto, a impedir o seritido da revitalizacão e do desenvolvimento da àrea, pudemos identificar dois entraves principais. Primeiramerte, a postura dos grupos sociais envolvidos, a logistą̧áo existente to próprio perîit fundiario se reve: laram fortes 1 imitadores: de um lado preservam o 
território dos bairros tiadicionais, mais residenciais; 0 de encosta, de outro impossibilitam ocupações diferenciadas nos trechos planos e subutitizados. O poder publico $\theta$ os grupos representativos interessados precisam, portanto, trabalhar em conjuito para superar estas barreiras, tracar objetivos comuns para a revitalizaçáo, e fazer uso do pleno potencial da Area Portuária.

Em um segundo momento, o entrave localiza-se na realidade definida por uma imagem final negativa que verificamos existir em relaça á àrea. Como vimos inicialmente, um dos problemas primordiais a afligir os centros das metrópoles tem origem na dimensão da percepcão humana. As experiências acumuladas da população e as imagens que os diversos grupos sociais percebem colnos representativos daquelas áreas podem estar recebendo uma avaliaçăo final negativa, acabando por influenciar a formacăo de opiniåo e as eventuais condutas resultantes.

No caso da Area Portuária, constatainos que a sua percepcão indireta, promovida pelos jornais e pela literatura, de modo geral veiculam imagens negativas da àrea, principarmente no que diz respeito aos seus grupos populacionais.

A pesquisa de campo revelou que a percepcáo dirota dos respondentes è, no todo, tambèm bastante negativa, estivessem eles morando, trabalhando ou apenas se utilizando da àrea. Estas imagens negativas mostraram-se conformadas principaimente por categorias imagéticas relativas á administraça ambienta1, como policiamento, conservacăo e embelezamento. Os elementos fisicos citados e assumidos como formadores de mapas mentais estavam, em sua grande maioria, ligados á siua própria função ou uso 
experienciado pelo respondente. Poucos foralr os Elementos citados que pudessemos distinguir por singularidades esteticas ou visuais; referenciais de base significaite, poitanto.

A partir da identificacáo e definisão do una poltiica urbana, de um processo de pianejamento e progranas de aç̃̃o que possam perseguir os objetivos do rovilalizaçã, cuja meta primordial e implicita doverà ser a recuperacão de imagens positivas e consolidação de mapas mentais ricos e ciaros, o desenho urbano assume pape 1 de destaque. Nós o conceituamos enquanto campo disciplinar capaz de lidar corn a organização fisico-ambiental da cidade atraves da dimensão do cotidiano do cidadåo, de seus valores, percepcões e condutas. Portanto, $\ell$ neste sentido que vai contrihuir o estudo da percepção ambienta 1 .

\section{1. As contribuicoes Espectficas da Pesquisa:}

Acreditamos que ao $10 n j o$ de nosso trabalho, em especial ros comentarios analiticus destinvolvidos nos captulos XI e XII, já foram expostos divereos achados concernentes á percepça da Area Portuaria que podurão vir a ajudar numa melhor compreensão das questões voltadas para o desenho urbano e sua revitalização.

Nossa contribuiça serà concluida atravès de algumas consideracões gerais sobre nossos estudos, procurando integrar os achados anteriores e apresenta-los de uma forma mais sintetica, reforcando a comprovaça de nossa tese inicial, no sentidu da utilidade e da operacionalizaçăo dos estudos de percepcäo ambienta 1 .

Evidentemeite, os cumertários que se seguem, sobre os dadus encontrados e sua aplicabilidade, possuem três caracteristicas 
básicas que precisam ser ressaltadas. Primeiramente, apesar de ordunados segundo tumas especificos, eles não devem ser tomados como estailques e sempre possuem rebatimentos multiplos.

Em segundo lugar, os comentarios não buscam solucões ou diretrizes uspecificas de intervencăo a partir de constataços, mas apenas fazemos sugestốs gerais de caminhos posstveis. Por um lado, porque a pesquisa da psicologia ambiontai não busca relacoós liretas causanefeito, como jà pudemos observar anteriormentes, além do limitado corpo de conhecimentos aqui exposto impedir este tipo de atitude. Pelo outro, porque nosso objetivo jrincipal sompre foj o de testar um corpo teórico e uma metodologia decorrente.

Finalmente, tenha-se em conta que as consideracōes săo interpretacôes de carater eminentumente pessoal, embora baseados fictualmente, pincipalmente em nossa pesquisa de campo, e em ampla pesquisa teörica. O carater qualitativo das informacões buscadas, fato para o qual chamávamos a atencăo em capitulos procedentes, juntamente com o pioneirismo desta temática, tendem a impedir conciusões de caráter univoco e facilmente genera 1 zàveis.

os comentảrios gerais conclusivos seguem definicão temática conceituada anteriormente, no Capitulo IV, quando desenvolviamos considerações sobre a operacionalizaçăo dos estudos de percepcâa ambiental atraves de fontes diretas.

XIII. 1.1. As Imagons Recorrentes:

As imagens mais recorrentes que encontramos sobre a Area Portuaria e seus bairros são em sua major parte negativas. Fato 
que foi confirmado tanto pelos estudos das funtes indiretas, 1 iteratura e jornais, quanto das fontes diretas em nossa pesquisa de sampo.

Vimos que o pủblico que não possuj conhecimento direto da Aroa Portuária, tende inicialmente a imagens que conotam ambientes deteriorados, fisica e socialmente, influenciados pelo folclore dominanto relativo a áreas de entorno de portos. Com o aprofundamente deste conhecimento indireto, o lojtor vai se dando corita de que a diversidade imagécica é bem maior do que isto, ás vezes contraditória, dependendo mesmo das interpretacões que os pióprios autores fáem e tirasmitem a seu publico. Entretanto, vorificamos que a maior parte destas imagens é negativa, no que diz respeito a caractertsticas sociais e estado geral da àrea. Quando positivas, as imagens transmitidas referem-se via de regra aos aspectos arquitetônicos e culturais, principalmente aqueles ligados á potencialidade do patrimônio histórico. Esta dicotomia se dả tanto com as obras literárias quanto com as matèrias dos periódicos: como a dimensăo física pudesse ser dissociada da dimensão social.

As imagens mais constantes nos periodicos referem.se ás possjbilidades de desenvolvimento da Area Portuária a partir do fortalecimento do comércio internacional, e um contro com este objetivo es veiculado como o elemento catalizador mais positivo que là poderia acontecer. Os bairros e os conjuntos arquitetônicos residenciais, tiudicionais, poderiam sier mantidos, dentro destas imagens, como fomento ao turismo e ao folclore cultura1. Inagens muito citadas neste sentido são de experiências de revitalizaçăo de àreas portuárias no extrangeiro. Năo se fala, 
por exemplo, das dificuldades a serem enfreriadas em conciliar interesses, proteger grupos locais do aumento do valor do solo face as eventuais intervencobse urbantsticas, ou de como atrair novą populacöes o quais seriam elas.

Por sua vez, os dados obtidos através de nossa pesquisa de campo tambem nos mostraram quo as categorias imageticas recorridas plos respondentes săo negativas, tanto a ntvel de bairios, qualito, bem mais, a nivel da Area Fortuaria. As imagens destacadas são relativas a questões de administração urbanà: insegurança (o grande destaque), conservaça e nivel de servicos em gera1. Não encontramos diferencas perceptivas significativas entre os três grupos populacionais destacados.

Fstes resultados mostram a necessidade de priorizaça de investimentos da atuaço pủblica neste sentido, enfocando, por exemp 10, programas de conservação, manutenção gera1, policiamento mais ostensivo, e embelezamento atravès de mobiliário urbano, principalmente nos locais mais importantes dos bairros e da Area Portuária, como aqueles revelados pelas mapas mentais indiretos compostos através das respostas ao questionário.

Os olementos fisicos foram uma das categorias imagéticas mais recorridas nas respostas de primeira imagem, tanto do bairro quanto da Area Portuária. Entretantio, o menor número de respostas citando elementos fisicos para esta última reivela um conhecimento menor do territorio da Area Portuária como um todo, o que se expressou com maior intensidade no grupo dos "usuarios".

Nos dois niveis de percepcão, notamos uma prevalência de elementos fisicos relacionados a usos intensos e localizados; isto porque os elementos destacados nas primeiras imagens 
recorrentes não possuiam, especialmente, fatores îtsicos uu estéticos de destaque. O fator uso dos elementos fisicos foi, portanto, muito importante em seu destaque polos respondentes, que pareciam escolher para simbolos dos bairros e dá Area Portuária os elementos de uso mais intenso, mesmo que em rulação aos bairros estes elementos tivessem caráter extra*1ocal ou inetropolitans.

outro resultado que demonstra a importância do uso percebido ria formacão da imagem do bairro, foi que um significativo numero de rsspondentes apelou para respostas que iåo sugeriă nenhuma imagem especifica, inas utilizavam-se de imagens; iolativas á razão de ostarem no local de aplicaça do questionário, comu o parente ou amigo a ser visitado, pegar ônibus;, usar um servico, etc.

A categoria imagética de atividades portuárias mostrou resultados interessantes no sentido que rão está presente na percepcão dos bairros, para nenhum dos cub*grupos populacionais respondentes mas, siln, na percepcăo da Area Portuária como um todo, ao contrário do que podertamos pensar.

Aliàs, neste sentido, se fez notar que nenhum dos resultados encontrados confirma uma prercepcão dos respondentes semelhanté á nossá, técnicos e especialistas, ao menos a nivel consciente e de primeira recorrência. Assim, aspectos de interesse revelados nas entrevistas que fizemos com técnicos (Anexo I.), tais como caracteristicas histórico-arquitetônicas, paisagens e as vistas distantes patrocinadas por certos 1ocais, impacto de elementos como o a via elevada da Perimetral, entre outros, não se mustraram como importances para os sujeitos 
através de nossa pesquisa. Esta questão já foi explorada por outros estudos, mencionados no capitulo IV, e explica também porque quase nenhum dos elementos flsicos citados nas respostas ao questionários foram coincidentes com a 1 istagem de imóveis tombados. O poder público sem dúvidas deveria desenvolver a maiores estudos de percepcão diretamente cum a populacão, para proceder å protęão de bens arquitetônicos e ambientais.

XIII. 1.2. As Referências $e$ as Estruturas Ambiontais:

As fontes 1 iterárias pesquisadas exploram referências ambientais do tipo "lugares", como ambiências para os romances ou para os fatos históricos. Assim menciona-se o Morro dá conceicão, a Saúde, o Valongo, a Gamboa, entre outros. Percursos tambèm săo cxplorados, como no caso de Machado do ASSIS em "Quincas Borba", mas apenas como cenario para ambientar a argumentaçãu e imprimir o caráter do lugar buscado pelo autor em sua narrativa.

As matérias jornalisticas destacam, por um lado, edificaçơes e áreas, a mäioria não espeçfica, para enfatizar sua sub-utilizaçă, pelo outro, poucos locais e edificacones especificas para enfatizar seu potencial cultural e históricoarquitetônico, como a Praça Mauá e o Morro da concoicăo. Os elementos fisicos transmitidos por estas matérias raăo permitom ao leitor sua porcepcão de forma integrada, dificultando a cumposicăo de estruturas espaciais mentais e a compreensão da interelą̧ão destes elementos. Quase sempre eles săo abordados em sua individualidade especifica.

Já os dados obtidos na pesquisa de campo, revelou que as referências ambientaie, ou seja, os elementos fisicos recorridos 
nas citacõos, assumiam grande importância por uso e sigrificado, fatores para seu destaque na cognịão dos respondentes. A categoria "ruas" foi a mais citada, tanto a nivel dos bairros quanto, embora com menos intensidade, a nivel da Area Portuária. As ruas destacadas possuem intensa funcionalidade, coincidindo com os percursos dos ônibus; as estruturas 1ógicas transmitem, portanto, esta funcionalidade do cotidiano. Não só em número de citacõos as "iuas" tomaram este detaque, mas em diversidade e no fato dos outros olementos mencionados estarem sempre localizados corca de uma rua também participante do mapa composto.

A diferenca notada entre os grupos de respondentes; reforca nossa conclusão ielativa á importância do fator ulititário dos elementos fisicos em sua cognicăo. Embora os respondentes de menor contacto com a área, como os "usuários", tenham apelado mais as tipologias fisicas de "edificacoros" e "lugares", os elementos citados tinhain forte conotaça de uso.

ouanto ao repertório imagético de elementos físicos mencionados, verificamos que a quantidade e a varitidade são funçăo da intensidade de relaça dos respondentes com as àreas e do sua escala. Os "usuários" tendiam a possuir repertorio mais limitado, e a escala da Area Portukiria tendia a dificultar a expressão deste reportorio, não importa qual o grupo do respondente. Os mapas compostos tambèm rovelaram esta mesma dificuldade na defiricăo de posstveis estruturacões espaciais. Este fato reforca ainda mais a conclusão sobro a dimensão utilitaria da percepcăo dos referenciais fisicos e suas interre1ą̧os. 
Os resultados sugerem que as intervencõos nos bairros e na Area Portuária devem vir a reforgar os elementos mutuamente, através do usos diretos e funcũes especificadas oxternamente, facilitanto năo apenas a identificacăo e o destaque de certos elementos, mas a cognicăo de uma estrutura que os relacione, facilitando a "imageabilidade", principalmente da Area Portuária. A implantaçåo desta diretriz estaria, inclusive, facilitada pelo potencial que a Area Portuária apresentou para transformacăo, como a localização e a propriedade das áreas mais propicias á intervenção imediata (vide Figs. 57 \& 66). Estas observaçõei $\in \circ$ estudo dos mapas mentais compostos (Figs. 73 ․ 74) podem sugerir diretrizes para a discussăo da re-estruturacão da àrea.

XIII. 1.3. Os Territórins:

Os morros e suas areas residenciajs sẩo os territorios preferidos abordados nas obras literárias mas náo há como definirmos delimitações a partir destas 1eituras. O mesmo se pode dizer das materias jornalisticas, menos especificas ainda quanto a estes 1 imites.

com a pesquisa de campo, pudemos constatar que para os respondentes a percepgão dos territórios dos bairros, e sua cunsequente: identidade, é auxiliada por dois aspectos principais, a "imageabitidade" do Tugar e a sua unidade socio-erpacia1: a forte constância de alguma àrea ou elemento(s) fisico(s) e a percepcăa de uma imagem funcional mais ou menos homogênea cujo territorio \& definido sócio-espacialmente.

Por contia destes fatores, encontramos incompatibilidades entre os bairros oficialmente definidos e os reconhecidos pela 
populaçâo em suas respostas. Este reconhecimento foi verificado tanto através da declaraça de que bairro o respondente se encontrava no momento da abordagem, como tambem pelos elementos Hisicos poi ele citados para o bairro (vide Figs. 6E, 71 \& 72 ). Três territórios de bairros destacaram-se na Area Portuária, quais sejam, Praça Mauá, Saude e santo cristo. Estes poderiam ser assumidos pelo poder publico como us Bairros formadores da Area Portlária, seus limites e suas identidades especificias a serem consolidados através do reforco a elementos referenciais com a orientacão de investimentos públicos como arruamentos, mobiliário urbano, localização de usos näo residenciais, entre outros.

No caso da Praça Mauá, sua localizacão no infcio da avenida mais importante do centro, seu papel simbolico historico de porta do Brasil e sua funçóes 1 igadas a atividades portuárias, fazem com que sua "imageabilidade" seja muito forte. Os limites: perceptivos de seu território săo bem definidos apenas junto ao cais e na subida do Morro da conceicăo; na direçăo interna, o único 1 imite forte á "imageabilidade" da Praça Mauá só aparece com o Hospital dos Servidoies.

o bäirro da salude teve sua "imageabilidade" e sua identidade reforciadas através do uso a da tradicăo da Praça da Harmonia, sua insercão na estrutura viária, das zonas residenciais tradicionais, caracteristicas morfológicas diferenciadas, e diversos importantes elementos fisicos e equipamentos, como o Moinho Fluminense, o centro cultural José Bonifácio, o quartel da Poltcia Militar, o Morro e a Igreja da Saúde, dentre outros. 
A percepcão do cerritório do santo cristo é facilitada pela maior importância das vias e seu papel de coneccăo ao sistema metropolitano, a existência da Prága e da Igrejinha em sew centio, e até pelo fato de piraca e bairro possulrem o mesmo nome. Embora as áreas residericiais no santo cristo não sejam tão intensas quanto na saude, sud localizacão concentradä nas encostas dos morros reforca os limites percebidos para o teritiório do bairro.

Jà a nivel da Area Portuária collo um todo, parece que, ao mesmo tempo que seus 1 imites externos são bem definidos, sua extensa årea, dificuldades de integracăo interna e caracteristicas de uso des seus equipamentos extra-locais, nåo facilitam sua "imageabilidade" aos entrevistadus, muito embora possua uma identidade especifica de conjunto. Outra prova disto, que já mencionamos acima, é que a categoria imagética "atividades portuárias" só está presente nas primeiras imagens dos respondentes á Area Portuária como um todo, e não em relacão aos bairros especificos.

A "imageabilidade" da Area Portuária deve ser dirigida no sentido de reforç--1a como um conjunto de bairros, lias ao mosmo tempo consolidando elementos fisico-sspaciais que destaquem sua presenca e importancia como "lugar do Porto", e integrador destes mesmos bairros. Neste sentido poderia-se acentuar a linearidade da Area Portuaria através dos elomentos fisicos junto ao cais, ao mesmo tempo en que se reforcasse a relacão cidade/bata através destes mesmos cais. 
XIII. 1.5. Ava i ią̧oses e condutas:

Um dos majis fortes aspectos de nossa área de estudo, como bem mostrou a pesquisa indireta, e que a tem caracterizado através dos tempos, è justamente o seu caràter contraditorio, sua riqueza de leituras diferenciadas, suas imagens complementares. A variedade lá encontrada de fatos, grupos sociais mais populares e tradicionais, usce e atividades, tipologias arquitetonicas, lugares significativos, conteudos históricos e culturais, enfim, sua complexidade social o ambiental são paite de sua "imageabi1idade", sua identidade, seu "gerius loci".

Sem duvidas, como nosso quadro teórico nos fez ver, compreende..se que as formas e os elementos estruturädores das cidades perfazem uni fenômeno único com suas funçoess, as idẻias e os valores que as pessoas associam a eles. Mas o problema perceptivo básico que aflige a area, revelado pela pesquisa das fontes literàrias e jornalisticas, è que as imagens transmitidas Tevain a atitudes negativas, na distincăo dos atributos ielativos a tematicas sociais, enquanto levam a atitudes positivas rolativas á paisagem e á arquitotura.

F. por isto que deve-se promover a divulgacão das possibilidades de intervencão e revitalizaça na área através de imagens completas e integradas, năo só em relaçăo ao território completo atingido, mas tambéin em relação aos diveirsos programas setoriatis especiffcos e complementares.

Por seu lado, a pesquisa de campo revelou que atitudes e atributos percebidus, assim como as prelerências e expectativas de desenvolvimento, expressados pelos respondentes confirmaram percepção negativa de temáticas ligadas s. administ.ração pủblica e 
oferta de servicos, como aconteceu nas primeiras imagens mentais recorrentes. O cenário de desenvolvimento preferido pela maioria, do revitalizacão, \& o mais capaz de incorporar as múltiplas imagens e riqueza de leituras, aspectos tipicos mostrados pela evoluçăo dá área. Não obstante a possibilidade do cenário de "renovaçăo" foj claramente interpretado como "expulsăo", os respondentes admitein a necessidade de se fazer algo a respeito do estado atual da àréa.

Embora reconhecamse o alto potencial da àrea para trabalhar, decididamente uma percepcăo no campo positivo, e para receber novos usos habitacionais, tambem demonstrou-se percepcões negativas quanto as condiçôs complementares ao uso habitacional, como o 1azer, locais de encontros sociais, a conerercio 1ocal. Existe um reconhecimento do potencial geral da Area Portuària mas uma insatisfação com o estado das coisas.

De novo ao contrário do que as nossas percecões de técnicios poderiam prever, os aspectos paisaglsticos não foram reconhecidos como atributos positivos exceto pelo vies da preservacão da arquitetura antiga. Outra àrea de conflito de imagens foi revelada através da inseguranca expressada em relaçăo á possłveis expestativas futuras; fato gerador de muitas atitudes negativas em relação a questőes como o impacto do turismo sobre os moradores.

A àrea da Rodoviária despontou como a de percepcões mais riegativas, con fortes atitudes de rejeicão $\Leftrightarrow$ não reconhecinento de atributos positivos. Como a grande maioria dos respondentes neiste local foi de "usuários", e também revelaram um yraride desconhecimento do resto da Area Portuaria nos itens anteriores, 
pode-se destacar a importância de meinoiar a imagem da Rodoviária e seu entorno imediato, aléin das coneções com o resto do conjunto, cono forma efetiva de melhorar a imagem da Area Purtuária como um todo para estes usuários.

Neste sentido de promocão da Area Portuària como um todo, as atitudes também mostraram sor desejảvel umà major integracăo da Areal Portuaria com o contro e manutenção das atividades portuárias, confirmando os objetivos conclutdos para a reestruturacao sugerida a parijir dos mapas mentais.

XTT. . 2. As Invisqveis Cidades da Mente:

Acreditamos que o desenvolvimento desta pesquisa, emuasado om sólido corpo conceitual, foi capaz de demonstrar a importancia - a aplicabilidade do estudo da percepcăo ambiental para o desenho urbano e a revitalizaça de àreas centrais de cidades, comprovando nosia hipótese inicial. Isto foi denonstrado airavés do estudo de caso da Area Portuária do Rio de Janeiro.

Se tivéssemos que destacar algum aspucto especifico €Videnciado por nossos estudos da Area Portuária, optar apontar a importância da dimeisão utilitária no percepcão ambiental urbaria, fato destacado tanto a nivel cognitivo (categorias imageticas $\epsilon$ elementos fisicos recorrentes) quanto a nival de avaliaço e conduta (atitudes, preferêricias e expectativas). A percepcáo das possibilidades de uso das áraas pesquisadas e de seus elementos formadores, bem como a percepcão de sua funcionalidade se revelaram como fundamentais na sua "imageabilidade" e na cognicão de suas interelaç̃es. 
As observaçoos constantes neste capłtulo, sobre temáticas levantadas por nossa pesquisa, além dos diversos fatos indicados ao longo dos dois capttulos anteriores, poderão ser válidos e úteis como diretrizes iniciais em um processo de intervencão pública na Area Portuaria, com vistas á sua revitalizaça. Facilmente o Poder Publico e as comunidades interessadas podem iniciar um frutifaro processo de discussăo de objetivos, politicas e programas de gerenciamento fisico-ambiental, tomando por baso estudos semelhantes $\epsilon$ consideraçoses como as aqui levantadas.

Poi. outro lado, estamos conscientes de que $O$ corpo du conhecimeritos que pudomos trayer á tona, principalmente em terinos de inetudologia de investigação $\Leftrightarrow$ instrumentos de aforicão, deverả mostrar-ise de utjlidade para que fituros pesquisadores possam adiantar ainda mais o fertil campo disciplinar que rovela ser o estudo da percencăo ambiential aplicada.

Acreditamos que o estudo desta questäo revelou-se extremamente importante dentro de uma polftica maior de revitalizacão pois, como demunstrou o caso da Ared Portuaria do Rio do Janeiro, ele evidericia imagens, atitudes e expectativas ambientais de grupos significativos da populaça usuária. Alguns destes aspectos revelaram..se, inclusive, inèditos ou de conotaça conflitante com interpretaços comumente aceitas.

Assim, trata-se de buscar o conhecimento da cidade e das suas mủtiplas imagens que estäo na mente dos usuarios; dentro de cada um de nós, na tentativa de alcancar um quadro composto que possa representar a coletividade e suas expectativas de destino. o desenho urbano e a revitalizacăo de áreas centrais deverăo 
seguir este caminho, fazendo vistveis as invistveis cidades da mente, se quiserem perseguir o mesmo destino.

Mais uma vez, apelamos para a obra de CALVINO e suas metáforas poeticas para ajudar-nos a simbolizar nosso pensamento em palavras. Em "cidades Invisiveis", o imperador Kublaj Khan reclamava a Marco Polo que, em sua missão de relatar. 1 he viagens e visitas a cidades, jamais the descrevera sua cidade natal, Veneza; eis o diàlogo que se seguiu:

" - Todas as vezes que descrevo uma cidade digo algo a respeito de Veneza.

- Quando pergunto das outras cidades, quero que você me fale a respeito delas. E de Veneza quando pergunto a respeito de veneza.

- Para distinguir as qualidades das outras cidades, devo partir de uma primeira que permanece implicita. No meu caso, trata-se de Veneza." (CALVINO 1990: 82) 
ANEXO I

Técnicos e Representantes de Entidades e Orgãos Entrevistados sobre o Desenvolvimento da Area Portuária. 


\section{ANEXO I :}

Listagem de Técnicos e Representantes de Entidades e orgãos Entrevistados sobre o Desenvolvimento da Area Portuária.

Associação de Moradores e Amigos da Praca Mauá (AMA-Mauá):

- Carlos Henrique Leite Martins

- Daniel Gonçalves

Associação de Moradores e Amigos da Saúde (AMA Saúde):

- Carlos Machado

- Enedir Santos

Associąão de Moradores e Amigos do Santo Cristo (AMA. St.Cristo)

- Manoel de sá Rodrigles (Neca)

- Cectlia Noah

Poder Executivo Muilicipa1:

Secretaria Municipal de Desenvolvimento Urbano

- Lilia Varella dos Santos (superindentende de planos locais)

- Lucia Helena Fontes (superindentente de planejamento)

Escritório Técnico do Corredor Cultural/Fundacăo Rio-Arte:

- Augusto Ivan de F. Pinheiro (coordenador)

Secrotaria Municipal de Educaçăo e cultura

- Luiz Eduardo Pinheiro (diretor, divisão de preservacão de buns arquitetônicos)

Rede Ferroviària Fodoral S. A. (RFFSA)

- Mario Antonio sidrim Rourp (chete do sistema operacional Rio)

- Agenor (engenheiro-chefe do patio de inaritima)

Companhia Docas do Rio de Janeiro (CDRJ)

- Marcio Macedo (presidente)

- Pedro Batouli (ex-presidente)

RIO-PART Participações

- Amaury Temporal (presidente)

- Sérgio Aguiar (diretor-executivo)

Associação Comercial do Rio de Janeiro

- Paulo Protassio (presidente) 


\section{ANEXO II:}

Relaçăo de Bens Tombados na Area Portuåria e Entôrno Imediato 


\section{ANEXO II:}

Relaçăo de Bens Tombados na Area Portuária e Entôrno Imadiato

1. Nivel Federal:

- Fortaleza da Conceicão, Morro da Cunceição (Servico geográfico do Exécito),

- Palácio Episcopal, Morro da Conceicão (Servico Geográfico do Exercito),

- Igreja Săo Francisco da Prainha, Morro da Conceiçăo,

- Igreja Nossa Senhora da Saude (Rua Gilvino Montenegro, Saudo),

- Conjunto arquitetônico Jardim e Morro do valonso (especialmente casa 21 , perto da AV. Marechal Floriano),

- Igreja, Mostojiro e Morro de São Bentu,

- Antiga Estaça Linha Carris e Vila Guarani (Rua Pedro Alveo 210 , santo cristo) (ocupado por empresa de ônibus),

2. Nivel Estadual.

- Pedra do Sal (Ruá Argemiro Butcăo, Saude),

.. Cemitèrio dos Inglêsee (Rua da Gamboa 181, Säủde),

3. Nivel Municipal:

- Solar \& Rua Pedro Ernesto so, Saude (antiga escola J.osé Bonifácio, atual Centro cultura1)

- Diversos imóveis situados dentro dos 1 imites do Projeto SAGAs:

- Conjunto de casas, Rua Farnese 45, 49 e 51,

- Fabrica de Chocolates Bhering, Rua Sara, Santo cristo,

- Galpões da Central do Brasi1, RFFSA, Sarito Cristo,

- Trapiche á Rua Santo Cristo 152, Santo Cristo,

- Oratorio, Morro da Providência,

- Igreja são Pedro, Rua Cardoso Marinho 59, Santo Cristo,

- Conjunto do Hospital Nossa Senhora da Saude e Igreja sianto Cristo dos Milagres, Morro da Gamboa,

- Prédio sindicato dos condutores de Velculos Rcuoviários e Trabalhadores Urbanos de Passageiros do Municipio, Rua Camerino 66, Saude/Centro,

- Moninho Fluminense, Rua da Gambaa 280, Gamboa,

- Escadaria á Rua Costa Barros, Saúde,

- Fundicão Manuel Lino Costa, Rua Sacadura Cabral 152/154, Saude,

- Loja á Rua Sacadura Cabra 1 145, Saude,

- Edificio á Rua Barăo da Gamboa 164/184, Santo cristo,

- Vila Operária, Rua Barão da Gamboa 150, 152, 154, 156, 160, Santo Cristo,

- Vila á Rua Marques de Sapucaj 14, Centro 
ANEXO III

Instrumento de Medida: Questionário 


\section{ANEXO III:}

Instrumento de Medida: Questionário Aplicado a Transeuntes (250)

(os espaços indicados para as respostas são apenas indicativos dos existentes no modelo originalmente aplicado)

Questionàrio

Loca 1

Data Hora

Este questionário faz parte de uma pesquisa de pós-graduacão em Urbanismo e tem por objetivo captar as opiniôes da população sobre a Area Portuária do Rio de Janeiro e seus Bairros. Agradecemos se você puder responder as perguntas o mais corretamente quanto posslvel. Qualquer dúvida pergunte ao entrevistador. Obrigado.

1. Nume (opciona 1 )

2. So

3. Iciade 4. Bupaçăo

5. Escolaridade:

Primeiro Grau

C I Segundo Gratt C. I Técnico Outros

C I Superior C I

6. Domictio 7. Quanto tempo?

8. Local de Trabalho 9. Quanto tempo?

10. Em que Bairro nós estamos?

11. Se você vem de vez em quando aqui, qual a frequência? semana (vezes) mes (vezes) outra

12. O que normalmente vem fazei?

13. Diga a primeira coisa que vem á sua cabeqa quando você pensa neste Bairro:

14. Diga a primeira coisa que vem á suá caheçà quando você nensa na Area Portuária como um todo:

15. Diga quais os cinco prèdios, lugares ou ruas que você mais lembra aqui do Bairro:

16. Diga quais os cinco prédios, lugares ou ruas que você mais lembra da Area Portuária como um todo: 
17. Esta pergunta e a próxima săo para conhecer as suas preferências. Nas afirmativas abaixo, relativas a este BAIRRO, indique o quanto você concorda com elas, marcando um $X$ seguindo a escala abaixo.

não concorda indiferente concorda muito

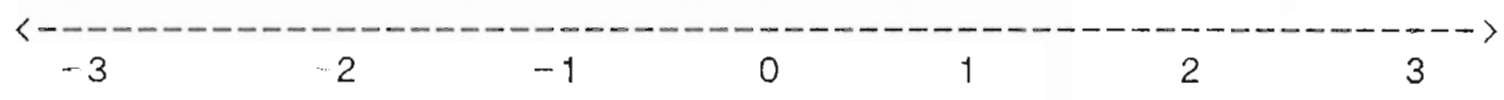

$\begin{array}{lllllllll}\text { Este bairro é bom para moiar } & -3 & -2 & -1 & 0 & 1 & 2 & 3\end{array}$

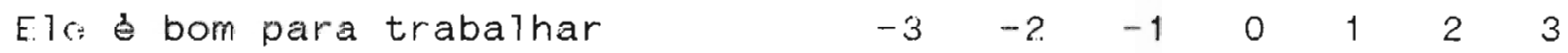

A comunidade deveria tomar parte

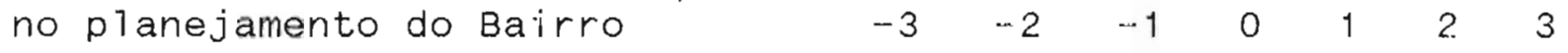

O Bairro é mal frequentado e

\begin{tabular}{|c|c|c|c|c|}
\hline perigoso & -3 & -2 & -1 & 0 \\
\hline
\end{tabular}

Tum muita sujeira e mau cheiro $\quad \begin{array}{llllllll}-3 & -2 & -1 & 0 & 1 & 2 & 3\end{array}$

E. ayradáve1, com casas e

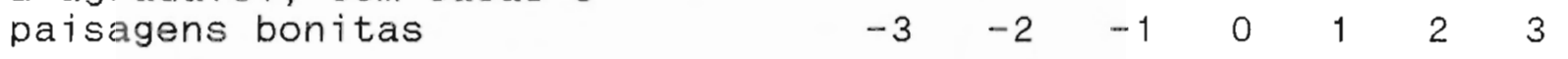

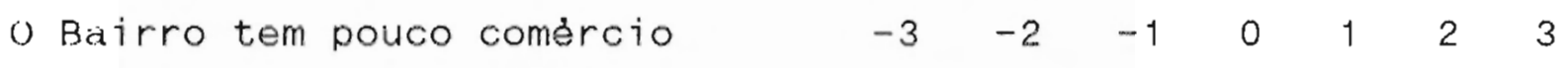

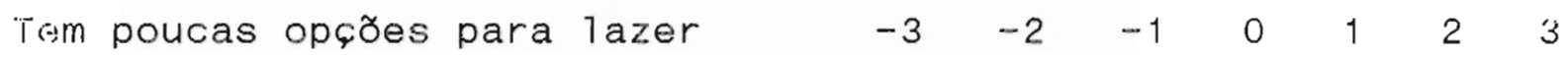

O Bairro precisa de ponto

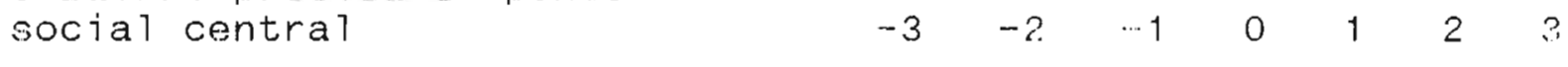

Gostaria de me mudar do bairro $\quad \begin{array}{llllllll}-3 & -2 & -1 & 0 & 1 & 2 & 3\end{array}$

18. Nas afirmativas abaixo, relativas a AREA PORTUARIA como um todo, indiuue o quanto você concorda com elas llarcando um $X$ segundo a escala abaixo:

não concorda indiferente concorda muito

$\begin{array}{cccccc}-3 & -2 & -1 & 0 & 1 & 2\end{array}$
A àrea Portuária tem 1ugares
e paisagens muito bonitos
$\begin{array}{lllllll}-3 & -2 & -1 & 0 & 1 & 2 & 3\end{array}$

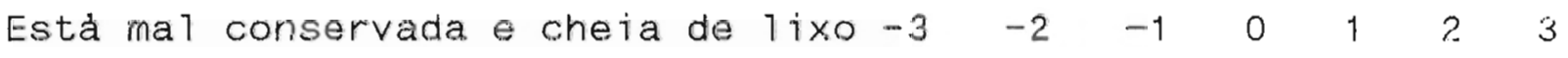




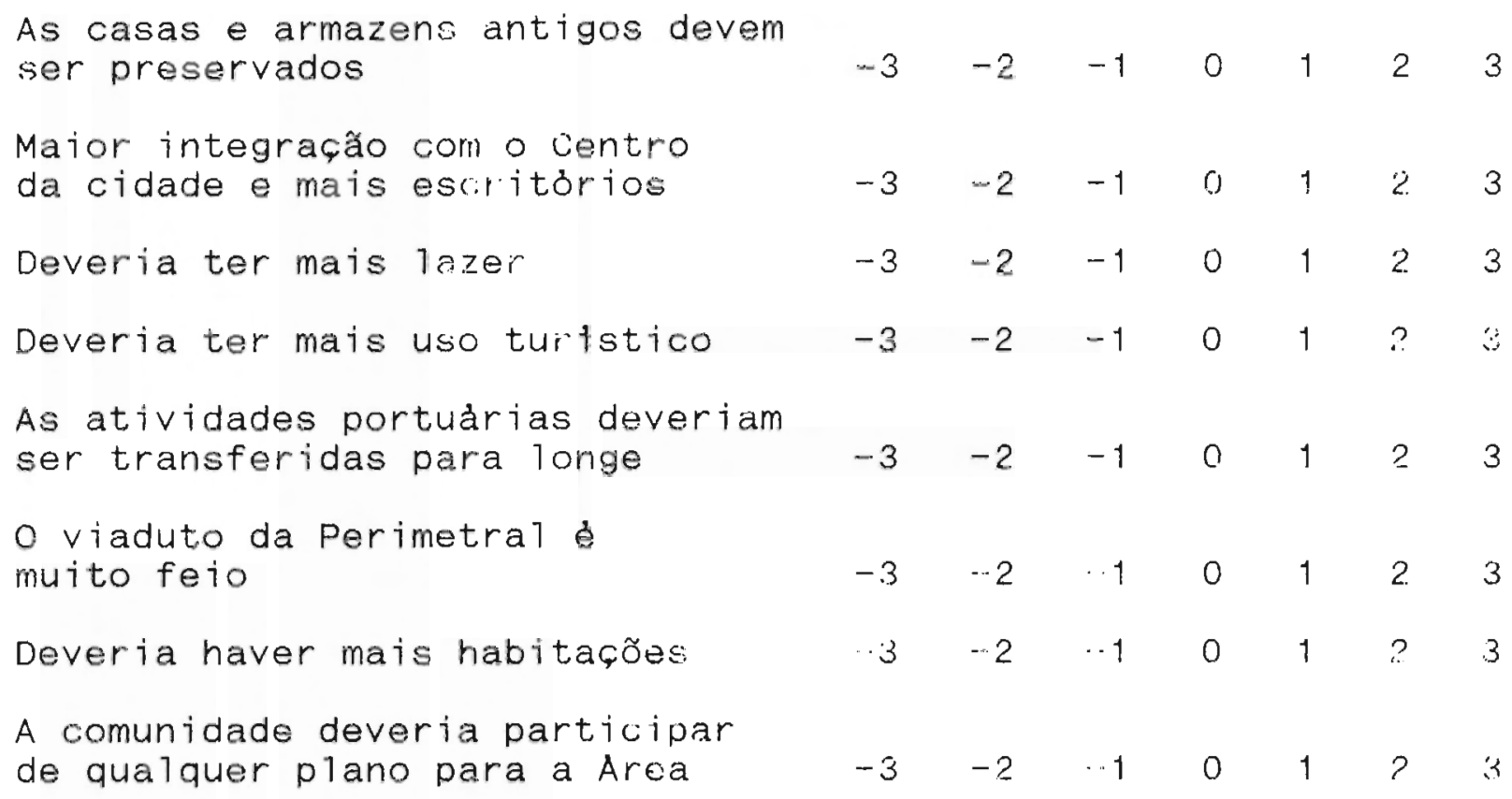

19. Esta pergunta se refere a possibilidades de desenvolvimento de seu Bairro e da Area Portuaria 110 futuro. Scio descritas TRES possibilidades do que pode aront.ecer, numere-as sejundo sua ordem de preferência, de 1 (mais preferida) a 3 (menos preferida). Em seguida, marque a sua orlem da expectutiva para cada uma das afirmativas descritas.

\section{POSSIBILIDADE A:}

Preferéncia:

Tudo mudaria muito pois a Prefaitura, al iada aos fmpresários, resolveria fazer um plano moderno para renovacão total.

- Os ediftcios velhos seriam demulidos dando lugar a modernas construços, lojas e escitórios $-\cdots 10+1$

- O uso residencial seria desencorajado $\quad-10$ +1

- Seriam construldos shopping-centers $\quad \cdots+1 \quad 0+1$

-. O Porto continuaria funcionando na Area, fortalocerido as suas funções.

- A Area seria uma continuacăo do centro como ele é atualmente

$\begin{array}{lll}-1 & 0 & +1 \\ -1 & 0 & +1\end{array}$


POSSIBILIDADE B:

Preferência:

Tiddo mudaria bastante pois a Prefeitura, os Empresários e a Comunidade elaborariam juntos um Plano de Desenvolvimento, integrado e envolvendo todos os aspectos da área.

- As areas residenciais existentes seriam mantidas e novas residências seriam construidas $\quad-1 \quad 0 \quad+1$

- As casas e arinazéns antigos seria preservados $\epsilon$ re-utilizados

$-1 \quad 0 \quad+1$

- Novos usos comerciais seriam promovidos

$-1 \quad 0+1$

- Novos usos de lazer e turismo seriam promovidos $\quad \cdots 1 \quad 0 \quad+1$

- Em alguns tiechos do Porto seria permitido - acesso á água para o lazer

$\cdots 1 \quad 0+1$

POSSIBILIDADE C:

Prefarência:

Mudaria muito pouco pois a Prefeitura não tem interesse politico ou recursosi. Nem a comunidade nem os Empresàrios conseguem convence-1ia a fazei iulutos investimentos no local.

- Novos prédios comerciais seriam construidos rarainente

$\begin{array}{lll}-1 & 0 & +1 \\ -1 & 0 & +1 \\ -1 & 0 & +1 \\ -1 & 0 & +1 \\ -1 & 0 & +1\end{array}$

- o uso residencial não seria encurajado

- O Porto continuaria a utilizar as suas instalacões da mesma forma como o faz hoje

- A Area continuaria pouco integrada ao centro e ao resto da cidade

- Muitos prédios continuariam abandonados 
ANEXO IV

Tabelas a Partir de Dados Obtidos na Pesquisa de Campo 
Tab. 11: Distribuição dos Respondentes por Sexo e Faixa Etária

\begin{tabular}{|c|c|c|c|c|c|c|}
\hline $\begin{array}{l}\text { FAIXAS } \\
\text { ETARIAS }\end{array}$ & $\overline{\text { MASC }}$ & $\%$ & FEM. & $\%$ & $\overrightarrow{T O T A L}$ & $\%$ \\
\hline 15 a 20 & 16 & 6,40 & 3 & 1,20 & 19 & 7,6 \\
\hline 21 a 30 & 63 & 25,2 & 22 & 8,8 & 85 & 34,0 \\
\hline 31 a 40 & 54 & $21, \overline{6}$ & 21 & 8,4 & 75 & 30,0 \\
\hline 41 a 50 & $\overline{36}$ & 14,4 & 12 & 4,8 & 48 & 19,2 \\
\hline+50 & 4 & 7,6 & 19 & 1,6 & 23 & 9,2 \\
\hline TOTAL & 188 & 75,2 & 62 & 24,8 & 250 & $100 \%$ \\
\hline
\end{tabular}

Tab. 12: Distribuição dos Respondentes por Sexo e Escolaridade

\begin{tabular}{|l|cccccccc|}
\hline ESCOLARIDADE & MASC. & $\%$ & FEM. & $\%$ & TOTAL & $\%$ \\
\cline { 2 - 8 } 10. Grau Comp. & 46 & 18,4 & 10 & 4,0 & 56 & 22,4 \\
\hline 10. Grau Incomp. & 41 & 16,4 & 10 & 4,0 & 51 & 20,4 \\
\hline 20. Grau Comp. & 23 & 9,2 & 8 & 3,2 & 31 & 12,4 \\
\hline 20. Grau Incomp. & 17 & 6,8 & 9 & 3,6 & 26 & 10,4 \\
\hline 30. Grau Comp. & 37 & 14,80 & 15 & 6,0 & 52 & 20,8 \\
\hline 30. Grau Incomp. & 6 & 2,40 & 7 & 2,80 & 13 & 5,2 \\
\hline CURSO TECNICO & 13 & 5,2 & 1 & 0,4 & 14 & 5.6 \\
\hline Nao Respondeu & 5 & 2,00 & 2 & 0,80 & 7 & 2,8 \\
\hline TOTAL & 188 & 75,2 & 62 & 24,8 & 250 & $100 \%$ \\
\hline
\end{tabular}


Tab. 13: Distribuição dos Respondentes por Domicílio e Tempo de Moradia.

\begin{tabular}{|l|c|c|c|c|c|}
\hline TEMPO DOMICIL. & $\begin{array}{c}\text { BAIRRO DA } \\
\text { ENTREVISTA }\end{array}$ & $\begin{array}{c}\text { AREA } \\
\text { PORTUARIA }\end{array}$ & $\begin{array}{c}\text { RO } \\
\text { RIO }\end{array}$ & $\begin{array}{c}\text { FORA DO } \\
\text { RIO }\end{array}$ & TOTAL. \\
\hline$\vdots 1$ ano & 4 & 4 & 12 & 1 & 22 \\
\hline$\geqslant 1$ a 5 anos & 4 & 1 & 27 & 8 & 40 \\
\hline$\geqslant 5$ a 10 anos & 2 & 4 & 17 & 7 & 30 \\
\hline$\geqslant 10$ a 15 anos & 5 & 3 & 40 & 3 & 51 \\
\hline$\geqslant 15$ a 20 anos & 8 & 6 & 27 & 2 & 43 \\
\hline$\geqslant 20$ anos & 13 & 6 & 35 & 10 & 64 \\
\hline TOTAL & 36 & 24 & 158 & 31 & 250 \\
\hline
\end{tabular}

Obs.: Sem Resposta/Prejudicado: $1(0,4 \%)$.

Tab. 14: Distribuição dos Respondentes por Local e Tempo de Trabalho.

\begin{tabular}{|c|c|c|c|c|c|c|}
\hline $\begin{array}{ll} & \text { LOCAL } \\
& \text { TRAB. } \\
\text { TEMPO } & \end{array}$ & $\begin{array}{l}\text { BAIRRO OA } \\
\text { ENTREVISTA }\end{array}$ & $\begin{array}{c}\text { AREA } \\
\text { PORTUARIA }\end{array}$ & $\begin{array}{l}\text { NO } \\
\text { RIO }\end{array}$ & $\begin{array}{c}\text { FORA DO } \\
\text { RIO }\end{array}$ & $\begin{array}{c}\text { NO LAR, EM } \\
\text { CASA, APOSENT. }\end{array}$ & TOTAL \\
\hline$\therefore 1$ ano & 15 & 2 & 9 & 0 & 47 & 73 \\
\hline$\geqslant 1$ a 5 anos & 24 & 8 & 21 & 0 & 2 & 55 \\
\hline$\geqslant 5$ a 10 anos & 29 & 15 & 16 & 2 & 1 & 63 \\
\hline$\geqslant 10$ a 15 anos & 10 & 2 & 8 & 0 & 1 & 21 \\
\hline$\geqslant 15$ a 20 anos & 7 & 8 & 7 & 0 & 1 & 23 \\
\hline$\geqslant 20$ anos & 7 & 7 & 3 & 1 & 0 & 15 \\
\hline TOTAL & 92 & 64 & 64 & 3 & 52 & 250 \\
\hline
\end{tabular}

Obs.: Desempregados: $8(3,2 \%)$

Prejudicados: $4(1,6 \%)$ 
Tab. 15: Frequência dos Respondentes ao local de aplicação do questionário (Questão 11).

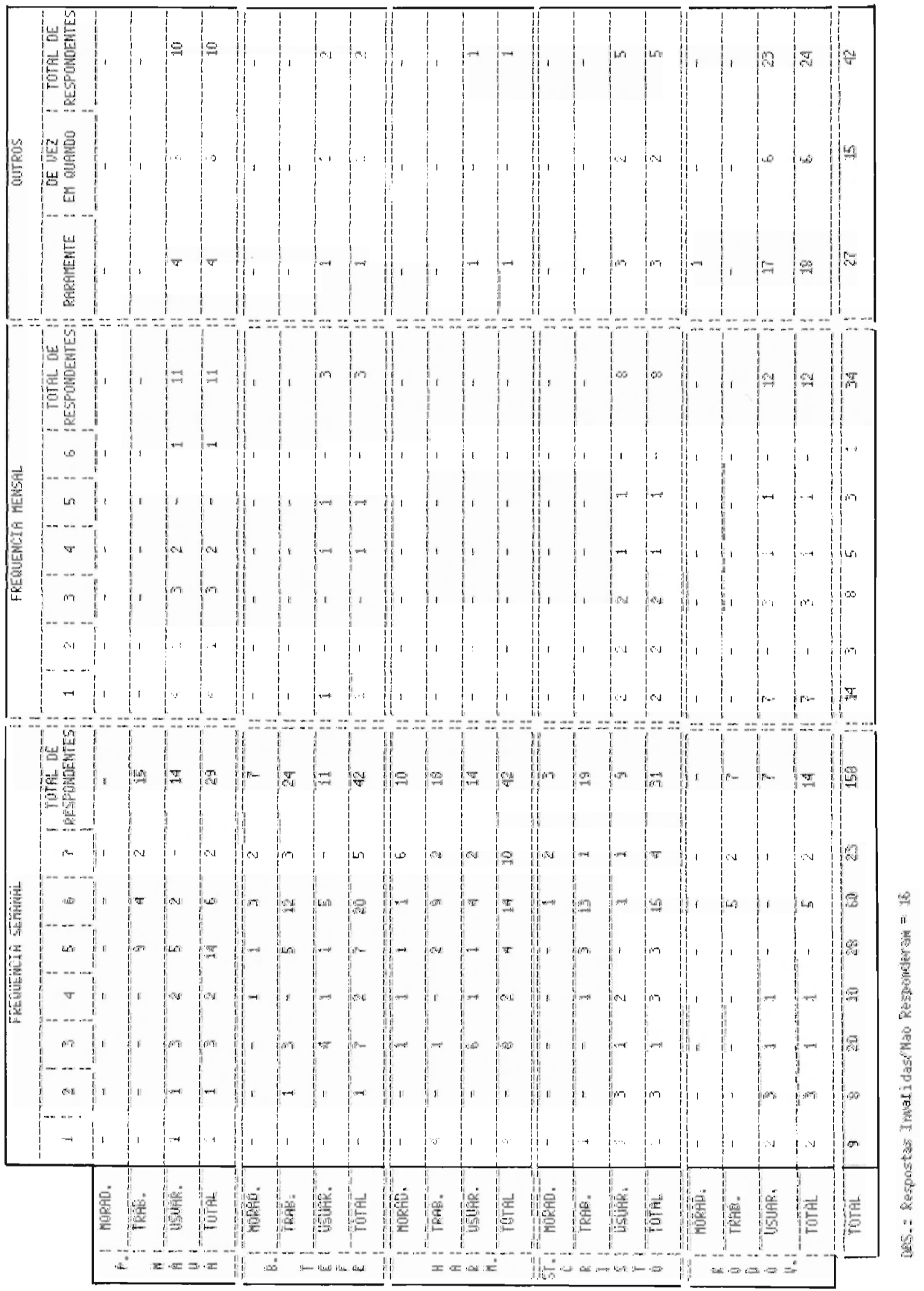


Tab. 16: Atividades dos Respondentes no local de aplicação do questionário (Questão 12).

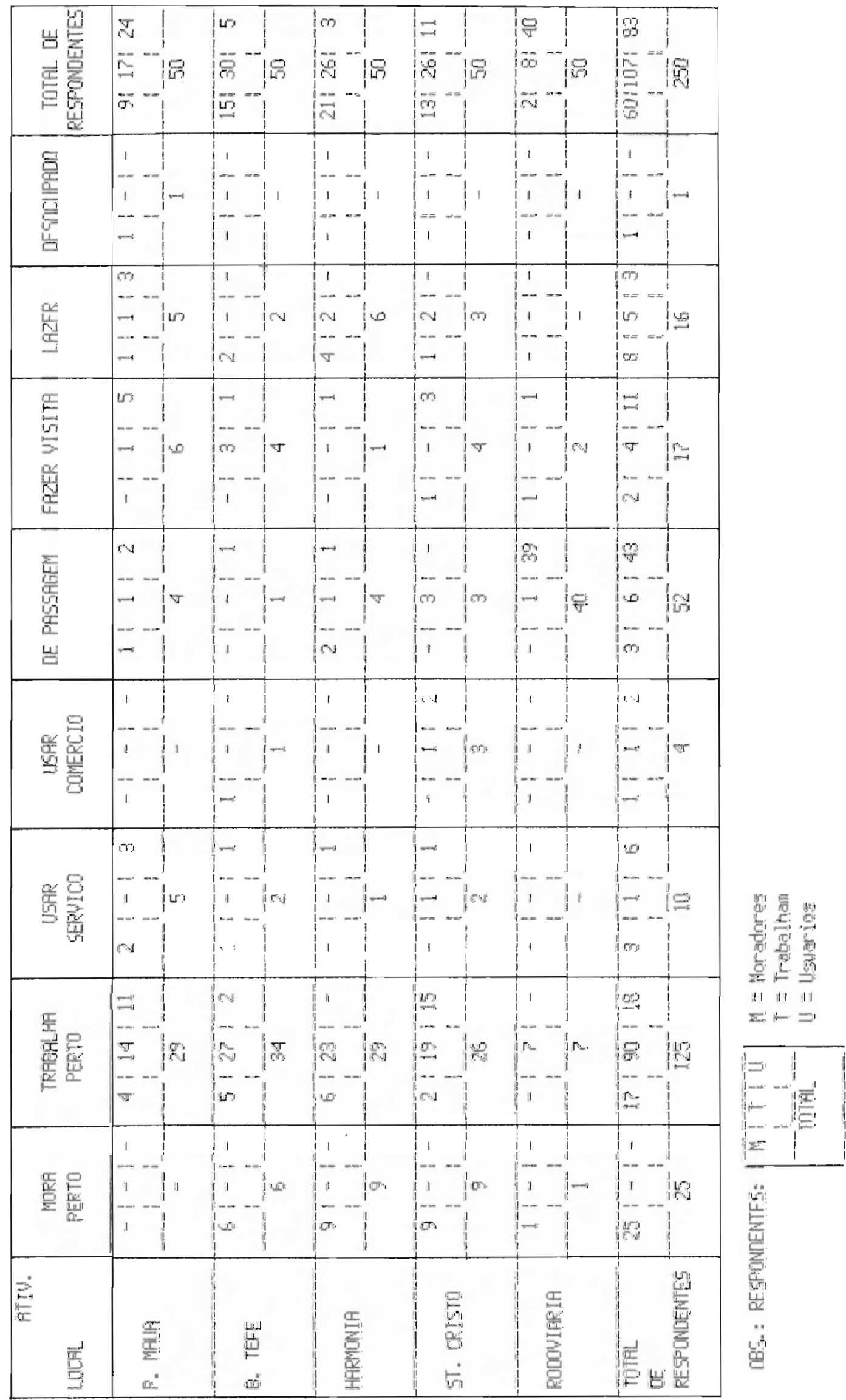


Tab. 17: Respostas a "em que bairro nós estamos?" segundo os locais de aplicação dos questionários (Questão 10)

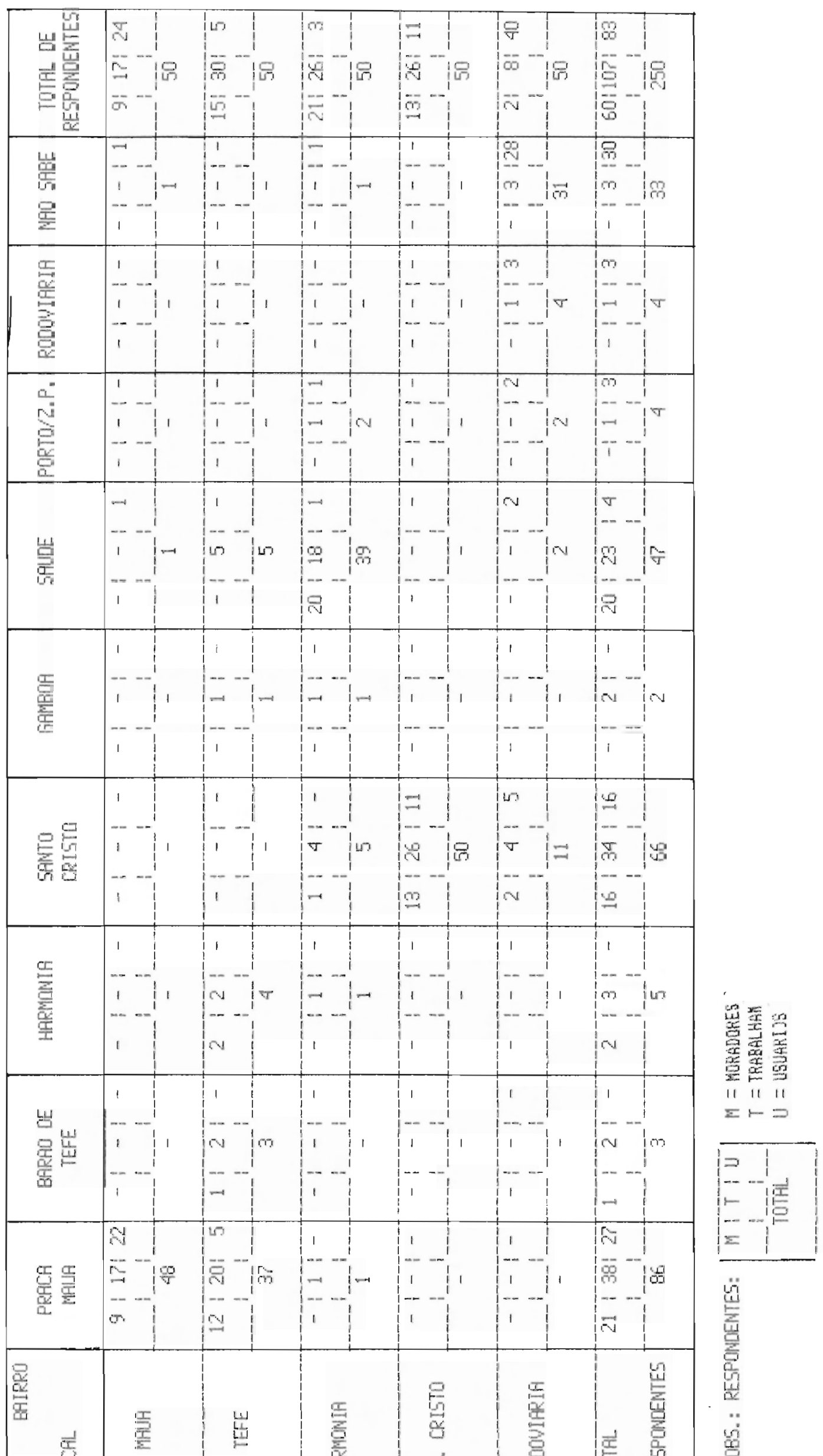




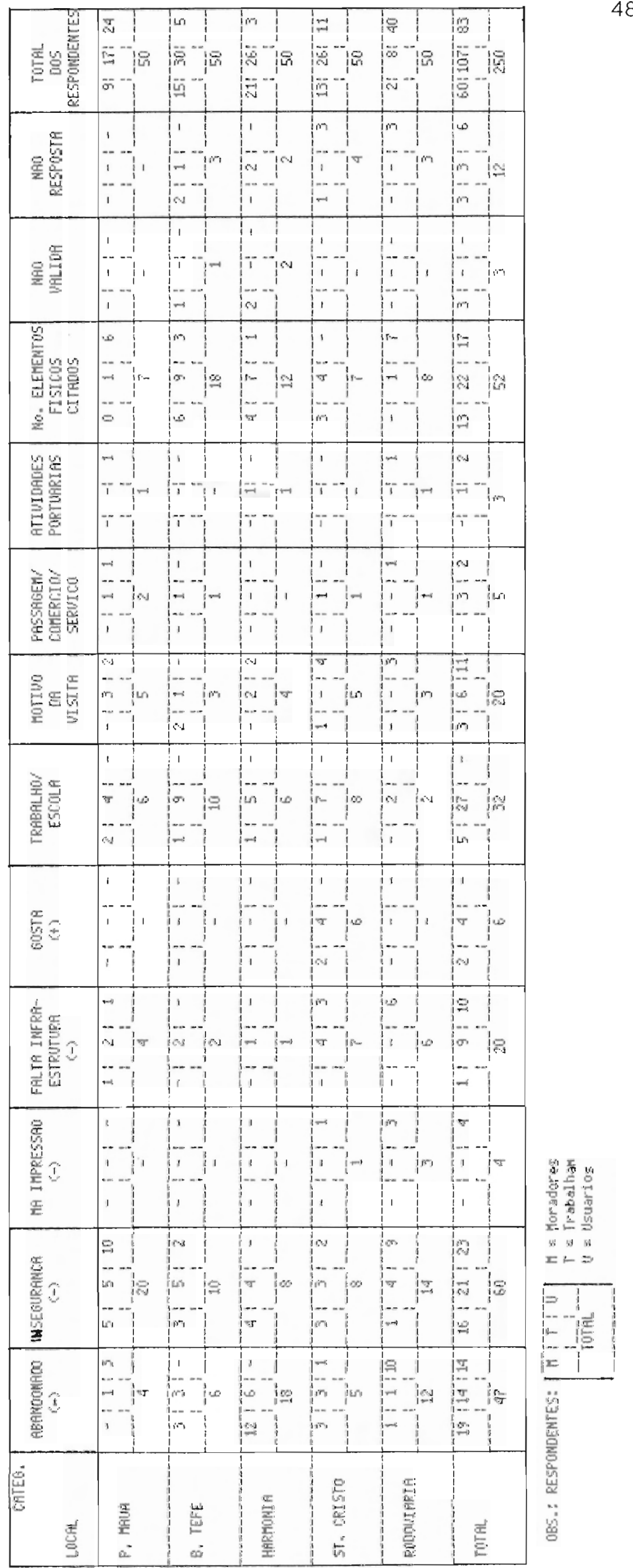

$=$
0
4
4
-1
0
0
0
0
0
0
$\Xi$
0
0
0
$\Xi$
.

๘

-

茛

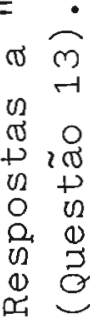

$\ddot{\infty}$

$\dot{0}$

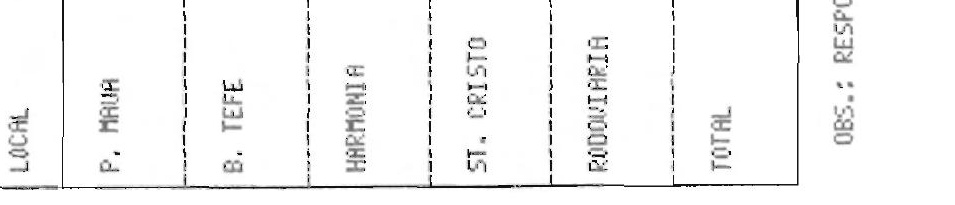


Tab. 19: Tipologia dos Elementos Físicos citados como "primeira imagem" do bairro e da Área Portuária, segundo locais de aplicação dos questionários (Questões 13 \& 14).
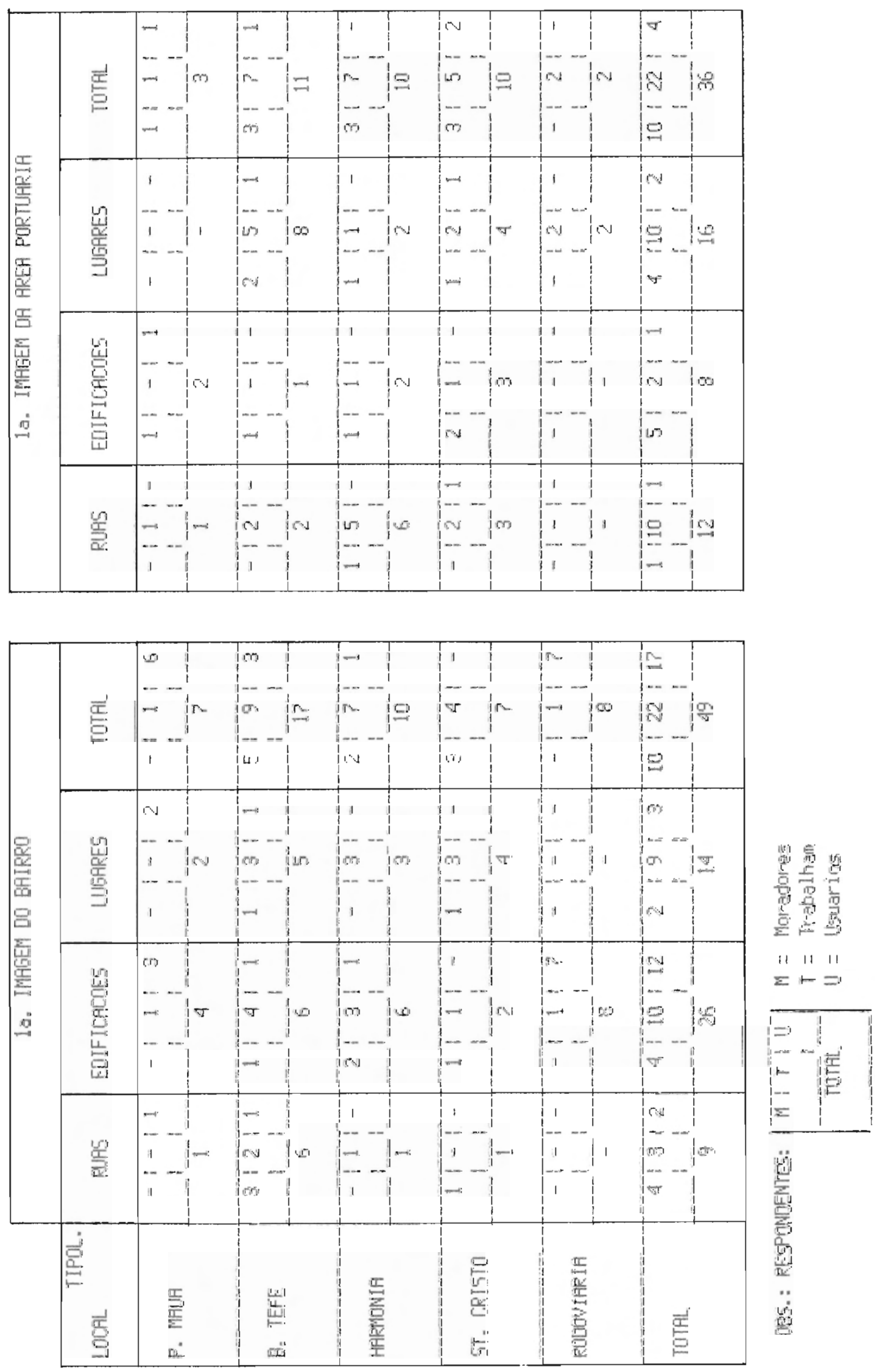


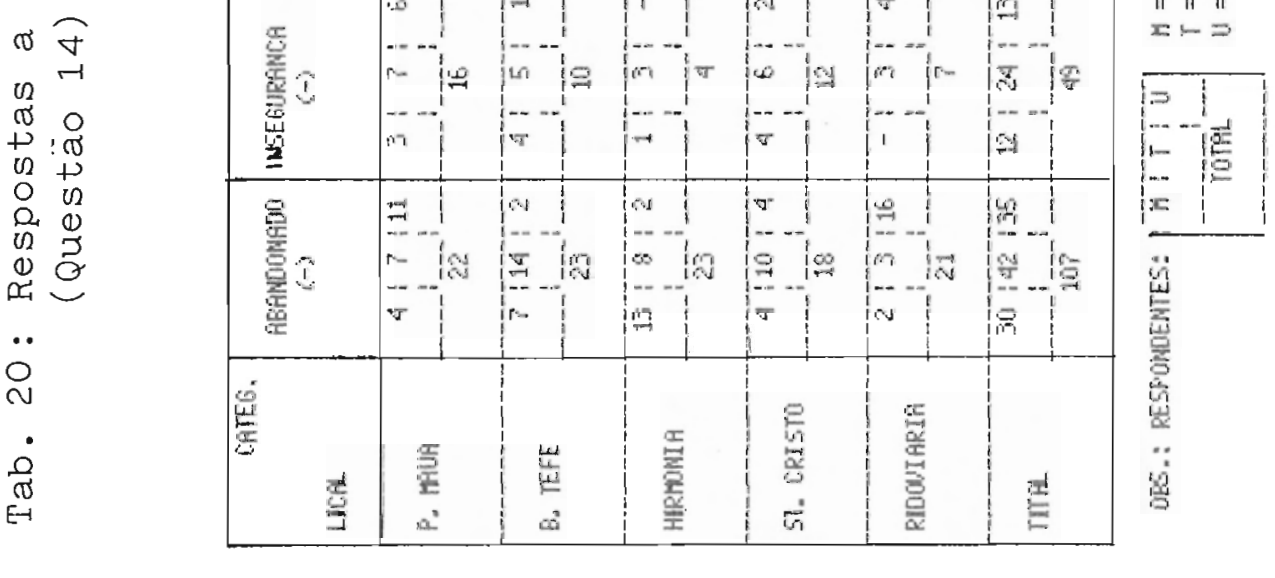


Tab. 21: Tipologia dos Elementos Físicos citados em 1 lugar dos cinco citados para o bairro e a Área Portuária, segundo locais de aplicação (Questões 15 \& 16).

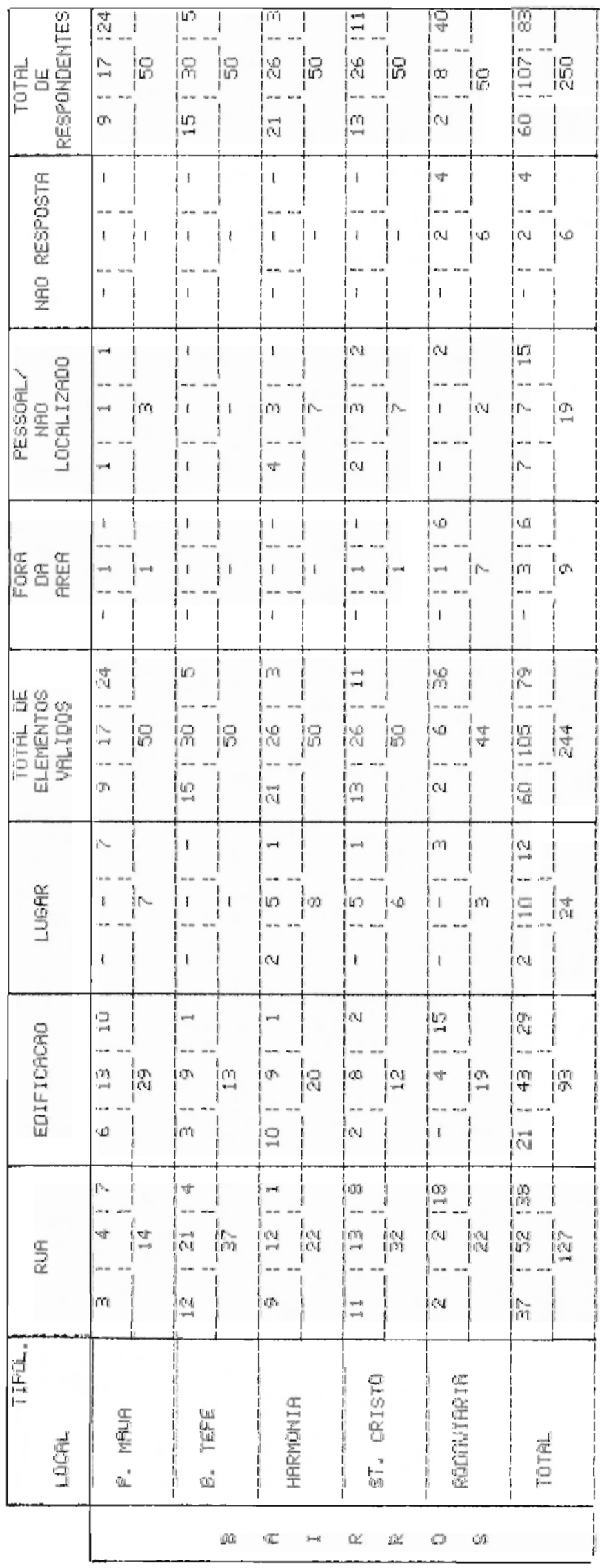

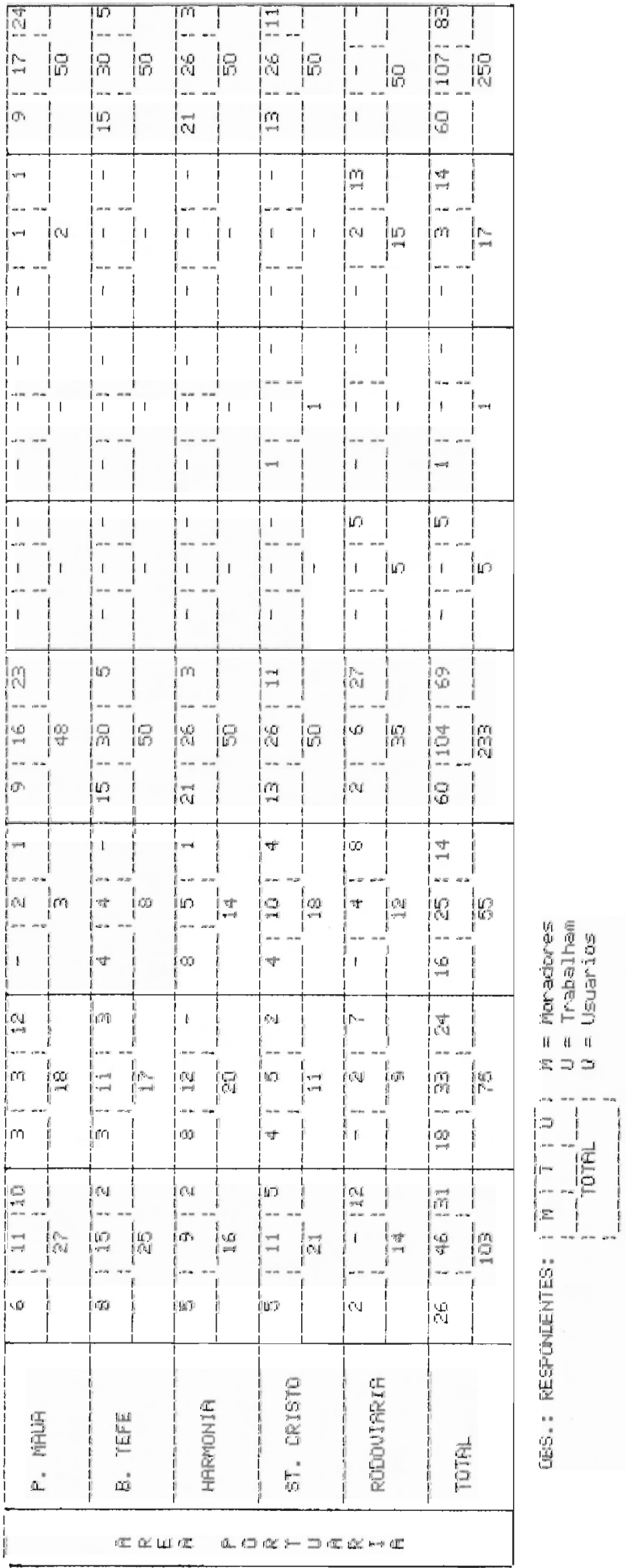


Tab. 22: Os cinco Elementos Físicos mais citados em 1 lugar para o bairro, segundo locais de aplicação (Questão 15).

(Nome do Elemento Fisico/Tipologia/No. de Citacoes)
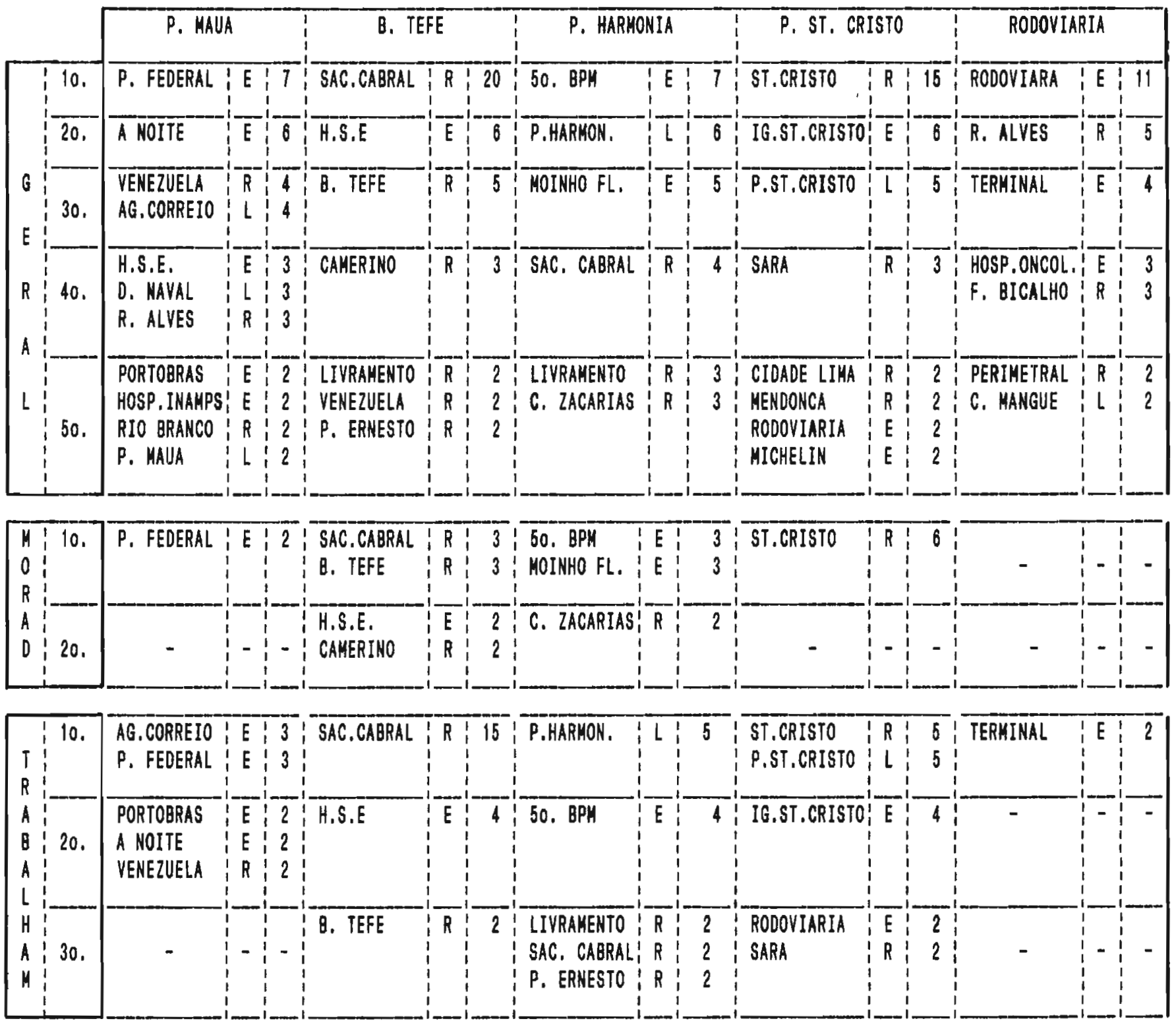

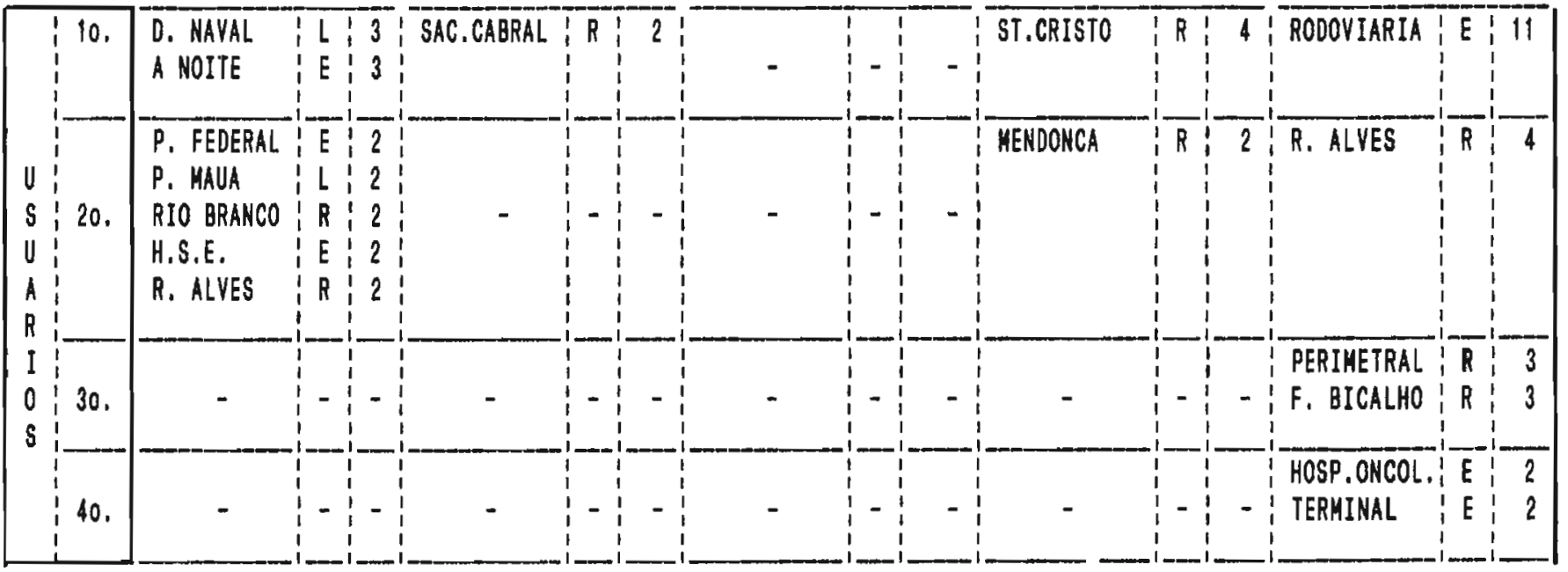


Tab. 23: Tipologia dos Elementos Físicos citados para o bairro e a Área Portuária, segundo locais de aplicação (Questões 15 \& 16).

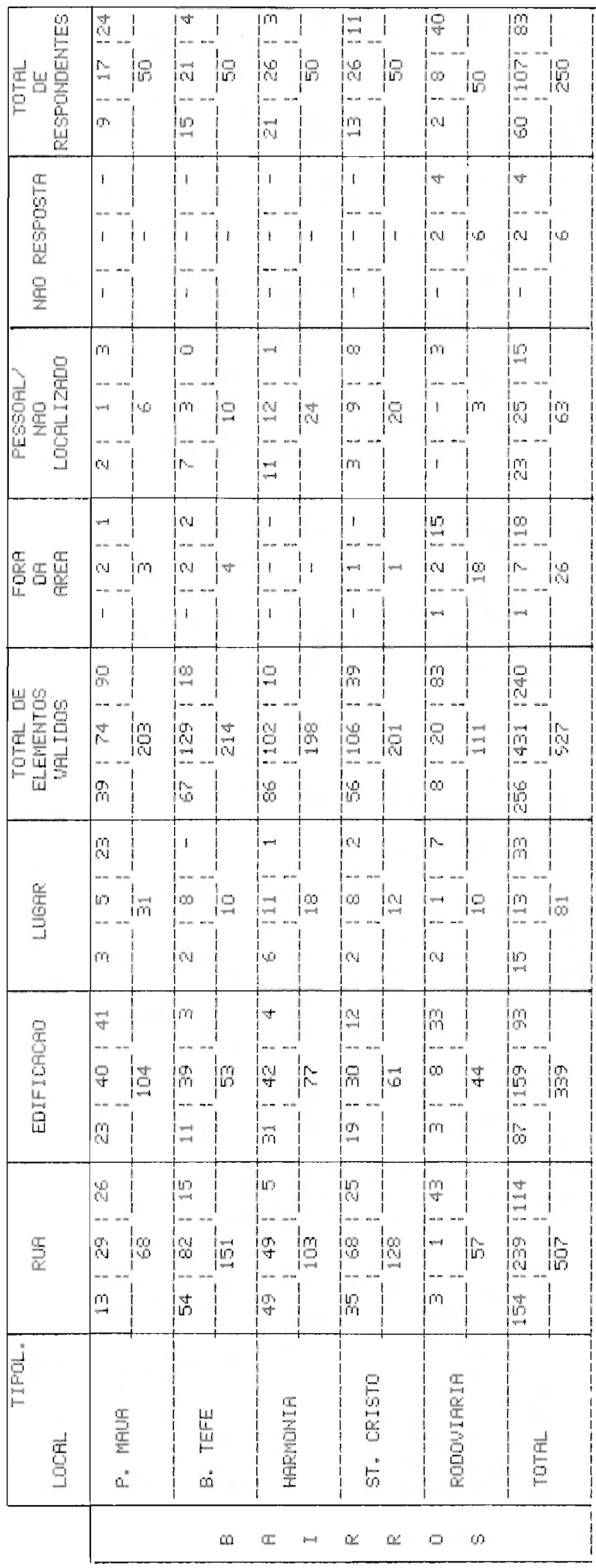

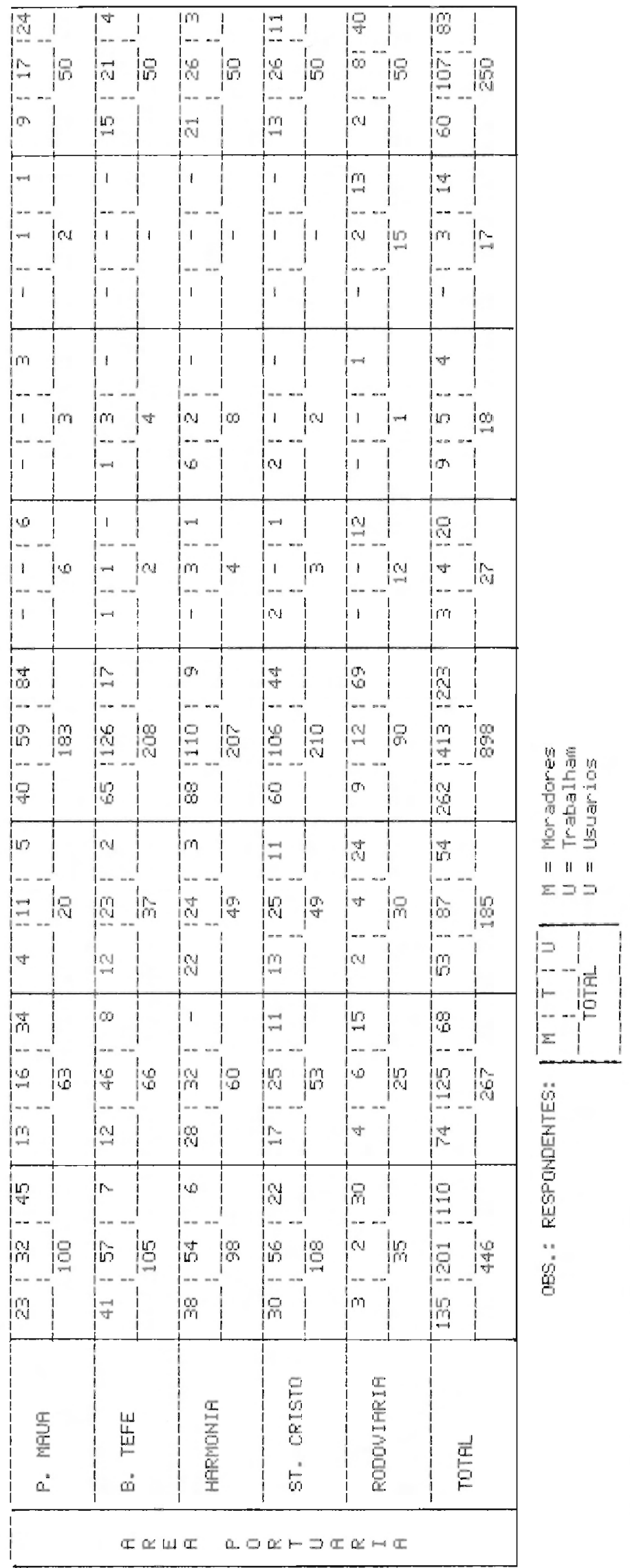


Tab. 24: Os cinco Elementos Físicos mais citados para o bairro, segundo local de aplicação (Questão 15).
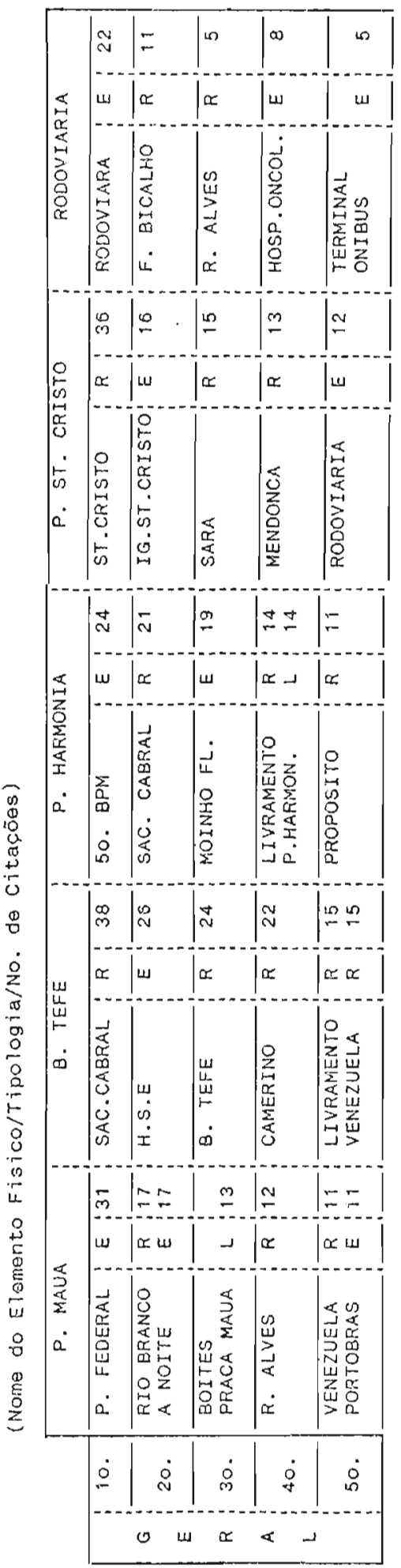
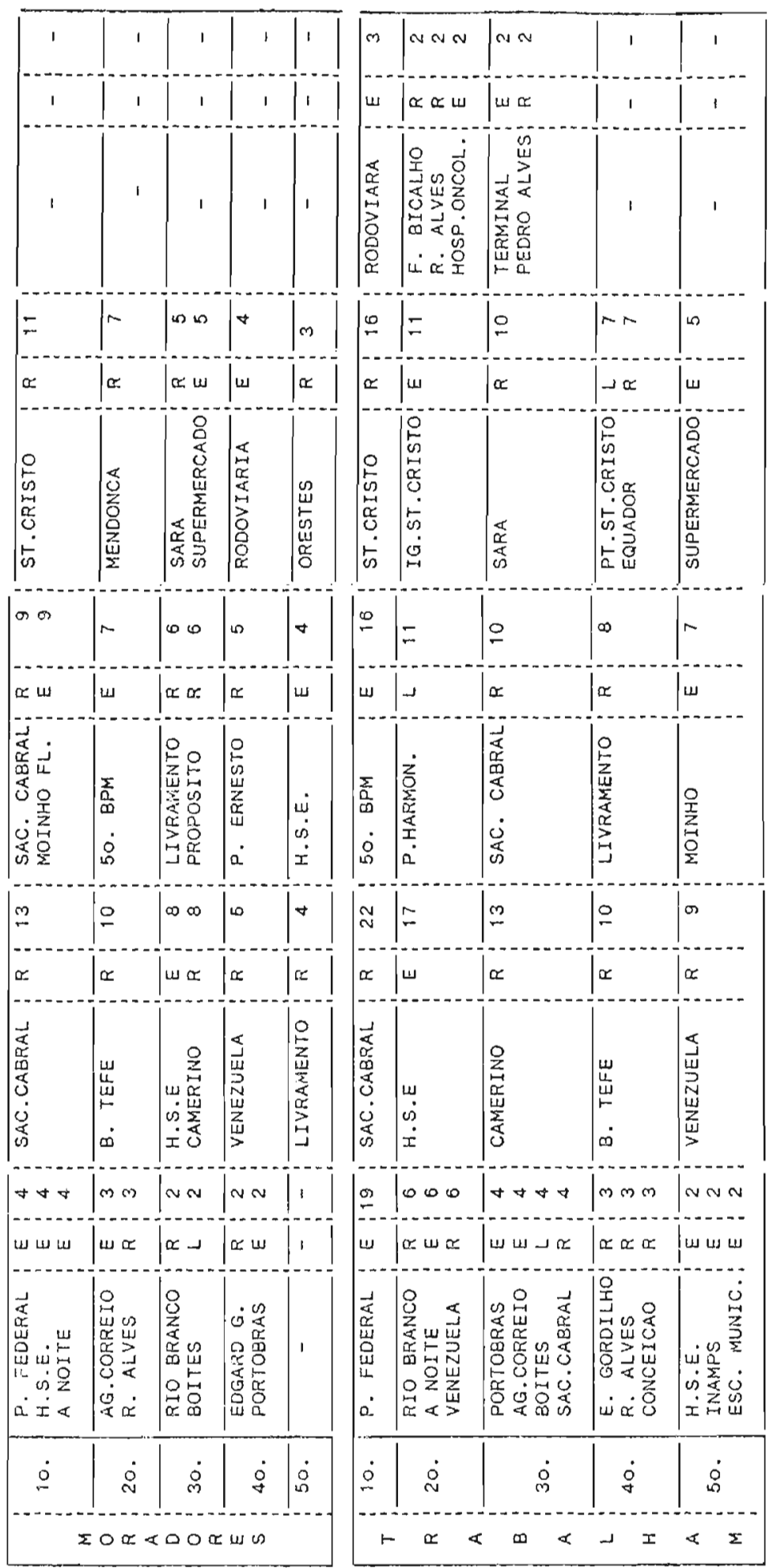

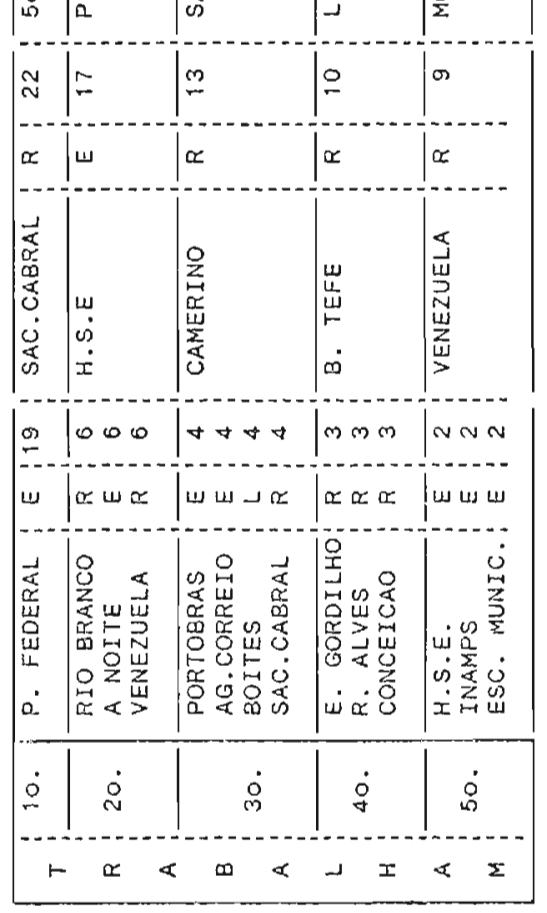

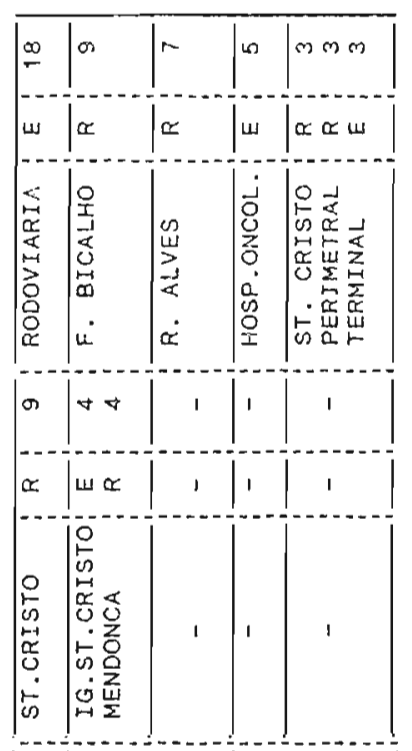
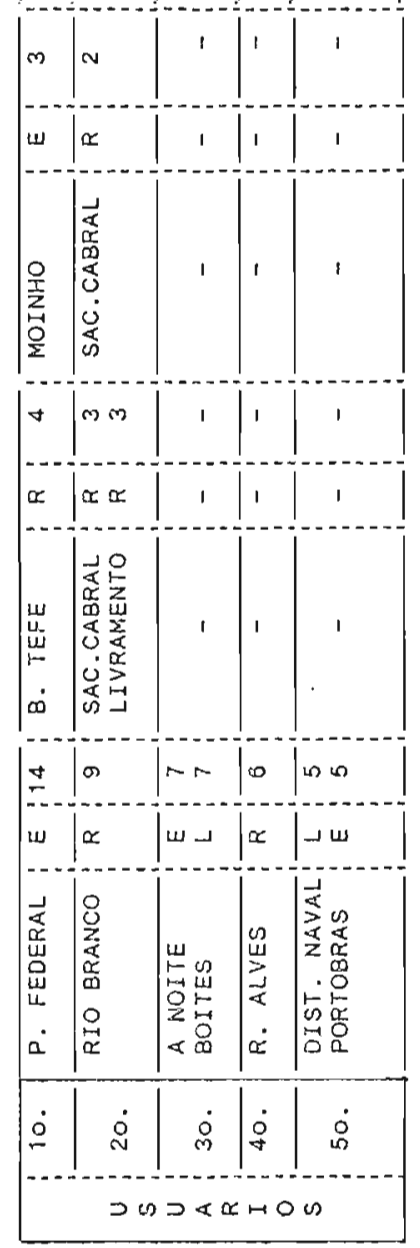
Tab. 25: Os cinco Elementos Físicos mais citados em 1 lugar para a Área Portuária, segundo locais de aplicação

(Questão 16).

\begin{tabular}{|c|c|c|c|c|c|c|c|c|c|c|c|c|c|c|c|c|c|c|c|}
\hline & 昰 & 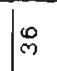 & $\stackrel{m}{m}$ & $m$ & 10 & 0 & 100 & $\infty$ & do & $m$ & $N$ & $\infty$ & 10 & $\forall+$ & $\operatorname{man}$ & $\cong$ & $==$ & in & NNNN \\
\hline & 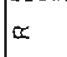 & $\alpha$ & 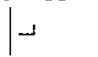 & $\alpha$ & $\alpha$ & - & $\mid c w$ & - & - & $\alpha$ & $\alpha$ & w & - & $\mid+\infty$ & $\mid x \propto-$ & |w & $\mid \ll-1$ & 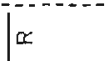 & $\mid \propto ⿻ 山\rfloor$ \\
\hline ह & $\begin{array}{l}n \\
w \\
\frac{3}{\alpha} \\
\dot{\alpha} \\
\dot{0} \\
\alpha\end{array}$ & 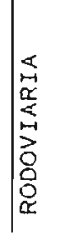 & 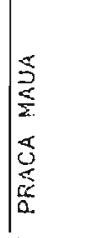 & 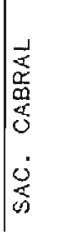 & 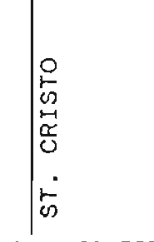 & 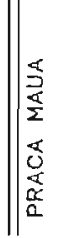 & 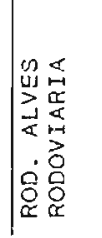 & 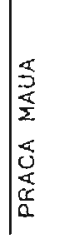 & 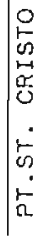 & 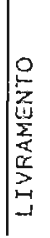 & 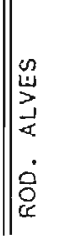 & 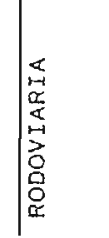 & 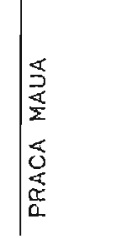 & 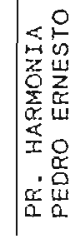 & 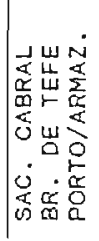 & $\begin{array}{l}x \\
0 \\
\alpha \\
\alpha \\
4 \\
0 \\
0 \\
0 \\
0 \\
\propto\end{array}$ & 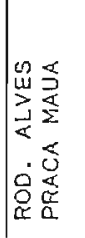 & 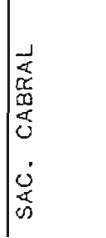 & 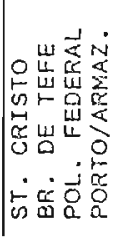 \\
\hline \multirow[b]{3}{*}{$\begin{array}{l}\text { oे } \\
\text { o } \\
x\end{array}$} & or & 0. & $m$ & In & & 1 & 1 & 1 & 1 & 1 & $m$ & 1 & 1 & 1 & 1 & 0 & 4 & $\sim \sim N$ & 1 \\
\hline & \lrcorner & lø & נـ & |ce w & 1 & 1 & 1 & 1 & | 1 & | & $\|\lrcorner$ & 1 & 1 & 1 & I & $\Delta$ & ar & | « & 1 \\
\hline & 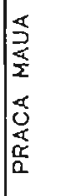 & $\begin{array}{l}0 \\
\ddot{M} \\
\frac{1}{\alpha} \\
\dot{\alpha} \\
\dot{\alpha}\end{array}$ & 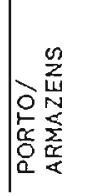 & 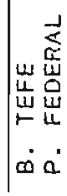 & I & 1 & 1 & 1 & 1 & 1 & 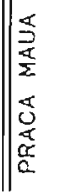 & 1 & 1 & 1 & 1 & 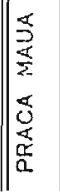 & 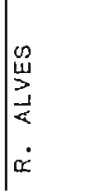 & 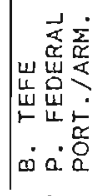 & 1 \\
\hline \multirow{3}{*}{ 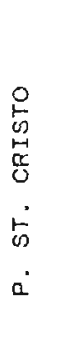 } & $\dddot{m}$ & 0 & ws & + & Na N & $\alpha \approx$ & 1 & 1 & 1 & 1 & $\| r$ & to & Nan & d & 1 & $\|+$ & $\sim$ & 1 & 1 \\
\hline & 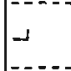 & $a$ & $w$ & 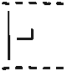 & $\mid \propto \alpha \propto \alpha$ & ג $د$ & 1 & 1 & 1 & 1 & $\triangle$ & a & w & $x$ & 1 & - & $\omega$ & 1 & 1 \\
\hline & 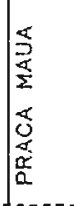 & $\begin{array}{l}\stackrel{n}{\mathscr{m}} \\
\dot{\vec{\alpha}} \\
\dot{\alpha} \\
\dot{\alpha}\end{array}$ & 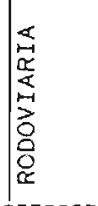 & 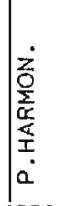 & 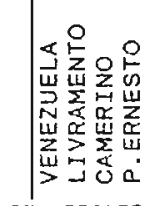 & 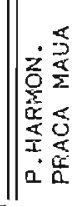 & 1 & 1 & 1 & 1 & 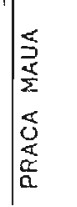 & $\mid \begin{array}{l}3 \\
\ddot{2} \\
\vec{\alpha} \\
\dot{\alpha}\end{array}$ & 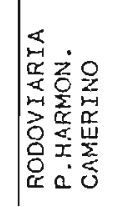 & 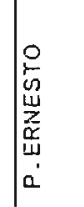 & 1 & 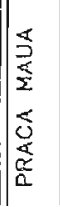 & 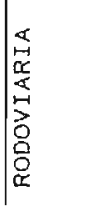 & 1 & 1 \\
\hline \multirow{3}{*}{ 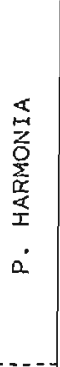 } & 0 & $\infty$ & $r$ & NN & U & م & INNN & a & 1 & 1 & $\infty$ & $\infty$ & $m$ & No & 1 & $\mid 1$ & 1 & 1 & 1 \\
\hline & - & $\mid x$ & I & $1 \times x$ & ـ ـ & $\Delta$ & | $\propto$ 《uा & IJ & 1 & 11 & $\approx$ & is & I & | س & 1 & 1 & 1 & 1 & 1 \\
\hline & 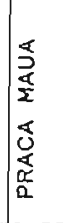 & $\mid \begin{array}{l}m \\
\vec{w} \\
\vec{z} \\
\frac{a}{\alpha} \\
\dot{\alpha}\end{array}$ & 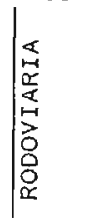 & 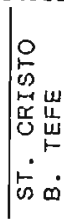 & 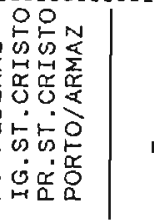 & 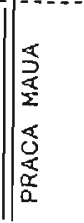 & 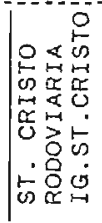 & 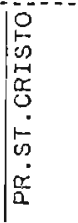 & 1 & 1 & 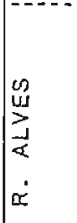 & 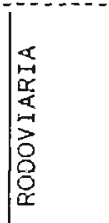 & 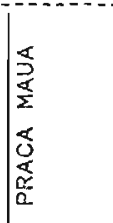 & 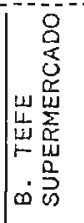 & 1 & $\mid 1$ & 1 & 1 & 1 \\
\hline \multirow[b]{3}{*}{$\begin{array}{l}\text { 岀 } \\
\stackrel{w}{H} \\
\dot{m} \\
\dot{m}\end{array}$} & 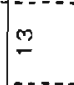 & $1 \cong$ & is & a & IN N & mm & L $\sim \sim$ & I & : & 1 & $\infty \infty$ & |vos & 1 & 1 & 1 & N & 1 & I & I \\
\hline & $w$ & $x$ & lor & 1. & $\mid\lrcorner-\alpha$ & $\propto w$ & $\mid$ & 1 & i & 1 & ळ山 & لـ & 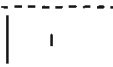 & 1 & 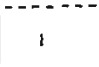 & $m$ & 1 & 1 & 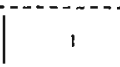 \\
\hline & 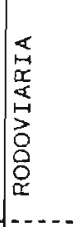 & : & 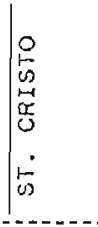 & 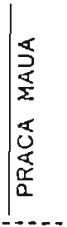 & 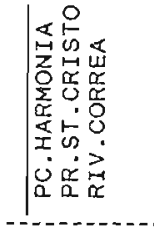 & 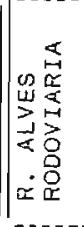 & 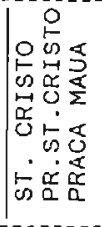 & 1 & 1 & 1 & 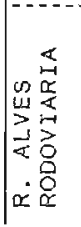 & 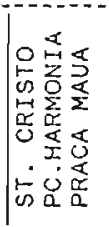 & 1 & 1 & 1 & 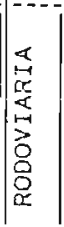 & I & 1 & ' \\
\hline \multirow{5}{*}{ 更 } & $\because 2$ & $1 \infty$ & I $N \times N$ & & 1 & $m$ & 1 & 1 & 11 & 1 & 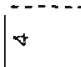 & $\mathrm{mm}$ & In & 1 & 1 & - & $+\infty$ & 1 & , \\
\hline & $x w$ & Ix & $\mid \propto ⿻ \propto ⿻$ & & 1 & $\propto$ & 1 & 1 & 1 & . & $\pi$ & $a w$ & $x$ & 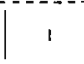 & 1 & $w$ & $\alpha \sigma$ & 1 & 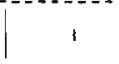 \\
\hline & 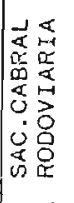 & 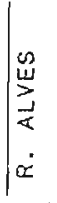 & 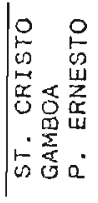 & & 1 & 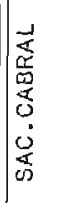 & 1 & 1 & 1 & 1 & $\begin{array}{l}\frac{9}{4} \\
\frac{1}{\alpha} \\
\dot{x}\end{array}$ & 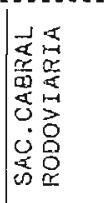 & 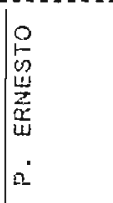 & ' & 1 & 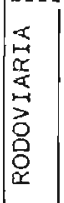 & 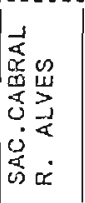 & 1 & 1 \\
\hline & $\dot{0}$ & $\dot{\dot{\sim}}$ & $\dot{m}$ & & $\therefore$ & $\therefore$ & $\stackrel{i}{\sim}$ & $\dot{8}$ & o & is & $\stackrel{\circ}{\circ}$ & $\dot{\stackrel{N}{ }}$ & $\dot{m}$ & $\dot{q}$ & in & $\stackrel{\circ}{\circ}$ & $\dot{\mathrm{N}}$ & $\dot{g}$ & $\dot{g}$ \\
\hline & & & ע ט & $\alpha$ & ــ & & $0 \ll \alpha C$ & $0 \ll u$ & & & & $1-a<$ & I & & & & & $\cos$ & HOO \\
\hline
\end{tabular}


Tab. 26: Os cinco Elementos Físicos mais citados para a Área Portuária, segundo locais de aplicação (Questão 16).

\begin{tabular}{|c|c|c|c|c|c|c|c|c|c|c|c|c|c|c|c|c|c|c|c|c|}
\hline & مે & $\infty$ & or & $\tilde{q}$ & m & i & 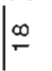 & $\approx$ & $\because$ & $\forall \rightleftarrows$ & $\stackrel{\infty}{+}$ & 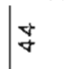 & 品 & $=$ & $\dddot{0}$ & $\infty$ & 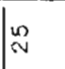 & $\stackrel{d}{a}$ & $\because$ & $\mid \infty$ \\
\hline & $\propto$ & |w & لـ & 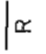 & $\mid x$ & 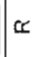 & |- & wu & $\propto$ & $\mid \propto \propto\lrcorner$ & $\| \propto$ & $w$ & \lrcorner & $\propto$ & \lrcorner & 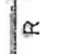 & $\mid\lrcorner$ & w & 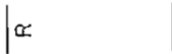 & $\pi$ \\
\hline $\begin{array}{l}\overrightarrow{5} \\
5 \\
0 \\
k\end{array}$ & 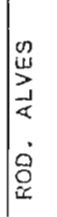 & 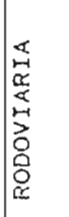 & 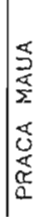 & $\begin{array}{l}1 \\
\frac{a}{2} \\
x \\
0 \\
0 \\
0 \\
0 \\
0 \\
0 \\
0 \\
0\end{array}$ & 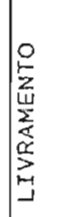 & 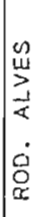 & 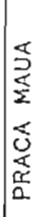 & 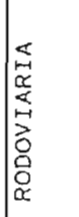 & 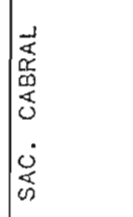 & 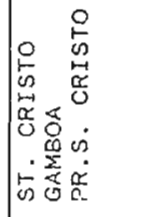 & $\mid \begin{array}{l}n \\
3 \\
\frac{1}{2} \\
\alpha \\
0 \\
0 \\
0\end{array}$ & 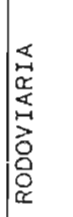 & 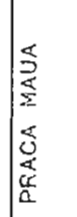 & 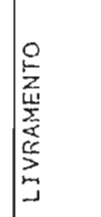 & $\begin{array}{l}0 \\
0 \\
0 \\
0 \\
\frac{5}{0} \\
\dot{0} \\
0 \\
0 \\
0\end{array}$ & $\mid \begin{array}{l}m \\
3 \\
< \\
0 \\
0 \\
0\end{array}$ & $\mid \begin{array}{l}\frac{5}{3} \\
\frac{1}{2} \\
\frac{1}{2} \\
0 \\
\frac{1}{\alpha} \\
a\end{array}$ & 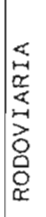 & 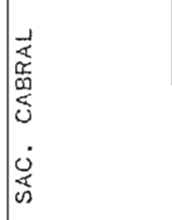 & 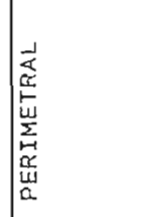 \\
\hline & $\because$ & $\stackrel{0}{-}$ & $\infty$ & $\infty$ & 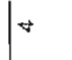 & $\infty$ & 1 & 1 & 1 & I & 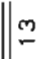 & 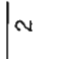 & 1 & 1 & 1 & in & $\omega$ & in & 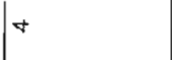 & mm \\
\hline$\$$ & \lrcorner & \lrcorner & $\mid \propto$ & |w & m & $\llbracket$ & 1 & 1 & 1 & 1 & $\|$ & $w$ & 1 & 1 & 1 & - & \lrcorner & 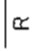 & w & $\omega x$ \\
\hline $\begin{array}{l}a \\
4 \\
3 \\
8 \\
0 \\
0\end{array}$ & 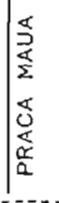 & 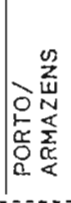 & $\mid \begin{array}{l}\infty \\
w \\
3 \\
4 \\
\alpha \\
x\end{array}$ & $\begin{array}{l} \\
\dot{\omega} \\
\dot{0} \\
\dot{1} \\
\dot{1}\end{array}$ & 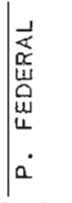 & 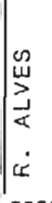 & 1 & 1 & 1 & 1 & 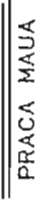 & $\begin{array}{l}\dot{4} \\
\dot{n} \\
\dot{I}\end{array}$ & 1 & 1 & 1 & $\mid \begin{array}{l}\frac{3}{3} \\
\frac{\pi}{2} \\
x \\
0 \\
\mathbb{2} \\
0\end{array}$ & 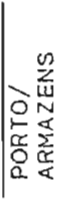 & $\begin{array}{l}0 \\
w \\
\frac{1}{4} \\
\frac{1}{4} \\
\dot{x}\end{array}$ & 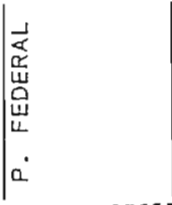 & 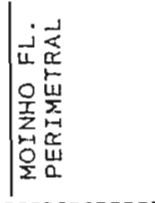 \\
\hline & $\hat{\sim}$ & $\mid \mathfrak{N}$ & $\mathscr{2}$ & $\cong$ & $==$ & r & | & $4 \nabla$ & लयलक & NNN & $\| \sim$ & $\stackrel{m}{-}$ & a & 00 & ما & $\infty$ & 10 & $\nabla$ & mm & UN N N \\
\hline ro & - & $\mid \llbracket$ & $\mid \ltimes x$ & $\omega$ & $\alpha-$ & $\propto$ & ــ & $\mid \simeq \perp$ & 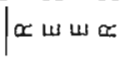 & 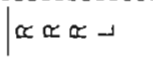 & & $\alpha$ & 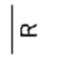 & $w \Subset$ & w & -1 & a & $\omega$ & $\propto \alpha$ & $\ltimes \omega \omega \simeq \simeq$ \\
\hline $\begin{array}{l}0 \\
0 \\
0 \\
0\end{array}$ & 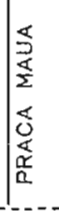 & 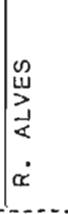 & 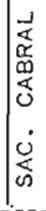 & 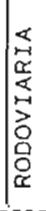 & 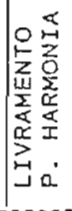 & $\begin{array}{l}\frac{1}{\alpha} \\
\frac{\pi}{0} \\
0 \\
0 \\
0 \\
0 \\
0 \\
0 \\
0\end{array}$ & 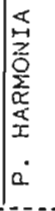 & 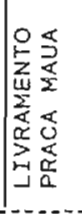 & 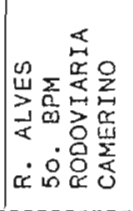 & 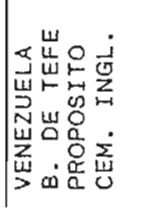 & 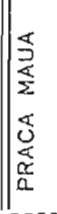 & 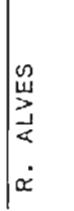 & 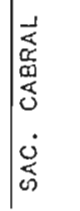 & 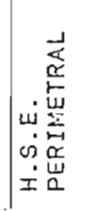 & 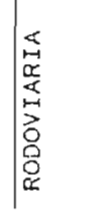 & 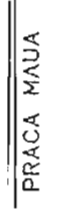 & 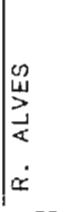 & 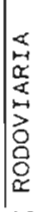 & 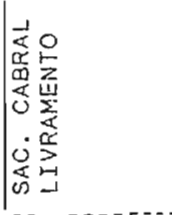 & 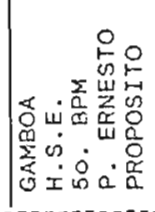 \\
\hline & $\stackrel{m}{N}$ & $\stackrel{m}{\sim}$ & in & $=$ & 10 & $=$ & r & 10 & م & आलmल & $\stackrel{2}{\circ}$ & $m$ & 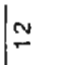 & $\infty$ & مـ & $\| \sim \sim$ & 1 & 1 & & I \\
\hline 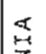 & \lrcorner & re & $w$ & $\alpha$ & |- & ـ & w & |x & $\mid \approx x-$ & $\mid \propto w \propto ⿻ 山 \omega$ & $\propto$ & |w & 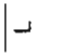 & $\mid x$ & $\mid x-$ & |ix & 1 & | 1 & 1 & 1 \\
\hline $\begin{array}{l}\frac{0}{0} \\
\frac{0}{2} \\
\frac{2}{2} \\
0 \\
0\end{array}$ & 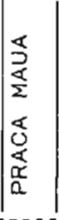 & 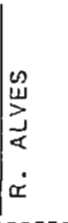 & 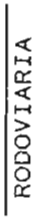 & 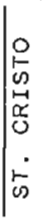 & $\mid \begin{array}{l}0 \\
0 \\
0 \\
0 \\
0 \\
0 \\
\dot{0} \\
\dot{0} \\
\dot{0} \\
\dot{x} \\
a\end{array}$ & 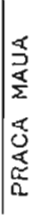 & $\begin{array}{l}\alpha \\
a \\
\alpha \\
\alpha \\
\vdots \\
0 \\
0 \\
0 \\
0 \\
0 \\
\alpha\end{array}$ & 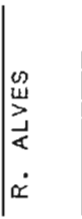 & 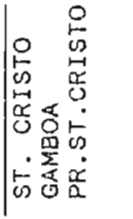 & 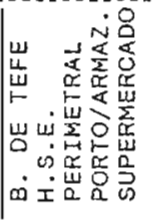 & $\begin{array}{l}0 \\
u \\
2 \\
\alpha \\
x\end{array}$ & 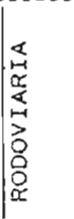 & 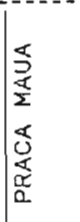 & 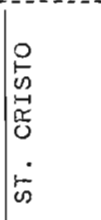 & 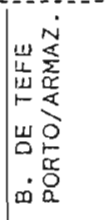 & 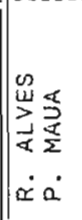 & 1 & 1 & 1 & 1 \\
\hline & $\stackrel{0}{\circ}$ & $\stackrel{m}{N}$ & 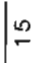 & \pm & $m$ & $\infty$ & a & L 10 & $\theta+\phi$ & $m m$ & $=$ & $m$ & $\infty \infty$ & lar & 1000 & $\|$ - & $N \sim$ & 1 & 1 & 1 \\
\hline & $w$ & $\alpha$ & $\mid x$ & $\infty$ & |w & 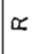 & $\propto$ & $w \alpha$ & ــ س ــ & $\mid x \propto x$ & $\omega$ & $\alpha$ & $\propto \alpha x$ & $\mid x \propto-$ & |س & $\| \omega$ & 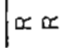 & 1 & 1 & 1 \\
\hline $\begin{array}{l}\text { 岕 } \\
\stackrel{w}{⺊} \\
\infty\end{array}$ & $\mid \begin{array}{l}2 \\
1 \\
0 \\
0 \\
0 \\
1 \\
0 \\
0 \\
0 \\
0 \\
0\end{array}$ & $\begin{array}{l}\infty \\
w \\
\geq \\
\vec{\alpha} \\
\dot{a}\end{array}$ & $\begin{array}{l}x \\
0 \\
0 \\
0 \\
\vdots \\
0 \\
0\end{array}$ & $\begin{array}{l}0 \\
0 \\
0 \\
0 \\
0 \\
0 \\
0 \\
0 \\
0 \\
0\end{array}$ & $\begin{array}{l}\frac{\Sigma}{0} \\
0 \\
0 \\
0 \\
0 \\
0\end{array}$ & $\begin{array}{l}\stackrel{p}{\sharp} \\
\frac{\sim}{\alpha} \\
\alpha\end{array}$ & $\mid \begin{array}{l}5 \\
0 \\
0 \\
2 \\
5 \\
0\end{array}$ & 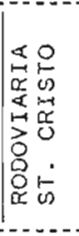 & 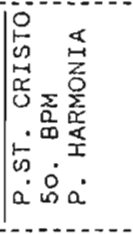 & 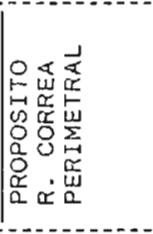 & $\begin{array}{l}a \\
a \\
\alpha \\
\alpha \\
\vdots \\
\vdots \\
0 \\
0 \\
0 \\
0\end{array}$ & 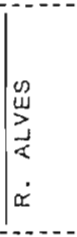 & 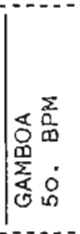 & 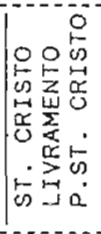 & 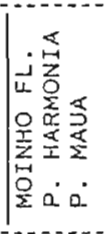 & 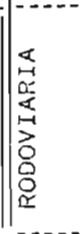 & 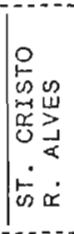 & 1 & 1 & 1 \\
\hline & 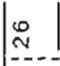 & $\left.\right|_{-\infty} ^{\infty} \stackrel{\infty}{-\infty}$ & lm & $1=$ & $\infty$ & 10 & in & $\forall \theta$ & m & Nan & or & 100 & | & $\leftrightarrow+$ & mmin & $\| \nsubseteq$ & $=$ & is & mmलmm & INNN \\
\hline & w & $\propto \propto$ & 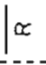 & \lrcorner & $\propto$ & $\simeq$ & $\alpha$ & $\mid$ & $w$ & $\llbracket \simeq ш ш$ & $w$ & $\alpha \pi$ & ـ & $\llbracket \propto$ & $\mid x \propto x$ & $w$ & $\simeq$ & $x$ & $\mid \simeq \simeq \simeq \simeq U$ & $\propto ш$ \\
\hline $\begin{array}{l}\frac{\pi}{2} \\
\frac{\pi}{2} \\
0\end{array}$ & 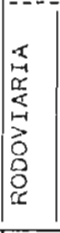 & 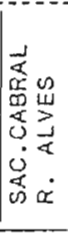 & 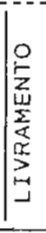 & $\mid \begin{array}{l}0 \\
0 \\
0 \\
0 \\
0 \\
0 \\
0 \\
0 \\
5 \\
0 \\
0 \\
\alpha \\
\alpha \\
\alpha\end{array}$ & 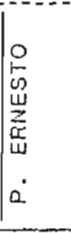 & 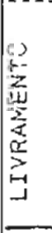 & 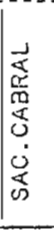 & 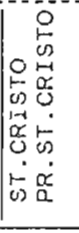 & $\begin{array}{l}\omega \dot{x} \\
\dot{\omega} \\
\dot{x}\end{array}$ & 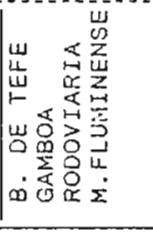 & $\begin{array}{l}\alpha \\
0 \\
0 \\
0 \\
1 \\
1 \\
3 \\
8 \\
8 \\
0 \\
0\end{array}$ & 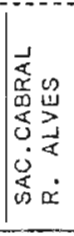 & $\begin{array}{l}0 \\
0 \\
0 \\
0 \\
0 \\
0 \\
1 \\
\vdots \\
0 \\
0 \\
\alpha \\
0 \\
0\end{array}$ & 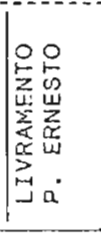 & 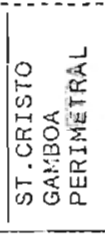 & $\mid \begin{array}{c}x \\
x=1 \\
x \\
x \\
5 \\
3 \\
3 \\
8 \\
0 \\
0 \\
x\end{array}$ & $\begin{array}{l}m \\
w \\
3 \\
\dot{\alpha} \\
\dot{x}\end{array}$ & 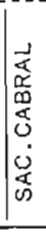 & 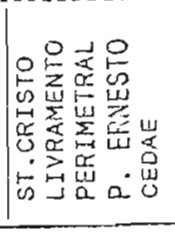 & 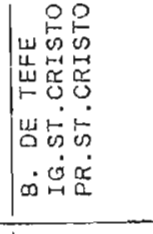 \\
\hline & $\div$ & $\stackrel{\dot{D}}{\sim}$ & $\dot{0}$ & $\stackrel{4}{q}$ & 8 & 10 & $\stackrel{i}{N}$ & $\stackrel{\circ}{\circ}$ & $\dot{q}$ & 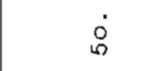 & $\because$ & $\stackrel{\circ}{\mathrm{N}}$ & $\therefore$ & g & $\dot{0}$ & $\dot{\dot{g}}$ & $\stackrel{\dot{O}}{N}$ & m & $\stackrel{9}{+}$ & is \\
\hline & 0 & $w$ & $\propto$ & $<$ & لـ & $\Sigma$ & 0 & $\propto \alpha$ & 00 & $\propto \omega \omega$ & & & $<0$ & $\Delta I$ & & & n & $د$ & $\propto \propto$ & 00 \\
\hline
\end{tabular}


Tab. 27: Atitudes relativas a Participação Comunitária no planejamento do bairro e da Área Portuária, segundo locais de aplicação (Afirmativa 3/Questão 17; Afirmativa 10/Questão 18)

I) A Comunidade deveria tomar parte do planejamento do bafrro

\begin{tabular}{|c|c|c|c|c|c|c|c|c|c|}
\hline & & \multirow{2}{*}{\multicolumn{3}{|c|}{ NAO CONCORDA }} & \multirow{3}{*}{ INDIF } & \multirow{2}{*}{\multicolumn{2}{|c|}{ CONCORDA }} & \multirow{3}{*}{ MUITO } & \multirow{3}{*}{$\begin{array}{c}\text { MEDIA } \\
\text { PONDERADA }\end{array}$} \\
\hline & & & & & & & & & \\
\hline & RESPONDENTES $(n)$ & -3 & -2 & -1 & & 1 & 2 & & \\
\hline \multirow{4}{*}{$\begin{array}{l}G \\
E \\
R \\
A \\
L\end{array}$} & MORAD. (60) & - & $\overline{-}$ & - & - & 3 & 6 & 51 & $+2,80$ \\
\hline & TRAB. $(107)$ & - & - & 1 & - & 2 & 13 & 91 & $+2,80$ \\
\hline & USUAR. (83) & - & - & - & - & 1 & 8 & 74 & $+2,88$ \\
\hline & GERAL (250) & - & - & 1 & - & $\theta$ & 27 & 216 & $+2,83$ \\
\hline \multirow{4}{*}{$\begin{array}{l}P . \\
M \\
A \\
U \\
A\end{array}$} & MOR.40. (9) & - & - & - & - & - & 1 & 8 & $+2,89$ \\
\hline & TRAB. (17) & - & - & - & - & - & 3 & 14 & $+2,82$ \\
\hline & USUAR. $(24)$ & - & - & - & - & - & 4 & 20 & $+2,83$ \\
\hline & GERAL $(50)$ & - & - & - & - & - & 8 & 42 & $+2,84$ \\
\hline \multirow{4}{*}{$\begin{array}{l}\mathrm{B} . \\
\mathrm{T} \\
\mathrm{E} \\
\mathrm{F} \\
\mathrm{E}\end{array}$} & MORAD. (15) & - & - & - & - & 1 & - & 14 & $+2,87$ \\
\hline & TRAB. $(30)$ & - & - & 1 & - & 1 & 4 & 24 & $+2,67$ \\
\hline & USUAR. (5) & - & $\cdot-$ & - & - & - & - & 5 & $+3,00$ \\
\hline & GERAL $(50)$ & - & - & 1 & - & 2 & 4 & 43 & $+2,76$ \\
\hline \multirow{4}{*}{$\begin{array}{l}H \\
A \\
R \\
M \\
O \\
N .\end{array}$} & MORAD. (21) & - & - & - & - & 1 & 3 & 17 & $+2,76$ \\
\hline & TRAB, (26) & - & - & - & - & 1 & 2 & 23 & $+2,85$ \\
\hline & USUAR. (3) & - & - & - & - & - & - & 3 & $+3,00$ \\
\hline & GERAL $(50)$ & - & - & - & - & 2 & 5 & 43 & $+2,82$ \\
\hline \multirow{4}{*}{$\begin{array}{l}S T . \\
C \\
R \\
I \\
S \\
T \\
0\end{array}$} & MORAD. (13) & 一 & - & - & - & 1 & 2 & 10 & $+2,69$ \\
\hline & TRAB. (26) & - & - & - & - & - & 3 & 23 & $+2,88$ \\
\hline & USUAR. $(11)$ & - & - & - & - & - & 3 & 8 & $+2,73$ \\
\hline & GERAL $(50)$ & - & - & - & - & 1 & 8 & 41 & $+2,80$ \\
\hline \multirow{4}{*}{$\begin{array}{l}R \\
O \\
D \\
O \\
V .\end{array}$} & MORAD. (2) & - & - & - & - & - & - & 2 & $+3,00$ \\
\hline & TRAB. (B) & - & - & - & - & - & 1 & 7 & $+2,75$ \\
\hline & USUAR. (40) & - & - & - & - & 1 & 1 & 348 & $+2,93$ \\
\hline & GERAL $(50)$ & - & - & - & - & 1 & 2 & 47 & $+2,92$ \\
\hline
\end{tabular}

II) A Comunidade deveria partfcipar de planos para a Area Portuarta

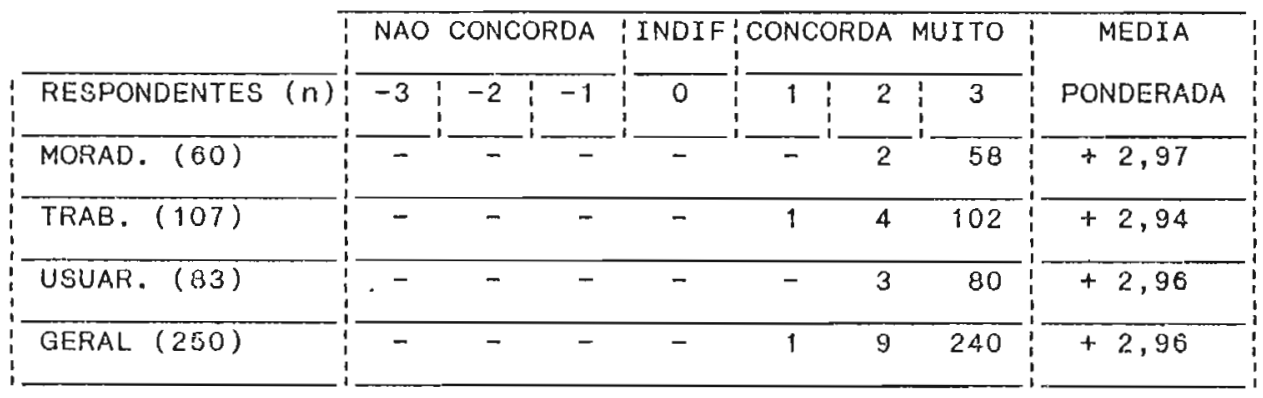


Tab. 28: Atitudes e Atributos Percebidos relativos ao bairro, segundo Campos Perceptivos Negativo e Positivo, no conjunto dos respondentes (Questão 17)
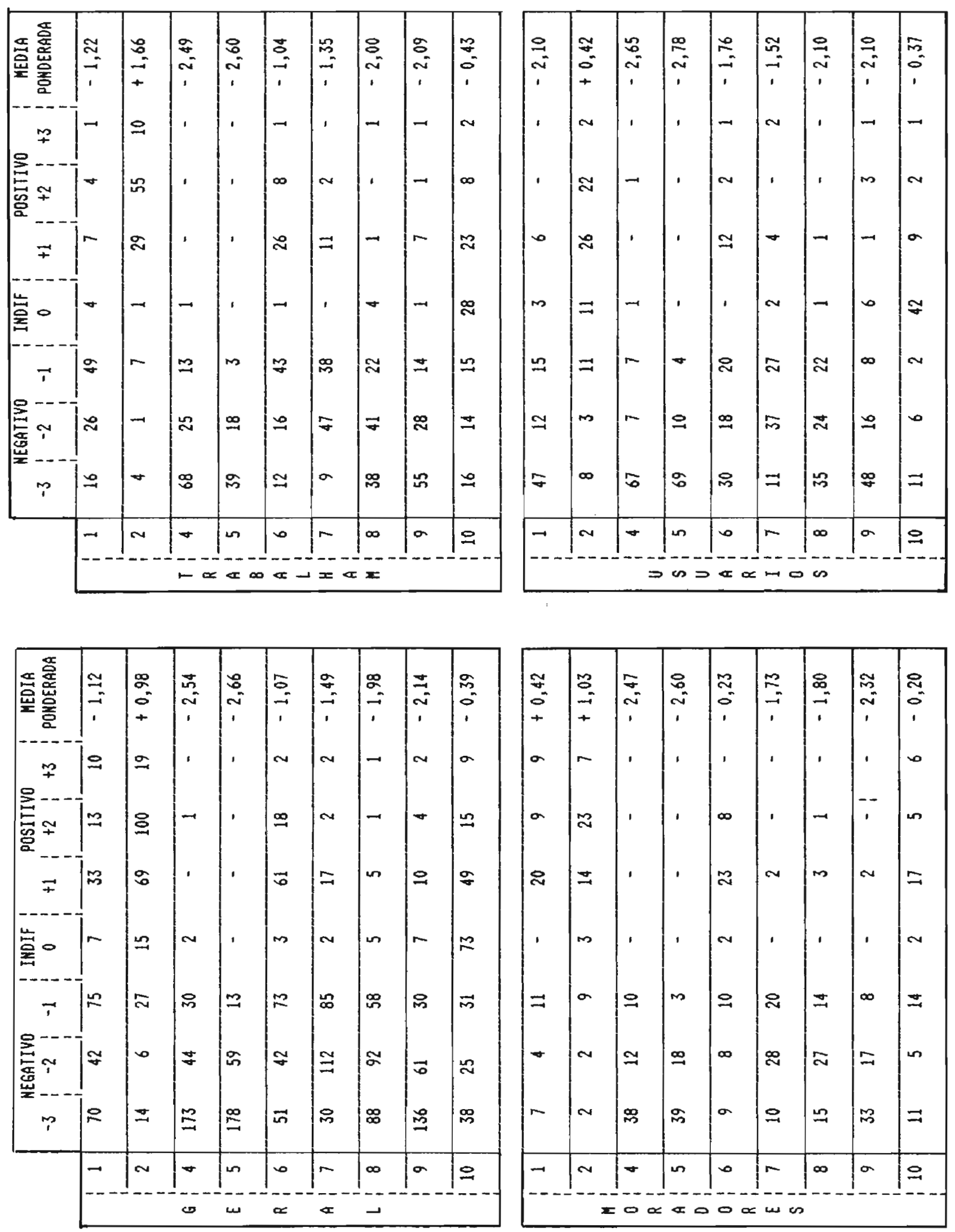

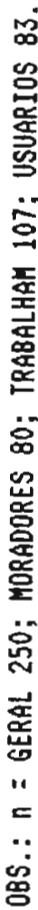


Tab. 29: Atitudes e Atributos Percebidos relativos a bairro, segundo Campos Perceptivos Negativo e Positivo por respondentes na Praça Mauá (Questão 17).
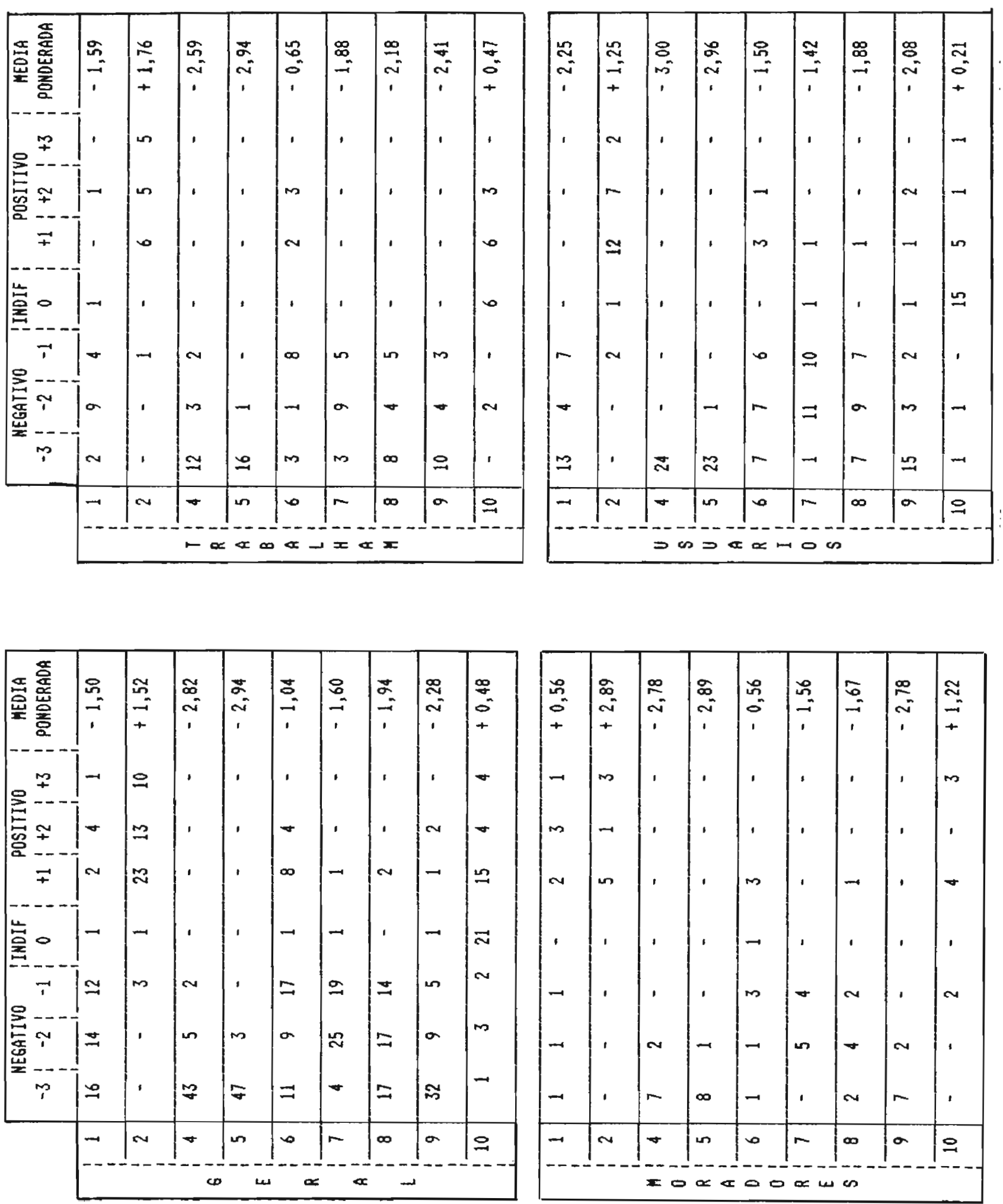

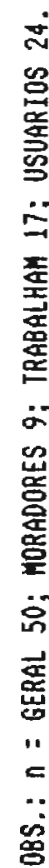


Tab. 30: Atitudes e Atributos Percebidos relativos a bairro, segundo Campos Perceptivos Negativo e Positivo por respondentes na Praça Barão de Tefé (Questão 17).
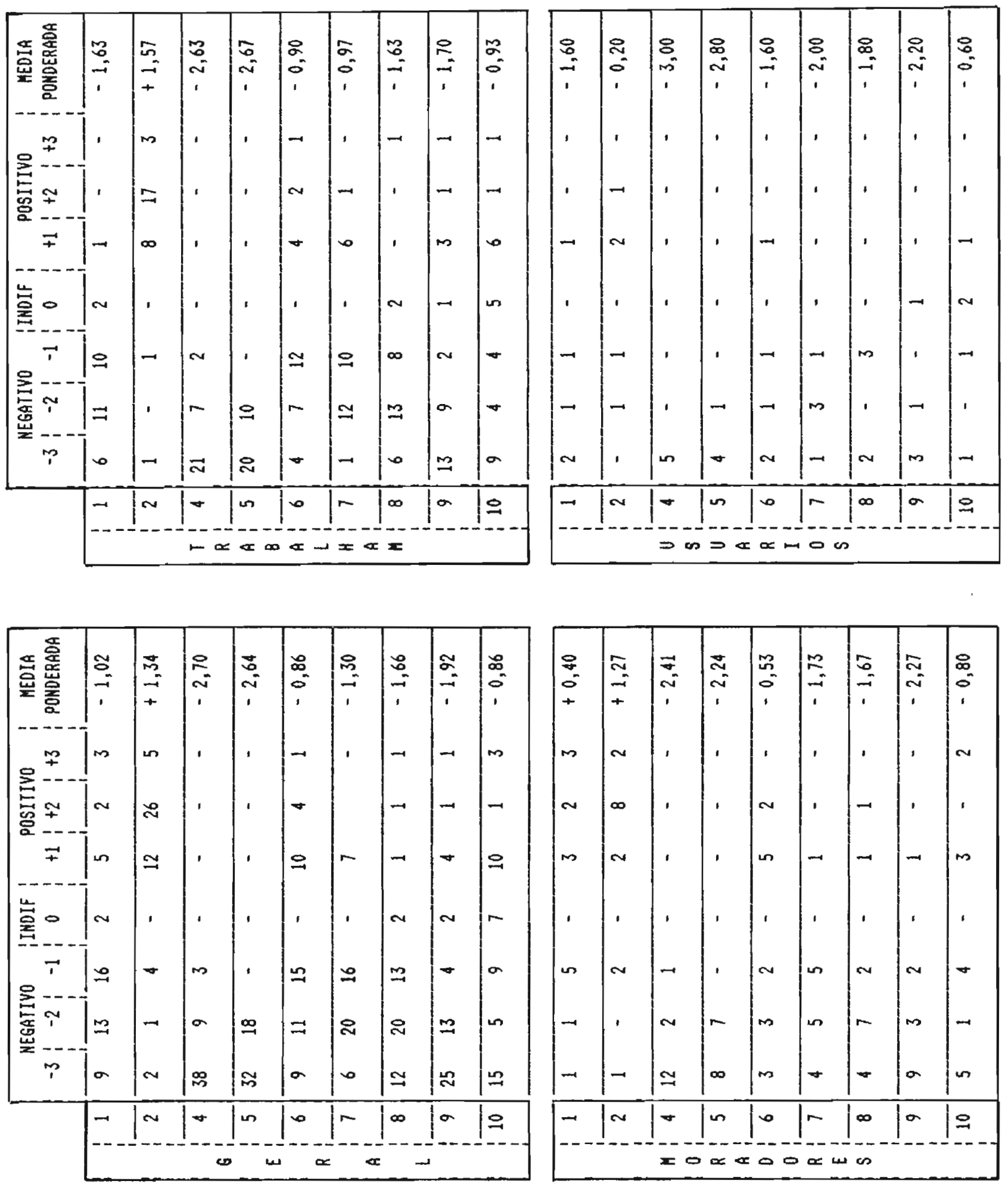

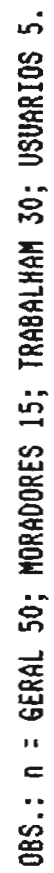


Tab. 31: Atitudes e Atributos Percebidos relativos a bairro, segundo Campos Perceptivos Negativo e Positivo por respondentes na Praça da Harmonia (Questão 17).
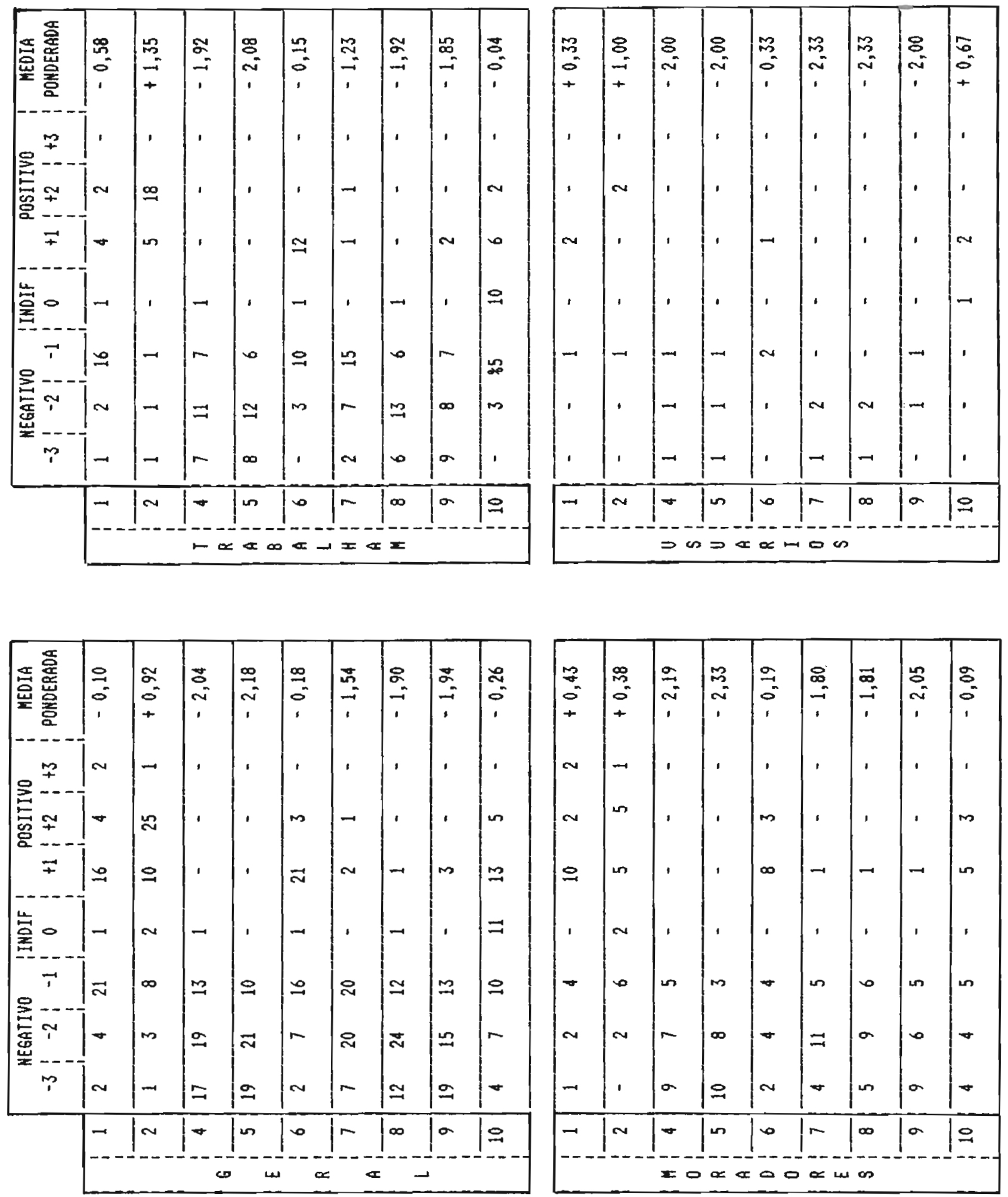

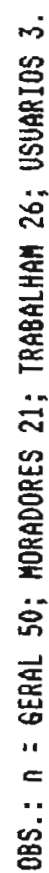


Tab. 32: Atitudes e Atributos Percebidos relativos a bairro, segundo Campos Perceptivos Negativo e Positivo por respondentes na Praça de Sto Cristo (Questão 17).
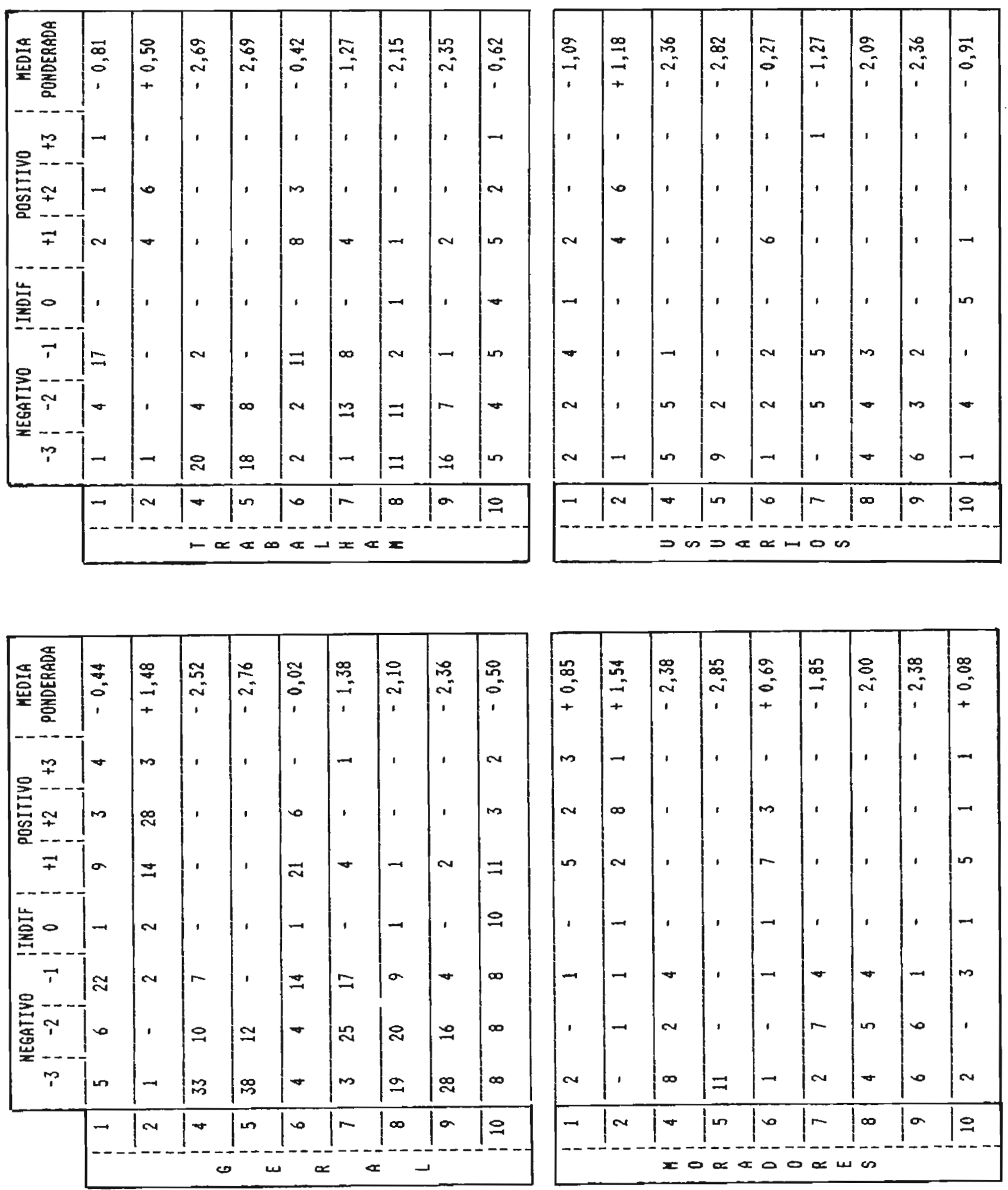

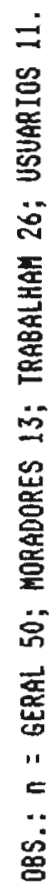


Tab. 33: Atitudes e Atributos Percebidos relativos a bairro, segundo Campos Perceptivos Negativo e Positivo por respondentes na Rodoviária (Questão 17).
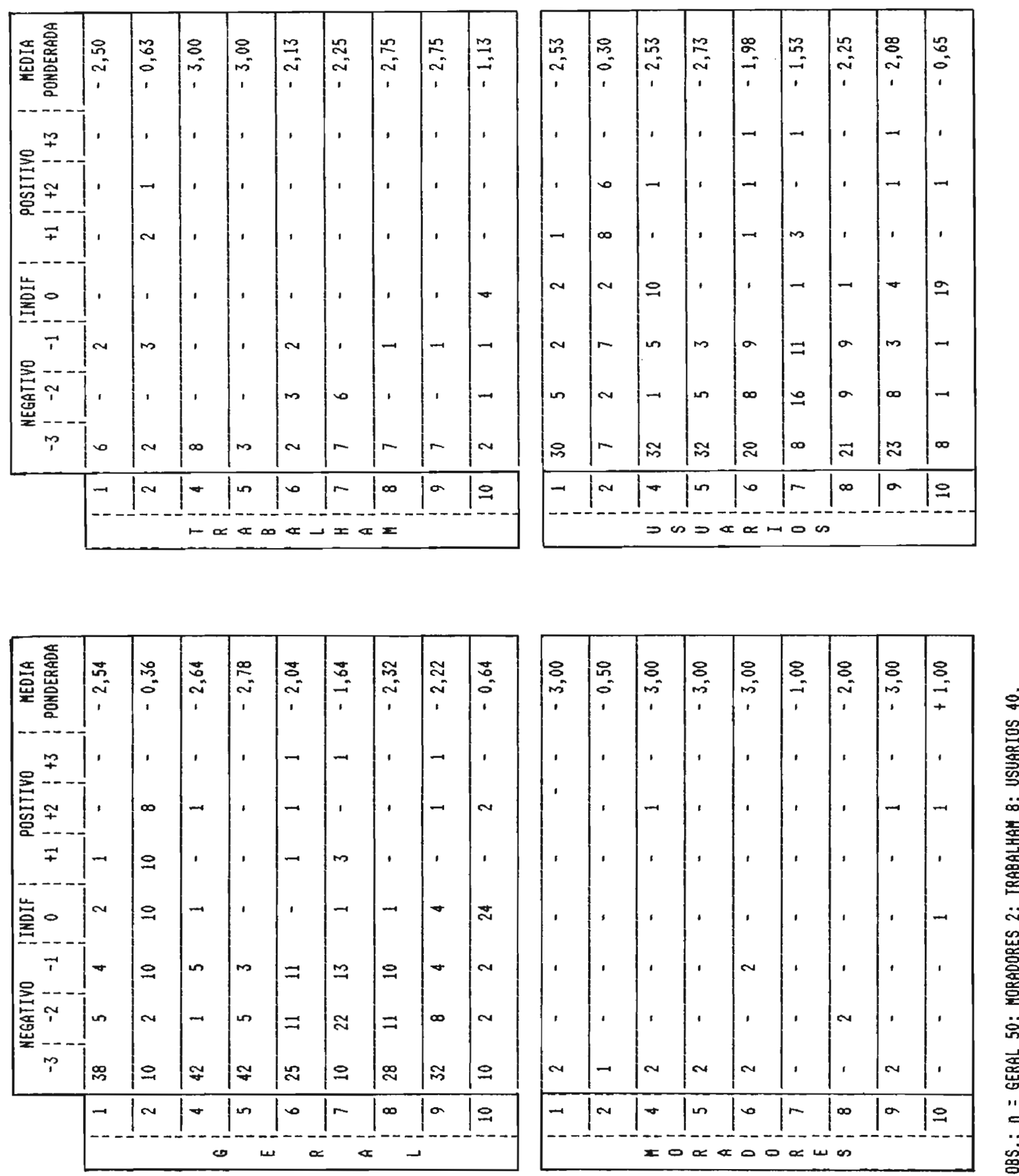
Tab. 34: Atitudes e Atributos Percebidos relativos a Área Portuária, segundo Campos Perceptivos Negativo e Positivo, no conjunto dos respondentes (Questão 18).
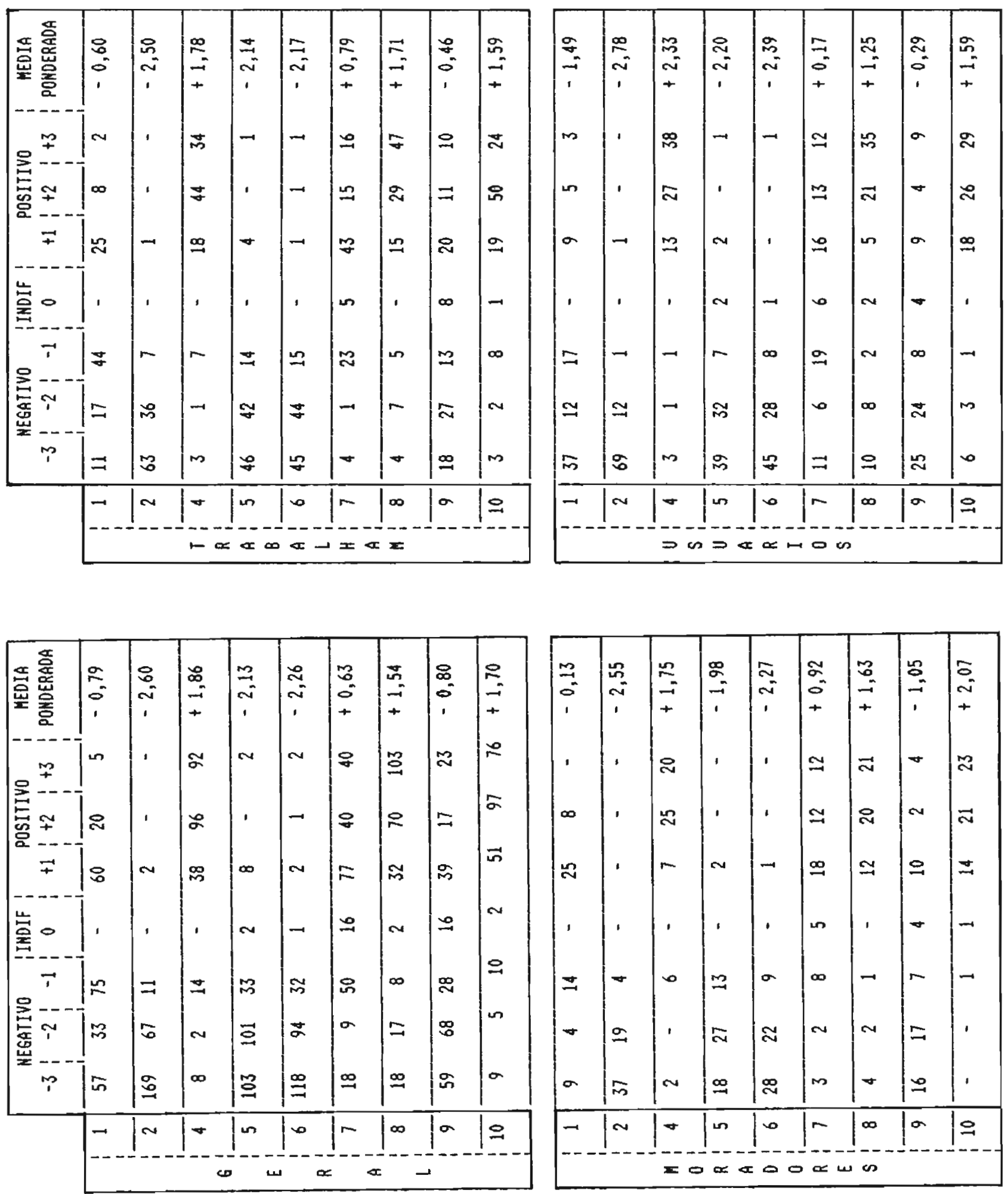

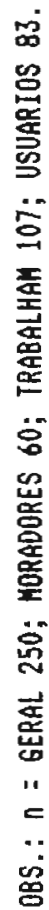


Tab. 35: Preferências relativas a Cenários de Desenvolvimento para a Área Portuária (Questão 19).

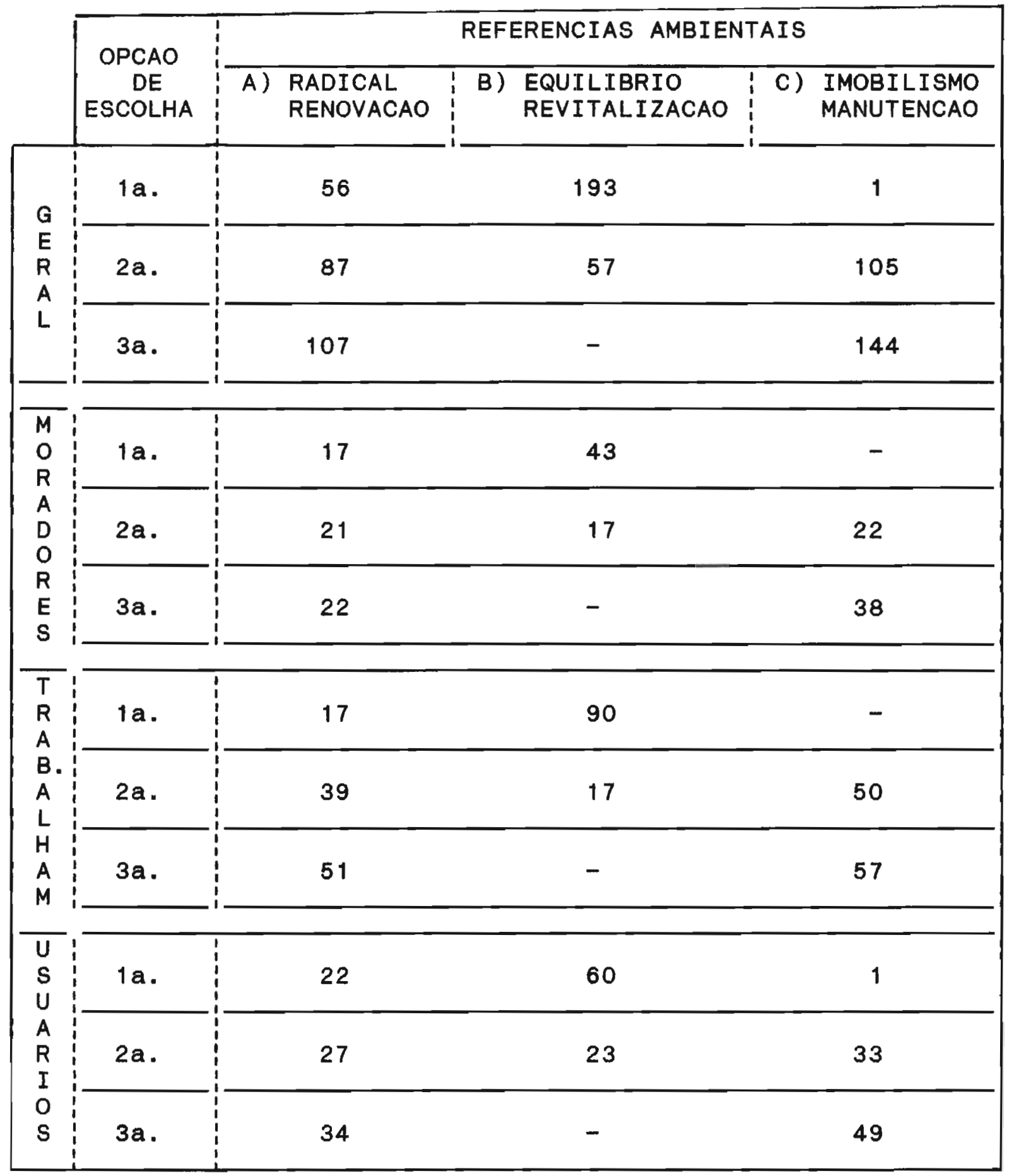

OBS.: $n=$ GERAL 250; MORADORES 60; TRABALHAM 107; USUARIOS 83 . 
Tab. 36: Expectativas Ambientais por Cenários de Desenvolvimento para a Área Portuária (Questão 19).

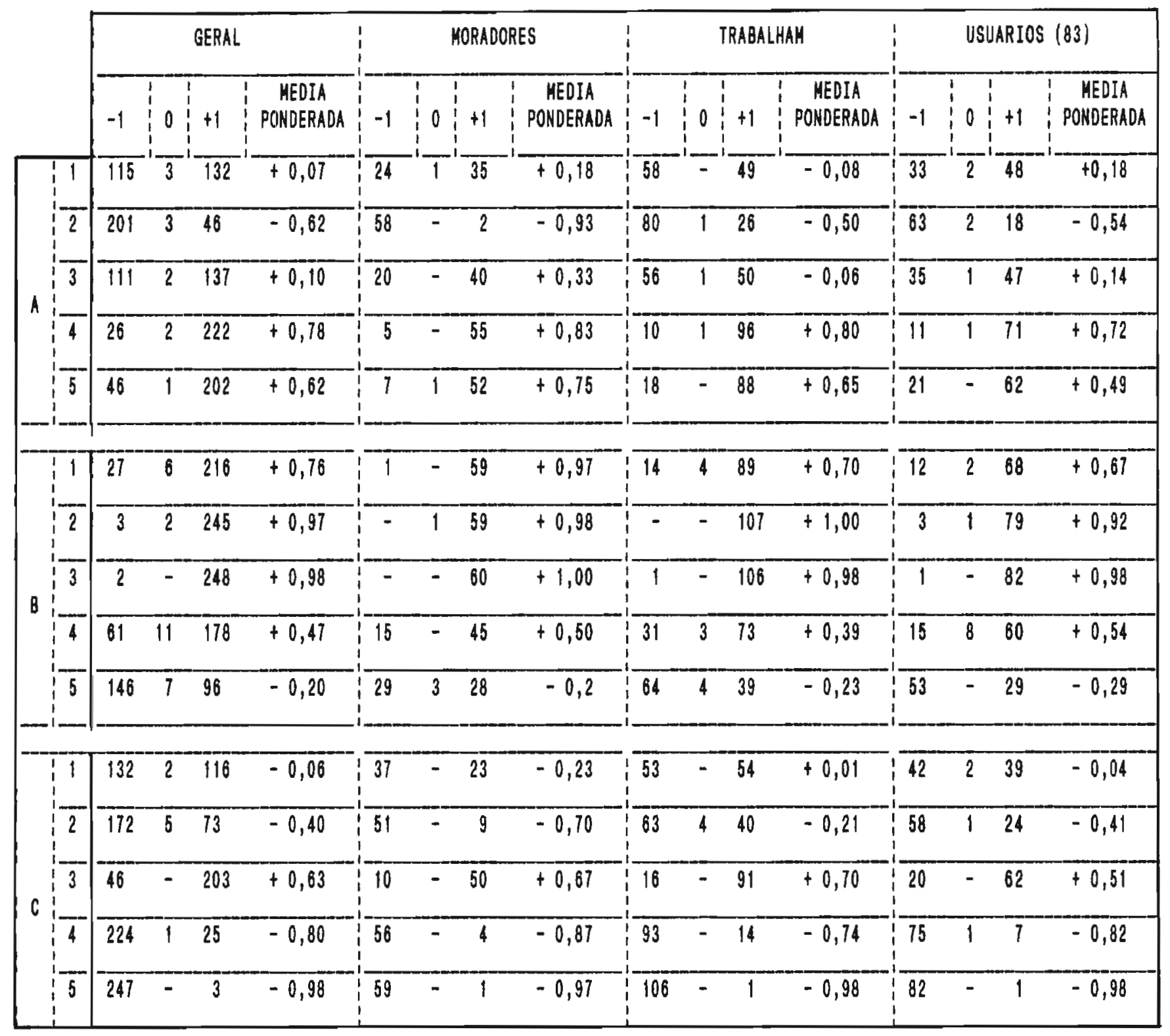

OBS,: $n=$ GERAL 250; HORADORES 60; TRABALHAM 107; USUARIOS 83. 


ANEXO $V$

Elementos Fisicos da Area Portuária Citados nos Questionários segundo Tipologia Imagética 


\section{ANEXO $V$ :}

Listagem dos Elementos Fisicos Citados nos Questionários Identificados como Pertencentes á Area Portuària, segundo Tipologia Imagética.

1. Categoria RUAS:

Cordeiro da Graca

Capibaribe

Orestes

Rivadávia Maia

Souza e Silva

Silvino Montenegro

Cidade de Lima

Sacadura Cabra 1

Santo Cristo

Rua do Livramento

Ladeira do Rodrigues Alves

Barăo de Tefé

Venezue la

Gamboa

Av. Rio Branco

Edgar Gorditho

Conceicăo

Camerino

Pedro Ernesto

Propósito

Conselheiro Zacarias

Mendonça

Sara

Equador

Prof. Pereira reis

Uniăo

Francisco Bicalho e Viaduto

Pedro Alves

Rivadávia Correa

Renato Teixeira

são Francisco da Prainha

Senador Pompeu

Viaduto da Perimetral

Viaduto para Catumbi/Tủne1 Santa Bárbara

\section{Categoria EDIFICAÇOES:}

Corpo de Bombeiros

Agência BANERJ (Santo cristo)

Colégio Benjamim Constant

padaria sublime

Indústria de Café sublime

Paróquia Sagrada Familia 
Armazém Frigortfico

Albergue Fundaçăo Leăo XIII

Hospital dos Servidores do Estado (HSE)

Policia Federal

Quartel do 5o Batalhăo de Pollcia Militar

Rodoviaria Novo Rio

Moinho Fluminense

Viaduto Perimetral

Igreja de Santo Cristo

Armazém 18

Hote 1 Barão de Tefé

Escritório Central CEDAE (Cia. Estadual de Agua e Esgotos)

Agência Banco do Brasil (Praça Mauá)

Hopedagem Livramento

Hopedagem Portuária

Prédio "A Noite"/Rádio Nacional

Agência dos Correios (Praça Mauá)

Terminal Rodoviàrio Praça Mauá

Portobràs

Rádio Tupy

Igreja N.S. Benção

Sociedade dos Alcólatras Anônimos

Jornal do Comércio

Escola Municipal Darcy Vargas

Escola Municipal José Bonifácio

Estande de Tiro do 50 B.P.M.

sindicato dos estivadores

Supermercado Mundial

Companhia de Pneus Michelin

Posto Shell (Praça Santo Cristo)

Hospital de Oncologia

Terminal de Onibus Marechal hermes

Bar Recanto da Saúde

Agência BANERJ (AV. Rodrigues Alves)

Vi la Portuåria

Armazem 6

Ediflcio Garagem junto á Rodoviária

Hospital do INAMPS

Escritórios da XEROX

Escola Municipal Vicente Cardoso

Caixa Beneficente Servidores do Estado

Armazem do Ministério da Agricultura

Instituto Nacional de Tecnologia

Agencia UNIBANCO (Rua do Propósito)

Hospital Pró-Matre

I Delegacia de Poltcia Civil

3. Categoria LUGARES:

Boites da Praça Mauá

Trithos

Praça da Harmonia (Ce1. Assumpção)

Praca Santo Cristo

Praça Mauá 
Morro da Conceiçăo

Distrito Naval

Praça Barăo de Tefé

Porto/Armazens/Cais

Largo João da Bahiana

Morro da Saúde

Cemitério dos Inglêses

Morro do Pinto

Cana 1 do Mangue

Gamboa (bairro)

Pier da Praca Mauá

Mosteiro/Colégio São Bento

Morro do Livramento 
BIBLIOGRAFIA 
ABRAMS, Char les. "Man's struggle for shelter in an urbanizing Wor 1d", Cambridge MA: M.I.T. Press, 1964.

ABREU, Mauricio. "Da Habitacăo ao Habitat: A Questăo da Habitacăo Popular no Rio de Janeiro e sua Evolucăo" in Revista Rio de Janeiro, Universidade Federal Fluminense, vol.1 \#2, pp. $\frac{47-}{47}$ $58,1986$.

- "Evolucão Urbana do Rio de Janeiro", Rio de Janeiro: IPLANRIO/Zahar, 1987.

ALBRECHT, Johann. "Current Downtown Revitalization: A Precarious Assumption" in Urban Design Review, Chicago, vo1.8 \#1/2, pp. 12-13, 1985.

ALEXANDER, Christopher. "A City is not a Treo" in Architectural Forum, vol.122 \#1 (pp. 58-62) \& \#2 (pp. 58-61), 1965.

- "A Pattern Language", Oxford: Oxford University Press, 1977.

ANASTASI, ANNE. "Psychological Testing", 4a. Edicăo, Nova Iorque: Collier MacMillan, 1976.

ARNAUT, Jurema Kopke. "Morro da Concelção, Rio: Uma Proposta de Preservaçăo sem Tombamento" in Revista do Patrimônio Historico e Artistico Nacional \#19, $97-111,1984$.

ASSIS, J.M. Machado de. "Memórias Póstumas de Brás Cubas", Rio de Janeiro: Lia, 1881.

- "Quincas Borba", Rio de Janeiro: Tecnoprint, 1892.

APPLEYARD, Dona1d. "Why Buildings are Known: A Predictive Tool for Architects and Planners" in BROADBENT G., BUNT R. \& LLORENS T. (org.) "Meaning and Behavior in the Built Environment", Londres: John Wijey, 1980.

APPLEYARD, Donald. "The Environment as a social symbol" in Ekistics \#278, pp. 272-281, 1979.

- (org.) "The conservation of the European city", Cambridge MA: MIT Press, 1979.

- "Planning a Pluralist city: conflicting Realities in ciudad Guayana", Cambridge MA: MIT Press, 1976.

Nota: Quando entendido como essencial á argumentaçăo do texto, incluimos a data da ediça original da obra, ao final da nota bibliográfica. 
APPLEYARD, Donald and JACOBS, Allan. "Toward an urban Design Manifesto", Berkeley: Institute of Urban and Regional Development/University of California, Work Paper \#384, 1982.

BACON, Edmund. "Design of Cities", 2a ediçăo, Londres: Thames \& Hudson, 1974 (edicăo original 1967).

BAILLY, Antoine S. "La Perceptión del Espacio Urbano: Conceptos, Metodos de Estudio y su Utilización en la Investigación Urbanistica", Madri: Instituto de Estudios de Administración Loca 1, Colección Nuevo Urbanismo \#29, 1979.

- "La Perception des Paysages Urbains" in BAILLY, Antoine. "L'Organisation Urbaine: Theorie et Modeles", Paris: Centre de Recherche d'urbanisme, pp. 161-187, 1975.

BANDEIRA, M. e ANDRADE, Carlos Drummond de (org.) "O Rio de Janeiro em Prosa e Verso", Rio de Janeiro: Jose Orympio, Colecão Rio de Janeiro Quatro séculos vol.5, 1965.

BARKER, Roger et a1. "Habitats, Environments and Human Behavior", são Francisco: Jossey Bass, 1978.

BARNETT, Jonathan. "Introduction to Urban Design", Nova Iorque: Harper and Row, 1982.

BARREIROS, Eduardo. "Atlas da Evolucão Histórica do Rio de Janeiro: 1565 a 1965", Rio de Janeiro: Instituto Histórico e Geográfico Brasileiro, 1965.

BARRETO, A.H. Lima. "Vida e Morte de M.J. Gonzaga de sa", (editora desconhecida), 1919.

- "Recordacões do Escrivão Isalas Caminha", Rio de Janeiro: Editora Atica, 1909.

BARTHES, Roland. "Semiologie et Urbanisme" in L'Architecture d'Aujourd Hui, Paris, \#153, 1970.

BATCHELOR, Peter \& LEWIS, David. (org.) "Urban Design in Action", Raleigh: School of Design, North Carolina State University, Student Publication \#29, 1985.

BAUZER, Riva. "Crescer numa cidade Grande: Percepcões de um Grupo de Adolescentes Moradores do Rio de Janeiro", Rio de Janeiro: Nova Fronteira, 1983.

BECHTEL, Robert. "The Semantic Differencial and Other Paper-andPencil Tests" in MICHELSON W. (org.) "Behavioral Research Methods in Environmental Design", stroudsburg: DowdenHutchinson \& Ross, 1975.

BELL, Judith. "Doing Your Research Project: A guide for First Iime Researchers in Education and Social science", Milton Keynes: Open Untversity Press, 1987. 
BELL, Pau1; FISHER, Jeffrey \& LOOMIS, Ross. "Environmental Psychology", Filadelfia: W.B. Saunders, 1978.

BENCHIMOL, Jaime. "Pereira Passos: Um Haussmann Iropical, As Transformacőes Urbanas na cidade do Rio de Janejro no

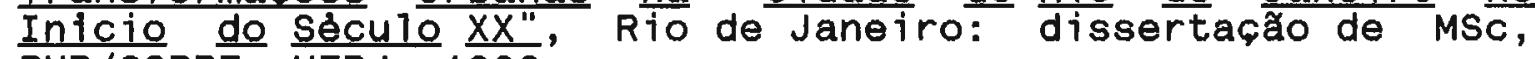
PUR/COPPE, UFRJ, 1982 .

- "A Modernização do Rio de Janeiro" in BRENNA, Giovanna del. (org.) "O Rio de Janeiro de Pereira Passos", Rio de Janeiro: PUC/Index, 1985

BENEVOLO, Leonardo. "The origins of Modern Town Planning", Cambridge MA: MIT Press, 1971 (edicăo original 1963).

- "O Ultimo Capttulo da Arquitetura Moderna", Lisboa: Martins Fontes, 1985.

BENTLEY, Ian. "The Urban Designer as Socially Conscious Developer" in GOODEY B. (org.) "Five Papers on Urban Design", Oxford: Oxford Polytechnic, mimeo, 1979.

BIRKHOLZ, Lauro B. "O Estudo do Planejamento Ierritorial", săo Pau10: Faculdade de Arquitetura e Urbanismo, USP, tese de cátedra, 1967.

BLAKE, Peter. "Form Follows Fiasco: Why Modern Architecture Hasnt Worked Qut", Boston: Little Brown, 1974.

BLAY, Lineu. "Percepcão do Espaco Urbano: o Centro de Curitiba", Rio Claro: Instituto de Geociências e ciências Exatas, UNESP, tese de MSc., 1982.

BOUCHER, Frèdèrique. "Pour une Approche Réaliste des Problemes de Rénovation" in L'Architecture d'Aujourd'Hui, Paris, \#202, pp. 2-6, 1979.

BUCHANAN, Peter. "Quays to Design: Urban Design Guidelines in London Docklands" in Architectural Review, Londres, \#1106, pp. 39-44, 1989 .

BURNETTE, Charles. "The Mental Image and Design" in LANG J. et a1. (org.) "Designing for Human Behavior: Architecture and the Behavioral Sciences", Stroudsburg: McGraw Hi11, 1974.

CADMAN, David. "Large-scale Urban Renewa 1: Mechanisms for Change" in Built Environment, Oxford, vol.12 \#4, pp. 187188,1987 .

CANTER, David. "The Psychology of Place", Londres: Architectura1 Press, 1977.

- "Introducción a la Psicologia Ambiental" in CANTER D. \& STRINGER P. (org.) "Interaccion Ambiental", Madri: Instituto Estudios de Administración Local, Nuevo Urbanismo \#26, 1978. 
CARDOSO, Elizabeth et al. "História dos Bairros: Saude, Gamboa e Santo Cristo: Zona Portuária", Rio de Janeiro: João Fortes Engenharia/Editora Index, 1987.

CARR, Stephen. "The city of the Mind" in PROSHANSKY, H.; ITTELSON, W. \& RIVLIN, L. (org. ) "Environmental Psychology: Man and His Physical Setting", Nova Iorque: Holt-Rinehart \& Winston, 1970.

CARVALHO, José Murilo de. "O Rio de Janeiro e a Republica" in Revista Brasiletra de História, São Paulo, vol.5 \#58/9, pp. $117-138,1985$.

CASTELLS, Manue1. "La Questión Urbana", México: Siglo XXI, 1979.

- "Problemas de Investigación en Sociologia Urbana", México: Siglo XXI, 1979.

CASTEX, J.; DEPAULE, J. \& PANERAI, P. "Formes urbaines: de l'Il10t a la Barre", Paris: Dunod, 1977.

CHIAVARI, Maria Pace. "As Transformaç̃es Urbanas do Século XIX" in BRENNA, G. (org.) "O Rio de Janeiro de Pereira Passos", Rio de Janeiro: PUC/Index, 1985.

CHING, Francis "Architecture: Form, Space, Order", Nova Iorque: Van Nostrand Reinhold, 1979.

CHOAY, Françoise "The Modern City: Planning in the XIX Century", Nova Iorque: George Brazil1er, 1969.

- "El Urbanismo: Utopias $y$ Realidades", Barcelona: Editorial Lumen, 1976. (edicão origina1 1965).

COARACY, Vivaldo. "Memorias da cidade do Rio de Janeiro", Rio de Janeiro: José 01ympio, 1955.

COLLINS, C. J. "Large-Scale Urban Renewa 1: A Developer's Viewpoint" in Built Environment, Oxford, vol. 12 \#, pp. 208$215,1987$.

CRULS, Gastão. "A Aparência do Rio de Janeiro", Rio de Janeiro: Jose Olympio, 1949.

CULLEN, Gordon. "El Paisage Urbano", Madri: Blume, 1974. (edição original 1961)

CUNNINGHAM, Michae 1. "Can Downtown be Reinvented?" in Ekistics, Atenas, \#256, pp. 159-164, 1977.

CUTLER, Lawrence \& CUTLER, Sherry. "Recycling cities for People: The Urban Design Process", Nova Iorque: Van Nostrand Reinhold, 1983. 
DAVIDOFF, Paul. "Advocacy and Pluralism in Planning" in FALUDI, Andreas. (org.) "A Reader in Planning Theory", Oxford: Pergamon Press, 1973. (edicăo original 1965).

DAVIDOFF, Paul \& REINER, Thomas. "A Choice Theory in Planning" in FALUDI Andreas. (org.) "A Reader in Planning Theory", Oxford: Pergamon Press, 1973.

DAVIES, Colin. "Ad Hoc in the Docks" in Architectural Design, Londres, \#1080, pp. 30-37, 1987.

DEL RIO, Vicente. "Introducão ao Desenho urbano no Processo de Planejamento", Săo Pauto: Editora Pini, 1990.

- "Um Caso de Revitalizacão Urbana: Baltimore, EUA", São Pau 10: Faculdade de Arquitetura e Urbanismo, USP, fotocopiado, trabalho programado $\mathrm{p} /$ doutoramento, 1985.

- "Urbanismo e Desenho Urbano: Para Um Debate de Definicões" in XII Congresso Brasileiro de Arquitetos, Belo Horizonte, 1985. Anais, Rio de Janeiro: Avenir/Revista Módulo, $1985 \mathrm{~b}$.

- (org.) "Desenho Urbano" Rio de Janeiro: Faculdade de Arquitetura e Urbanismo, UFRJ, Publicação \#9, 1982.

DOWNS, Roger \& STEA, David. "Maps in Minds: Reflections on Cognitive Mapping", Nova Iorque: Harper and Row, 1977.

ECO, Umberto "A Estrutura Ausente", 3a. edicão, são Pauto: Perspectiva, Ediçăo, 1976. (ediçăo original 1968)

EDMUNDO, Luis "O Rio de Janeiro do Meu Tempo", Rio de Janeiro: Imprensa Naciona $1,1938$.

EMBRATUR "Rio Antigo: Roteiro Turistico-cultural do Centro da Cidade", Rio de Janeiro: Empresa Brasileira de Turismo, 1979.

FALUDI, Andreas (org.) "A Reader in Planning Theory", Oxford: Pergamon Press, 1973.

FAREBEE, Ann (org.) "Education for Urban Design", Anais do Urban Design Educators' Retreat (San Juan, Porto Rico). Nova Iorque: Institute for Urban Design, 1982.

FERRARA, Lucrécia D’Alesso. "Ver a cidade" São Paulo: Nobe1, 1988

FURTADO, Ce1so. "Formacão Econômica do Brasil", são Pau1o: Companhia Editora Naciona1, 1977.

GANS, Herbert "People and Plans", Nova Iorque: Basic Books, 1968.

GASTAL, A1fredo. "Desenho Urbano $X$ Identidade Cultural" in TURKIENICZ, Benamy (org.) "Desenho Urbano III", São Paulo: Projeto, 1984. 
GERSON, Brasi1. "Historia das Ruas do Rio", Rio de Janeiro: Brasiliana Editora, 1965.

GIBSON, James. "The Senses Considered as Perceptual systems", Boston: Houghton Miffiin, 1966.

- "La Percepción del Mundo Visual", Buenos Aires: Infinito, 1974. (ediçăo origina] 1950).

GEHL, Jan. "A Changing street Life in a changing society" in Places, Nova Iorque, vol.6 \#1, pp. 8-17, 1990.

- "Life Between Buildings: Using Public Space", Nova Iorque: Van Nostrand-Reinhold, 1987. (edicão origina1 1980).

GOLD, John. "An Introduction to Behavioral Geography", oxford: Oxford University Press, 1980 .

GOODEY, Brian. "Towards a Participatory Culture in the Built Environment", Estrasburgo: Conselho de Europa, 1981 .

- "Towards a Debate on Urban Design" in GOODEY, B. (org.) "Five Papers on Urban Design", Oxford: Oxford Polytechnic, 1979.

GOODEY, Brian \& GOLD, John. "Geografia do Comportamento e da Percepcão", Belo Horizonte: Instituto de Geociências, UFMG, Pub1 icação Especia1 \#3, 1986.

- "Environmental Perception: The Relationship with Urban Design" in Progress in Human Geography, Londres, vo1.11 \#1, pp. 127-133, 1987 .

GOODEY, Brian et. a1. "City scene: An Exploration into the Image of Central Birmingham as seen by Area Residents", Birmingham: Centre for Urban and Regional Studies, University of Birmingham, Research Memorandum \#10, 1977.

GOODMAN, Robert. "Después de los Urbanistas, Qué?", Madri: B7ume, 1977. (edicão original de 1971)

GOODRICH, Ronald J. "Surveys, Questionnaires and Interviews" in LANG J. et a1. (org.) "Designing for Human Behavior: Architecture and the Behavioral Sciences", stroudburg: McGraw Hi71/Dowden-Hutchinson Ross, 1974.

GOSLING, David \& MAITLAND, Barry. "Concepts of urban Design", Londres: Academy Editions, 1984.

GOULD, Peter \& WHITE, Rodney. "Mental Maps", Nova Iorque: Penguin, 1974 .

GUSEVICH, Miriam. "Meaning and Means in Urban Design: A Case Study in American Urbanism, South La Salle Street, Chicago" in Journal of Architectural Education, Washington DC., vol.39 \#3, pp. 24-30, 1986. 
GUTMAN, Robert (org.) "People and Buildings", Nova Iorque: Basic Books, 1972.

HALL, Edward. "A Dimensăo oculta", Rio de Janeiro: Francisco Alves, 1977. (edição original de 1966).

HARRISON, James \& HOWARD, William. "The Role of Meaning in the Urban Image" in BROADBENT, $G$; BUNT, R. \& LLORENS, T. (org.) "Meaning and Behavior in the Built Environment", Londres: John Wiley, 1980.

HARVEY, Joan \& HENNING, Don. (org.) "Public Environments", Otawa: Anais do XVIII Congresso da Environmenta1 Design Research Association (EDRA), Otawa, 1987.

HAUSER, Arnold. "Historia Social de la Literatura $y$ del Arte" (Volume I), 12a. Ediçăo, Madri: Guadarrama, 1974.

HOME, Robert K. "Inner city Regeneration", Londres: Spon, 1982.

INTERNATIONAL Building Exibition "First Projects in Carefu1 Urban Renewa 1", Berlim: catålogo de exposição, 1984.

JACOBS, Jane. "The Death and Life of Great American Cities", Middlesex: Pelican, 1974. (edicăo original de 1961)

JENCKS, Charles. "The Language of Post-Modern Architecture", Londres: Academy Editions, 1977.

- "Modern Movements in Architecture", Middlesex: Penguin, 1973.

JENCKS, Charles \& BAIRD, George "El significado en Arquitectura", Madri: Blume, 1975. (ediçâo original de 1969)

JOHNSON-MARSHALL, Percy. "Renovación de ciudades", Madri: Instituto de Estudios de Administracion Loca1, 1979. (edicão original 1966)

KELLER, Suzanne. "The Urban Neighborhood: A Sociological Perspective", Nova Iorque: Random House, 1968.

KAMERON, Joe1. "Experimental studies of Environmental Perception" in ITTELSON W. (org.) "Environment and Cognition", Nova Iorque: Seminar Press, 1973.

KOHLSDORF, Maria Elaine. "Breve Histórico do Urbano como Campo Disciplinar" in FARRET, R. (org.) "O Espaco da cidade", são Pau10: Projeto, 1985.

- "As Imagens de Brastlia" in PAVIANI A. (org.) "Brasilia: Ideologia e Realidade, Espaco Urbano em Questão", São Paulo: Projeto, 1985b.

- "Manual de Técnicas de Apreensão do Espaco Urbano", Brasilia: DAU/UnB, mimeo, 1984. 
KOHLSDORF, Maria Elaine. "A Apreensão do Espaco Urbano: Sobre as Possibilidades e Limitacöes das Técnicas de Análise visual no Caso de Barra das Garcas", Brastila: DAU/UnB, dissertacão de MSc., 1979.

- "Gesta7t Urbana: Consideracōes sobre os Espacos do Plano Piloto de Brast1ia", Brast1ia: DAU/UnB, mimeo., 1975.

KRIER, Rob. "Urban Space", Londres: Academy Editions, 1975.

LAMARAO, Sérgio. "Dos Iraoiches ao Porto: Uma Contribuicăo ao Estudo da Producão da Area Portuária do Rio de Janeiro", Rio de Janeiro: PUR/COPPE, UFRJ, dissertaçăo de MSc., 1984.

LANG, Jon. "Teaching Urban Design: The Penn Experience", Porto Alegre: trabalho apresentado no Encontro Nacional sobre Ensino de Projeto Arquitetónico, UFRG, 1989.

- "Creating Architectural Theory: The Role of the Behavioral Sciences in Environmental Design", Nova Iorque: Van Nostrand Reinhold, 1987.

LANG, Jon et a1. (org.) "Designing for Human Behavior: Architecture and the Behavioral Sciences", Stroudburg: McGraw Hill /Dowden-Hutchinson \& Ross, 1974.

LeCOMPTE, Wi11iam F. "Behavior Settings as Data-Generating Units for the Environmental Planner and Architect" in LANG, J. et a7t. (org.) "Designing for Human Behavior: Architecture and the Behavioral Sciences", Stroudburg: McGraw Hill/DowdenHutchinson \& Ross, 1974.

LEE, Terence. "Psicologia e Meio Ambiente", Rio: Zahar, 1977.

- "Urban Neighbourhood as a Socio-Spatial Schema" in PROSHANSKY, H.; ITTELSON, W. \& RIVLIN, L. (org.) "Environmental Psychology: Man and His Physical Setting", Nova Iorque: Holt-Rinehart \& Winston, 1970.

LEEDS, Anthony. "Tipos de Moradia, Proletarização e Estrutura Social da Cidade" in LEEDS, A. \& LEEDS, E. (org.) "A Sociologia do Brasil Urbano", Rio de Janeiro: Zahar, 1977.

LERUP, Lars. "Environmental and Behavioral Congruence as a Measure of Goodness in Public space: The Case of Stockholm" in Ekistics, Atenas, \#204, pp. 341-358, 1972.

LEVI-STRAUSS, Claude "Tristes Irópicos", Lisboa: Ediçôes 70, 1955

LOWENTAL, David. "Environmental Assessment: A Case study of Boston", Nova Iorque: , American Geographical Society, Publications in Environmental Perception \#2, 1972.

LOZANO, Eduardo. "Visual Needs in the Urban Environment" in Town Planning Review, vol.45 \#4, pp. 351-374, 1974. 
LUCAIN, Pierre. "Art Urbain, Urban Design ou Urbanite?" in L'Architecture D'Aujourd'Hui, Paris, \#217, pp. 2-7, 1981.

LYNCH, Kevin. "A Theory of Good city Form", Cambridge MA: M.I.T. Press, 1981.

- "Teaching Urban Design" in GOODEY, B. (org.) "Five Papers on Urban Design", Oxford: Oxford Polytechnic, 1979.

- "Managing the Sense of a Region", Cambridge MA: M.I.T. Press, 1976.

- "The Image of the city", Cambridge MA: MIT Press, 1960.

MACEDO, J. Manue 1 de. "As Mulheres de Mantilha", Rio de Janeiro: Tecnoprint, 1871.

MACHADO, Lucy M.C.P. "A Serra do Mar Paulista: Um Estudo de Paisagem Valorizada", Rio Claro: Instituto de Geociências e Ciências Exatas, UNESP, tese de doutoramento, 1988.

MACKIE, D. \& METHUEN, A. "Design Briefing in Towns", Edimburgo: JOHNSON-MARSHALL \& Ass/Scotland Department of Development, relatório mimeo., 1978.

MACQUADE, Walter. "O Centro Urbano se Renova" in "Conservacão Ambiental: Uma Missão Nacional para a Decada dos Setenta", Rio de Janeiro: Fundação Brasileira para a conservação da Natureza/Fundação Getủi io Vargas, 1972.

MAGALHAES, José Cezar de. "O Porto: Fator de Expansão da Cidade" in ASSOCIAçAO DE GEOGRAFIA BRASILEIRA (Seçăo Rio) "Curso de Geografia da Guanabara", Rio de Janeiro: IBGE, 1968.

MANDEL, David. (1978) "Methodological Approaches to Environmental Psychology" in BELL, Pau1; FISHER, Jeffrey \& LOOMIS, Ross. "Environmental Psychology", Filadelfia: W.B. Saunders, 1978.

MANGIN, Wi11iam \& TURNER, John. "Barriada Movement" in Progressive Architecture, Nova Iorque, \#5, pp. 154-162, 1968.

MARANS, Robert $W$. "Survey Research" in MICHELSON, Wi11iam (org.) "Behavioral Research Methods in Environmental Design", Stroudsburg: Dowden-Hutchinson \& Ross, 1975.

MARMOT, Alexi \& WORTHINGTON, John. "Great Fire to Big Bang: Private and Public Designs on the City of London" in Built Environment, Oxford, vol.12 \#4, pp. 216-233, 1987.

MESQUITA, Samira N. de. "A Cidade do Rio de Janeiro e a Obra de Machado de Assis" in Revista Tempo Brasilejro, Rio, \#85, 1986

MERCER, Charles. "Living in cities: Psychology and the urban Environment", Middlesex: Penguin Books, 1975. 
METROCONSULT/DUCTOR. "Projeto de Remodelacão dos sistemas de Transporte Ferroviário de carga e urbano de Passageiros na Area de Influência do Subürbio do Grande Rio" (Volume II: Análise do Sistema Atual de Carga e Passageiros), Rio de Janeiro: CBTU/STU, 1988.

MOCELLIN, Raque1 Jardim. "Percepcão do Meio Urbano: o Caso do Grande Rio", Rio de Janeiro: Dept. de Geografia, Instituto de Geo-ciências, UFRJ, dissertą̧ão de MSc., 1977.

MOORE, Gary. "Knowing About Environmental knowing: The current state of Theory and Research on Environmental Cognition" in Environment and Behavior, vol.11 \#1, pp. 33-70, 1979.

MOORE, Gary \& GOOLEDGE, Reginald. "Environmental Knowing: Concepts and Theories" in MOORE, G. \& GOOLEDGE, R. (org.) "Environmental Knowing: Theories, Research and Methods", Stroudsburg: Dowden-Hutchinson \& Ross, 1976.

MUNFORD, Lewis. "The City in History: Its origins, Its Transformations and Its Prospects", Nova Iorque: Harcourt/Brace/ Jovanovich, 1961 .

NASAR, Jack L. "The Evaluative Image of the city" in $\underline{x}$ Congresso Anual da Environmental Design Research Association (EDRA). Anais. Washington: EDRA, 1979.

NEWMAN, Oscar. "Defensible Space: People and Design in the violent city", Nova Iorque: MacMillan, 1972.

OLIVEIRA, Livia de. "O Lixo Urbano: Um Problema de Percepcăo Ambiental" in VII Simpósio Anual da ACIESP. Anais. São Paulo: Pub1 icação ACIESP, \#40 Vol.II, 1983.

- "Estudo Metodológico e Cognitivo do Mapa", São Paulo: Instituto de Geografia, Universidade de São Paulo, Série Teses e Monografias \#32, tese de livre docência,1978.

PERIN, Constance. "With Man in Mind: An Interdisciolinary Prospectus of Environmental Design", Cambridge: MIT Press, 1970.

PERLMAN, Janice "O Mito da Marginalidade: Favelas e Politicas no Rio de Janeiro", Rio de Janeiro: Paz e Terra, 1977.

PFEIFFER, Toni "Behaviour and Interaction in Built space" in Built Environment", Oxford, vol.6 \#1, pp. 53-50, 1980.

PIAGET, Jean. "Main Irends in Interdisciplinary Research", Nova Iorque: Harper Torchbooks, 1973.

- "The Mechanics of Perception", Nova Iorque: Basic Books, 1969. (edicão original 1961) 
PIAGET, Jean. "Le Dévelopement des Perceptions en Fonction de 1'Age" in PIAGET, $J$. \& FRAISE, P. (org.) "Traité de Psychologie Experimentale: La Perception", Paris: Presses Universitaires de France, 1963.

PIAGET, Jean \& INHELDER, Barbe1. "The child's conception of Space", Nova Iorque: Norton, 1967. (edicăo original 1948)

PIPKIN, John. "Structuralism and the Uses of Cognitive Images in Urban Planning" in PIPKIN, J.; La GORY, M. \& BLAU, J. (org.) "Remaking the city: Social science Perspective on urban Design", Nova Iorque: state University of New York, 1983.

PLANAVE. (dados em elaboração para Plano de Desenvolvimento da Retaguarda do Porto do Rio), Rio de Janeiro, 1989.

- "Plano do Rio de Desenvolvimento $\frac{\text { Portuário }}{\text { daneiro", Rio de }} \frac{1987 / 1996:}{\text { Ministério }} \frac{\text { Porto }}{\text { dos }}$ Transportes/Portobrás, 1987.

PORTAS, Nuno. "Notas Sobre a Intervenção na cidade Existente" in Revista Sociedade \& Ierritório, Porto, \#2, pp. 8-13, 1985.

PORTOBRAS. "Anuário Estatistico Portuário", Rio de Janeiro: Portobràs, diversas datas.

PRAK, Niels. "The Visual Perception of the Built Environment", Delft: Delft University Press, 1977.

PROCESS (Revista de Arquitetura) "Waterfronts", Toquio, \#52, 1984

PROSHANSKY, Harold "Environmental Psychology and the Design Professions" in LANG, Jon et a1. (org.) "Designing for Human Behavior: Architecture and the Behavioral sciences", Stroudburg: McGraw Hi11/Dowden-Hutchinson \& Ross, 1974.

PROSHANSKY, Harold \& ALTMAN, Irwin (1979) "Overview of the Fie1d" in WHITE, W. (org.) "Resourses in Environment and Behavior", Washington: American Psychological Association, 1979.

PROSHANSKY, Harold; ITTELSON, Wi11iam \& RIVLIN, Leanne. "The Influence of the Physical Environment on Behavior: Some Basic Assumptions" in PROSHANSKY, ITTELSON \& RIVLIN (org. 1970) "Environmental Psychology: Man and his Physical Setting", Nova Iorque: Holt-Rinehart \& Winston, 1970.

RABHA, Nina Maria. "Cristalizaçăo e Resistência no Centro do Rio de Janeiro" in Revista Rio de Janeiro, Niterói, vol.1 \#1, pp. 35-44, 1985.

RAGGETT, Brian. "Post-War Urban Renewal: Past and Present Partnership Schemes" in Built Environment, Oxford, vo1.12 \#4, pp. 189-197, 1987 . 
RAPOPORT, Amos "The Meaning of the Built Environment: A Nonverbal Communication Approach", Bever1y Hil1s: Sage, 1983.

- "Human Aspects of Urban Form", Oxford: Pergamon Press, 1977.

- "House, Form and Culture", Englewoods: Prentice Ha11, 1969.

- "Whose Meaning in Architecture?" in Interbuild/Arena, Londres, \#83, pp. 44-46, 1967

RAPOPORT, Amos \& KANTOR, Robert. "Complexity and Ambiguity in Environmental Design" in American Institute of Planners Journal, Chicago, vol.33 \#4, pp. 210-221, 1967.

REIS, José de oliveira. "O Rio de Janeiro e seus Prefeitos: Evolucão Urbanistica da Cidade, 1889 a 1960", Rio de Janeiro: Prefeitura Municipal, c. 1975.

REZENDE, Vera. "Planejamento Urbano e Ideologia: Quatro Planos para a cidade do Rio de Janeiro", Rio de Janeiro: Civilizaçăo Brasileira, 1982 .

RIO, Joåo do. "A Alma Encantadora das Ruas", Rio de Janeiro: Biblioteca Carioca, 1908.

RIOPART. "Cadastro Fisico da Area Portuária do Rio de Janeiro", relatório elaborado pelo centro de Apoio à Pequena e Média Empresa do Rio de Janeiro para a RIOPART Participaçôes $\theta$ Empreendimentos S.A., 1983.

RODRIGUES, Ferdinando. "Desenho Urbano: Cabeca, Campo $\underline{\theta}$ Prancheta", são Pau1o: Projeto, 1985.

ROTHEMBERG, J. "Elimination of Blight and Slums" in STEWART, $M$. (org. 1972) "The city: Problems of Planning", Middlesex: Penguin, 1972.

ROSENTHAL, Donald (org.) "Urban Revitalization", Beverly Hills: Sage, 1980.

RossI, A1do. "La Arquitetura de la Ciudad", Barcelona: Gustavo Gi11i, 1979. (edicăo origina1 1966).

ROWE, Col1in \& KOETTER, Fred. "Collage city, Cambridge MA: M.I.T. Press, 1978.

RUDOWSKY, Bernard. "Arquitectura sin Arquitectos", Buenos Aires: Editorial Universitária, 1976. (edicăo original 1964)

SAARINEN, E1ie1. "La ciudad: Su crecimiento, su Declinación y su Futuro", México: Limusa Wiley, 1967. (edicăo original 1943).

SAARINEN, Thomas. "Environmental Planning, Perception and Behavior", Boston: Houghton Miff1in, 1976. 
SAMUELS, Ivor. 1987) "The Historical Centre in Britain", Oxford: Oxford Polytechnic, mimeo, c. 1987.

SAN FRANCISCO Department of City Planning. "Urban Design. An Element of the Master Plan of the city and county of San Francisco", são Francisco: Prefeitura de săo Francisco, 1984.

- "Downtown: Proposal as Adopted by the city Planning Commission as Part of the Master Plan (29/11/1984)", Săo Francisco: Prefeitura de Săo Francisco, 1984.

SAUNDERS, Peter. "Urban Politics: A Sociological Interpretation", Middlesex: Penguin, 1980.

SAMPAIO, Antonio H. (1986) "Desenho urbano: Indagaçoes Criticas" in TURKIENICZ, B. \& MALTA, M. (org.) "Desenho Urbano", Săo Pau10: CNPq/Pini, 1986.

SANOFF, Henry. "Measuring Attributes of the Visual Environment" in LANG, Jon et a1. (org.) "Designing for Human Behavior: Architecture and the Behavioral Sciences", Stroudburg: McGraw Hi11/Dowden-Hutchinson \& Ross, 1974.

SANTOS, Carlos N. F. "Movimentos Urbanos do Rio de Janeiro", Rio de Janeiro: Zahar, 1981.

- (coord.) "Quando a Rua Vira casa", săo Pau1o: Projeto, 1981.

SANTOS, J. Rufino dos. "Quatro Dias de Rebe1ião", Rio de Janeiro: Jose Olympio, 1980.

SANTOS, Pau1o. "Quatro séculos de Arquitetura", Rio de Janeiro: Instituto de Arquitetos do Brasi1, 1981.

SCOTT, Me1. "American city Planning since 1890", Berkeley: University of California Press, 1969.

SCHUMACHER, E. F. "Sma11 is Beautiful: Economics As If People Mattered", Nova Iorque: Harper \& Row, 1973.

SENNET, Richard. "The Fall of Public Man", Cambridge: Cambridge University Press, 1974.

- "The Uses of Disorder: Personal Identity and City Life", Nova Iorque: Alfred Knoff, 1970.

SERRA, Carios A. T. "A Funçao Portuària" in INSTITUTO BRASILEIRO DE GEOGRAFIA E ESTATITICA "Area Central do Rio de Janeiro", Rio de Janeiro: Divisão de Geografia, IBGE, 1967.

SILVA, Sérgio Costa e. "Os Setenta Anos do Porto do Rio" in Revista Portos \& Navios, \#251, 1980.

SINGER, Pau1. "Economia Polftica da Urbanizacăo", Săo Paulo: Brasiliense, 1978. 
SHIRVANI, Hamid. "The Urban Design Process", Nova Iorque: Van Nostrand Reinhold, 1985.

SIMMIE, James. "Citizens in conflict: The sociology of Town Planning", Londres: Hutchinson Educationa1, 1974.

SMITH, Peter F. "The Dynamics of Urbanism", Londres: Hutchinson Educationa 1, 1974.

SOMMER, Robert. "Espaco Pessoal: As Bases Comportamentais de Projetos e Planejamentos", São Paulo: Editora Pedagógica Universitária/Editora da USP, 1973. (edicăo original 1969).

STEA, David. "Architecture in the Head: Cognitive Mapping" in LANG J. et a1. (org.) "Designing for Human Behavior: Architecture and the Behavioral Sciences", Stroudburg: McGraw Hi11/DowdenHutchinson \& Ross, 1974.

STRINGER, Peter. "La Compreensión de 1a Ciudad" in CANTER D. \& STRINGER P. (org.) "Interaccion Ambienta 1", Madri: Instituto Estudios de Administración Loca1, Nuevo Urbanismo \#26, 1978.

TANGHE, J.; VLAEMINCK, S. \& BERGOEF, J. "Living cities: A Case for Urbanism and Guidelines for Reurbanization", Oxford: Pergamon Press, 1984.

TATI, Miécio. "O Mundo de Machado de Assis", Rio de Janeiro: SEEC/Livraria săo José, 1961.

TUAN, Yi-Fu. "Literature, Experience and Environmental Knowing" in MOORE, G. \& GOOLEDGE, R. (org.) "Environmental Knowing: Theories, Research and Methods", stroudsburg: DowdenHutchinson \& Ross, 1976.

- "Topofilia: Uma Estudo da Percepcăo, Atitude e Valores do Meio Ambiente", Săo Pauto: Difel, 1980 (edição original 1974)

TURKIENICZ, Benamy et a1. "As Dimensões Morfológicas do Processo de Urbanização: Uma Posstvel e Necessåria Metodologia de Pesquisa" in TURKIENICZ, B. \& MALTA, M. (org.) "Desenho urbano" (Anais do II Seminário de Desenho urbano no Brasil, Brasilia), Săo Paulo: CNPq/Pini, 1986.

- (org.) "Desenho Urbano" (Anais do I Seminàrio de Desenho Urbano no Brasil, Brasilia), São Paulo: Projeto, Cadernos Brasileiros de Arquitetura \#12/13/14, 1984.

- "A Forma da Cidade: Agenda para um Debate" in TURKIENICZ B. (org.) "Desenho Urbano" (Anais do I Seminário de Desenho Urbano no Brasil, Brasi1ia), săo Paulo: Projeto, Cadernos Brasileiros de Arquitetura \#12/13/14, 1984.

TURKIENICZ, Benamy \& MALTA, Mauricio. "Desenho Urbano" (Anais do II Seminario de Desenho urbano no Brasil. Brasilia). Săo Paulo: CNPa/Pini. 1986. 
VALDEZ, Ney Camara. "Sugestöes para o Porto do Rio" in Revista Portos e Navios \#251, 1980 .

VALLADARES, Llcia do Prado. "Passa-se uma Casa: Análise do Programa de Remocão de Favelas do Rio de Janeiro" \& Rio de Janeiro: Zahar. 1978.

VAZ, Lilian Fessler. "Notas sobre o Cabeca de Porco" in Revista Rio de Janeiro, Niterdi, vol.1 \#2, UFF, pp. 29-36, 1986.

VENTURI, Robert. "Complexity and Ambiguity in Architecture" . Nova Iorque: The Museum of Modern Art, 1966.

WARD, Regina1d "London: the Emerging Docklands City" in Built Environment, oxford, vol. 12 \#3, pp. 117-127, 1987.

WHYTE, Anne "Guidelines for Field Studies in Environmental Perception". Paris: UNESCO, MAB Technical Notes \#5, 1977.

WOLFE, Iom "From Bauhaus to Our House" \& Nova Iorque: Washington Square Press, 1981.

ZEISEL, John "Inquiry by Design: Tools for Environment-Behavior Research" . Cambridge: Cambridge University Press, 1981.

ZUBE, Erwin "Environmental Evaluation: Perception and Public Policy" + Cambridge: Cambridge University Press, 1980. 